\title{
LIBERACKość \\ DZIEŁA LITERACKIEGO
}




\section{SZTUKA/MEDIA/KULTURA}

seria pod redakcją Ryszarda W. Kluszczyńskiego

Dotychczas opublikowane:

PERSPEKTYWY BADAŃ NAD KULTURĄ

pod redakcją Ryszarda W. Kluszczyńskiego i Anny Zeidler-Janiszewskiej

Katarzyna Prajzner

TEKST JAKO ŚWIAT I GRA.

Modele narracyjności w kulturze współczesnej

Blanka Brzozowska

SPADKOBIERCY FLÂNEURA.

Spacer jako twórczość kulturowa - współczesne reprezentacje

Kamila Żyto

STRATEGIE LABIRYNTOWE W FILMIE FIKCJI

Dagmara Rode

POLITYKA W PIERWSZEJ OSOBIE.

Twórczość Dereka Jarmana

TRAJEKTORIE OBRAZÓW.

Strategie wizualne w sztuce współczesnej

pod redakcją Ryszarda W. Kluszczyńskiego i Dagmary Rode

PARADYGMATY WSPÓŁCZESNEGO KINA

pod redakcją Ryszarda W. Kluszczyńskiego,

Tomasza Kłysa i Nataszy Korczarowskiej-Różyckiej

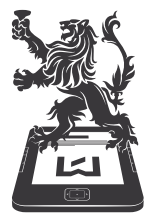

WYDAWNICTWO 
Agnieszka Przybyszewska

\section{LIBERACKOŚć DZIEŁA \\ LITERACKIEGD}


Agnieszka Przybyszewska - Uniwersytet Łódzki, Wydział Filologiczny

Instytut Kultury Współczesnej, Katedra Teorii Literatury, 90-236 Łódź, ul. Pomorska 171/173

\author{
RECENZENT \\ Ewa Szczęsna
}

REDAKTOR WYDAWNICTWA UŁ

Bogustawa Kwiatkowska

\author{
SKŁAD I ŁAMANIE \\ AGENT PR
}

PROJEKT OKŁADKI

Grzegorz Laszuk

Książka finansowana w ramach projektu Liberatura i liberackość z dotacji celowej na badania młodych naukowców i doktorantów na Wydziale Filologicznym UŁ w 2014 r. (nr projektu B1411300000512.02)

(C) Copyright by Uniwersytet Łódzki, Łódź 2015

Wydane przez Wydawnictwo Uniwersytetu Łódzkiego

Wydanie I. W.06705.14.0.M

Ark. wyd. 31; ark. druk. 25,875

ISBN 978-83-7969-417-4

e-ISBN 978-83-7969-836-3

Wydawnictwo Uniwersytetu Łódzkiego

90-131 Łódź, ul. Lindleya 8

www.wydawnictwo.uni.lodz.pl

e-mail:ksiegarnia@uni.lodz.pl

tel. (42) 66558 63, faks (42) 6655862 
wszystkim mniej i bardziej liberackim księgom 



\section{SPIS TREŚCI}

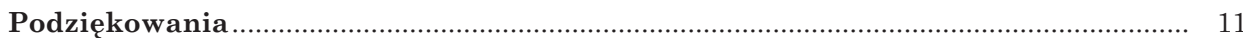

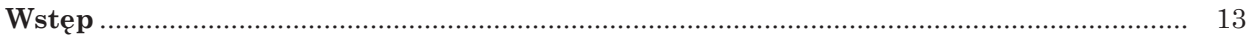

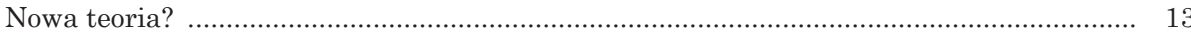

Struktura relacji z poszukiwań liberackości ................................................................. 16

Zaledwie otwarta dyskusja i liberacka przyjemność tekstu................................................ 19

\section{CZĘŚĆ I: DEFINIOWANIE LIBERATURY. OD LIBERATURY DO LIBERACKOŚCI}

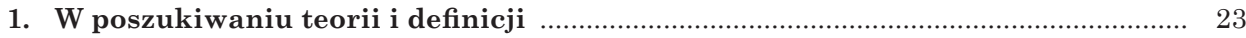

1.1. LiBeratura - antidotum na śmierć literatury? .......................................................... 23

1.2. (Dziś już zdystansowany) ojciec, czyli liberatura według Zenona Fajfera ................... 25

1.3. (Niepoważny) „przyszywany” wujek, czyli liberatura według Radosława Nowakowskiego

1.4. (Uczona) matka, czyli liberatura według Katarzyny Bazarnik ................................... 45

1.5. Raczej „liberackość” albo o medialnie uwikłanej sztuce słowa i książkowych inter-

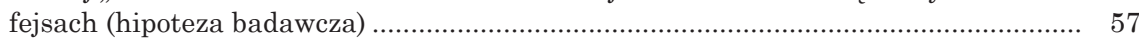

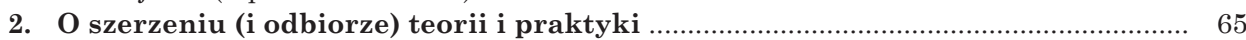

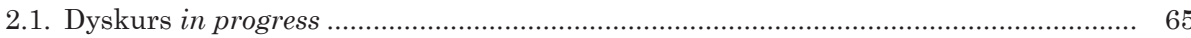

2.2. Naukowe rozmowy nie tylko w kuluarach............................................................. 67

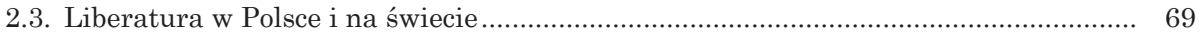

\section{CZĘŚĆ II: SZUKANIE LIBERATURY. LIBERACKOŚĆ MIĘDZY MEDIAMI}

I LIBERATURA A LITERATURA WIZUALNA ……................................................. 77

1. Liberatura a poezja wizualna ………………........................................................ 77

1.1. O oczywiście (?) wizualnej liberaturze i twórczości spod znaku Mallarmégoi Apollinaire'a

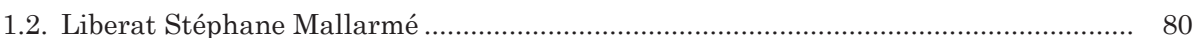

1.3. Literatura wizualna i literatura uksiążkowiona..................................................... 84

1.4. Dlaczego nie Apollinaire, czyli czemu liberaci nie lubią kaligramów ........................... 86

1.5. O liberaturze i konwencji z innej perspektywy, czyli o totalnej sztuce słowa w kontekście dawnej poezji wizualnej ................................................................................ 91

1.6. Adam Nieradzki - siedemnastowieczny liberat ............................................................. 95

1.7. Liberatura - poezja wizualna - literatura wizualna - literatura intermedialna ....... 99

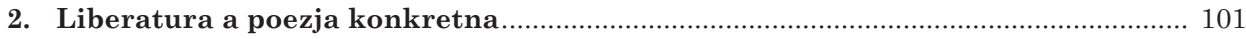

2.1. Nie-konkretna kawiarnia liberacka, czyli szkic sytuacyjny zamiast wstępu ............... 101

2.2. O tym, co kluczowe w (problematycznej) definicji poezji konkretnej ............................ 108

2.3. Redukcja contra rozszerzenie, czyli co liberat zrobiłby z jabłkiem .............................. 110

2.4. Znów żywe: uwolnione i uprzestrzennione słowa liberatów i konkretystów ................. 117

2.5. Liberackie play-activity i konkretna interaktywna ergodyczność - ciag dalszy podobieństw teoretycznych 
2.6. W walce o teorię sztuki słowa zdolną opisać zastaną rzeczywistość literacką............ 122

2.7. Znacząc konkretne formy (nie)książki i totalne tomy liberackie .............................. 124

2.8. Idealna liberatura konkretna .......................................................................... 126

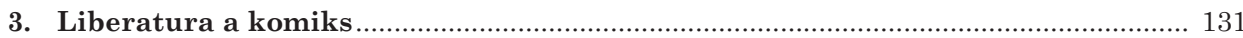

3.1. Podobieństwa widoczne gołym okiem ............................................................ 131

3.2. O opowiadaniu słowem i/czy obrazem, czyli o narracyjnych powinowactwach ........... 133

3.3. Kolejne kwestie sporne: nobilitująca(?) pansemantyczność i (nie)szablonowy bohater elitarnej(?) liberatury ......................................................................... 135

3.4. „Myślenie stroną” i „myślenie książką”, czyli kilka słów o metakadrze ...................... 137

3.5. Na manowcach autopromocji lub o zamkniętych kręgach wtajemniczonych .............. 138

3.6. Właściwy początek: jedność ikono-lingwistyczna versus pansemantyczność ............... 140

3.7. Konwencja jedności ikono-lingwistycznej versus dowolność jedności pansemantycznej, czyli o poetykach normatywnych i postulatywnych lub czytelniczych przechadzkach po (innym) lesie

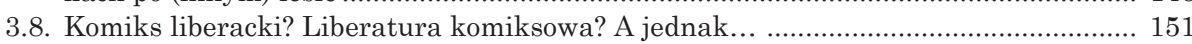

3.9. Różnice niewidoczne gołym okiem ................................................................ 155

4. Coda. „Garderoba” współczesnych opowieści.............................................. 157

II. LIBERATURA A EKSPERYMENTY TYPOGRAFICZNE .................................... 161

1. Liberackie znaki, chwyty i struktury ............................................................... 161

1.1. Platon, Derrida (?) i Nowakowski - zamiast wstępu .......................................... 161

1.2. Liberatura a kategoria znaku ................................................................. 164

1.3. Liberatura, lingwistyka i formalizm albo o lit/beraturze wskrzeszonej..................... 171

1.4. Chwyty lit/berackie - ciag dalszy formalistycznego wybijania z automatyzmu lek-

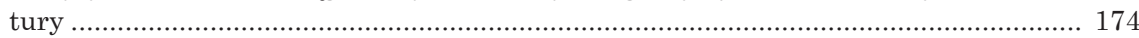

1.5. Lit/beracka narracja mówiona/zapisana ........................................................ 178

1.6. Lit/beracka odczuwalność formy .................................................................... 179

1.7. Lit/berackie miejsca wspólne, czyli o powracających reinterpretacjach..................... 181

1.8. Strukturalizm, czyli o liberackim czytaniu de Saussure'a raz jeszcze ....................... 183

1.9. Nowe nośniki znaczeń i struktura lit/beracka .................................................. 188

1.10. O płynnym przechodzeniu między funkcjami, czyli walka dominanty estetycznej

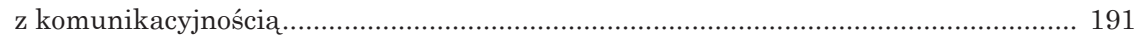

1.11. Tworzywo lit/beratury: słowo zmysłowe ........................................................ 193

2. Liberatura i awangardowa typografia na tle historii druku............................. 195

2.1. Dwie drogi typografii ...................................................................................... 195

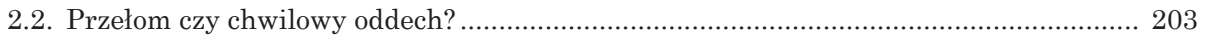

3. Liberatura a koncepcja druku funkcjonalnego............................................. 209

3.1. Liberatura funkcjonalna albo o równoległym projektowaniu znaczeń (czyli o nie tak prostym związku liberatury z teorią druku funkcjonalnego) ................................ 209

3.2. Analogie werbalnej i wizualnej kompozycji czy drażniący czytelnika happening ty-

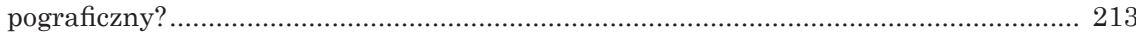

3.3. Typograficzna interpretacja contra dzieło totalne .............................................. 216

3.4. To samo?... A jednak zupełnie inaczej... ......................................................... 221

4. Liberatura a typografia futurystyczna ............................................................ 223

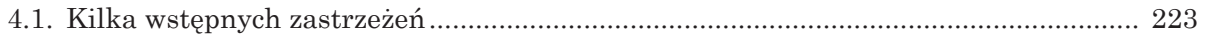

4.2. Futurystyczna literackość i rewolucja typograficzna.......................................... 229

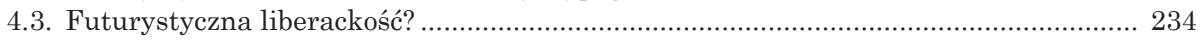

4.4. Bliżej futurystyczno-liberackiej praktyki: tablice synoptyczne i symultaniczność liberacka 
4.5. Zniewolone słowa na wolności .................................................................... 244

4.6. Ku nowym - liberackim i futurystycznym - sposobom komunikacji........................ 247

4.7. Zamiast zakończenia: liberacko-futurystyczne nic wcielone................................... 255

5. Liberatura a typografia nowomedialna .......................................................... 259

5.1. „Nowa”(?) typografia „nowej”(?) literatury ............................................................. 259

5.2. Bliżej praktyki: nowomedialna opowieść słowa ................................................ 267

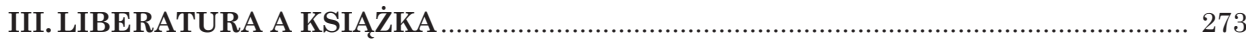

1. Literatura totalna w perspektywie sztuki książki, czyli o liberaturze i (nie tylko) książce artystycznej ......................................................................... 273

1.1. Podwójna opozycja ................................................................................................. 273

1.2. Zgodny głos sprzeciwu i dwa różne rozwiązania ................................................. 274

1.3. O artystycznym i liberackim „,robieniu książek” ............................................ 280

1.4. Odnaleziona przestrzeń wspólna ........................................................................ 283

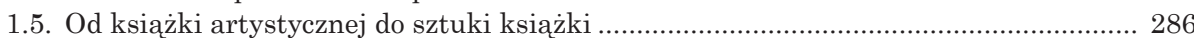

1.6. Od Clive'a Phillpota do Richarda Kostelanetza .................................................. 288

1.7. Między sztuka, książką i literaturą .......................................................................... 290

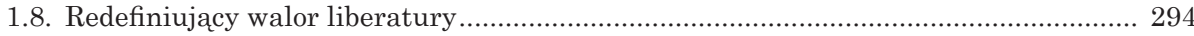

2. Literatura totalna w perspektywie bibliologii (i nie tylko), czyli o liberaturze i ,zwykłej" książce ................................................................................................ 297

2.1. Nowe (?) kompleksowe spojrzenie na książkę ...................................................... 297

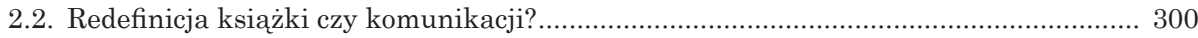

2.3. Książkowa komunikacja .................................................................................. 301

2.4. Propozycja Janusza Lalewicza .................................................................................. 303

2.5. Propozycja Teodora Zbierskiego ................................................................................ 307

2.6. Komunikacja liberacka .................................................................................... 309

2.7. Bratnie nauki albo o noszeniu i prze-noszeniu tekstów ........................................... 312

2.8. Bookishness, technotext i liberackość ................................................................ 316

IV. LIBERATURA A LITERATURA ELEKTRONICZNA …....................................... 321

1. Od galaktyki Gutenberga ku galaktyce Turinga .................................................... 321

1.1. Dziwny przypadek Mallarmégo i Joyce'a........................................................... 321

1.2. Hipertekstowa dygitalna e-cyber-literatura $2.0 \mathrm{w}$ dobie remediacji......................... 325

2. Daleko czy jednak blisko? $\mathrm{O}$ tym, co łączy liberatów i e-literatów ........................ 333

2.1. Niemieszczące się w biblioteczkach literackie dziwolagi, które trzeba czytać ina-

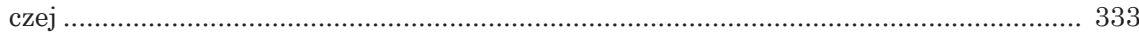

2.2. Espen Aarseth i liberatura ........................................................................... 335

2.3. Medialnie niema literatura czy medialnie niedowidzace analizy?........................... 340

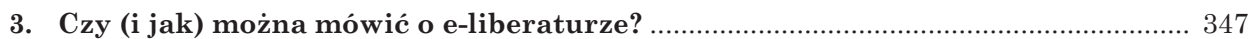

3.1. Rozgryzanie definicji - geneza problemu............................................................ 347

3.2. W poszukiwaniu wirtualnych kodeksów i elektronicznej lit/berackości ..................... 350

3.3. Wątpliwość, która podważa wszystko? ......................................................... 352

3.4. (Jednak obecna) konkluzja ............................................................................. 355

\section{CZĘŚĆ III: CZYTANIE LIBERATURY. KONKLUZJE}

1. Liberatura - przekaz grafemiczny w postmedialnym świecie konwergencji ....... 359

1.1. W dialogu z Seweryną Wysłouch i Marylą Hopfinger ........................................... 359

1.2. Intermedium na tle współczesności ................................................................... 362

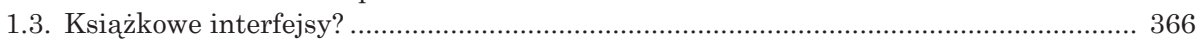




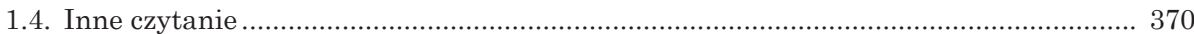

1.5. Ocalić literaturę?....................................................................................................... 374

1.6. Liberackość nasza współczesna albo o zwrocie interfejsologicznym w literaturoznawstwie

2. Konkluzje 383

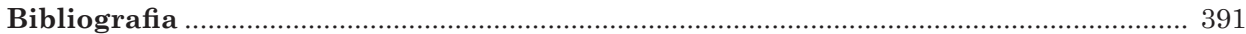

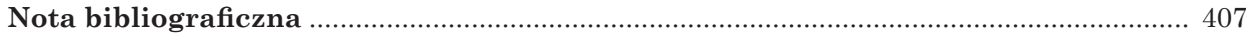

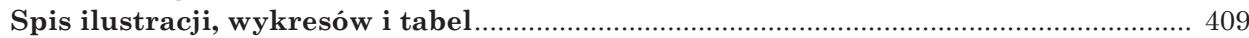

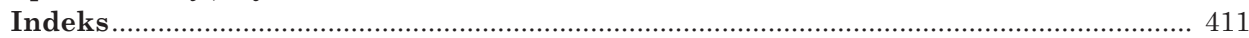




\section{Podziękowania}

Ani książka ta, ani będąca jej podstawą rozprawa doktorska (złożona we wrześniu 2011 r. i obroniona kilka miesięcy później) nie powstałaby bez wsparcia różnych osób. Szczególne podziękowania należą się Profesorom: Grzegorzowi Gaździe oraz Ryszardowi Kluszczyńskiemu, moim promotorom i merytorycznym opiekunom, zawsze gotowym w odpowiednich momentach podsunaćc ciekawe teksty do doczytania lub tupnąć noga, aby właśnie nic już nie doczytywać, nie poprawiać i nie dopisywać. Niezmiernie wdzięczna jestem również Profesor Danucie Szajnert za jej towarzyszące mi od początku kariery akademickiej dyskusje, rozmowy i „pogróżki”, których ślad na pewno w tej książce jest widoczny. Osobne podziękowania należą się też Studentom uczestniczacym przez kilka ostatnich lat w prowadzonych przez mnie zajęciach o liberaturze, e-literaturze i zjawiskach pokrewnych, którzy nieraz z podziwu godnym zapałem angażowali się w dyskusje będące dla mnie okazją do weryfikowania wielu ze stawianych w tej książce tez.

Tekst ten nie miałby również szans powstać bez udziału Katarzyny Bazarnik i Zenona Fajfera, którzy - choć nie zawsze się zgadzamy i mimo iż nieraz stanowczo krytykuję formułowane przez nich sądy - z ogromnym zaangażowaniem wspierali moje badania, udostępniając wiele tekstów, dbając o to, bym była na bieżąco z liberackimi nowinkami i zawsze odpowiadając (o dowolnej porze dnia i nocy) na każde moje pytanie. Osobne podziękowanie należy im się tu za napisanie Oka-leczenia - utworu, który stał się dla nich przyczynkiem do sformułowania teorii liberatury. W moim zaśs przypadku czytelnicza przygoda z nim zaowocowała przekonaniem, że zarówno sama książka, jak i kategorie teoretycznoliterackie, których wprowadzenie postulowali jej autorzy, warte sa dalszych badań.

Z pewnością nie udałoby mi się ukończyć prac bez wsparcia Najbliższych. Rodzicom i Chrzestnym dziękuję za rozbudzenie we mnie pasji badawczej (i wiary w to, że nie ma rzeczy niemożliwych), a także psychiczne i finansowe wsparcie. Tomkowi i Pepe - za niedajacca się (nawet liberacko) wysłowić cierpliwość i wyrozumiałość dla każdego „jeszcze tylko...”; Przyjaciołom - za to, że byli i wspierali, niezależnie od wszystkiego.

Wszystkim tym osobom winna też jestem podziękowania za wiarę we mnie, bez której tekst ten nadal pewnie leżałby w szufladzie. 



\section{Wstęp} Żadnych drzwi nie znaleziono, zamiast twierdzy
zobaczyliśmy przechodnie podwórze.

Boris Ejchenbaum ${ }^{1}$

\section{Nowa teoria?}

Pod koniec czerwca 1999 r. Zenon Fajfer ogłosił teorię liberatury. Swoje tezy po raz pierwszy zaprezentował podczas krakowskiej Wystawy Ksiażki Niekonwencjonalnej. Ubrane w formę manifestu (Liberatura. Aneks do słownika terminów literackich), 30 czerwca zostały opublikowane na łamach „Dekady Literackiej”. Od tego zdarzenia (czy dwóch, powiązanych ze sobą wydarzeń) liczyć wypada historię liberatury określanej również (za jej twórca) mianem literatury totalnej. Niemniej, rok 1999 jest tu tylko pozorna granica: wyznacza moment narodzin terminu, poczatek towarzyszacych jego doprecyzowywaniu dyskusji, staje się datą istotną dla teorii liberatury. Ona zaś sama, już od pierwszych definicji, traktowana jest jako kategoria ponadczasowa. Określa typ sztuki słowa, w obrębie którego artysta projektujący utwór literacki zastanawia się nie wyłącznie nad słowami, w jakie pragnie ująć ideę dzieła, lecz i nad owych słów kształtem, forma, materia, a także - najszerzej rzecz ujmując - i nad książką, w której będą one zamknięte. Wszystkie te elementy, w „zwykłej” literaturze najczęściej nieme i nieznaczące, dla liberata są istotne, gdyż na równi ze słowem mają współtworzyć sensy dzieła. Jednak tysiąclecia historii literatury pokazuja, iż zawsze bywali artyści szukający w owych niekanonicznych przestrzeniach sposobów pogłębienia możliwości ekspresji, postrzegający za swoje tworzywo nie wyłącznie wyzute z wszelkiej materialności systemowe twory językowe. Stąd, choć rok 1999 wyznacza początek teorii liberatury, jej przykładów - jak słusznie zauważa Fajfer i wtórujący mu teoretycy i praktycy literatury totalnej - szukać można i na długo przed tą data.

Książka, którą oddaję w ręce czytelników jest próbą przyjrzenia się tej przywołanej - liczącej nieco więcej niż dekadę i ciagle rozwijanej - teorii. Interesować będzie mnie jednak nie tylko to, czym jest liberatura, lecz i kilka dookolnych kwestii. Po pierwsze, jestem przekonana, że warto zastanowić się, czy tezy Fajfera i kontynuatorów jego myśli, mówiące o tym, że nigdy wcześniej nie zwracano uwagi na uwzględniane przez nich aspekty dzieła literackiego,

\footnotetext{
${ }^{1}$ Cyt. za: Stanisław Dąbrowski, Literatura i literackość, Kraków 1977, s. 162.
} 
są słuszne. Czy, aby na pewno, nie podejmowano wcześniej tych tematów i w rozważaniach teoretycznych? Czy Fajferowskie próby redefinicji pojęć, takich jak forma, tworzywo literatury czy książka (które w istocie wydają się krytyka pojmowania procesu literackiej komunikacji) rzeczywiście sa pierwsze? Czy może jednak liberaci wyważają przysłowiowe otwarte drzwi, próbują - jak ujmuje to Ejchenbaum - włamać się na otwarte podwórze?

Już samo zdefiniowanie przedmiotu tzw. wiedzy o literaturze, a zatem i określenie ram sztuki słowa, wymuszało namysł nad poruszanymi przez liberatów kwestiami. Przykładem tekstu ujmującego problem literackości od tej strony i śledzącego (w części przynajmniej) refleksję o (nie)wyłączności tworzywa językowego dla literatury jest choćby praca Stanisława Dąrowskiego Literatura i literackość ogłoszona drukiem przecież ponad dwie dekady przed sformułowaniem teorii liberackiej i przywołujaca teksty Stefanii Skwarczyńskiej publikowane więcej niż pół wieku przed manifestem Fajfera, bo już w latach trzydziestych. Jej autor wprost stwierdza, że teoria (literatury) „zatrzymała się na linii progu, który nie istnieje”. Badacz wyjaśnia, że „progiem tym jest zasada «jednotworzywowości» dzieła literackiego” ${ }^{3}$. W dalszej części wywodu powie nawet dobitniej, że owa jednotworzywowość jest „abstrakcja”, a nawet „fikcją teoretyczną" Ja zaś poszukiwać będę wypowiedzi teoretyków i artystów, którzy nie tylko ową jednotworzywowość kwestionuja, ale przede wszystkim - robią to w sposób analogiczny do twórców literatury totalnej. A wielokrotnie - zgodnie z nakazami chronologii - należałoby tu mówić o wskazywaniu dawnych ujęć, do których analogiczny jest wywód liberacki.

Po drugie, interesować będzie mnie, dlaczego ów - tu, jak sądzę, można się z liberatami zgodzić - niedominujacy sposób traktowania materialności, fizyczności literackich artefaktów: namysł nie tylko nad kwestią języka, lecz i kształtem tekstu, powrócił właśnie w 1999 r. Słowem - będę stawiać pytania o kondycję współczesnej sztuki, przede wszystkim sztuki słowa, by ująć teorię liberacką nie w oderwaniu od rzeczywistości, lecz w ścisłym powiązaniu z paradygmatem kultury, której stała się owocem. Można by więc powiedzieć, że traktuję teorię liberacką jako swoistą odpowiedź na postulaty i pytania Seweryny Wysłouch, która w ostatnich latach co najmniej dwukrotnie zwracała uwagę na konieczność pewnych „porządków teoretycznych”, wynikająca z nowego kształtu otaczającej nas rzeczywistości literackiej (czy ogólnie: sztuki, a wręcz - właśnie - paradygmatu kultury). W 2004 r. (podczas Zjazdu Polonistów) badaczka sugerowała, że nowa sytuacja kulturowa (zanurzenie w multimedialności) sprawia, że „niemożliwa do utrzymania wydaje się językoznawcza definicja tekstu”6. Zaś dwa lata później, pisząc wstępny rozdział do tomu przekładów Ut pictura poesis sugerowała, że aktualny stan

\footnotetext{
${ }^{2}$ Ibidem, s. 156.

${ }^{3}$ Ibidem.

${ }^{4}$ Ibidem, s. 173.

5 Ibidem.

${ }^{6}$ Seweryna Wysłouch, Nowa genologia - rewizje i reinterpretacje, [w:] Polonistyka w przebudowie, red. Małgorzata Czermińska i in., t. I, Kraków 2005, s. 106.
} 
kultury (również konfiguracja medialna) owocuje nawrotem Horacjańskiego nurtu w refleksji o relacji słowa i obrazu, a także kształtowaniem tekstów, które doprasza się „nowej (alternatywnej?) teorii literatury”7. Sformułowanie teorii liberatury traktuję jako jeden z przejawów reakcji na sytuację opisywaną (nie tylko) przez Wysłouch. Istotne jest dla mnie również to, że równolegle z teorią liberacką na świecie formułowane sa i inne koncepcje odpowiadajace na ten sam brak i akcentujące te same kwestie (w dalszej części wywodu jako symptomatyczne przywoływać będę ujęcia Jessiki Pressman oraz Katherine Hayles).

Po trzecie, szukać będę odpowiedzi na pytanie, czym jest liberatura. Jednak w centrum moich zainteresowań pozostanie nie tyle ona sama, lecz konstytuująca ją liberackość (co zapowiada już sam tytuł książki). Skąd takie ujęcie? Po pierwsze - liberaci (co uważam za zasadne) podkreślaja, że literatura totalna jest odmiana sztuki słowa i jawnie protestuja przeciw wyrzucaniu jej poza granice literatury. Stąd, z formuły „liberatura to taka literatura, która jest liberacka” wybieram właśnie liberackość jako cechę, którą należy poddać analizie. Po drugie - sądzę, iż przymiotnikowa forma terminu jest trafniejsza i - przez to - użyteczniejsza, nie zmusza nas bowiem do etykietowania ani przyjmowania czarno-białej wizji literatury. Nie jest moim celem wskazywanie palcem poszczególnych utworów i (zawłaszczające) krzyczenie „to jest liberatura!”, co nieraz zdają się czynić liberaci. Raczej zamierzam (w zamian) odpowiedzieć na pytanie, co takiego sprawia, że mogę - w mniejszym lub większym stopniu - mieć ochotę tak krzyczeć. Innymi słowy: szukać będę takich cech literatury, które prowokują do tego, by nazwać dzieło liberackim. A że w obrębie poszczególnych tekstów może być takich aspektów aktualizowanych wiele lub zaledwie jeden czy kilka - trzecią przyczyną mojego przedkładania przymiotnikowej wersji terminu nad jego rzeczownikową formułę jest właśnie możliwość stopniowania. Sądzę, że mówienie o liberaturze - etykietowanie świata dzieł literackich - prowadzi ku kłótniom o wyraźne granice pojęcia, wyklucza pograniczność, co w przypadku terminu zrodzonego niejako $\mathrm{z}$ istoty takiego bycia pomiędzy literatura a innymi dziedzinami sztuk wydaje się nieco absurdalne. Rozważanie liberackiego aspektu dzieła pozwala ową cechę stopniować i tym samym stwarza wygodną sytuację dla porównywania utworów opisywanych tą kategoria. Jestem też przekonana, że wszelkie liberackie manifesty mówią w istocie o pewnych cechach, własnościach tekstów literackich, stąd zaproponowana forma terminu nie kłóci się, jak sądzę, z intencją autorów teorii. Samo zaś określenie „liberatura” (jako krótsza formuła do opisania takich utworów literackich, które cechuje liberackość) jest - owszem - wygodne. Stąd, nie przeczę, będę się nim nierzadko posługiwać.

7 Seweryna Wysłouch, Ut pictura poesis - stara formuła i nowe problemy, [w:] Ut pictura poesis, red. Marek Skwara, Seweryna Wysłouch, Gdańsk 2006, s. 8. 


\section{Struktura relacji z poszukiwań liberackości}

Moje poszukiwania, próby ujęcia istoty zjawiska i „przygody” z czytaniem liberatury prezentuję tu w trzech częściach: I. Definiowanie liberatury, II. Szukanie liberatury oraz III. Czytanie liberatury. Pierwsza z nich przynosi rekapitulację dotychczasowej refleksji liberackiej oraz własną propozycję ujęcia istoty liberackości. Referuję w niej tezy trójki artystów fundujące interesujący mnie dyskurs: Zenona Fajfera, Radosława Nowakowskiego oraz Katarzyny Bazarnik. Staram się również odpowiedzieć na pytania o dotychczasową recepcję nie tylko samej teorii literatury totalnej, ale i zjawiska. Tym samym, charakteryzuję tė̇ liberacką serię wydawnicza, wspominam o (nie tylko naukowych) dyskusjach uwzględniających zaproponowaną w 1999 r. kategorię czy przywołuję instytucje związane z promowaniem teorii i twórczości liberackiej.

Wyjaśnienia wymaga tu rama czasowa, jaka przyjmuje dla moich rozważań. Zajmując się teorią tworzoną na moich oczach, aktualizowana, dopowiadana, korygowaną i zmienianą (zarówno w trakcie pisania rozprawy doktorskiej stanowiącej podstawę tej publikacji, jak i w czasie prac redakcyjnych nad tą książka), nieraz stawałam przed problemem niemożliwości wiecznego aktualizowania prezentowanych tu faktów. Stąd, z czasem przyjęłam, że podstawą swoich odwołań uczynię pierwszą dekadę liberacką. Ta została ukoronowana wydaniem wyboru tekstów Fajfera dotyczących zjawiska, zaś obchodom dziesięciolecia liberatury towarzyszyło również opracowanie jej kalendarium, opublikowanego na łamach jubileuszowego numeru „Ha!artu”, poświęconego niemal w całości liberaturze.

Choć próbuję konsekwentnie trzymać się wyznaczonych w ten sposób granic i nie przywoływać wydarzeń późniejszych niż te uwzględnione w owym kalendarium, zdarza się, iż czynię inaczej. Powołuję się m.in. na trzy zdarzenia, które miały miejsce już w 2011 r., jestem jednak przekonana, że uwzględnienie ich w wywodzie pozwoliło dobitniej i wyraźniej powiedzieć pewne kwestie. Dotyczy to: warsztatów liberackich Uwolnij ksiązkę, które odbyły się we Wrocławiu podczas Europejskiego Kongresu Kultury (9-10 września 2011 r.), późniejszego „liberackiego tournée” Fajfera i Bazarnik po USA z cyklem prelekcji i wystaw związanych m.in. z Brooklyn Book Festival (druga połowa września 2011 r.) oraz publikacji tomu pokonferencyjnego Od liberatury do e-liberatury, będącego pokłosiem pierwszej edycji konferencji pod takim tytułem (książka ukazała się drukiem w październiku 2011 r.).

Odwołanie się do uczestnictwa w Brooklyn Book Festival wydaje mi się istotne szczególnie dlatego, że stosunek liberatów do książki artystycznej zmieniał się w czasie, a wydarzenia z września 2011 r. pozwalają wyraźniej określić kierunek tej ewolucji. Z kolei zaistnienie liberatury w Czytelni towa-

8 Liberatura - kalendarium, „Ha!art” 2010, nr 30, s. 28-29. Uznając, że nie ma potrzeby dublować czyjejś pracy, nie uwzględniam tu takiego kalendarium. Sądzę, że to przygotowane dla „Ha!artu” jest satysfakcjonujące, wymaga raczej wyłącznie uzupełnień o charakterze aktualizującym, dotyczących ostatnich wydarzeń. O nich piszę dalej w tekście głównym. 
rzyszącej Europejskiemu Kongresowi Kultury jest faktem pomagającym dopowiedzieć kwestie związane z idea promowania, rozpowszechniania liberatury wszędzie, gdzie się tylko da, w konsekwencji których to działań nieraz niknie, gubi się jej istota. Publikacja Od liberatury do e-liberatury wspomniana zostaje w przypisach rozdziału poświęconego definiowaniu liberatury. Publikowany tam szkic Bazarnik nieco się różni od wersji, którą autorka umieściła jako code w redagowanym przez siebie wyborze tekstów Fajfera, wydanym na dziesięciolecie liberatury. Ponieważ artykuł ten traktuję jako zamykający pierwsze dziesięciolecie refleksji liberackiej, uznałam za istotne odnotowanie uzupełnienia, jakiego dokonała badaczka i ustosunkowanie się do niego.

Odstęp czasowy między złożeniem rozprawy doktorskiej a pracami redakcyjnymi nad tą książka z jednej strony przyniósł jeszcze kilka wydarzeń, o których warto byłoby tu choć wspomnieć (jak choćby zaistnienie teorii liberackiej na światowych konferencjach Electronic Literature Organization, publikacja Powiek Fajfera w szczecińskiej Formie czy pojawienie się ławeczek liberata oraz Bazarnik jako części projektu Kody Miasta w ramach działań związanych z przyznaniem Krakowowi tytułu Miasta Literatury UNESCO), z drugiej przekonał mnie, że podjęta we wrześniu 2011 r. decyzja była jak najbardziej słuszna. Stąd, by nie zaciemniać wywodu i nie wprowadzać zbędnego chaosu, zdecydowałam się na jedynie niewielką aktualizację tekstu i przywołanie wyłacznie tych naprawdę najistotniejszych wydarzeń z pięciu ostatnich lat historii teorii liberackiej, gdyż - istotnie - poza przywołanymi już faktami czas miniony od 2011 r. nie przyniósł już wielkich przełomów.

Druga, najobszerniejszą część książki stanowi zapis moich prób śledzenia liberackości. Podjęłam w niej wątki wskazywane dotychczas w rozmaitych dyskusjach dotyczacych literatury totalnej. Wyszłam jednak z założenia, że owe debaty prowadziły - jak na razie - wyłącznie do (skrytykowanego już tu) wskazywania palcem na konkretne teksty czy zjawiska i dumnego orzekania „to jest liberatura!”, co miało uprawomocniać tworzoną teorię. Stąd, przede wszystkim, próbowałam podejść do przywoływanych dzieł tzw. prekursorów liberatury krytycznie i zweryfikować, czy w istocie sa liberackie (uprzedzając fakty, powiem: okazało się, że nie zawsze). Konsekwencją szukania punktów zbieżnych przywołanych zjawisk, nurtów czy form i teorii liberackiej jest weryfikacja - w praktyce - sensowności zaproponowanego w pierwszej części książki ujęcia teoretycznego. Takie porównania są też nieraz okazją do wskazania rozmaitych teorii sprzed 1999 r., które poruszają interesujące liberatów kwestie.

Moje poszukiwania skoncentrowałam w tym wypadku wokół czterech metaforycznie ujmujac - przestrzeni relacji liberatury i innych zjawisk, co znalazło swój wyraz w tytułach poszczególnych rozdziałów tej części: Liberatura a literatura wizualna, Liberatura a eksperymenty typograficzne, Liberatura a ksiaj̇ka oraz Liberatura a literatura elektroniczna. Muszę tu wyjaśnić, czemu rozdzieliłam literaturę wizualną od eksperymentów typograficznych, wyłączając tym samym rozważania o proponowanej przez Marinettiego formie zapisu słów oraz analizy koncepcji druku funkcjonalnego z rozdziału mówiącego 
o literaturze wizualnej, mimo iż oba te zjawiska są często podawane jako jej egzempla. Zgadzam się, że podział ten może wydać się problematyczny, nie do końca poprawny, kontrowersyjny. Jednak wyróżnione cztery rozdziały tej części w istocie koncentrują się również wokół czterech różnych kategorii pozwalających mówić o liberackości ((1) łączenia jakości werbalnych i wizualnych, (2) kwestii rozumienia znaku, w tym - rzeczywiście - również jego formy wizualnej, (3) książki oraz (4) intermedialności, wielomedialności i zjawisk pokrewnych). I właśnie owo, przyznaję, niewypowiedziane dodatkowe uporządkowanie zadecydowało w tym wypadku o „dziwnym” podzieleniu pomiędzy dwa rozdziały zjawisk zazwyczaj rozpatrywanych łącznie. Wpłynęło też na kolejne - zapewne również dające się postrzegać jako kontrowersyjne - przyporządkowania. Po pierwsze - rozważania o komiksie dającym się scharakteryzować jako narracja słowno-wizualna (czy słowno-obrazowa) zostały umieszczone w rozdziale dotyczacym literatury wizualnej, mimo iż nie wszyscy badacze komiks do takowej zaliczaja. Po drugie - fragment dotyczacy liberatury na tle semiotyki, formalizmu i strukturalizmu włączyłam do części poświęconej typografii jako konieczne uzupełnienie poruszanych w tym fragmencie książki kwestii.

I tak - w części pierwszej mierzę się z mitem tego, że cała literatura wizualna jest liberacka, że każde włączenie w tekst elementów wizualnych musi już być zabiegiem o charakterze liberackim. Tym samym, w moich rozważaniach istotne staje się sfunkcjonalizowanie wizualności (i wynikającej z niej przestrzenności) samego tekstu oraz włączanie w jego obręb elementów plastycznych. Wybierając kluczowe dla tak określonej przestrzeni badawczej zagadnienia, przyglądam się w tym rozdziale relacjom: liberatura-poezja wizualna, liberatura-poezja konkretna (jako jej szczególna odmiana) oraz liberatura-komiks.

Kolejny rozdział można potraktować jako próbę podążenia tropem wskazywanym m.in. przez Wojciecha Kalagę9: zwrócenia uwagi, że liberackość zaczyna się już na poziomie pojedynczej litery. Innymi słowy - przekonana, że nie wizualność decyduje o liberackości dzieła, zwracam się ku analizie sposobów zapisu tekstu, ku zagadnieniom druku i typografii, by sprawdzić, czy poszukiwana istota liberackości nie wiąże się z tą przestrzenią artystycznej kreacji. Kontekstem badawczym sa tu dla mnie określane jako liberackie: typograficzne eksperymenty futurystów i koncepcja druku funkcjonalnego. Dodatkowo - zapowiadając, że poruszane kwestie będę rozwijać w dalszej części pracy - przyglądam się (poszukując liberackości) również typografii nowomedialnej.

Rozdział ten, odwołujacy się w dużej mierze do pojmowania istoty znaku, staje się dla mnie też okazją do ważnych, jak sądzę, uzupełnień teoretycznych. Porównanie liberackiej teorii z przywołanymi przestrzeniami artystycznych

${ }^{9}$ Por. Wojciech Kalaga, Liberatura: słowo, ikona, przestrzeń [wstęp], [w:] Zenon Fajfer, Liberatura czyli literatura totalna. Teksty zebrane z lat 1999-2009, red. Katarzyna Bazarnik, Kraków 2010, s. 9-19. Tekst ten jest skrótem artykułu Tekst hybrydyczny. Polifonie i aporie doświadczenia wizualnego, z tomu Kulturowe wizualizacje doświadczenia, red. Włodzimierz Bolecki, Adam Dziadek, Warszawa 2010. 
realizacji poprzedza w tym wypadku odniesienie jej do: Desaussure'owskiego przełomu w myśleniu o znaku (i dalszych jego reperkusji), koncepcji formalizmu oraz strukturalizmu.

Kolejny rozdział przynosi perspektywę zgoła przeciwna - próbuję w nim bowiem przyjrzeć się nie najniższemu poziomowi działań liberackich, lecz temu, który wydaje się najwyższym. Centrum moich zainteresowań staje się tu książka, kategoria, która w miarę rozwoju liberackiej teorii wybrzmiewała coraz silniej. Tym samym, rozważam tu stosunek liberatury zarówno do książki artystycznej, jak i do klasycznej jej odmiany. Punktem wyjścia jest przypomnienie, że liberaci oczekiwali zredefiniowania tej ostatniej, zaś kontekstem bibliologia, w obszarze której można, jak sądzę, znaleźć i takie ujęcia książki, które nie kłócą się z wizją liberacką.

Punktem dojścia moich rozważań jest konfrontacja liberatury z literatura elektroniczna, kwestia - podobnie jak wszystkie inne tu wymieniane - wskazywana w dyskusjach, lecz raczej niepodejmowana w naukowych analizach. Tym samym, mam również okazję przyjrzeć się liberaturze w kontekście możliwości, jakie stały przed sztuką słowa w chwili, gdy wybrzmiała teoria literatury totalnej. W konsekwencji, mogę poszukać odpowiedzi na nurtujące mnie pytanie, dlaczego teoria ta sformułowana została właśnie w takim, a nie innym, momencie. W rozdziale tym skupiam się nie tylko na podobieństwach literatury totalnej i elektronicznej, lecz również kwestii tego, czy pierwsza z wymienionych może zaistnieć w świecie wirtualnym. Stąd jeden z podrozdziałów poświęcam kategorii tzw. e-liberatury.

Książkę zamykają konkluzje zebrane w swoistym zakończeniu zatytułowanym Czytanie Liberatury. Konkluzje, pozwalającym - jak sądzę - pokazać, czemu teoria literatury totalnej zrodziła się akurat na przełomie tysiacleci, będącym tė̇ w istocie domknięciem rozważań dotyczących relacji liberaturaliteratura elektroniczna.

\section{Zaledwie otwarta dyskusja i liberacka przyjemność tekstu}

Choć tytuł niniejszej publikacji zdaje się zapowiadać zamiar powiedzenia wszystkiego, jej monograficzny charakter, kończąc książkę, jestem pewna, że wiele kwestii zostało zaledwie dotkniętych i wymaga dalszych badań oraz dopowiedzeń. Pisząc, z każdym dniem przekonywałam się, że choć teoria literatury totalnej nie ma zbyt długiej historii, ma ją z pewnością każda z teorii, a także każde ze zjawisk artystycznych, na tle których należałoby liberaturę rozpatrywać.

Inspiracją do napisania tej książki była „zwykła” fascynacja, lit/berackie zauroczenie. Impulsem do badania liberackości stała się czysta przyjemność, jaka płynęła z lektury opisywanych tą kategorią tekstów. Zaś zanurzenie się w ten obszar sztuki słowa pokazało mi, że nie wszystkie dzieła liberackie daja 
taką satysfakcję. I słusznie - w istocie liberackości nie ma przecież niczego, co przesądzałoby o tym, że liberatura ma być dobrą literaturac. Choć na pewno warto pokazać, że może nią być.

Niemniej, pozostaje mi żywić nadzieję, że tak, jak dla mnie poszukiwanie kontekstów liberackich było - nazywając rzecz po imieniu - przyjemne, tak i namiastkę owej przyjemności pozostawiłam w tej publikacji. Innymi słowy, mam nadzieję, że mimo większych i mniejszych niedociagnięć, których z pewnością nie udało mi się w trakcie jej pisania uniknąć, będzie ona choć po części tak ciekawym doświadczeniem czytelniczym dla jej odbiorców, jak były dla mnie teksty, które stały się inspiracją do jej napisania. 
CZĘŚŚ I

\section{DEFINIOWANIE LIBERATURY OD LIBERATURY DO LIBERACKOŚCI}





\section{W poszukiwaniu teorii i definicji}

The word is not dead, it is merely changing its skin. Stowo nie jest martwe, ono jedynie zmienia skórę.

Dick Higgins, Aphorisms for Rainy Day

\subsection{LiBeratura ${ }^{1}$ - antidotum na śmieré literatury?}

Dlaczego słowo miałoby być martwe? 30 czerwca 1999 r. na łamach „Dekady Literackiej” ukazał się artykuł Zenona Fajfera przypominający hasła o „wyczerpaniu" literatury i analizujący przyczyny współczesnego kryzysu sztuki słowa. Krakowski autor za główną z nich uznał: „rozdźwięk między strukturą tekstu a materialną strukturą książki i utożsamienie literatury z samym tylko tekstem"2 i - w nieco dyktatorskim tonie - zaproponował sposób rozwiązania problemu. „Jedyna”” - jego zdaniem - możliwością przezwyciężenia kryzysu literatury miało być zrewidowanie teoretycznoliterackich pojęć takich jak: tworzywo, forma, dzieło literackie i książka. Ponowne przyjrzenie się tym terminom miało doprowadzić do nowego ujęcia możliwości literatury, znieść „dogmaty paraliżujące inwencję pisarzy i przyczyniające się do istniejącego stanu rzeczy"4, do martwoty słowa. Miała zaczać powstawać - będąca dla Fajfera odnowieniem i przyszłością literatury - LIBERATURA.

Bo właśnie takim terminem określił on wszelkie rodzaje twórczości literackiej, w której funkcje słowa oraz jego przestrzennego, materialnego czy graficznego ukształtowania sa do siebie zbliżone. $\mathrm{W}$ tak pojętym dziele - jak podkreśla teoretyk - warstwa wizualno-materialna nie ma charakteru interpretacyjnego, ilustracyjnego czy inkrustacyjnego, lecz - składając się na szerzej niż tradycyjnie rozumianą formę - przyczynia się do kreowania znaczeń tekstu, stając się jednocześnie równie istotnym elementem dzieła co same słowa. Zmiana sposobu ich zapisu czy struktury materialno-przestrzennej książki w większości przypadków prowadzi w liberaturze do zmiany sensu utworu lub wręcz uniemożliwia jego odczytanie (zob. ilustracja 1) .

${ }^{1} \mathrm{~W}$ taki sposób w pierwszych tekstach zapisywano ten termin. Z czasem pisownia ujednoliciła się do klasycznej formy liberatura.

2 Zenon Fajfer, Liberatura. Aneks do stownika terminów literackich, „Dekada Literacka” 1999, nr 5-6, s. 8.

${ }^{3}$ Ibidem.

${ }^{4}$ Ibidem.

${ }^{5}$ Przykładem może być tu Ulica Sienkiewicza $w$ Kielcach Radosława Nowakowskiego. W tej dziesięcioipółmetrowej opowieści, po złożeniu wyglądającej niemal niczym „normalna 


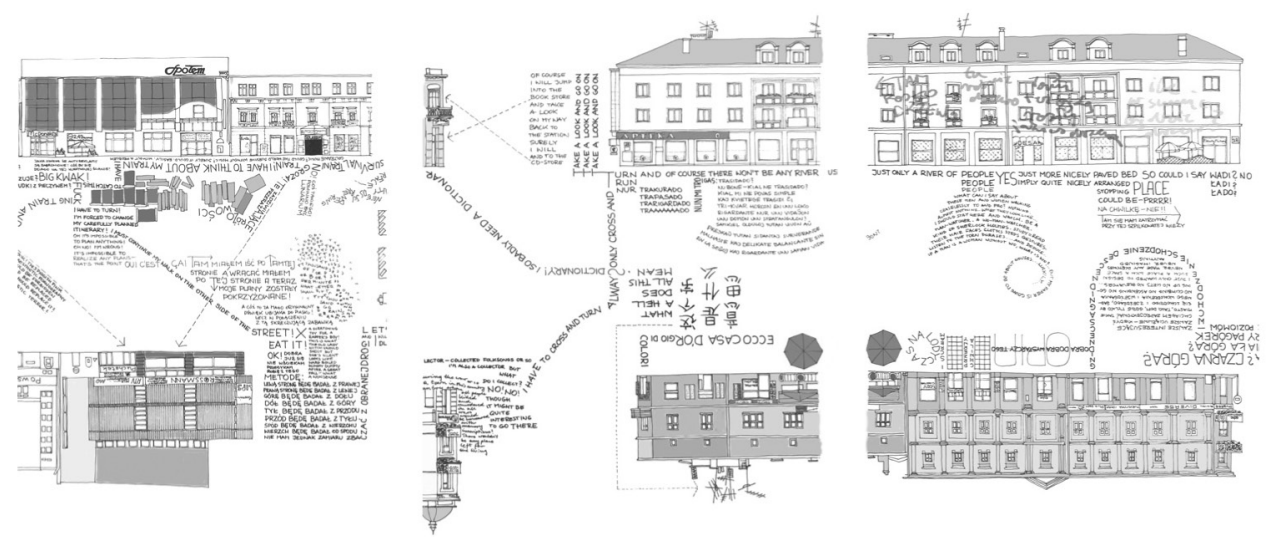

Ilustracja 1. Radosław Nowakowski, Ulica Sienkiewicza w Kielcach, Kielce 2003 (fragmenty) (źródło: zdjęcia własne autora)

Esej Fajfera nie wywołał burzliwych dyskusji w świecie teoretyków i praktyków literatury, jednak wprowadzenie nowej kategorii nie pozostało też bez echa. Termin pojawia się w recenzjach, szkicach krytycznych czy w rozprawach naukowych, po zaledwie trzech latach stał się też częścią tytułu książki wydanej w wydawnictwie Universitas ${ }^{6}$. Jednym z moich celów jest - jak zaznaczałam we Wstępie - próba odpowiedzenia na pytanie, czy wprowadzone przez Fajfera pojęcie rzeczywiście jest użyteczne. By podołać temu zadaniu, zacząć wypada od zreferowania głównych punktów piętnastoletniej już teorii ${ }^{7}$, przyjrzeć się bliżej fundującym ją tekstom, wskazać głównych teoretyków.

książka”, monolog bohatera zapisany jest tak, by unaoczniał tor jego ruchu, swoim kształtem i miejscem w przestrzeni oddając trasę wędrówki. W warstwie werbalnej pełen jest odniesień do elementów świata zewnętrznego przedstawionych w książce poprzez obraz, a do zrozumienia wielu z tych fragmentów kluczowe jest dostrzeżenie przestrzennych relacji między konkretnym fragmentem monologu a innymi (plastycznymi) elementami powieści. Szczególnie liczne zaimki (ten, tamten, tamtędy) byłyby nieczytelne gdyby, zapisawszy tekst inaczej, wyrwać je z (wizualnego) kontekstu. Co więcej - w tym wypadku również typograficzne ukształtowanie monologu jest istotne, gdyż o ile jego kształt w przestrzeni dopowiada informacje o torze ruchu bohatera, charakter użytych czcionek oddaje np. tempo tego ruchu (gdy bohater biegnie litery są bardzo rozciagnięte, gdy zwalnia - zapisane spokojniej). Por. Radosław Nowakowski, Ulica Sienkiewicza $w$ Kielcach, Kielce 2003 (w przypadku większości pozostałych utworów tego artysty - wydawanych przez niego w tzw. książkarni Ogon słonia, później przemianowanej na Liberatorium - data wydania nie daje się jednoznacznie określić: artysta numeruje kolejne egzemplarze produkowane w odstępach czasowych, często na zamówienie konkretnych czytelników; stąd w przypadku tych utworów bądź nie będę podawała daty wydania, bądź też przywołam konkretny egzemplarz).

${ }^{6}$ Od Joyce’a do liberatury. Szkice o architekturze słowa, red. Katarzyna Bazarnik, Kraków 2002.

${ }^{7}$ Pragnę jednak raz jeszcze zaznaczyć, iż głównym punktem odniesienia będzie dla mnie pierwsze dziesięciolecie refleksji liberackiej. 


\section{2. (Dziś już zdystansowany) ojciec, czyli liberatura według Zenona Fajfera}

Z. Fajfer, ojciec polskiej liberatury, opublikował kilkanaście tekstów na jej temat ${ }^{8}$. Trzy z nich - przywołany na samym początku esej Liberatura. Aneks do „Stownika terminów literackich”, dwa lata późniejszy aneks do tegoż aneksu z „FA-artu” [LIBERATURA czyli literatura totalna (Aneks do „Aneksu do Stownika terminów literackich”)] oraz odautorski komentarz Liberum veto? z 2005 r., towarzyszący przedrukowi dwóch w/w tekstów w książce TEKST-TURA. Wokót nowych form tekstu literackiego i tekstu jako dzieła sztuki - łączą się w tryptyk, w obrębie którego sformułowane zostały postulaty stanowiące podstawę Fajferowskiego, a także całego późniejszego dyskursu o liberaturze.

Po pierwsze: teksty te przynoszą definicję liberatury jako „literatury totalnej", a więc takiej, w której autor ukształtował nie tylko każde słowo, sytuację, miejsce i czas akcji czy bohaterów, ale zadbał również o przestrzeń samej książki, sposób graficznego przedstawienia tekstu, wygląd poszczególnych stron (o ile zdecydował się na podział tekstu na strony) czy kodeksu (o ile zaplanował, że książka przyjmie taka właśnie formę). Z całokształtu wypowiedzi Fajfera daje się jednocześnie wyłonić stwierdzenie, iż niektóre z tych elementów mogą pozostać neutralne, lecz owa neutralność również powinna być świadomą decyzją autorską ${ }^{10}$.

Po drugie: z artykułów tych wyłaniają się „nowe” definicje kluczowych dla rozmowy o literaturze i liberaturze terminów. Fajfer, polemizując z ujęciami zaproponowanymi przez Stownik terminów literackich, postulował ponowne opisanie pojęć takich jak tworzywo, forma, dzieło literackie czy książka. Niesiona przez Stownik... definicja pierwszego z wymienionych jest - zdaniem Fajfera - niewystarczająca, gdyż zakłada ograniczenie go wyłącznie do słów traktowanych niczym transparentne futerały na treść. A według krakowskiego

8 Większość publikacji Fajfera znaleźć można w wydanym na dziesięciolecie liberatury dwujęzycznym tomie: Zenon Fajfer, Liberatura czyli literatura totalna. Teksty zebrane $z$ lat 1999-2009/Liberature or total literature. Collected Essays 1999-2009, red. Katarzyna Bazarnik, Kraków 2010 (o ile w tym rozdziale - dla podkreślenia chronologii - przywołuję teksty Fajfera, podając lokalizację pierwodruków, w kolejnych rozdziałach podaję już lokalizację z przywołanego tomu, określając go skrótem LCLT i podając odpowiednie numery stron). Warto też przywołać tu ważniejsze obcojęzyczne publikacje Fajfera: broszurę Liberature, Kraków 2005 (wspólnie z Bazarnik), a także duński przekład głównego manifestu artysty („Den Blå Port” 2008, nr 10).

9 Z czytelnym odwołaniem do dziewiętnastowiecznej kategorii Gesamtkünstwerk.

${ }^{10}$ Co więcej - owa skonwencjonalizowana forma jest ta, której najtrudniej nadać znaczenie. Zob. też Zenon Fajfer, W stronę liberatury, [w:] Ikoniczność znaku. Stowo-przedmiot-obraz-gest, red. Elżbieta Tabakowska, Kraków 2006, s. 161-179. Zaś w Liberatura: hiperksięga w epoce hipertekstu [„Ha!art” 2003, nr 1(14), s. -10--1 (paginacja ujemna) lub przedruk w Liternet.pl, red. Piotr Marecki, Kraków 2003, s. jw.], gdzie autor pisze o tym, że książka liberacka może mieć dowolny kształt, czytamy: „Może, lecz nie musi. Istnieje szereg liberackich czy protoliberackich książek, które mają budowę tradycyjną, kodeksową" (s. -7). 
artysty nie tylko słowo, ale również sposób jego zapisania (czcionka, kolor i kształt tekstu), rozmieszczenie w przestrzeni strony (lub w innej, nawet i rzeczywistej przestrzeni, takiej jak np. miasto), faktura papieru (lub innego materiału, na którym zapisano utwór) moga być tworzywami literatury, składnikami dzieła w dużym stopniu budujaccymi jego sens. Tym samym choć Fajfer nie pisze o tym wprost - neutralnie zapisane słowo przestaje być wyróżnikiem literatury, a podziały między sztukami trzeba zaczaćc budować w oparciu o inne niż dotychczas kryteria.

Przy takim ujęciu forma - „opracowanie tworzywa, jego ukształtowanie”11, jak pisze skrytykowany przez Fajfera Głowiński - staje się mocniej niż zwykle zwiąana z rzeczywistym, przestrzennym kształtem dzieła i jego materialnością. Definiowana na łamach Słownika... jako „ułożone w określony sposób słowa i zdania"12 zaczyna odwoływać do znaczeń budowanych przez samo owo ułożenie, fizyczny kształt słów i zdań ${ }^{13}$.

Czym jest przy takim ujęciu rodzące się na styku formy i treści dzieło literackie? Janusz Sławiński definiował je jako: ,językowy twór sensowny (wypowiedź) spełniający warunki literackości” ${ }^{14}$, odróżniający się od innych dzieł sztuki „poprzez odmienność swojego tworzywa, którym jest język”15. Zdaniem krytykującego takie ujęcie Fajfera pożądane byłoby jednak stworzenie definicji uwzględniajacej inne rodzaje tworzywa niż sam język, gdyż - jak chce artysta - fizyczny kształt i budowa książki nie powinny być sprawą wyłącznie drukarza, introligatora, wydawcy, ani też nie muszą być skutkiem obowiązujących norm. Mogą być częścią składową dzieła literackiego, równie ważną dla budowania znaczenia, jak np. układ rymów.

Fizyczna budowa książki - powiada Fajfer - nie powinna być wynikiem przyjętych konwencji, lecz spowodowana autonomiczną decyzją autora, tak jak perypetie bohaterów czy dobór tego a nie innego słowa. Materialna i duchowa strona dzieła literackiego, czyli książka i wydrukowany w niej tekst, powinny się nawzajem dopełniać, tworzyć harmonię ${ }^{16}$.

Tym samym postuluje Fajfer odrzucenie definicji książki, jaką niesie za sobą Stownik terminów literackich czy nawet zwykły Słownik języka polskiego. Bo książka nie musi wcale być „przedmiotem materialnym w postaci zszytych kartek tworzacych wolumen, zawierajaccy tekst słowny utrwalony w znakach graficznych"17. Pytanie stawiane przez Fajfera brzmi:

11 Słownik terminów literackich, red. Janusz Sławiński, Wrocław 2000, s. 162-163.

12 Ibidem, s. 163.

${ }^{13}$ Warto podkreślić jednak, że wszelkie gry słowno-literowe, wpisywanie w tekst akrostychów, mezostychów itp. to również, zdaniem Fajfera, zabiegi związane z formą. Zatem owo kluczowe dla teorii liberatury pojęcie nie powinno być kojarzone ani wyłącznie z aspektami wizualno-materialnymi utworu, ani tylko z tym, co za formę dzieła literackiego uznaje się najczęściej. Sugerowany przez liberata szerszy zakres terminu nie wyklucza więc jego dotychczasowych znaczeń, lecz je uzupełnia.

14 Stownik..., s. 116.

15 Ibidem, s. 117.

16 Z. Fajfer, Liberatura. Aneks do stownika..., s. 9.

17 Stownik..., s. 266. 
Czy kształt okładki, kształt i kierunek pisma, format, kolor i liczba stron, słów a może nawet liter nie powinny być przedmiotem refleksji twórcy jak każdy inny element jego dzieła, wymagający od niego nie mniejszej inwencji niż dobieranie rymów czy konstruowanie fabuły? ${ }^{18}$

Jeżeli odpowiemy na nie: „tak, kwestie te mogą być przedmiotem refleksji pisarza", okaże się, że książka wcale nie musi być tradycyjnym kodeksem. Może być butelką ${ }^{19}$, przybrać kształt harmonijki (tzw. leporello) ${ }^{20}$ czy nie mieć okładek i składać się z tekstu na luźnych kartkach włożonych do pudełka ${ }^{21}$. Tą drogą Fajfer doszedł do nowej książki:

Książki - jak pisze w jednym z późniejszych tekstów - rozumianej już nie jako zewnętrzny wobec dzieła obojętny futerał na słowa, lecz tegoż integralny składnik ${ }^{22}$.

Jeśli konsekwentnie podążymy za wywodem Fajfera, dzieło literackie okaże się znacznie bliższe książce jako obiektowi (za Butorem ${ }^{23}$ ), a jednocześnie kluczowe staną się kategorie czasu i przestrzeni dzieła. Jednak ujęte nie tak, jak w Stowniku... - jako czas i przestrzeń w dziele literackim, odnoszące się do warstwy semantycznej czy fabuły utworu, ale jako określenia dotyczące tekstu samego w sobie, książki-obiektu, bytu temporalno-przestrzennego ${ }^{24}$. Warto tu dodać, że w późniejszych esejach Fajfera stopniowo to właśnie książka urasta do rangi kluczowego dla liberatury pojęcia ${ }^{25}$. Niezwykle to ciekawy trop interpretacyjny, rozwijać go będę dalej w jednym z rozdziałów.

Trzecim postulatem stawianym przez teksty Fajfera jest uznanie liberatury za czwarty - obok dotychczas wyróżnianych trzech - rodzaj literacki i to właśnie ta teza wydaje się jedną z najbardziej kontrowersyjnych. W opublikowanym w 2006 r. szkicu czytamy:

Stopienie się [słowa - AP] z materią i przestrzenią jest na tyle głębokie, że zasadne staje się pytanie o przynależność gatunkową i status ontologiczny takich [liberackich - AP] utworów. Czy aby przypadkiem nie mamy tu do czynienia z całkiem odrębnym gatunkiem, albo wręcz rodzajem literackim - rodzajem, którego cechą konstytutywną byłaby nierozerwalna więź tekstu ze sfera pozawerbalną książki ${ }^{26}$ ?

${ }^{18}$ Z. Fajfer, Liberatura. Aneks do stownika..., s. 9.

${ }^{19}$ Idem, Spogladajac przez ozonowq dziurę, Kraków 2004, 2009.

${ }^{20}$ Radosław Nowakowski, Nieopisanie świata, część III.

${ }^{21}$ Idem, Nieposktadana Teoria Sztuki czy Bryan S. Johnson, Nieszczęśni, Kraków 2008 (warto jednak mieć na uwadze, że nie jedyne to przykłady).

${ }^{22}$ Z. Fajfer, $W$ stronę liberatury, s. 162.

${ }^{23} \mathrm{O}$ Butorowskich prze-czuciach liberatury pisała Katarzyna Bazarnik w szkicu „Ksią̇ka jako przedmiot" Michela Butora czyli o liberaturze przed liberatura, [w:] Od Joyce'a do liberatury, s. 171-194.

${ }^{24}$ Bo liberatura na tle Lessingowskiego podziału sztuk sytuuje się - zdaniem Fajfera „pomiędzy”, jest „literaturą czasoprzestrzenną” (Zenon Fajfer, Nie(o)pisanie liberatury, „Ha!art” 2003, nr 2(15), bez numeracji stron).

${ }^{25} \mathrm{Z}$ kolei u Bazarnik od początku właśnie materialność książki wydaje się najistotniejsza.

${ }^{26}$ Z. Fajfer, $W$ stronę liberatury, s. 162. 
Podobnie, jeszcze w 2003 r., pisał Fajfer o:

liberaturze jako odrębnym rodzaju literackim. Rodzaju, w którym oprócz tekstu nośnikami znaczenia są także elementy graficzne i fizyczna przestrzeń książki²7.

Postulat ten Fajfer to zarzuca, to znów broni go z pełnym przekonaniem. Jednak w Liberum veto? (a także w późniejszych tekstach) stara się rozwinaćc tezę postawioną już w pierwszym manifeście. Twierdzi, że jego korekta opisu literatury sięga głębiej niż to dotychczas opisałam, a

istotną nowością było nie tyle zwrócenie uwagi na aspekt przestrzenny i materialny w dziele literackim, na rolę pisma i książki (robiono to już przede mna), lecz raczej stwierdzenie, iż owo zrośnięcie się słowa z materią i przestrzenią jest faktem na tyle doniosłym, że wymaga skorygowania kanonicznego trójpodziału rodzajów literackich i uznania liberatury za rodzaj czwarty $^{28}$.

Stąd mniemam, iż mimo pewnych niekonsekwencji w jej podtrzymywaniu, można i należy przyjać tezę o istnieniu kolejnego rodzaju literackiego za jedna z ważniejszych dla wywodu Fajfera. I warto przeanalizować, jak rozwijała się ona w czasie. W 1999 r. Fajfer nieśmiało postuluje „wyjście kompromisowe" ${ }^{29}$ :

Uznanie, że obok trzech dotychczas znanych rodzajów literackich - epiki, liryki i dramatu (podział nie wyczerpujacy do końca całego bogactwa literatury), istnieje jeszcze czwarty 'liberyka', do którego odnosiłoby się wszystko to, co powiedziane zostało wyżej [tezy przytoczone na początku tego rozdziału - AP] ${ }^{30}$.

${ }^{27}$ Idem, Nie(o)pisanie liberatury, bez numeracji stron. Co ciekawe, w poprzednim numerze czasopisma czytamy z kolei: „[liberatura - AP] jest to nie tyle nowy prąd czy styl, lecz bardziej sposób myślenia: o słowie, o literaturze, o książce, z uwzględnieniem ich cech fizycznych, na ogół ignorowanych przez czytelników, pisarzy i krytyków. Dlatego liberatura jest różnorodna i obejmuje utwory gatunkowo i czasowo odległe od siebie" (Zenon Fajfer, Liberatura: hiperksięga $w$ epoce hipertekstu, s. -5), podkreślenie moje. Zwrócenie uwagi na ową różnorodność gatunkowa jest jedyną wypowiedzią odnoszącą nas ku genologii, a w całym artykule liberatura jawi się właśnie jako „sposób myślenia” czy nurt od dawna istniejący w literaturze.

${ }^{28}$ Zenon Fajfer, Liberum veto?, [w:] TEKST-TURA. Wokót nowych form tekstu literackiego $i$ tekstu jako dzieta sztuki, red. Małgorzata Dawidek Gryglicka, Kraków 2005, s. 18. Warto może dodać, iż wśród krytyków zajmujących się „nowymi” postaciami literatury próby wskazywania na czwarty rodzaj są częste - Mariusz Pisarski np. upatrywał go w cybertekście (pojęcie zaczerpnięte od Espena Aarsetha). „Epika, liryka, dramat, cybertekst. Czy tak będzie wyglądała wkrótce lekcja polskiego na temat rodzajów literackich?" - pytał młody badacz w tekście Kartografowie i kompilatorzy. Pót żartem, pót serio o praktyce i teorii hiperfikcji w Polsce ([w:] Liternet.pl, s. 22).

${ }^{29}$ Z. Fajfer, Liberatura. Aneks do stownika..., s. 9.

${ }^{30}$ Ibidem. Podobny charakter maja wypowiedzi zawarte w artykule liberatura ([w:] Od Joyce'a do liberatury, s. 233-239), paradoksalnie mimo tytułu nieprzynoszacym - w przeciwieństwie do wielu pozostałych - ujęcia liberatury jako czwartego rodzaju: „Można się spierać, jaki jest status liberatury. Czy to jest sposób zapisu tekstu, czy też coś więcej? Czy istnieje coś takiego jak liberacka proza, poezja i dramat, czy raczej należałoby uznać liberaturę za odrębny rodzaj literacki, w dodatku od dawna istniejący? [...] Zostawiam to teoretykom. Jako praktyka, zdecydowanie bardziej frapują mnie perspektywy czysto artystyczne" (Ibidem, s. 237). 
Jeśli do liberyki (czy jak później, ze względu na brzmienie terminu, poprawił Fajfer - liberatury) jako rodzaju literackiego mielibyśmy odnieść owo „wszystko, co powiedziane zostało wyżej”, jego wyznaczniki byłyby następujące:

1. Stosunek do tworzywa literatury - uznanie za nie nie tylko języka;

2. Stosunek do formy (dzieła literackiego) - uznanie za nią również fizycznego kształtu słów i zdań oraz fizycznego kształtu i budowy książki;

3. Stosunek do przestrzeni w dziele literackim - dostrzeżenie znaczenia przestrzeni samego dzieła;

4. Stosunek do czasu w dziele literackim - uwzględnienie czasu lektury jako jakości ważnej dla znaczenia tekstu.

Tu, dla prześledzenia logiki wywodu, należałoby oprzeć się na definicji rodzaju literackiego, a przede wszystkim jego wyróżników, zaczerpniętej z tego samego źródła, po jakie sięgnął Fajfer, ze Stownika terminów literackich. Okazuje się jednak, że te odtworzone $\mathrm{z}$ wywodu polskiego liberata nie mają nic wspólnego z tymi, które wyróżnia Sławiński ${ }^{31}$. A jednak, kiedy w 2005 r. Fajfer próbuje rozwinąć swoją koncepcję i stara się - odwołując się do kryteriów stosowanych w europejskim literaturoznawstwie - opisać cechy „rodzajowe” liberatury, twierdzi, że sięga właśnie po wyróżniki wskazane przez przywołanego badacza. Tym samym pisze:

ad 1. [Sposób uzewnętrzniania się podmiotu literackiego w obrębie utworu - AP] ze względu na całkowita dowolność gatunkową tekstu w dziele liberackim, należałoby stwierdzić, że podmiot literacki może się ujawniać na każdy z [...] wymienionych sposobów;

ad 2. [Budowa świata przedstawionego (kompozycja) - AP] ze względu na jedność tekstu i przestrzeni zapisu, za inherentną część świata przedstawionego należałoby uznać świat przedstawiający: ksiażkę, a w przypadku krótszych utworów np. powierzchnię kartki;

ad 3. [Budowa językowo-stylistyczna dzieła - AP] podobnie jak w punkcie 1. - styl dzieła może być najzupełniej dowolny, natomiast istotne są także cechy pisma czy materialnego podłoża; w konsekwencji: analizując utwór liberacki, oprócz sfery werbalnej, należałoby uwzględniać także układ typograficzny i budowę tomu ${ }^{32}$.

Jak widać, Fajfer - wbrew zapowiedziom - nie odniósł się do wyróżników proponowanych w Stowniku... ${ }^{33}$ lub odniósł się do nich niezwykle nieporadnie. Kryterium sposobu uzewnętrzniania się podmiotu literackiego uznano za pomocne i właściwe właśnie dlatego, że w każdym z rodzajów przejawia się on inaczej (cytujac, paradoksalnie, za Fajferem: „w liryce jest to podmiot

31 Dla porządku przypomnę, iż są to: sposób uzewnętrzniania się podmiotu literackiego, budowa świata przedstawionego i językowo-stylistyczna budowa dzieła; zob. Stownik..., hasło 'rodzaj literacki', s. 475.

${ }^{32}$ Z. Fajfer, Liberum veto?, s. 19.

${ }_{33}$ Te zresztą są propozycją dwudziestowieczna, wyróżników tych w dziejach teorii literatury proponowano przecież wiele (zob.: Teresa Michałowska, Rodzaje czy rodzaj? Problemy taksonomii literackiej, [w:] Problemy teorii literatury, red. Henryk Markiewicz, seria 4, Wrocław 1998). Chciałabym zaznaczyć, że temat genologicznej koncepcji liberatury podchwytuje i rozwija Katarzyna Bazarnik. Stąd szersze komentarze tych kwestii oraz obszerniejszą bibliografię zagadnienia (z uwzględnieniem nowszych niż dotychczas przywoływane koncepcji) podaję w podrozdziale poświęconym teorii literatury totalnej w ujęciu tej badaczki. 
liryczny, w epice narrator, natomiast dramat nadrzędnego podmiotu nie posiada" ${ }^{34}$ ). Mówiąc, że w liberaturze może być i tak, i tak, i tak, teoretyk-artysta wprowadza niepotrzebny bałagan. Próba dodania do istniejącego już podziału kolejnego elementu, w którym cecha dystynktywna przestaje być takowa, tylko ten podział zaciemnia. Jeżeli autor Aneksu do „Stownika terminów literackich" chce określić liberaturę jako czwarty rodzaj, dodany do dotychczas wyróżnianych trzech, powinien pokazać, że w jej przypadku mamy do czynienia z jeszcze innym sposobem uzewnętrznienia się podmiotu. Liberat zaś nie dość, że czyni przeciwnie, przekreśla (nie wyrażając tego wprost) trójpodział, który próbuje uzupełnić. Pisząc o „całkowitej dowolności gatunkowej" dzieł liberackich, ignoruje fakt, iż obok aksjomatu o trójpodzielności rodzajowej przyjęty jest w europejskim literaturoznawstwie również aksjomat o hierarchiczności układu genus-spiecies-individuum i co za tym idzie, że poszczególnym rodzajom przypisane są konkretne gatunki ${ }^{35}$. W ujęciu Fajfera zaś, liberatura nie obejmie jako czwarty rodzaj literacki innych gatunków niż liryka, epika czy dramat, lecz wszystkie, które dotychczas dzielono między tamte trzy. Nie jawi się zatem jako rodzaj dodatkowy, lecz jako coś, co jest ponad podziałami.

Dalsze wywody Fajfera uzmysławiaja, jak nieporadnie (bądź tendencyjnie) żongluje on terminami, po które sięga. Odnosząc się do drugiego z wyróżnionych przez Sławińskiego kryteriów, a więc kompozycji świata przedstawionego, krzeszowicki liberat pisze wyłącznie o tym, że warstwa materialna dzieła (świat przedstawiajacy) powinna być uznana za element świata przedstawionego. Jeśli przyjąć wcześniejsze poprawki Fajfera, korekta ta wydaje się logiczna. W słownikowej definicji świata przedstawionego wystarczy do słów „całokształt zaprezentowanych $\mathrm{w}$ nim [w utworze - AP] zjawisk [...], będacy przedmiotowym korelatem semantycznej warstwy wypowiedzi literackiej: sfera fikcyjnych desygnatów konstytuowana przez znaczenia słów, zdań i większych odcinków tekstu” ${ }^{36}$ dodać „oraz ich przestrzenne i materialne ukształtowanie”. Cały problem polega jednak na tym, że w ujęciu Sławińskiego, kluczowym słowem jest „kompozycja”, a o niej Fajfer, omawiając liberaturę, nie wspomina. Zaznacza, że w przypadku liryki mamy do czynienia z afabularnościa, w epice - z fabuła, $\mathrm{w}$ dramacie - z akcja, pozornie uwzględniając, że owa kompozycja to:

budowa świata przedstawionego dzieła, układ i powiązanie jego elementów, sieć wzajemnych relacji między motywami oraz stosunków łączących poszczególne motywy z całościowym schematem konstrukcyjnym ${ }^{37}$.

Jednak mówiąc o domniemanym czwartym rodzaju, liberat nie wspomina o sposobach wiązania materiału tematycznego (ani żadnego innego). Nic w tym zresztą dziwnego - gdyż jeśli liberackie mogą być dzieła wszelkich gatunków,

\footnotetext{
${ }^{34}$ Z. Fajfer, Liberum veto?, s. 19.

35 T. Michałowska, Rodzaje czy rodzaj?...

36 Stownik..., hasło 'świat przedstawiony', s. 565.

${ }^{37}$ Ibidem, hasło 'kompozycja', s. 254.
} 
zbudowane w nich relacje kompozycyjne dadzą się objać formułami, których używamy do opisu liryki, epiki czy dramatu. Co za tym idzie - liberatura i pod tym względem nie różni się od trzech dotychczas opisywanych rodzajów, nie tworzy nowej kategorii.

$\mathrm{Z}$ podobną sytuacją - tzn. mówiąc wprost, z tym, że próbując mówić o jednym, mówi Fajfer o czymś zupełnie innym - mamy do czynienia w jego „ad 3”, gdzie znów powtarza swoje tezy o wadze aspektów materialnych dla interpretacji dzieła. W konsekwencji z jednej strony wyróżnia (za Stownikiem...) monolog liryczny, narrację lub dialog jako właściwą dla poszczególnych rodzajów budowę językowo-stylistyczna, z drugiej - twierdzi, że styl dzieła liberackiego „może być najzupełniej dowolny” ${ }^{38}$. Po raz kolejny wyróżnik, na jaki się autor powołuje, nie jest cechą dystynktywną dla postulowanego czwartego rodzaju.

A można by na problem spojrzeć inaczej. W 2005 r. Fajfer, nawołując w swoim Liberum veto? do wyróżnienia czwartego rodzaju literackiego, stwierdzał:

Życzę teoretykom literatury: aby pogodzili się z istnieniem dzieł wykraczajacych poza sferę słowa mówionego czy pisanego i zmierzyli z przestrzenią, w której słowo to egzystuje i która do owego słowa należy ${ }^{39}$.

Czy rzeczywiście owi teoretycy pozostają spętani spojrzeniem niedostrzegającym kwestii, o których mówi Fajfer? Pozwolę sobie zareplikować autorowi rok wcześniejszą (lecz publikowaną już też w 2005 r.) wypowiedzią Seweryny Wysłouch:

Podział na rodzaje literackie wydaje się całkowicie niesatysfakcjonujący i beznadziejnie przestarzały. Tradycyjne wyróżniki: konstrukcja podmiotu wypowiedzi, formy podawcze, fabuła, konstrukcja czasu - nie przystają do współczesnej produkcji literackiej, w świetle której epika okazuje się nieepicka, liryka - nieliryczna, a dramat - niedramatyczny. Cechy przypisywane liryce - wyrazista kreacja podmiotu lirycznego i bezpośredni monolog liryczny - nie pasują ani do poezji oświeceniowej, ani do awangardy krakowskiej. W strukturze epiki, charakteryzowanej za pomocą takich wyznaczników jak pośredniość przedstawienia, duży dystans czasowy, przezroczysty język - mieści się tylko dziewiętnastowieczna narracja auktorialna, ale nie mieszczą się ani formy starsze (np. powieść XVIII wieku czy gawęda), ani nowsze (jak powieść strumienia świadomości czy gatunki afabularne). Podobnie z dramatem, który rezygnuje z wielopodmiotowości, dialogu, akcji ${ }^{40}$.

W tym samym szkicu Wysłouch zwraca uwagę na przesunięcie, jakie miało miejsce we współczesnej genologii - większe zainteresowanie „peryferiami”: tym co multimedialne i nieliterackie. Sytuacja ta - jak słusznie podsumowuje badaczka - wymaga przemyślenia stosowanych dotychczas narzędzi badawczych, gdyż muszą one teraz „uwzględnić specyfikę mediów i różnice

38 Z. Fajfer, Liberum veto?, s. 19.

${ }^{39}$ Ibidem.

${ }^{40}$ Seweryna Wysłouch, Nowa genologia - rewizje i reinterpretacje, [w:] Polonistyka w przebudowie, red. Małgorzata Czermińska i in., t. I, Kraków 2005, s. 107. 
tworzywa" ${ }^{41}$. Przysłowiowym dolaniem oliwy do ognia byłoby tu pewnie przypomnienie, że Wysłouch (odwołując się zresztą i do dawno już te kwestie poruszającej Maryli Hopfinger) podkreśla także, że w obliczu nowej, multimedialnej kultury odejść musimy też od takich definicji tekstu, które wykluczaja z komunikatu (też literackiego) inne niż słowo tworzywa ${ }^{42}$. Odpowiadając na pytanie, jaka perspektywa potrzebna jest do mówienia o współczesnej sztuce i literaturze, badaczka przyznaje, że wskazana byłaby:

Rezygnacja z lingwistycznej definicji tekstu jako sekwencji zdań stanowiącej względnie autonomiczną całość znakową i przyjęcie definicji kulturowej, która pozwala uznać za teksty komunikaty różnotworzywowe, słowno-plastyczne czy słowno-muzyczne, funkcjonujące i dialogujące w danej kulturze ${ }^{43}$.

Trzeba pamiętać, że czas, w którym „ojciec liberatury” głosił swoją, wielką liberacką rewolucję genologiczną", przypadł na okres, w którym genologiczne kwestie były już nieźle w polskiej humanistyce przepracowane. Dość przypomnieć, że druk Liberum veto? wypada już po opublikowaniu choćby Genologii multimedialnej Edwarda Balcerzana czy Zagłady gatunków Stanisława Balbusa ${ }^{44}$, a nawet po pierwszych sugestiach, by w teorii literatury wykorzystać lingwistykę kognitywna, a w szczególności zaczerpniętą z niej kategorię prototypu (w 2001 r. Bożena Witosz proponowała, by gatunek literacki uznać za prototyp ${ }^{45}$ ). Sądzę, że „grzech” Fajfera polega nie tylko na tym, że nieudolnie odnosił się do rodzajowych wyznaczników, jakie przyjął za Słownikiem terminów literackich, lecz i na tym, że wybrał dziwaczny punkt odniesienia.

Jeśli bowiem korekta - jak mówi - wprowadzona do humanistyki literówka, korekta zakładająca rewizję rozmaitych pojęć kluczowych dla dyskusji humanistycznych, miałaby być zasadna, odnosić należałoby się do terminów istotnie w dyskursie funkcjonujących. Mówiąc wprost - przymierzanie się do walki ze współczesną genologią przy odniesieniu się wyłącznie do Słownika terminów... jest jak przysłowiowe wyważanie otwartych drzwi. Już sensowniej byłoby pytać o to, czy liberatura nie jest szczególną postacią Balcerzanowskiego gatunku polimedialnego, przykładem słuszności tez badacza o potrzebie stworzenia Nowej Genologii (jak by jej nie nazywał), bądź innym niż Piesek

${ }^{41}$ Ibidem, s. 110.

${ }^{42} \mathrm{O}$ tym, że wcześniejsze ujęcia literackiej komunikacji uwzględniają raczej wyłącznie słowo jako jej tworzywo (czy kod) piszę szerzej w rozdziale poświęconym relacji liberatury i książki.

${ }^{43}$ S. Wysłouch, Nowa genologia..., s. 110.

${ }^{44}$ Oba teksty przedrukowane w: Genologia dzisiaj, red. Włodzimierz Bolecki, Ireneusz Opacki, Katowice 2000, a następnie w: Polska genologia literacka, red. Danuta Ostaszewska, Romuald Cudak, Warszawa 2007. Warto jednak dodać, że pierwodruk artykułów w „Tekstach Drugich” przypada na pamiętny dla liberatury rok 1999 (nr 6).

${ }^{45}$ Por. Bożena Witosz, Gatunek - sporny (?) problem wspótczesnej refleksji tekstologicznej, „Teksty Drugie” 2001, nr 5, przedruk w: Sporne i bezsporne problemy współczesnej wiedzy o literaturze, red. Włodzimierz Bolecki, Ryszard Nycz, Warszawa 2002. O liberaturze z punktu widzenia prototypów będzie w 2010 r. pisała Bazarnik, do czego wrócę w dalszej części rozdziału. 
przydrożny Miłosza egzemplum określania swoich dzieł kategorią ksiażki jako wygodnym „uniwersalnym i pozagenologicznym” terminem ${ }^{46}$.

Podsumowując - nie udało się Fajferowi obronić tezy, jakoby istniały podstawy dla uznania liberatury za kolejny rodzaj literacki, choć twierdził on, iż bez trudu można tę słownikową kategorię rozszerzyćc ${ }^{47}$. Nie powiodło się pokazanie, że liberatura różni się od liryki, epiki i dramatu. Genialnie zaś (choć, jak sądzę, zupełnie niezamierzenie) wykazał Fajfer, że stoi ona ponad tym podziałem. Podkreślając, że istniejące ujęcia i próby kategoryzacji dzieł sztuki nie obejmują wszystkich możliwości i że być może należy z tego powodu od nich odejść, przywoływał przykład opery i ballady jako typów sztuki „nieczystych”, „hybrydycznych”. Zapominał jednak o tym, że to, co jest ich gatunkowym wyróżnikiem to właśnie synkretyzm. Że podział (istniejący) jest im potrzeby po to, by się od niego odbić, by mogły być właśnie tym, co ponad nim. Wreszcie - że sam Stownik... wspomina o gatunkach pogranicznych i, że od dłuższego czasu nie są już one problemem dla teoretyków. Przywoływana tu Wysłouch słusznie przekonywała:

Gatunek stanowi najbliższy kontekst utworu, a zarazem jest niezbędny w interpretacji dzieła literackiego. Dzięki konfrontacji dzieła z wzorcem gatunkowym identyfikujemy elementy konwencjonalne, ale możemy także ukazać odejście od konwencji i wszelkie autorskie innowacje ${ }^{48}$.

Schemat trychotomiczny obecny jest w europejskiej humanistycznej refleksji właściwie od starożytności ${ }^{49}$ (choć, jak twierdzi Teresa Michałowska, „trwałość wykazywała jego rama, podczas gdy nazwy i definicje pojęć rodzajowych, a także zestawy podporządkowanych im gatunków przejawiały dużą płynność" $\left.{ }^{50}\right)$. Ma znaczenie przede wszystkim porządkujące, jest - że tym razem ja pozwolę sobie zacytować tak często tu przywoływany Stownik...: „el e m e n t a r n y m poziomem stosowanych powszechnie klasyfikacji” ${ }^{51}$. Jeśli nie zburzyły go kłótnie między obozem zwolenników rodzaju literackiego i jego przeciwników zapoczątkowane badaniami Stefanii Skwarczyńskiej oraz inne, równie burzliwe dyskusje genologów (choćby ta z przełomu tysiącleci, z która

${ }^{46}$ Por. Edward Balcerzan, Nowe formy w pisarstwie $i$ wynikajace stad porozumienia, [w:] Polska genologia literacka, red. D. Ostaszewska, R. Cudak, s. 262. Zob. też idem, W stronę genologii multimedialnej, [w:] ibidem, s. 269-287. Warto też dodać - skoro już sygnalizowałam, że problem genologicznej sytuacji liberatury podejmie też Katarzyna Bazarnik - że w zamykającym pierwsza dekadę liberatury szkicu przypomina ona problemy z genologicznym zakwalifikowaniem dzieł (powieści?) Joyce’a i podkreśla, iż sam pisarz uznał, że właśnie kategoria książki jest tu lepszym ich określeniem niż dowolny termin genologiczny (badaczka stwierdza: „napisałem książkę - powiedział - a teraz niech krytycy przez kolejne trzysta lat martwia się, jaki to gatunek", Katarzyna Bazarnik, Liberatura czyli o powstawaniu gatunków (literackich), [w:] LCLT, s. 152).

47 Z. Fajfer, Liberum veto?, s. 19.

48 S. Wysłouch, Nowa genologia..., s. 97. Rozwijając to spostrzeżenie w kontekście liberatury, można by wręcz powiedzieć, że gdyby nieistniejące konwencje, od których się może odcinać - i ona nie dałaby się w ogóle dostrzec.

49 T. Michałowska, Rodzaje czy rodzaj?..., s. 249.

50 Ibidem.

51 Stownik..., hasło 'rodzaj literacki’, s. 475, podkreślenie moje. 
związana jest większość przywoływanych tu szkiców, dyskusja określana przez Romana Cudaka poststrukturalistyczną rewolta, genologia w przebudo$w i e)^{52}$, nie widzę powodu, by miała go znieść liberatura. Co więcej, sądzę, że nie genologiczna odrębność stanowi o wyjątkowości tego zjawiska i nie podzielam poglądu Fajfera i Bazarnik, by warto ten temat drążyć. Jestem przekonana, że jakości związane z liberackością dzieła wpisują się w inny, ważniejszy dla interpretacji utworów porządek niż tylko genologiczny, o czym - mam nadzieję - uda mi się czytelników tej książki przekonać.

Tu należałoby przywołać również felieton Liberatura - 496 stów podsumowania, opublikowany w tomie Liberatura czyli literatura totalna ${ }^{53}$ jako rodzaj teoretycznego domknięcia pierwszej dekady liberackiej. W nim to Fajfer stwierdza, że jego walka z genologią była być może nieopatrzna.

Pewnie byłbym teraz ostrożniejszy - pisze z perspektywy dziesięciu a nie sześciu lat. - Może nie ubierałbym liberatury w jakieś „czwarte rodzaje”, bo w ogóle nie widzę już sensu wyróżniania takich trójkolorowych podziałów ${ }^{54}$.

Warto jednak mieć na uwadze i to, że na następnej stronie znajdziemy szkic Katarzyny Bazarnik, rozwijajacy genologiczną teorię literatury totalnej. Zaś w swoim podsumowaniu Fajfer podkreśla, że to ta badaczka właśnie „wprowadza liberaturę na grunt akademicki”55, który - nie ma co ukrywać jest znacznie lepszą niż artystyczne manifesty przestrzenią do podejmowania teoretycznych dyskusji.

Na zakończenie warto możne wspomnieć o jeszcze jednym elemencie wyłaniającym się z wywodów Fajfera, takim, który najbardziej ewoluował na przestrzeni lat i którego przemiana jest ponadto dowodem okrzepnięcia myśli liberackiej. Jak zaznaczałam we wstępie do tego rozdziału - dla Fajfera liberatura początkowo miała być takim rodzajem twórczości literackiej, który przywróci sztuce słowa jej prawdziwa wielkość, zażegna kryzys literatury. Stąd artysta-teoretyk buńczucznie rozkazywał innym pisarzom, otwarcie formułował swoje oczekiwania w stosunku do nich i nawoływał do „poprawy”. W (poświęconych redefinicjom kluczowych pojęć teorii literatury) fragmentach pierwszych tekstów Fajfera czytamy, iż „pisarz m u s i sobie wreszcie uświadomić, że są to zbyt ważne sprawy, aby beztrosko powierzać je innym" ${ }^{56}$, że

jego obowiązkiem [...] jest uwzględnienie w procesie twórczym fizycznego wyglądu książki i wszystkich związanych z tym czynników, na równi z tekstem (a nawet jeśli nie na równi, to przynajmniej powinien te sprawy uwzględniać) ${ }^{57}$.

${ }^{52}$ O rozwoju polskiej myśli genologicznej zob. Romuald Cudak, Rzut oka na polska genologie literacka, [w:] Polska genologia literacka, s. 13-44.

${ }^{53} L C L T$, s. 148-149. Szkic dostępny jest również na portalu Korporacji „Ha!art”, http://ha.art. pl/felietony/947-zenon-fajfer-liberatura--496-slow-podsumowania.html [dostęp 30.09.2011].

54 Z. Fajfer, Liberatura - 496 stów podsumowania, s. 149.

${ }^{55}$ Ibidem, s. 148.

${ }^{56}$ Z. Fajfer, Liberatura. Aneks do stownika..., s. 9, podkreślenie moje.

${ }^{57}$ Ibidem, podkreślenie moje. 
Fajfer „oczekiwał” od innych artystów sztuki słowa podobnego jak własne traktowania przestrzeni tekstu ${ }^{58}$, a tych, którzy śmieli czynić inaczej, surowo oceniał:

Dlaczego więc literaci nie decydują się na ten krok? Inercja i siła przyzwyczajenia ${ }^{59}$.

Jeszcze w 2001 r., kierowany chęcią ganienia nie-liberatów, przywołując pomysł przedrukowania znanego tekstu inna czcionka (by pokazać, jak zmieni to znaczenie tekstu), użył nie do końca chyba przemyślanego przykładu:

A Ty, Drogi Czytelniku, który nie możesz powstrzymać swego ironicznego uśmiechu, wiedz, że doskonale zdaję sobie sprawę z pułapek wynikających z takiego rozumowania. Ja również nie uznałbym Pana Tadeusza drukowanego pismem bezszeryfowym za coś różnego od Pana Tadeusza drukowanego antykwą. To się odnosi wyłącznie do tekstów tych pisarzy, dzięki którym posługiwanie się terminem literatura [...] ma jeszcze jakiś sens ${ }^{60}$.

Z czasem praktyk i teoretyk liberatury zgodził się, że liberatura jest częścią literatury i przyzwolił na powstawanie dzieł „klasycznych”, odwołując większość swych buńczucznych żądań, nagan i poleceń. Sam też krytycznie ocenił rolę swojego założycielskiego dla teorii liberatury tekstu. W Liberum veto? czytamy bowiem:

Dystansu nabrałem [...] do drugiego, zanadto dydaktycznego aspektu [...] eseju-m a $\mathrm{n}$ if e s t $\mathrm{u}$ z 1999 roku. Mam na myśli skierowany już nie do teoretyków, lecz do samych pisarzy, kategoryczny w tonie postulat czy wręcz apel oświadome uprawianie liberatury. Z perspektywy sześciu lat oceniajacc, jest to $\mathrm{n}$ ajs $\mathrm{j}$ abs z y p unkt zarysowanego tam programu, grzeszący naiwnością i iście misjonarskim zapałem. Niech każdy swoje, pisze, jak umie. Byle pisał dobrze, a czy to jest liberackie czy nie, nie ma większego znaczenia. Pociesza mnie tylko fakt, że większość manifestów w historii sztuki grzeszy tym samym ${ }^{61}$.

\section{3. (Niepoważny), „przyszywany” wujek, czyli liberatura według Radosława Nowakowskiego}

Fajferowski termin podchwycony został przede wszystkim przez dwójkę humanistów - Katarzynę Bazarnik, żonę artysty, współautorkę części jego tekstów teoretycznych i artystycznych, oraz Radosława Nowakowskiego - do 1999 r. uznawanego za twórcę książki artystycznej, po tej zaś dacie również za jednego z praktyków i teoretyków liberatury. Warto dodać, że cała trójka to współorganizatorzy Wystawy Książek Niekonwencjonalnych, z która - jak wskazywałam - wypada łączyć narodziny teorii liberackiej. Ostatni z wymienionych
58 Ibidem.
${ }^{59}$ Ibidem.
${ }^{60}$ Ibidem, s. 10.
${ }^{61}$ Z. Fajfer, Liberum veto?, s. 22, podkreślenia moje. 
to autor Traktatu kartkograficznego czyli rzeczy o liberaturze $e^{62}$, przez lata (do wydania Liberatury czyli literatury totalnej) jedynej pozycji książkowej w całości poświęconej omawianemu tu zagadnieniu ${ }^{63}$.

Nowakowski wydaje się jednym z najbardziej płodnych polskich liberatów, choć jego dzieła najczęściej można obejrzeć na wystawach książek artystycznych czy w muzeach je kolekcjonujacych ${ }^{64}$. Jedynie wspominana tu już Ulica Sienkiewicza wielcach oraz powieść hipertekstowa Koniec świata wedtug Emeryka (przywoływana tu, bo okrzyknięto ja e-liberatura) doczekały się wydania w większym nakładzie (pierwsza pozycja w kieleckim BWA, druga w Ha!arcie). Pozostałe, ręcznie robione przez artystę w niewielkiej liczbie egzemplarzy (często na zamówienie konkretnych czytelników), w różnych wariantach (z okładkami papierowymi i sztywniejszymi, bardziej lub mniej poręczne) nierzadko sprzedawane są do kolekcji książek artystycznych i raczej jako takie właśnie funkcjonują w obiegu ${ }^{65}$.

Wydaje się też, że o ile Fajfer - choć stwierdzał, że może i powinien zostawić teoretyzowanie o liberaturze teoretykom - intensywnie włączał się do dyskusji, Nowakowski zachowywał dystans i skupiał się przede wszystkim na działalności artystycznej. Szkice o charakterze teoretycznym, owszem, pisywał, nie domagał się jednak, by jego wizja liberatury stała się tą jedyną obowiąujaccą ${ }^{66}$. Wydał około dwudziestu utworów dajacych się postrzegać jako liberackie, ale nigdy nie upierał się, by tak o nich mówiono. A jednak - podobnie jak Fajfer - przekonany był, że odbiegają one od wszystkich okołoksiążkowych i okołoliterackich form, jakie je otaczaja.

Lata temu, wydawcy byli zdziwieni i przestraszeni - pisał. - Chcieli tylko słów [...] Wiele lat minęło, a oni nadal boją się i są zdziwieni i chcą tylko słów. Myślą, że poważna książka dla poważnych dorosłych może mieć w środku tylko poważne czarne litery na poważnym białym papierze. (Czy Księga z Kells była wariacką książką dla świrów?) ...... Czy moje książki są pięknie drukowane? Nie używam przecież ręcznej prasy. Czy są to tak zwane książki artystyczne? Nie, jest w nich zbyt dużo do czytania, zbyt dużo opowieści, zbyt długie historie, zbyt bliskie są one literatury. Czy są to normalne książki? Nie, zbyt daleko

${ }^{62}$ R. Nowakowski, Traktat kartkograficzny czyli rzecz o liberaturze, korzystałam z egzemplarza broszurowego numer czternaście (Bodzentyn 2002). Fragmenty tej książki publikowane były w „Ha!arcie!” (2003, nr 1 (14), s. -23--16, paginacja ujemna). Warto jednak zwrócić uwagę, że utrzymany w odcieniach szarości przedruk nie powiela wszystkich sensów pierwowzoru i aż dziw, że Nowakowskiemu to nie przeszkadzało. W Traktacie... wszelkie znajdujące się obok głównego tekstu komentarze (rodzaj rozmaicie umieszczanych w przestrzeni strony przypisów) zapisane sa czerwoną czcionka. Sam zaś tom oprawiony jest w czerwoną okładkę, dzięki czemu daje się interpretować jako jeden wielki przypis - komentarz do twórczości Nowakowskiego, ale także i do całej liberatury. W ha!artowskim przedruku jakość ta zupełnie nie wybrzmiewa.

${ }_{63}$ Nie ma takiego charakteru Od Joyce'a do liberatury.

${ }^{64} \mathrm{~Np}$. w Muzeum Książki Artystycznej w Łodzi.

${ }_{65}$ Por. http://www.liberatorium.com/info/info.html [dostęp 30.09.2011].

${ }^{66}$ Choć zdarzały mu się „mentorskie wtręty”. Na s. 37 Traktatu... czytamy: „Pamiętaj, pamiętaj! To na czym piszesz, to na czym drukujesz może być bardzo istotne. I powinno być przedmiotem twojego zainteresowania. I nie może być przedmiotem twojej nieuwagi. Pamiętaj, że wszystko znaczy. Tu nie ma rzeczy nie znaczacych. Tu - w liberaturze". 
są od literatury. Czy są to książki dla dzieci? Nie, są stanowczo zbyt poważne. Czy są to książki dla dorosłych? Nie, są zbyt zwariowane. Czy są to nie-książki? ..... Zawsze są one pomiędzy pod za obok...... ${ }^{67}$

Dzieląc się swoimi doświadczeniami z tworzenia takich właśnie tomów, Nowakowski napisał Traktat..., swoistą poetykę dzieła liberackiego, analizującą możliwości, jakie daje autorowi każdy nawet najmniejszy element książki: od pojedynczej litery, poprzez sposoby zapisu ich sekwencji (słów, zdań, stron), wybór odpowiedniego materiału (papier gładki/chropowaty, gruby/ cienki, barwny/przezroczysty), łączenie kart (i nie tylko), konstruowania okładek itp. (zob. ilustracja 2$)^{68}$.
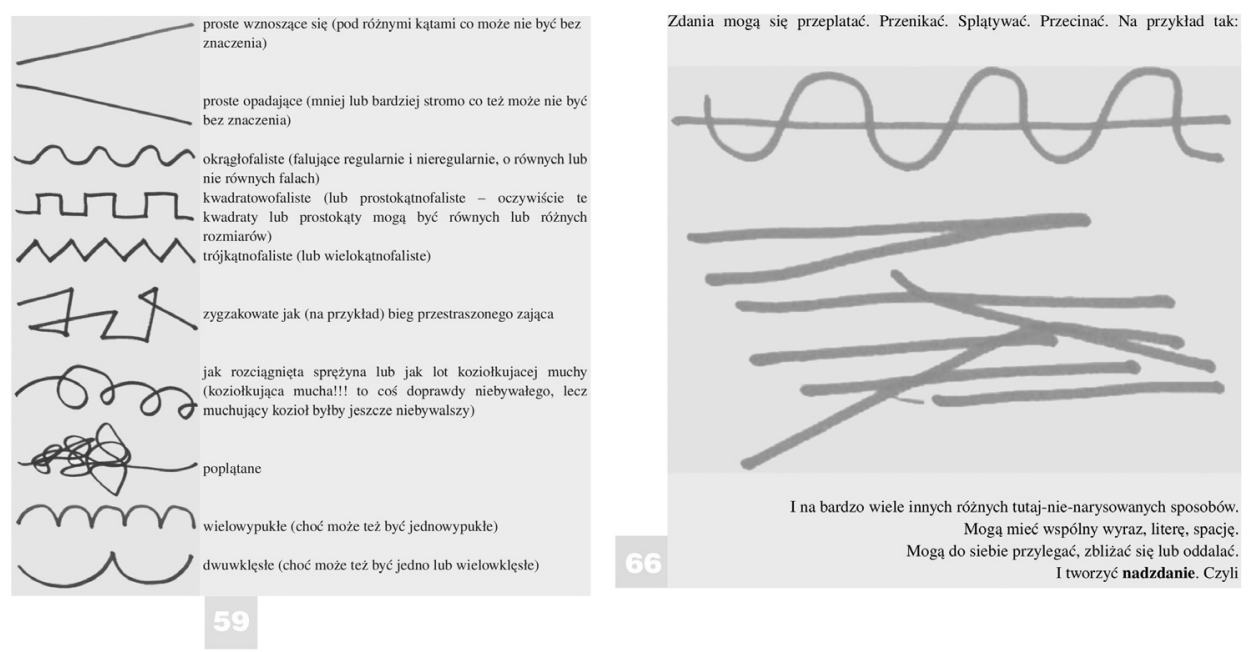

Ilustracja 2. Radosław Nowakowski, Traktat kartkograficzny czyli rzecz o liberaturze, fragmenty dotyczące sposobu liberackiego kształtowania zdania (s. 59, 66) (źródło: zdjęcia własne autora)

Trudno jednak przypisać temu dziełu charakter normatywny - jest ono raczej zbiorem możliwości, sugestii, propozycji dla tych, którzy podobnie jak jego autor pragną świat zmieścić w książce. Warto też pamiętać, iż mimo niekwestionowanego pierwszeństwa Traktatu... jako pozycji teoretycznej dotyczacej literatury totalnej ${ }^{69}$ jego autor do samej idei miał stosunek, rzekłabym, nieco zdystansowany. Jak dowcipnie stwierdzał w szkicu Dlaczego moje ksiażki sa takie jakie sa:

${ }^{67}$ Radosław Nowakowski, Dlaczego moje ksiażki sq takie jakie sa, [w:] Od Joyce’a do liberatury, s. 230-231.

68 Dziesięć poziomów kształtowania tekstu, które podlegają analizie u autora, to jak sam podkreśla: (1) pusta strona (kartka rozumiana jako nośnik), s. 27-37, (2) litera, s. 39-46, (3) słowo, s. 47-54, (4) zdanie (zatem i sposób jego zapisu), s. 55-66, (5) akapit, s. 67-72, (6) strona, s. 73-75, (7) kartka (karta), s. 76, (8) kartki, s. 78-84, (9) okładka, s. 85-87, (10) książka, s. 88.

69 Synonimu tego - wprowadzonego przez Fajfera - Nowakowski nie stosuje. 
LIBERATURA - to słowo wymyślił jeden z moich przyjaciół. Twierdzi, że to jest właśnie to, co robię $e^{70}$.

A co „robi”? Cała twórczość literacka Nowakowskiego jest próbą opisania (czy jak sam mówi „nieopisania”) świata ${ }^{71}$. Materialny aspekt książki, możliwość eksperymentowania z jej forma, wykorzystywanie grafiki, różnicowanie koloru i kształtu czcionek stały się dla artysty ważnymi zabiegami pomagającymi w konstrukcji sensu dzieła ${ }^{72}$. Jak wyjaśnia:

Opisania używają płaskiego i linearnego pisma. Nieopisania mogłyby używać wielowarstwowego i nielinearnego niepisma będącego rezultatem połączenia różnych systemów (piktogramów, hieroglifów, alfabetów, rysunków i innych) i wykorzystania wszelkich ich wad i zalet ${ }^{73}$

Początkowo jego utwory miały postać tradycyjnych kodeksów ${ }^{74}$, potem autor coraz częściej „bawił się forma”. Choć, rzecz jasna, sformułowanie „bawił się" jest tu nadużyciem - wszelkie niekonwencjonalne rozwiązania służyć miały ulepszeniu artystycznego przekazu, nie rozrywce czy wyłącznie celom estetycznym. Jak stwierdzał Nowakowski: ,ja nie chcę pisać pięknie - ja chcę pisać coraz bardziej znacząco" ${ }^{75}$. Stąd, znaczenia próbuje konstruować

${ }^{70}$ R. Nowakowski, Dlaczego moje ksiażki..., s. 231.

71 Jego utwory układają się w cykl pod takim właśnie tytułem: poszczególne teksty nazywane są kolejnymi częściami Nieopisania świata (wyjątkiem jest tylko tzw. część zerowa, czyli Ogon stonia). Zob. też R. Nowakowski, Dlaczego moje ksiażki..., s. 224-226 (podrozdział 22. [Nieopisanie świata]) oraz Rashomon do potęgi entej. O hipertekstowej i hasarapańskiej opowieści „Koniec świata wedtug Emeryka” z Radosławem Nowakowskim rozmawia Piotr Marecki, „Ha!art” 2003, nr 2 (15), bez numeracji stron.

${ }^{72}$ Podobnie jak Fajfer, i ten artysta stwierdzał, że „każdy element dzieła liberackiego jest, a przynajmniej powinien i ma być, znaczący” (R. Nowakowski, Traktat..., s. 48).

${ }^{73}$ R. Nowakowski, Dlaczego moje ksiażki..., s. 224. Warto też zaznaczyć, że to Nowakowski niemal we wszystkich swoich tekstach podkreśla to, o czym inni teoretycy nierzadko zapominają: inne tradycje pisma. Sugeruje, że i o nich należy myśleć, tworząc historię „protoliberatury”. W przywołanym szkicu czytamy również: „Bardzo często (czy mógłbym powiedzieć «zwykle»?) redaktorzy i wydawcy w Polsce, którym pokazywałem moje książki, wskazywali na niektóre eksperymenty dadaistyczne (może myśleli także o Apollinairze, Cendrarsie, futurystach...... może) jako na źródło moich pomysłów. Nigdy nie pomyśleli o egipskich hieroglifach, o chińskim piśmie-malarstwie, o japońskich zwojach i drzeworytach, o arabskiej kaligrafii, o iluminowanych księgach Indii, Azji Środkowej, Europy, o kodeksach Majów i Azteków, o tabliczkach rongo-rongo i znakach nsibidi, o piktogramach na skałach i w jaskiniach, o pisaniu na liściach, na bambusie, na skórze, na glinie, na jedwabiu, z góry do dołu, z dołu do góry, z lewej do prawej, z prawej do lewej, i bustrofedonem..... nigdy nie wspomnieli o mnóstwie innych rzeczy" (s. 220). Nie zgadzam się jednak, by była to w pełni właściwa perspektywa dla mówienia o liberackości. Choć Nowakowski uważa, że to wartościowe rozszerzenie horyzontu, mam wrażenie, że tak zakreślone spektrum odniesień jest aż nadto szerokie. Do czegóż bowiem prowadzi? Do zastanawiania się nad każdym plastycznym elementem tekstu jako czyniącym zeń liberaturę? Nad każdym eksperymentem typograficznym jako diametralnie zmieniającym sens wypowiedzi? Nie sądzę, by było warto.

74 Warto tu dodać, że w swojej ksiażkarni Nowakowski wydał również w 1991 r. tłumaczenie Maori Myths and Tribal Legends Retoled by Anthony Alperm (opublikowanego w 1964 r.). Nie jest to raczej książka liberacka, lecz klasycznie wydany kodeks o różnobarwnych kartkach.

75 R. Nowakowski, Dlaczego moje ksiażki..., s. 221. W Traktacie... naukę takiego pisania określi semografia (s. 50). 
również poprzez kształt swoich tekstów. W konsekwencji - z czasem nie wystarczały już ilustracje i zabiegi związane ze zmienianiem czcionek i układu przestrzennego tekstu: Nowakowski sięgną po chwyty, takie jak zmiana kształtu kodeksu na trójkąt (Hasa Rapasa), nadanie książce formy leporello, czyli harmonijki (Nieopisanie świata-część trzecia), wykorzystanie struktury hipertekstowej (Koniec świata wedtug Emeryka ${ }^{76}$, Liberlandia ${ }^{77}$ ) czy wreszcie rozpisanie książki w realnej przestrzeni fabryki (Libro $2 N^{78}$ ). Wszystko to, by być bliżej prawdy o świecie, by oddać w książce jego złożoną strukturę ${ }^{79}$. Zaś, jak sam podkreśla, właśnie książka (kluczowa przecież i dla liberatury w ujęciu Fajfera) miała być środkiem do mówienia (czy: niemówienia) o świecie:

Książka ma wiele wymiarów - czytamy w Dlaczego moje ksiażki... - Nie wiem ile, z cała pewnością więcej niż cztery. Niektóre z nich są mało zbadane, inne zaś wcale, są dziewicze. Zapraszają mnie. Zapraszają nas. Ogromne, nieznane terytorium rozciaga się przede mna. przed nami ${ }^{80}$.

Badanie tego terytorium dało doświadczenia, którymi autor dzieli się w Traktacie... . Miał ich juz - w momencie pisania tego tekstu - sporo. Pierwszą swoją książkę wymyślił w 1981 r. W zamierzonej formie udało mu się ją wykonać dopiero po 12 latach, kiedy kupił komputer. Wtedy też założył swoje własne wydawnictwo (czy jak sam mówi „książkarnię”) Ogon słonia ${ }^{81}$, choć pomysł samodzielnego oprawiania tekstów zrodził się jeszcze w latach osiemdziesiatych. Zainspirowany prozaicznymi okolicznościami dnia codziennego, borykając się z analogicznymi jak Fajfer i Bazarnik problemami z wydawaniem swoich dzieł, Nowakowski dochodził do podobnych co i oni wniosków, a rodzące się z nich pomysły zaczął realizować wcześniej niż przywołana dwójka artystów-teoretyków.

${ }^{76} \mathrm{O}$ powieści tej (i związku zastosowanej struktury z wizją świata) szerzej piszę w szkicu Porzadek czy chaos, sieć czy zbieranina, logiczna konstrukcja czy zagmatwany labirynt? Na marginesie hipertekstowej powieści Radosława Nowakowskiego, [w:] Hiperteksty literackie. Literatura i nowe media, red. Piotr Marecki, Mariusz Pisarski, Kraków 2011, zaś szerszą bibliografię podaję, omawiając kategorię e-liberatury w rozdziale poświęconym relacji literatury totalnej i nowych mediów.

77 Więcej o tej pracy zob. Mariusz Pisarski, Cyfrowe kaligramy Liberlandii, „Ha!art” 2010, nr 30, s. 124-125 oraz R. Nowakowski, Zwodnik po Liberlandii, ibidem, s. 122-123.

78 Więcej o tym projekcie zob. Radosław Nowakowski, Powieść w przestrzeń i... o uksią̇̇kowieniu fabryki, „Autoportret” 2006, nr 4, s. 14-17.

79 Zaczynał od opisywania przestrzeni wielkich i odległych (pierwsze książki to relacje z Sahary, Egiptu itp.), by coraz bardziej skupiać się na przestrzeniach małych, dobrze sobie znanych. Przykładem może być właśnie poświęcona tzw. Sienkiewce, Ulica Sienkiewicza w Kielcach, próba opisu znanej autorowi przestrzeni miejskiej.

${ }^{80}$ R. Nowakowski, Dlaczego moje ksiażki..., s. 215.

81 Nazwa pochodzi właśnie od tytułu pierwszej książki. Z pewnością wart jest tu odnotowania fakt, iż z czasem (co ważne - po 1999 r.) „książkarnia” ta zmieniła nazwę, zaś od 1 kwietnia 2009 r. zyskała status wydawnictwa (co być może wpłynie na dostępność dzieł Nowakowskiego). Pod jakim nowym szyldem działa autor cyklu Nieopisanie świata? LIBERATORIUM. Wydaje się, że fakt ten można interpretować jako jawne dołączenie do nurtu. 
W związku z chronicznym brakiem papieru w tamtych czasach zacząłem wystukiwać swoje teksty po dwóch stronach kartki, a potem wpadłem na pomysł, żeby maszynopisy oprawiać - tłumaczył autor Ulicy... - Tak oto zacząłem robić książki! I cóż się okazało - po pierwsze nie muszę już tłumaczyć komuś, jak moja książka ma wyglądać, nie muszę jej, a właściwie jej wyobrażenia, powierzać redaktorowi, komuś od przepisywania, drukarzowi, grafikowi; mogę ją pokazać i powiedzieć: chcę żeby była taka. Po drugie, odkryłem nowe, wspaniałe terytorium: mogę zapanować nad książką jako całością, nie tylko nad samym tekstem; mogę myśleć książką, a nie tylko tekstem. Nagle tekst okazał się tylko jednym z elementów książki - ważnym i podstawowym, ale nie jedynym. Okazało się też, że książka nie jest tylko opakowaniem tekstu, ale sama może być nośnikiem znaczeń. Pojawiła się nowa, wspaniała warstwa znaczeniowa do zagospodarowania. Pojawiła się wielowarstwowość... ${ }^{82}$

Choć Nowakowski jako teoretyk nie dopomina się o skrupulatne odnotowywanie jego postulatów, warto zwrócić uwagę na jeszcze jeden aspekt jego Traktatu... Pozycja ta jest ważna dla moich badań nie tylko ze względu na przedstawiony $\mathrm{w}$ niej opis zabiegów liberackich związanych $\mathrm{z}$ rozmaitymi „warstwami” - by przywołać przed chwilą cytowany tekst - dzieła (stanowiący trzon książki, jej środkową - najobszerniejszą - część). W tekście tym Nowakowski przyjmuje również perspektywę historyczna, wpisuje liberaturę w dzieje przemian sztuki słowa, co wydaje się ciekawym i wartościowym tropem badawczym, wartym głębszego rozważenia ${ }^{83}$. Autor Traktatu... zaczynał od stwierdzenia:

Najpierw była ORATURA. Potem była LITERATURA. A teraz będzie LIBERATURA. Tak byłoby najprościej. Wszystko jak nanizane na sznurek. Jedno po drugim. Jedno z drugiego wynikające. Poprzedzające i następujące. Ale tak nie jest. Nigdy nie jest prosto ${ }^{84}$.

Wydaje się, że ujęcie prezentowane przez autora można traktować jako analogiczne do postaw badaczy zajmujących się archeologią mediów, jak np. Paul Levinson ${ }^{85}$ czy Walter Ong ${ }^{86}$. Choć porównanie takie może wydawać się nadużyciem, gdyż (w gruncie rzeczy) wywód Nowakowskiego pozbawiony jest znamion naukowości. Warto chyba jednak zastanowić się nad taką perspektywą.

Autor próbuje rozwikłać zależności czasowe między oratura, literaturą i liberaturą. Początkowo przyjmuje, że najwcześniej pojawiła się pierwsza z nich, druga zaś „była wtedy, kiedy jeszcze była oratura i kiedy już jej nie było”87. Nie zginie ona też - parafrazując słowa Nowakowskiego - nawet wtedy, gdy przyj-

${ }^{82}$ Rashomon do potęi entej..., s. 3, podkreślenia moje.

${ }^{83}$ Te rozważania otwierają Traktat... . By dopełnić całości opisu muszę dodać, że kończą go refleksje ogólne: uwagi do czytelników, wydawców, liberatów, namysł nad książką artystyczna.

${ }^{84}$ R. Nowakowski, Traktat..., s. 9.

${ }^{85}$ Zob. Paul Levinson, Miękkie ostrze, czyli historia i przyszłość rewolucji informacyjnej, tłum. Hanna Jankowska, Warszawa 2006.

${ }_{86}$ Zob. Walter J. Ong, Oralność i piśmienność. Stowo poddane technologii, tłum. Józef Japola, Lublin 1992.

${ }^{87}$ R. Nowakowski, Traktat..., s. 9. Autor zauważa jednocześnie, że zjawiska takie jak głośne odczytania książek nagrane na kasety bądź płyty to swoisty powrót oratury. 
dzie liberatura, której początków można by szukać nawet jeszcze przed pojawieniem się oratury. Wszystkie trzy mogą zatem współegzystować ${ }^{88}$. Mają też podobne cele, choć nieco inaczej nazwane - oratura to omawianie świata, literatura to jego opisywanie, liberatura zaś - jego uksiqżkowianie (zob. ilustracja 3).

Ilustracja 3. Radosław Nowakowski, Traktat kartkograficzny czyli rzecz o liberaturze, fragment (s. 20) (źródło: zdjęcie własne autora)

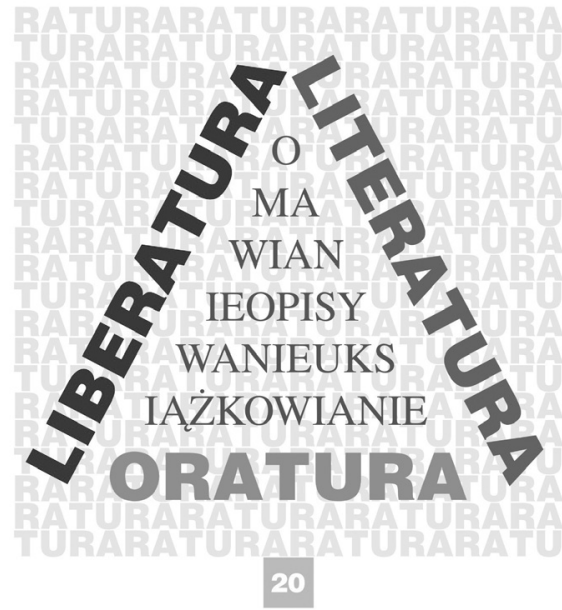

Nowakowski stawia w końcu ważne skądinąd pytanie: „co dzieli się na oraturę, literaturę i liberaturę? (albo na co składają się oratura, literatura i liberatura?)"89. Odpowiada na nie jednak wymijająco i pół żartem, pół serio, najpierw proponujac: „zostawmy to na potem [...] albo lepiej zostawmy w ogóle" ${ }^{90}$, potem zaś stwierdzając, że wspólna część tych trzech to RATURA. Trudno jednak traktować poważnie kogoś, kto wprowadzając nowy termin, mówi:

A co to jest RATURA? Ha! Żebym to ja wiedział [...] RATURA jest bardzo niezwykła. Wręcz niebywała. Zawiera się w oraturze, literaturze i liberaturze i jednocześnie zawiera w sobie oraturę, literaturę i liberaturę. To niemożliwe, ale tak właśnie jest i jest to kompletną bzdurą. Co ja mogę na to poradzić, że tak właśnie jest? ${ }^{91}$

Co więcej - taka postawa autora każe postrzegać Traktat... nie jako dzieło teoretyczne, lecz jako niepoważny żart, igraszkę, zabawę słowną. Szczególnie, gdy liberat pisze: „Ten traktat nie jest i nie ma być teoria liberatury. Nie wiem czym on jest i czym miał i ma być" 92 .

88 Ten wątek rozważań autora pozwala spojrzeć na jego wywód w kontekście Bolterowskiej teorii remediacji i proponowanej w jej ramach logiki następowania mediów.

${ }^{89}$ R. Nowakowski, Traktat..., s. 10.

90 Ibidem.

91 Ibidem, s. 19.

92 Ibidem, s. 107. 
Czy zatem warto w ogóle przywoływać tu tekst czy teksty ${ }^{93}$ Nowakowskiego? Niezależnie od wszystkiego, co wyżej napisane, autor ten - wiążąc charakter sztuki słowa z medium, za którego pośrednictwem jest ono przekazywane - otwiera drogę ku nieco innemu niż Fajferowskie, lecz również dającemu się z wywodu „ojca liberatury” wyprowadzić, ujęciu literatury totalnej.

Idąc w kierunku mgliście wskazanym przez tezy Nowakowskiego, można próbować spojrzeć na liberaturę jako na nowy, bardziej współczesny, związany z innym medium rodzaj sztuki słowa. Lub przynajmniej: taki typ literatury, który w świecie współczesnych technologii medialnych może stać się bardziej popularny i zacząć wkraczać do głównego nurtu. Wymaga to przyjrzenia się również najnowszej, nowomedialnej twórczości artystów sztuki słowa i porównania jej z literatura totalna. Zadania tego podejmę się w jednym z kolejnych rozdziałów. A jakie - inspirowane Nowakowskim - hipotezy badawcze można postawić już teraz?

Wydaje się, że literatura nowomedialna ${ }^{94}$ jest przepełniona zabiegami o charakterze liberackim: kolorowa, dźwięcząca, przestrzennie i graficznie ukształtowana. Jednak często są to tylko zwodzace nas dodatki ${ }^{95}$. A z Fajferowskiego wywodu wyłania się wizja liberatury jako twórczości zakorzenionej w medium, w jakim jest tworzona, wcielającej w życie McLuhanowskie hasło środek przekazu jest przekazem. Jeśli liberat sięga po różne kody i łączy je w obrębie jednego tekstu - a łatwość i naturalność takich kombinacji to jedno z zasadniczych novum przyniesionych przez media elektroniczne - czyni to tak, by dopiero na styku tych technik przekazu rodziły się znaczenia, by żadna z nich nie okazała się zbędna. A zatem: jeśli literat tworzy, używając nie tyle druku i kartki papieru, co właśnie nowych mediów, by jego teksty zasługiwały na miano liberackich, również musiałby świadomie wykorzystać właściwości środka przekazu, po który sięgną. Stąd należałoby postawić też pytanie o możliwość zaistnienia e-liberatury (terminu już używanego do określania choćby Końca świata wedtug Emeryka), co zamierzam w dalszej części książki uczynić.

${ }_{93}$ Poza Traktatem... Nowakowski jest również autorem różnych szkiców nt. liberatury, publikowanych zarówno w Internecie, jak i w czasopismach i książkach zbiorowych. Z ważniejszych warto przywołać kilkakrotnie już tu cytowany szkic Dlaczego moje ksią̇ki... czy też już cytowany, oscylujący nie tylko wokół hipertekstu wywiad Rashomon do potęgi entej... oraz O czytaniu oczu tańczeniu („Ha!art!” 2003, nr 2(15), bez numeracji stron). Większość z nich można obecnie znaleźć na oficjalnej stronie Nowakowskiego i jego wydawnictwa (http://www.liberatorium.com/teksty/ teksty.html).

${ }_{94}$ Używam tu możliwie szerokiego terminu na określenie literatury powstałej z wykorzystaniem nowych mediów. Zaproponowane przeze mnie pojęcie pokrywa się zasadniczo z określeniem e-literatura w rozumieniu Katherine N. Hayles (por. eadem, Electronic Literature. New Horizons for the Literary, Notre Dame 2008), jednak ten ostatni termin długo był w Polsce błędnie utożsamiany wyłącznie z literaturą hipertekstowa. Dlatego też wolę go unikać w sytuacjach, kiedy nie ma możliwości dokładnego doprecyzowania pojęcia. Szerzej o sygnalizowanych tu kwestiach piszę w rozdziale poświęconym relacji liberatury i nowych mediów.

${ }_{95}$ Piotr Czerski słusznie pisał kiedyś o złudnych „,nowych przestrzeniach” majaczących na horyzoncie pisarzom i krytykom zafascynowanym możliwościami Internetu; słusznie wyśmiewał „nowe światy” otwierane brzydkimi, w najprostszy sposób wstawionymi linkami czy animowanymi giftami (zob. Piotr Czerski, Raport z przecią̇̇onego serwera, [w:] Liternet.pl, s. 63). 
Ale można postawić problem inaczej: czy powyższe charakterystyki da się odnieść do tekstów, które najczęściej znajdujemy w Internecie - nie chciałabym powiedzieć: „jedynej”, lecz jednak głównej, dostrzeganej przez polskich badaczy i czytelników, przestrzeni występowania literatury nowomedialnej ${ }^{96}$ ? Przede wszystkim, jako łączące w swym obrębie różne techniki, wydają się one bliskie intermediom Dicka Higginsa ${ }^{97}$, co wyznacza jeszcze jedna przestrzeń odniesień dającą się wywieść z wywodu autora Traktatu... . Ale teksty te często określane bywają też jako „multimedialne”. A Dan Visel, pisząc o różnicy między intermediami a multimediami, słusznie podkreślał, że wyłącznie te pierwsze rodzą się z (ważnej - czego chyba nie muszę tłumaczyć - w refleksji liberackiej) kategorii beetweenness (pomiędzości) ${ }^{98}$, drugie zaś sa zwykłą „mieszanka”, tym co przywołany Higgins określał mianem mixed media (a ja - za Czerskim - scharakteryzowałam jako utwory pełne zwodzących dodatków).

Multimedia - twierdzi Visel - to coś, co pojawia się zawsze kiedy mówimy o tym, co komputery zmieniają w czytaniu. Pomysł jest prosty: bierzesz książkę, dodajesz obrazki, pliki muzyczne i filmiki. Dla mnie zawsze sugeruje to złożenie różnych mediów za pomocą gumki recepturki dookoła nich (programu komputerowego czy strony www); złożenie, które zwykle nie działa, ponieważ tworzące go elementy są od siebie zbyt odmienne ${ }^{99}$.

Takie właśnie zestawienie zdaje się charakteryzować część twórczości, która postrzegamy jako nowomedialną. Nic w niej z liberatury - wiele z jej pozorów. A jednak z drugiej strony - sporo e-utworów wydaje się prawdziwie intermedialnymi. Stąd - z pewnością warto przywołany tu z inspiracji Nowakowskim temat poruszyć i owe podwójne intermedialno-nowomedialne liberackie relacje zanalizować. Zwłaszcza, że kiedy Higgins w latach sześćdziesiątych wprowadzał pojęcie intermediów, a także kiedy krytycznie się mu przyglądał w roku 1981, podkreślał, że ich istotą jest to, że składających się nań technik nie da się oddzielić, że są ze sobą „pojęciowo stopione”, że dzieło rodzi się właśnie „pomiędzy” mediami, na ich styku. A wszystkie te stwierdzenia niewiele się różnią od tego, co po kilkudziesięciu latach głosi Fajfer $^{100}$.

${ }^{96}$ Do kwestii tego, że e-literatura funkcjonuje nie tylko w Sieci oraz „grzechów” polskiej refleksji w tym zakresie powracam w części poświęconej relacjom liberatury i literatury elektronicznej.

97 Termin ten - jak zwracała uwagę również Bazarnik - bliski jest koncepcji liberatury; puste miejsca zostawione dla nowych rodzajów sztuki w eseju wizualnym Higginsa Intermedia Chart wydają się właśnie na nią czekać. O innych związkach teorii Higginsa z liberaturą pisałam również w dwóch tekstach: Którędy do literatury nowomedialnej? („Fragile” 2008, nr 2, s. 13-18) oraz Nowa? Wizualna? Architektoniczna? Przestrzenna? Kilka słów o tym, co może literatura $w$ nowych mediach, [w:] e-polonistyka, red. Aleksandra Dziak, Sławomir J. Żurek, Lublin 2009, s. 41-52, temat ten rozwijam też w dalszej części książki.

98 Do której będę jeszcze wracać w końcowej części książki.

99 Dan Visel, Multimedia vs intermedia, tłumaczenie moje, www.futureofbook.org/blog/archives/2005/11/multimedia_vs_intermedia.html [dostęp 30.08.08]. O ile nie zaznaczam inaczej, wszystkie tłumaczenia z języków obcych podaję we własnym tłumaczeniu.

${ }_{100}$ Wracam do tych kwestii w kolejnych rozdziałach książki. 
Oczywiście, niewielka, acz istotna, różnica tkwi w podejściu do literackości. Dla Higginsa w intermedium nie obowiąuje żadna hierarchia, wszystkie wykorzystane techniki są równie ważne. Co więcej - żadna z nich nie jest nieodzowna, konstytutywna dla dzieła. Co za tym idzie - intermedium może nie mieć nic wspólnego z literatura (w eseju z 1995 r. jako intermedia wymienia Higgins przecież teatr tańca - DanceTheater - czy graficzne notacje muzyczne - Graphic $\mathrm{Mu}$ sic Notations $\left.{ }^{101}\right)$. Zaś liberatura zawsze będzie rodzajem twórczości literackiej.

Istota ciagłego Fajferowskiego zwracania uwagi na to, że liberatura jest literaturą tkwi właśnie w leżącym u jej podłoża zakorzenieniu w słowie. Wśród kodów czy mediów, jakie moga ją współtworzyć, zawsze musi się pojawić ten jeden - słowo. Od „zwykłej” literatury odróżnia zaś liberaturę fakt, iż nie ma ono obowiązu być kodem czy medium jedynym. Eksploatowanie przestrzenności, materialności, wizualności czy audialności ${ }^{102}$ tegoż słowa aktywuje inne sposoby komunikacji i czyni z dzieła literackiego przekaz wielokodowy.

Gdzie zaś budowane sa znaczenia? Podobnie jak w Higginsowskich intermediach - w owej przestrzeni pomiędzy mediami. Owa pomiędzość - ze względu na obowiązkowe występowanie słowa - ma nieco inny charakter i stąd istotne wydaje się rozróżnienie liberatury od intermediów (pojęcia te tylko częściowo będą się pokrywały). Umożliwi to formułowanie opisu liberatury w relacji do teorii Higginsa, nie zaś na jej podstawie ${ }^{103}$.

Zatem, zasugerowane przez Nowakowskiego ujęcie liberatury odwołujące się do refleksji w duchu archeologii mediów jako próba spojrzenia na tego typu literaturę z perspektywy wykorzystania w niej medialności tekstu wydaje się dość kuszące. Być może Fajferowski termin okaże się pomocny w opisie nowych odmian sztuki słowa, w przypadku których konteksty wielokodowości czy intermedialności wydają się nieodzowne. Jednocześnie, równoległe stosowanie go do opisu tekstów tak odległych czasowo od tego, co nowomedialne, jak choćby starożytna literatura wizualna, pozwala dostrzec w tej „nowej” sztuce słowa kontynuację starej tradycji w nowym medium. Tym samym, od Nowakowskiego do Levinsona i Onga okazuje się jednak wcale nie tak daleko.

I tak - choć w swoich rozważaniach odwoływać będę się głównie do tez Fajfera i Bazarnik, nie sposób było tu o Nowakowskim nie wspomnieć. Mimo że Traktat... nie jest pozycją wartą (czy wymagająca) głębokiej analizy, prezentowane tam tezy, choć w wielu miejscach wywodu wyrażone w irytująco banalny sposób, będą dla mnie inspiracją ${ }^{104}$. Tym, co sprawia, że sam opis dzieła

101 Zob. Esej wizualny Dicka Higginsa, [w:] Dick Higgins, Nowoczesność od czasu postmodernizmu oraz inne eseje, oprac. Piotr Rypson, tłum. zbior., Gdańsk 2000, s. 2.

102 Nowe technologie pozwalają rozszerzyć zakres środków aktualizujących akustyczne aspekty języka pisanego.

${ }_{103}$ Trzeba też pamiętać o funkcjonującym w krytyce terminie literatura intermedialna, o którego różnym rozumieniu będę jeszcze wspominać.

104 Że podążenie ścieżkami badawczymi wyznaczanymi przez Nowakowskiego w sposób bardziej naukowo wyważony prowadzić może ku wartościowym konstatacjom dowodzi przywoływany już tu szkic Wojciecha Kalagi Liberatura: słowo, ikona, przestrzeń. Autor przyjmuje w nim podobna jak liberat strategię opisu kreowania znaczeń w literaturze totalnej od poziomu litery do poziomu kodeksu. 
liberackiego przezeń proponowany nie do końca mnie przekonuje jest fakt, iż choć Nowakowski traktuje liberaturę jako - jak sam po wielokroć mówi - „robienie książek", koncentruje się przede wszystkim na wizualnych aspektach dzieła $^{105}$. Bo, choć analizuje różne poziomy samej książki, w istocie interesuje go przede wszystkim ich plastyczne i wizualne opracowanie ${ }^{106}$. Stwierdza, że „fundamentalnego pytania: «czy można pisać okragłymi literami o rzeczach i sprawach kanciastych" nikt nie potraktuje jako fundamentalnego"107, nie apeluje jednak tym razem, by wątpliwość ta dotyczyła też kanciastej bądź nie formy tomu. I tak, kategoria książki, która z czasem zaczęła coraz silniej wybrzmiewać w wystapieniach Fajfera (i Bazarnik), u ksiażkarza Nowakowskiego - paradoksalnie - nie do końca ma szansę zaistnieć. A powinna - by nie upraszczać - być kluczowa.

\section{4. (Uczona) matka, czyli liberatura według Katarzyny Bazarnik}

Katarzyna Bazarnik, trzecia z osób współtworzących teorię liberatury w początkowej fazie kształtowania się tej koncepcji, najpełniej (co dość oczywiste) wpisuje się w naukowy dyskurs. Badaczka - w przeciwieństwie do Nowakowskiego - wnosi do refleksji o liberaturze trochę porządku, akademickiej rzetelności i niebanalnych kontekstów. To również dzięki związaniu przez nią kategorii liberatury z twórczościa Joyce'a idea wywędrowała w świat ${ }^{108}$. Nawet sam Fajfer po dziesięciu latach przyznaje, jak wiele jego teoria zawdzięcza nie nikomu innemu, lecz właśnie Bazarnik (dość dodać, że dyskusje małżonków obrosły w środowisku legenda). W przywoływanym już szkicu Liberatura

105 Warto zaznaczyć, że wprowadzał tė̇ w swoim Traktacie... kategorie rymu wizualnego czy rytmu graficznego.

${ }^{106}$ Dość przywołać tu jeszcze jedna definicję zjawiska autorstwa tego artysty: „Literatura jest obszarem, na którym słowo toczy wojnę z obrazkiem. Liberatura jest obszarem, na którym słowo nie toczy wojny z obrazkiem" (Radosław Nowakowski, Pojedynek słowa z obrazem, http://www. liberatorium.com/teksty/pojedynek.html [dostęp 11.05.2010]). Tekst powstał przy okazji wystawy książek autora w Wojewódzkiej Bibliotece Pedagogicznej w Kielcach w 2004 r.

107 R. Nowakowski, Traktat..., s. 45. Jako ciekawostkę przywołać można tu traktat ortograficzny Jakuba Parkoszowica z Żurawicy powstały w połowie XV w., który taką właśnie - uwzględniająca kanciastość głosek twardych i miękkość miękkich - ortografię proponował. Por. Zenon Klemensiewicz, Historia języka polskiego, wyd. 7 uzup., Warszawa 1999, s. 96-99.

${ }^{108}$ Dzięki wystapieniom Bazarnik kategoria liberatury pojawiała się systematycznie na sympozjach joyceologicznych. Por. też K. Bazarnik, Od Joyce’a do liberatury, oraz eadem, Globalne spojrzenie na „Finnegans Wake”, [w:] Wokót Jamesa Joyce’a: szkice monograficzne, red. Katarzyna Bazarnik, Kraków 1998, s. 143-155 (ten szkic, choć wydany przed 1999 r. wiele mówi o nienazwanej jeszcze liberackości dzieła Joyce’a). Relacji Joyce’a i literatury totalnej poświęcona jest też podoktoratowa książka badaczki Joyce \& liberature. W kalendarium liberatury publikowanym w 30 numerze „Ha!artu” (2010) znaleźć można było informację, że wydawnictwo Litteraria Pragensia zapowiada jej wydanie na 2010 r. (ibidem, s. 29), w efekcie jednak publikacja ujrzała światło dzienne rok później. W serii Liberatura ma zaś ukazać się jej polski przekład. 
- 496 stów podsumowania, zamykającym wybór pism teoretyka (zredagowany nota bene - przypomnę - przez żonę Fajfera) wyznaje:

\begin{abstract}
Wprawdzie sam termin wyszedł od wyżej podpisanego, to jednak niekwestionowaną współautorką koncepcji liberatury jest niżej niepodpisana współautorka Oka-leczenia Katarzyna Bazarnik. To w dużej mierze jej ostrożne intuicje i trzeźwe ustalenia pozwoliły wprowadzić liberaturę na grunt akademicki i skierować na głębsze, bardziej eksterytorialne wody, jej cierpliwości i wyobraźni zawdzięczam też angielski przekład moich esejów i wierszy [...] Sporo też wniosły prowadzone przez nią badania nad przestrzenną strukturą Finnegans Wake - struktura, jak wiele znaków na niebie i księdze wskazuje, globalnie liberacka. „Każdy ma taki przypadek, na jaki zasłużył”, jak mawiał Tadeusz Kantor. Cóż, najwidoczniej czymś sobie musiałem zasłużyć na taką dobrą żonę ${ }^{109}$.
\end{abstract}

Choć oboje piszą o tym samym, używając podobnych sformułowań, wywody tych liberatów maja, moim zdaniem, nieco inny charakter. Wydaje się, że Bazarnik wydobywa z koncepcji Fajfera to, co w niej najważniejsze, rezygnując (choć częściowo) z nieco buńczucznego, charakterystycznego dla artystycznych manifestów, charakteru. Dla (często irytującego akademickiego odbiorcę) Fajferowskiego twierdzenia o nierozerwalnym związku formy i treści, współtworzeniu przez nie znaczenia - ona znajduje zgrabniejszą formułę, stwierdzajac, że „treść jest [...] nierozłącznie związana z fizyczną formą książki, a przekaz werbalny i niewerbalny uzupełniają się tworząc organiczną całość" ${ }^{110}$. Inne przykłady? On mówi o książce „rozumianej już nie jako zewnętrzny wobec dzieła, obojętny futerał na słowa, lecz tegoż dzieła integralny składnik"111, podczas gdy ona pisze:

Książka nie jest, jak nazwał ją Milton „przezroczystą fiolką” czy, jak nalegał Ingarden, nieistotną podstawą materiałowa, lecz integralną częścią dzieła literackiego, widzialnym i namacalnym tekstem zajmującym konkretną ograniczoną fizycznie przestrzeń ${ }^{12}$.

W istocie Bazarnik lokuje teorię Fajfera wśród innych, podobne tezy przynoszących koncepcji i podejmuje próbę krytycznego odczytania dotychczasowej refleksji o przestrzeni książki. Choć i jej zdarza się popełniać grzech niedostrzegania, że o poruszanych przez liberatów kwestiach mówiono już nie raz, także w gronie teoretyków literatury, któremu Fajfer i Bazarnik zarzucaja całkowite ignorowanie innych niż werbalny aspekt tekstu ${ }^{113}$.

${ }^{109}$ Z. Fajfer, Liberatura 496 stów podsumowania, [w:] LCLT, s. 148.

${ }_{110}$ Katarzyna Bazarnik, Liberatura, czyli literatura w formie ksiażki, [w:] Druga rewolucja ksiażki, red. Violetta Trella, Gdynia 2008, s. 22.

111 Z. Fajfer, W stronę liberatury, [w:] Ikoniczność znaku..., s. 162.

${ }^{112}$ Katarzyna Bazarnik, Liberature: a New Literary Genre?, [w:] Insistent Image, ed. Elżbieta Tabakowska, Christina Ljungberg, Olga Fisher, Amsterdam 2007, s. 192.

${ }^{113} \mathrm{~W}$ dalszej części pracy będę przywoływać akcentujace te aspekty dzieła i domagajace się ich interpretacji wypowiedzi m.in. Stefanii Skwarczyńskiej, Stanisława Balbusa czy Grzegorza Gazdy. Por. m.in. Stefania Skwarczyńska, O paru zagadnieniach poetyki nie podjętych przez badania języka poezji (literatury), [w:] Z zagadnień języka artystycznego, red. Józef Bubak, Aleksander Wilkoń, Kraków 1977, s. 11-21; Stanisław Balbus, Graficzny inwariant tekstu literackiego, [w:] O języku literatury, red. Józef Bubak, Aleksander Wilkoń, Katowice 1981, s. 230-256; Grzegorz Gazda, 
W swoich pierwszych artykułach ${ }^{114}$, omawiając tezy męża i opisując jako liberatów Mallarmégo, Johnsona i Nowakowskiego, badaczka przywołuje sformułowana na łamach Le livre comme objet oraz Sur la page Butorowska koncepcję książki jako przykład analogicznego do Fajferowskiego traktowania materialności tekstu. W późniejszych szkicach i rozprawach głównymi (ale nie jedynymi) kontekstami będa prace powstałe na gruncie anglosaskim, z których najważniejsza (omawiana przez badaczkę w kilku publikowanych w Polsce i zagranica artykułach ${ }^{115}$ ) wydaje się nietłumaczona na język polski Fictional Space in the Modernist and Postmodernist American Novel Carla Darryla Malmgrena ${ }^{116}$.

Zdaniem tego amerykańskiego badacza przestrzeń jest kluczowa dla dzieła w trzech znaczeniach. Po pierwsze tekst zajmuje materialna, rzeczywista przestrzeń, książka jako nośnik tekstu jest przedmiotem przestrzennym (badacz odwołuje się do Butora oraz Genette’a). Po drugie, z tekstu wyłania się przestrzeń świata fikcyjnego, którą odbiorca konkretyzuje i aktualizuje w procesie dekodowania znaczeń. Po trzecie zaś, dzieło rodzi też przestrzeń interpretacji $i^{117}$.

Z tej uwzględniającej trzy centra (autora/narratora ${ }^{118}$, odbiorcę i książkę-obiekt) teorii, dla Bazarnik największą inspiracją stał się fragment dotyczący przestrzeni fikcji literackiej (Fictional Space). Malmgren dzieli ja ${ }^{119}$ na przestrzeń w narracji (Narratival Space), z której wyłania się świat przedstawiony ${ }^{120}$, oraz przestrzeń narracji (Narrational Space) powstająca - jak twierdzi w konsekwencji wprowadzenia do utworu tej ostatniej. Składają się na nią zaś: przestrzeń dyskursu (Dicursive Space) ${ }^{121}$ oraz - kluczowa dla Bazarnik - przestrzeń ikoniczna (Iconic Space), rodząca się z konieczności zapisania narracji na jakimś nośniku. Amerykański badacz podkreśla, że wprowadza ten ostatni termin, by opisać rodzaj prozy narracyjnej, w której mamy do czynienia z „namacalną korespondencją między tym, co oznacza a oznaczaną rzeczywistościa,

Architektonika graficzna poetyckiego utworu drukowanego, [w:] Literatura i metodologia, red. Jan Trzynadlowski, Wrocław 1970, s. 213-227.

114 Katarzyna Bazarnik, Krótkie wprowadzenie do liberatury, „Er(r)go” 2003, nr 2 oraz eadem, „Ksią̇ka jako przedmiot” Michela Butora czyli o liberaturze przed liberatura, [w:] Od Joyce'a do liberatury, s. 171-194.

115 Liberatura: ikoniczne oka-leczenia literatury, [w:] TEKST-TURA, red. Małgorzata Dawidek Gryglicka, Kraków 2005, s. 23-40 oraz Liberature: a New Literary Genre?, [w:] Insistent Image, s. 191-206.

116 Carl D. Malmgren, Fictional Space in the Modernist and Postmodernist American Novel, Lewisburg, 1985. Omówienie teorii przestrzeni dzieła literackiego znajduje się w części pierwszej książki (s. 13-60).

117 Ibidem, s. 25-26.

118 Bazarnik mówi częściej o narratorze, Malmgren najczęściej pisze: author.

${ }^{119} \mathrm{~W}$ odniesieniu do tego, co w niej tekstowe - Amerykanin wyróżnia bowiem jeszcze paraprzestrzeń dopełniającą przestrzeń tekstu.

${ }^{120}$ Malmgren mówi wprost, że jest to przestrzeń generowana przez wydarzenia przedstawione w narracji.

${ }^{121} \mathrm{~W}$ jej definiowaniu Malmgren podkreśla, iż każda narracja jest aktem wypowiedzi. 
literaturę, w której uwagę czytelnika przyciaga materialność [...] dyskursu"122. Zaproponowana kategoria obejmuje, jak podsumowuje Bazarnik, „graficzne i materialne cechy dzieła literackiego" ${ }^{123}$. Polska badaczka podkreśla, że:

Przestrzeń ikoniczna generowana jest poprzez takie użycie nośnika znaku w fikcji literackiej, że oznaczające przypomina lub staje się częścią oznaczanego, w takim sensie jak Beckett wyraził się o Finnegans Wake: „[p]isarstwo Joyce’a nie jest o czymś, ono samo jest tym czymś”. Inaczej mówiąc, materialność znaczącego staje się częścią świata przedstawionego poprzez wejście z nim w ikoniczną relację $e^{124}$.

Bazarnik nie tylko używa w swoich analizach zaproponowanych przez Malmgrena czterech typów przestrzeni ikonicznej korespondujących z tylomaż aspektami materialnymi tekstu ${ }^{125}$, lecz uzupełnia wywód badacza o kategorię liberatury, traktując ją jako perspektywę teoretyczną dla opisywania omawianego rodzaju przestrzeni literackiej. Malmgren, „roboczo” - jak mówi polska badaczka ${ }^{126}$ - wprowadzał w tym miejscu kategorię typologii tekstów ikonicznych ${ }^{127}$.

Bazarnik, czyniac punktem wyjścia artykuły Fajfera oraz przywołana Malmgrenowska koncepcję przestrzeni dzieła literackiego, buduje teorię liberatury mocno zakorzenioną $\mathrm{w}$ anglosaskiej krytyce. W tej zaś, warto pamiętać, nie brakowało nigdy analiz eksponujących przestrzenność tekstu literackiego ${ }^{128}$, kategorii, która stanie się kluczowa w wywodzie badaczki. To jej zresztą poświęca Bazarnik swoją rozprawę doktorska (Some Aspects of Spatiality of the Literary Work as exemplified by James Joyce's "Giacomo Joyce", "Ulysses" and "Finnegans Wake" [with a reference to L. Sterne, S. Mallarmé, B. S. Johnson, and R. FedermanJ). Warto też pamiętać, że kategoria ta kluczowa jest - zgodnie z postulatami Fajfera - dla literatury totalnej. Tym zaś, co spaja przestrzenność tekstu z jego liberackością (której omówieniu poświęca Bazarnik niemała część swojej dysertacji) jest ikoniczność rozumiana w duchu Malmgrena.

Sądzę, że potrzebne jest tu jednak jedno dopowiedzenie. Ikoniczność nie jest kategoria prostą czy jednoznaczną: dość przypomnieć, że choć najczęściej słysząc to pojęcie, odnosimy się do ikoniczności obrazowej, mówić możemy

${ }^{122}$ C. D. Malmgren, Fictional Space..., s. 45. Zdaniem badacza to dopiero powieść wiąże tekst z medium (a zatem coraz pełniej wyłaniający się z tekstów Bazarnik postulat, by kategorię liberatury odnosić raczej wyłącznie do dzieł epickich, również wydaje się inspirowany tezami amerykańskiego badacza).

${ }^{123}$ K. Bazarnik, Liberatura: ikoniczne oka-leczenie..., s. 32.

${ }^{124}$ Ibidem.

125 Przestrzeń ikoniczna kompozycyjna, paginalna, leksykalna i alfabetyczna. W artykule Liberatura: ikoniczne oka-leczenie... Bazarnik analizuje w ten sposób Oka-leczenie, którego jest współautorka, w doktoracie poszerza spektrum interpretowanych tekstów.

${ }^{126}$ K. Bazarnik, Liberatura: ikoniczne oka-leczenie..., s. 32.

${ }^{127}$ Ibidem.

${ }^{128}$ W zakończeniu swojego doktoratu Bazarnik przytacza też definicję interpunkcji zaczerpnięta z The Penguin Dictionary of Literary Terms, w której wyraźnie podkreśla się znaczenie dosłownej przestrzeni kreowanej poprzez słowa i zbudowane z nich w obrębie tekstu większe całości. 
przecież i o ikoniczności diagramatycznej ${ }^{129}$. Bazarnik „pożycza” sobie ten - na pierwszy rzut oka - wygodny do mówienia o literaturze totalnej termin, nie wyjaśnia jednak, jak go rozumie, w jakim zakresie będzie się nim posługiwać. Tym samym, odbiorca jej wywodu, szczególnie ten, który zetkną się z kilkoma najbardziej popularnymi dziełami liberackimi i ma w pamięci ich nie-klasyczny wygląd, spodziewa się raczej, że mowa tu o ikoniczności obrazowej. Warto jednak, jak sądzę, postawić pytanie, czy jest to postawa uzasadniona.

Materialność oraz - jak można interpretować tezy Malmgrena - eksplorowanie medium sztuki słowa i wizualność explicite wynikajacca z ikoniczności to nie to samo. Warto też pamiętać, że Malmgren mówi także o ikoniczności kompozycyjnej, która od razu powinna nasuwać kontekst ikoniczności diagramatycznej. Ponadto, w swoim doktoracie jako przykład ikonicznej przestrzeni leksykalnej Bazarnik podaje powieści lipograficzne. Czy konsekwentne unikanie określonej litery jest zabiegiem wizualnym? Inaczej - czy rzeczywiście mamy tu do czynienia z (prosto rozumiana) ikonicznością? Higgins, wyrzucajacy poza marginesy poezji wizualnej akrostychy i formy do nich podobne, raczej by się z takim ujęciem nie zgodził ${ }^{130}$.

Wyróżnione przez Malmgrena poszczególne elementy przestrzeni ikonicznej (to, co związane z poziomem kompozycji, strony, leksyki czy alfabetu) raczej uciekają od bycia transparentnymi, mogą wyraźnie zwracać na siebie uwagę, podkreślając, jak zrobiony jest tekst, a przede wszystkim samo to, że jest z nich (czy z konkretnego kodu) właśnie „zrobiony”. Odnoszą się zatem nie tyle do wizualności, plastyczności tekstu, co do jego struktury. Ich wyodrębnienie na poziomie teoretycznym ma, moim zdaniem, podkreślić, jaką warstwę medium autor w danym momencie eksploruje. Stąd, odnosząc się do tez Malgrema, a także do bazujących na nich sformułowań Bazarnik, warto mieć na uwadze, że znacznie ważniejsza jest tu kategoria ikoniczności diagramatycznej ${ }^{131}$. Innymi słowy, warto pamiętać, że Malmgren - a za nim Bazarnik - mówią o „namacalności” i „materialności” dyskursu, nie zaś wyłącznie o jego wizualności.

Konstatacja ta o tyle jest dla mnie ważna, iż staje się istotnym argumentem na rzecz tego, by nie traktować literatury wizualnej jako jedynego słusznego punktu odniesienia dla badań liberatury. Warto tu też dodać, że z czasem o ikoniczności literatury totalnej zaczą mówić i Fajfer i - co ważniejsze - również dla niego to diagramatyczna jej odmiana bliższa jest liberackiemu ideałowi:

129 Zob. np. Seweryna Wysłouch, Znak ikoniczny w koncepcji Umberta Eco - nowatorstwo $i$ niekonsekwencje, [w:] eadem, Literatura i semiotyka, Warszawa 2001, s. 37-52 oraz Olga Fischer, Dowody na ikoniczność w języku, tłum. Małgorzata Majewska, [w:] Ikoniczność znaku..., s. $15-45$

${ }^{130}$ Zob. Dick Higgins, Pattern Poetry. Guide to Unknown Literature, New York 1987 (szczególnie rozdział Analogues of Pattern Poems, s. 171-196).

131 Zatem, być może, zapożyczona przez Bazarnik kategoria ikoniczności, z której rodzą się takie określenia jak liberatura - ikoniczne oka-leczenie literatury, jest nieco mylaca. A przynajmniej domaga się wyjaśnień dotyczących tego, o jakim rodzaju ikoniczności tu mowa; w świetle niektórych teorii tezy Bazarnik da się bowiem być może podtrzymać. 
Zależało mi na ikoniczności doskonałej: aby to, co w zwykłym ludzkim doświadczeniu niewidzialne, pozostawało niewidzialne także dla czytelnika - tłumaczył we $W$ strone liberatury, odnosząc się do konstrukcji Oka-leczenia. - Czułem, że tylko wtedy będzie to prawdziwe ${ }^{132}$.

Do kwestii tych przyjdzie mi jeszcze powrócić, wcześniej - dla porządku - wypada jednak dokończyć rekapitulację tez doktoratu Bazarnik. Wydaje się to o tyle istotne, iż właśnie ta badaczka wskazuje (częściowo przynajmniej) spektrum ciekawych teoretycznych odniesień dla refleksji o liberackości. Komentując dotychczasowe badania nad przestrzennością literatury, polska teoretyczka za kluczowe dla swoich rozważań uznaje tezy Josepha Franka, Josepha Kestnera, Sharon Spencer, rosyjskich formalistów oraz strukturalistów ${ }^{133}$. Bazarnik nie zapomina jednak też o umieszczeniu własnej koncepcji w kontekście wywodów Jacquesa Derridy, W. J. Thomasa Mitchella, Donalda Francisa McKenziego czy Raymonda Federmana.

Przywołując sformułowaną w $O$ gramatologii koncepcję książki jako zasłaniającej „prawdziwy tekst”, Bazarnik dyskutuje z jej autorem, argumentując, iż „wydaje się, że Derrida (przynajmniej w «O gramatologii») nie może uwolnić się od logocentryzmu, który z taką pasją dekonstruował"134. Dla teoretyczki liberatury książka nie jest, oczywiście, tym, co czyni słowo martwym i zabija sens, lecz czymś, co również służy budowaniu znaczeń tekstu. Tezy francuskiego badacza zestawia Bazarnik z wywodem Mitchella sformułowanym na łamach Picture Theory oraz Spatial Form in Literature, przypominajac, że jego zdaniem pismo sprawia, iż język staje się dosłownie wizualny ${ }^{135}$. Zdaniem Bazarnik, w świetle tych rozważań wydaje się oczywiste, że forma przestrzenna w najbardziej dosłownym jej rozumieniu (fizycznie istniejącego, materialnego tekstu) staje się wyznacznikiem literatury. Może być też poddawana różnego rodzaju modyfikacjom $^{136}$. W pierwszej części doktoratu - jeszcze zanim wprowadzi w swój wywód kategorię liberatury i poświęci jej cały podrozdział - badaczka podkreśla:

Mimo iż jest prawda, że w angielskim, a także w innych językach posługujących się pismem alfabetycznym, materialność tekstu jest zwykle margin a li z ow a na, nie znaczy to, że nie może ona być znaczącym aspektem dzieła literackiego ${ }^{137}$.

132 Z. Fajfer, W stronę liberatury, [w:] LCLT, s. 97.

${ }^{133}$ Część z tych badaczy przywołuje w swoich rozważaniach również Malmgren.

${ }^{134}$ Katarzyna Bazarnik, Some Aspects of Spatiality of the Literary Work as Exemplified by James Joyce's "Giacomo Joyce", "Ulysses" and "Finnegans Wake" (with a reference to L. Sterne, S. Mallarmé, B. S. Johnson, and R. Federman) [rozprawa doktorska ukończona na UJ w 2006 r.], s. 55.

${ }^{135}$ Trzeba też pamiętać - jak podkreśla badaczka za teoretykiem - że u początków historii zapisu słowa tkwią piktogramy oparte na ikonicznej relacji między znaczącym a znaczonym (K. Bazarnik, Some Aspects of Spatiality..., s. 56). Warto tu zwrócić uwagę na zbieżność z poglądami Nowakowskiego.

${ }^{136}$ Badaczka podkreśla też, iż tak pojmowana forma - która wydaje się kluczowa dla jej rozważań - jest tylko jedną z czterech wyróżnionych przez Mitchella.

${ }_{137}$ K. Bazarnik, Some Aspects of Spatiality..., s. 57, podkreślenie moje. Dalej zaś (bardzo pobieżnie) analizuje w tym kontekście przypadek poezji konkretnej oraz książki artystycznej, które ze względu na sposób traktowania znaków tekstu wydają się liberackie. Problem ten powraca też w zakończeniu pierwszej części pracy Bazarnik, zob. szczególnie s. 71-77. 
Kolejnym kontekstem przywołanym przez badaczke jest rozprawa Bibliography and Sociology of Text McKenziego. Kluczowa sprawą w rozważaniach tego badacza jest dla Bazarnik kwestia fałszowania przekazu tekstu poprzez jego złą edycję. Choć przytoczony przez badaczkę za McKenziem przykład ${ }^{138}$ mówi raczej o problemach czysto edycyjnych (takich jak: podział wersów, pisownia małą i wielka litera, literówki) i w gruncie rzeczy mało związanych z tym, co liberackie, formułuje ona tezę jakoby:

Przykład podany przez McKenziego dowodził, że nie tylko fizyczna forma książki i rozmaite elementy graficzne mogą coś znaczyć, lecz także, że również autor może wybrać wpisanie swoich intencji w fizyczny kształt dzieła ${ }^{139}$.

O ile w samym doktoracie passus ten wydaje się mało przekonujący, artykuł Popsuta przestrzeñ ${ }^{140}$ przynosi przykłady, które powalają zrozumieć, iż błędy edycyjne moga wiązać się z rzeczywistym niezrozumieniem przez wydawców znaczenia zamierzonego przez autora wizualnego, przestrzennego czy materialnego ukształtowania tekstu i, tym samym, być opisywane z liberackiej perspektywy. W tekście tym Bazarnik sprawnie pokazuje, jak - w wyniku ingerencji wydawców - wypaczone zostały sensy utworów Wawrzyńca Sterna, Bryana Stanleya Johnsona czy Williama Blake’a. Przywołane wydania zaś nazywa „książkami popsutymi przez zniekształcenie ich fizycznej przestrzeni" ${ }^{141}$.

Ostatni z badaczy, jakich Bazarnik przywołuje w kontekście rozważań o przestrzeni książki i wadze komponowania tejże jako przemyślanej przez autora całości, to Federman. Zastanawiające, iż z rozważań tego autora dla żony Fajfera istotna staje się refleksja o konieczności dzielenia się autorstwem z edytorami tekstu (którą badaczka dobrze zresztą ilustruje omówieniem wydania jednej z jego powieści), nie zaś tezy dotyczące kształtu i budowy książki czy przestrzeni tomu, tak bliskie przecież jej wywodom. W szkicu, który Bazarnik przywołuje, Federman pisał wszakże o konieczności zmiany formy książki, wprowadzeniu nowej - paginalnej, a nie gramatycznej składni, podkreślał, że należy porzucić neutralność i przezroczystość książki samej w sobie.

Jeśli mamy uczynić z powieści formę sztuki - zaznaczał - to musimy wynieść słowo drukowane do rangi środka przekazu, tak aby mi ej s c e i s p o sób umieszczenia słów na zadrukowanej stronie miały związek z tym, co powieść mówi ${ }^{142}$.

138 Tekst Congreve'a w dwóch różnych edycjach.

139 K. Bazarnik, Some Aspects of Spatiality..., s. 60.

${ }^{140}$ Katarzyna Bazarnik, Popsuta przestrzeń. O odpowiedzialności wydawcy, „Autoportret” 2006, nr 4, s. 4-7.

141 Ibidem, s. 7

${ }_{142}$ Raymond Federman, Surfikcja - cztery propozycje $w$ formie wstęu, tłum. Jarosław Anders, [w:] Nowa proza amerykańska, oprac. Zbigniew Lewicki, Warszawa 1983, s. 427, podkreślenie moje. 
Dziwne, iż do tego akurat fragmentu Bazarnik bardzo długo się nie odno$\operatorname{siła}^{143}$.

Samej liberaturze poświęca badaczka dwa fragmenty swojej rozprawy podrozdział części pierwszej (omawiającej rozmaite koncepcje przestrzenności literatury), zatytułowany Przestrzeń ksiażki: ,liberatura” oraz część zamykającą cała dysertację: Konkluzja: Nowe przestrzenie. W stronę liberatury. Pierwszy z tych fragmentów przynosi z jednej strony rekapitulację poglądów Fajfera jako twórcy terminu „liberatura” (przy czym trzeba zaznaczyć, że Bazarnik koncentruje się głównie na roli książki ${ }^{144}$ ), z drugiej - tłumaczy, czemu wprowadzenie tego nowego pojęcia wydaje się nie tylko pomocne, ale i potrzebne. Badaczka, zwracając uwagę na różnorodność tekstów literackich, które można określić jako liberackie, słusznie zauważa, iż liberatura wydaje się terminem, który zdołałby objąć je wszystkie, podkreślając jednocześnie zarówno ich odmienność, jak i wzajemne podobieństwa. Przywołując raz jeszcze typologię przestrzeni literackiej zaproponowana przez Malmgrena, uzupełnioną już o kategorię liberatury, Bazarnik stwierdza:

Jak dotąd żadne narzędzie krytyki literackiej, z wyjątkiem Malmgrenowskiego pomysłu przestrzeni ikonicznej, nie było zdolne stawić czoła szczególnemu pisarstwu Blake’a czy Johnsona. To znaczące, że byli oni zawsze odsuwani na marginesy literatury ${ }^{145}$.

Wcześniej zaś zwraca uwagę, że wyodrębnienie i nazwanie takiej grupy tekstów może w znacznym stopniu ułatwić badanie i opisywanie utworów wyżej wymienionych autorów, a także dzieł Mallarmégo czy Sterna, które określa jako „"wysoko werbalne» książki artystyczne”"146. Do przykładów wymienionych przez Bazarnik można by dodać jeszcze wiele innych. Podobnie jak można by dyskutować z tym, czy rzeczywiście teoria Malmgrena jest jedyna, w świetle której da się analizować przywołane teksty. W jednym jednak ma badaczka z pewnościa rację - choć dzieła tego rodzaju powstawały w rozmaitych epokach i kulturach, choć znajdują się wśród nich utwory poetyckie i prozatorskie, istnieje coś, co je łączy i wyodrębnia jako spójną grupę w obszarze sztuki słowa.

Bazarnik proponuje, by wyróżnić je jako odrębny rodzaj literacki (argumentując m.in. tym, że większości tych tekstów trudno przypisać jednoznaczny status genologiczny ${ }^{147}$ ). Tym samym, dochodzimy do zapowiadanego już powrotu kwestii genologicznego umiejscowienia liberatury. Warto zwrócić uwagę, iż anglosaskie rozumienie genologicznych podziałów, na którym fun-

${ }^{143}$ Dopiero w 2008 r. (w szkicu Liberatura, czyli literatura $w$ formie ksia $\dot{z} k i$ ) wspomina o tym, że „postulował podniesienie graficznego aspektu słowa do rangi pełnoprawnego środka stylistycznego, na równi z figurami retorycznymi i tropami” (K. Bazarnik, Liberatura, czyli literatura..., s. 23).

${ }^{144}$ K. Bazarnik, Some Aspects of Spatiality..., s. 69.

145 Ibidem, s. 75.

146 Ibidem. Por. też dalszą część tej książki (rozdział poświęcony związkom liberatury i książki artystycznej).

${ }^{147} \mathrm{Z}$ czym też nie w pełni można się zgodzić. 
duje Bazarnik swoją tezę, ma nieco inny charakter niż tradycyjna polska genologia z jej wielostopniowym podziałem, choć rodzimej refleksji na pewno nie da się zamknąc w ramach, jakie wyznaczał jej Fajfer. Warto też pamiętać, że już od dawna poruszane były u nas kwestie, które Bazarnik wprowadzała w swoich tekstach niczym wielkie przełomy teoretyczne (jak zastosowanie w genologii kategorii prototypu $)^{148}$.

O ile opatrzone odniesieniami do Stownika terminów literackich Fajferowskie żądanie uznania liberatury za czwarty rodzaj literacki daje się łatwo obalić, o tyle postulat okrzyknięcia jej nowym literackim genre - najobszerniej wyjaśniony przez Bazarnik w szkicu Liberature: a New Literary Genre? ${ }^{149}$ - wydaje się nieco mniej kontrowersyjny (choć - w moim odczuciu - nadal mało przekonujący). Współautorka Oka-leczenia używa jednak w swojej argumentacji przywołanego określenia genologicznego wymiennie z type o bardziej neutralnym, nienacechowanym teoretycznie charakterze. Fakt ten zdaje się potwierdzać, iż to, co przesądza o odrębności liberackich dzieł, to nie ich genologiczna specyfika. Upór dwójki polskich praktyków i teoretyków liberatury przy konieczności dopisania jej do podziałów, które mają współcześnie charakter już raczej wyłacznie systematyzujący, zdaje się przesłaniać sedno zagadnienia. Bazarnik, podsumowując swoje rozważania, zauważa:

\begin{abstract}
Zdefiniowanie genre takiego jak „liberatura” mogłoby implikować dochodzenie statusu i natury literatury a także, być może, ponowne przyjrzenie się jej medium. Jeśli „liberatura” nie przynależy do sztuk pięknych, lecz, istotnie, tworzy oddzielny literacki genre, może to służyć przeniesieniu bliżej centrum grupy marginalizowanych, ekscentrycznych dzieł, przywróceniu ich literaturze i - w końcu - skłonieniu nas do ponownego ich przeczytania z nowej, świeżej perspektywy ${ }^{150}$.
\end{abstract}

Spostrzeżenie Bazarnik - pominąwszy genologiczne wtręty, które sprawnie można zastapić postulatem traktowania liberatury jako rodzaju działania o charakterze prymarnie literackim - wydaje się słuszne. Co ważne, odpowiada też na zasadnicze, a nie zawsze stawiane pytanie: po co nam ta cała liberatura?

Jednak tezy o traktowaniu literatury totalnej jako oddzielnego genre Bazarnik rozwijała, podtrzymywała w swoich wystapieniach i w kuluarowych dyskusjach. Ostatnią jej propozycją jest zaś spojrzenie na liberaturę z punktu widzenia genologii inspirowanej kognitywizmem ${ }^{151}$. W podsumowujaccym

${ }^{148}$ Por. np.: B. Witosz, Gatunek - sporny (?) problem; Romuald Cudak, Sytuacja gatunków we współczesnej poezji polskiej a perspektywy genologii, [w:] Genologia i konteksty, red. Czesław Dutka, Zielona Góra 2000, s. 25-38; Ryszard Nycz, Tekstowy świat. Poststrukturalizm a wiedza o literaturze, Warszawa 1995 (zwłaszcza s. 69).

${ }^{149}$ K. Bazarnik, Liberature: a New Literary Genre?

150 K. Bazarnik, Some Aspects of Spatiality..., s. 76.

151 Dla porządku należałoby tu przywołać również szkic Chronotope in liberature, [w:] James Joyce and After: Writer and Time, ed. Katarzyna Bazarnik, Bożena Kucała, Newcastle 2010, s. 117-132, w którym autorka próbuje uprawomocnić tezę o genologicznej odrębności liberatury, odnosząc się do koncepcji Bachtinowskiej. 
pierwszą dekadę literatury totalnej szkicu Liberatura czyli o powstawaniu gatunków (literackich) ${ }^{152}$, zamykającym opublikowany z tej okazji wybór szkiców Fajfera, badaczka daje wyraz przekonaniu, że jest to najwłaściwsze ujęcie.

A w konsekwencji przyjętej perspektywy artykuł ten przynosi również katalog wyznaczników liberatury. Jako najaktualniejsza pozycja dotycząca zagadnienia wymaga tu przywołania, jako propozycja - jak sądzę - nieco kontrowersyjna i nie w pełni spójna: uważnego zanalizowania. Punktem wyjścia do sformułowania najważniejszych tez jest w nim przyznanie, że liberatura daje się rozumieć dwojako: albo jako związany z określonym czasem i miejscem nurt literacki stanowiący reakcję na aktualną sytuację literatury w medialnym świecie (dygitalizację) albo jako etap ewolucji form literackich, efekt poszukiwań artystycznych. To drugie rozumienie prowadzi - zdaniem Bazarnik - ku postrzeganiu literatury totalnej jako nowego gatunku literackiego.

Po pierwsze, jak już sygnalizowałam, badaczka porzuca tu jednak wyrażane wcześniej sądy o tym, że najzgrabniej liberaturę jako byt genologiczny charakteryzuje formuła genre. Uznaje, że użyteczniejsza (jak pisze: „stosowniejsza"153) byłaby tu kategoria prototypu wprowadzona do badań filologicznych przez kognitywistów. Bazarnik przywołuje przykład zastosowania jej do rozumienia gatunku literackiego przez Dirka De Geesta i Hendrika Van Gorpa w 1999 r. ${ }^{154}$ Opierając się na ich propozycji, badaczka uznaje Oka-leczenie za prototyp liberatury, wypunktowuje też cechy, które zbliżają dzieło do tak określonego centrum. Jak już wspomniałam wcześniej - w momencie powstawania tego szkicu propozycja takiego spojrzenia była już w Polsce znana i czego nie dodałam - nie tylko zapoznana, lecz i skrytykowana ${ }^{155}$. Postawione w stosunku do niej zarzuty sa, moim zdaniem, słuszne i sprawdzają się w pełni także w odniesieniu do próby ujęcia liberatury z takiej perspektywy.

Odnoszaca się krytycznie do ujmowania gatunku jako prototypu Wysłouch przekonująco argumentuje, że taka perspektywa prowadzi do uproszczeń i - co ważniejsze - nie odnosi się do żadnej obiektywnej rzeczywistości, ujmuje jedynie „prywatna świadomość gatunkowa”, jak twierdzi badaczka, „nie porządkuje i nie systematyzuje zjawisk"156. Tym samym - jako ujęcie subiektywne - nie pozwoli obiektywnie wskazać dzieł liberackich, obrazując jedynie indywidualny stosunek do tej kwestii poszczególnych jednostek interpretujących, unaoczniajac, jak trafnie podsumowuje Wysłouch, „elastyczność i «rozciagliwość» gatunku"157.

I Bazarnik zwraca uwage na ten aspekt proponowanej perspektywy badawczej, podkreślając, że i w ujęciu inspirujących ją badaczy to, jak definiujemy obiekt naszej refleksji

${ }_{152}$ Katarzyna Bazarnik, Liberatura czyli o powstawaniu gatunków (literackich), [w:] LCLT, s. $151-163$.

153 Ibidem, s. 157.

154 Ibidem, s. 157-158.

155 S. Wysłouch, Nowa genologia..., s. 100. Porównaj też bibliografia podana w przypisie 148.

156 Ibidem.

157 Ibidem. 
Nie jest zakorzenione w obiektywnie istniejącej rzeczywistości, lecz w dużym stopniu uzależnione od subiektywnej wiedzy podmiotu definiującego dany przedmiot, jak również od dominującego w danym momencie dyskursu, a nawet czynników instytucjonalnych ${ }^{158}$.

Co ważne, jak sama zauważa - decydujące o przynależności do liberatury staja się tym samym też orzekajace o takim statusie dzieła instytucje: Czytelnia Liberatury czy „Ha!art” (konkretnie: seria wydawnicza Liberatura). Tu jednak subiektywność tych wyborów rysuje się jako podwójnie wręcz problematyczna. Redaktorzy serii Liberatura (Fajfer i Bazarnik), kierujący Czytelnią Liberatury (Fajfer i Bazarnik) oraz czytelnicy poddani działaniom tychże (zatem: Fajfera i Bazarnik) oceniaja, czy dzieło jest wystarczająco bliskie „ideałowi” (prototypowi, modelowemu egzemplarzowi), jakim jest Oka-leczenie (Fajfera i Bazarnik)... Czyżby zatem artyści stworzyli sobie teorię zdolną opisać ich dzieło i próbowali teraz przekonać do niej wszystkich? ${ }^{159}$ Choć można by, istotnie, stawiać takie zarzuty (dodajacc, że liberatura to pewnie po prostu kolejny „ciekawy produkt” wypromowany przez „Ha!art”), daleka jestem od takich stwierdzeń. Dostrzegając przesłanki ku tak krytycznym ocenom, negatywnie ustosunkowuję się jednak nie do całej idei liberatury, lecz do jej konkretnych ujęć. Do takich z pewnością należy ostatnie z zaproponowanych przez Bazarnik. Sam koncept liberatury - jak będę przekonywać w całej tej książce - wydaje mi się słuszny i (co może ważniejsze) użyteczny i wygodny. Niemniej, odrzeć go trzeba z zadęcia i (zgubnej) ideologii.

Jakie są kolejne wnioski badaczki? Zwróciwszy uwagę na brak możliwości obiektywnej oceny liberackości, Bazarnik uznaje, że zasadniczą zaletą perspektywy kognitywistycznej jest możliwość gradacji owej definiującej literaturę totalna cechy. Niemniej, trzeba by zapytać, czy konieczne jest aż odwoływanie się do teorii zbiorów rozmytych, szukanie centrum i peryferii, by móc - zamiast wskazywać „to jest liberatura” - mówić: „to jest liberackie”? Sądzę, że nie. Co więcej, uważam, że właśnie liberackość (a nie liberatura) powinna być przez teoretyków i czytelników wskazywana. Jednak wcale nie łączę jej ani z genologia, ani z teoria prototypów. Traktuję ją jako silniej lub słabiej ujawniajaccą się cechę pewnej grupy utworów literackich, a do jej pełniejszego zdefiniowania wrócę w dalszej części tego rozdziału.

A jak rozumie ową liberackość Bazarnik? Z omawianego tu szkicu wynika, że byłoby nią spełnianie „cech gatunkowych liberatury” ${ }^{160}$, których Bazarnik wymienia osiem: (1) użycie niewerbalnych i typograficznych środków wyrazu, (2) przestrzenną organizację tekstu, (3) ikoniczność (obrazowa i diagramatyczna), (4) autorefleksyjność czy metatekstualność, (5) hybrydyczność czy polimedialność, (6) interaktywność i ergodyczność, (7) materialność, (8) specyfikę

${ }^{158}$ K. Bazarnik, Liberatura czyli o powstawaniu gatunków..., s. 158.

159 Okrutnie można by dodać: publikując za pieniądze Ministerstwa „kanoniczne” pozycje, których nie można kupić - casus zbioru tekstów Fajfera (LCLT) wydany ze środków Ministra Kultury i Dziedzictwa Narodowego w ramach programu Promocja kultury polskiej za granica, który jest przez autorów rozdawany (publikacja bezpłatna).

${ }^{160}$ K. Bazarnik, Liberatura czyli o powstawaniu gatunków..., s. 159. 
medium ${ }^{161}$. Liberacki prototyp - Oka-leczenie - istotnie wszystkie wymienione cechy posiada. Zaś zgodnie z przyjęta przez Bazarnik perspektywą w dowolnym innym utworze liberackim nie musimy znaleźć każdej z nich.

Badaczka wypunktowuje jednak jeszcze jedna, zastanawiająca kwestię. Charakteryzując cechy liberackie zauważa, że „niektóre z nich sa ze sobą powiąane i wynikaja jedna z drugiej" ${ }^{162}$. Z jednej strony trudno taki wniosek wyciagnąć z prowadzonego przez nią wywodu (czy wyznaczniki takie nie powinny być właśnie wyraźnie określone, tym samym też łatwe do wskazania?), z drugiej - w gruncie rzeczy - trafnie definiuje on rażący brak zaproponowanej charakterystyki. Sądzę, że wymienione przez Bazarnik cechy nie tylko pozostają we wzajemnych relacjach, lecz często są względem siebie synonimiczne. Nie tyle wynikają jedna z drugiej, co mówią o tym samym w szerszym bądź węższym zakresie. Również ze względu na tę nieścisłość trudno mi uznać przywołany artykuł Bazarnik za pozycję tak ważna, jak można by się było spodziewać (po szkicu zamykającym pierwszą dekadę liberacka, stanowiącym też codę wydanego z tego powodu tomu rekapitulującego owe dziesięć lat).

Przede wszystkim, „użycie niewerbalnych i typograficznych środków wyrazu, hybrydyczność czy polimedialność” oraz „ikoniczność obrazowa” to w gruncie rzeczy to samo. Każdy z opisów odnosi się do innego niż konwencjonalne kształtowania tekstu (w dużym stopniu odwołujacego się do jego wizualności). Z kolei „przestrzenna organizacja tekstu” (rozumiana przez Bazarnik raczej jako przestrzenna konstrukcja tomu), „ikoniczność diagramatyczna”, „interaktywnośćc i „ergodyczność"163, a także cecha nazwana przez badaczkę

161 Ibidem, s. 159-161. W wersji artykułu opublikowanej w tomie pokonferencyjnym (Od liberatury do e-literatury, red. Eugeniusz Wilk, Monika Górska-Olesińska, Opole 2011, s. 15-27) Bazarnik wymienia jeszcze jedną cechę: jako siódma pojawia się intencyjność (zamiar autorski), definiowana przez badaczkę jako: „respektowanie autorskiego kształtu i kompozycji zarówno werbalnego, jak i niewerbalnego materiału, które nie powinny być modyfikowane przez redaktora, typografa czy grafika opracowującego książkę" (s. 24). Warto zwrócić uwagę, że cecha ta wydaje się przypisana do zupełnie innego porządku niż pozostałe. Tamte odnoszą się do charakterystyki tekstu tworzonego przez pisarza, ta natomiast do jakości konkretnej edycji tego tekstu. Sądzę, że Bazarnik mogła mieć na myśli to, iż utwory liberackie są tak zaprojektowane, że wymuszają respektowanie przez wydawców autorskiego projektu kształtu dzieła, niemniej, w ujęciu, jakie proponuje badaczka w swoim szkicu, cecha ta zdaje się sygnalizować, że o liberackości przesądza sposób edycji, nie zaprojektowania tekstu. Innymi słowy: Oka-leczenie jest liberackie tylko wydane tak, jak je wydano. Jednak, czy zatem - można by zapytać - Mallarmé stał się liberatem dopiero po wydaniu go w serii Liberatura, a wręcz - czy dopiero opublikowanie Rzutu kośćmi... przez Fajfera i Bazarnik nadało dziełu cechy liberackie? Tak, jak w dalszej części tekstu głównego poddaję krytyce pierwsze podane przez Bazarnik wyróżniki literatury totalnej, tak i dodanego przez nią uzupełnienia nie uznaję za wartościowe.

162 Ibidem, s. 159.

${ }_{163}$ Ta kategoria dookreślona jest przez Bazarnik jako: „zaangażowanie czytelnika w determinowanie przebiegu narracji, jego aktywny współudział w nadawaniu ostatecznego kształtu, jaki utwór przybierze w trakcie lektury" (s. 160) żeruje niejako na micie interaktywności i, jak sądzę, wymagałaby kilku dopowiedzeń ze strony autorki (choćby odwołania się do Dzieła otwartego Eco bądź kontekstów nowomedialnych, aby czytelnik wiedział, w którą stronę ma iść jego interpretacja). Por. np. Katarzyna Prajzner, Interaktywność. Kilka uwag o definiowaniu pojęcia, [w:] Między słowem a obrazem, red. Małgorzata Jakubowska, Tomasz Kłys, Bronisława Stolarska, Kraków 2005, s. 555-567. Co ciekawe, w wystapieniu konferencyjnym (konferencja Od liberatury 
„materialnościa”" ${ }^{164}$ mówią o analogicznym aspekcie całej książki (już nie tylko zapisanego tekstu) ${ }^{165}$. Z kolei ogólnym ujęciem wszystkich tych cech razem wydaje się ostania z nich, ósma, lepiej opisana niż nazwana: „wykorzystanie swoistych cech nośnika"166. Jeżeli, jak stwierdza w innych szkicach Bazarnik, liberatura to „literatura w formie książi” ${ }^{167}$, to być może warto przyjaćc, że jej medium jest właśnie książka. Zaś „myślenie nią” (jak również mówią liberaci), czyli innymi słowy właśnie eksplorowanie cech tego medium, nadaje dziełu liberacki charakter. Nie bez powodu Bazarnik przyznaje: „ta swoistość czy specyfika medium, czyli organiczna więź tekstu z formą i przestrzenią nośnika zapisu, wydaje się jedna z kluczowych cech liberatury"168. Swoją propozycję rozumienia liberackości chciałabym oprzeć na tej właśnie cesze ${ }^{169}$.

\subsection{Raczej „liberackość” albo o medialnie uwikłanej sztuce słowa i książkowych interfejsach (hipoteza badawcza)}

Pierwsza część tego rozdziału przyniosła rekapitulację dotychczas głoszonych ujęć liberatury. Przypomniane zostały fundujące dyskurs o literaturze totalnej postulaty Fajfera: (1) uznanie jej za typ twórczości, w którym

do e-literatury, Kamień Ślaski, listopad 2009), którego pokłosiem jest publikacja omawiająca wyznaczniki liberatury, Bazarnik mówiła wyłącznie o interaktywności, nie mieszając do tego Aarsethowskiego ergodyzmu, którego to terminu zreszta zupełnie nie wyjaśnia. Kategoria ta pojawiła się w dyskusji konferencyjnej, jednak jej odniesienie do liberatury wymagałoby kilku dopowiedzeń (szerzej piszę o tym w rozdziale poświęconym relacji liberatury i nowych mediów).

${ }^{164}$ Więcej o materialności pisze Bazarnik w szkicu Materialność jako wyznacznik gatunkowy liberatury, [w:] Materia sztuki, red. Michał Ostrowicki, Kraków 2010, s. 109-118, rzeczowo i rozważnie odnoszac teorię liberatury do Ingardenowskiej koncepcji dzieła literackiego. Jeżeli wspominałam o wzajemnych inspiracjach tez małżonków, warto dodać, że w tym samym tomie znajdziemy również szkic Fajfera Od libeartury do tekstu niewidzialnego (autoportret $z$ Ingardenem w tle) (s. 119-128). Szkic ten wart jest przywołania nie tylko dlatego, że nie przedrukowano go w LCLT, lecz również (a wręcz przede wszystkim) i z tego powodu, że słusznie autointerpretuje tam Fajfer swoją teorię jako dopowiedzenie do dokonanej przez Henryka Markiewicza oceny pracy Ingardena (por. s. 121).

${ }^{165} \mathrm{~W}$ omówieniu tym świadomie pomijam wyróżnioną przez Bazarnik jako czwartą autorefleksyjność czy metatekstualność. Sądzę, że właściwość tę odnieść można wyłącznie do trzech przywołanych przez teoretyczkę przykładów (Joyce, Sterne i - jakże by inaczej - duet FajferBazarnik), stad nie wydaje mi się ona istotna dla szerszego omawiania kategorii liberackości. Co więcej - dość enigmatycznie jest przez badaczkę wyjaśniona.

${ }^{166}$ Ibidem, s. 161.

${ }^{167}$ Por. K. Bazarnik, Liberatura, czyli literatura $w$ formie ksią̇ki.

${ }^{168}$ K. Bazarnik, Liberatura czyli o powstawaniu gatunków..., s. 161.

${ }^{169}$ Ważnym momentem w rozwoju refleksji liberackiej jest również zwrot ku badaniom ponownie stawiającym w centrum zainteresowań właśnie książę. Przykładem świeżo opublikowany tekst Bazarnik, w którym sytuuje ona liberaturę w kontekście (leciwych już) rozważań Jerome'a McGanna o kondycji tekstualnej. Zob. Katarzyna Bazarnik, Introduction: Modernist Roots of Liberature, [w:] Incarnations of Material Textuality: From Modernism to Liberature, ed. Katarzyna Bazarnik, Izabela Curyłło-Klag, Newcastle 2014. Por. też. Jerome J. McGann, The Textual Condition, Princeton 1991. 
artysta obmyśla nie tylko świat przedstawiony, lecz i sposób jego przedstawienia, zakorzenia swój tekst w określonej materialnej (i przestrzennej) rzeczywistości (książce) tak, by i ona sama nabrała znaczeń, (2) wynikająca z takiego rozumienia dzieła konieczność nowego spojrzenia na ważne dla teoretyków literatury pojęcia oraz (3) propozycja uznania liberatury za czwarty rodzaj liberacki. Z nich najważniejsze wydaje mi się zwrócenie uwagi na inne niż językowe jakości literatury. W dalszej części książki będę też zastanawiać się, czy formułowane przez Fajfera wnioski nie zmuszają również do poważniejszych, niż sugeruje artysta i teoretyk, „porządków terminologicznych”, czy nie prowadzą np. do innego spojrzenia na całą literacką komunikację.

Odniosłam się także do Nowakowskiego i, choć nie uznałam jego wywodu za istotny głos w naukowej debacie o liberaturze, podkreśliłam inspirujące tropy interpretacyjne, jakie wskazuje. Nieodzowne stało się przywołanie tego artysty również jako autora Traktatu kartkograficznego..., pierwszego teoretycznego dzieła o liberaturze.

Szkicową charakterystykę zamyka podsumowanie wywodów Bazarnik, jak sądzę, najprężniej (i najrzetelniej, najwartościowiej) rozwijającej analizowany tu dyskurs. Wśród jej zasług dla rozwoju teorii liberackiej wymienić należy z pewnością: (1) podniesienie poziomu dyskusji o literaturze totalnej: osadzenie teorii w szerszym kontekście i wprowadzenie do naukowych dyskusji (nie tylko polskich), (2) poruszenie kwestii ikoniczności jako cechy liberackiej oraz (3) rozwinięcie (sugerowane już przez Fajfera) refleksji o roli przestrzeni tekstu dla budowania jego znaczeń, (4) zwrócenie uwagi na wypaczenie sensów dzieł przez ich złą edycję prowadzące ku podkreśleniu faktu, że zaprojektowany przez autora kształt dzieła może być istotny (jak dzieje się w liberaturze), a także (5) rozwinięcie genologicznej koncepcji liberatury (w moim odczuciu - zupełnie zbędne).

Czy, przywoławszy te rozwijane, zmieniane, aktualizowane teorie, moge podjać się próby zdefiniowania literatury totalnej? Przecież, jeśli - jak podsumował wypowiedzi Bazarnik i Fajfera Richard Kostelanetz - „koncepcja liberatury jest potrzebna" ${ }^{170}$, trzeba jasno odpowiedzieć na pytanie, co ową liberatura jest. A jednak, rodzi to kilka problemów.

Po pierwsze, problematyczne (jak już sugerowałam) jest wskazanie wyznaczników liberackości czy - szerzej - liberatury (w ujęciu Bazarnik: jej cech gatunkowych). Za niesatysfakcjonujace uznałam te zaproponowane w szkicu Liberatra czyli o powstawaniu gatunków... . Czas zatem wskazać inne. Inspirujace jest tu dla mnie coraz wyraźniejsze podkreślanie przez liberatów, że liberatura to „literatura w formie książki”. Ową kategorię (uznawaną przecież

${ }^{170}$ Cytat ten (często przez duet Fajfer-Bazarnik przywoływany) pochodzi ponoć z prywatnej korespondencji. Weryfikacja jest tu jednak niemożliwa, gdyż jak tłumaczą autorzy: „Wypowiedź zacytowaliśmy w «Ha!arcie» nr 15/2003 [...], niestety bez podania daty tej korespondencji. Późniejsza awaria poczty sprawiła, że nie jesteśmy już w stanie tej daty ustalić" (K. Bazarnik, Liberatura czyli o powstawaniu gatunków (literackich), [w:] LCLT, s. 159 - przypis 14). 
za kluczową już od pierwszych Fajferowskich wystapień ${ }^{171}$ ) warto, jak sądzę, połączyć z ostatnią z wyróżnianych przez Bazarnik cech liberatury, skupiająca - jak wskazywałam - w sobie wszystkie inne. Tym samym, liberatura byłaby sztuką słowa, która za swoje medium uznaje książkę i szuka rozmaitych możliwości semantycznego eksplorowania tegoż nośnika.

Jednak, jak słusznie zarzucał liberackiej teorii Krzysztof Bartnicki, odwoływanie się do - jak mówi - „książkowości (nieokreślonej)”172 stanowi jeden z jej najsłabszych punktów, gdyż wśród tekstów określanych jako liberackie znajdziemy i takie, o których trudno powiedzieć, by rzeczywiście były książkami. Bartnicki, przywołując Spogladajac przez ozonowa dziurę-przezroczysty, zapisany emanacyjnym tekstem zwój włożony w butelkę - argumentuje:

Proszę mnie poprawić, gdzie błądzę:

(1) albo butelka jest książka, albo

(2) książką jest zwój z butelki, a sama butelka [bez zwoju] jest liberacką nieksiążka, albo

(3) dzieło to, nazwane przez wydawcę „przykładem sztandarowym” liberatury, nie jest liberackie, albo

(4) zakres liberatury sięga poza książkę.

Ja bym chciał (4), ale sądzę, że teoretykowi najbezpieczniej będzie wybrać możliwość (1) - że książka może być butelką. Jeżeli jednak książka może być butelka, to dopytuję - czy książka może być dowolny obiekt materialny, który niesie albo zawiera jakikolwiek tekst? ${ }^{173}$

Przypomnę, że z takich właśnie powodów Fajfer uznawał, że samo pojęcie książi należy od nowa przemyśleć174. Ja - na razie na poziomie badawczej hipotezy, która w tej książce zostanie poddana weryfikacji - uznałabym, że (dla liberatów) książka rozumiana jako medium ich sztuki jest sposobem podania tekstu, wpływajacym na tegoż tekstu znaczenia. Innymi słowy - jak powiedzieliby badacze nowych mediów - jest interfejsem literatury, lecz rozumianym w duchu Manovichowskim: niepozostającym bez znaczenia dla odbioru dzieła, przyczyniajaccym

171 Warto tu dodać, że w pierwszych szkicach rzeczywiście nie wybrzmiewała ona aż tak silnie, choć zdecydowanie nie można powiedzieć, że była tam nieobecna. Muszę też przyznać, że przez długi czas i ja w swojej lekturze Fajferowskiej teorii prymat przyznawałam innym - wyraźniej, buńczuczniej przez artystę wyrażanym - aspektom dzieła liberackiego, choć autor tych szkiców wiązał je z samą postacią książki. Wyrazem takiego „zbłądzenia” było opracowane przeze mnie hasło 'liberatura' do Słownika rodzajów i gatunków literackich, czym być może przyczyniłam się i do cudzych, nie do końca właściwie rozkładających akcenty, interpretacji zjawiska. Por. Agnieszka Przybyszewska, Liberatura, „Zagadnienia Rodzajów Literackich” 2007, nr 50, s. 255258 (poprawiona wersja hasła w wydaniu książkowym Stownik rodzajów i gatunków literackich, red. Grzegorz Gazda, Słowinia Tynecka-Makowska, wyd. 2, Warszawa 2012).

172 Krzysztof Bartnicki, O liberaturze bez-wiednie, „Ha!art” 2010, nr 30, s. 91.

173 Ibidem.

${ }^{174}$ Nieco ironicznie - pokazując, że opisywane nowe podejście do kategorii książki, książkowości to raczej jeszcze ciagle work in progress - można by tu przywołać fragment opublikowanej na portalu Biura Literackiego recenzji Kolaży Herty Muller wydanych w 2013 r., w której czytamy: „Warto dodać, że jest to pierwsza książkowa publikacja kolaży w naszym języku. Jedyny wcześniejszy zbiór - Strażnik bierze swój grzebień - ukazał się nakładem korporacji ha! art w 2010 r. w edycji pudełkowej", http://www.biuroliterackie.pl/biuro/biuro.php?site=1A0\&news_ID=2013-04-18 [dostęp 1.07.2013], podkreślenia moje. 
się do tworzenia jego sensów (co będę rozwijać w rozdziale poświęconym relacji liberatury i nowych mediów, a także w zamykających tę książkę konkluzjach) ${ }^{175}$. Tym samym, staje się związana z tym, co Bazarnik (ale warto dodać, że nie jako jedyna) nazwała specyfika medium - dlatego też sugerowałam, że moja propozycja połączy dwie z proponowanych przez liberatów kategorii.

Co jednak najważniejsze - takie ujęcie pozwala usytuować liberaturę na tle równolegle z nią formułowanych (acz, warto podkreślić: nieco później niż ona artykułowanych) teorii zagranicznych. Z nich kluczowe wydają się: koncepcja technotekstu (technotext) Katherine Hayles (z której wyłania się właśnie postulat traktowania książkowej formy jako jednego z interfejsów literatury) oraz teoria estetyki ksiażkowości (aesthetic of bookishness) Jessiki Pressman, którą najkrócej definiuje sama autorka następującymi słowy:

To, co nazywam „estetyką książkowości” to pewien trend w powieściach publikowanych od 2000 roku. Nie ogranicza się on ani wyłącznie do powieści amerykańskich, ani w ogóle anglojęzycznych i jest - jak będę przekonywać - czymś więcej niż zwykłym zbiegiem okoliczności: wydaje się nową literacką strategią odpowiadającą na moment kulturowy, w którym jesteśmy. Takie powieści eksploruja potencjał drukowanej strony w sposób, który przyciaga uwagę do książki jako formatu multimedialnego [...]. Definiują one książkę jako formę estetyczna, której siła była przez stulecia celowo wykorzystywana przez sztukę słowa, co będzie miało też nadal miejsce w epoce dygitalnej ${ }^{176}$.

Do obu tych koncepcji - sformułowanych po pamiętnym dla liberatury 1999 r. ${ }^{177}$ - będę w tej książce nawiązywać.

Zaś - odpowiadając Bartnickiemu - muszę dodać, że w takim ujęciu książka jest nie tylko to, co „niesie i zawiera jakikolwiek tekst”, lecz to, co umożliwia nam obcowanie $\mathrm{z}$ tym tekstem i nie musi być wcale sprowadzone (jak czyni to autor Prospektu emisyjnego) do jego „pojemnika”178. Powiem więcej - o ile Fajferowską butelkę da się określić mianem (cokolwiek awangardowej), ale

175 Jak widać, traktuję książkę zarówno jako medium liberatury, jak i jej interfejs. Mając świadomość, że kwestia ta wymagałaby bardziej szczegółowej analizy (na którą tu nie ma już miejsca), niejako na swoją obronę, chciałabym przywołać tu opinię Piotra Celińskiego, który rozważając różnice między współczesnym zakresem używania obu tych terminów - zaznaczał, iż „w domenie mediów analogowych [a zatem i książek liberackich - AP] medium równa się interfejs”, gdyż w tym obszarze „obie kategorie są tożsame i nierozłączne” (Piotr Celiński, Interfejsy. Cyfrowe technologie w komunikowaniu, Wrocław 2010, s. 68).

176 Jessica Pressman, The Aesthetic of Bookishness in Twenty-First-Century Literature, „Michigan Quarterly Review", fall 2009, s. 467.

177 Dookreślenie to wydaje się istotne zwłaszcza w kontekście Pressman, której tezy publikowane były już w momencie domykania moich badawczych poszukiwań (przywołany artykuł pochodzi z 2009 r.) i stały się dla mnie potwierdzeniem, iż moje intuicje są nie tylko słuszne, ale i nieosamotnione. W dalszej części książki postaram się podkreślić także istotne, jak sądzę, różnice między proponowanym przeze mnie ujęciem a koncepcją badaczki. Warto tu przywołać też wpisującą się w ten sam krag badań publikację Lori Emerson Reading Writing Interfaces: From the Digital to the Bookbound, wydaną w momencie składania tej książki.

178 A warto też dodać, że liberaci po wielokroć powtarzaja, że książka nie jest zwykłą przezroczystą fiolka, w którą włożony jest tekst. Jakże inaczej w tym kontekście wybrzmiewa (zapisany na przezroczystej folii i umieszczony w szklanej butelce) tekst Spogladajac przez ozonowa dziurę... Jakże ironiczne to nabicie czytelnika w butelkę. 
jeszcze książki, o tyle już (przywoływany przez Bazarnik i Fajfera jako przykład liberatury) rozpisany na stojących na polanie 48 kamiennych słupach poemat Andrzeja Bednarczyka Pole anielskich szeptów (zob. ilustracja 4) ${ }^{179}$ trudno już tak zakwalifikować ${ }^{180}$. To, co wspólne dla tych dzieł - a także dla liberackich mniej lub bardziej klasycznych książek - to zwrócenie przez ich autorów uwagi na rodzaj medium, jakim się posługują. Kluczowe jest tu wręcz nie tyle skupienie się na materialności, o którym mówili Fajfer czy Bazarnik, lecz aktywizowanie rozmaitych cech materialnego nośnika, jakim się artyści posługują i - co za tym idzie - dostrzeżenie w książce materialnej technologii literatury (tak chyba należałoby rozumieć kategorię media-specyfic pojawiająca się nie tylko w wywodzie Bazarnik, ale też choćby u Hayles i Pressman). Dzieło konstruowane jest wtedy w dużej mierze w oparciu o takie aspekty medium, które w klasycznej literaturze najczęściej zostałyby niewydobyte. Warto dodać, że angażowanie jakości grafemicznych pisma (owocujące wizualnościa literatury) jest tu jednym z najprostszych rozwiązań.
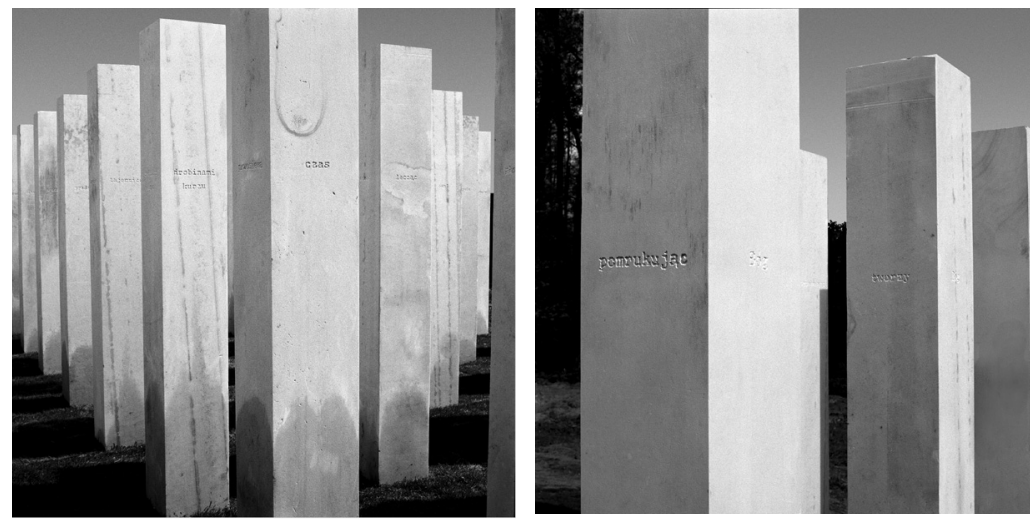

Ilustracja 4. Andrzej Bednarczyk, Pole anielskich szeptów (źródło: zdjęcia własne autora)

Drugi problem, jaki pojawi się wraz z próbą konsekwentnego sformułowania teorii liberatury, to ciagłe spory o to, co liberatura jest, a co nie. Oka-leczenie Fajfera i Bazarnik czy Ulica Sienkiewicza $w$ Kielcach Nowakowskiego sa nią z pewnościa, Bazarnik twierdzi jednak, że liberacki jest Joyce, Mallarmé, Blake... Gdyby się zastanowić - Norwidowskie czy Różewiczowskie operowanie grafią tekstu również mogłoby nas skłonić do określenia tych twórców mianem

${ }_{179}$ Praca ta, dostępna w muzeum sztuki w Orońsku to kamienny hipertekst - poemat o aniołach rozpisany na poszczególnych ścianach słupów. Na każdej z nich znajduje się jedno słowo, a chodząc między słupami wyznaczamy własne ścieżki lektury. Nie bez znaczenia pozostaje też usytuowanie tekstu w przestrzeni (kierunki świata).

${ }^{180}$ A problematyczna jest przecież też kwestia zaliczanej (przynajmniej w większości sytuacji) przez Fajfera i Bazarnik do liberatury poezji wizualnej (nie zawsze zebranej w książce!) oraz tzw. e-liberatury, która postaci materialnego woluminu w ogóle nie przybiera. O wskazywanych tu problemach piszę w dalszej części pracy. 
liberatów ${ }^{181}$. Może jednak czas położyć kres dyskusjom o tym, kto liberaturę tworzy, a kto nie. Spory te w większości sytuacji sa jałowe i nie prowadzą do żadnych konstruktywnych wniosków. Ot, okazuje się, że jedne utwory są bardziej, a inne mniej liberackie. I, wbrew oczekiwaniom Bazarnik, termin Fajfera nie wydaje się tak prosty w zastosowaniu, gdyż jego autor wcale nie wskazał „na konkretne cechy, pozwalające na wyodrębnienie grupy utworów na podstawie obiektywnych kryteriów” 182 . Przypomnę, że obiektywnie nie da się wskazać przykładów literatury totalnej zgodnie z ostatnią badawczą propozycją Bazarnik.

Stąd sądzę, iż sensowniej niż o liberaturze byłoby mówić o liberackim aspekcie dzieła, co nie tylko zwolniłoby nas z obowiązku wyznaczania wyraźnych granic tego rodzaju twórczości słowa, lecz pozwoliłoby również porównywać ze sobą teksty, których autorzy w różnym stopniu wykorzystywaliby potencjał drzemiacy $\mathrm{w}$ medium ${ }^{183}$.

Podsumowując: sugerowałabym wprowadzenie jako terminu nie pojęcia liberatura, lecz określenia liberacki stosowanego do opisywania tekstów literackich jawnie eksplorujących swoją medialność, nietraktujacych (by posłużyć się metaforami używanymi przez twórców pierwotnego terminu) słów jako neutralnych pojemników na sens, a zdań - czy nawet większych jednostek, czy też całego utworu - jako równie przezroczystych futerałów na słowa. Termin ten pozwalałby wyróżnić z całokształtu twórczości literackiej - od jej najstarszych, antycznych form, do tych najmłodszych, elektronicznych, nowomedialnych - grupę tekstów o podobnym charakterze. Jednocześnie, jego przymiotnikowy, stopniowalny charakter chroniłby nas przed dosłownym wrzucaniem do jednego worka dzieł, takich jak Maty Ksiaże, Finnegans Wake, Kaligramy, Spogladajac przez ozonowa dziurę czy Wejście/Wyjście. I znów - taka perspektywa wydaje się też trafnie dialogować z ogólnoświatowymi dyskusjami, pokazuje polską koncepcję jako o tyle sprawniejszą i użyteczniejszą niż choćby te proponowane przez Hayles czy Pressman, że jeszcze silniej niż one pozwala podkreślić ponadmedialną i ponadhistoryczną wspólnotę pewnych tendencji ${ }^{184}$.

181 Por. Witold Sadowski, Wiersz wolny jako tekst graficzny, Kraków 2004 (nie tylko w odniesieniu do wspomnianych przeze mnie twórców).

182 K. Bazarnik, Liberatura: ikoniczne..., s. 24.

${ }^{183} \mathrm{Na}$ użyteczność wprowadzenia przymiotnikowej formy terminu zwracał Bazarnik uwagę Finn Fordham w prywatnej korespondencji, podkreślając, że jeśli chce ona uwypuklić analogię tego pojęcia do genologicznych określeń liryka, epika, dramat (ang. lyric, epic, dramatic), taki kształt terminu wydaje się atrakcyjniejszy. Zob. K. Bazarnik, Liberature: a New Literary Genre?, s. 199. Zaś jeśli Bazarnik upiera się przy traktowaniu liberatury jako kategorii genologicznej, może warto byłoby tu przywołać koncepcję Emila Staigera, która, w moim odczuciu, do mówienia o liberaturze mogłaby być inspirująca. Gdybym uznała, że traktowanie literatury totalnej jako kategorii genologicznej jest zasadne, pewnie właśnie do Grundbegriffer de Poetik bym się odwoływała. Por. S. Wysłouch, Nowa genologia..., s. 108-109.

184 Szczególnie wyraźnie widać to w zestawieniu z Pressman, ograniczającą się wyłącznie do formy powieściowej (czego przyczyny zresztą wyjaśnia). Jej propozycja silnie też związana jest ze współczesnościa, choć badaczka akcentuje później, że „estetyka książkowości jest tak stara, jak sama forma książki” (J. Pressman, The Aesthetic of Bookishnes..., s. 466). Niemniej, kategoria liberackości wydaje się bardziej ahistoryczna. 
Kolejne rozdziały tej pracy, zebrane w część zatytułowaną Szukanie liberatury, pomyślane są jako szukanie liberackości w (rozmaicie medialnych) przestrzeniach sztuki słowa dotychczas wskazywanych jako związane z literaturą totalną lub takiego wskazania się dopraszające. Mało które z tych wskazań zostało poparte rzeczowymi rozważaniami, stąd sądzę, że takie spojrzenie jest istotne. Żywię przekonanie, że przedstawione analizy i porównania pozwola z jednej strony zweryfikować, czy zaproponowane przeze mnie ujęcie sprawdzi się w praktyce, z drugiej - czy ono i cała koncepcja liberatury sa potrzebne, czy istotnie zaproponowana już ponad dziesięć lat temu kategoria pozwala uchwycić jakości literatury, dla których opisania nie mamy innego terminu (i czy taki opis jest pożądany). Jednocześnie, mam nadzieję, że szukając liberackości zdołam zbliżyć się też do odpowiedzi na pytanie, skąd bierze się potrzeba tworzenia takich utworów oraz co takiego zmieniło się w kulturze, że teoria liberacka doczekała się sformułowania.

Nim przejdę do wskazanych tu zagadnień, chciałbym podkreślić, że nie zajmuję się pojęciem które zaproponowane w 1999 r. przeszło bez echa. O liberaturze „mówi się”. Jak i gdzie - charakteryzuję pokrótce w kolejnym, dotyczacym recepcji omawianej tu teorii fragmencie. 



\section{O szerzeniu (i odbiorze) teorii i praktyki}

\subsection{Dyskurs in progress}

Można powiedzieć, że minione piętnastolecie (zwłaszcza zaś jego pierwsza dekada) przyniosło fundujace dyskusję o liberaturze teksty oraz ich rozwinięcie. Termin raczej przyjął się i - choć nie wywołał wielkich dyskusji - nie ma chyba potrzeby wieszczyć mu krótkiego żywota, zważywszy na to, że coraz częściej bywa używany w tekstach czy rozmowach. O ile, kiedy w 2002 r. w Universitasie ukazywała się zredagowana przez Bazarnik pozycja Od Joyce'a do liberatury ${ }^{185}$ to ostatnie słowo często postrzegane było jeszcze jako literówka, o tyle dziś pojawia się w wypowiedziach badaczy, krytyków czy czytelników jako zadomowiony już w refleksji humanistycznej termin. Co ważne - liberatura stała się kontekstem przywoływanym nie tylko przy analizach zwiąków słowa i obrazu (jak np. marginalnie u Beaty Śniecikowskiej ${ }^{186}$ przy okazji charakterystyki działań awangardowych czy już nie marginalnie - jako przykład współczesnego tekstu wizualnego u Małgorzaty Dawidek Gryglickiej ${ }^{187}$ ), lecz również w odniesieniu do najnowszej sztuki, także w jej interaktywnej odmianie (jak - marginalnie - u Ryszarda Kluszczyńskiego w kontekście dyskusji z Zimmermanowskim pojęciem interaktywności ${ }^{188}$ czy u Katarzyny Prajzner w kontekście - inspirowanych teorią cybertekstu - rozważań o książkowych interfejsach ${ }^{189}$ ). Warto tu - wykraczając poza granice pierwszej dekady refleksji liberackiej - zaznaczyć też (a będę o tym pisać i później), że od 2013 r. literatura totalna stała się również punktem odniesienia dla światowych dyskusji o e-literaturze - a to dzięki zaistnieniu w wystapieniach (oraz towarzyszacym im dyskusjach) polskich

${ }_{185}$ Tej chyba książce należałoby przyznać status „pierwszej poważnej pozycji”; dostępna już w trzy lata po ogłoszeniu manifestów Fajfera, już samym tytułem sytuuje liberaturę w kontekstach ważkich problemów literaturoznawczych. Przez wiele lat szczyciła się też opinią najpełniejszego omówienia zjawiska (por. Beata Śniecikowska, Stowo-obraz-dźwięk. Literatura i sztuki wizualne w koncepcjach polskiej awangardy 1918-1939, Kraków 2005, s. 79).

186 Zob. B. Śniecikowska, Stowo-obraz-dźwięk..., przypis 103 na s. 72 (w odniesieniu do Czyżewskiego), przypis 121 na s. 79 (w kontekście poezjografii Strzemińskiego) oraz s. 412.

187 Zob. Małgorzata Dawidek Gryglicka, Historia tekstu wizualnego. Polska po 1967 roku, Kraków 2012.

188 Zob. Ryszard W. Kluszczyński, Sztuka interaktywna. Od dzieła-instrumentu do interaktywnego spektaklu, Warszawa 2010, s. 168-169.

189 Katarzyna Prajzner, Tekst jako świat i gra. Modele narracyjności $w$ kulturze współczesnej, Łódź 2009, s. 143-145. 
i zagranicznych (!) prelegentów podczas dwóch konferencji Electronic Literature Organization ${ }^{190}$.

Od 1999 r. wyznaczono zatem spektrum problemów związanych z kategorią liberackości: kwestię nie-neutralności sposobu zapisu tekstu literackiego, potencjalną nośność semantyczną materiałowego nośnika utworu, znaczaca postać samego tomu jako medium literackiego, problematyczną kwestię liberackiej odrębności genologicznej. Z czasem do głównych tematów poruszanych w dyskusji dołączyły: ikoniczność jako cecha liberatury, próby śledzenia historii zjawiska, problem medialności (a także cechy nazwanej przez Bazarnik specyfikq medium ${ }^{191}$ ) i intermedialności oraz definiowania literatury totalnej w kontekście nowych mediów (to ostatnie szczególnie po opublikowaniu liberackiej powieści hipertekstowej Koniec świata wedtug Emeryka Nowakowskiego ${ }^{192}$ ). Większość z nich to tematy, które ciagle jeszcze wymagają wielu dopowiedzeń. Dopiero teraz liberacka refleksja zaczyna na poważnie odnosić się do Ingardenowskich rozważań o znaczących i nieistotnych semantycznie elementach tekstu literackiego ${ }^{193}$. W dyskusjach powoli też dochodzą do głosu przywołania twierdzeń teoretyków spod znaku archeologii mediów (co pozwala łatwiej dostrzec ciagłość i logikę historii liberatury). A przecież - jak wskazywałam - na wpół poważny Nowakowski jawnie zapraszał do dyskusji choćby z Ongiem. Gdyż chyba nie bez powodu idea liberatury narodziła się właśnie teraz, po zwrocie ikonicznym i performatywnym, w dobie określanej mianem zmierzchu Galaktyki Gutenberga ${ }^{194}$, na który - jak ujmuje to Jakub Żuchowski - liberatura mogłaby być swoistym antidotum ${ }^{195}$.

Zaczynają też pojawiać się pojedyncze teksty analizujące nie takie proste relacje między liberaturą a książką artystyczną ${ }^{196}$, literaturą wizualną ${ }^{197}$ czy

190 Mam tu na myśli paryską konferencję z września 2013 r. (gdzie liberatura pojawiła się jako ważny kontekst w wystapieniu Anny Nacher oraz moim) oraz czerwcową w Milwaukee z roku 2014 (gdzie o liberaturze wspominał Nick Montfort, co ważne o tyle, że na tej samej konferencji prezentowała swoje tezy również Jessica Pressman).

191 K. Bazarnik, Liberatura czyli o powstawaniu gatunków (literackich), s. 161.

${ }_{192}$ O związkach tych pisałam także i ja, m.in. w szkicach: Liberackie marginesy tekstu sieciowego, [w:] Tekst (w) sieci, red. Anna Gumkowska, t. 2, Warszawa 2009, s. 177-186; Nowa? Wizualna? Architektoniczna? Przestrzenna?... oraz Daleko czy jednak blisko? O tym co łaczy liberatów i e-literatów, [w:] Od liberatury do e-liberatury.

193 Por. przypis 164.

${ }^{194}$ Choć - jak pokażę w końcowych rozdziałach tej książki - charakterystyki współczesności silniej akcentujące rolę użytkowników/uczestników kultury (kultura uczestnictwa, kultura konwergencji) stanowią równie dobry (a chwilami i lepszy) punkt odniesienia.

195 Ukończona w 2006 r. praca magisterska tegoż autora (Liberatura-antidotum na ,zmierzch Galaktyki Gutenberga”) została wyróżniona w II Konkursie PTWK im. Leona Marszałka.

${ }^{196} \mathrm{Z}$ wymienionych problemów ten wydaje się najszerzej dotychczas opisany, zob. m.in.: K. Bazarnik, Liberatura: ikoniczne oka-leczenie literatury oraz eadem, Liberatura czyli literatura $w$ formie ksią̇̇ki, a także Zenon Fajfer, Jak liberatura redefiniuje ksiȧ̇kę artystyczna (fragment), [w:] LCLT, s. 134-140.

197 Zwracają na to uwagę Fajferowie w licznych tekstach, również w zamieszczonej na stronie www.liberatura.pl historii liberatury (przedruk mniej aktualnej niż obecna wersji tego szkicu zatytułowany Krótka historia liberatury zob. LCLT, s. 85-92; szkic miał również anglojęzyczną publikację w broszurce przygotowanej przez Fajfera i Bazarnik na 5. Symposium in Iconicity in 
komiksem ${ }^{198}$ lub też twórczością spod znaku Oulipo ${ }^{199}$. Wciąż trzeba jeszcze czekać na wiele dopowiedzeń odnośnie do porównań z poezją konkretna czy literaturą elektroniczną (a nie brak wśród światowych badaczy przecież i takich, którzy w poprawnie definiowanej literaturze elektronicznej dostrzegaja jawne przedłużenie działań awangardowych, ludzi traktujących jedno i drugie jako „praktykę bazującą na materialności medium” ${ }^{200}$ ). W książce tej podejmuję większość wymienionych tu wątków.

\subsection{Naukowe rozmowy nie tylko w kuluarach}

O liberaturze mówi się w środowiskach akademickich i to nie tylko przy okazji dyskusji po spotkaniach promocyjnych, w pojedynczych szkicach czy nielicznych większych rozprawach. O ile początkowo zagadnienie pojawiało się sporadycznie przy okazji różnych konferencji (np. w wygłoszonym podczas konferencji w 2004 r. w Łodzi referacie Piotra Mareckiego Polska literatura najnowsza - poza kanonem czy w kolejnym roku choćby w moich referatach na VIII Tygodniu Polonistów w Lublinie oraz olsztyńskiej konferencji Wielość sztuk-jedność sztuki. Wokót granic interakcji sztuk), o tyle z czasem zaczęło dopraszać się o bardziej centralne miejsce w dyskusji. Rok 2005 przyniósł dwie naukowe sesje, w których liberatura stała się tematem niebagatelnym - mam tu na myśli przede wszystkim połaczony z wystawa poematów-znaków Fajfera panel dyskusyjny (z udziałem m.in. Fajfera, Bazarnik, Mareckiego, a także piszącej te słowa) zorganizowany przez poznańską ASP w październiku 2005 r. (którego pokłosiem była wspominana już tu książka pod redakcją Dawidek Gryglickiej), a także zorganizowane przez Uniwersytet Jagielloński we współpracy z ośrodkami z Zurychu i Amsterdamu V Sympozjum Iconicity in Language and Literature (które zaowocowało późniejszymi publikacjami zarówno w języku polskim, jak i angielskim ${ }^{201}$ ). To na jego potrzeby stworzono również anglojęzyczną broszurę Liberature, wydaje się też, że konferencja ta przyczyniła się do pogłębienia refleksji o liberaturze w kontekście ikoniczności.

Language and Literature: Zenon Fajfer, Katarzyna Bazarnik, A Brief History of Liberature, [w:] Liberature, Kraków 2005, s. 12-23).

198 Jakub Żuchowski James Joyce versus Koziołek Matołek albo Święty Franciszek kontra

Tarzan. O zwiazkach liberatury i sztuki komiksu, „Ha!art” 2007, nr 27, s. 148-155.

199 W minimalnym stopniu porusza tę kwestię Fajfer w szkicu Od kombinatoryki do liberatury.

O nieporozumieniach zwiazanych z tzw. „literaturq eksperymentalna”, [w:] Raymond Queneau, Sto tysięcy miliardów wierszy, tłum. Jan Gondowicz, Kraków 2008. Podobnie problem jest sygnalizowany (nie: szeroko omawiany) w tekście Perec i liberatura. Nota redaktorów serii, [w:] Georges Perec, Życie. Instrukcja obsługi, tłum. W. Brzozowski, Kraków 2009. Głębsze analizy przynosi tom Perec instrukcja obstugi, Kraków 2010 (pod żartobliwą redakcją Conica Chessmastera).

${ }^{200}$ Loss P. Glazier, Digital Poetics. The Making of E-Poetries, Tuscaloosa 2002. Zob. też.:

K. N. Hayles, Electronic Literature... oraz przywoływany szkic Daleko czy jednak blisko?... . 201 Przywoływane już Insistent Images... oraz Ikoniczność znaku... . 
Akademickie zainteresowanie liberaturą jest na tyle duże, że jej twórcy i teoretycy zapraszani są z odczytami w wiele różnych miejsc ${ }^{202}$. Podczas lubelskiej e-polonistyki 2 (w 2009 r.) zarówno Fajfer, jak i Nowakowski zostali poproszeni o zabranie głosu. Niezwykle ważną rolę odgrywają tu oczywiście zagraniczne wystapienia promujące polską koncepcję. I tak, w czerwcu 2009 r. Fajfer i Bazarnik prezentowali swoją teorię w Bristolu podczas konferencji Traditional and emerging formats of artists' books: Where do we go from here?, zaś rok później podczas konferencji Displaying Word and Image (Belfast) Bazarnik koordynowała cały panel poświęcony liberaturze. Wyręczając dwójkę polskich artystów, Emiliano Ranocchi prezentował koncepcję liberatury (oraz Primum Mobile Fajfera) na odbywającej się w kwietniu 2010 r. w Instytucie Polskim w Rzymie konferencji Awangarda XXi XXI wieku ${ }^{203}$.

Wychodząc jeszcze mocniej poza ramy pierwszej dekady, trzeba przywołać wrzesień i październik 2011 r. oraz tournée po Stanach Zjednoczonych, jakie odbyli wtedy Fajfer i Bazarnik, wygłaszajac odczyty, prowadząc warsztaty i promując nie tylko twórczość własna, ale i całą liberacką serię $e^{204}$. Ze względu na przełomowy charakter niektórych wydarzeń związanych z tym wyjazdem, będę się jeszcze w tej książce do nich odnosić, przekraczając początkowo przyjęte przeze mnie ramy czasowe ${ }^{205}$. Tu warto zaznaczyć, że zawiąane wtedy kontakty owocują dla literatury totalnej po dziś. Przykładów nie trzeba daleko szukać - z jednej strony liberaci pozostają w kontakcie z profesor Kathleen Walkup (opiekunka innowacyjnego kursu Creative Writing and Bookmaking w Mills Collage), która była inspiratorka zaproszenia ich do USA i pracuja z nią nad kolejnymi projektami, zaś z drugiej - poznany wtedy Shinsuke Takasaki był gościem festiwalu ha!wangarda w 2013 r. Dodam, że kolejne miesiące przyniosły jeszcze promocję liberatury i naukowe dyskusje na Tajwanie (podczas mającego miejsce w listopadzie i grudniu 2011 r. Taipei Poetry Festival, gdzie zorganizowano cały panel LIBERATURA: Creative Publishing and Poetics ) i w Japonii (w związku z wykładem Bazarnik w uniwersytecie w Tokyo) ${ }^{206}$.

Jednocześnie w Polsce liberatura pojawiła się także jako jeden z głównych tematów konferencji - dość przypomnieć zorganizowaną przez Uniwer-

${ }^{202}$ Wymieniam tu zdarzenia inne niż dyskusje towarzyszące promocji książek liberackich czy spotkania o kameralnym charakterze. Te pomniejsze, w uzasadnionych wypadkach, przywołuję jednak w poszczególnych rozdziałach tej pracy.

${ }^{203}$ Z kolei w maju tego roku Fajfer i Bazarnik gościli na łódzkiej konferencji Futuryzm. Przyszłość sto lat później. Nie uważam jednak, by to ich wystapienie należało uznać za wnoszące coś do rozwoju refleksji liberackiej. Szerzej piszę o tym w rozdziale poświęconym relacji liberatury i futurystycznej typografii.

${ }^{204}$ Liberaci gościli wtedy w Nowym Jorku (w ramach Brooklyn Book Festival oraz Dumbo Arts Festival; we współpracy z Instytutem Kultury Polskiej oraz galerią Central Booking Gallery), Chicago (w ramach festiwalu After Miłosz) oraz w Oakland (w Mills College).

205 Zobacz część poświęcona relacji liberatury i książki.

206 Więcej o tych wydarzeniach zob. http://ha.art.pl/wiadomosci/2134-katarzyna-bazarnik-izenon-fajfer-na-tajwanie-i-w-tokio.html [dostęp 30.06.2014]. 
sytet Opolski w listopadzie 2009 r. sesję Od liberatury do e-literatury, na która zaproszono Fajfera i jego małżonkę z prezentacjami. Oboje uczestniczyli też w drugiej edycji tej konferencji w maju $2011 \mathrm{r}$.

Warto może też podkreślić, że zjawisko staje się nieraz przedmiotem wybranych zajęć z najnowszej literatury polskiej, a w niektórych uczelniach (np. w Uniwersytecie Jagiellońskim czy Łódzkim) prowadzone były też oddzielne kursy fakultatywne poświęcone (już wyłącznie) liberaturze ${ }^{207}$. Jak dodaje odwiedzająca zagraniczne ośrodki Bazarnik:

Uczą [o niej - AP] nie tylko na uczelniach polskich - także na University of the West of England w Bristolu, Kunst und Design Akademie w Genk w Belgii (nawet przywieźli studentów do Czytelni), a wkrótce będzie w Mills College w Oakland w USA ${ }^{208}$.

Zapowiadana dopiero w tej wypowiedzi współpraca z Mills College (związana z przywołanym wyjazdem artystów do USA) jest tu niezwykle znacząca. Z jednej strony wspomniana już Walkup mówi na swoich kursach o koncepcji literatury totalnej już od 2009 r., z drugiej poprowadzone przez Fajfera i Bazarnik w październiku 2011 r. warsztaty Liberature or Writing of the Book zaowocowały wydanym w 2012 r. w liberackiej serii tomem Sonnet of Sonnets. To kolejne fakty dowodzace, że zrodzona pod koniec zeszłego tysiąclecia nad Wisłą koncepcja idealnie trafia w dzisiejsze potrzeby humanistyki.

\subsection{Liberatura w Polsce i na świecie}

Zaznaczyć trzeba jednak, że liberatura jako sztuka słowa stała się pożywką nie tylko dla krytyków i teoretyków, lecz przede wszystkim dla czytelników. Mniej czy bardziej naukowym rozważaniom na jej temat nieustannie towarzyszył pomysł (i zapał) promowania idei na całym świece, udostępniania tekstów liberackich coraz większemu gronu odbiorców (co zważywszy na to, że dość często są to unikatowe egzemplarze - wcale nie jest zadaniem łatwym). Niebagatelne było tu znaczenie dwóch (krakowskich) instytucji - Korporacji Ha! art! oraz Małopolskiego Instytutu Kultury.

Choć założycielski liberacki manifest ukazał się na łamach „Dekady Literackiej”, kolejny zaś w „FA-arcie” (podobnie jak i pierwsze recenzje liberackich tekstów), to właśnie krakowski „Ha!art” jako pierwszy poświęcił więcej miejsca nowemu na gruncie polskiej literatury zjawisku. W dwóch pierwszych numerach czasopisma z 2003 r. pojawił się szereg artykułów o liberaturze, zaś sami Fajfer i Bazarnik byli głównymi bohaterami jednego z nich. Oddzielny dział „Liberatura” powrócił jeszcze w 2007 r. (w numerze 27.), by w roku 2009 (jak dotąd w jednym tylko przypadku) rozwinąc się $\mathrm{w}$ samodzielny dodatek

${ }^{207} \mathrm{~W}$ kontekście dalszych rozważań warto podkreślić, że uczestnikami tych zajęć byli m.in. studenci specjalności twórcze pisanie.

${ }^{208}$ W prywatnej korespondencji z badaczką. Por. też www.liberatura.pl 
o takim samym tytule. Trzydziesty numer czasopisma, wydany na dziesięciolecie liberatury, był jej poświęcony niemal w całości ${ }^{209}$.

Co więcej - to pod skrzydłami „Ha!artu!” powstała seria wydawnicza $L i$ beratura, której redaktorami są Fajfer i Bazarnik. Ci ostatni dumnie twierdzą o niej, że jest „całkowicie oryginalnym przedsięwzięciem, dodając, że przedsięwzięciem już docenionym, dzięki czemu w tym roku [2010 - AP] wydamy tyle, ile przez te wszystkie lata razem wzięte" ${ }^{210}$. Co ważne - nie jest to samochwalcza i odosobniona opinia. Na łamach „Przeglądu” Leszek Bugajski, oceniając rok 2008, stwierdzał:

Pereł w minionym roku zbyt wiele w kulturze nie było, zwłaszcza zaś trudno dostrzec je w literaturze [...] Ale na prawdziwa perłę wyrosło wydawnictwo ha!art - nie z powodu nowej prozy, którą drukuje, ale dlatego, że konsekwentnie szuka ciekawych i zwariowanych zjawisk na obrzeżach literatury (scenariusz Stanisława Czycza „Arw”, „Sto tysięcy miliardów wierszy” Raymonda Queneau, powieść B. S. Johnsona) i tym samym rozwija chyba najbardziej zaskakująca serię wydawnicza, jaką jest u nas ich „Liberatura”11.

I rzeczywiście, znaczne dotacje Ministerstwa Kultury i Dziedzictwa Narodowego pozwoliły w ramach wspomnianej serii wydać dotychczas kilka nad wyraz interesujących pozycji, dość wspomnieć pierwsze (nie tylko polskie, ale i światowe) tłumaczenie książki Strażnik bierze swój grzebień Herty Müeller (o której Fajfer i Bazarnik, ale - jak z radością opowiadaja - i sama autorka, mówią: „liberacka”) czy Finneganów tren.

Pierwszy przynależny do serii tom $((O)$ patrzenie autorstwa samych redaktorów) dodany był jeszcze do wspomnianego „czarnego” „Ha!artu” z 2003 r., pozostałe funkcjonowały już od początku jako teksty niezależne: książki niekoniecznie konwencjonalnie wydane - oprawione w butelki, z pociętymi stronami czy wysypujące się z pudełek - jednak dostępne szerokiemu gronu odbiorców. Dziś na serię składa się już ponad dwadzieścia tomów (z których niemal połowę wydano w 2010 r.) i trwają intensywne prace nad kolejnymi pozycjami ${ }^{212}$.

${ }^{209} \mathrm{~W}$ nim też, jak wspominałam we wstępie, zamieszczono kalendarium liberatury.

${ }^{210} \mathrm{Z}$ prywatnej korespondencji z autorami.

$211 \mathrm{http} / / /$ www.przeglad-tygodnik.pl/index.php?site=kultura\&name=336 [dostęp 30.08.2010].

${ }^{212}$ Kolejne pozycje serii to: Zenon Fajfer, Katarzyna Bazarnik, (O)patrzenie (2003, 2009), Zenon Fajfer, Spoglądajac przez ozonowa dziurę (2004, 2009), Stéphane Mallarmé, Rzut kośćmi nigdy nie zniesie przypadku (2005), Stanisław Czycz, Arw (2007), Bryan Stanley Johnson, Nieszczęśni (2008), Raymond Queneau, Sto tysięcy miliardów wierszy (2008), Georges Perec, Życie instrukcja obstugi (2009), Z. Fajfer, K. Bazarnik, Oka-leczenie (2009), Perec instrukcja obstugi (2010), Z. Fajfer, dwadzieścia jeden liter (2010), Z. Fajfer, ten letters (2010), Z. Fajfer, Liberatura czyli literatura totalna. Teksty zebrane z lat 1999-2009, red. Bazarnik (2010), Paweł Dunajko, [bez tytułu] (2010), Krzysztof Bartnicki, Prospekt emisyjny (2010), Herta Müller, Strażnik bierze swój grzebień (2010), Raymond Federman, Podwójna wygrana jak nic (2010), Bryan Stanley Johnson, Przełożona w normie. Komedia geriatryczna (2010), James Joyce, Finneganów tren (2012), Katarzyna Bazarnik, Zenon Fajfer \& Mills College students, Sonnet of Sonnets (2012), Robert Szczerbowski, Antologia (2013), Dariusz Orszulewski, Jezus nigdy nie byt tak blady (2013), Nick Montfort, Zegar światowy (2014). 
Czy można ją określić mianem spójnej? Zasadniczo - poza liberackością (liberackim przypadkiem?) pewnie trudno znaleźć tu jeden klucz. Niemniej różnorodność taka w gruncie rzeczy wcale nie okazała się zła. Z jednej bowiem strony w obrębie serii wydane zostały teksty, które nigdy wcześniej nie ukazały się w polskim przekładzie (np. Sto tysięcy miliardów wierszy Queneau) oraz takie, które wydawane już były, jednak zła edycja zaburzała ich komunikatywność (m.in. Rzut kośćmi nigdy nie zniesie przypadku Mallarmégo), z drugiej zaś - utwory, których nie chcieli przyjać zwykli wydawcy, a które dla historii liberatury odegrały znacząca rolę (jak inspirujace jej powstanie Oka-leczenie duetu Fajfer-Bazarnik). W efekcie - obok dzieł znanych i zaliczanych do klasyki - pojawiły się teksty tajemnicze, nowe bądź niepopularne, co pokazało, że termin liberatura nie ma charakteru wartościujaccego ani też historycznego i że liberackie mogą być zarówno teksty złe czy nijakie, jak i dobre, a wręcz świetne, utwory sprzed roku 1999 oraz napisane już po nim. Ten ostatni fakt, poparty pojawianiem się liberackich analiz tekstów „poważnych”, „starych” i przynależących do kanonu (jak zaproponowane przez Zbigniewa Władysława Solskiego odczytanie Kartoteki Różewicza $\left.{ }^{213}\right)$, pokazuje, że termin rzeczywiście wydaje się przydatny do opisu pewnych nurtów i tendencji w sztuce słowa (których korzenie sięgają starożytności, a nie 1999 r.). Trzeba tė̇ jednak pamiętać, że zdarza się, iż liberaturę (i to nawet tę jak najbardziej stuprocentowo liberacka) wydaje się poza „Ha!artem” i jego seria - przykładem nie tylko Ulica Sienkiewicza w Kielcach Radosława Nowakowskiego wydana przez kieleckie BWA, ale i tomik Powieki Fajfera (2013), za którym stoi szczecińskie wydawnictwo Forma ${ }^{214}$.

Inna z kolei instytucja, Małopolski Instytut Kultury, stoi za otwartą 8 października 2002 r. Czytelnią Liberatury, początkowo mieszczącą się w Krakowie pod adresem Stary Rynek 25, później przy ulicy Karmelickiej 27. Obecnie Czytelnia jest częścią Arteteki Wojewódzkiej Biblioteki Publicznej w Krakowie i tym samym znajduje się w nowoczesnym budynku przy ulicy Rajskiej 12 . To tam można znaleźć nie tylko wiele dzieł liberackich z całego świata, lecz również większość dotychczas opublikowanych tekstów o liberaturze. Na księgozbiór zaś składają się prywatne książki Fajfera i Bazarnik, dary twórców i zainteresowanych zjawiskiem oraz teksty dodatkowo zakupione przez Instytut (m.in. z dofinansowania Ministerstwa Kultury i Dziedzictwa Narodowego dla projektu Wstap do Liberatury). Małopolski Instytut Kultury jest również częstym partnerem licznych spotkań promujacych liberaturę. Pod jego patronatem działa też strona internetowa www.libertura.pl.

$\mathrm{Na}$ tejże zaś znaleźć można ciągle aktualizowane kalendarium i bibliografię liberacka (choć owo wieczne dopisywanie skutkuje - co naturalne dla tego typu działań - dość roboczym charakterem całości), elektroniczne wersje

${ }^{213}$ Zbigniew W. Solski, Tadeusz Różewicz w sieci. Od liberatury do e-dramatu, [w:] Od liberatury do e-literatury, s. 283-294.

${ }^{214}$ Choć warto zaznaczyć, że mimo tej instytucjonalnej rewolty „ojca założyciela”, Powieki były promowane na ha!wangardzie. 
części tekstów teoretycznych, przydatne adresy, rekomendacje książek liberackich, a także zarchiwizowane poświęcone liberaturze Czytańce Bogdana Zalewskiego, prezentowane wcześniej w cyklu Między słowami w radiu RMF Classic.

Być może coraz intensywniejsze ostatnio działania promocyjne, być może rzeczywista waga zjawiska, spowodowały, że zainteresowały się nim nie tylko środowiska akademickie, lecz również nauczyciele. W lutym 2009 r. na łamach „Polonistyki” (w której zamieszczono przy tej okazji szkic Łukasza Jeżyka o Spogladajac przez ozonowa dziure Fajfera ${ }^{215}$ ) postulowano, by zaliczyć tegoż liberata do grona istotnych dla młodej literatury twórców, w samych zaś działaniach liberackich dostrzec udział w „kształtowaniu nowego modelu poetyckiego" 216 .

Co zaś dzieje się poza granicami? Sami Fajferowie niejednokrotnie przywoływali słowa Richarda Kostelanetza: „yes, the concept of liberature is useful" wypowiedziane, gdy otrzymał on książkę Od Joyce'a do liberatury217. O zagranicznych konferencjach i sympozjach, na których mówi się o liberaturze już pisałam. Trzeba tu też przypomnieć duński kwartalnik literacki „Den Blå Port”, który już w 2008 r. pokusił się o przekład manifestu Fajfera, wzbogacony wtedy przez autora komentarzem dla zagranicznego czytelnika oraz podkreślić, że związana z filologia angielską Bazarnik często właśnie poza granicami kraju o liberaturze opowiada, czy zaznaczyć, że i późniejszym (marginalnie tu wspominanym) zagranicznym prelekcjom towarzyszyły publikacje (o mniej lub bardziej naukowym charakterze) w tamtejszej prasie.

Jak już zaznaczałam, przywołując liberackie tournée po Stanach Zjednoczonych z 2011 r., wykroczyłam poza ramy czasowe, które wyjściowo wybrałam dla moich rozważań, motywując tę decyzję przełomowym charakterem zdarzeń, które miały podczas tego wyjazdu miejsce oraz jego daleko idacymi konsekwencjami. Ten sam rok zaowocował jeszcze jednym eventem, o którym chciałabym jednak wspomnieć: udziałem Bazarnik i Fajfera w Europejskim Kongresie Kultury we Wrocławiu. Oba te fakty sa - jak sądzę - na tyle istotne przy interpretacji charakteru liberackiej działalności duetu Fajfer-Bazarnik, że nie chciałabym ich w swoich rozważaniach pominąć. Do roli, jaką w ewolucji teorii liberackiej miał wyjazd do Stanów powrócę jeszcze w jednym z kolejnych rozdziałów. Zaś przywołujacc poprowadzone przez Bazarnik i Fajfera liberackie warsztaty Uwolnij ksiażkę, które odbyły się w ramach Europejskiego Kongresu Kultury ${ }^{218}$, chciałabym, przede wszystkim, zastanowić się nad ich znaczeniem dla kształtowania grona odbiorców literatury totalnej. Czy przypadkiem idea promowania liberatury nie przysłoniła w tym wypadku jej samej? Uczestnicy warsztatów nie tylko mogli dowiedzieć się od samych auto-

${ }^{215}$ Łukasz Jeżyk, Spod spodu. O „Spogladajac przez ozonowa dziurę” Zenona Fajfera, „Polonistyka" 2009, nr 2, s. 38-41.

216 Jerzy Borowczyk, Krzysztof Hoffmann, Wymarzona przygoda, „Polonistyka” 2009, nr 2, s. 6.

217 Por. przypis 170.

218 Program dostępny na stronie: http://www.culturecongress.eu/event/czytelnia_liberatura [dostęp 30.09.2011]. 
rów Oka-leczenia, czym jest forma emanacyjna, ale i... recyklingować nowele pozytywistyczne, tworząc z nich nowe, własne już opowieści (panel Liberacki recycling, czyli co się kryje w podtekście?), czy też spróbować stworzyć dzieła z wykorzystaniem technik kolażu (panel Kolaż, czyli spróbuj pisać cudzymi słowami). Wydaje się, że taka aktywność Fajfera i Bazarnik - choć bezsprzecznie przyczynia się do promowania idei liberatury - przedstawia ja jako działalność mająca znacznie więcej wspólnego ze sztuką książki niż z... literatura, a nawet liberatura w takim rozumieniu, jakie można wynieść z lektury tekstów tej dwójki teoretyków zjawiska.

Nie da się ukryć, że idea liberatury poszła w świat (i to nie tylko dzięki wystapieniom Bazarnik na sympozjach Joyceologicznych) i radzi sobie - jak na byt tak młody - chyba całkiem nieźle. Jak będzie dalej - trudno jeszcze powiedzieć. Patrząc jednak na dotychczasowy rozwój i recepcję zjawiska skłaniałabym się ku przytaknięciu Kostelanetzowi i przyznaniu, że - rzeczywiście - zaproponowany w zeszłej dekadzie przez Fajfera termin poddany próbie czasu wyszedł z niej obronna ręka i wydaje się nie tylko użyteczny, ale i potrzebny. Co więcej - do czego jeszcze będę tu wracać - idealnie wpisuje się w najbardziej aktualne dyskusje o współczesnej kondycji (i przemianach) sztuki słowa. Coraz liczniejsze grono czytelników i dość spora grupa recenzji książek wydanych w liberackiej serii zdają się potwierdzać taki stan rzeczy. Mam też nadzieję, że sensowności wprowadzenia nowego terminu dowiedzie również ta książka. Zwłaszcza, że rok jej złożenia do druku przyniósł jeszcze jedno historyczne dla liberatury i jej twórców zdarzenie.

Zaczać trzeba od tego, iż w październiku 2013 r. Kraków został siódmym na świecie Miastem Literatury UNESCO. Na oficjalnej polsko- i anglojęzycznej stronie internetowej www.miastoliteratury.pl wśród wyjaśnień, czemu akurat Kraków znajdziemy i takie:

Kraków jest jednym z tych nielicznych, wyjątkowych na skalę światową miast, w których na każdym kroku można się zetknąć ze śladami literackiej przeszłości i z żywa, pulsującą obecnością najnowszej literatury, która objawia się w postaci nieokiełznanych form, szalonych eksperymentów, ryzykanckich prób, śmiałych prowokacji i budzących podziw zmieszany z przestrachem wyskoków. To tutaj u schyłku średniowiecza powstały podwaliny polskiego teatru, tu w Renesansie i późniejszych epokach uczyli się i tworzyli najważniejsi twórcy polskiej kultury i tu na przełomie XX i XXI wieku Katarzyna Bazarnik i Zenon Fajfer wymyślili termin „liberatura”, nazywający być może najciekawsze zjawisko w najmłodszej historii książki. W najelegantszych restauracjach Krakowa przedstawiciele literackiej śmietanki prowadzili eleganckie dyskusje, zaś w najpodlejszych knajpach upijali się poeci przeklęci, a upadłe gwiazdy wspominały minioną świetność. Stąd Joseph Conrad wyruszył na podbój światowej literatury i tu powrócił opromieniony chwałą Czesław Miłosz, swoim magnetycznym wpływem przyciągając do grodu Kraka najwybitniejszych poetów całego globu ${ }^{219}$.

219 http://miastoliteratury.pl/miasto-literatury/zycie-literackie/miejsca-literackie-w-krakowie [dostęp 21.07.2014], podkreślenie moje. 
Jednocześnie, 2014 r. przyniósł związany z przyznanym tytułem projekt Kody miasta, w ramach którego na krakowskich Plantach pojawiły się ławeczki owych najsłynniejszych pisarzy (twórców dawnych i jak najbardziej współczesnych), odsyłajace poprzez tabliczki z kodami QR do informacji o artystach itp. Warto o nim wspomnieć w kontekście literatury totalnej, bo na swoje piętnastolecie i liberatura doczekała się takiego upamiętnienia: w październiku 2014 r. odsłonięto ławeczki Fajfera i Bazarnik ${ }^{220}$.

${ }^{220}$ Więcej o samym projekcie zob.: http://kody.miastoliteratury.pl [dostęp 21.07.2014]. 
CZĘŚŚ II

SZUKANIE LIBERATURY LIBERACKOŚĆ MIĘDZY MEDIAMI 



\title{
I. LIBERATURA A LITERATURA WIZUALNA
}

\section{Liberatura a poezja wizualna}

\subsection{O oczywiście (?) wizualnej liberaturze i twórczości spod znaku Mallarmégo i Apollinaire’a}

\begin{abstract}
Dialektyka stowa $i$ obrazu zdaje się być statym elementem tkaniny znaków, jaka przędzie wokót siebie kultura. To, co ulega zmianie, to specyfika splotu, zwiazek między osnowa a watkiem. Historia kultury to po części dzieje rozlegtej walki o dominację między znakami wizualnymi $i$ językowymi.
\end{abstract}

W. J. T. Mitchell, Iconology: Image, Text, Ideolog $y^{1}$.

Zapewne wielu czytelników tej książki, sięgając po nią, oczekiwało, że rozpocznie ją rozdział omawiający stosunek praktyk liberackich do obszaru artystycznych działań, który określam tu możliwie szerokim terminem literatura wizualna. Istotnie, tak właśnie jest, jednak nie zmienia to mojego - wyrażanego już tu - przekonania, że zwiazki literatury totalnej z tekstami wizualnymi to wyłącznie przysłowiowy wierzchołek góry lodowej i wcale nie jedyna perspektywa przydatna w mówieniu o interesujacym mnie obszarze sztuki słowa.

Celem tego rozdziału jest wskazanie istotnych kwestii wynikających z zakładanego (najczęściej uznawanego za oczywiste) pokrewieństwa liberatury i literatury wizualnej, zbadanie, czy zjawiska te rzeczywiście sa sobie tak bliskie, jak zazwyczaj się uważa. Stąd, interesować będą mnie przede wszystkim charakterystyki porównawcze oraz wskazanie momentów przełomowych, nie zaś ujęcie całościowe, monograficzne. Dlatego też porządek wywodu wyznaczy tu odniesienie się do trzech zaledwie zjawisk: lirycznej, wizualnie uwikłanej twórczości Mallarmégo i Apollinaire’a (z panoramą wcześniejszej poezji wizualnej w tle dla podkreślenia wagi przełomu, którego ikoną wydają się przywołani artyści), poezji konkretnej (jako przykładu nowoczesnej odmiany poezji wizualnej) oraz komiksu (jako niepoetyckiej realizacji związków słowa i obrazu). Wieńczace ten rozdział omówienie stosunku liberatury do współczesnej

1 William J. Thomas Mitchell, Iconology: Image, Text, Ideology, Chicago 1986, s. 43; cyt. za: Willard Bohn, Kryzys znaku, tłum. Krzysztof Majer, „Literatura na Świecie” 2006, nr 11-12, s. 14. 
prozy wizualnej ma zaś charakter cody uzmysławiającej, że dzisiejszy kształt książek (i literatury) podważa nie tylko ustalony tradycją związek słowa i obrazu, lecz i wiele innych porządków. Jednocześnie, jak tłumaczyłam już we wstępie, $\mathrm{z}$ racji przyjętego przeze mnie porządku wywodu, zagadnienia związane $\mathrm{z}$ typografia i drukiem omawiać będę $\mathrm{w}$ innym rozdziale i tam dopiero przywołane zostana (często wspominane, gdy mowa o literaturze wizualnej) typograficzne eksperymenty futurystów czy druk funkcjonalny.

W rozdziale tym porzucam też perspektywę chronologiczną. Nie zaczynam od starożytności, lecz za punkt wyjścia przyjmuję początek XX w., moment nie tylko zawsze wskazywany jako zwrotny w rozważaniach o wizualności sztuki słowa w ogóle, lecz i równie często przywoływany w (podejmowanych także przez samych liberatów) dyskusjach dotyczących związków literatury totalnej i wizualnej.

Bezsprzecznie jednym z najbliższych liberatom artystów wspomnianego przełomu jest - operujaccy rozrzuconymi po stronie (a właściwie: kompozycjach stron verso i recto) słowami i niewahajacy się używać w obrębie jednego tekstu zróżnicowanych czcionek (zob. ilustracja 5) - Stéphane Mallarmé. Fajfer i Bazarnik nie tylko często przywołuja go w swoich wywodach teoretycznych, ale i wprost traktuja jak liberata: jego Rzut koścmi nigdy nie zniesie przypad$k u$ został przecież opublikowany w redagowanej przez nich liberackiej serii ${ }^{2}$. Wypracowana przez twórcę poetyka, zgodnie przez badaczy określana jako przełomowa w historii literatury wizualnej ${ }^{3}$, rzeczywiście wyznacza nowe perspektywy dla sztuki słowa, otwiera drogę ku odrodzonej (wtórnie odkrytej) poezji wizualnej: już „niemimetycznej”, jak stwierdzała Maryla Hopfinger ${ }^{4}$, „nowoczesnej” (modern) - jak mówił Willard Bohn ${ }^{5}$. Ostatni z przywołanych podkreślał też, że Mallarmé to jeden z tych, którzy już pod koniec XIX w. dostrzegali zapomniana (można - w duchu liberackim - powiedzieć: przykurzoną konwencja) prawdę, że pismo jest nie tylko tym, co czytamy, lecz i tym, na co patrzymy ${ }^{6}$. Nie mogło to umknąć uwadze Fajfera i Bazarnik.

${ }^{2}$ Stéphane Mallarmé, Rzut kośćmi nigdy nie zniesie przypadku, tłum. Tomasz Różycki, Kraków 2005.

${ }^{3}$ Grzegorz Gazda swego czasu zwracał również uwagę na szerszy zasięg dokonanej przez Mallarmégo rewolty, podkreślając, że „od chwili powstania poematu S. Mallarmégo «Un coup de dés jamais n'abolira le hasard» ukształtowanie graficzne wersu stało się nieodłącznym elementem strukturalnym utworu poetyckiego, tworzyło określone sensy i znaczenia" (Grzegorz Gazda, Architektonika graficzna poetyckiego utworu drukowanego, [w:] Literatura i metodologia, red. Jan Trzynadlowski, s. 217). Nie sądzę, by z dzisiejszej perspektywy można było przypisać poematowi francuskiego poety aż taką zasługę, niemniej zgodzić się trzeba, że rola Mallarmégo dla rozwoju poezji niewyłącznie wizualnej była ogromna.

${ }^{4}$ Maryla Hopfinger, Doświadczenia audiowizualne. O mediach w kulturze wspótczesnej, Warszawa 2003, s. 163.

${ }^{5}$ Willard Bohn, Modern Visual Poetry, Newark 2001.

${ }^{6} \mathrm{Za}$ kluczowego dla omawianego przełomu uznaje poetę również Hopfinger. Por. np. Maryla Hopfinger, Wzory wiersza wizualnego: Mallarmé i Apollinaire, [w:] eadem, W laboratorium sztuki XX wieku. O roli stowa i obrazu, Warszawa 1993, s. 87-98 (część poświęcona Mallarmému: s. 87-90). 
Jednak oczywiście Mallarmé, który na drodze oszałamiajacej - jak podsumowuje Bohn - zabawy słowem i litera niczym „wizualnymi żetonami”, zasadniczo zradykalizował spojrzenie na język poezji, wskazując nowe horyzonty jej wizualnej odmiany (tradycją sięgającej starożytności), nie był jedynym, który przyczynił się do takiego stanu rzeczy. W większości przypadków, kiedy mowa o nowoczesnej poezji wizualnej, o odrodzeniu tradycji tej postaci literatury w XX w., pojawia się przecież kolejne nazwisko - Guillaume Apollinaire (dodam: bohater wcześniejszych niż przywołana tu książek Bohna ${ }^{8}$ ). I w kontekście liberatury nie jest inaczej, niemniej - co ciekawe - od razu widać, iż dla twórców literatury totalnej autor Kaligramów wydaje się mniej ważna inspiracja i nie tak istotnym punktem odniesienia. Dlatego też, dla mnie, kluczowa będzie nie tylko relacja poezji wizualnej Mallarmégo do dzieł literatury totalnej czy to, czemu właśnie autor Rzutu kośćmi... tak silnie inspirował liberatów, ale też i przyczyny, dla których Apollinaire nie zasłużył na aż takie uznanie w ich oczach.
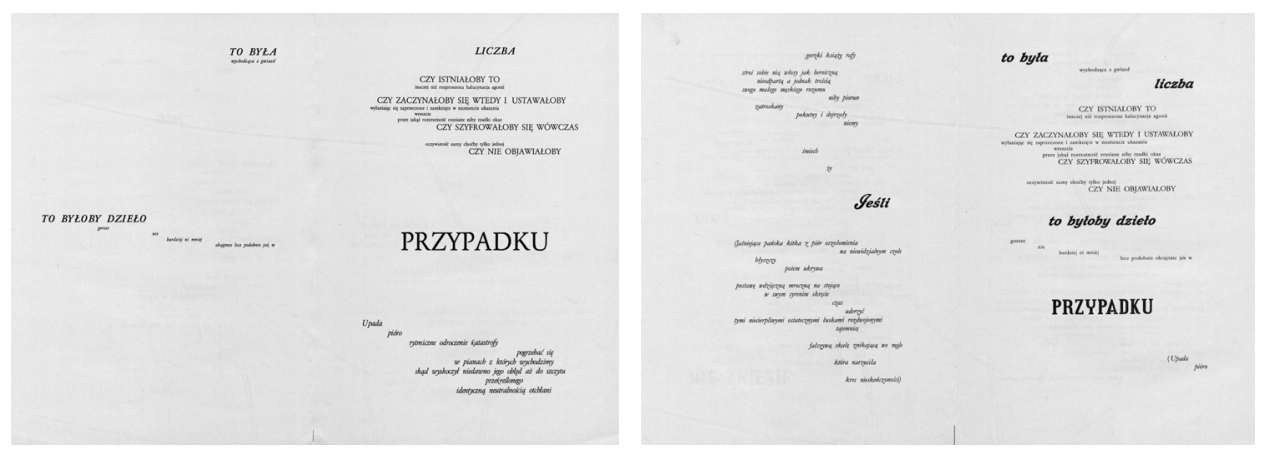

Ilustracja 5. Stéphane Mallarmé, Rzut kośćmi nigdy nie zniesie przypadku (fragmenty wersji z 1914 r. oraz 1897 r. w polskim tłumaczeniu Tomasza Różyckiego) (źródło: Stéphane Mallarmé, Rzut kośćmi nigdy nie zniesie przypadku, Kraków 2005, bez numeracji stron)

W kontekście tym warto pamiętać, że i badacze nie są zgodni co do tego, który spośród przywołanych dwóch - bezsprzecznych - prekursorów nowoczesnej literatury wizualnej wpłynął na jej rozwój w większym stopniu ${ }^{9}$ Najsłuszniej, jak

${ }^{7}$ Willard Bohn, Kryzys znaku, tłum. Krzysztof Majer, „Literatura na Świecie” 2006, nr $11-12$, s. 10 .

${ }^{8}$ Apollinaire and the Faceless Man [Apollinaire i człowiek bez twarzy] z 1991 r. oraz Apollinaire, Visual Poetry and Art Criticism [Apollinaire, poezja wizualna i krytyka sztuki] z 1993 r.

${ }_{9}$ W. Bohn, Kryzys znaku, s. 11. Zdaniem Bohna to twórca Pada deszcz, zainspirowany Mallarmém, tak naprawdę zapoczątkował (właśnie kaligramami) nowoczesną poezję wizualna jednak nie należy chyba tak szybko odbierać autorowi Rzutu kośćmi... zasług (szczególnie, że chronologia stoi po jego stronie). Warto też dodać, że teorię o podchwyceniu i rozwinięciu przez Apollinaire’a poetyki Mallarmégo podważają także ustalenia Michaela Webstera, który zwraca uwagę na to, że pierwsza edycja Rzutu kośćmi... (wydanego zresztą zaledwie w 100 egzemplarzach) ukazała się już (miesiąc) po tym, jak Apollinaire opublikował List oceaniczny na łamach „Les Soirées de Paris" (Michael Webster, Reading Visual Poetry after Futurism. Marinetti, Apollinaire, Schwitters, Cummings, New York 1995, s. 63). 
sądzę, mówić o obu tych artystach jako tych, którzy do omawianego tu przełomu się przyczynili ${ }^{10}$, zwłaszcza że w gruncie rzeczy wskazali oni dwa kierunki, w których współczesna poezja wizualna może się rozwijać - bardziej i mniej mimetyczny, silniej i słabiej związany z tradycją antyczną. Zatem nic też chyba dziwnego w tym, że twórczość jednego z przywołanych poetów w większym stopniu przypadła do gustu liberatom.

\subsection{Liberat Stéphane Mallarmé}

Z pewnościa warto zastanowić się, po jakie radykalne - jak mówi Bohn środki sięgnął Mallarmé, że jego poetyka stała się tak przełomowa i (co chyba nawet ważniejsze w moim wywodzie) czemu były one bliskie liberatom. Adam Ważyk pisał o autorze Rzutu kośćmi..., że znalazł on drugi wymiar składni: „składnię na płaszczyźnie”11, zaś Maryla Hopfinger, podejmując ten wątek, dopełniała go - stwierdzajacc, że „składnię zdania zastapił poeta składnią przestrzenną powierzchni stronic"12. Charakteryzując ten zabieg, badaczka wypunktowywała, że ów nowy sposób pisania wykorzystuje nie tylko świadomie rozplanowane usytuowanie słów na płaszczyźnie (które uwzględnia położenie jednych wyrazów w stosunku do drugich, zarówno tych z nimi sąsiadujących, najbliższych, jak i wszystkich znajdujących się na stronie $\left.^{13}\right)$, lecz i sposób zapisu poszczególnych fragmentów tekstu. A takie podejście do przestrzeni dzieła wybrzmiewało już przecież w pierwszych manifestach liberatów ${ }^{14}$. Na łatwo uchwytne analogie refleksji (i praktyki) Mallarmégo z myśla (i twórczościa) Fajfera i Bazarnik wskazuje też trafna uwaga Hopfinger o zasadniczym novum utworu francuskiego symbolisty na tle dotychczasowej literatury, novum iście liberackiego:

To, co towarzyszyło dotąd pisaniu, tworzeniu poetyckiemu jako element niezbędny wprawdzie, ale „przezroczysty”, niewidoczny przez najdalej posuniętą i oswojoną konwencję, teraz stało się czynnikiem współustanawiającym sens wypowiedzi - twierdzi badaczka. - Zadrukowane strony książki zmieniły dzięki Mallarmému swoją funkcję z niezauważanej, usługowej techniki przekazu na środek wyrazu, nośnik sensu. Nośnik, którego znaczenie będzie w przyszłości wzrastać ${ }^{15}$.

W świetle tych słów nie może dziwić, że Mallarmé stał się swojego rodzaju patronem myśli liberackiej, że jego Rzut kośćmi... „musiał” ukazać się w li-

10 Tak czyni np. Hopfinger.

11 Adam Ważyk, Przedmowa, [w:] Stéphane Mallarmé, Wybór poezji, red. Adam Ważyk, Warszawa 1980, s. 18.

12 M. Hopfinger, W laboratorium sztuki XX wieku..., s. 88.

${ }_{13}$ Dodać należałoby, że wręcz na przestrzeni dwóch stron, gdyż w przywołanym poemacie całostką przestrzenno-wizualną jest dla Mallarmégo taki właśnie układ.

14 Por. pierwsza część tej książki.

${ }_{15}$ M. Hopfinger, W laboratorium sztuki XX wieku..., s. 88. 
berackiej serii ${ }^{16}$. Poeta, określony przez Hopfinger mianem „prekursora nowoczesnej literatury wizualnej”17 (zatem - podkreślmy - nie tylko poezji) dla Fajfera i Bazarnik był też jednym z tych, którzy przyczynili się do - jak można by powiedzieć - „liberackiego przewrotu w historii sztuki słowa”. Redaktorzy serii, oddając w ręce czytelników nową edycję Rzutu kośćmi..., tak piszą o jego autorze:

Mallarmé przyczynił się [właśnie przywołanym poematem - AP], jak mało kto przed nim i niewielu po nim, do iście einsteinowskiego przewrotu w literaturze. Przewrotu, który polega na odejściu od neutralnego statusu przedmiotu zwanego książką i włączeniu go w obręb dzieła.

Przewrót ten nazywamy liberaturą ${ }^{18}$.

Nie bez znaczenia jest też fakt, iż Rzut kośćmi... jest trzecią pozycją wydaną w serii liberackiej. Poprzedzaja go jedynie autorskie teksty redaktorów ${ }^{19}$, stąd w zasadzie trzeba przyznać, że - choć trzeci - jest tak naprawdę pierwszy. Jednocześnie mamy tu do czynienia z oficjalnym wskazaniem na liberata w gronie pisarzy wcześniej wpisanych do kanonu. Fajfer i Bazarnik nie mieli wątpliwości, że to od Mallarmégo należy zaczać takie rewizje, co wprost potwierdzili w 2005 r., stwierdzając w jednym z komentarzy, iż wśród głoszących „podobne liberaturze intuicje [...] pierwszeństwo, pod każdym względem, należało się francuskiemu symboliście" ${ }^{20}$.

A łączyło go z twórcami literatury totalnej nie tylko podejście do materii książki zakładające, że przynależy do niej i materia zdania, w konsekwencji czego tekst i powierzchnia, jaka zajmuje (powierzchnia Księgi), staja niepodzielną całością. Istotą omawianego liberackiego pokrewieństwa nie była też wyłącznie chęć odrzucenia konwencji neutralnego sposobu pisania, choć, wskazane przez Hopfinger, uczynienie ze strony nie środka przekazu, lecz środka wyrazu, jest tu kluczowe. Mallarmé to nie tylko poeta wizualny, ale i twórca (idei) Księgi, w obrębie której - jak podsumował Adam Ważyk - „wszystko się będzie łączyło ze wszystkim, sens, dźwięki, składnia, typografia" "21. W swoich rozważaniach o książce (bo - podobnie jak Fajfer - twórca Rzutu kośćmi..., nie tylko tworzył nowe typy literatury, lecz i o nich teoretyzował) poeta pisał o - jak to podsumuja polscy liberaci - przestrzeni książki, która przybiera

${ }^{16} \mathrm{O}$ stosunku tej edycji do wcześniejszych polskich publikacji oraz problemach związanych z wydawaniem Rzutu kośćmi... piszą Fajfer i Bazarnik w szkicu O wcześniejszych przypadkach „Rzutu kośćmi”. Nota redakcyjna, [w:] S. Mallarmé, Rzut kośćmi..., s. 25-29.

${ }^{17}$ M. Hopfinger, W laboratorium sztuki XX wieku..., s. 87. Jak podkreśla badaczka, pogląd o tym, że przywołany w tekście głównym poemat wyznacza nowy okres w dziejach poezji wizualnej podzielają tė̇ Jeremi Adler i Ulrich Ernst.

18 Zenon Fajfer, Katarzyna Bazarnik, Dwa „Rzuty kośćmi” czyli szczególna i ogólna teoria liberatury, [w:] S. Mallarmé, Rzut kośćmi..., s. 122.

19 (O)patrzenie oraz Spogladajac przez ozonowa dziurę.

20 Z. Fajfer, K. Bazarnik, Dwa „Rzuty kośćmi”..., s. 123.

${ }^{21}$ A. Ważyk, Przedmowa, s. 17. Por. też: Jacek Olczyk, „Księga jest więc jak bóg: konieczna, obecna, nieistniejaca. O nieukończonym dziele Stéphane’a Mallarmégo, „Autoportret” 2006, nr 4, s. 20-23. 
charakter dynamiczny i, przyjmując formę zależną od treści utworu, aktywnie dopełnia jego semantykę $e^{22}$.

Taką iście liberacką charakterystykę materii dzieła dawał Mallarmé choćby w szkicu Ksią̇ka, narzędziem duchowym, w którym pisał o woluminie będacym „całkowitą ekspansją litery”" ${ }^{23}$, ale też (za każdym razem inna) „gra”" ${ }^{24}$ z przestrzenia pisma, grą która „potwierdzi fikcję”25. Jeśli przypomnieć tu tezy liberatów głoszących, że kształt książki ma zawsze wiązać się z jej idea, przesłaniem (jak często upraszczają: treścia), to wypowiedź Mallarmégo pozwoli podważyć pozorną banalność tych stwierdzeń, nierzadko im przecież zarzucana. Liberatom chodziłoby przecież właśnie o owo „potwierdzanie fikcji”, odnajdowanie w strukturze i przestrzeni książki „odpowiedników”26 (jak mówił poeta) treści wyrażonej słowem.

Zapewne właśnie ze względu na wskazywane tu analogie Fajfer jeszcze trzy lata przed wydaniem Rzutu kośćmi... w liberackiej serii nie tylko przywoływał słowa, w których jego autor wyrażał znużenie „nieznośną kolumną” ${ }^{27}$ tekstu (wiecznie tak samo usytuowana w przestrzeni strony), ale i przypominał aspiracje artysty, by ten stan zmienić. Pytał wtedy też: „Może więc liberatura to nic innego, jak pisanie Księgi, której nie udało się stworzyć Mallarmému?"28

Jako tom, który miał zastapić Księgę odczytywał Rzut kośćmi... również Ważyk ${ }^{29}$. Wydając ten poemat, redaktorzy ha!artowskiej serii Libeatura również przyznawali, że - znosząc podział na strony verso i recto, mówiąc biela i czernią kartki, wybrzmiewając ciszą i krzykiem zapisanego słowa, zmuszając czytelników do porzucenia wyuczonych nawyków lekturowych ${ }^{30}-$ z pewnościa

${ }^{22}$ Z. Fajfer, K. Bazarnik, Dwa „Rzuty kośćmi”..., s. 121. Zaś w 2003 r. Fajfer pisał: „Gdy tylko nieliczni uczynili swym tworzywem także podłoże, na którym znajduje się tekst, a co za tym idzie, uwzględnili w procesie twórczym fizyczną budowę książki - jej przestrzenny charakter. Modelowym przykładem będzie tu słynny poemat Mallarmégo «Rzut kości». Dzieło zbyt poważne, aby je zignorować i głosić, że literatura to tylko słowa” (Z. Fajfer, Nie(o)pisanie liberatury, [w:] LCLT, s. 61).

23 Stéphane Mallarmé, Wariacje na pewien temat [fragment zatytułowany: Ksią̇̇a, narzędziem duchowym], tłum. Ewa Dorota Żółkiewska, [w:] S. Mallarmé, Wybór poezji, s. 89.

${ }^{24}$ Ibidem.

25 Ibidem.

${ }^{26}$ Ibidem.

27 Ibidem, s. 91.

28 Z. Fajfer, Liryka, epika, dramat, liberatura, s. 238.

29 A. Ważyk, Przedmowa, s. 20.

${ }^{30}$ O samym poemacie por. także Michał P. Markowski, Nicość i czcionka. Wprowadzenie do lektury „Rzutu kośćmi” Stephane’a Mallarme, [w:] S. Mallarmé, Rzut kośćmi..., s. 7-23, Jacek Trznadel, Wszystko jest proste (nad poematem Mallarmégo: „Rzut kości nigdy nie obali przypadku”), [w:] idem, Płomień obdarzony rozumem. Poezja w poezji i poza poezja. Eseje, Warszawa 1978, s. 285-289, Adam Ważyk, Przedmowa, s. 18-20 oraz Wiktoryna Husarzewska, Linearna opowieść o literaturze nielinearnej [2], „Autoportret” 2006, nr 4, s. 19. Por. też: analiza dokonana przez Michela Butora w jego Sur la page, przywołana przez Bazarnik (w niepublikowanym przekładzie Radosława Nowakowskiego) w szkicu „Ksiażka jako przedmiot” Michela Butora czyli o liberaturze przed liberatura ([w:] Od Joyce'a do liberatury, s. 188-194, interesujący mnie tu fragment: s. 188-194). 
należy on do literatury totalnej. Jednocześnie Bazarnik określiła go mianem „odprysku Księgi” ${ }^{31}$ i wraz z mężem podsumowywała:

\begin{abstract}
Autor Rzutu kośćmi wiedział doskonale, że książka (czy powierzchnia kartki) nie musi być biernym pojemnikiem na słowa, lecz częścią dzieła, podlegająca procesowi twórczemu na równi z innymi elementami utworu. Nie tylko wiedział, ale i dowiódł, że poeta może mówić całą książką. Że również jej fizyczna, materialna przestrzeń może być tworzywem poety, przynależeć do jego języka. A skoro tak, to konstrukcja książki, jej kształt i materiał z którego zostanie wykonana, moga być najzupełniej dowolne. Twórca nie musi poddawać się żadnym edytorskim konwencjom. Ani, wynikającym z nich, czytelniczym nawykom ${ }^{32}$.
\end{abstract}

I tak - wcale nie przypadkiem - właśnie Mallarmé, artysta otwierający przed poezją wizualną nowe horyzonty, okrzyknięty został też liberatem, zaś jego Rzut kośćmi... rozpoczął serię re-edycji wpisanych w kanon literatury (bądź jego obrzeża) dzieł liberackich. Pozostaje jednak pytanie: czy tym samym można przyznać, że poezja czy - szerzej - literatura wizualna są najwłaściwszym kontekstem do mówienia o liberackości? A wątpliwość ta doprasza się też dookreślenia, jak w tym wypadku należy rozumieć samą wizualność sztuki słowa

Ta, której historię rozpoczyna Mallarméański zwrot, rzeczywiście bliska jest koncepcji literatury totalnej. Dziedzictwem autora koncepcji Księi jest bowiem wizja poezji, w której wizualność wiąże się nie tylko z aktualizowaniem obrazowego aspektu zapisu języka. Postmallarméańska poezja wizualna to utwory, w których sposób ukształtowania tekstu (jego układ przestrzenny czy typografia, a nieraz i wykorzystanie innych tworzyw) nie tylko - jak to bywało wcześniej - konkretyzuje treść utworu, lecz i ją dopełnia. I czyni to rzeczywiście liberacko, gdyż w takich wypadkach sposób zapisu współ-decyduje o sensie słowa, bowiem inaczej usytuowane w przestrzeni strony czy tomu, co innego będzie znaczyć. Ów nowy rodzaj poezji wizualnej, zrodzony - tu wypada się zgodzić z Bohnem - z (niejednego) kryzysu znaku i nowych poszukiwań w języku ${ }^{33}$, właśnie poprzez namysł nad samym tworzywem literackiej komunikacji zbieżny jest z poglądami na substancję literatury formułowanymi przez liberatów. W obu wypadkach podważone zostaje bowiem dotychczasowe rozumienie literackiej komunikacji (i - uprzedzę dalsze wywody - roli, jaka pełni w niej książka). Dlatego przywoływane przez Bohna charakterystyki owej współczesnej poezji wizualnej w pełni nadadzą się do opisu dzieł liberackich. Utwory zaliczane do jednego i drugiego nurtu wytrącają czytelników z lekturowych schematów, oczekuja „nowego czytania”: często nielinearnego, ale też niełączącego sensu dzieła wyłącznie z arbitralnymi znakami językowymi ${ }^{34}$.

${ }^{31}$ K. Bazarnik, Liberatura czyli o powstawaniu gatunków (literackich), [w:] LCLT, s. 153.

32 Z. Fajfer, K. Bazarnik, Dwa „Rzuty kośćmi”..., s. 122.

${ }_{33}$ Por. W. Bohn, Modern Visual Poetry.

${ }^{34}$ Por. także. Dick Higgins, Strategia poezji wizualnej: trzy aspekty, tłum. Krzysztof Brzeziński, [w:] idem, Nowoczesność od czasu postmodernizmu oraz inne eseje, oprac. Piotr Rypson, tłum. zbior., Gdańsk 2000, s. 163-180. 
Do jednych i drugich odnieść możemy słowa Jean-Pierre’a Goldensteina, który stwierdza, że poezja wizualna zmusza odbiorcę do:

Rozpatrzenia nieskończonej liczby ścieżek poprzez wykorzenienie go z jego uprzednio ukonstytuowanego miejsca czytania w obecnej kulturze znaku, sensu, linearności, po to, aby poprzez przygodę pisania - zaoferować mu przygodę czytania ${ }^{35}$.

Wskazywane przeze mnie pokrewieństwo wiąże się z tym, że zrodzona z Mallarméańskiej rewolucji poezja zakłada namysł nad tworzywem, jak sugeruje (już w kontekście Apollinaire’a) Grzegorz Gazda: obranie sobie za cel „przełamania granic wyznaczonych przez możliwości tworzywa literackiego"36. Poeta - jak stwierdza Eduardo Mitre - przeobraża się w „budowniczego”, architekta wiersza, eksplorując różnorakie możliwości języka rozumianego jako substancja nie tylko audialna i wizualna, ale przede wszystkim - materialna ${ }^{37}$. Dość tu przypomnieć, że liberaturę określano też architektura słowa ${ }^{38}$.

\subsection{Literatura wizualna i literatura uksiążkowiona}

W świetle moich dotychczasowych konstatacji można by zapytać: czy zatem należy rozróżniać poezję wizualną od liberatury? Innymi słowy, czy zaproponowany przez Fajfera termin nie wydaje się w obliczu przedstawionych tu rozważań zbędny, synonimiczny w stosunku do pojęć już istniejacych? Trzeba jednak zauważyć, że liberatura, stojąc ponad podziałami genologicznymi, obejmuje zarówno prozę, jak i mowę wiązana, stąd mówić by w tym wypadku należało nie tylko o poezji, ale i o całej literaturze wizualnej. Tu jednak sprawa zaczyna się komplikować. Z jednej bowiem strony w obszar tej ostatniej należałoby zaliczyć wszelkie formy łączące obraz i słowo, zatem np. również i komiks (zespalajacy kod werbalny z wizualnym na innych jednak zasadach niż dzieje się to w przypadku omawianego tu typu poezji). Z drugiej strony, nawet rozszerzając w opisany sposób przyjęta perspektywę, nie zdołamy objąć wszystkiego, co liberackie, gdyż literatura totalna wcale nie musi być wizualna (choć, bezsprzecznie, nierzadko bywa). Zgubne byłoby więc patrzenie na porównywane tu kategorie jako synonimy.

Nie bez powodu to Mallarmé - a nie Apollinaire - został tak szybko uznany za liberata. Rzut kośćmi... operuje nie tyle wizualnością mimetycz-

${ }^{35}$ Jean-Pierre Goldenstein, La Lecture au défi: remarques sur quelques aspects de l'Esprit nouveau en poésie, [w:] En hommage á Michel Décaudin, réd. Pierre Brunel i in., Paris 1986, s. 160; cyt. za: W. Bohn, Kryzys znaku, s. 17.

${ }^{36}$ Grzegorz Gazda, hasło 'kaligram', [w:] Stownik rodzajów i gatunków literackich, red. Grzegorz Gazda, S. Tynecka-Makowska, Kraków 2006, s. 331.

37 W. Bohn, Kryzys znaku, s. 18.

${ }^{38}$ Fajfer, omawiając w Nie(o)pisaniu liberatury wagę kategorii przestrzeni w dziełach literatury totalnej, stwierdzał wprost: „Liberatura, czyli architektura słowa. Architektura, czyli sztuka najbardziej przestrzenna z przestrzennych” (s. 61). Warto tė̇ przypomnieć, że podtytuł redagowanego przez Bazarnik tomu Od Joyce’a do liberatury to właśnie: szkice o architekturze słowa. 
na, co eksploruje materię języka wraz z jego wizualnością. Autor słynnego poematu idzie jednak o krok dalej, myślac również o przestrzeni poszczególnych kart (czy ich kompozycji), wreszcie - również na poziomie wypowiedzi teoretycznych - i o całym tomie. W jego koncepcji pojawia się zatem, kluczowa dla liberatów, książka. Dlatego tak bliski stał się twórcom literatury totalnej.

Zatem, nawet szeroko rozumiana literatura (już nie tylko poezja) wizualna wydaje się pojęciem węższym niż liberatura, bowiem ta ostatnia eksploruje (niczym nowoczesna poezja wizualna) nie tylko materialność swego tworzywa, jakim jest język, lecz i potencję swojego medium, książki (z czym w obszarze klasycznie definiowanej wizualnej sztuki słowa nie mamy już do czynienia). $\mathrm{Na}$ dodatek wymienione zabiegi wcale nie muszą wiązać się z wizualnościa. Niemniej, ci, którzy oczekiwali, że opis liberatury w świetle literatury wizualnej będzie stanowił sporą część tej książki, intuicję mieli dobrą w jednym przynajmniej aspekcie: takie analizy byłyby nad wyraz interesujące. Jednakże równie dobrze mogłyby złożyć się na oddzielną publikację.

Próbując scharakteryzować podobieństwa i różnice dwóch omawianych tu zjawisk, zmuszona jestem ograniczyć się do pokazania punktów granicznych i (przynajmniej częściowo) poprzestać na wskazaniu fascynujących badawczych horyzontów. I tak, zwróciwszy uwagę na kluczowa w tym kontekście, dokonaną przez Mallarmégo rewoltę, chciałabym w dalszej części tego rozdziału przyjrzeć się relacji liberatury i poezji konkretnej, będącej przecież bardzo dobrym przykładem owej nowej poetyki wizualnej. Sądzę, że wskazawszy aspekty sugerujące, iż opisywane zjawiska moga być bardzo bliskie, warto zastanowić się i nad tym, czy istnieją powody, by je jednak wyraźnie oddzielać. A obszar wybrany tu do dalszych analiz jako reprezentatywny pozwoli, jak sądzę, wyraźnie uwypuklić pewne istotne w tym kontekście aspekty. Podobnie - zasygnalizowawszy, że mówiąc o liberaturze w kontekście wizualnej sztuki słowa (ze względu na różnorodność gatunkową i rodzajową form, jakie ona obejmuje), nie można ograniczyć się wyłącznie do poezji, chciałabym przyjrzeć się również relacji literatury totalnej i komiksu jako przykładu prozy integrującej w sobie słowo i obraz. Jestem przekonana, że i w tym wypadku skupienie się w rozważaniach na wybranym (dość wasskim) obszarze odniesień pozwoli z jednej strony ukazać najważniejsze problemy, z drugiej zaś zarysować perspektywy koniecznych i ciekawych dalszych poszukiwań badawczych. Jednocześnie warto zaznaczyć, że oba przywołane konteksty pojawiały się w komentarzach dotyczących liberatury, niemniej ich relacja z literatura totalną nie została dotychczas dokładniej opisana.

Jednak zanim skupię się na wypunktowanych tu zagadnieniach, chciałabym jeszcze dopowiedzieć „zagubiony początek”: scharakteryzować - choć pokrótce (co, uprzedzę, wynika z charakteru omawianej relacji) - stosunek twórczości liberackiej do wcześniejszej niż Mallarméańska poezji wizualnej. Kwestia ta - poniekąd zaskakująco - wiąże się z odpowiedzią na pytanie, czemu to francuski symbolista, a nie Apollinaire stał się patronem liberatów. 


\subsection{Dlaczego nie Apollinaire, czyli czemu liberaci nie lubią kaligramów}

Twórczość Apollinaire’a nie spotkała się, jak wspominałam, z aż tak wielkim uznaniem liberatów. Jego utwory, choć wymieniane w kontekście literatury totalnej (choćby jako przykłady bliskiej Fajferowi i Bazarnik wrażliwości na medium, jakim jest pismo ${ }^{39}$ ), nie zostały - jak Rzut kośćmi... - wydane w redagowanej przez tych autorów serii, nic nie wiem też o tym, by taki pomysł w ogóle rozważano. Jakby tego było mało, o - podkreślę - „niektórych” kaligramach Fajfer mówił, że to „Apollinaire'owskie tautologie - nie pozostawiajace zbyt wiele miejsca dla wyobraźni krawaty, serca czy mandoliny" ${ }^{40}$ (zob. ilustracja 6). Stwierdzał też wprost:

Sądzę [...], że to wielka sztuka stworzyć kaligram, który nie zabija poezji. Oka trzeba używać bardzo ostrożnie ${ }^{41}$

Jak wytłumaczyć tę „,antykaligramową” liberacką postawę w świetle formułowanych tu wcześniej twierdzeń o bliskości i zwiąkach poetyki Mallarméańskiej i tej cechujacej twórczość Apollinaire’a? Niech punktem wyjścia do odpowiedzi na to pytanie stanie się opublikowany w 1988 r. szkic Jerzego Falickiego Kod stowny a kod rysunkowy. Próba typologii utworów piktograficznych na przyktadzie „Kaligramów” Apollinaire'a ${ }^{42}$.

Badacz ten - jak słusznie zwraca uwagę Hopfinger - przyjmuje, że w utworach nierozerwalnie łączących obraz (rysunek) ze słowem, które określa mianem „tekstów piktograficznych”, to słowo jest nadrzędne ${ }^{43}$. Element wizualny w ujęciu Falickiego przedstawia się jako redundantny, tautologiczny wobec języka i jego zapisu, choć nierozerwalnie z nim związany. W konsekwencji, mimo owej - tak właśnie krytykowanej przez Fajfera - powtarzalności jednego

${ }^{39}$ Zenon Fajfer, Katarzyna Bazarnik, Liberatura. Aneks do historii literatury (czyli o korekcie poczynionej za pomoca literówki), http://www.liberatura.pl/1909-1969-czyli-od-futuryzmu-do-ksiazki-artystycznej.html [dostęp 30.09.2011].

${ }^{40}$ Z. Fajfer, W stronę liberatury, [w:] LCLT, s. 96.

${ }^{41}$ Ibidem.

${ }_{42}$ Jerzy Falicki, Kod stowny a kod rysunkowy. Próba typologii utworów piktograficznych na przyktadzie „Kaligramów” Apollinaire’a, [w:] Studia z literatury polskiej i obcej, red. Lech Ludorowski, Lublin 1988, s. 355-362.

${ }^{43}$ Warto tu dodać, że podobne sady często pojawiaja się w wypowiedziach Fajfera czy Bazarnik. Ja, interpretujac ideę liberatury i rozwijając jej teorię, zwracam uwagę na to, że owa „nadrzędność" sprowadza się w gruncie rzeczy do tego, że słowo - w przeciwieństwie do obrazu - jest dla literatury totalnej tworzywem konstytutywnym, niezbędnym i po prostu musi się pojawić. W moim jednak rozumieniu (wynikającym z interpretacji tekstów liberackich) obie „sfery” utworu projektowane są równolegle, gdyż jeśli znaczenia rozpisane maja być pomiędzy nie, żadna nie może być „ważniejsza”. Stąd, sformułowania mówiące o tym, że tekst dyktuje kształt tomu (bądź wizualna postać tekstu) odczytuję bardziej jako przyznanie, że postać dzieła nie pozostaje bez związku z jego idea (co nie każe uznawać słowa ową ideę wyrażającego za ważniejsze niż ucieleśniajacy ją obraz). Por. np. Katarzyna Bazarnik, Liberatura, czyli literatura w formie ksiażki, [w:] Druga rewolucja ksiażki, red. Violetta Trella, Gdynia 2008. 

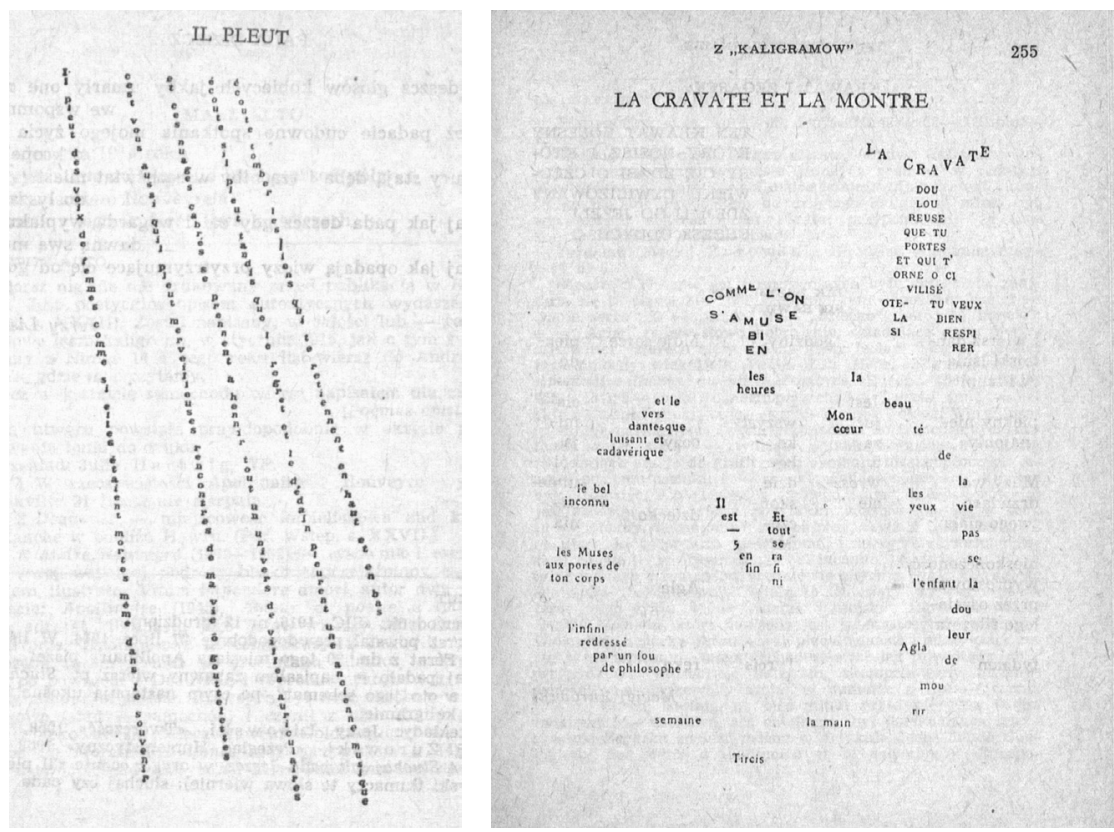

Ilustracja 6. Guillaume Apollinaire, Kaligramy (od lewej: Deszcz oraz Krawat i zegarek) (źródło: Guillaume Apollinaire, Wybór poezji, oprac. Jerzy Kwiatkowski, Wrocław 1975, s. 271 oraz s. 255)

tworzywa względem drugiego, możemy mówić o spójności znaczeniowej słowa i obrazu w obrębie kaligramów. Istotnie, owo - powiedzmy - „ilustrowanie idei” pozostaje w większym związku z tekstem (jak mówi Falicki: w związku nierozerwalnym) niż - stanowiące zupełnie inny typ relacji tworzyw w obrębie jednego dzieła - ornamenty towarzyszące utworom ${ }^{44}$.

Nie jest to jednak rodzaj spójności satysfakcjonujący liberatów. To właśnie o nim Fajfer napisze, że zabija poezję, że nie zostawia pola dla wyobraźni. Dlaczego? Falicki słusznie zauważa, że w opisywanych utworach temu samemu znaczonemu przypisywane jest jedno znaczące słowne i jedno obrazowe. Stąd rodzi się tautologia. Liberacki ideał byłby zaś taki, by o jednym znaczonym na zmianę opowiadały różne (związane $\mathrm{z}$ odmiennymi tworzywami) znaczące, by funkcja sensotwórcza była przekazywana między słowem a obrazem, w efekcie czego zrodzi się - inaczej niż przez Falickiego interpretowana - spójność znaczeniowa. Dlatego - z punktu widzenia literatury totalnej - krytyce należało poddać wszelkie mniej lub bardziej dosłowne powiązania elementów wizualnych i językowych cechujace kaligramy. Tym samym, negatywnie ocenione powinny zostać zarówno wymieniane przez Falickiego piktogramy o odniesieniu bezpośrednim (niezmetaforyzowane i o charakterze synekdochicznym), jak i te o odniesieniu pośrednim (zmetaforyzowane, oparte na metonimii oraz związane z symbolem) ${ }^{45}$.

\footnotetext{
${ }^{44}$ J. Falicki, Kod stowny a kod rysunkowy..., s. 355-356.

${ }^{45}$ Zob. ibidem, s. 360-361.
} 
Kolejnych wyjaśnień i argumentów dostarcza teza Jerzego Kwiatkowskiego, który - dostrzegając ogromną różnorodność form Apollinaire’owskich kaligramów - zwraca (słusznie) uwagę na to, że w części z nich, rzeczywiście, związek między wizualnym ukształtowaniem tekstu a jego przesłaniem nie jest dla budowania sensów bardzo istotny, gdyż (właśnie w związku z podwójna artykulacja znaczącego) w tych wypadkach „tekst legitymuje się samoistna wartością literacka, spotęgowana, ale bynajmniej nie ufundowana na pomysłach graficznych" ${ }^{46}$. Dominujaca w tych tekstach zasada wiersza-przedmiotu postrzegana jest przez badacza jako:

Próba przybliżenia się do wiecznie nieziszczalnego celu poetów: by słowo rzeczą się stało.

Utwór o deszczu wydrukowany jest „w kształcie” deszczu, o zegarku - „w kształcie” zegarka, o krawacie - „w kształcie” krawata... ${ }^{47}$

Nie możemy jednak uznać, że ziścił się tu cel liberatów, że „jak” stało się częścia „,o”" tworzyw nie jest tu tak silne, typografia nie funduje sensu utworu. Dla moich rozważań kluczowa jest uwaga badacza dotycząca tego, iż kaligramy takie jak Deszcz spokojnie dają się - bez utraty znaczeń - przepisać inaczej, wydrukować jako klasyczne teksty. Taką - jak mówi Kwiatkowski - „próbę druku”, przechodzą bez szwanku dla swych znaczeń. Tym samym - nie zdają prostego egzaminu liberackości, tautologiczność ich kształtu wobec przekazu werbalnego jawnie ukazuje się odbiorcy.

Niemniej, Fajfer - jak podkreślałam - mówi w krytyczny sposób o „niektórych” tylko kaligramach. Z tego samego powodu Hopfinger, choć przywołuje systematyzację Falickiego ${ }^{49}$, słusznie wskazuje na jej niedopatrzenia, a Kwiatkowski kilkakrotnie zwraca uwagę na różnorodność stosowanych przez Apollinaire'a form. W dorobku tego artysty poza utworami, do których w pełni da się odnieść przypomnianą tu typologię, zaliczyć trzeba - rzeczywiście mniej liczne, ale wcale nie mniej istotne - kaligramy, przekraczające zarysowane przez Falickiego charakterystyki (jak np. List oceaniczny, zob. ilustracja 7) ${ }^{50}$. To ich analizy znajdziemy w opracowaniach Hopfinger, Kwiatkowskiego, Bohna czy Johanny Drucker (która w tej pracy będzie jeszcze często przywoływana) i in-

\footnotetext{
${ }^{46}$ Jerzy Kwiatkowski, Wstęp, [w:] Guillaume Apollinaire, Wybór poezji, Wrocław 1975, s. CXXXI-CXXXII

47 J. Kwiatkowski, Wstęp, s. CXXX.

${ }^{48}$ Od Joyce'a do liberatury. Szkice o architekturze słowa, red. Katarzyna Bazarnik, Kraków 2002 , s. II.

${ }^{49}$ Uznając ją za porządkująca, użyteczną i instruktywną. Zob. M. Hopfinger, W laboratorium sztuki XX wieku..., s. 95.

${ }^{50}$ I G. Gazda podkreśla, że nie zawsze relacje słowo-obraz dadzą sie w kaligramie sprowadzić do lirycznego ideogramu stanowiącego wizualną konkretyzację przedmiotów ewokowanych w wierszu. Inspirując się interpretacjami Butora, badacz wskazuje sytuacje, w których tak rozumiana wizualizacja wzbogacona jest o ciekawą symbolikę związaną właśnie z plastycznym (przestrzennym) ukształtowaniem tekstu, co nie pozwala postrzegać omawianych relacji jako zwykłej słowno-wizualnej tautologii (por. G. Gazda, Architektonika graficzna..., s. 222-225).
} 
nych badaczy ${ }^{51}$. We wszystkich tych interpretacjach - licznie już powtarzanych w literaturze przedmiotu - podkreślane jest nowatorstwo zastosowanych przez Apollinaire'a form, odejście od konwencji ikonicznej, zaprzęniecie wizualności do kreowania symultanicznych obrazów, silne eksplorowanie możliwości literatury nielinearnej. Wszystkie one prowadzą też do wniosku, że w tym wypadku trudno mówić o prostych zależnościach słowa i obrazu, że ich uwikłania są wielopoziomowe i w niejeden sposób prowadzą ku konstruowaniu sensu.
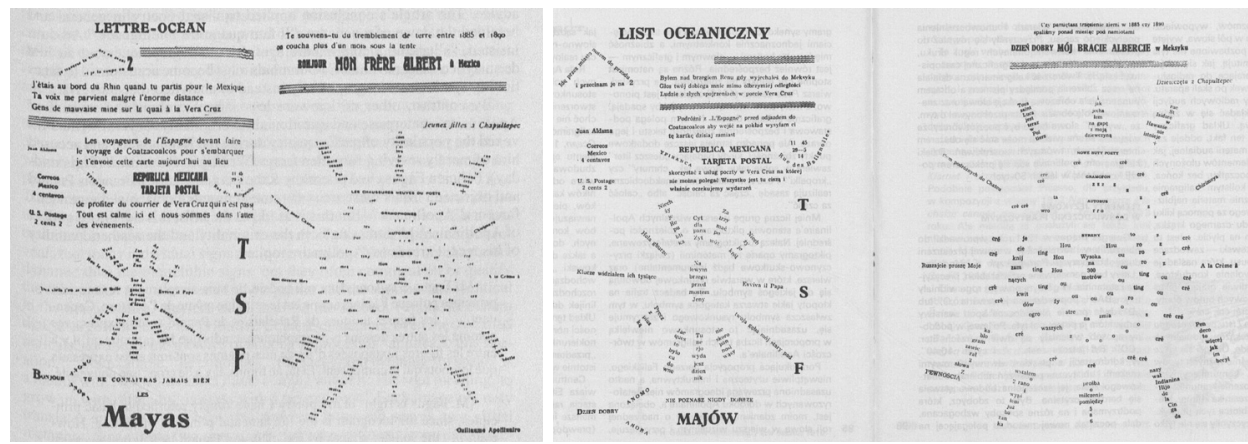

Ilustracja 7. Guillaume Apollinaire, List oceaniczny (wersja oryginalna oraz polskie tłumaczenie) (źródło: Willard Bohn, Modern Visual Poetry, Newark 2001, s. 41 oraz Maryla Hopfinger,

W laboratorium sztuki XX wieku. O roli stowa i obrazu, Warszawa 1993, s. 96-97)

To one przede wszystkim sa podstawa budowania tez o nowatorstwie Apollinaire'a. To one wreszcie pozwalają łączyć poetykę tego artysty z Mallarméańską ${ }^{52}$. One też, rzeczywiście, wyznaczały nowe perspektywy poezji wizualnej, gdyż jak pisała już lata temu Hopfinger:

Twórczość kaligramiczna działała na rzecz zbliżenia pomiędzy pismem a obrazem i unaoczniała obrazową funkcję słowa oraz znaczeniową rolę obrazu. Poeta - dodaje badaczka - przekonywał o tym, że „wygląd” słowa może być poezjotwórczy, że wizualna strona wiersza może stać się obszarem interesujących, twórczych poszukiwań ${ }^{53}$.

${ }^{51}$ Por. M. Hopfinger, W laboratorium sztuki XX wieku..., s. 95-98; J. Kwiatkowski, Wstep, s. CXXVII-CXXXIII; Willard Bohn, Guillaume Apollinaire, [w:] idem, Modern Visual Poetry, s. 38-50; Michael Webster, Engraved Sounds of Guillaume Apollinaire, [w:] idem, Reading Visual Poetry after Futurism..., s. 43-81; Johanna Drucker, Apolliniare: Figuring the Vernacular, [w:] eadem, The visible word. Experimental Typography and Modern Art, 1909-1923, Chicago-London 1996, s. 140-168.

52 Zob. przypis 47.

${ }^{53}$ M. Hopfinger, W laboratorium sztuki XX wieku..., s. 98. Badaczka kończy swój wywód stwierdzeniem, że ten typ wiersza był prekursorski wobec poezji konkretnej. Ja zaś chciałabym zasygnalizować, że o podobnych przesunięciach relacji słowa i obrazu mówi się w kontekście nowych mediów (już nie tylko kultury audiowizualnej), dość przywołać tu wprowadzone przez Mike'a Sandbothe'a kategorie upiśmiennienia mowy i oralizacji pisma, a także ikonizacji pisma i upiśmiennienia obrazu. Tym samym, zapowiadam od razu, że poruszane tu kwestie powróca w rozdziale poświęconym nowym mediom i liberaturze. Por. Mike Sandbothe, Transwersalne światy medialne. Filozoficzne rozważania o Internecie, tłum. Krystyna Krzemieniowa, [w:] Widzieć, 
Stąd - w przypadku tych kaligramów, które przekraczają prostą relację równoległego przypisywania jednemu znaczonemu dwóch znaczących, nie tyle uzupełniajacych się, co wzajem potwierdzających - możemy mówić o bliskości takiej formy literatury wizualnej i liberatury. Dlatego Fajfer i Bazarnik, mimo przywołanych tu ich krytycznych uwag do twórczości Apollinaire’a, w swoim Aneksie do historii literatury wskazują na pokrewieństwo w metodzie twórczej i z tym artysta. Jak podkreślał Kwiatkowski, poeta ten przywiązany był do dialektyki nowatorstwo-tradycja, stąd i jego kaligramy wikłały się zarówno w relacje z wywodzonymi ze starożytności wierszami-obrazami (dla liberatów niekoniecznie inspirujacymi), jak i z (ciekawszymi z punktu widzenia twórców literatury totalnej) nowoczesnymi eksperymentami poetycko-typograficznymi (Mallarmé, futuryści) ${ }^{54}$. Zaś zwróciwszy uwage na to, że wybrane kaligramy - nie te „stosunkowo proste” ${ }^{55}$ czy przywołujace tradycję antycznej (i późniejszej) poezji wizualnej, lecz takie, które przekraczają wcześniej wypracowane konwencje łączenia słowa i obrazu - mogą być jako liberackie traktowane i doceniane $^{56}$, muszę zapytać o dalsze konsekwencje płynące z krytyki tych pozostałych $^{57}$.

myśleć, być. Technologie mediów, red. Andrzej Gwóźdź, Kraków 2001, s. 205-231 oraz Jay D. Bolter, Eksplozja obrazów, tłum. Jolanta Mach, [w:] Ekrany piśmienności. O przyjemnościach tekstu w epoce nowych mediów, red. Andrzej Gwóźdź, Warszawa 2008, s. 119-156.

${ }^{54}$ J. Kwiatkowski, Wstęp, s. CXXVIII-CXXIX. Na charakterystyczne dla Apollinaire’a łączenie nowoczesności z tradycją zwracała też uwagę Drucker (por. J. Drucker, Apollinaire: Figuring the Vernacular, [w:] eadem, The visible word..., s. 140-168).

${ }_{55}$ M. Hopfinger, W laboratorium sztuki XX wieku..., s. 95.

${ }^{56}$ Choć warto tu dodać, że jeszcze w 2003 r. Fajfer pisał o wierszach figuralnych George’a Herberta czy (ogólnie) tekstach Apollinaire’a jako wzorowych przykładach liberatury, uznając, że sytuacja, w której sam tekst uktada się w jakiś obraz jest w pełni liberacka. Nie dodawał też wtedy ani słowa o znaczeniu relacji między kształtem utworu a niesioną przezeń ideą (Z. Fajfer, Nie(o)pisanie liberatury, [w:] LCLT, s. 62).

${ }^{57}$ Muszę jednak zaznaczyć, że zdaję sobie w pełni sprawę, iż problem liberackości twórczości Apollinaire’a nie musi ograniczać się wyłącznie do jego kaligramów. Odwołanie się do nich uznałam za najistotniejsze i na nim w zasadzie poprzestaję, niemniej mam nadzieję, że będę miała okazję powrócić jeszcze kiedyś do tej problematyki. Tu chciałabym zasygnalizować, że ciekawym i z pewnością wartym podjęcia tropem interpretacyjnym sa choćby - związane z futuryzmem - refleksje artysty o książce. W Antytradycji futurystycznej oraz manifeście Duch nowych czasów i poeci Apollinaire ciekawie wypowiada się o książce (jako medium!) i kwestie te (szczególnie jako rozwijające moje rozważania o relacji liberatury i futuryzmu) byłyby interesującym uzupełnieniem stawianych tu tez. W drugim z przywołanych manifestów czytamy: „Jakże to eksperymentowanie mogłoby nie interesować poety, skoro może mu ono przyczynić się do nowych odkryć na terenie myśli i liryzmu? [...] Efekty typograficzne stosowane radykalnie z dużą odwagą mają tę zaletę, że dzięki nim powstaje liryzm wzrokowy, prawie całkiem nieznany przed naszą epoka. Efekty te moga pójść jeszcze dalej i dokonać syntezy wszystkich sztuk, muzyki, malarstwa, literatury" (Guillaume Apollinaire, Dwa manifesty, tłum. Maciej Żurowski, „Przegląd Humanistyczny” 1968, nr 6, s. 11). Z kolei w Antytradycji... mowa o książce - ,życiu schwytanym czyli fonokinematografii czyli wyobraźni bez drutu” (G. Apollinaire, Dwa manifesty, s. 9). Choć dalsza interpretacja tych wypowiedzi wydaje się kuszaca, zmuszona jestem je pominąć, gdyż ich znaczenie dla kwestii poruszanych w tym rozdziale jest raczej marginalne, szczególnie w porównaniu z koncepcją Księgi Mallarmégo. 


\title{
1.5. O liberaturze i konwencji z innej perspektywy, czyli o totalnej sztuce słowa w kontekście dawnej poezji wizualnej
}

Jak już wskazałam, Apollinaire’owskie wiersze-przedmioty w prosty sposób prowadzą nas ku tradycjom starożytnej poezji wizualnej ${ }^{58}$. Tym samym, nie sposób uniknąć tu pytania o to, jak z perspektywy liberackiej oceniać tego typu utwory. Szczególnie, że narodziny nowoczesnej poezji wizualnej wiązały się bezsprzecznie z powrotem do tej dawnej tradycji, z próba jej dokładniejszej charakterystyki, z ważnymi reinterpretacjami. Większość badaczy zgodna jest też co do tego, że namysł nad poezją konkretną w znaczacym stopniu przyczynił się do takiego zwrotu. O niej właśnie pisząc, Seweryna Wysłouch konstatowała:

\begin{abstract}
Poezja wizualna ma starożytne tradycje, jej najdawniejsze świadectwa pochodzą sprzed naszej ery. Do niedawna jednak traktowana była jako swoista dewiacja, dziwaczna odmiana sztuki słowa. Jeszcze zamiłowany szperacz, Julian Tuwim, pisał w Pegazie dęba (1950) o wierszach obrazkach i wierszach-kobiercach jako o pozbawionych głębszego sensu kuriozach. Ale sytuacja diametralnie się zmieniła za sprawą poetów-konkretystów [...]. Dawna poezja wizualna znalazła swoich historiografów i doczekała się niespodziewanej rehabilitacji jako ciekawa tradycja nurtu współczesnej poezji konkretnej ${ }^{59}$.
\end{abstract}

Piotr Rypson, którego badania są na polskim gruncie najlepszą (i niedająca się przecenić) charakterystyką poezji wizualnej ${ }^{60}$, sprzeciwiał się traktowaniu tych wierszy wizualnych jako zabaw, ćwiczeń czy wprawek poetyckich, uznawaniu ich za (jak podsumował Janusz Pelc) „niewydarzone dziwactwo i przejawy zwyrodniałego gustu" ${ }^{1}$ czy (jak stwierdza przywoływany Falicki) „figliki literackie” wychodzące spod pióra raczej drugorzędnych pisarzy ${ }^{62}$. Rypson negatywnie odnosił się do niedostrzegania i wielowiekowej tradycji tej postaci sztuki słowa, i bogactwa jej form. Piszacc o szczytowym okresie świetności „dawnej” poezji wizualnej (XVII w.) podkreślał, że wcale nie zabawa czy naśladowanie już istniejących form było celem twórców:

Formalna oryginalność [...] nie płynęła jedynie, jak sądzą niektórzy, z imperatywu zadziwienia czytelnika pomysłowościa, dowcipem autora, sformułowane [go? - AP] przez barokowe poetyki i teorię retoryczna, ale z żywotnej i autentycznej potrzeby eksperymentowania możliwościami, jakie oferowała odkryta na nowo „obrazowość” tekstu literackiego ${ }^{63}$.

${ }^{58}$ Por. też J. Kwiatkowski, Wstęp, s. CXXVII-CXXVIII.

59 Seweryna Wysłouch, Od słowa do ornamentu. Semiotyczne problemy poezji konkretnej, [w:] eadem, Literatura i semiotyka, Warszawa 2001, s. 116.

60 Zob. Piotr Rypson, Obraz słowa. Historia poezji wizualnej, Warszawa 1989 oraz idem, Piramidy-słońca-labirynty. Poezja wizualna w Polsce od XVI do XVIII wieku, Warszawa 2002.

61 Janusz Pelc, Barok - epoka przeciwieństw, wyd. 2 popr., Kraków 2004, s. 174.

62 J. Falicki, Kod stowny a kod rysunkowy..., s. 356.

${ }^{63}$ P. Rypson, Obraz słowa..., s. 167. 
Z jednej więc strony, tak opisywane „eksperymenty”, tradycją sięgające starożytności, bliskie wydają się liberackiemu podejściu do tworzywa sztuki słowa, z drugiej - wciąż w pamięci mamy Fajferowską krytykę wyuczonej na tych utworach obrazowości. Skąd taka sprzeczność?

Rypson stwierdzał, że dopiero porzucenie „«manierystycznych» uprzedzeń” pozwoliło badaczom dostrzec we wszelkich odmianach literatury wizualnej tradycję, zauważyć, że taki nurt stale towarzyszył sztuce słowa ${ }^{64}$. Jednocześnie, wskazując na ponaddwutysiącletnią historię tego typu tekstów, badacz daje taką ich charakterystykę, którą bardzo łatwo odnieść do dzieł liberackich (przynajmniej tych, które w jakimkolwiek stopniu są wizualne). Pisze bowiem:

Wszystkie wiersze wizualne, w tym również teksty „konkretne”, łączy przede wszystkim usiłowanie stworzenia kompozycji słowno-obrazowej, w której widzialna forma utworu, nierozerwalnie z tekstem połączona (lub zeń wynikająca) i użyta w sposób świadomy, nadaje mu znaczenie lub określa jego funkcje. Tekst uzyskuje przez to nowy wymiar, nieobecny w zapisie tradycyjnym, rozciagający się między semantyką słów a ich ikonografią ${ }^{65}$.

Warto jednak zastanowić się nad swoistego rodzaju „drugim dnem” wskazywania wzorów nowoczesnej poezji wizualnej w tych najstarszych formach, podkreślania pewnego continuum tradycji. Rypson (inspirujac się też pracami innych badaczy, m.in. opracowaniami Jeremy'ego Adlera, Ulricha Ernsta czy Dicka Higginsa) w rzeczywistość wykonuje bowiem pracę podwójna, kreśli dwoisty portret polskiej i europejskiej literatury wizualnej. Z jednej strony daje charakterystyke podstawowych form, w jakie omawiana tendencja była ubierana, skrupulatnie wykazując również, jak jedne wpływały na drugie, jak z jednych (warto to podkreślić) skonwencjonalizowanych form, gatunków rodziły się kolejne, również określane zespołem wyraźnie wyróżnianych wyznaczników (przykładem omówione przez badacza zależności między wierszami twórcy tzw. wierszy kratkowych - łac. carmina cancellata - Publiusza Optacjana Porfyriusza ${ }^{66}$ a tymi autorstwa

${ }^{64}$ Ibidem, s. 17.

${ }^{65}$ Ibidem, podkreślenie moje.

66 Twórca ten komplikuje nieco nasze spojrzenie na relację liberatury i poezji wizualnej. Twórczość Publiusza Optacjana Porfiriusza jako tego, który wymyślił carmina cancellata niezaprzeczalnie jest (mimo konwencjonalności zaproponowanej formy) ciekawym kontekstem dla rozważań o twórczości Fajfera. Stworzona przez żyjącego na przełomie antyku i cywilizacji chrześcijańskiej poetę forma: teksty o regularnym kształcie (prostokąta), w które wpleciono akro-, mezo- i telestychy tak, by ich linie przecinały tekst, tworząc w jego wnętrzu dodatkowe figury, bliska jest ojcu polskiej liberatury, autorowi - przypomnę - tekstów emanacyjnych, opartych właśnie na szkatułkowej konstrukcji akrostychu. Dodatkowo, warto zwrócić uwagę na fakt, iż odżegnujący się od wszelkiej konwencjonalności Fajfer konsekwentnie wykorzystuje przywołany tu zabieg poetycki w kolejnych swoich pracach, czyniąc zeń rodzaj nie czego innego, lecz właśnie autorskiej, skonwencjonalizowanej formy gatunkowej. O ile bowiem w przypadku Oka-leczenia (czy nawet jeszcze (O)patrzenia) formuła taka wydaje się silnie zintegrowana z przesłaniem tekstu, w przypadku innych utworów trudniej już takie analogie wskazać (choć sądzę, że intencje takie ma np. Łukasz Jeżyk, por. idem, Widziećwierzyć-wiedzieć. Zenona Fajfera podejrzenia i spojrzenia, [w:] Między językiem a wizualnościa, red. Magdalena Bednarek, Maciej Junkiert, Joanna Klausa-Wartacz, Poznań 2008, s. 129-141 lub przedruk w $L C L T$, s. 174-186). W konsekwencji można by powiedzieć, że i Optacjanowska konwen- 
Wenancjusza Fortunata ${ }^{67}$ ). Z drugiej strony, szeroka panorama zjawiska, jaka daje Rypson, pełna jest wskazań wierszy, które na tak zarysowanym tle wydają się nowatorskie, wymykają się skrupulatnie budowanym przez autora typologiom. Nie zmienia to jednak faktu, że pierwsza fala przypominania antycznej poezji wizualnej była próbą imitowania owych dających się ujać w sztywne ramy form $^{68} \mathrm{i}$ dopiero na tym tle rysowały się wyjątkowe, prekursorskie w stosunku do nowoczesnej poezji wizualnej dzieła.

Nie bez znaczenia pozostaje tu też uwzględnienie przez Juliusa Caesara Scaligera w jego Poetices Libri Septem (z 1561 r.) poezji wizualnej. To pierwszy taki przypadek w historii poetyki, niebagatelnie też wpłyną na rozwój popularności form słowno-obrazowych, rozumianych jednak nie jako świadome autorskie eksperymenty z tworzywem (jak w interesujacych mnie jako kontekst dla działań liberackich tekstach z XX i XXI w.), lecz właśnie jako kontynuacja tradycji, tworzenie utworów spełniających ściśle określone kryteria gatunkowe, wpisujacych się w skodyfikowaną (m.in. właśnie dzięki Scaligerowi) konwencję (której - przypomnę - tak wyraźnie sprzeciwiali się liberaci). Jak podsumował Rypson:

Autorytet poetyki Scaligera przyczynił się bez watpienia zarówno do ugruntowania pozycji wierszy wizualnych jako prawidłowego gatunku literackiego o właściwych sobie prawidłach wersyfikacyjnych, jak i do rozpowszechnienia gatunku przez ówczesną dydaktykę szkolna. Etienne Tabourot [...] wspomina swe czasy szkolne, gdy wzorem Greków pisał wiersze

cja przyczyniła się do rozwoju liberatury. Zapewne dalszym ciekawym kontekstem byłby średniowieczny kontynuator wypracowanej przez Optacjana poetyki - Hraban Maur, u którego również odpowiednie ułożenie liter owocuje tym, iż część z nich funkcjonuje na kilku poziomach tekstu, tworzac teksty ukryte, dodatkowe (por. P. Rypson, Piramidy-stońca-labirynty, s. 25-29). Sygnalizując zaledwie tę ciekawą kwestię, pozostaje mi oddać głos Rypsonowi, który nad wyraz trafnie ujmuje istotę poetyki Optacjana, wskazując jednocześnie na takie jej elementy, które dla liberatów mogą być inspirujące. Badacz stwierdzał: „Litery akrostychów, wpisane w tekst zasadniczy, tworzą sens autonomiczny, pozostając jednocześnie częścią treści tego pierwszego”. Dalej, cytując Adlera, dodaje: „"najgłębsza istota wiersza może się w pełni wyłonić dopiero poprzez figurę, przebijając się przez diachroniczną ciagłość tekstu i ustanawiając znaczenie, które będzie zrozumiane jedynie wówczas, gdy zostanie zobaczone: wiersz staje się dwuwymiarowy». [...] Z pomocą wizualizacji języka poetyckiego Optacjan buduje znaczenia dwupoziomowe, w których słowo, jak biblijny werset, staje się ciałem" (P. Rypson, Piramidy-stońca-labirynty..., s. 16-18). Analizując Oka-leczenie Fajfera i Bazarnik, warto zwrócić uwagę właśnie na taką wielopoziomową strukturę tekstu, zwiazaną z zastosowaniem akrostychów, szczególnie mając w pamięci Fajferowskie marzenia o tym, by słowo stało się ciałem, forma (w uproszczeniu) treścia, ,jak” częścia „co” (por. Agnieszka Przybyszewska, Liberacka analiza tekstu (o czytaniu „Oka-leczenia” Zenona Fajfera i Katarzyny Bazarnik), [w:] Polska literatura najnowsza - poza kanonem, red. Paulina Kierzek-Trzeciak, Łódź 2008, eadem, Liberacki kanon literatury. O czytaniu „Oka-leczenia” Zenona Fajfera i Katarzyny Bazarnik. Podwójne zapiski z lektury dwukrotnej, czyli w dialogu z sama soba, „Ha!art” 2010, nr 30 oraz eadem, Close Reading of the Liberary Canon. On "Oka-leczenie" ("Eyes-Ore") by Zenon Fajfer and Katarzyna Bazarnik, [w:] Incarnations of Textual Materiality: From Modernism to Liberature, ed. Katarzyna Bazarnik, Izabela Curyłło-Klag, Newcastle 2014, a także M. Dawidek Gryglicka, Wewnętrzna i zewnętrzna architektura ksiażki na przykładzie utworu liberackiego autorstwa Zenona Fajfera i Katarzyny Bazarnik, [w:] eadem, Historia tekstu wizualnego...).

${ }^{67}$ Zob. P. Rypson, Piramidy-stońca-labirynty..., szczególnie rozdział Formy wierszy wizualnych-odmiany gatunkowe (s. 153-177).

${ }^{68}$ Zob. Rypson, Piramidy-stońca-labirynty..., szczególnie rozdział Recepcja starożytnej i średniowiecznej poezji wizualnej w epoce renesansu i wczesnego baroku (s. 36-54). 
w kształcie kielicha poetyckiego, kotła i innych form. Była to zapewne sytuacja dość typowa i niejeden XVI- lub XVII-wieczny wiersz wizualny jest dziełem studenta, pobierającego nauki kunsztu poetyckiego ${ }^{69}$.

Rypson zwraca uwagę na rolę szkół jezuickich - to właśnie członkowie tego zgromadzenia nie tylko tworzyli wiersze wizualne (bo to miało miejsce i w innych zakonach: u franciszkanów, pijarów, paulinów, trynitarzy, bazylianów), lecz kładli szczególny nacisk na wykorzystanie takich form w edukacji ${ }^{70}$. Podczas zajęć praktycznych dążyli do nauczenia studentów posługiwania się omawianymi technikami, pragnąc wyrobić w podopiecznych odpowiednie nawyki twórcze. Jak podsumowuje Rypson, przekazywana podczas tych spotkań wiedza miała charakter nie tylko informacyjny, ale i normatywny ${ }^{71}$. Częstym ukoronowaniem takich studiów były również liczne wizualne publikacje w albumach uświetniajacych promocję, uzyskanie bakalaureatu ${ }^{72}$. W konsekwencji, przez długi czas wiersze wizualne, których „wytwórstwa” przyszli adepci sztuki literackiej uczyli się przez lata, wykorzystywane były jako literatura „użytkowa”, formy majace zastosowanie w życiu publicznym (panegiryki, satyry polityczne itp.). Z racji takiej swej użyteczności były też (nadal) uczone w szkołach.

Zapytam więc jeszcze raz: czy te wiersze są dobrym kontekstem do mówienia o nowoczesnej poezji wizualnej albo liberaturze? Jeżeli dostrzeżemy silny nacisk, jaki kładziono tu na realizację ściśle wyznaczonych (skodyfikowanych, spisanych, wyuczonych) form - do liberatury na pewno im daleko. Podobnie jak do łączącego literaturę totalna z postmallarméańską poezją wizualną eksperymentowania z literackim tworzywem, dążenia do znalezienia nowych perspektyw dla słowa.

Niemniej, dla zarysowania właściwego tła dla tych dwóch przywołanych w ostatnim zdaniu odmian sztuki słowa istotne wydają się wiersze określane przez Rypsona jako wyjątkowe, niedające się zamknąć w konwencji, niemieszczące się $\mathrm{w}$ formułowanych przezeń typologiach ${ }^{73}$. W nich, istotnie, uruchamiane były podobne jak w XX i XXI w. mechanizmy, stąd nie dziwi, że Rypson domagał się docenienia ich jako kontekstu dla badań współczesności. Tym samym, te właśnie utwory - jako przekraczające konwencjonalne układy mogłyby być również (podobnie jak część twórczości Apollinaire’a czy Mallarmégo) traktowane jako liberackie. Jednak cała bogato opisana „reszta” już nie do końca powinna być w tym kontekście odczytywana.

${ }_{69}$ P. Rypson, Piramidy-stońca-labirynty..., s. 53-54.

70 Ibidem, s. 88.

${ }^{71}$ Ibidem, s. 75. Warto też dodać, iż np. w Polsce dostrzec można różnice w zakresie tego, jakie formy (nie tylko poezji wizualnej, ale i - szerzej - kunsztownej) były dominujące, różnice uwarunkowane odmiennymi nieraz inspiracjami konkretnych środowisk (ibidem, s. 87).

${ }^{72}$ P. Rypson, Piramidy-słońca-labirynty..., s. 113.

${ }^{73}$ Warto pamiętać, że z nurtu wizualnego wywodzą się nie tylko próby nadania utworom konkretnego kształtu, ale też np. eksperymenty związane z operowaniem kolorem czcionek - przykładem osiemnastowieczny wiersz Johanna Benthera z Gdańska, w którym zastosowano czcionkę czarną i czerwona, tak, że tą drugą drukowano słowa symbolizujące rany wpisanej w tekst postaci Chrystusa (zob. P. Rypson, Piramidy-stońca-labirynty..., s. 186). 


\subsection{Adam Nieradzki - siedemnastowieczny liberat}

Szukając przykładów, warto na pewno odwołać się do (wydanego anonimowo) siedemnastowiecznego tomu Kirys hartowny starożytnego rycerza, najprawdopodobniej autorstwa Adama Nieradzkiego ${ }^{74}$. Cały zbiór odnosi się do ówczesnego buntu niepłatnego wojska (które walczyło o swoje prawa jako Związek Święcony - Nexus Sacer ${ }^{75}$ ). Żołnierze ci domagali się wypłaty należnego im żołdu, nieraz egzekwując swe prawa na własną rękę: grabieżami i gwałtem. Tekst zamykający cały zbiorek (zob. ilustracja 8, lewa strona) przedstawia oskarżenia w stosunku do tych żołnierzy w sposób niezwykle obrazowy - również w sensie dosłownym, gdyż połączono tu słowa z formą wizualną (w tomie znajdziemy jeszcze dwa inne teksty tego rodzaju).
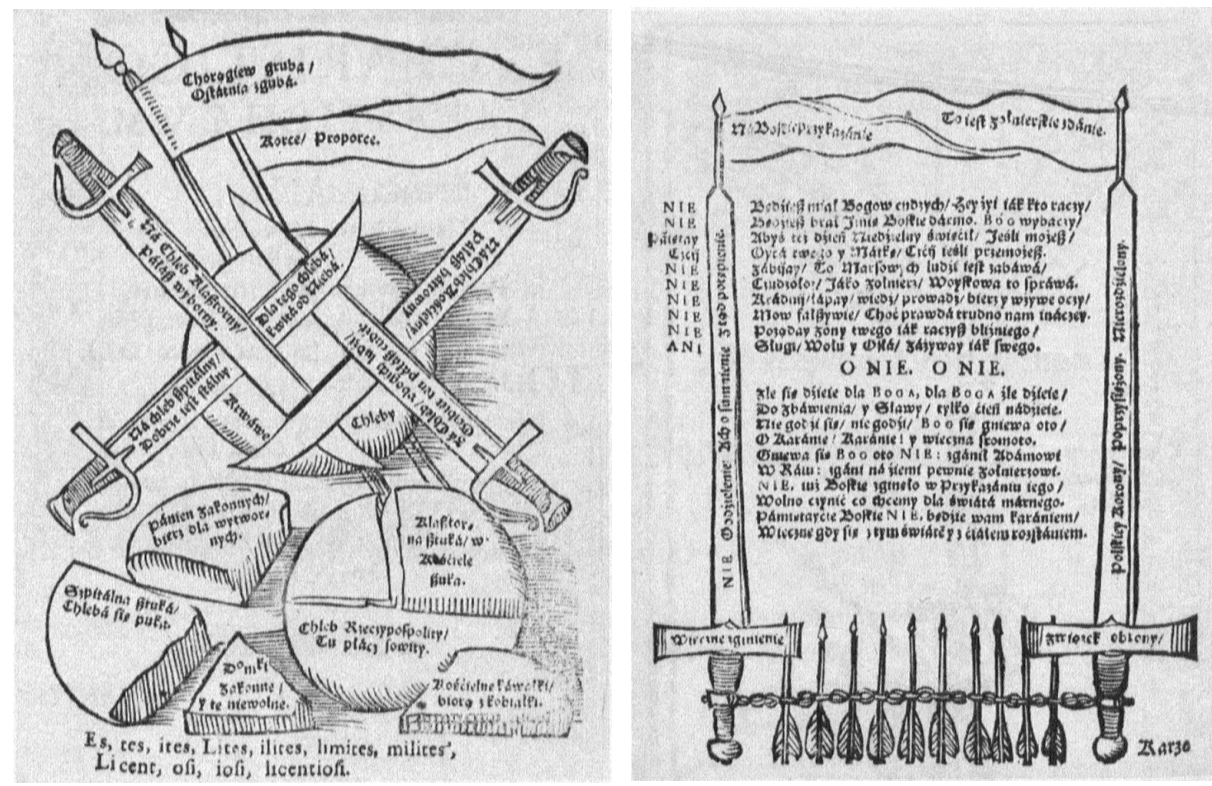

Ilustracja 8. Adam Nieradzki, Kirys hartowny starożytnego rycerza (źródło: Piotr Rypson, Piramidystońca-labirynty. Poezja wizualna w Polsce od XVI do XVIII wieku, Warszawa 2002, s. 336)

Ukazana na drzeworycie broń (pałasze) opatrzona jest napisami, takimi jak „na chleb klasztorny, pałasz wyborny” czy „za chleb ubogich ludzi, grzbiet ten pałasz cudzi”. Inskrypcje te nie tylko dopowiadaja wydarzenia, lecz i, w pełen

${ }^{74}$ Por. P. Rypson, Piramidy-słońca-labirynty..., s. 103-108 (podrozdział „Kirys hartowny”wiersze wizualne $w$ satyrze politycznej).

75 Szeroki rys historyczny pomagający w interpretacji tego utworu daje Piotr Wilczek w szkicu Funkcje wierszy wizualnych $w$ utworze Adama Nieradzkiego „Kirys Hartowny starożytnego żotnierza”, [w:] O literackiej ramie wydawniczej w ksią̇kach dawnych, red. Renarda Ocieczek, Katowice 1990, s. 21-43 (przywołany tu fragment: s. 23-27). 
ironii sposób, sugerują ocenę postaw osób ich używających. Wpisane w kształty pałaszy frazy sa bowiem ewidentnym nawiązaniem do tradycji umieszczania na broni formuł wychwalających czyny jej właścicieli bądź też wzywajaccych Boga i świętych, by chronili walczacych. Przywołane napisy jawnie dyskredytują posługujących się pałaszami żołnierzy ${ }^{76}$, a podobnie sfunkcjonalizowane są też choćby słowa z choragwi (,choragiew gruba, ostatnia zguba”).

Z kolei porozkrawane czy porabane wspomnianą bronią chleby, które widzimy na dole drzeworytu, opatrzone sa słowami „Krwawe chleby” itp. Wilczek, podobnie jak Rypson, zwraca uwagę na wieloznaczność użytego tu obrazu. Wizualny symbol odwołuje się nie tylko do chleba jako (1) typu pieczywa, (2) pożywienia, (3) zarobku, ale i do (4) tzw. chleba zimowego (tzw. hiberny): dawanej z królewszczyzn żywności dla wojska (później zastapionej datkami finansowymi) ${ }^{77}$. Równie wielopoziomowo obraz mówi o tym, co grabią ci, którzy posługują się pałaszami.

Zatem, jak widać, opowieść o wykroczeniach żołnierzy oraz jej ocena nie sa w tym utworze wypowiedziane wprost, lecz właśnie na styku słowa i obrazu. Działania żołnierzy opisuje obraz, zaś odbiór (ocenę) tych działań przedstawiają słowa z tym obrazem związane. Rypson słusznie zauważa, że tak zaprojektowana struktura werbalno-wizualna odznacza się dynamicznym charakterem, a „krzyżujące się i biegnące we wszystkie strony linie przywołują obraz pola bitewnego, szczęku oręża, zgiełku i ruchu"78. Nie ma tu historii opowiedzianej słowem i zilustrowanej obrazem - jest za to opowieść, która rozgrywa się na styku tych dwóch kodów. Trudno zatem mówić w tym wypadku o tak prostej relacji tworzyw, jak w inspirowanych dawniejszą poezja, innych utworach epoki. Gra znaczacych przypomina tu liberackie gry z sensem i na pewno to, co plastyczne nie jest tu powtórzeniem tego, co wypowiedziane słowami.

Drugi tekst, o jakim chciałabym wspomnieć, również pochodzi z przywołanego tomu i także odnosi się do okrucieństwa żołnierzy: do łamania przez nich dekalogu (zob. ilustracja 8, prawa strona). Wart jest tu przywołania m.in. dlatego, iż jego wizualność jest w gruncie rzeczy znikoma, a mimo to bez jej odczytania nie odkryjemy sensu utworu. Sformułowany w nim dekalog ujęty jest w ramy dwóch sczepionych mieczy, zwieńczonych choragwiami, na których dostrzec można napisy dajace się interpretować jako tytuł utworu (ponieważ wskazuja na przedstawiony w nim problem): „Na Boskie przykazanie” oraz dopowiedzenie na drugiej choragwi: „To jest żołnierskie zdanie”. Owe dwa miecze (wraz z łączącym je łańcuchem, w który wplecione są strzały) stanowią właściwie cała obrazową część utworu, przy czym lewy odcina od moralnych nakazów (klasycznie zapisanego tekstu) partykułę „nie” (oraz słowa „czcij” i „patrzaj”), a wspomniane strzały wycelowane sa w „okaleczony” spis przykazań (choć - spętane węzłami z mieczami - raczej nie mogą weń

\footnotetext{
${ }^{76}$ P. Wilczek, Funkcje wierszy wizualnych..., s. 38.

77 Ibidem, s. 36.

78 P. Rypson, Piramidy-słońca-labirynty..., s. 106.
} 
wystrzelić). W konsekwencji w obrębie tekstu, wewnątrz swoistej (zbudowanej z żołnierskich atrybutów) ramy, możemy wyróżnić przestrzeń zawierająca tytułową wojskową wersję boskiego prawa oraz opozycyjną doń (nie tylko z racji położenia) sferę zewnętrzna. Ich wzajemne (wizualne) relacje unaoczniaja zaś, iż nowy dekalog sformułowany został jako negatyw pierwotnego, poprzez odcięcie od niego fragmentów zdań. W jednym z zebranych w Kirysie... epigramatów Nieradzki odmalowuje słowami podobny obraz:

97. Novarum Legum, Siempra Inventores

Żołnierz na wspak wywrócił Boskie Przykazanie

Nie Czcij Ojca, Zabijaj, Kradnij, Bierz co sstanie.

Nowe prawa i BOGU, i ludziom nadaja

I tak w Polnej Koronie ich wszyscy słuchają ${ }^{79}$.

O ile w przypadku tego wiersza ocena i komentarz działań Nexus Sacer wyrażone są wprost, w sposób tradycyjny, werbalny, w przywołanym utworze wizualnym dopiero jego obrazowa forma pomaga w ogóle „odczytać”, kto łamie dekalog. Ponadto, to w owym plastycznym ukształtowaniu tekstu znajdujemy też sugestię, iż wśród tych, którzy jakkolwiek z mieczem są związani (żołnierzy posługujących się bronia), nie do końca możliwy jest sprzeciw wobec nowej formuły boskiego prawa (symbol łańcucha zatrzymującego strzały). Idąc tym tropem interpretacyjnym, należałoby przyznać, że żołnierze, owszem, postępują niezgodnie z dekalogiem, ale też, że - należąc do wojska - niezbyt maja możliwość sprzeciwu wobec takiej sytuacji (jeżeli jej nie akceptuja). A w efekcie (zwizualizowanego) wypaczenia boskich przykazań otrzymujemy m.in. następujące nakazy kierujące działaniami Nexus Sacer:

Będziesz miał Bogów cudzych, Hej żyj jak kto raczy,

Będziesz brał Imię Pańskie darmo, Bóg wybaczy ${ }^{80}$,

czy

Zabijaj, to marsowych ludzi jest zabawa,

Cudzołóż, jako żołnierz, wojskowych to sprawa ${ }^{81}$

Zatem i w tym wypadku pełne zrozumienie samej sytuacji przedstawionej w utworze wymaga od nas szukania sensu na styku słowa i obrazu, co każe traktować wiersz jako wyjątkowy na tle innych z epoki. Rypson ocenia go jako fascynujacy, niemieszczący się „w katalogu dotychczas poznanych gatunków poezji wizualnej" 82 . A warto dodać, że o wyjątkowej wrażliwości autora na wizualne aspekty literatury przekonuje również dalsza - pozornie nijak nieodwołująca się do obrazowości - część utworu. W niej to czytamy:

\footnotetext{
${ }^{79}$ Podaję za: P. Wilczek, Funkcje wierszy wizualnych..., s. 42.

80 Podaję za: P. Rypson, Piramidy-stońca-labirynty..., s. 107.

81 Ibidem.

82 Ibidem, s. 106.
} 
Gniewa się Bóg o to NIE, zganił Adamowi, w Raju, zgani na ziemi pewnie żołnierzowi.

NIE, już boskie zginęło w przykazaniu jego,

Wolno uczynić co chcemy dla świata marnego.

Pamiętajcie boskie NIE, będzie wam karaniem,

Wiecznie gdy się z tym światem i z tym ciałem rozstaniem ${ }^{83}$.

Nie widząc tekstu, nie wiedzielibyśmy, o jakim (napisanym wersalikami) „nie” mowa. Nie widząc, gdzie w przestrzeni wiersza znajduje się owa partykuła, nie wiedzielibyśmy, że pod sformułowaniem „gniewać się o to NIE” kryje się sprzeciw wobec przekraczania granic, łamania prawa, konstruowania własnego dekalogu jako negatywu praw boskich. Nie widząc miecza, nie bylibyśmy też tak pewni, kto ten grzech popełnia. Podkreślone przeze mnie zapisanie słowa „nie” wersalikami nie jest zabiegiem niebanalnym. Tak samo graficznie ukształtowane jest przecież „nie”, które od właściwego tekstu odcina miecz. O jakie zatem „nie” gniewa się Bóg? O to odcięte mieczem: konkretne, materialne, liberacko w tekście powtórzone. Czemu twierdzę, że liberacko? A czyż zastosowany tu zabieg nie przypomina umieszczania w dziełach literatury totalnej innych tekstów w ich własnej postaci, nie zaś ich opisywania?

Innymi słowy - oba przywołane i pokrótce zanalizowane tu wiersze sa wyjątkowe, znacznie odbiegają od normy wyznaczanej przez współczesne im utwory wizualne. Ich autor odchodzi zarówno od tautologicznego powtarzania w warstwie wizualnej jakości treściowych uprzednio wyrażonych słowem (co drażniło Fajfera), jak i od wszelkiego rodzaju wyuczonych, skonwencjonalizowanych gier i zabaw kształtem wiersza. W zamian tworzy teksty, w których nie dostrzeżemy żadnej tautologii, gdyż ich sens tworzy się dopiero, można by powiedzieć, w przestrzeni między dwoma porządkami znaczeń: wyraża go i to, co wizualne, i to, co werbalne, przy czym najważniejsza wydaje się tu właśnie owa koniunkcja, zespolenie obu tych poziomów.

Na początku moich rozważań zaznaczałam, że już z pierwszych wypowiedzi Fajfera wyłaniała się wizja liberatury jako takiej sztuki słowa, której nijak nie da się „przepisać” inaczej, w której miejsce poszczególnych wyrazów (i wszelkich elementów składających się na tekst) w przestrzeni tomu czy pojedynczej kartki musi pozostać bez zmian, gdyż w innej sytuacji - utwór zacznie inaczej znaczyć lub stanie się niekomunikatywny. W przypadku przywołanego dzieła Nieradzkiego mamy do czynienia z takim samym zjawiskiem - gdyby pozbawić je elementów wizualnych, stałoby się bezsensowne. Podobny skutek przyniosłoby inne graficzne ukształtowanie tekstu (choćby zmiana typograficznej postaci „nie” czy inny układ tekstu dekalogu w przestrzeni strony, np. za mieczem, a nie przed nim).

Jeżeli sugeruję, że wszelkie odmiany poezji wizualnej, w której tekst upodabnia się swym kształtem do czegoś, co w wierszu jest opisywane, nie są tak bliskie liberaturze, jak by się na pierwszy rzut oka wydawało, to właśnie ze

${ }^{83}$ Podaję za: ibidem, s. 107. 
względu na omawiany tu aspekt. W przypadku takich wierszy w sytuacji innego ich zapisania nie zatraca się przesłania, co najwyżej same teksty stają się mniej atrakcyjne. Ponieważ sens sugerowany przez warstwę wizualną powtarza w nich ten konstruowany w werbalnej: przy innym zapisie może i mniej on wybrzmi, jednak nie zginie. Zaś w liberaturze i w przywołanych tu jako bliskich jej tekstach (wymykających się prostym formułom wierszy-obrazów) jest to już nieco bardziej skomplikowane.

\subsection{Liberatura - poezja wizualna - literatura wizualna - literatura intermedialna}

Zatem: czy warto mówić o liberaturze w kontekście poezji wizualnej? Problematyczne wydają się tu dwie kwestie. Po pierwsze (co już wielokrotnie sygnalizowałam) liberatura nie musi być wizualna ${ }^{84}$ i co za tym idzie: albo powinniśmy zrezygnować z objęcia refleksja całej literatury totalnej, albo z charakterystyk zabiegów wizualizujacych poezję wyłuskać istotę procesu budowania znaczeń (można powiedzieć, że takie wydają się aspiracje Bohna), uogólnić ten model i - pozbawiony uwikłania w konkretne tworzywa - odnosić do liberatury. Innym rozwiązaniem byłoby zapewne spojrzenie na nią z perspektywy literatury nie tyle wizualnej, co intermedialnej, jednak takie ujęcie przekraczałoby ramy stawianych w tym rozdziale pytan ${ }^{85}$.

Druga problematyczną kwestią jest to, że i sama poezja (a i szerzej: literatura) wizualna nie jest nurtem jednolitym. W jego obrębie wskazać można zrodzona już w XX w. nowoczesna, (w dużym stopniu) niemimetyczną jej odmianę, silnie uwikłaną w problem kryzysu znaku (jak twierdzi Bohn - niejednego), eksplorująca w dużym stopniu przestrzeń tekstu, nie zawsze jawnie wizualna. Do powinowactw z nią przyznaja się wprost i sami liberaci (casus Mallarmégo). Z drugiej jednak strony istnieje cała długa tradycja wierszy wizualnych kształtowanych na wzór greckich technopaegni, w których związek słowa i obrazu nie jest tak bardzo istotny dla semiozy tekstu, i które sa formami w dużym stopniu skonwencjonalizowanymi. Te, tylko pozornie bliskie są liberaturze, choć owo nieprawdziwe podobieństwo silnie rzuca się w oczy

${ }^{84}$ O różnych odmianach liberatury - niekoniecznie wizualnych - Fajfer pisał w 2003 r. na łamach „Ha!artu” (szkic Nie(o)pisanie liberatury, zob. LCLT, s. 60-65), wyróżniajac również odmianę architektoniczną (eksponującą budowę, strukturę książki) oraz silnie materialną (eksponującą materię, na jakiej zapisany jest tekst).

${ }^{85}$ Warto też pamiętać, że używająca tego terminu Hopfinger odnosi go i tak do literatury łączącej słowo i obraz: zalicza doń literaturę wizualną (pisząc zresztą zasadniczo o jej nowoczesnej, wywiedzionej od Mallarmégo i Apollinaire'a odmianie) oraz komiks (M. Hopfinger, Doświadczenia audiowizualne..., s. 163-171). O kategorii literatury intermedialnej por. tė̇ Andrzej Hejmej, Intermedialność i literatura intermedialna, [w:] Kulturowe wizualizacje doświadczenia, red. Włodzimierz Bolecki, Adam Dziadek, Warszawa 2010 oraz cała część Przestrzenie intermedialności, [w:] idem, Komparatystyka. Studia literackie - studia kulturowe, Kraków 2013. 
i często bywa wskazywane, nie tylko w kawiarnianych dyskusjach miłośników zjawiska, lecz i w naukowych dysputach ${ }^{86}$.

Podsumowując - wszędzie tam, gdzie wizualna forma tekstu nie jest wyłącznie zabawa, gdzie znaczenia rozpisane są nie: równolegle (ale i tautologicznie) w warstwie werbalnej i wizualnej, lecz dokładnie pomiędzy nimi - tam możemy mówić o (większej lub mniejszej) liberackości. Ta, w proponowanym przeze mnie ujęciu, wiąże się przecież z próbą eksplorowania medium tekstu, zatem właśnie poszukiwaniami, których pokłosiem ma być rozszerzenie jakości tworzywa literatury, wspólne dla Mallarmégo i nowoczesnych poetów wizualnych oraz autorów nieschematycznych, przekraczajacych podziały gatunkowe utworów wizualnych związanych z nurtem poezji kunsztownej. Nie wszystko jednak, co przyciaga wzrok, ewokuje zarazem sensy, eksponowanie obrazowości tekstu nie zawsze jest związane z semantyką dzieła. Stąd, błędne może być, jak sądzę, traktowanie wizualności jako cechy, która miałaby nas w prosty sposób kierować ku liberackości utworu. Niemniej, jak wspominałam, w wielu wypadkach właśnie na takim poziomie rozgrywa się część ciekawych, liberackich procesów.

Warto też - jak już wspominałam - rozpatrzyć z tego powodu odrębne, jak sądzę, przypadki poezji konkretnej i komiksu, zastanawiając się, czy są one istotnie bliskie idei literatury totalnej, czy też może - wbrew narzucajaccego się, właśnie przez wizualny kształt, podobieństwa - wyraźnie się od niej różnia. Zagadnieniom tym poświęcam kolejne rozdziały.

${ }^{86}$ Por. Wojciech Kalaga, Liberatura: stowo, ikona, przestrzeń [wstęp], [w:] LCLT. Warto tu też ponowne przywołać szkic Nie(o)pisanie liberatury, w którym i Fajfer na takie zwiąki zwraca uwage. 


\section{Liberatura a poezja konkretna}

\subsection{Nie-konkretna kawiarnia liberacka, czyli szkic sytuacyjny zamiast wstępu}

Na okładce Od Joyce'a do liberatury ${ }^{87}$ (zob. ilustracja 9), pierwszej polskiej książkowej pozycji poświęconej literaturze totalnej, widnieją dwa zdjęcia Dantego Fajfera, syna pomysłodawców terminu i czołowych przedstawicieli tego nurtu. Czy umieszczenie fotografii pierworodnego na okładce tomu było zwykłą matczyną fanaberią redagującej książkę Bazarnik? Jeśli tak - to w podwójnym sensie, gdyż trzeba też pamiętać o Kasi-matce, bohaterce Oka-leczenia autorstwa wspomnianej pary artystów. A tym samym sfotografowany Dante - kilkakrotnie przez samego Fajfera opisywany jako „prototyp” Dantego z przywołanego trójksięgu - staje się symbolem, dając się odczytywać jako znak liberatury ucieleśnionej, nie tylko rzeczywiste, lecz też metaforyczne dziecko Bazarnik i Fajfera. Ponadto obie wspomniane fotografie pochodza z cyklu mDiAęNdTzEy, którego tytuł, nawet tych, którzy zdjęć nie widzieli, odnieść musi do jeszcze jednego kontekstu. Dante zdecydowanie bowiem stoi (czy wręcz tkwi) między: między literami między (fotografowany był we wnętrzu słynnej pracy Stanisława Dróżdża). Zredagowany przez Bazarnik tom już samą swą wizualnością stawia więc dwa pytania: pierwsze o to, czy czytelnik może liczyć na zapowiadane tytułem książki wyjaśnienie związku Joyce'a z liberaturą i kolejne, dotyczące relacji między tą ostatnią a poezją konkretna. Powiem od razu, że publikacja z 2002 r. nie daje odpowiedzi na druga z wątpliwości. Niemniej, zasiewa jej ziarno. Być może, jego plon potrzebuje wiele czasu, by dojrzeć - bo jak dotąd pojawiały się wyłącznie sporadyczne komentarze o tym, że „tak, poezja konkretna jest liberacka”88. Zatem może czas spróbować zastanowić się, co kierowało redaktorką Od Joyce'a do liberatury przy projektowaniu okładki ${ }^{89}$, sprecyzować, czy od poezji konkretnej do liberatury jest daleko.

${ }^{87}$ Od Joyce'a do liberatury.

${ }_{88}$ Pokrewieństwo zaznaczają sami Fajfer i Bazarnik: „Pisząc o antycypujących czy pokrewnych liberaturze tendencjach awangardowych z okresu powojennego, wypada wspomnieć o ruchu lettrystów, zainicjowanym w 1946 roku we Francji przez rumuńskiego poetę Isodore Isou, autora manifestu "Introduction à une nouvelle poesie et une nouvelle musique» (1942, ogłoszony w 1947) oraz o nurcie poezji konkretnej, której pierwsze realizacje datują się na lata pięćdziesiatte ubiegłego wieku" [http://www.liberatura.pl/1909-1969-czyli-od-futuryzmu-do-ksiazki-artystycznej.html (dostęp 24.11.2010)].

${ }^{89}$ Czy właściwie Fajferem, gdyż to on jest odpowiedzialny za jej kształt. 


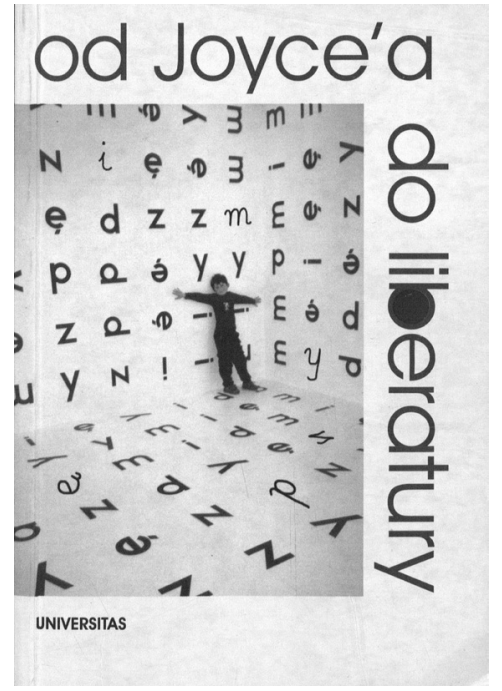

Ilustracja 9. Okładka Od Joyce’a do liberatury. Szkice o architekturze słowa, red. Katarzyna Bazarnik, Kraków 2002 (przód) (źródło: zdjęcie własne)

Przy okazji warto zadać pytanie o to, co by było, gdyby twórcy i teoretycy liberatury i poezji konkretnej naprawdę się spotkali. Co by się zdarzyło, gdyby przestrzenią tej konfrontacji stał się rzeczywisty pokój, o ścianach niekoniecznie pokrytych literami? Dla uplastycznienia obrazu możemy ustalić, że w zamian wisiałyby na nich dwa obrazy: po jednej stronie poemat-znak Fajfera (Autoportret, zob. ilustracja 10), po drugiej zdjęcie jednej z prac Iana Hamiltona Finlaya (Nienaturalne kamyki, zob. ilustracja 10). A jak mogłyby wyglądać toczone tam dyskusje?
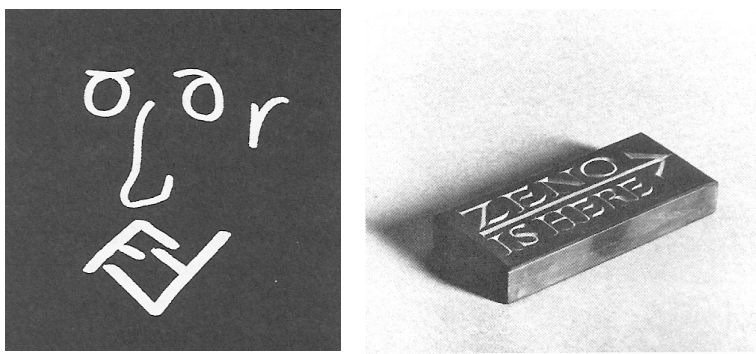

Ilustracja 10: Zenon Fajfer, Autoportret (źródło: zdjęcie własne autora) oraz Ian H. Finlay, Nienaturalne kamyki (źródło: „Literatura na Świecie” 2006, nr 11-12, s. 50)

Kiedy Fajfer pytałby: „Czy kształt okładki, kształt i kierunek pisma, format, kolor i liczba stron, słów a może nawet liter nie powinny być przedmiotem refleksji twórcy jak każdy inny element jego dzieła, wymagający od niego nie mniejszej inwencji niż dobieranie rymów czy konstruowanie fabuły?" ${ }^{90}$, Max

${ }_{90}$ Z. Fajfer, Liberatura. Aneks do stownika..., s. 9. 
Bense - komentujac manifest grupy Noigandres - wtórowałby mu zapewne słowami: „Uwzględnienie graficznych wartości pozycyjnych słowa lub zespołu słów na płaszczyźnie jest sprawą równie oczywistą jak wykorzystywanie faktów fonetycznych na granicy zjawisk akustycznych przy [o]mówieniu"91. Być może Fajfer dodałby jeszcze: „Fizyczna budowa książki nie powinna być wynikiem przyjętych konwencji, lecz spowodowana autonomiczna decyzja autora, tak jak perypetie bohaterów czy dobór tego a nie innego słowa"92. Czy Bense odpowiedziałby mu, że przecież „znaczenie tekstu, jego semantyka, rozwija się nie w gramatycznym kontekście, lecz w wizualnym połączeniu słów"93? Czy nadmieniłby, że „chodzi o tworzenie zespołów słów, które jako całość stanowią werbalna, wokalną i wizualna przestrzeń przekazu" 94 ?

Siegfrid Schmidt rozsiadłby się pewnie wygodnie w krześle i dodał, że „zapisana stronica, kształt i układ znaków pisarskich na płaszczyźnie, została [...] na nowo odkryta i włączona jako element konkretnej postaci tekstu, oraz, że odkrycie przestrzeni, włączenie wartości płaszczyzny i wartości graficznych do procesu tworzenia tekstu" ${ }^{95}$ charakteryzuje poezję konkretną. Fajfer, myślac o swojej liberaturze i patrząc na Bazarnik, zapewne wyjaśniłby, że istniejące literaturoznawcze terminy nadają się w związku z tym do wymiany ${ }^{96}$, że tworzywem literatury nie jest samo słowo. Tu pewnie przerwałby mu Bense, mówiąc o tegoż słowa „werbalnej, wokalnej i wizualnej materialności”97. A Bazarnik prawdopodobnie podchwyciłaby to ostatnie hasło, zwracając też uwagę, że „zastosowanie [...] niekonwencjonalnych materiałów nie ma wyłącznie funkcji ikonicznej, bowiem istotne są również cechy fizyczne tych materiałów i związane z nimi skojarzenia"98. Poszłaby może o krok dalej, rozwinęła temat i dodała coś jeszcze o „specyfice medium”, o tym, że ta „organiczna więź tekstu z formą i przestrzenią nośnika zapisu, wydaje się jedna z kluczowych cech liberatury" 99 .

Być może to Józef Bujnowski powróciłby do kwestii stosunku teoretyków i dotychczas sformułowanych teorii do omawianych zjawisk, mówiąc o obowiąkach literaturoznawstwa (konieczności „ustalania granic” ${ }^{100}$ ), o tym, że musi się ono zmienić, gdyż definicji czy opisu nowych struktur „nie da się [...] przeprowadzić w ramach tradycyjnej poetyki"101. Tadeusz Sławek, być może wiercąc się na krześle, zaznaczyłby - sugerując, że wyjątkowo ostre terminy

${ }_{11}$ Max Bense, Konkrete Poesie (cyt. za: Józef Bujnowski, Poezja konkretna, „Poezja” 1976, nr 6, s. 49; dalej oznaczane jako J. Bujnowski z numerem strony).

92 Z. Fajfer, Liberatura. Aneks do stownika..., s. 9.

${ }_{93}$ Max Bense, Einführung in die informations-theoretische Ästhetik. Grundlage und Anwendung in der Textheorie, (cyt. za: J. Bujnowski, s. 6).

${ }_{94}$ M. Bense, Konkrete Poesie (cyt. za: J. Bujnowski, s. 49).

95 S. J. Schmidt, Ästhetische Prozesse, s. 44-45 oraz 45 (cyt. za: J. Bujnowski, s. 46).

96 Z. Fajfer, Liberatura. Aneks do stownika..., s. 9.

97 M. Bense, Konkrete Poesie (cyt.za: J. Bujnowski, s. 49).

${ }_{98}$ K. Bazarnik, Liberatura czyli o powstawaniu gatunków (literackich), s. 161.

99 Ibidem.

100 J. Bujnowski, s. 40.

101 Ibidem oraz s. 41. 
niewiele tu pomoga - że przecież „chodzi o to, by normatywność konkretu zastapić jego operatywnościa, tzn. by nie mówić o poezji konkretnej jako o odrębnym rodzaju literackim, lecz by poszukać miejsc ujawniania się konkretności, realizacji konkretu w każdym tekście"102. Ja, gdybym miała przyjemność uczestniczyć w dyskusji (bo właściwie czemu miałabym jej sobie odmówić) przyklasnęłabym mu ochoczo, stwierdzajac, że również kategoria liberackości wydaje się bardziej poręczna niż sama etykietka „liberatura”103. Bujnowski pewnie dodałby wtedy, że przecież „niektóre struktury poezji konkretnej występowały już wcześniej [...]. Zawsze jednak struktury te i tendencje do nich prowadzące były na torze bocznym, zapowiadając możliwość rozwoju literatury i w tym kierunku, ale nie wybijając się na plan pierwszy"104. Ja (skoro już ustaliliśmy, że też tam będę) wtrąciłabym swoje trzy grosze o tym, że te boczne tory Piotr Rypson nazywa „inną tradycją"105, a współczesność to czas, w którym rzeczywiście zaczynają one coraz wyraźniej akcentować swoją obecność i że liberatura jest tego doskonała egzemplifikacją ${ }^{106}$. Fajfer być może kiwałby głowa, już widząc oczami wyobraźni rzeczywiste aneksy do Stowników terminów literackich.

Od słowa do słowa artyści zaczęliby zapewne wspominać tych, którzy stali się dla nich inspiracją. „Mallarmé!”, „Joyce!”, „Pound”... przerzucaliby się autorzy Manifestu poezji konkretnej z 1958 r. oraz liberaci z Krzeszowic. Fajfer może wspomniałby też Becketta. Przypomniałby sobie, jak chciał, aby i o nim mówiono jak autor Czekajac na Godota o Joysie („Pisarstwo Joyce’a nie jest o czymś, ono samo jest tym czymś” ${ }^{107}$ ). Być może wspólnie z Bazarnik wyszeptałby wtedy, że „w dziele liberackim chodzi o [...] integralność tekstu i obrazu, że «jak» jest częścią "co»"108. Czemu nie miałby wtedy odezwać się Tadeusz Sławek, by - przywołujac wiersz Eugena Gomringera czarna tajemnica jest tutaj, podkreślić, że tam nie tylko same słowa, ale i ich przestrzenne ukształtowanie czy nawet (związany z nim) ich brak, współkreują sensy. Zwracając uwagę na znaczaca pustą przestrzeń, okoloną czarnymi rzędami liter, stwierdziłby: „biel nie jest przerwą w wypowiedzi, lecz jej kontynuacją przy pomocy innego medium”109. Podsumowałby potem, że poezja konkretna „zamiast stwarzania słownych ekwiwalentów rzeczy przeobraża słowo w rzecz, że krótko mówiąc

102 Tadeusz Sławek, Między literami. Szkice o poezji konkretnej, Wrocław 1989, s. 41 (dalej oznaczane jako T. Sławek z numerem strony).

103 Por. pierwsza część tej książki, a także Agnieszka Przybyszewska, Liberackie marginesy tekstu sieciowego, [w:] Tekst [w] sieci, red. Anna Gumkowska, Warszawa 2009.

104 J. Bujnowski, s. 3.

105 Piotr Rypson, Posłowie, [w:] D. Higgins, Nowoczesność od czasu postmodernizmu..., s. 224 .

106 Agnieszka Przybyszewska, Nowa? Wizualna? Architektoniczna? Przestrzenna? Kilka słów o tym, co może literatura w dobie Internetu, [w:] e-polonistyka, red. Aleksandra Dziak, Sławomir J. Żurek, Lublin 2009.

107 Samuel Beckett, Dante... Bruno. Vico... Joyce, tłum. Antoni Libera, „Teatr” 1991, nr 4, s. 27.

108 Od Joyce'a do liberatury, s. II.

109 T. Sławek, s. 23. 
- wiersz nie mówi o czymś, lecz jest «tym czymś»"110. Tu Fajfer musiałby się uśmiechnąć.

W którymś momencie rozmowa pewnie zeszłaby na temat problemów wydawniczych. Może odezwałby się Radosław Nowakowski? Może Fajfer i Bazarnik opowiedzieliby o serii wydawniczej Liberatura? Może właśnie wtedy użaliłby się Marian Grześczak, przypominając, że przecież „większość jego wierszy nadsłownych nie ujrzała światła z przyczyn technicznych i konwencjonalnych”"111. Sławek przyznałby zaś, że nawet to, „co da się przykroić do formatu strony, nie zawsze da się przykroić do planów wydawcy"112. Fajfer może oburzyłby się tu trochę, gdy Bujnowski mówiłby o tym, że w gruncie rzeczy „listy w butelkach, słowa w pudełkach [...] itp. «inwencje» to eksperymenty [...] nastawione na szokowanie" ${ }^{113}$. Nie wiem, czy liberat dałby się udobruchać stwierdzeniem, że napisy na przezroczystych arkuszach już nimi nie sa. Autor napisów na przezroczystym arkuszu w butelce (Spogladajac przez ozonowa dziurę) pewnie by się trochę naburmuszył.

Być może rozchmurzyłoby go wtargnięcie Pierra Garniera wykrzykującego, iż „wiersz był dotychczas miejscem zniewolenia słów. Wyzwólcie słowa. Szanujcie słowa. Nie czyńcie z nich niewolników fraz. Pozwólcie im zająć własne miejsce w przestrzeni"114. Można się chyba spodziewać, że Fajfer odbiłby piłeczkę, mówiąc, że liberatura to właśnie „wolność, otwartość artystyczna, przekraczanie granic między gatunkami i sztukami, to literatura nie spętana ograniczeniami narzuconymi przez reguły, kanony, krytyków"115.

Zapewne długo można by jeszcze ciagnąć ową wyimaginowaną rozmowę. Pozwolić mówić zebranym także o tekstach, analizować, pokazywać, jak „różnica wielkości czcionek wskazuje na natężenie głosu” ${ }^{116}$ nie tylko w dziełach liberackich, nie tylko u Fajfera i Bazarnik, lecz i np. w poezji konkretnej Boba Cobbinga. Dać im możliwość dalej udowadniać, że jeśli chodzi o podejście do tworzywa tekstu, widzenie materialności i przestrzenności słowa, kwestie prekursorów i inspiratorów, doświadczenia z wydawaniem tekstów i jeszcze kilka innych elementów - nie ma niemal niczego, co by ich dzieliło.

A jednak... Co by było, gdyby ta zszyta z cudzych wypowiedzi rozmowa zaczęła się od innych zdań? Czy jej uczestnicy byliby aż tak zgodni? Wystarczyłoby bowiem, żeby Garnier dokończył myśl, która tak bezczelnie przerwałam mu w połowie: „Słowa nie sa bowiem ani po to, by je pisać, ani po to, by uczyć, ani po to, by mówić: słowa są przede wszystkim po to, by istnieć" ${ }^{117}$. Dla

\footnotetext{
110 Ibidem, s. 96 oraz 98.

111 Marian Grześczak, Wiersze wybrane, Warszawa 1977, s. 246 (cyt. za: T. Sławek, s. 52).

112 T. Sławek, s. 52.

113 J. Bujnowski, s. 40.

114 Pierre Garnier, Spatialisme et poésie concrete, Paris 1968, s. 131 (cyt. za: T. Sławek, s. 11).

115 Od Joyce'a do liberatury, s. II.

116 J. Bujnowski, s. 29.

117 P. Garnier, Spatialisme et poésie concrete, s. 131 (cyt. za: T. Sławek, s. 11).
} 
Fajfera są po coś więcej: po to, by mówić. Oczywiście, nie tylko na zasadzie ustalonych konwencji, arbitralnie przypisanych znaczeń, lecz by właśnie - jak chcą przecież też konkretyści - mówić soba, swoim kształtem, kolorem, faktura, umiejscowieniem w przestrzeni. Jednak nie tylko tym.

Gdyby Sławek stwierdził, że „działanie konkretystyczne polega [...] na usunięciu nieautentycznej warstwy semantycznej ustalonej jako podstawa tego, co Heidegger nazywa "pustą mową" (Gerede), «obiegową dostępnością» (Öffentlichkeit) i siłą anonimowego "się» (das Man)" "118, ktoś ze strony liberatów musiałby zareplikować, że działanie liberackie polega z kolei na dodaniu do tej warstwy kolejnych, na pogłębieniu, rozszerzeniu konwencjonalnych znaczeń, nie zawsze na drodze ich podważania i redukcji. Choć Sławek mógłby tu też zaznaczyć, że przecież w poezji konkretnej element semantyczny jednak „nie podlega zniesieniu”, jakkolwiek „napięcie między znakiem a przedmiotem zostaje w znacznej mierze zredukowane, a ciężar przeniesiony na związki międzyznakowe" 119 .

Liberaci zgodziliby się też pewnie w pełni ze stwierdzeniem Bensego, że słowa „używa się [...] jako elementu materiałowego konstrukcji w ten sposób, że znaczenie i struktura wzajemnie się uwypuklają i określają", trudno jednak, by podpisali się również pod poprzedzającą tę wypowiedź tezą badacza, iż „nie jest [ono, słowo - AP] zasadniczo używane jako intencjonalny nośnik znaczenia"120.

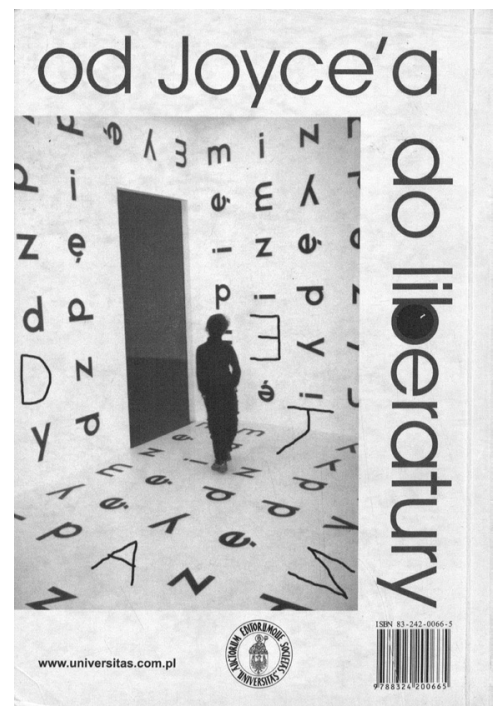

Ilustracja 11. Okładka Od Joyce’a do liberatury. Szkice o architekturze stowa, red. Katarzyna Bazarnik, Kraków 2002 (tył) (źródło: zdjęcie własne)

118 T. Sławek, s. 11.

119 Ibidem, s. 29

${ }^{120}$ Cyt. za: T. Sławek, s. 18, ten zaś cytuje za: Mary E. Solt, A World Look at Concrete Poetry, Bloomington 1968, s. 68. 
Tu zaczęłyby się pewnie coraz ostrzejsze wymiany zdań. Choć Mary Ellen Solt mówiłaby o tym, że poemat konkretny pozostaje poematem, że literackość odróżnia go od plakatu czy grafiki ${ }^{121}$, jest to przecież inaczej rozumiana literackość niż ta liberacka. Podobnie jak inne jest liberackie i konkretne uwalnianie słów. Może więc lepiej, że do opisanego spotkania nie doszło. Może lepiej, że nie pozwolimy jego uczestnikom rozmawiać dalej. Choć wiele ich łączy, choć zdecydowanie mają wspólny punkt wyjścia (jak powiedzieliby Brazylijczycy: świadomość, że „historyczny cykl [...] zamkną się; następnym krokiem jest uświadomienie sobie przestrzeni graficznej jako elementu struktury. Przestrzeń zostaje nazwana: struktura czasowo-przestrzenna miast linearno-czasowego rozwoju" ${ }^{122}$ ), punkt dojścia wydaje się jednak już inny.

Dante Fajfer na tylnej okładce zredagowanego przez Bazarnik tomu zdaje się odchodzić, zmierzać ku wyjściu z wnętrza pracy Dróżdża (zob. ilustracja 11). Być może słusznie, gdyż zdaje się, że relacja między tymi dwoma nurtami nie jest ani tak przyjazna, ani tak oczywista, jak mogło się na pierwszy rzut oka wydawać. Im dokładniej bowiem wczytywać się w teksty ich twórców i teoretyków, tym bardziej widać, że w wielu kwestiach tylko pozornie się zgadzaja. Nie bez powodu kiedy w 2010 r. podczas Festiwalu Conradowskiego jeden z uczestników spotkania poświęconego liberaturze zapytał o jej relacje z poezją konkretna, Bazarnik mówiła o łączących te nurty podobieństwach („«unikatowość» pojedynczych dzieł”), Fajfer zaś o dzielących je różnicach (,przesunięcie akcentu z wymiaru literackiego na graficzny") ${ }^{123}$. Uczestnicy przedstawionego tu nie-spotkania pewnie prędzej czy później poszliby śladem Dantego: w stronę wyjścia. Niemniej, podniesiona kwestia pozostaje interesujaca. Na czym bowiem opiera się paradoks tego, iż tak podobne w głównych tezach swoich programów nurty są zarazem tak różne? Pytanie o to, czy od poezji konkretnej do liberatury jest daleko nie powinno pozostać bez odpowiedzi. Również dlatego, że - jak być może rzuciłaby przez ramię, wychodząc z nie-konkretnej kawiarni liberackiej Mary Ellen Solt, dziś artysta „nie może już sobie pozwolić na traktowanie słów jako arbitralnych, nośników idei [...] słowo istnieje jako obiekt materialny jako rzecz, rządząca się własnymi prawami; [...] posiada ono formę wizualną na stronie książki; [...] składa się ono z liter z których każda posiada jaką́s formę plastyczną [...]”. Jesteśmy też wyczuleni „na stronę wizualną” tekstu „na kartkach książki i na zależność między formą a treścia, która [...] ma nam przekazać”124. Mówiłaby o liberaturze? O naszej „liberackości powszedniej"? Nie, podsumowywałaby znaczenie poezji konkretnej pod koniec lat siedemdziesiątych.

${ }^{121}$ Inny rodzaj kontaktu. Z prof. Mary Ellen Solt rozmawia Marek Hotyński, „Nowy Wyraz” 1977, nr 10, s. 63.

${ }^{122}$ Program poezji konkretnej (cyt. za: J. Bujnowski, s. 42).

${ }^{123} \mathrm{http}: / /$ www.conradfestival.pl/pl/4/1/143/co-jesli-liberatura-zwyciezy [dostęp 24.11.2010].

${ }_{124}$ Mary E. Solt, poezja konkretna, „Nowy Wyraz” 1977, nr 10, s. 61. 


\subsection{O tym, co kluczowe w (problematycznej) definicji poezji konkretnej}

Wszystkie definicje poezji konkretnej moga być zredukowane do jednej formuty: forma=treść/treść $=$ forma $^{125}$.

Jak zatem scharakteryzować nurt, który ma być głównym punktem odniesień w tym rozdziale? W antologii Concrete Poetry. A World View ${ }^{126}$, opublikowanej po raz pierwszy około dziesięć lat przed przeprowadzeniem cytowanego tu wywiadu, Mary Ellen Solt (jedna z czołowych badaczek konkretyzmu, a także artystka tworząca $\mathrm{w}$ tym nurcie ${ }^{127}$ ) zaczyna swoje rozważania od przyznania, iż termin „poezja konkretna” jest niczym worek bez dna. „Współcześnie mamy do czynienia z tak wieloma odmianami poezji eksperymentalnej określanej jako «konkretna»" - pisze - „że trudno powiedzieć, co owo słowo miałoby znaczyć" ${ }^{128}$. Mówiąc o całym tym zamieszaniu terminologicznym ${ }^{129}$, Solt podkreśla też, że wielokrotnie to sami artyści zaliczają się (lub nie) do nurtu konkretyzmu (dodajac zaraz, że i tak wszystko zależy od tego, jak tenże konkretyzm zdefiniujemy). Badaczka przyznaje jednak, że nawet dla bardzo różnorodnych ujęć (od tych najwęższych po te najbardziej otwarte ${ }^{130}$ ) daje się znaleźć pewne elementy łączace rozmaite poetyki ${ }^{131}$.

I rzeczywiście, próbując wyakcentować to, co wspólne dla wszystkich przyjętych w badaniach perspektyw (a to, nie zaś ścisłe definiowanie konkre-

${ }^{125}$ Mary E. Solt, Concret Poetry. A World View, London 1971 (dalej oznaczane jako M. E. Solt $\mathrm{z}$ numerem strony).

${ }^{126}$ Zob. przypis 38 .

${ }^{127}$ Ciekawe wydaje się, że - podobnie jak w przypadku liberackich tekstów teoretycznych piszą je głównie ci, którzy zajmują się zjawiskiem również od strony praktycznej.

${ }_{128}$ M. E. Solt, s. 7.

${ }^{129}$ Dick Higgins, zajmujący się poezją konkretną przy okazji swoich badań nad poezją wizualna, również podkreślał, że zamieszanie terminologiczne panujące wokół określeń związanych z różnymi rodzajami literatury wizualnej wydaje się nie do ogarnięcia i postulował wprowadzanie nie tyle wyraźnych rozróżnień jakościowych, co ilościowych, akcentujących, które z mediów składających się na intermedialną strukturę dominuje. Poezję konkretną do lat siedemdziesiątych (która będzie tu głównym nurtem odniesień) cechowała jego zdaniem dominanta słowna, nie - jak w przypadku nurtu poesia visiva z lat siedemdziesiatych - wizualna (Dick Higgins, Strategie poezji wizualnej: trzy aspekty, tłum. Krzysztof Brzeziński, [w:] Nowoczesność od czasu postmodernizmu..., s. 169).

${ }_{130}$ Za reprezentanta „klasycznego” szerokiego ujęcia można uznać Grzegorza Gazdę rozpatrującego ten nurt z perspektywy awangardowej korespondencji sztuk, a nawet poezji antycznej (por. hasło 'poezja konkretna' w: Grzegorz Gazda, Stownik europejskich kierunków i grup literackich XX wieku, wyd. 2, Warszawa 2009, s. 505-512). Badacz ten zgadza się jednak z opinia, że lata siedemdziesiąte kończą okres poezji konkretnej. Z kolei Jerzy Jarniewicz twierdzi (w 2006 r.), ,że mimo odprawianych nad nią funebralnych ceremonii, poezja konkretna ma się dobrze", co byłoby inną odmianą szerokiego ujęcia (Jerzy Jarniewicz, Tłumacze na urlop!, „Literatura na Świecie” 2006, nr 11-12, s. 58).

${ }_{131}$ M. E. Solt, s. 7. 
tyzmu, wydaje się potrzebne dla moich rozważań), dostrzeżemy, że zasadniczo zawsze napotkamy na twierdzenia rewaloryzujące kategorię tworzywa poetyckiego. W dominującej grupie wypowiedzi będzie nim słowo, mniej liczne ujęcia dopuszczą tu również elementy nielingwistyczne (np. plastyczne) ${ }^{132}$. Niemniej, owo konkretne słowo nie pozostaje ciagiem liter odsyłajacym do znaczenia na zasadzie relacji symbolicznej, nie jest obojętnym znakiem w funkcji wyłącznie referencyjnej, nie kieruje jedynie ku przestrzeniom wirtualnym (jak ma to, zdaniem Willarda Bohna, miejsce w poezji tradycyjnej $\left.{ }^{133}\right)$. Tutaj wyrazy zwracają uwage na siebie, zmuszają nie tylko do czytania, lecz i do oglądania/ słuchania. Chca znaczyć tu i teraz całym swoim jestestwem: tym, co werbalne, co wizualne i wokalne (członkowie brazylijskiej grupy Noigandres mówia tu o strukturze „verbalno-wokalno-wizualnej przestrzeni lingwistycznej”). Innymi słowy - celem poety konkretnego nie jest tworzenie okragłych zdań (no chyba, że w istocie będą one przybierały taki kształt; analogicznie można by powiedzieć, że gładkie zdanie liberata nigdy nie będzie chropowate). Max Bense, rozwijając teorię verbi-voco-visual, twierdzi wręcz, że twórca, o jakim w takich wypadkach mowa, w ogóle dąży nie do tworzenia zdań, lecz konstrukcji czy zespołów (ensembles). Stąd słowa powinny być wybierane zgodnie $\mathrm{z}$ zapotrzebowaniem owych konfiguracji na elementy o funkcjach wizualnych, wokalnych bądź semantycznych (odpowiadających trójwymiarowemu schematowi komunikacji), nie zaś ze względów składniowych czy - szerzej - generalnie gramatycznych ${ }^{134}$. Gdzie indziej Bense dodaje, że „znaczenie tekstu, jego semantyka, rozwija się nie w gramatycznym kontekście, lecz w wizualnym połaczeniu słów"135. Konkret, a nie abstrakt ma znaczyć.

Wyróżniając ten wspólny dla wielu (w gruncie rzeczy nie tak bardzo przecież różnych i pozostających ze sobą w dialogu) poetyk konkretystycznych postulat skupienia się na materialności słowa, nie chcę - podobnie jak nie było to moim celem w przypadku referowania teorii Fajfera - sugerować, że w tzw. tradycyjnej literaturze wygląd czy brzmienie słowa pozostaja bez znaczenia. Byłoby przecież wierutną bzdurą twierdzić, iż elementy te nie współtworzą formy dzieła bądź że nie wpływają na jego strukturę czy

${ }^{132}$ M. E. Solt, próbując określić tworzywo sztuki (poezji) konkretnej twierdzi, że zasadniczo jest nim ,język: słowa zredukowane do elementów, jakimi są litery (które można zobaczyć) lub sylaby (które można usłyszeć)" (M. E. Solt, s. 7, podkreślenie moje). Zauważa, że niektórzy twórcy sięgają wręcz po fragmenty liter bądź pojedyncze, wyizolowane dźwięki mowy. Badaczka podkreśla również, że wykorzystany przez artystów materiał nie-lingwistyczny (np. plastyczny) funkcjonuje w obrębie utworów na dokładnie tych samych zasadach, co słowa bądź ich części - wchodząc w analogiczne relacje semantyczne (M. E. Solt, s. 7).

${ }_{133}$ Rozwijając postulowane przez Bensego heglowskie rozumienie terminu konkretny, Bohn podkreśla jak bardzo namacalność, materialność wiąże się z konkretnością: „Podczas gdy tradycyjna poezja działa na poziomie konceptualnym, poezja konkretna bazuje na percepcji. Kiedy poezja tradycyjna zajmuje wymiar wirtualny, konkretna zawłaszcza niezaprzeczalną obecność" (W. Bohn, Modern Visual Poetry, s. 234-235).

134 M. E. Solt, s. 74.

${ }_{135}$ Max Bense, Einführung in die informations-theoretische Ästhetik... (cyt. za: J. Bujnowski, s. 6). 
odczytanie. Jednak w przypadku liberatury i poezji konkretnej istotne jest właśnie znaczące przesunięcie akcentu, skoncentrowanie się na tych właśnie elementach i nad wyraz świadome ich eksplorowanie. Taka zaś zmiana dominant prowadzi do dalszych konsekwencji. Jak zwracali uwagę brazylijscy konkretyści w swoim Plano-piloto para poesia concreta ${ }^{136}$ z 1958 r., jeśli tworzywem staje się słowo rozumiane jako „dźwięk, wizualna forma” i „semantyka”, jego problemem okazują się „funkcjonalne odniesienia w obrębie tworzywa" 137 [a problem of functions-relations of this material - Solt, s. 72]. Kolejne aspekty dzieła wymagaja rewizji, a w konsekwencji zmiany podejścia do języka jako takiego, przeobraża się też chociażby stosunek do przestrzeni tekstu czy jego linearności.

I właśnie podążenie tropem skutków takiej zmiany rozłożenia akcentów powinno doprowadzić do istoty konfliktu między tak pozornie podobnymi zjawiskami jak liberatura i poezja konkretna. Bowiem śledząc logikę prowadząca do tzw. redukcji języka i jej konsekwencje, zastanawiając się nad wolnościa konkretnego czy liberackiego słowa - dostrzeżemy wyraźne różnice. A jestem przekonana, że wiążą się one właśnie z rozumieniem granic wspomnianego tu przesunięcia dominant.

\subsection{Redukcja contra rozszerzenie, czyli co liberat zrobiłby z jabłkiem}

Proponuję zatem skupić się na ujęciu rodzącym się z tekstów teoretycznych głównych przedstawicieli konkretyzmu związanych z różnymi regionami świata (jako że poezja konkretna to ruch o charakterze międzynarodowym). Punktem odniesienia będą dla mnie przede wszystkim wypowiedzi czołowych przedstawicieli nurtu, ze szczególnym uwzględnieniem Szwajcara Eugena Gomringera, artystów zrzeszonych w brazylijskiej grupie Noigandres (bracia Haroldo i Augusto de Campos, Décio Pignatari), środowiska stuttgartskiego z Maxem Bensem na czele oraz Amerykanki Mary Ellen Solt (w wielu przypadkach również jako tłumaczki i komentatorki wypowiedzi pozostałych twórców). Skupiając się na manifestach autorstwa wymienionych, chciałabym stworzyć podstawę do kluczowego dla tego rozdziału porównania dwóch, formułowanych w odstępie kilkudziesięciu lat, teorii. Ponieważ interesować będzie mnie poezja konkretna nie sama w sobie, lecz jako kontekst dla opisu liberatury, skupię się na takich jej aspektach, które domagają się porównania, marginalnie wspominajac o (zasadniczo rzadziej analizowanym) nurcie poezji fonicznej (dźwiękowej) - z racji pomijania kwestii dźwiękowości w refleksji

${ }^{136}$ Augusto de Campos, Décio Pignatari, Haroldo de Campos, Pilot Plan for Concrete Poetry (Plano-piloto para poesia concreta), tłum. własne autorów; M. E. Solt, s. 71-72.

${ }^{137}$ Tu podaję tłumaczenie za Bujnowskim (J. Bujnowski, s. 43), który opierał się na przekładzie niemieckim. Ja bazuję na przekładzie angielskim dokonanym przez samych autorów (M. E. Solt, s. 71-72). 
liberackiej - a także poezji nie-semantycznej, opartej na niekoniecznie lingwistycznych elementach (i nie przez wszystkich do konkretyzmu zaliczanej) ${ }^{138}$.

Wróćmy zatem raz jeszcze do pytania o konstytutywne cechy poezji konkretnej. Nie można tu zapomnieć o - jak to formułuje Solt - „skoncentrowaniu się na fizycznym materiale, z którego wiersz czy tekst jest zrobiony"139. Również Gomringer w jednym ze swoich późnych, pisanych z perspektywy czasu, manifestów (Wiersz jako przedmiot funkcjonalny - The poem as a functional object, $1960^{140}$ ) - w okresie, w którym już zastapił termin konstelacja właśnie określeniem poezja konkretna- uznaje, że:

Dziś „Poezja Konkretna” to ogólny termin obejmujący spora liczbę eksperymentów poetycko-lingwistycznych (czy to w formie konstelacji, ideogramu, stochastycznej poezji etc.) charakteryzujących się świadomym studiowaniem materiału i struktury [...]: materiał oznacza tu sumę wszelkiego rodzaju znaków, z których tworzymy wiersz ${ }^{141}$.

Ten znaczacy namysł nad tworzywem rozumianym jako rzeczywista podstawa materiałowa tekstu (stającego się tym samym także przedmiotem estetycznym) wskazywany jest jako główna cecha poezji konkretnej przez wszystkich, którzy podejmowali wyzwanie zbudowania jej słownikowych definicji, przy czym podkreślane jest to, jak na plan pierwszy wysuwa się owa (w innych kontekstach zazwyczaj niemal neutralna) graficzna, wizualna, przestrzenna wartość znaku ${ }^{142}$.

Podobnie (ale czy identycznie?), jak w przypadku liberatury ${ }^{143}$. Charakteryzując ja, Wojciech Kalaga również pisał o „połączeniu semiozy tekstowej

138 Solt podkreśla, że dwa najważniejsze (Gomringerowski i brazylijski) manifesty nurtu skupiają się wyłącznie na poezji - jak ją nazywa - „zrobionej ze słów” (M. E. Solt, s. 15). Badaczka zauważa równolegle, że to w Brazylii właśnie powstał cały nurt konkretyzmu od słów niejako się odżegnujący: poezja semiotyczna Pignatariego i Luiza Ángelo Pinto (twórcy ci opublikowali w 1964 r. manifest pod tytułem Nova lingua gem, nova poesia). Warto jednak pamiętać, że i w obrębie głównego nurtu brazylijskiej poezji konkretnej dadzą się znaleźć prace pozbawione słów (zob. M. E. Solt, s. 15).

139 M. E. Solt, s. 7, podkreślenie moje.

${ }^{140}$ Eugen Gomringer, The poem as a functional object, transl. Irène M. Sinor oraz Mary E. Solt, [w:] M. E. Solt, s. 69-70.

${ }^{141}$ Cyt. za: M. E. Solt, s. 69, podkreślenie moje.

142 Janusz Sławiński mówi o maksymalnym sfunkcjonalizowaniu materialności tworzywa w obrębie utworów poetyckich, które nazywa „konceptami graficzno-semantycznymi” (Janusz Sławiński, hasło 'poezja konkretna', [w:] Stownik terminów literackich, s. 403-404), Jacek Wesołowski stwierdza, że dźwięk i jakości wizualne słowa są dla konkretystów podstawą konstrukcji tekstu (Jacek Wesołowski, hasło ‘poezja konkretna', [w:] Stownik rodzajów i gatunków literackich, red. Grzegorz Gazda, Słowinia Tynecka-Makowska, Kraków 2006, s. 550-551), Grzegorz Gazda podkreśla, że interesujący nas twórcy akcentowali przede wszystkim aspekty graficzne i wizualne (bądź wokalno-brzmieniowe) języka (G. Gazda, hasło 'poezja konkretna', [w:] Stownik europejskich grup..., s. 505-512).

${ }_{143}$ Analogicznie kwestia ta wybrzmiewa również w jej definicjach słownikowych, por.: hasło 'liberatura', [w:] Paulina Potrykus-Woźniak, Słownik nowych gatunków i zjawisk literackich, Warszawa 2010, s. 98-101; Piotr Marecki, hasło 'liberatura', [w:] Tekstylia bis. Stownik młodej polskiej kultury, red. Piotr Marecki, Kraków 2006, s. 215-216 oraz przywoływane już hasło 'liberatura' mojego autorstwa. 
z semiozą materialnego nośnika" ${ }^{144}$. W ujęciu tego badacza najmniejszą liberacką jednostką służącą kreowaniu znaczeń jest litera (ku czemu zdaje sie prowadzić go Nowakowski z jego swoistą instrukcją tworzenia liberatury ${ }^{145}$ ). Co więcej, Kalaga podkreśla jakoby to właśnie poezja konkretna uświadamiała nam, że nawet zapis głoski może być „nie tylko nośnikiem znaczenia, ale tworzywem tekstu wizualnego - «sememem» tekstobrazu"146. Jak widać, zarówno liberaci, jak i konkretyści zwracają uwagę na fakt, że zapomniano o tak istotnej cesze słowa pisanego, jak to, że jest ono właśnie zapisane.

Brazylijczycy, jak już wspomniałam, mówią o eksplorowaniu wszystkich aspektów struktury werbo-woko-wizualnej ${ }^{147}$. Teoretycy obu nurtów podkreślają też, że na przestrzeni dziejów dwa ostatnie z tych elementów były wyraźnie marginalizowane. Józef Bujnowski - w odniesieniu do konkretyzmu - sytuację tę podsumował słowami:

W dotychczasowej konwencji poetyckiej wybijał się na plan pierwszy czynnik werbalny, semantyczny (V3), podporządkowując sobie czynnik wokalny (V2) przeważnie w funkcji onomatopeicznej, przy zasadniczym lekceważeniu czynnika wizualnego (V1), który tylko w manuskryptach, starodrukach i w niektórych formach „manieryzmu” odgrywał pewną rolę ${ }^{148}$.

Fajfer zaś stwierdzał, że niektóre książki - w opozycji do tych klasycznych, tradycyjnych, konwencjonalnych chca być „do czytania wzrokiem, słuchem i dotykiem"149. Bense, teoretyzując o wykorzystywaniu materialności zapisu, zaznaczał z kolei, że możliwość budowania znaczenia zarówno w porządku semantycznym, jak i estetycznym oparta jest „o symultaniczną eksploatację wszelkich wymiarów elementów lingwistycznych” 150 .

Zdawać by się więc mogło, że i liberaci, i konkretyści dążą do zrównania wagi poszczególnych aspektów znaku, że postulaty te równoznaczne sa z - upraszczającym - stwierdzeniem Fajfera, że forma znaczyć ma w równym stopniu co treść. A jednak... Bujnowski kontynuuje swoje rozważania, stwierdzając, że „wartość semantyczna nie może być całkowicie wyłączona, nie odgrywa jednak takiej roli jak w poezji konwencjonalnej”'151. Zaś Bense w innym manifeście z tego samego roku co wcześniej cytowany, pisząc o poezji konkretnej

${ }^{144}$ Wojciech Kalaga, Liberatura: stowo, ikona, przestrzen, [w:] LCLT, s.11. Tekst ten jest skrótem artykułu Tekst hybrydyczny. Polifonie $i$ aporie doświadczenia wizualnego, z tomu Kulturowe wizualizacje doświadczenia, red. Włodzimierz Bolecki, Adam Dziadek, Warszawa 2010.

145 Por. pierwsza część książki.

146 W. Kalaga, Liberatura: słowo, ikona, przestrzeń, s. 11.

147 M. E. Solt prowadzi to do twierdzenia, że utwór konkretny staje się zbiorem znaków trójwymiarowych. Wskazując trzy wymiary (a więc i kształt foniczny), poeci z Noigandres - jak podkreśla Solt - idą o krok dalej niż Gomringer ze swoją podkreślającą wizualność (ale i przestrzenność - co umyka badaczce) teorią konstelacji (M. E. Solt, s. 14).

148 J. Bujnowski, s. 36-37.

149 Z. Fajfer, Po czym odróżnić liberaturę od literatury (wybrane szczegóty anatomiczne), [w:] $L C L T$, s. 81. Nie zachowuję typografii oryginału.

150 M. E. Solt, s. 73.

151 J. Bujnowski, s. 37. 
jako „stylu poezji materialnej” ${ }^{52}$, zauważa, że wszelkie elementy składowe (np. dźwięki, sylaby, słowa czy ich konstelacje) sa reprezentacją niezależnego od zewnętrznej rzeczywistości świata lingwistycznego. Innymi słowy - poezja konkretna odsuwa na drugi (czy, idąc za wskazaniami Bujnowskiego, wręcz trzeci) plan czyste znaczenie słów, dystansując się tym samym od rzeczywistości. Jerzy Jarniewicz stwierdzał, że w tym wypadku język wydaje się niczym szyba, która nijak nie chce być przezroczysta, a wręcz przeciwnie - przyciąga naszą uwage swoim istnieniem, nie tyle będąc pośrednikiem w przekazie świata zewnętrznego, co ów przekaz eliminując ${ }^{153}$. Jak wskazywali w swoim manifeście członkowie grupy Noigandres, poemat konkretny „jest przekazem swojej własnej struktury. Jest przedmiotem samowystarczalnym [samym $\mathrm{w}$ sobie - $\left.\mathrm{AP}^{154}\right]$, a nie przedstawieniem innego przedmiotu zewnętrznego albo mniej lub bardziej subiektywnych uczuć"155. A zatem dystansuje się od świata, zarzuca funkcję referencyjną.

Niezależnie bowiem od przyjętej poetyki, konkretysta będzie chciał dokonać tzw. redukcji języka w imię uwalniania, oczyszczania ${ }^{156}$. Z jednej strony poszerzając granice potencjalności znaczeniowej znaku (o dotychczas często lekceważone jego aspekty), z drugiej zaś odzierając go z sieci uwikłanych w licząca nieraz i tysiące lat tradycję odniesień, poeta konkretny „próbuje” - zdaniem Solt - „oswobodzić poezję od kilkusetletniego brzemienia symbolicznej referencji, aluzji czy monotonnej, powtarzalnej zawartości emocjonalnej”'157, odniesień do świata zewnętrznego nijak z samym słowem niezwiązanego, a zabierającego mu jego własną indywidualną egzystencję. Czy - jak Solt dodaje w końcowej części swojego wywodu - oswobadza on słowa od „nic nie znaczących, znoszonych związków gramatycznych, oczyszczając język" ${ }^{158}$. Owa redukcja ma służyć pozbyciu się naleciałości, które sprawiaja, że przestajemy wiedzieć, co znaczą słowa, których używamy, że trudno nam zobaczyć pod ich symbolicznym wymiarem, zmultiplikowanymi kulturowo odniesieniami to, czym są naprawdę. W rozumieniu konkretystów słowo powoli umierało, przestawało

${ }^{152}$ Gdyby zamiast określenia „poezja” użyć tu słowa „literatura” być może byłby to dobry synonim dla terminu liberatura. O materialności jako wyznaczniku liberatury - przypomnę - pisała też Bazarnik (Bazarnik, Materialność jako wyznacznik gatunkowy...). Por. też uwagi o formalistach i narracji mówionej oraz kategorii narracji materialnej w dalszej części książki (rozdział poświęcony liberaturze i typografii).

${ }^{153}$ Zob. J. Jarniewicz, Ttumacze na urlop!, s. 55.

154 Angielskie an object in and by itself, portugalskie um objeto em o por si mesmo, niemieckie Mitteilung seiner eigenen Struktur (będące podstawą dla tłumaczenia Bujnowskiego).

${ }^{155}$ Przekład podaję za Bujnowskim (J. Bujnowski, s. 42-43), zaznaczając swoje ewentualne korekty. Różnice mogą wynikać z tego, że ja opierałam się na wersji portugalskiej i angielskim tłumaczeniu autorstwa samych autorów z antologii Solt (s. 70-72), Bujnowski natomiast opierał się na dosłownym przekładzie na język niemiecki.

${ }^{156}$ Wśród polskich krytyków prosto i przekonująco, bez zbędnych metafor omawia kategorię redukcji języka Małgorzata Dawidek Gryglicka, analizując twórczość Emmetta Williamsa (Małgorzata Dawidek Gryglicka, Poezja konkretna Emmetta Williamsa, „Czas Kultury” 2001, nr 4, s. 60-63).

157 M. E. Solt, s. 8.

158 Ibidem, s. 59 . 
znaczyć, milkło w tej krzykliwej plątaninie komunikatów, w jaką było uwikłane ${ }^{159}$. Gomringer już w pierwszym swoim manifeście (From line to constellation, 1954) oznajmiał, że konstelacja „jest rzeczywistością samą w sobie, a nie wierszem o czymś"160, o jakiejś zewnętrznej rzeczywistości.

By zobrazować ten problem Jarniewicz zapożyczył się u Jacquesa Préverta, opowiadając na łamach „Literatury na Świecie”161 (a potem cztery lata później na spotkaniu w ramach łódzkiego festiwalu Puls Literatury) anegdotkę o malarzu, który nijak nie mógł namalować jabłka, gdyż nie potrafił zobaczyć w nim zwykłego owocu o określonym kształcie, barwie czy fakturze. „Przed oczyma artysty” - pisał w 2006 r. Jarniewicz - „przesuwały się znajome sceny: Ewa w rajskim ogrodzie, strzegace złotych jabłek Hesperydy, syn Wilhelma Tella z jabłkiem na głowie, Izaak Newton kontemplujący pod jabłonią"162. Nie mogac sprostać zadaniu, artysta kładzie się spać, nie zamalowawszy płótna. Wtedy pojawia się kolejny bohater - Picasso. Dostrzega jabłko przez otwarte okno i... zjada je. Ów gest staje się dla Jarniewicza idealnym gestem poety konkretnego ${ }^{163}$. W Łodzi historyjka ta stała się punktem wyjścia dla całego spotkania. Paradoksalnie jednak, podczas panelu poświęconego poezji konkretnej, w którym po jednej stronie stołu siedział Jerzy Jarniewicz i Agnieszka Taborska, po drugiej duet Zenkasi, nie zadano pytania o to, co liberat zrobiłby z jabłkiem... ${ }^{164}$. A może jednak warto dać się owym owocem skusić i rzeczone pytanie postawić?

Szczególnie, iż od jabłka właśnie wychodząc, zaczynając (od jabłka, nie od jajka, choć przy poruszanych tu kwestiach również i ten drugi początek byłby literacko symboliczny) zauważymy, że liberat i konkretysta nie chadzają tymi samymi ścieżkami. Ten pierwszy bowiem nie podążyłby żadna ze wskazanych w anegdotce Jarniewicza-Préverta dróg. Nie pociaga go ta, którą wyznaczaja symboliczne odniesienia, mityczne konteksty, ani też ta, która je odrzuca. Liberat nie chce wybierać. On widzi jabłko. Czerwone, błyszczące, obłe, nieidealnie kragłe, pachnące. Widzi je takie w ręku Ewy. Owoce w ogrodzie Hesperyd są bardziej chropowate, zaś to na głowie Wilhelma Tella mniej pachnie, choć z pewnością bardziej ciąży. Liberat nie chce oddzielać jednego od drugiego. Dla niego jabłko, które skusiło Adama, nie byłoby jabłkiem, gdyby nie rozsiewało woni. O ile sięgajacy po owoc konkretysta będzie próbował pozbyć się balastu zbędnych jego zdaniem odniesień i - na drodze oczyszczania, redukcji języka

159 Odnośnie do takiego „oczyszczania” słowa z „nalotu tradycji” zob. też fragment poświęcony relacji liberatury i formalizmu (szczególnie fragment poświęcony Szkłowskiemu) w jednym z kolejnych rozdziałów.

${ }^{160}$ Eugen Gomringer, From line to constellation, transl. Mike Weaver, [w:] M. E. Solt, s. 67.

161 Jerzy Jarniewicz, Ttumacze na urlop!

162 Ibidem, s. 54

${ }^{163}$ Badacz dodaje: „Poeci konkretni [...] nie zapominaja, że jabłko można zjeść, a jego smak może być źródłem podniebnych przyjemności. Nie przekładająjabłka na język mitu” (ibidem).

${ }_{164}$ Właściwie konstruktywnych pytań było w tym panelu niewiele, takowych odpowiedzi jeszcze mniej. Uczestnicy spotkania dowiedzieli się pewnie trochę o poezji konkretnej (z ust Jarniewicza), trudno jednak powiedzieć, jaki był cel zaproszenia do udziału w dyskusji Fajfera i Bazarnik. O relacji liberatura-poezja konkretna w każdym razie niewiele można tam było usłyszeć. 
- paradoksalnie poszerzać możliwości ekspresji twórczej ${ }^{165}$, o tyle pisarz liberacki zapragnie osiagnaćc to samo bez odrzucania jakiejkolwiek przestrzeni znaczeń.

Fajfer chciał, by waga wszelkich podejmowanych przez autora decyzji była taka sama, niezależnie od tego, do której warstwy znaku się one odnosiły. Razem przecież konstytuowały znaczenie. Konkretyści zaś - choć podobnie jak liberat dążyli do zniesienia tradycyjnej hierarchii - nie rugowali jej jednak definitywnie jak Fajfer, lecz po prostu na jej miejsce wprowadzali nowa, odwróconą (co idealnie pokazują - wizualne - schematy Bujnowskiego). Co prawda wydaje się, że Nowakowski - który w swojej teorii bywa mniej od Fajfera konsekwentny - mąci sugerowane klarowne podziały, stwierdzając, że:

Liberatura jest także literatura. Ale literatura nie jest liberaturą. W literaturze ważny jest tylko tekst. W liberaturze ważna jest cała książka, bowiem każdy jej element (papier, okładka, typografia, kolory, sposób otwierania, kształt...) bierze udział w tworzeniu opowieści, choć niewątpliwie głównym opowiadającym jest tekst (chociaż już nie zawsze) ${ }^{166}$.

Czy w istocie więc liberatura zrównuje, nie tworzy własnych hierarchii? Pozostanę na stanowisku, że właściwie - tak. Owszem, ustanawia element nieodzowny (czego w poezji konkretnej brak): słowo, tekst. Upiera się, by być literatura. $\mathrm{Na}$ mocy decyzji autorskich wprowadza inne elementy znaczace (aspekt wizualny, materialny, strukturalny, przestrzenny). I te - od momentu swego pojawienia się - budują już sensy na równi ze słowem. Jego wyższość polega wyłącznie na tym, że musi być obecne (a możemy spotkać poezję konkretną bez słów - dość przypomnieć tu poezję semiotyczną Pignatariego i Luiza Ángelo Pinto ${ }^{167}$ ). Tak więc, choć i w tekstach Fajfera przeczytamy wprost, że „słowo nadal jest najważniejsze”168 (co ma odróżniać zresztą liberaturę od książki artystycznej), to chodzi tu o słowo, które - „poprzez pismo - zrosło się z materią i związało z przestrzenią" ${ }^{169}$, które musi być obecne, lecz w którym materialne, graficzne, przestrzenne aspekty są równie istotne (i komunikatywne) jak inne denotowane przezeń informacje.

Można próbować spojrzeć na opisywany tu problem z innej jeszcze perspektywy - uznać, że liberatura chce odpowiednie dać rzeczy słowo, a poezja konkretna odpowiednie słowo w rzecz przekuć. Ta ostatnia to przestrzeń

${ }^{165} \mathrm{O}$ poszerzeniu znaczeń wynikającym z redukcji języka interesująco pisze też Elżbieta Łubowicz. Badaczka pokazuje, że słowo pozbawione odniesień (nie tylko symbolicznych lecz i - co ciekawe w jej ujęciu - wizualnych) nie ma już do czego odsyłać. Pozbawione zaś relacji z desygnatem wskazuje na cały paradygmat, mnożąc możliwości odczytań. Spostrzeżenia te Łubowicz wykorzystuje przy interpretacji pracy lub Stanisława Dróżdża (Elżbieta Łubowicz, Rzeczywistość jest tekstem. O poezji konkretnej Stanisława Dróżḋ̇a, „Odra” 1999, nr 7-8, s. 88-89).

${ }^{166}$ R. Nowakowski, Pojedynek słowa $z$ obrazkiem, http://www.liberatorium.com/teksty/pojedynek.html [dostęp 24.11.2010].

167 Zob. przypis 51.

168 Z. Fajfer, W strone liberatury, s. 93

169 Ibidem. 
„Słowoprzedmiotów (rozpiętych w czasoprzestrzeni)” $170 \mathrm{i}$ - by sięgnąć po rodzimy termin - pojęciokształtów. O nich zaś Dróżdż mówił, że ich nazwa wywodzi się z tego, iż swoim wyglądem odbijają coś zdeterminowanego obiektywnymi przesłankami, niebędącego subiektywnym aktem kreacji ${ }^{171}$. Trudno o tej twórczości powiedzieć, by jej celem było opisanie świata. Ona go raczej tworzy - składając z kształtów liter (czy ich czastek), z przestrzennych układów małe alternatywne, lingwistyczne światy. Liberatura zaś nie chce odcinać się od opisywania świata. Chce go - jak przekonywał Nowakowski - zamknać w książce, gdyż jest (analogicznie do opisujacej świat literatury i omawiającej świat oratury) - jego „uksiążkowianiem"172.

A zatem: czy poezję konkretna i liberaturę więcej łączy czy dzieli? Czy sa sobie bliskie czy - dalekie? Coraz wyraźniej widać, że zarazem i takie, i takie, bo z tego, co dla tych nurtów wspólne rodzi się jednocześnie to, co je wyraźnie dzieli. Powtórzę raz jeszcze, że tekstu liberackiego nie da się „przepisać”, bo przestanie znaczyć. Doskonałym przykładem jest tu Ulica Sienkiewicza w Kielcach Radosława Nowakowskiego, w której - przypomnę - sposób zapisania tekstu odzwierciedla tor ruchu bohatera (niemożliwy do zrekonstruowania w inny sposób), tempo, w jakim się on porusza (gdy biegnie, rozstrzelone fonty „biegna” wraz z nim), a nawet czas, jaki w poszczególnych miejscach spędza (znów na zasadzie zagęszczenia bądź rozrzedzenia zapisu). Przepełniony zaimkami odsyłajacymi do przestrzeni, postaci i wydarzeń związanych z ikoniczną warstwa tekstu, przepisany inaczej utwór stałby się niekomunikatywnym bełkotem.

Niby podobnie Solt (skądinąd słusznie) napomina, że „zmiana stylu czcionek w wierszach Gomringera byłaby aktem nieodwracalnym przemocy wobec tych utworów"173. Badaczka zauważa również, że kiedy poeta konkretny (czy wizualny) przechodzi od teorii do praktyki, musi stawić czoło „pewnym problemom przynależnym materiałowi, w jakim pracuje" ${ }^{174}$. Decydując się na pracę ze słowem w jego wizualnym wymiarze, musi podjąć wyzwanie operowania typografia, wyzyskiwania z kształtu i formy liter, z rodzajów czcionek, kolejnych znaczeń. Solt - podobnie jak Fajfer - zwraca uwagę na wagę (i obowiąek) podejmowania przez autora decyzji odnośnie do wizualno-typograficznego kształtu dzieła: ,jest sprawa projektanta zadecydować, jaki rodzaj czcionki, czy też czcionek, najlepiej przekona odbiorcę jego reklamy do kupienia produktu, który sprzedaje. Troski typograficzne poety są dużo bardziej subtelne i znaczace i powinien on być może przykładać nawet jeszcze większą wagę do podejmowanych

${ }_{170}$ Określenie Grupy Noigandres, M. E. Solt, s. 72.

171 Stanisław Dróżdż, Zbigniew Makarewicz, Pojęciokształty. Rozbiór dramatyczny przedmiotu, „Odra” 1968, nr 12, s. 75. Dróżdż nie posługując się terminem redukcji języka, pisze o analogicznym celu, jaki pragnie osiagnąc w swoich pojęciokształtach: słowo (o którym pisze, że w języku literackim jest ono już zdewaluowane) jest modernizowane „na zasadzie doprowadzenia go do znaczenia tak wiele, by przestawało znaczyć, przestawało „kłamać”, a służyło tylko jako intersubiektywny znak skojarzeniowy treści indywidualnych i rozumiane było w informacji tylko przez analogię" (ibidem).

${ }_{172}$ R. Nowakowski, Traktat kartkograficzny....

173 M. E. Solt, s. 62.

174 Ibidem, s. 61. 
decyzji typograficznych"175. Zatem dwoje przywołanych twórców i teoretyków a za nimi całe zastępy liberatów i konkretystów - podobnie podchodzi do roli decyzji związanych z aspektami dzieła dotąd najczęściej uznawanymi za raczej błahe, uznając, że umiejscowienie słowa w przestrzeni jest równie ważne, jak jego wybór. Choć różnie podchodzą do jabłka, ich podejście do tworzywa sztuki słowa jest podobne. Choć do rozszerzenia możliwości artystycznej ekspresji dochodzą różnymi drogami (metodą redukcji i w sposób zgoła przeciwny), ich celem jest właśnie uwalnianie słów, pragnienie (dosłownego) oddania im przestrzeni. W swych ujęciach są zatem zarazem zgodni, jak i zupełnie sprzeczni.

\subsection{Znów żywe: uwolnione i uprzestrzennione słowa liberatów i konkretystów}

Zdaje się, że, aby pokazać jeszcze dobitniej z czego wynika paradoksalna wspólnota programowa programowo niezgodnych liberatów i konkretystów, warto odwołać się do historycznych początków drugiego z wymienionych ruchów i wskazać na pozornie mało istotny fakt znajomości między Gomringerem (a później i Bensem) a Maxem Billem ${ }^{176}$. Ten ostatni był przecież członkiem DE STIJL ${ }^{177}$, w którego manifeście z 1920 r. czytamy:

SŁOWO JEST MARTWE...

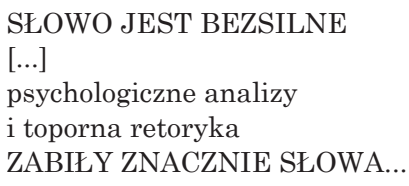

słowo musi zostać zrekonstruowane

$[\ldots]$

jeśli w starej poezji

poprzez dominację relatywnych i

subiektywnych uczuć

nieodłączne znaczenie słowa zostało zniszczone

chcemy, używając wszelkich możliwych środków

syntaksy

prozodii

typografii

arytmetyki

ortografii

dać nowe znaczenie słowu i nową siłę ekspresji178

\footnotetext{
175 Ibidem.

176 Wojciech Pogonowski, Poezja konkretna - ksztattowanie się ruchu artystycznego, Bydgoszcz 1979.

${ }_{177}$ O roli holenderskiego czasopisma De Stijl dla polskiej rewolucji typograficznej pisał (w kontekście druku funkcjonalnego) Piotr Rypson (Piotr Rypson, Ksiażki i strony, Warszawa 1992, s. 33).

178 M. E. Solt, s. 11. Badaczka zaś podaje za: Mike Weaver, The Lugano Review, Appendix B (from De Stijl, 3rd year, 1919-1920, s. 45-54), transl. Mike Weaver, s. 124-125.
} 
Czyż podobnie o słowie nie myśleli konkretyści? I czy Fajfer nie pisał już w pierwszym swoim manifeście o martwocie słowa i kryzysie literatury? Łaczące twórców obu nurtów dążenie do przywrócenia (bądź dania) słowu owej „siły ekspresji”, owocujace eksploracją tworzywa i pogłębioną refleksją o tej kategorii, wywodzi się w prostej linii od dojrzenia problemu, o którym pisali też neoplastycyści w latach dwudziestych. Nie bez powodu więc Willard Bohn, kiedy w swojej poświęconej modernistycznej poezji wizualnej książce dochodzi do konkretystów, przyznaje, że historia literatury wizualnej zatacza w tym miejscu koło. Ci bowiem jako swoich inspiratorów i mistrzów przywołują tych poetów, od których Bohn zaczynał swoje rozważania: Ezrę Pounda, Guillauma Apollinaire’a, futurystów. I liberaci właśnie do nich się odwołuja ${ }^{179}$. Rzeczywiście więc cyklicznie powraca ożywiona - reaktywowana w początku XX w., a sięgająca starożytności - tradycja literatury wizualnej. Lata pięćdziesiąte to czas, w którym (po mającym miejsce w pierwszych dziesięcioleciach stulecia odświeżeniu) znów była ona postrzegana jako banalna w swej istocie ciekawostka, niewiele wnoszaca zabawa formalna, a jej poetyka wydawała się wyczerpana. Jednak narodziny konkretyzmu „uratowały” - jak mówi Bohn - „ten rodzaj od zapomnienia i ożywiły werbo-wizualna tradycję"180. Ocaliły ten typ literatury, gdyż spod pozoru igraszek formalnych wydobyły to, co było ich podstawą: uważny namysł nad tworzywem. Ten zaś - tak jak w manifeście DE STIJL - miał prowadzić ku odkrywaniu nowych dróg literackiej ekspresji. Podobnie jak liberatura - jeśli zaufać postulatom, jakie przyniosły teksty ją fundujące.

Jak zgrabnie podsumowuje (przyjmujacy podobna perspektywę co Bohn) César Espinosa, wszelkie typy owej - jak to określa - nowej eksperymentalnej poezji (włączając tu m.in. modernistyczna poezję wizualną i konkretyzm) to liberating writing - pisarstwo wyzwalajace ${ }^{181}$. Pobrzmiewaja w tym stwierdzeniu słowa na wolności Marinettiego ${ }^{182}$ czy przywoływane już hasła zwiąanego ze spacjalizmem Pierre’a Garniera. I rzeczywiście, liberaci i konkretyści podjęli postulat uwalniania słów. Jedni i drudzy czynili to na zasadzie przywracania im przestrzeni - przestrzeni strony czy pojedynczego słowa (o która dopominali się konkretyści), czy przestrzeni książki (dla większej już grupy słów), o którą Fajfer pytał w następujący sposób:

Nikogo nie dziwi, że miejsca, w których przebywają ludzie, w których mieszkaja, pracuja, słuchają muzyki, modlą się czy robią zakupy, różnią się wielkością i bryłą budynku, standardem wyposażenia i wystrojem wnętrz. I to niezależnie od tego, czy porównujemy obiekty o odmiennym przeznaczeniu, czy też takie, które spełniać mają podobne funkcje.

${ }^{179} \mathrm{O}$ związkach liberatury i Apollinaire’a już pisałam, relacja literatury totalnej i futuryzmu będzie przedmiotem jednego z kolejnych rozdziałów.

180 W. Bohn, Modern Visual Poetry, s. 232.

181 César Espinosa, Corrosive Signs: For a Liberating Writting, [w:] Corrosive Signs. Essays on Experimental Poetry (Visual, Concrete, Alternative), ed. César Espinosa, transl. Harry Polkinhorn, Washington 1990, s. 7.

${ }^{182}$ Choć działalność tego artysty prowadzi nas przede wszystkim ku przestrzeniom rewolucji typograficznej, o czym będę szerzej pisać w rozdziale poświęconym relacji liberackiego pisania i typografii. 
A co z miejscami, w których przebywają słowa? Czy między przestrzenią domu lub miasta a przestrzenią książki można dostrzec jakieś analogie? Nawet jeśli tak, to niestety nie wypadają one dla książki zbyt korzystnie. O ile budowle oryginalne zwykle wywołują w nas podziw, to nietypowo wyglądająca książka częściej budzi niepokój. Nudzą nas osiedla, w których wszystkie domy wyglądają tak samo, nie nudzą natomiast identyczne woluminy tej czy innej serii wydawniczej ${ }^{183}$.

Na nowo - świadomie i przestrzennie - zapisane słowo odnajdywało swoje nowe (znaczace) miejsce. W przypadku utworów konkretnych uprzestrzenniało się, gdyż - jak słusznie podsumowuje Bohn - „w braku konwencjonalnej gramatyki, wiersz zatrudniał syntaksę przestrzenną"184. W przypadku tekstów liberackich owa składnia wizualna uzupełniała tradycyjna gramatykę. Tak zapisane słowa stają się wolne zarówno od konwencji, „tyranii zdania na osi syntagmatycznej i paradygmatycznej” ${ }^{185}$, jak i do „łączenia się ze sobą w równym stopniu werbalnie, jak i wizualnie, wertykalnie jak i horyzontalnie"186. Nie muszę chyba przypominać tu dość oczywistego faktu, że wolność ta, wymuszając większą odpowiedzialność za tekst, zmuszając do szukania możliwości konkretnego typograficzno-przestrzennego publikowania, pociaga za sobą pewne problemy.

Jednak dla artystów, którzy decydowali się eksperymentować z nowym wymiarem tekstów owa przestrzenność słowa zdawała się pomocna, wydawała się rzeczywiście otwierać nowe drogi ekspresji. Tak traktuje ją m.in. Franz Mon, wprost przyznający się do ogromnej inspiracji Mallarmém, który - jego zdaniem - „Zwrócił literaturze powierzchnię jako «konstytutywny element tekstu»"187. Niemiecki konkretysta podkreśla, że zabiegi, które stosował w swoich własnych utworach (poetry of surface - poezji powierzchni - jak je określał) nie sa zwykła zabawa, lecz nieodzownym środkiem, technicznym rozwiązaniem problemów komunikacji i ekspresji, z którymi jako twórca się spotkał. „Przestrzennie artykułowany język pisany” - twierdzi komentująca jego teorię Solt - „nie został zaproponowany dla zastapienia czasowo artykułowanego języka pisanego [a więc rozumianego jako notacja mowy - AP], lecz, by uczynić możliwym wyrażenie tego, z czego wysłowieniem język konwencjonalny nie potrafi sobie poradzić"188.

Poeci grupy Noigandres podkreślaja, że zwrócenie uwagi na przestrzeń jako przydatny element struktury utworu jest logicznym krokiem $\mathrm{w}$ historii rozwoju form tekstu literackiego, ewolucji, w której coraz to inaczej postrzegano samą kategorię znaku. Wyraźnie też zaznaczaja, że przestrzeń, z jaka mamy do czynienia w przypadku poezji konkretnej, to przestrzeń nie byle jaka, lecz qualified space (portugalskie espaço qualificado). Bujnowski tłumaczy ten zwrot jako „przestrzeń nazwana”, ja zaś skłaniałabym się ku wydobyciu w przekładzie tego słowa jakości podkreślających specjalizację, przygotowanie

${ }^{183}$ Zenon Fajfer, Liberatura - literatura przestrzeni, „Autoportret” 4/2006, s. 2 (tekst nieprzedrukowany w $L C L T$ ).

${ }^{184}$ W. Bohn, Modern Visual Poetry, s. 235.

185 Ibidem.

186 Ibidem.

${ }^{187}$ M. E. Solt, s. 18 (autorka cytuje tu F. Mona, jednak nie podaje źródła).

188 Ibidem. 
do oznaczania, proponowałabym mówić właśnie o przestrzeni nie-bezznaczącej, nie neutralnej, lecz przestrzeni komunikującej. Nie tyle nazwanej, co przygotowanej, wykwalifikowanej do tego, by samą sobą nazywać (oznaczać, znaczyć). Przestrzeni znaczacej, zdefiniowanej, prawdziwej przestrzeni przywróconej literaturze, jak powiedzieliby i liberaci, i konkretyści.

Czyż nie o niej bowiem Fajfer pisał:

\begin{abstract}
Bo czymże jest przestrzeń dzieła literackiego? Chcąc wierzyć przytaczanemu już Stownikowi terminów [literackich - AP] - niczym. Nie ma takiego hasła, jest tylko „przestrzeń w dziele literackim”, inaczej mówiąc (i nieco upraszczając) miejsce akcji. A przecież pierwszą i podstawową przestrzenia, widoczną jeszcze zanim zagłębimy się w lekturę, jest... książka - materialny obiekt! Wygląd, liczba i układ stron (o ile muszą być strony), wygląd okładek (o ile muszą być okładki) - to jest właśnie przestrzeń dzieła literackiego, w której zawierają się wszystkie pozostałe przestrzenie utworu. I w przeciwieństwie do tamtych, jest ona realna ${ }^{189}$.
\end{abstract}

A analogicznie do liberata z Krzeszowic broniła tej kategorii (pisząc o niej z punktu widzenia konkretystów) choćby Marianna Bocian, stwierdzajacca bez ogródek że „słowo poezji ma się jak gdyby dopiero stać w obopólnym kontakcie twórcy i odbiorcy w samym tworzywie jakim jest dla nich przestrzeń" ${ }^{190}$. Przestrzeń jak najbardziej konkretna i liberacka.

\title{
2.5. Liberackie play-activity i konkretna interaktywna ergodyczność - ciąg dalszy podobieństw teoretycznych
}

Omówione podejście do problemu literackiej przestrzeni przynosi, oczywiście, dalsze konsekwencje. Jej eksplorowanie wiąże się bowiem (co powiedziane jest też wprost w Plano-Piloto para Poesia Concreta) również z odejściem od struktur linearnych (statycznych, tradycyjnych) ku czytaniu wielotorowemu, ku odrzuceniu klasycznej sekwencyjności. Zdania, wyrazy, które łączy wizualna (a nie gramatyczna) składnia, to „wolność, otwartość artystyczna” (za liberatami ${ }^{191}$ ) czy „struktura czasowo-przestrzenna miast tylko linearno-czasowego rozwoju" (jak wyczytamy w przywołanym manifeście konkretystów ${ }^{192}$ ). Dlaczego? I co z tego wynika?

Jak zauważa Higgins ${ }^{193}$, już samo wprowadzenie do tekstu elementu wizualnego burzy zastaną strukturę, zatrzymuje pęd oka podążającego za linio-

189 Zenon Fajfer, Liberatura. Aneks do słownika terminów literackich, [w:] LCLT, s. 26.

${ }_{190}$ Marianna Bocian, Przestrzeń w poezji konkretnej, Bydgoszcz 1979, s. 3. Dalej autorka dopowiada: „Dla konkretysty najważniejszym od początku było jedno - dojść do przestrzeni. Dojść, to znaczy wyzwolić ją pod jakikolwiek zapis, znak. Jest to pierwszy sygnał kontaktu człowieka z przestrzenią. W przestrzeń wyzwoloną pod zapis musi wkroczyć twórca i odbiorca” (s. 8).

191 Od Joyce'a do liberatury, s. II.

192 Plano-piloto..., tłum. J. Bujnowski (J. Bujnowski, s. 42).

${ }^{193} \mathrm{~W}$ odniesieniu do szerszej grupy zjawisk (ogólnie: literatury wizualnej). 
wym układem ${ }^{194}$. Owo przerwanie linearności, wpuszczenie „innego” prowadzi ku kinetyczności, dynamiczności czy potencjalnej wielotorowości utworu, choć - warto zaznaczyć - badacz ów wtręt określa mianem statycznego. Skąd ten paradoks? Takie (statyczne właśnie) miejsca zatrzymania w istocie poszerzają semantykę tekstu, dając znakom nowe możliwości - to w nich właśnie dochodzi do głosu wolność do łączenia się poszczególnych elementów przekazu w rozmaite (dynamiczne) konfiguracje (czy też: konstelacje). Zdaniem Solt taka otwartość tekstu rodzi się właśnie w przypadku istotnego skupienia się nad problemami tworzywa czy relacji tworzywo-forma (struktura).

O niej właśnie mówi też Gomringer swoim (nieprzetłumaczalnym chyba) terminem play-activity (niemieckie: denkgegenstanddenkspiel) ${ }^{195}$. Zdaniem poety-teoretyka wiersz zawierajacy w sobie pewien potencjał, realizuje się właśnie na drodze otwarcia na współpracę z odbiorca (jest „obiektem nadającym się do oglądania i do używania"196). Zdaje się, że Claus Bremer zyskał wielkie uznanie w oczach Gomringera właśnie dlatego, że jego utwory zmuszaja czytelnika do pełnego zerwania z linearnościa - nie tylko nie pozwalaja się czytać w jednej linii, lecz wymuszają różnorodne kierunki lektury tego samego fragmentu, czyniac teksty swoiście kinetycznymi. Realizacje te stopniem swojej play-activity przeszły pewnie oczekiwania nawet samego Gomringera.

Analogiczne poszukiwania miejsca na obcowanie odbiorcy z tekstem, pragnienie odnajdowania literatury, w której - niczym w dziele otwartym - tekst nie znajduje swej pełnej formy bez współudziału czytelnika, możemy dostrzec i w liberaturze. Formułując w 2010 r. jej ośmiopunktową charakterystykę gatunkowa, Bazarnik (jako punkt szósty) wymienia przecież „interaktywność i ergodyczność". Wydaje się, że owa (szerzej omówiona w innych rozdziałach ${ }^{197}$ ) cecha dzieła liberackiego w pełni odpowiada Gomringerowskiej play-activity. Obie rodzą się z przełamania konwencjonalnego rozumienia tworzywa tekstu literackiego i odejścia od klasycznych reguł operowania nim. Obie zakładaja prowokowana przez dzieło aktywność odbiorcy, w jednym i drugim przypadku mowa bowiem o czytelniku, który podejmuje wyzwanie i wkracza w swoisty obszar gry. Ta ostatnia kategoria nieobca jest - przypomnę - i konkretystom. Gomringer w swoim manifeście z 1954 r. podkreśla przecież, że:

Konstelacja to uporządkowanie, a zarazem w tym samym czasie obszar gry o ustalonych wymiarach.

Konstelacja jest uporządkowana przez poetę. To on określa obszar gry, pole i siłę oraz sugeruje jej możliwości. Czytelnik, nowy czytelnik, podejmuje ideę gry i wchodzi w nią ${ }^{198}$.

194 Słowa przestają mieć też monopol na przenoszenie znaczeń. D. Higgins, Strategie poezji wizualnej..., s. 163.

195 M. E. Solt, s. 67.

196 Ibidem.

197 Zob. część poświęconą definiowaniu liberatury, a także rozdział dotyczący jej relacji z nowymi mediami.

198 M. E. Solt, s. 67. 
A podobnie mówiono przecież i o liberaturze, szczególnie w czasach publikacji spod znaku liternetu, a więc wtedy, gdy hipertekst (powieść hipertekstowa) i literatura totalna postrzegane były jako zjawiska pokrewne i nad wyraz bliskie ${ }^{199}$.

\subsection{W walce o teorię sztuki słowa zdolną opisać zastaną rzeczywistość literacką}

Choć więc między liberaturą a poezją konkretną znajdziemy jedną różnicę fundamentalna, faktem jest, że równocześnie nad wyraz wiele oba zjawiska łączy. Zwłaszcza na poziomie teorii (a te były tu porównywane). Wśród wspólnych postulatów nie można zapomnieć i o tym, który wskazuje na brak terminów do opisania nowo powstającej literatury. Ilustrowała ten problem przedstawiona na początku rozdziału zmyślona dyskusja Bujnowskiego, Sławka i Fajfera; dość tu przypomnieć, że o miejsce dla poezji konkretnej i innych zjawisk niebagatelizujących kwestii zapisu czy materialności tekstu dopominała się też choćby Stefania Skwarczyńska ${ }^{200}$. Manifesty konkretystów skłaniały do namysłu nad istota podstawowych literaturoznawczych kategorii czy samej definicji literatury (czego oczekiwał po wprowadzeniu terminu „liberatura” Fajfer). I Marianna Bocian twierdzi, że na Zachodzie (w przeciwieństwie do Polski) wywołały one nie tylko ożywienie myśli teoretycznej, ale też właśnie „częściowo zmieniły stosunek badacza do samego «tekstu literackiego»" ${ }^{201}$. Obecnie podobnym literackim gzem wydają się manifesty i postulaty liberatów.

Reprezentanci porównywanych tu nurtów traktują ponadto tworzone przez siebie postaci sztuki słowa jako naturalne szczeble w ewolucji (rozwoju) literatury ${ }^{202}$. Wiążą też ich pojawienie się z szerokim kontekstem ogólnych

199 Zob. m.in. Liternet.pl (tam publikowany był m.in. szkic Fajfera Liberatura: hiperksięga $w$ epoce hipertekstu). Pokłosiem takiego rozumienia relacji tych dwóch zjawisk sa np. definicje hipertekstu i liberatury zamieszczone w przywoływanym tu już Stowniku nowych gatunków i zjawisk literackich Potrykus-Woźniak. Grywalność jako cecha literatury nie tylko elektronicznej jest zjawiskiem nader ciekawym, pozwalającym też uwypuklić związki między działaniami awangardowymi (choćby właśnie poezją wizualną czy konkretna), liberaturą a nowomedialną sztuką słowa. Szerzej rozwijam tę kwestię we fragmencie poświęconym relacji literatury totalnej i elektronicznej, o samej grywalności w kontekście teorii Gomringera piszę zaś w szkicu Ku literaturze grywalnej (kilka uwag wstęnych) (,Przegląd Kulturoznawczy” 2014, nr 2).

200 Stefania Skwarczyńska, O paru zagadnieniach poetyki nie podjętych przez badania języka poezji (literatury), [w:] Z zagadnień języka artystycznego, red. Józef Bubak, Aleksander Wilkoń, Kraków 1977.

201 M. Bocian, Przestrzeń w poezji konkretnej, s. 12. Ciekawie podchodzi też badaczka do kwestii literackości poezji konkretnej. Uznaje, że dla konkretystów również brak tekstu odczytywany być może jako tekst, że samo wpisanie (autorskie) dzieła w kontekst - czy jak mówi Bocian - w przestrzeń poezji konkretnej czyni utwór tekstem literackim, poetyckim (s. 16). Na wagę autorskiego samo-wpisania się w nurt zwracała uwagę też Solt.

${ }^{202}$ Tezy takie wyczytamy i w szkicach Nowakowskiego, i w artykułach Fajfera, a także w programowym manifeście grupy Noigandres. 
przemian kulturowo-społecznych. I liberatura, i poezja konkretna mają być odpowiedziami na ducha swoich czasów: zarówno korzystając z rozwiązań technicznych i nowinek technologicznych, jakie im podsuwa współczesnośćc ${ }^{203}$, jak i buntując się przeciw zastanej (przywoływanej już tu) „martwocie słowa" (zarazem różnie i podobnie przez przedstawicieli analizowanych nurtów rozumianej). Zdaniem Solt poeta konkretny jest pochłonięty „ustanawianiem nowej relacji jego lingwistycznego materiału z przestrzenią (stroną bądź jej ekwiwalentem) oraz czasem" ${ }^{204}$, oddalając się tym samym od klasycznej, linearnej pod względem czasowo-przestrzennym, struktury. Ponadto, wszelkie innowacje, jakie rodzi poezja konkretna, wynikają z przekonania o nieadekwatności zastanych - jak to określa badaczka - „starych gramatyczno-syntaktycznych struktur”205 w odniesieniu do współczesnego sposobu myślenia czy komunikowania. Z kolei Marek Garbala, komentując twórczość Stanisława Dróżdża, stwierdzał:

Dotychczasowe formy zapisu dzieła literackiego odczuwane sa jako anachronizm i po prostu niedogodne w świecie współczesnym. Chodzi więc o to, by zastapić je czymś innym, by - co za tym idzie - zmodernizować model dawnej estetyki, a w odbiorcy wykształcić zupełnie inna wrażliwośćco6.

Fajfer zaś w następujący sposób opisuje sytuację literatury, popychająca artystów ku nowym (czy może wcale nie tak nowym, ale nie tak często wykorzystywanym) rozwiązaniom:

Literatura pełna jest opisów ciał. Pięknych i brzydkich, i takich sobie [...] Ożywionych wyobraźnią poety; głosem śpiewaka i uchem słuchacza, wyobraźnią czytelnika karmionych. Dla tych ciał słowo jest tylko łożyskiem, poczwarka, z której wyfruwa motyl.

Czasem opisywanie nie wystarczy: wtedy opis sam chce być ciałem. Słowo chce być ciałem. Pismem nieprzyzwoicie nieprzezroczystym, widzialnym a nie tylko słyszalnym. Statecznym i pulchnym. Ciałem, nie (łożyskiem). (Tym ma być książka).

Ale nie każda książka chce (tym) być, niektóre książki same chcą Być. Ciałem do czytania. Dziełem literackim nie mniej cielesnym od dłoni, która przewraca kartki. Lub raczej liberackim już. Do czytania wzrokiem, słuchem i dotykiem ${ }^{207}$.

Co więcej, oba nurty, zarówno poezja konkretna, jak i liberatura, musiały/muszą dopominać się o swoje miejsce w kręgu literatury. Z problemami

${ }^{203}$ Czasem zamiary autorskie wyprzedzają wręcz możliwości technologiczne bądź realizacja zamiarów autorskich jest możliwa, lecz zbyt droga. Solt przytacza - wspierając się listami Augusto de Campos - historię o tym, jak autor Poetamenos pragną podczas publicznej prezentacji utworów wyświetlać kolorowe litery niczym na neonach reklamowych, z czego - z braku środków finansowych - zrezygnował, zastapiwszy neony barwnym drukiem (ale już dostępna dziś na UbuWeb praca hearthead realizuje podobne zamiary przy mniejszym nakładzie środków) [http://www. ubu.com/historical/decampos_a/hearthead.html, dostęp 11.01.2011].

${ }^{204}$ M. E. Solt, s. 7, podkreślenie moje.

205 Ibidem.

${ }_{206}$ Marek Garbala, Stanistawa Dróżḋa poezja konkretna, „Agora” 1968, nr 20, s. 58.

207 Z. Fajfer, Po czym odróżnić liberaturę od literatury..., s. 81. Nie zachowuję typografii oryginału. 
z uznaniem tego typu twórczości za teksty do czytania, utwory wpisujące się w obszar sztuki, lecz właśnie sztuki słowa, borykali się i artyści, i teoretycy. O literackość konkretyzmu dopominała się Solt ${ }^{208}$, o jego wymiar poetycki Stanisław Dróżdż ${ }^{209}$, a o kontrowersyjności literackości konstelacji pisał sam Gomringer ${ }^{210}$. Fajfer i Bazarnik zaś domagali się, by nie mylić liberatury z książką artystyczną i by nie wyrzucać jej poza marginesy literatury ${ }^{211}$.

\subsection{Znaczące konkretne formy (nie)książki i totalne tomy liberackie}

Wśród synonimów terminu poezja konkretna Grzegorz Gazda podaje również wiersze bez ksiażek ${ }^{212}$. Zatem wydawać by się mogło, że - szczególnie ze względu na wyjątkowy, bardziej galeryjno-wystawowy charakter utworów konkretnych i wyraźne (artykułowane od samego początku) dążenie twórców terminu literatura totalna do zabrania tej ostatniej z przestrzeni wystawienniczych i zamknięcia w czytelniach czy bibliotekach - myśląc o kluczowej dla liberatów kategorii książki trafimy na kolejny punkt zapalny, sprzeczność obu teorii. Okazuje się jednak, że nie.

Kluczem do rozwikłania tego paradoksu może być postać niemieckiego artysty Ferdinanda Kriwieta, który dążył do tego, by utwory konkretne wystawiać w galeriach, by były właśnie - niczym prace malarzy - oglądane. O ile zapewnienia poety, że obrazowość, wizualność dzieł nie jest wcale ważniejsza niż ich wartość słowna niewiele tu pomoga, jego stosunek do formy książki zdecydowanie naprowadzi na właściwy trop. Kriwiet twierdził bowiem, że w konsekwencji przemian literatury forma książki stała się forma znacząca, co z kolei musiało uwrażliwić twórców sztuki słowa na historię nastawionych na wizualność czy materialność bądź przestrzenność form literackich (bliskich ideom Fajfera i Bazarnik). Artysta argumentował, że - właśnie dzięki wkroczeniu książki w nową przestrzeń - oczywisty stał się fakt, że jest ona „szczególnym rodzajem obiektu funkcjonalnego i że «literatura w formie książki jest znacząca tylko wtedy, gdy jest to kształt specjalnie dlań zaprojektowany»" $"$ "13.

${ }^{208}$ Inny rodzaj kontaktu. Z prof. Mary Ellen Solt rozmawia Marek Hotyński, „Nowy Wyraz” $1977, \mathrm{nr} 10$

${ }^{209}$ Rozmowy o sztuce (VIII). Ze Stanistawem Dróżḋ̇em rozmawia Jaromir Jedliński, „Odra” 1999, nr 7-8.

${ }^{210}$ Eugen Gomringer, Max Bill and concrete poetry, tłum. Irène M. Sinor oraz Mary E. Solt, [w:] M. E. Solt, s. 68-69.

${ }^{211}$ Hasło „liberatura to literatura” przyświecało szczególnie pierwszej fazie propagowania teorii liberatury.

${ }^{212}$ Grzegorz Gazda, Poezja konkretna a problemy awangardy, [w:] The Structure and Semantics of Literary Text, ed. Mihály Péter, Budapeszt 1977, s. 52.

213 M. E. Solt, s. 20. 
Okazuje się zatem, że wybranie takiej, a nie innej przestrzeni odbiorczej staje się świadomą decyzją autorska, wynikająca z namysłu nad tworzywem czy kształtem dzieła. I tak: Fajfer podkreślał, że każdy wybór literata (zwłaszcza zaś: liberata) powinien być umotywowany (nawet wybór formy klasycznej winien mieć swoje przyczyny), a Gomringer konstatował, iż „konwencjonalna dystrybucja znaku jest rozważana jako jedna z wielu możliwości, jednak nie jest ani akceptowana, ani wykorzystywana bez uprzedniego poddania jej w wątpliwość’"214. Jak pokazuje działalność Kriwieta, poezja konkretna - tak jak liberatura - uczy, że dobrze jest poddać w wattpliwość również konwencjonalność tomu literackiego, opakowania na słowa i historie. Zaś świadoma rezygnacja konkretystów z formy książkowej zyskuje znamiona liberackości.

Namysł nad przestrzenią wystawienniczą i kategorią książki, zestawienie ze sobą małych w sensie ich literackiej objętości form (jakimi są często wystawiane w galeriach wiersze konkretne) i liberackich książek każe zastanowić się nad kategorią wielkości, nad tym, czy - tak, jak liberatura - konkret chce być totalny, czy też poprzestaje na małym. Niby łatwo byłoby dać się zwieść ilościowej mierze i przyznać, jak czyni to np. Joanna Roszak, że - w przeciwieństwie do liberatury - formy konkretne są możliwie krótkie. Na łamach „Autoportretu” badaczka ta pisała:

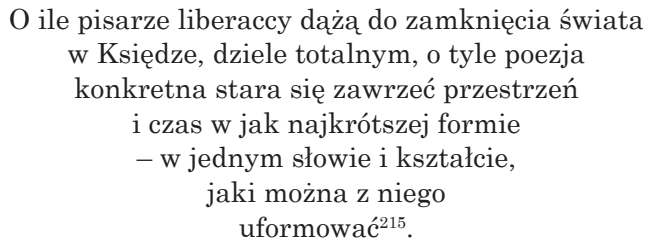

Rzeczywiście, spora grupa tekstów konkretnych to pojedyncze słowa (dość przywołać genialne słowo Dróżdża). Jednak nie uciekają one tym samym od aspiracji oddania totalności. Jak pokazuje chociażby analiza pracy lub Dróżdża (w jej wersji naściennej) przeprowadzona przez Elżbietę Łubowicz, nawet tekst zaledwie trójliterowy może aspirować do zagarniania wielkiej powierzchni i bycia - zdecydowanie - totalnym ${ }^{216}$. U podstawy pozornej różnicy między podejściem do wielkości u liberatów i konkretystów tkwi analogia w myśleniu o tym, że wielkość tekstu i rozmiar przestrzeni, jaka on zajmuje, sa istotne. Zatem podstawą rozróżnienia, jakiego dokonuje Roszak (a jakiego ja bym nie dokonywała) jest podobieństwo.

Już łatwiej (a przynajmniej bezpieczniej) byłoby poszukiwać różnic gatunkowych, gdyż przy zastrzeżeniu, że poezja konkretna jest literatura, pozostaje faktem, że jest też poezja. Liberatura zaś nie tylko nie ogranicza się do tej ostatniej, lecz (poprzez eksponowanie formy książki) silniej nieco niż z mową wiązaną wiąże się z prozą.

${ }^{214}$ Eugen Gomringer, Concrete poetry, tłum. Irène M. Sinor oraz Mary E. Solt, [w:] M. E. Solt, s. 67.

${ }^{215}$ „Autoportret” 2006, nr 4, s. 3 (notka w spisie treści).

${ }^{216}$ Elżbieta Łubowicz, Rzeczywistość jest tekstem. O poezji konkretnej Stanistawa Dróżdża, „Odra” 1999, nr 7-8, s. 88-89. 


\subsection{Idealna liberatura konkretna}

Czas przywołać raz jeszcze fotografie, które wspominane były na początku tego rozdziału. Co prowokuje Dantego, by opuścił między, by zmierzał ku wyjściu? Przypomnę, że kiedy w październiku 2005 r. podczas sesji naukowej Konstrukcja poprzez dekonstrukcję. Wokót nowych form tekstu literackiego i tekstu jako dzieła sztuki dyskutowano o liberaturze i poezji konkretnej, cykl wykładów poprzedzało otwarcie w galerii ENTER wystawy poematów-znaków Fajfera (pokazywano tam między innymi wspominany tu już Autoportret). Prace te sam ich autor charakteryzował jako nieco tautologiczne, zaznaczał jednak, iż mowa tu o tautologiczności sfunkcjonalizowanej, wykorzystanej strukturalnie (jak w przypadku cyklu Portret artysty, zob. ilustracja 12). Przypomnę, że dość sceptycznie nastawiony do mimetycznie wizualnych form tekstowych liberat twierdził, iż trudno stworzyć kaligram, który nie zabije poezji. Takie „złe” tautologie wskazywał Fajfer zaś nie tylko wśród utworów Apollinaire’a, lecz i Dróżdża (Zapominanie uznał za tekst banalny ${ }^{217}$ ), doszukał się jednak i tych „lepszych” (własnych czy „intrygującego”- jak mówi - Mikro Makro Dróżdża' ${ }^{218}$ ).
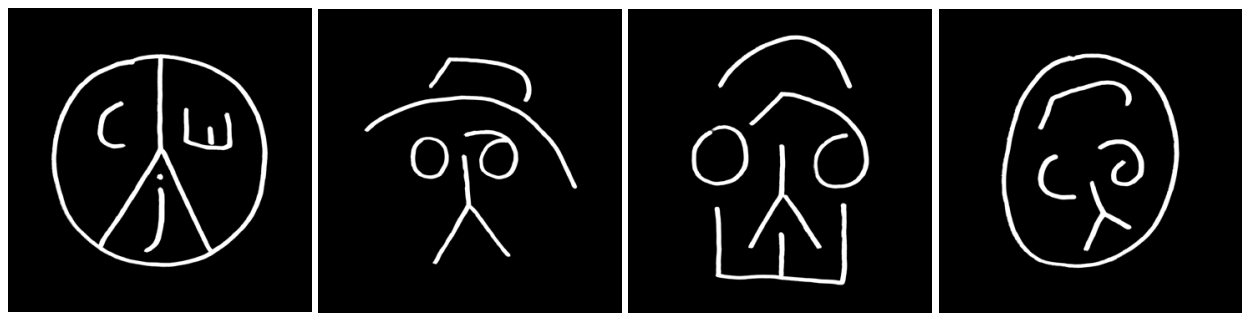

Ilustracja 12. Zenon Fajfer, Portret artysty. Od lewej: Portret artysty z czasów prenatalnych (1881), Portret artysty z czasów dojrzewania (1904), Portret artysty wieku dojrzałego (1922),

Portret artysty - maska pośmiertna (1941) (źródło: zdjęcia własne autora)

Ów sprzeciw wobec zbyt oczywistej figuralności czy wizualnej mimetyczności wydaje się kolejnym elementem łączącym poetyki konkretystów i liberatów. Ci pierwsi również dystansowali się od twórczości ściśle mimetycznej. „Jawnie sprzeciwiali się poezji wizualnej, która dążyła do reprodukowania kształtu konkretnego obiektu"219 - zauważa Bohn. W opinii Augusto de Campos w takich wypadkach wizualny kształt nie był wyprowadzany ze słów, lecz im narzucany ${ }^{20}$. De Campos przyznawał, że „Apollinaire, jak dotąd, skazał poetycki ideogram na zwykłą figuratywną reprezentację tematu”"221 (ale trzeba

217 Z. Fajfer, W strone liberatury, s. 96.

218 Ibidem.

219 W. Bohn, Modern Visual Poetry, s. 238.

${ }^{220}$ Ibidem.

${ }^{221}$ Ibidem (za: Augusto de Campos, Points-Periphery-Concrete Poetry, „Yearbook of Comparative Criticism 7" 1976, s. 263). 
tu zaznaczyć, że stwierdzenie to odnieść można zaledwie do części twórczości $\operatorname{artysty}^{222}$.

Faktem jest jednak, że ani liberaci, ani konkretyści wcale nie odwracali się konsekwentnie od kaligramów i figuratywności. Z jednej strony mamy poematy-znaki Fajfera, z drugiej teksty takie jak choćby Forsycja (Forsythia) Mary Ellen Solt ${ }^{223}$ (zob. ilustracja 13). Rzeczywiście, tekst Solt wizualnie ukształtowany jest w tytułowy krzew. Poszczególne jego pędy składają się z powtórzonych liter nazwy rośliny, pomiędzy które wkomponowane są odpowiadajace im symbole alfabetu Morse'a. Donicę, w której stoi forsycja, buduja słowa: „Forsythia out race spring's yellow telegramm hope insists action”, jej podstawek zaś - nazwa kwiatu. Trzeba przyznać, że figuralna forsycja istotnie wysyła telegram - jej kłącza przenoszą przecież poszczególne litery, jednak jak sugeruje zastosowanie innego niż alfabet łaciński systemu znaków - niekoniecznie jest to wiadomość adresowana do nas (i dla nas zrozumiała).

Ilustracja 13. Mary E. Solt, Forsythia (źródło: Mary E. Solt, Concret Poetry. A World View, London 1971, s. 243)

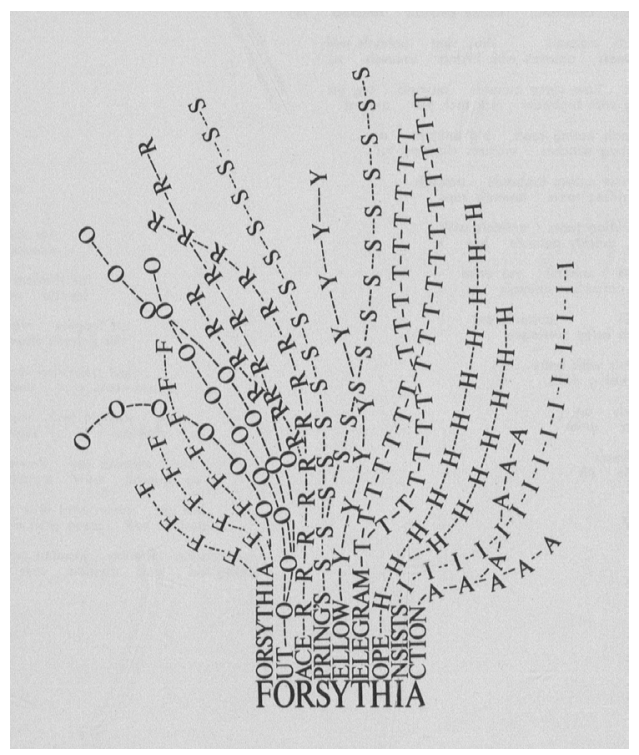

Co ważniejsze, wyrazy, z jakich zbudowana jest donica, zapisane w zaproponowanej powyżej kolejności (lub dowolnej innej), nie stworzą poprawnego pod względem gramatycznym, komunikatywnego zdania (z tego też powodu nie do końca dadzą się przetłumaczyć). To celowe odrzucenie klasycznej linearnej składni owocuje tym, iż słowa wiersza wchodzą w rozmaite relacje, domagajac się raz tej, raz innej formy gramatycznej. Związki zależności między nimi zaczyna budować przestrzeń, położenie na stronie, a za złożenie konkretnych struktur

\footnotetext{
${ }^{222}$ Por. uwagi w rozdziale poświęconym relacji liberatury i poezji wizualnej.

${ }^{223}$ Praca reprodukowana na okładce książki Solt, także w samym woluminie (s. 243).
} 
wyrazowych i układ akcentów odpowiada czytelnik. Dopiero dzięki jego zaangażowaniu z zaprojektowanego pola znaczeń wyłania się to, że forsycja wysyła telegram (lub telegramy), iż ma nadzieję, czy że oczekuje działania; pojawia się kategoria bycia obcym, kolor żółty, wiosna.

Można by zadać pytania: Czy tekst Solt jest do końca zrozumiały? Czy jest jednoznaczny? Ale z drugiej strony - czy człowiek ma szanse zrozumieć komunikat kwiatu? Czy posługujemy się tym samym kodem (zakładając, że kwiat może się komunikować)? Czym dla nas jest forsycja? Jeśli roślina, która wygląda, nie: mówi - nie wysyła przecież komunikatów. Nie na poziomie obrazu, lecz na poziomie zastosowania kilku kodów (klasycznego alfabetu, znaków z alfabetu Morse’a oraz kodu wizualnego) utwór mówi właśnie o tej niemożliwości komunikacji. Oczekiwanie akcji, działania (,insists action”) w tym kontekście staje się też metatekstualnym oczekiwaniem na wejście czytelnika w grę, na poukładanie i odczytanie komunikatu.

W konsekwencji, łatwo zauważyć, że wyjście poza mimetyczność czy figuratywność, z jakim mamy do czynienia w tym utworze, to nic innego jak przekroczenie ikoniczności obrazowej, wyjście ku ikoniczności diagramatycznej ${ }^{224}$. W przypadku Forsycji rzeczywiście nie tylko widzimy związek między znakiem i tym, co on oznacza, lecz również struktura znaku czy całego komunikatu oddaje sposób zorganizowania desygnatów w świecie. Utwór Solt daje się odczytać w pełni tylko wówczas, gdy skupimy się nie tylko na tym, co w nim powiedziane zostało obrazem, lecz i na tym, co dopowiada struktura tego obrazu.

Jeśli wrócić do poematów-znaków Fajfera odsyłajacych nas już samą swoją (przypominająca pojęciokształty Dróżdża) nazwą ku poezji konkretnej (która w istocie przecież sa), pozostanie nam zadać pytanie o ikoniczność w liberaturze. I tu okaże się, że owo niezabijanie kaligramem poezji, ostrożne używanie oka, do którego nawoływał Fajfer ${ }^{225}$, to właśnie analogiczne do wyżej opisanego sfunkcjonalizowanie ikoniczności językowych struktur. Dlatego Bazarnik wśród wyznaczników gatunkowych liberatury wymieniała właśnie oba typy ikoniczności (a o tej podwójności warto pamiętać, gdy próbujemy odebrać liberackość tekstom mało wizualnym).

Co więcej - tak jak dwukrotnie w moich rozważaniach pojawił się Dante Fajfer w kontekście Dróżdża: jako ten, który zamyka i ten, który otwiera tom pod redakcją Bazarnik, tak dwukrotnie muszą pojawić się Fajferowskie poematy-znaki. Owszem, ich wystawa otwierała poznańską sesję; kończyły ja jednak dyskusje o roli tych zbudowanych z liter obrazów w przestrzeni cokolwiek innej niż galeryjna - nie zabrakło bowiem głosów analizujacych ich rolę w Oka-leczeniu. Tam stają się one elementami większej struktury. Znaczą

${ }^{224}$ O obu rodzajach ikoniczności zob. m.in. O. Fischer, Dowody na ikoniczność... . O ikoniczności diagramatycznej przeczytamy tam: „struktura znaku lub zestawienie znaków na poziomie językowym przypomina sposób, w jaki owe desygnaty są uporządkowane w "świecie rzeczywistym», czyli zgodnie z naszą percepcją świata” (s. 20).

225 Z. Fajfer, W stronę liberatury, s. 96. 
już nie tylko ikonicznym podobieństwem do konkretnych postaci, lecz również swoim pojawianiem się (możliwością wyłaniania się z czerni strony) i znikaniem (w jej czeluściach). Nie bez znaczenia pozostaje nawet to, że zbudowane są z liter ${ }^{226}$.

I tak - paradoksalnie (?) - w samym centrum tego, co Fajfer i Bazarnik uznają za ideał liberackości, pojawia się poezja konkretna. Jak więc widać, pytanie o relację tych dwóch zjawisk nie było bezpodstawne. Dante Fajfer zaś słusznie zmierzał ku wyjściu. Wydaje się, że zdaniem jego rodziców to liberatura winna zawierać w sobie konkret, a nie na odwrót. Tym samym, choć Fajfer i Bazarnik podkreślają różnice między omawianymi tu zjawiskami, muszą sobie również zdawać sprawę z łączących je zasadniczych podobieństw. I choć warto rozdzielać porównywane w tym rozdziale obszary sztuki słowa, trzeba jednocześnie pamiętać, że w środku idealnego tekstu liberackiego może tkwić poemat konkretny, tak jak w środku idealnego (acz konkretnego) jabłka nieraz znajdziemy robaka. Tu zaś pozostaje oddać głos Reinhardtowi Döhlowi (zob. ilustracja 14).

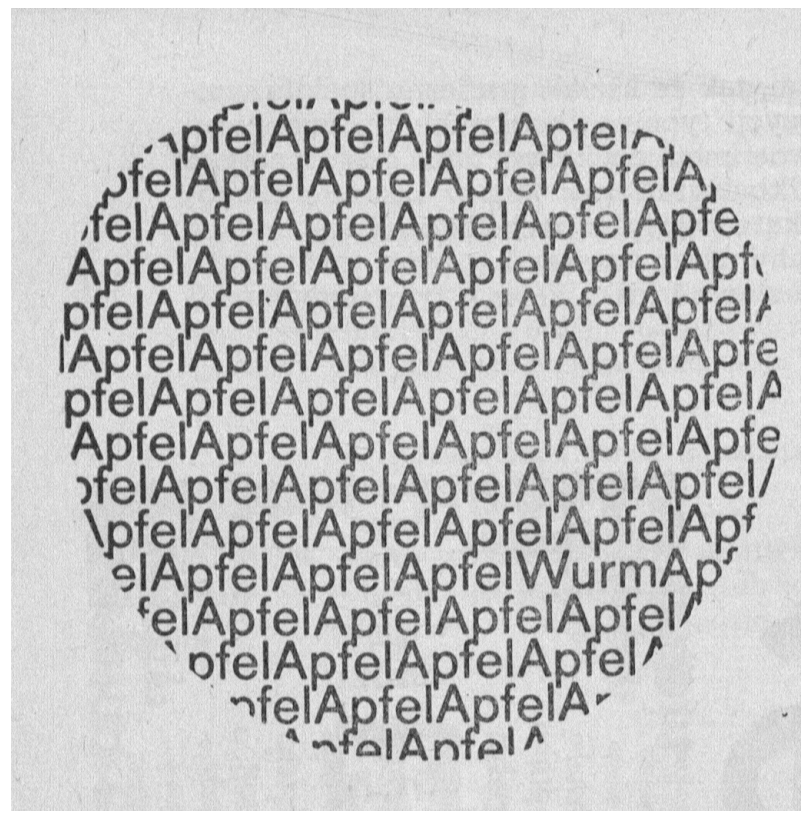

Ilustracja 14. Reinhardt Döhl, Jabłko (źródło: Józef Bujnowski, Poezja konkretna, „Poezja” 1976, nr 6, s. 16)

${ }^{226}$ Szerzej piszę o tym przy okazji analizy i interpretacji Oka-leczenia (odnośnie do bibliografii zob. przypis $66 \mathrm{w}$ rozdziale Liberatura a poezja wizualna). 



\title{
3. Liberatura a komiks
}

\subsection{Podobieństwa widoczne gołym okiem}

\author{
Już widzę te ironiczne uśmiechy na myśl o wpakowaniu \\ do jednego wora Joyce'a z Koziotkiem Matotkiem. \\ Trudno-niech się boda.
}

Zenon Fajfer 227

Kolejną pozwalającą się zestawić z liberaturą formą zespalającą w swojej strukturze słowo i obraz jest komiks (realizujacy formułe „literatury wizualnej” na innym niż poetycki gruncie $\left.{ }^{228}\right)$. Charakteryzując go, Jerzy Szyłak przywołuje anegdotę o Marku Twainie, który zdumiony zauważał, że literatura to zwykłe układanie rozmaitych kombinacji z dwudziestu sześciu znaków alfabetu. Zdaniem polskiego badacza $\mathrm{z}$ analogicznym procesem mamy od czynienia i w przypadku komiksu, jednak ilość elementów jest wtedy znacznie większa ${ }^{229}$. Myśl tę dałoby się rozwinąć, spoglądając i na liberaturę jak na taką oryginalną układankę. W literaturze totalnej użytych kodów (i tym samym poszczególnych puzzli) może być, oczywiście, jeszcze więcej niż w przypadku - angażującego wyłącznie słowo i obraz - komiksu. Jednak wyjście poza kod alfabetyczny, tworzenie jedności z wielości, zdaje się bezsprzecznie łączyć te dwa typy twórczości. Wydaje się, że podobieństwo intuicyjnie dostrzeże też czytelnik „mniej wtajemniczony”. Nawet nie znając definicji komiksu ${ }^{230}$, spojrzy nań nieco podejrzliwie ${ }^{231}$ (nie wiedząc, że byli i tacy, co określali go mianem

${ }^{227}$ Zenon Fajfer, Nie(o)pisanie liberatury, [w:] LCLT, s. 62.

${ }^{228}$ O problematyczności zaliczania komiksu do sztuki słowa (w konsekwencji zaś i do tzw. literatury wizualnej) będę jeszcze w tym rozdziale pisać. Tu pragnę zaznaczyć, że - podobnie jak niektórzy badacze, m.in. Hopfinger - traktuję formułę literackości na tyle szeroko, iż komiks daje się w nią wpisać.

229 Jerzy Szyłak, Poetyka komiksu. Warstwa ikoniczna i językowa, Gdańsk 2000, s. 172.

230 Z której satysfakcjonującym sformułowaniem komiksolodzy nadal się męczą - i jak podkreśla Agnieszka Janiak-Staszek - dużo jeszcze przed nimi pracy. Zob. Agnieszka Janiak-Staszek, Recenzja tomu „Antologii referatów 10. Sympozjum Komiksologicznego”, [w:] Komiks a komiksologia. Ku rozpoznaniu i charakterystyce wzajemnych relacji między gatunkiem a jego teoria, red. Krzysztof Skrzypczyk, Łódź 2010, s. 7-9.

${ }^{231}$ Choć dziś już może nie zastanawiając się nad tym, czy jest to lektura dla „półanalfabetów” czy też „zgrymaszonych intelektualistów”. Zob. Jerzy Skarżyński, Komiks (Comic strip), „Projekt” 1985, nr 6, s. 46. 
„podejrzanego medium”232), podobnie jak na „te dziwaczne książki liberackie" ${ }^{233}$. Bo jedne i drugie to niby książki, ale takie... ,jakieś inne”.

$\mathrm{Na}$ przywołane pokrewieństwo w 2003 r. zwracał uwagę również sam Fajfer $^{234}$. Czy zatem nie należałoby, rzeczywiście, postawić pytania o podobieństwa między tymi formami sztuki? Pytania o tyle niebagatelnego, że zmuszającego do zastanowienia się nad tym, co łączy Tarzana, Koziołka Matołka i Joyce’a (czego obawiał się liberat z Krzeszowic). A że „da się”, czy wręcz należy „wrzucać ich do jednego wora” przekonywał Jakub Żuchowski na łamach „Ha!artu!” w artykule James Joyce versus Koziołek Matołek albo Święty Franciszek kontra Tarzan, jedynym - jak dotąd - opracowaniu zależności liberatury i komiksu ${ }^{235}$. Pisał, że rzucona przez Fajfera uwaga:

\footnotetext{
Nieoczekiwanie otwiera nowe, szerokie pole do teoretycznych rozważań nad liberatura, daje impuls, by zestawić ją z jednym z najbardziej interesujących zjawisk na obszarze wydarzeń artystycznych minionego wieku - sztuką komiksu. [...] Ziarno rzucone przez Fajfera padło na podatny grunt - dodawał. - Nie pozostaje nic innego, jak tylko dokonać szczegółowego porównania sztuki komiksu ze sztuką liberatury, skrupulatnie wynotować zaskakująca ilość łączących je analogii, a także napomknąć o kilku niezwykle istotnych różnicach ${ }^{236}$.
}

Mimo że przywołany szkic Żuchowskiego jest miejscami chaotyczny czy niespójny i choć nie do końca zgadzam się z wnioskami autora, chciałabym uczynić go punktem wyjścia do rozważań o pokrewieństwach liberatury i komiksu. Decyzję taką motywuję charakterem tego opracowania: jedynego jak dotąd, ale też aspirującego do roli ujmującego problem całościowo. By móc orzec, czy rzeczywiście spełnia ono taką funkcję, zmuszona jestem zaczać od (próby) zreferowania głównych tez jego autora. A ponieważ - uprzedzę - jestem przekonana, że wymagają one wielu dopowiedzeń, rozwinięć i sprostowań, właściwe rozważania o bliskim bądź dalekim pokrewieństwie liberatury i komiksu zostaną tu, w konsekwencji, poprzedzone wstępem, który niekoniecznie poruszał będzie najważniejsze kwestie.

Żuchowski charakteryzuje zarówno podobieństwa łączące komiks i liberaturę, jak i dzielące je różnice. W'śód pierwszych wymienia: (1) dopominanie się o swoje miejsce w przestrzeni sztuki, połączone z poszukiwaniem antenatów (zdaniem Żuchowskiego niepotrzebnym w przypadku komiksu, a „zasadnym i oczywistym" ${ }^{237}$ w odniesieniu do liberatury), (2) podobieństwo do rebusu (czego

\footnotetext{
${ }^{232}$ Jerzy Szyłak, Komiks w kulturze ikonicznej XX wieku, Gdańsk 1999, s. 76.

${ }^{233}$ Należałoby dodać, że i ich definicja domaga się nadal dopracowania.

${ }^{234}$ Z. Fajfer, Nie(o)pisanie liberatury.
}

${ }^{235} \mathrm{O}$ kwestii tej wspomina też marginalnie (bo w przypisie i nie rozwijając jej zupełnie) Michał Wróblewski. Zob. Michał Wróblewski, Komiks w perspektywie literaturoznawstwa. Projekt komiksologii $w$ dobie kryzysu genologii esencjalnej, [w:] Komiks a komiksologia..., s. 42-46 (przypis 26).

${ }^{236}$ Jakub Żuchowski, James Joyce versus Koziołek Matołek albo Święty Franciszek kontra Tarzan. O zwiazkach liberatury $i$ sztuki komiksu, „Ha!art” 2007, nr 27, s. 148 (dalej określane jako Żuchowski wraz z numerem strony). Badacz zaznacza tė̇, że przyjęta perspektywa powinna umożliwić „spojrzenie z innej perspektywy na najistotniejsze pojęcia liberackie” (ibidem).

${ }^{237}$ J. Żuchowski, s. 149. 
dostrzeżenie prowadzi ku dużo ważniejszej obserwacji: zauważeniu zbliżonego charakteru modelowego czytelnika obu analizowanych form), (3) konstruowanie przekazu w taki sposób, że doskonałym sposobem jego opisu staje się termin jedność ikono-lingwistyczna (wprowadzony przez Bernarda Toussainta jako użyteczny do charakteryzowania mechanizmów rządzących tworzeniem znaczeń w sztuce komiksu), (4) operowanie dość obszerna, obejmująca cała stronę, jednostką kompozycyjną (tzw. metakadrem).

Z elementów odróżniających liberaturę od komiksu wskazuje Żuchowski zaś na: (1) dominację słowa w liberaturze (jak stwierdza autor, „obrazki, elementy graficzne [...] nigdy nie zyskują tak znaczącego statusu jak w komiksie"238), (2) możliwość sięgania w niej po inne niż papier nośniki - np. kamień (co zdaniem badacza „nobilituje”239 też liberackie dzieła), (3) elitarny (a nie masowy - jak w przypadku komiksu) obieg dzieł literatury totalnej oraz (4) inny status autora (który w komiksie - według Żuchowskiego - nieraz ginie zdominowany przez wykreowana przez siebie postać) ${ }^{240}$. Wydaje się, że nie we wszystkich kwestiach można zgodzić się z autorem. Zacznę od końca, od przywołanych przez badacza różnic.

\subsection{O opowiadaniu słowem i/czy obrazem, czyli o narracyjnych powinowactwach}

Po pierwsze, Żuchowski przyjmuje, że kategoria jedności ikono-lingwistycznej - sprowadzająca się do zaznaczenia komplementarności pisma i rysunku oraz podkreślenia równorzędności obu tych tworzyw (owocującej koniecznością nie tylko niebagatelizowania jednego $\mathrm{z}$ nich, ale $\mathrm{i}$ paralelnego odczytywania komunikatów w nich budowanych w celu pełnego zrozumienia tekstu) - może służyć do opisu i komiksu, i liberatury ${ }^{241}$. Tym samym, podkreślanie przez badacza służebności obrazków i innych elementów graficznych wobec słowa w przypadku literatury totalnej wydaje się pewnym nieporozumieniem. Odnoszę jednak wrażenie, że intencja autora mogła być nieco inna.

Przede wszystkim Żuchowski, sygnalizując, że liberatura zawsze wpisuje się w obszar sztuki słowa, podkreśla tė̇, że narracja konstruowana jest w niej poprzez słowo. Badacz, mimochodem, przywołuje też istotną cechę komiksu: fakt, że historia opowiadana jest w nim poprzez obrazy. Zdaje się dodawać, że w literaturze totalnej nie mają one takiej funkcji (i chyba dlatego właśnie opisuje je jako mniej znaczace). Tu jednak trzeba zastanowić się, czy mieć jej nie moga, i czy budowanie opozycji liberatura: sztuka opowiadania słowem komiks: sztuka opowiadania obrazem jest rzeczywiście uprawomocnione.

238 Ibidem, s. 152.

239 Ibidem, s. 153.

${ }^{240}$ Autor opisuje też inną sytuację - kiedy to z dwójki autorów (rysownika i scenarzysty) istotny staje się dla odbiorcy wyłącznie jeden.

${ }^{241}$ Do kwestii użyteczności tego terminu w opisie literatury totalnej wrócę w dalszej części rozdziału. 
Dla współczesnych badaczy narracyjność komiksu jest raczej niekwestionowalna ${ }^{242}$. Zgodni są również co do tego, iż formę tę od „zwykłej” literatury odróżnia właśnie to, jakie medium (czy kod) odpowiada za przekazywanie historii. Zresztą już na początku kształtowania się tego gatunku (w węższym rozumieniu jego historii ${ }^{243}$ ) Rudolphe Töpffer pisał:

Opowiadania można pisać dwojako. Można je ujmować w rozdziały, zdania i słowa, wtedy nazywają się literatura, albo też w serie obrazów i wtedy nazywają się opowiadaniami obrazkowymi ${ }^{244}$.

Jeżeli ujmiemy je w ramy książki, tomu (niekoniecznie kodeksu) - będą liberatura, dopowiedziałby dziś zapewne Fajfer (a nie dopowiada Żuchowski).

Komiksolodzy próbowali wykorzystać dostrzeżoną cechę komiksu do „nobilitowania" ulubionej przez siebie formy. Jego narracyjność - ewidentnie łacząca go z literatura - uprawomocnić miała przynależność tego gatunku do obszaru sztuki słowa. Niezwykle użyteczny okazał się tu „pożyczony” od Jerzego

${ }^{242}$ Toeplitz określa komiks jako „wizualną formę sztuki narracyjnej” (Krzysztof T. Toeplitz, Sztuka komiksu. Próba definicji nowego gatunku artystycznego, Warszawa 1985, s. 20), używa też formuły „forma narracji wizualnej” (ibidem, s. 31). Podobne określenia znajdziemy w pracach innych badaczy: „gatunek narracyjny o dominancie wizualnej” (Thierry Groensteen), „,narracja graficzna” (Pierre Fresnault-Deruelle), „powieść wizualna” (Martin Vaughn-James) (terminy podaję w tłumaczeniach Wojciecha Birka za: Wojciech Birek, Gtówne problemy teorii komiksu, praca doktorska napisana pod kierunkiem prof. dra hab. Stanisława Uliasza, Rzeszów 2004, s. 54, 92, 106). Z kolei Jerzy Szyłak traktuje narracyjność jako cechę odróżniająca proto-komiksy od komiksów właściwych. Tym samym, to właśnie umiejętność snucia fabuły obrazem traktuje jako wyznacznik komiksowości. W Komiksie w kulturze ikonicznej XX wieku czytamy: „Różnica pomiędzy owymi obrazkami a rysunkami komiksowymi polega jedynie na tym, że te drugie były - już w założeniach ich autorów - historiami opowiedzianymi przez obrazki. Te pierwsze natomiast stanowiły jedynie ilustrację pewnych tekstów słownych czy przedstawienie (najczęściej karykaturalne) rzeczywistych sytuacji znanych odbiorcom. Satyrycy pokazywali w swoich rysunkach portrety postaci i prezentowali rodzajowe scenki, twórcy historyjek obrazkowych opowiadali fabuły" (J. Szyłak, Komiks w kulturze ikonicznej..., s. 6).

${ }^{243}$ Można wyróżnić dwa sposoby patrzenia na historię komiksu. Z jednej strony znajdziemy grupę badaczy poszukujących analogicznych form aż w starożytności, których Bartosz Kurc - za Tomaszem Stawiszyńskim - określił mianem „ekstremistów” (zob. Bartosz Kurc, Komiks - opowiadanie obrazem, Łódź 2003, s. 12). Zaliczymy do nich m.in.: Andrzeja Banacha, Janusza Dunina, Gérharda Blancharda czy Waldemara Łysiaka, zaś doskonałą ilustracją ich perspektywy są słowa pierwszego z przywołanych: „W każdej epoce zjawisko nazywane dziś komiksem znajdowało dla siebie formy ekspresyjne i najlepiej związane z życiem kulturalnym" (Andrzej Banach, Mata historia komiksów, [w:] idem, Pismo i obraz, Kraków 1966, s. 166). Drugą grupę stanowią badacze wiążący narodziny komiksu z pierwszą połową XIX w. i pojawieniem się ilustrowanych historyjek tzw. wielkiej trójki (Rudolphe Töpffer, Gustave Doré, Wilhelm Busch). Typowymi reprezentantami takiego spojrzenia sa m.in.: Scott McCloud (zob. Scott McCloud, Understanding Comics. The Invisible Art, New York 1993) oraz Jerzy Szyłak, traktujący komiks właśnie jako „dziecko” XIX w. i wiążący jego powstanie z poszukiwaniami artystycznymi ówczesnych twórców, a także rozwojem mediów (zob. J. Szyłak, Komiks w kulturze ikonicznej..., s. 5, a także inne przywoływane tu prace tego autora). Por. też m.in.: K. T. Toeplitz, Sztuka komiksu... .

${ }^{244}$ Cyt. za: J. Szyłak, Poetyka komiksu..., s. 41. Szyłak cytuje zaś za: Ernst H. Gombrich, Sztuka i złudzenie. O psychologii przedstawienia obrazowego, tłum. Jan Zarański, Warszawa 1981, s. 324-325. 
Ziomka termin spowinowacenia przez fabułe $e^{245}$. Pozwalał z jednej strony wskazać wyraźne związki obu rodzajów twórczości, z drugiej - pomagał równolegle podkreślić dzielące je różnice. Stąd właśnie opozycja spowinowaconych: obie formy - powtórzę - mają charakter narracyjny, lecz zasadniczy zrąb opowieści przekazywany jest w nich przez różne media. Żuchowski - jak się wydaje proponuje, by do tej opozycji dołączyć liberaturę.

Jednak idąc wskazanym przezeń tropem, natrafimy na pewien problem. Nie dość, że literatura totalna nie zawsze do wspomnianego powinowactwa się przyzna (trzeba pamiętać, że dzieło liberackie - w przeciwieństwie do różnych form sztuki analizowanych przez Ziomka - w ogóle nie musi być narracyjne; przykładem poetyckie tomy liberackie, jak choćby Sto tysięcy miliardów wierszy Raymonda Queneau), to trudno też jednoznacznie wskazać w jej przypadku medium odpowiedzialne za opowiadanie historii. W (posiadajacych fabułę) dziełach literatury totalnej może być ona przekazywana przez różne elementy, tym samym przez rozmaite kody. Co więcej - to, przez jakie, może się zmieniać w obrębie jednego utworu (dość przywołać - analizowane przez Żuchowskiego - Oka-leczenie $\left.{ }^{246}\right)$. Tym samym, nie można się zgodzić ani ze stwierdzeniem, że słowo w liberaturze dominuje nad obrazem, ani też z sugestia, że zawsze to ono pełni funkcję narracyjna.

Co więcej, trzeba dodać, że Żuchowski - traktujący komiks i liberature jako media „które, by przekazać swoje treści, integrują ze sobą słowo i obraz w stopniu niespotykanym na taką skalę w żadnym innym medium"247 - zdaje się zakładać, że literatura totalna musi mieć w sobie element wizualny, co (jak już podkreślałam) nie jest prawdą. Niemniej, dla badacza takie założenie wydaje się punktem wyjścia do charakteryzowania podobieństw obu form, co prowadzi ku kolejnym niejasnościom.

\subsection{Kolejne kwestie sporne: nobilitująca(?) pansemantyczność i (nie)szablonowy bohater elitarnej(?) liberatury}

Patrząc na kolejne tezy Żuchowskiego, trzeba przyznać, że słusznie dostrzega on, iż liberatura - w przeciwieństwie do komiksu - może sięgać też po inne niż papier tworzywa. Jednak zupełnie bezzasadnie badacz dopatruje się w takich zabiegach „nobilitacji”. Istotne - i skądinąd wynikające z sugerowanej przez autora

${ }^{245}$ Zob. Jerzy Ziomek, Powinowactwa przez fabutę, [w:] idem, Powinowactwa literatury. Studia $i$ szkice, Warszawa 1980. Kategoria powinowactwa przez fabutę pozwala mówić również o bliskości komiksu i filmu. Ten zaś w badaniach komiksologicznych jest drugim - obok literatury - głównym punktem odniesienia.

246 Zewnętrzne kodeksy Oka-leczenia opisuje on jako „białe”, zupełnie jakby nie dostrzegł całej części historii, która jest w nich opowiedziana na kartach czarnych współtworzących te części książki. A w tych właśnie miejscach w Oka-leczeniu to nie słowo pełni funkcję narracyjną.

247 J. Żuchowski, s. 152. 
charakterystyki - jest tu nie tyle to, że jedni z artystów wykorzystują większą różnorodność mediów, lecz fakt, iż autorzy związani z literaturą totalną, sięgając po kolejne tworzywa, angażuja je w proces tekstowej semiozy w sposób analogiczny do tego, w jaki twórcy komiksów wykorzystują wyłącznie obraz.

Stąd (o czym będę też pisać szerzej w dalszej części rozdziału) zaproponowane przez Wojciecha Birka pojęcie pansemantyczności (nad wyraz bliskie jedności ikono-lingwistycznej) wydaje się nawet lepsze niż ten ostatni termin do charakteryzowania dzieł literatury totalnej. Pozwala bowiem opisać typową dla tych utworów sytuację, w której znaczą wszelkie możliwe kody i elementy utworu (nie zaś wyłącznie elementy ikoniczne i lingwistyczne). Zaś to, czy takie „pansemiotyczne” teksty sa - jak sugeruje Żuchowski - lepsze, czy „cieszą się większą estymą” zależy nie tyle od użytego medium, co od sensowności sfunkcjonalizowania takiego, a nie innego jego zastosowania ${ }^{248}$.

W obliczu starań Fajfera i Bazarnik o popularyzację dzieł liberackich, w kontekście coraz większych nakładów wydawanych w serii Liberatura tomów (nie mówiąc już o wznowieniach ${ }^{249}$ ) trudno też tak łatwo zgodzić się z teza, że liberatura funkcjonuje w obiegu elitarnym. Choć pewnie przez część odbiorców nadal bywa postrzegana jako praktyka eksperymentalna, mniej lub bardziej liberacki charakter szeroko dostępnych publikacji współczesnych (o których będę pisać dalej) pokazuje, że od (początkowej) elitarności literatura totalna coraz silniej się oddala. Podobnie jak komiks walczyła o swoje miejsce w świadomości krytyków i czytelników ${ }^{250}$, i - jak on - chyba je znalazła.

Trudno też przyznać, by formułowane przez Żuchowskiego tezy dotyczące bohatera komiksowego (do których prowadzi go refleksja o autorze) były istotne. Rzeczywiście, sposób konstruowania postaci może odróżniać komiks od liberatury. Batman, Superman czy inni bohaterowie-ikony kolejnych serii (o których

${ }^{248}$ Trzeba też dodać, że istnieją przecież komiksy nie-papierowe: tzw. komiksy sieciowe (inne spotykane określenia to: komiks internetowy lub webkomiks). Co istotne - owa sieciowość (wkroczenie w przestrzeń nowego medium) najczęściej nie jest tu semantycznie nośna. Komiksy te zazwyczaj pozostają komiksami, fabułami opowiedzianymi obrazem (uzupełnionym, lecz rzadko w twórczy sposób, o animację i dźwięk), w których wiele elementów dopowiada występujące w różnych postaciach słowo. Usieciowienie jest tu kwestia upowszechnienia, zmiany kanału dystrybucji, typowego dla współczesności przenoszenia tekstów z jednego medium do drugiego bez zmiany ich jakości (najczęściej w celu archiwizacji), owocem remediacji. Nierzadko nawet w przypadku komiksów niemających swoich papierowych odpowiedników nowe medium - jak dotąd - nie jest raczej twórczo wykorzystywane, co owocuje brakiem różnic między komiksem papierowym i internetowym i - tym samym - wątpliwą sensownością wyraźnego rozgraniczania tych form. Podobnie uważa Robert Wyrzykowski (Robert Wyrzykowski, Internetowość komiksu internetowego, http:// esensja.pl/magazyn/2007/08/iso/09_30.html [dostęp 20.07.2011]), stwierdzajacy wprost: „webkomiks z pewnością nie jest oddzielnym gatunkiem komiksu” (ibidem). Innego zdania jest Paulina Potrykus-Woźniak, badaczka nie podaje jednak przekonujących argumentów (por. Paulina Potrykus-Woźniak, hasło 'komiks internetowy', [w:] eadem, Słownik nowych gatunków i zjawisk literackich, Warszawa 2011, s. 89-91).

${ }^{249}$ W 2009 r. ukazało się drugie wydanie Spogladajac przez ozonowa dziure Fajfera.

${ }^{250}$ Znamienne może, że rok 2010 przyniósł jubileuszowy tom Komiks a komiksologia podsumowujący dziesięcioletnią pracę komiksologów współpracujących z organizowanymi w Łodzi Sympozjami Komiksologicznymi oraz - również wydany z okazji okragłej, dziesięcioletniej rocznicy - tom Liberatura czyli literatura totalna. 
Żuchowski pisze jako o tych, którzy „przeżyli” swoich autorów) sa - jak podsumowuje Krzysztof Toeplitz - „rodzajem ideogramów, reprezentujących niezmienne ludzkie postawy, niezmienne pytania egzystencjalne, niezmienne wartości”"251. Nie podlegają metamorfozom, nie dojrzewaja, nie przechodzą kryzysów. Są inni niż bohaterowie literaccy - bardziej szablonowi, typowi i nie niebanalni. Z kolei postaci pojawiające się na (niekoniecznie) kartach liberatury nie muszą dać się zidentyfikować na pierwszy rzut oka. Nie sa (i nie mogą być) elementem konwencji, gdyż literatura totalna się jej przecież sprzeciwia.

A zatem - choć sugerowane przez Żuchowskiego różnice wydają się błahe, zastanowienie się nad nimi może prowadzić w kierunku rozważań już nie całkiem banalnych: a mianowicie stosunku porównywanych przez autora form do konwencji. Kwestii tej jednak młody badacz nie porusza ${ }^{252}$, ja zaś (uznając ją za kluczową dla całego tego rozdziału) wrócę do niej później, znacząco ten temat rozwijając. Tu poprzestać muszę na stwierdzeniu, iż dywagacje badacza o liberackich oraz komiksowych autorach i bohaterach niewiele wnosza.

\section{4. „Myślenie stroną” i „myślenie książką”, czyli kilka słów o metakadrze}

Czas odnieść się do wskazywanych przez Żuchowskiego podobieństw. Na pewno dopowiedzenia wymaga kwestia łączącego twórców komiksu i literatury totalnej myślenia metakadrowego, patrzenia na stronę jako jednostkę kompozycyjna. Rzeczywiście, liberaci nieraz „myśla strona”. Jednak przede wszystkim, jak powtarzał po wielokroć Fajfer, liberatura to „myślenie książka”" i to ono jest tu kategoria najistotniejszą. Wyłamanie się konwencji patrzenia na pojedynczą kartkę jako uschematyzowaną przestrzeń zapisu to krok liberacki, dostrzeżenie w niej skomponowanej wizualnie całostki, która (właśnie jako tak zaprojektowana) może znaczyć - również. Niemniej - pozostaje pytanie o to, czy twórcy komiksu idą krok dalej i myślą też książką. Czy też podobieństwo ogranicza się do - kluczowego chyba dla ujęcia Żuchowskiego - otwarcia na wielolinearność opowieści, symultaniczność zapisu nierespektującego konwencjonalnego porządku aranżacji strony ${ }^{253}$ ?

${ }^{251}$ K. T. Toeplitz, Sztuka komiksu..., s. 80. Por. też m.in. Jerzy Szyłak, Komiks, Kraków 2000.

${ }^{252}$ Chciałabym podkreślić, że w gruncie rzeczy skupia się on wyłącznie na opisie sytuacji, w której bohater staje się ikoną serii i - zdaniem Żuchowskiego - urasta do rangi osoby istotniejszej dla odbiorcy niż autor.

${ }^{253}$ Dwa akapity, które autor poświęca omawianemu tu zagadnieniu są dość enigmatyczne. Niemniej, zdaje się, iż tak należałoby rozumieć myśl zawartą w słowach: „Zasługą «metakadru» jest więc to, że komiks bezdyskusyjnie zaliczany jest do gatunków sztuki, które posiadają zdolność symultanicznego prezentowania wydarzeń. A jak pamiętamy z lektury teoretycznoliterackich tekstów owa - zatracona na rzecz lektury linearnej - symultaniczność na kartach «odrodzonej literatury» byłaby wielce pożądana. Podporządkowanie wszystkich zgromadzonych na stronicy elementów przedstawiania (znaków ikonicznych i lingwistycznych) w celu spotęgowania zamierzonego przez autora znaczenia - tak w komiksie, jak i w liberackiej książce - prowadzi do «metakadru»" (J. Żuchowski, s. 152). 
Sądzę, że o ile liberat „myśli książka”, twórca komiksu - co najwyżej metakadrem lub historią. Jerzy Szyłak - zwracając uwagę, że niesłuszne jest bagatelizowanie istnienia dzieła w formie książki i oddzielanie (w konsekwencji) jego analiz od namysłu nad forma, w jakiej są przekazywane (istniejącym w kulturze obiektem) - przyznaje, że w przypadku komiksu książka to jednak obiekt „spełniający funkcje użytkowe - podobnie jak łyżka, grzebień czy krzesło" ${ }^{254}$. Zatem, twórcom tej formy obce jest typowe dla liberatów myślenie o materii i kształcie tomu niczym o środku przekazu, elemencie istotnym przy budowaniu sensu dzieła, składniku utworu o potencji znaczeniotwórczej. Co, oczywiście, nie przeczy - sygnalizowanemu przez Żuchowskiego - podobieństwu w odrzuceniu klasycznego pojmowania wartości pojedynczej strony. Sprawia jednak, że analogia ta jawi się jako mniej istotna.

\subsection{Na manowcach autopromocji lub o zamkniętych kręgach wtajemniczonych}

Więcej racji ma Żuchowski w swoim omówieniu podobieństw dotyczących „metod autopromocji”255. Rzeczywiście, zarówno komiks, jak i liberatura musiały się postarać, by teoretycy i „zwykli” czytelnicy poświęcili im trochę uwagi. W obu przypadkach, dążąc do tego, by ich zauważono, twórcy próbowali wskazywać na swoich poprzedników w odległej tradycji. Zakorzenienie w niej miało nobilitować, pokazywać, że ich dzieła nie sa żadnymi dziwacznymi tworami, wybrykami sztuki czy wręcz cudakami niedającymi się rozpatrywać w kategoriach estetycznych. Miało uprawomocnić wpisywanie ich w obręb działań artystycznych (przy czym komiks dopraszał się o nazywanie go w ogóle sztuka, liberatura zaś nie chciała być wyrzucana poza marginesy literatury).

Jednak nie sądzę, by Żuchowski miał rację, stwierdzając, że w przypadku liberatury takie poszukiwania są uprawomocnione, że tylko w odniesieniu do komiksu są pewnym nadużyciem. I może istotne jest tu też podkreślenie, że o ile wśród badaczy drugiej z przywołanych form możemy wyróżnić i takich, którzy szukają owych antenatów w możliwie dalekiej przeszłości (np. Andrzej Banach), jak i takich, którzy owemu szerokiemu ujęciu nie są zbyt przychylni (np. Jerzy Szyłak), to wśród zajmujących się liberaturą trudno byłoby wskazać tych, którzy zaliczą do niej wyłącznie twórczość powstała po roku 1999. I ja skupiam się na szukaniu liberackości tekstów powstałych przed XXI w.

254 J. Szyłak, Poetyka komiksu..., s. 154. Por. też cały rozdział Okładki i odbiorcy. Komiks jako ksią̇ka, ibidem, s. 154-157. Szyłak wskazuje wyłącznie okładkę jako element mogący się wyróżniać. Zauważa również - co urzekłoby liberatów i co wymaga (choć marginalnego) przywołania w tej pracy - że ci, którzy badaja ,język artystyczny” pomijają zupełnie kwestie jego zapisu - zajmują się „przekazem, który nie zmienia się w zależności od sposobu wydania” (s. 155), zaś badacze książek zastanawiają się nad konkretnymi publikacjami. Teoretycy i czytelnicy liberatury winni stawiać pytania podobne jak ci ostatni.

255 J. Żuchowski, s. 148. 
Pozornie nic w tym złego, bowiem na pierwszy rzut oka liberatura, rzeczywiście, wydaje się terminem zdolnym objąć całą historię sztuki słowa. Jednak zwłaszcza gdy mowa o nobilitowaniu literatury totalnej na drodze podkreślania jej związku z tradycją - niezwykle ważne wydaje się odejście od mówienia o liberaturze na rzecz rozważań o liberackości.

Jak już zaznaczałam, takie ujęcie pozwala określać stopnień nasycenia ową cechą utworów pochodzących z różnych epok, odnosząc je do wzorca, prototypu za jaki - sugerując się tezami Bazarnik - przyjmuję Oka-leczenie. Zaś niebezpieczeństwo szukania liberatury wszędzie tkwi w tym, że określa się tym mianem zarówno teksty od wzorca bardzo odległe, jak i nad wyraz mu bliskie. Sam termin bywa nieraz „naciagany”, co w połaczeniu z usilnym poszukiwaniem przykładów literatury totalnej wśród arcydzieł prowadzi do sytuacji, w której wprowadzone przez Fajfera pojęcie staje się wytrychem do mówienia o ogromnej grupie tekstów, w dużej części dość grafomańskich, nobilitowanych przez rzekome podobieństwo do arcydzieł. A taki „termin-worek” musi być odrzucony przez tych, którzy choć odrobinę krytycznie patrzą na pojawiające się nowe propozycje teoretyczne ${ }^{256}$.

I tak, choć jestem zwolenniczką poszukiwania liberackości, i choć uważam postulowane w tej książce spojrzenie na historię sztuki słowa i literackiej komunikacji za zasadne, słuszne i użyteczne, raczej przeciwna jestem Fajferowskim zapędom dostrzegania arcydzieł liberatury wszędzie. Prowadzi to nie tyle do nobilitacji literatury totalnej, co raczej ją ośmiesza. Przeciwna jestem też bezmyślnemu nieraz powtarzaniu przez teoretyków, że coś jest liberackie, bez zastanowienia się nad tym „dlaczego”. Część moich rozważań (m.in. ten rozdział) poświęcona jest przecież właśnie pokazaniu, że choć „koń jaki jest, każdy widzi”, niemniej nie wszystko, co do liberatury podobne (i co Fajfer czy Bazarnik jako taka przedstawiaja) w istocie musi nią być.

Podobnie sceptyczne podejście do zbyt drobiazgowego poszukiwania antenatów w przypadku komiksu reprezentuje Toeplitz. Pisze on o błędzie często popełnianym przez pasjonatów komiksu (również teoretyków), którzy „poszukując możliwie najdostojniejszych antenatów dla tej sztuki, skłonni są powoływać się na kolumnę Trajana, dywan z Bayeux lub cykl dziesięciu gobelinów, obrazujących żywot Aleksandra Wielkiego"257. Badacz zwraca uwagę na istotę problemu - takie rozszerzanie granic pojęcia oddala nas od zrozumienia jego istoty. Identycznie jest, jak sądzę, w przypadku liberatury.

Powiem więcej, sygnalizowane przez Żuchowskiego podobieństwo prowadzi ku jeszcze jednej konstatacji. Środowiska komiksologów i liberaturoznawców (?) są raczej zamknięte i rozproszone, lokują się też na peryferiach teoretycznoliterackich. W konsekwencji ich przedstawiciele komunikują się głównie sami ze sobą. W takiej sytuacji, nawet gdy pojawiają się głosy wyważone,

${ }^{256}$ Okazuje się bowiem np., że każda, nawet najmniejsza ingerencja w kształt typograficzny dzieła czyni je stuprocentową liberaturą. A przecież - jak pokażę na przykładzie analizy druku funkcjonalnego w kontekście literatury totalnej - jeśli nie zadamy pytania o cel tych innowacji, trop taki może prowadzić nie tyle ku liberaturze, co na manowce.

257 K. T. Toeplitz, Sztuka komiksu..., s. 51. 
przyczyniające się do rozwoju formułowanych teorii czy mogące inspirować dyskusje w szerszych kręgach, takie związanie z wiecznie tą samą grupa odbiorców hamuje dynamiczny rozwój refleksji i w efekcie doprowadza do jej zubożenia. Co więcej - jeśli terminy takie jak komiks czy liberatura mają stać się użyteczne - nie potrzebują wcale „promocji”258, lecz sprawdzenia, czy sa w stanie spełniać przypisywane im funkcje. Winny być używane, testowane w naukowych dyskusjach. W tym akurat zbytnie promowanie (którego nie potrzebowały chyba określenia takie, jak choćby przekaz intersemiotyczny, gatunek politypiczny czy - modne ostatnio - remediacja lub konwergencja) może im nieraz zaszkodzić.

\subsection{Właściwy początek: jedność ikono-lingwistyczna versus pansemantyczność}

Wszystkie przywołane dotychczas tezy Żuchowskiego wymagały uzupełnień, sprostowań lub wyjaśnień. Żadna też nie wydała się dotychczas inspirujacym tropem w mówieniu o relacji komiks-liberatura. Ani jedna nie potwierdziła, że - jak sugerował badacz - grunt, na który padło ziarno rzucone przez Fajfera jest podatny. Jednak dwa dotychczas przeze mnie nieanalizowane stwierdzenia autora (drugi i trzeci punkt spośród wymienionych tu podobieństw) wydają się wskazywać interesujące perspektywy. Skupienie się na nich pozwoli zakończyć (przydługi raczej) wstęp omawiający mniej istotne aspekty problemu związków porównywanych w tym rozdziale zjawisk, a przejść do scharakteryzowania tych, które rzeczywiście wydają się inspirujące.

I tak, rzeczywistym punktem wyjścia do rozważań o bliskości liberatury i komiksu chciałabym uczynić (powiązane ze soba) formułowane przez Żuchowskiego wnioski dotyczące użyteczności terminu jedność ikono-lingwistyczna do opisu obu tych przestrzeni działań artystycznych oraz uwagi związane z kategoria odbiorcy przywołanych form sztuki, wrażliwego na komunikaty wielotworzywowe i wszelkie związane z użytymi w nich kodami operacje o charakterze znaczeniotwórczym. Inspirujące, w szkicu badacza nikną one niestety $\mathrm{w}$ natłoku mniej istotnych refleksji, a równie trudno było im wybrzmieć we wstępnej części tego rozdziału.

Istnienie komiksu w obszarze pogranicznym sztuk wizualnych i literatury owocuje sporami o to, do której z tych dziedzin należy zaliczyć utwory spełniajace wymogi gatunku. Najczęściej wysuwanym przez badaczy wnioskiem wydaje się jednak stwierdzenie, iż właśnie owa „nieczystość kodu”, której skutkiem sa wspomniane problemy z klasyfikacją komiksu, jest jedna z jego cech dystynktywnych. W konsekwencji zaś, by dostrzec jakości prawdziwie

${ }^{258} \mathrm{~W}$ przypadku liberatury może nie bez znaczenia jest fakt, że kwestią jej wydawania, promowania, dystrybucji zajmuje się środowisko „Ha!artu”. 
komiksowe, należy zaniechać poszukiwania cech literackich czy wizualnych i skierować swoją uwagę - jak w przypadku obcowania z dziełem liberackim na większe (i bardziej złożone) struktury, w które wpisane jest znaczenie. Jak podkreślał Ryszard Przybylski:

Dopiero całość jaką jest komiks (tzn. tekst słowny i tekst ikoniczny) to znak autonomiczny, natomiast słowo i obraz to znaki nieautonomiczne, funkcjonalnie podporządkowane owej całości ${ }^{259}$

Co więcej, podążanie śladami wyłącznie jednego z kodów, niedostrzeganie złożonego charakteru czytanej struktury, może owocować wypaczeniem znaczeń (bądź też niemożliwością ich dostrzeżenia). Przed podobnym błędem lektury przestrzegał czytelników liberatury Fajfer. Odbiorców historyjek obrazkowych napominał zaś (m.in.) Jerzy Jarzębski:

Komiks bowiem jest sztuką synkretyczna; zakłada nierozerwalną więź słowa i obrazu, związek, którego naruszenie grozi utratą (lub istotnym zubożeniem) sensu całego komunikatu ${ }^{260}$.

Komiksolodzy podkreślają zatem - podobnie jak liberaci - nie tylko współistnienie w obrębie jednego tekstu różnych kodów, lecz i ich istotne zespolenie, sięgające tak głęboko, iż pełnię znaczeń odczytujemy, dopiero dostrzegając i analizując te współzależności. W obu przypadkach konstatacja ta prowadzi do opisu nowych sposobów lektury czy prób charakterystyki obszaru sztuki, do którego przynależą tworzone utwory, gdyż przestrzeń klasycznej literatury wydaje się tu zbyt ograniczająca. Jerzy Szyłak wpisuje sztukę komiksu w obszar komunikacji wizualnej (nie: wyłącznie literackiej), dla której charakterystyczne jest właśnie sumowanie przekazów pochodzacych z różnych kodów ${ }^{261}$. Randy Duncan i Matthew Smith mówią o związanych z pojawieniem się komiksu narodzinach „nowej literackości” ${ }^{262}$, opartej na konieczności

${ }^{259}$ Ryszard K. Przybylski, Świat komiksu, „Sztuka” 1978, nr 2, s. 19.

260 Jerzy Jastrzębski, Komiks i stereotypy, [w:] idem, Czas relaksu. O literaturze masowej i jej okolicach, Wrocław 1982, s. 223.

261 J. Szyłak, Komiks w kulturze ikonicznej... . Na s. 11 czytamy: „Odbiór komunikatu wizualnego polega zatem na sumowaniu informacji przekazywanych na kilka sposobów i odwołujących się do różnych konwencji oznaczania i kodów semantycznych. Podstawowym problemem przy tworzeniu komiksu jest w związku z tym kwestia ujednolicenia przekazu, podporządkowania go jakiemuś czynnikowi nadrzędnemu, którego istnienie byłoby wskazówką na temat sposobu jego odbioru jako całości. Widać to bardzo wyraźnie we wszystkich próbach scharakteryzowania i zdefiniowania komiksu, obracających się wokół problemów jedności, tworzonej w ramach historyjki obrazkowej przez napisy i obrazy, i spójność przekazów. Teoretyczną odpowiedzią na taka potrzebę wydaje się termin jedność ikono-ligwistyczna”, o którym piszę w dalszych fragmentach rozdziału.

${ }^{262}$ Randy Duncan, Matthew J. Smith, The Power of Comics. History, Form \& Culture, New York 2009, s. 14. Autorzy stwierdzają: „Istnienie komiksu nie tylko pomogło w podważeniu prymatu słowa drukowanego. Komiks przerwał, a w końcu i zamazał granice pomiędzy tekstami ze słów i tekstami z obrazów. Czytanie komiksu wymaga innego rodzaju literackości, ponieważ na jego stronie zarówno narysowane słowo, jak i narysowany obraz są obrazami do czytania, czytania jako jeden, zintegrowany tekst" (tłumaczenie moje). 
równoległego czytania/oglądania słów i obrazów. Z kolei Krzysztof Teodor Toeplitz wspomina o (związanej z przemianami galaktyki Gutenberga) „nowej poetyce lektury" ${ }^{663}$, rozumianej jako konsekwencja sięgania przez artystów po zapis eksplorujący materialność. Ja z kolei jako nową formę literackości traktuję liberaturę - tezy te będę rozwijać szczególnie w ostatnich rozdziałach tej książki (zwłaszcza analizując literaturę totalną w kontekście nowych mediów i całokształtu współczesnych przemian sztuki słowa) ${ }^{264}$.

Nie wyłącznie liberaci uznaja, że tworzone przez nich teksty nie są „literaturą rozumiana jako ciag wyrazów ułożonych w zdania"265 (tym razem cytuję komiksologa Bartosza Kurca, nie Fajfera). Nie tylko teoretycy literatury totalnej uważają też, że są sytuacje, w których „w narracji obraz stanowi jej istotny element, nie zaś ozdobę"266 (to z kolei słowa kolejnego nie-liberata: Janusza Dunina). Rzeczywiście więc - zgodnie z sugestią Zuchowskiego - projektowanie tekstów w oparciu o procesy oznaczania zakorzenione w więcej niż jednym medium, wykraczające poza właściwości samego „literackiego” słowa, wydaje się cechą łączącą liberatów i artystów komiksów.

W odniesieniu do drugiej z wymienionych odmian twórczości ową kluczową wewnętrzna, strukturalną zależność elementów wizualnych (ikonicznych) i werbalnych zwykło się - za Bernardem Toussaintem - określać mianem jedności ikono-lingwistycznej ${ }^{267}$. Możemy o niej mówić w przypadku utworów przyjmujaccych taką postać współdziałania znaków ikonicznych i umownych, która stanowi jedna, niepodzielną strukturę semantyczna. Nie odnajdziemy w niej tego, co Mieczysław Wallis określa mianem enklaw semantycznych: fragmentów dzieł złożonych z odmiennych niż reszta utworu znaków, tworzących autonomiczne w obrębie struktury tekstu całostki ${ }^{268}$.

Sam Toussaint zauważał jednak, że opisana przezeń jedność nie cechuje wyłącznie komiksu, lecz i inne formy, takie jak reklama, film czy - czego nie rozwiną jako wykraczającego poza ramy jego badań, a co dla moich rozważań ważne, bo uprawomocniające używanie tego terminu również w odniesieniu do liberatury - „niektóre teksty literatury nowoczesnej” ${ }^{669}$. Wydaje się, że równie użytecznym do opisu tej ostatniej może być pojęcie ideogramatyzacji postrze-

${ }^{263}$ K. T. Toeplitz, Sztuka komiksu... .

${ }^{264}$ A dość tu przypomnieć, że o konieczności nowego spojrzenia na samą wręcz kategorię tekstu w obliczu kultury - jak ją określa - multimedialnej pisała też Seweryna Wysłouch (S. Wysłouch, Nowa genologia..., s. 106).

265 B. Kurc, Komiks..., s. 48.

266 Janusz Dunin, Prolegomena do „komiksologii”, „Literatura Ludowa” 1972, nr 6, s. 6.

${ }^{267} \mathrm{Na}$ grunt polski termin ten zaszczepił Toeplitz. Por. K. T. Toeplitz, Sztuka komiksu..., s. 21-22. Zob. też: Bernard Toussaint, Idéographie et bande dessinée, „Communication” 1976, nr 24.

268 Zob. Mieczysław Wallis, Napisy w obrazach, [w:] idem, Sztuki i znaki. Pisma semiotyczne, Warszawa 1983. Badacz podkreśla, że enklawy „mają inną strukturę semantyczną, przemawiają odrębnym «językiem»" (s. 191), zaś jako przykłady podaje: napis w obrazach, posag z inskrypcja na cokole, monetę lub medal, rękopis iluminowany, książkę i czasopismo ilustrowane, ogłoszenie w piśmie, szyld z obrazkiem, znaczek pocztowy i plakat. Zaznacza też, że wprowadzony termin nie ma charakteru negatywnego, że enklawy nie muszą być niechcianymi wtrętami.

${ }^{269}$ Cyt za: K. T. Toeplitz, Sztuka komiksu..., s. 22. 
ganej przez Toussainta jako konsekwencja opisywanej jedności. Warto jednak zaznaczyć, że w definiowaniu tego terminu najistotniejsze wydaje się związanie z kategorią ideogramu jako znaku, nie zaś (podkreślana najczęściej przez komentatorów) dążność do kondensacji znaczeń, skrótowości ${ }^{270}$. Tym samym, istota problemu zostaje przesunięta właśnie na proces budowania znaczeń: nie z wyglądu rzeczy (obraz) czy brzmień zdań (jakości lingwistyczne, słowo), lecz właśnie z ich zespolenia ${ }^{271}$.

Tym, co kluczowe, staje się wzajemne przekazywanie sobie funkcji pomiędzy kodami. By mogła zaistnieć jedność ikono-ligwistyczna, konieczne jest odrzucenie schematycznych podziałów przypisujących elementom lingwistycznym zdolność oznaczania opartą na relacjach symbolicznych, zaś elementom wizualnym - na mimetyczności. Nieaktualne stają się już słowa opisu:

\begin{abstract}
Istotą tego systemu znaków, który nazywamy rysunkiem, jest jego ogromna wrażliwość na cechy indywidualnego przedstawienia, podczas gdy system znaków alfabetu fonetycznego jest na nie całkowicie obojętny i litera „a” nie traci ani téz nie zmienia swego znaczenia niezależnie od tego, jakim charakterem pisma czy też jaką techniką drukarską jest przedstawiana. Podczas gdy rysunek odwzorowuje rzeczywistość w całym bogactwie jej indywidualnych cech, pismo literowe (alfabet fonetyczny) symbolizuje ją jedynie w najbardziej abstrakcyjny, skonwencjonalizowany sposób ${ }^{272}$
\end{abstract}

W przypadku komiksu słowa i obrazy zamieniają się nieco miejscami pierwsze: wytłuszczone, uczynione typograficznie atrakcyjnymi, stają się bliższe oglądanym obrazom ${ }^{273}$, drugie: uproszczone, wymagajace od odbiorcy wykorzystania do ich zdekodowania uprzednio znanych informacji, stają się bardziej niczym słowa ${ }^{274}$. Oba typy znaków przekazują sobie funkcje, nie sposób - niczym w liberaturze - jedne (zgodnie z tradycja) czytać, a drugie oglądać, gdyż gubią się wtedy znaczenia.

270 Por. np. ibidem.

271 Toeplitz pisze: „Są to więc znaki bardziej niż przedstawienia plastyczne lub informacje lingwistyczne we właściwym rozumieniu; ich głównym dążeniem jest poszukiwanie ogólnego znaczenia, nie zaś specyficznego wyglądu rzeczy lub brzmień zdań” (K. T. Toeplitz, Sztuka komiksu..., s. 22).

${ }^{272}$ K. T. Toeplitz, Sztuka komiksu..., s. 100.

${ }^{273}$ Komiksowa typografia (zapewne jak i ta liberacka) mogłaby się stać przedmiotem oddzielnego studium. Por. m.in.: S. McCloud, Understanding Comics...; K. T. Toeplitz, Sztuka komiksu...; J. Szyłak, Poetyka komiksu...; B. Kurc, Komiks... .

${ }_{274}$ S. McCloud, Understanding Comics..., s. 49. Badacz zaznacza również, iż od czasu wynalezienia druku, koegzystencja słowa i obrazu była spychana na plan drugi, stajac się nie tyle reguła, co zjawiskiem wyjątkowym (do analogicznych charakterystyk użyteczny wydaje się Rypsonowski termin innej tradycji, o którym pisałam już wcześniej). Specjalizacja i uabstrakcyjnienie elementów werbalnych postępowało - zdaniem amerykańskiego praktyka i teoretyka - równolegle z upraszczaniem i schematyzacją elementów wizualnych. Warto też pamiętać, że McCloudowska reinterpretacja trójkąta semiotycznego opiera się właśnie na próbie uchwycenia chęci odejścia od wyraźnego rozdzielania przestrzeni słów i obrazów, przywrócenia tym pierwszym potencji przypominania, nie wyłącznie oznaczania, charakterystycznej, zdaniem badacza, nie tylko dla twórców komiksu, lecz i artystów spod znaku dadaizmu, futuryzmu i nie tylko (por. S. McCloud, Understanding Comics..., s. 143-147). 
Nawet bowiem jeśli czytam litery, z których złożone są zapisy zdań i dźwięków w komiksie, - stwierdza Toeplitz - to jednak nie mogę ich w pełni zrozumieć, jeśli nie uświadomię sobie, że są one rysowane i że w ich formie rysunkowej zawiera się ich decydujący walor treściowy. Komiks na długo przed rewelacjami McLuhana wydobył się z kultury druku właściwej „galaktyce Gutenberga”, przetwarzając środkami plastycznymi bezosobowy zapis alfabetu fonetycznego w pełną ekspresji kulturę oralną. Mamy tu do czynienia z niemożliwością nieomal, a więc z mową i dźwiękiem narysowanym, i to narysowanym nie tak, jak czyni to zapis nutowy, kojarzący w sposób konwencjonalny abstrakcyjne znaki z określonymi dźwiękami, lecz w sposób ekspresyjny, plastycznie wymowny i łatwy do identyfikacji ${ }^{275}$.

Na podobne aspekty literatury totalnej zwracał uwagę Radosław Nowakowski, stwierdzając, że „fascynująca jest łatwość, z jaką pisanie może przechodzić w rysowanie, a rysowanie w pisanie"276.

Co jednak najistotniejsze, i co zarazem najbardziej zbliża komiks do liberatury, to cel tworzenia takich ikono-lingwistycznych zbitek. Sedno tkwi nie w tym, by połaczyć obraz ze słowem, lecz by owo zespolenie pozwalało przekazać znaczenia lepiej niż każde z mediów z osobna ${ }^{277}$. Kluczowe wydaje się $\mathrm{tu}$ - podobnie jak w liberaturze - takie projektowanie utworu, by znaczenia (od samego początku) rozpisane były w przestrzeni łączącej warstwę ikoniczna i werbalna. Już w zamyśle autora siatka powiązań przenikająca te klasycznie oddzielane sfery utworu winna tworzyć spójną strukturę. Na fakt, iż w tym wypadku zastosowane media powinny współdziałać, wspierać się wzajemnie (pozwalając realizować się każdemu najpełniej w polu, w jakim jest najsilniejszy) zwraca też uwagę Scott McCloud, podkreślający, że częściowe przejęcie obowiązków znaczenia i snucia historii przez obraz jest rodzajem uwalniania słów ${ }^{278}$

Ten sam badacz określa komiks jako „medium jednozmysłowe” (mono-sensory medium $)^{279}$, a jego uwagi pozwalaja nam wskazać poszukiwany przez Toeplitza wspólny mianownik będący podstawą tworzenia jedności ikono-lingwistycznej: wszystko (dźwięki, odczucia temperatury, wrażenia węchowe oraz te rzeczywiście wizualne) sprowadzone jest do bodźców dających się po-

${ }^{275}$ K. T. Toeplitz, Sztuka komiksu..., s. 50.

${ }^{276}$ Radosław Nowakowski, Dlaczego moje ksiażki sa takie jakie sa, [w:] Od Joyce’a do liberatury. Szkice o architekturze stowa, red. Katarzyna Bazarnik, Kraków 2002, s. 220. Artysta wyraża takie przekonanie w kontekście rozmyślań nad pismem odręcznym. Trzeba jednak pamiętać, że właśnie je najczęściej naśladują używane przez autora czcionki, stąd pozwalam sobie na uogólnienie tego wniosku.

277 Jerzy Szyłak, komentując Maus Arta Spiegelmana, stwierdzał: „Sa to znaczenia nie tylko porównywalne z tymi, do artykułowania których jest zdolna literatura, ale i przez wyzyskanie komiksowego medium, bogatsze od sztuki słowa o sensy, które powstają wskutek napięcia pomiędzy narracja werbalną i obrazem" (J. Szyłak, Komiks w kulturze ikonicznej..., s. 81).

278 S. McCloud, Understanding Comics..., s. 157. Słuszna jest również obserwacja badacza dotyczaca konsekwencji przesunięcia funkcji pomiędzy warstwą werbalną i wizualna - obrazy zyskują możliwość mówienia o rzeczach niewidzialnych. M.in. dlatego właśnie nazywa on komiks sztukq niewidzialna (the invisible art) (dla twórcy tego terminu istotny jest także i fakt, że o rozwoju opowiadanej historii informuje nas to, czego nie widać, co zmienia się między jednym komiksowym kadrem a drugim, to, co czytelnik sobie dopowiada).

${ }^{279}$ S. McCloud, Understanding Comics..., s. 89. 
strzegać przy pomocy wzroku ${ }^{280}$. Tu zaś daje się dostrzec różnice w stosunku do liberatury.

Opisana wyżej istota jedności ikono-lingwistycznej (pomysł rozpisania znaczeń tekstu między jego dwie warstwy - wizualną i werbalna - oraz uczynienia podstawa utworu struktury opartej na ich relacjach i wzajemnym przenikaniu się) łączy podejście liberackie i komiksologiczne. Jednak twórca literatury totalnej otwarty jest również na inne zmysły niż wyłącznie wzrok. Szczególnie na poziomie teorii (w praktyce bowiem rzadziej się z tym zjawiskiem spotkamy) liberatura zaprzęga do kreowania swych znaczeń szeroko rozumianą materialność tekstu, więc również - poza tym, co wizualne - wszelkie aspekty postrzegane zmysłem dotyku (chropowatość podłoża czy kształt fragmentów przestrzennych tekstu - np. w przypadku wykorzystującej jako tworzywo kamień Światyni kamienia Andrzeja Bednarczyka). Zaś w wykorzystujących elektroniczne media pracach twórcy nie odżegnują się też od użycia dźwięków, angażując także zmysł słuchu swoich odbiorców ${ }^{281}$

Niemniej, niezależnie od ilości zaprzęgniętych do tworzenia znaczeń płaszczyzn, mediów, aspektów tekstu - istotna pozostaje kwestia zespalania ich w jedna, niepodzielną strukturę. Istota semiozy pozostaje wspólna dla wykorzystującego wyłącznie sferę ikoniczną i werbalną komiksu oraz dla - mogącej do przestrzeni słowa dołączać dowolne inne (nie wyłącznie i nie koniecznie wizualne) aspekty - liberatury. Jednak, kiedy mówimy o literaturze totalnej, wygodne pojęcie jedność ikono-lingwistyczna okazuje się nieraz zbyt wąskie, gdy twórcy sięgają po zabiegi związane nie tylko z warstwą ikoniczną utworu (a trzeba też pamiętać, że równie dobrze moga tej akurat przestrzeni nie eksplorować - liberatura nie musi wcale być wizualna). Dobrze byłoby zatem znaleźć termin równie trafnie ujmujący kluczowe kwestie, lecz nieco szerszy, pozwalający pełniej scharakteryzować opisywane tu relacje, uwzględniający wyjście w szersze przestrzenie semantyczne.

Propozycje taka - jak już sygnalizowałam - spotkamy w pracach Wojciecha Birka, który - zwracając uwage na to, że każdy element komiksowego komunikatu może być wykorzystany jako znaczacy - proponuje mówienie o pansemantyczności ${ }^{282}$, zastępując jedność ikono-lingwistyczna określeniem niewskazującym na żadne z mediów. Taka terminologia wydaje się użyteczniejsza dla budowania analogii liberacko-komiksowych, samo zaś pojęcie wygodne do opisu dzieł literatury totalnej. Choć, być może, jeszcze lepszym

280 Zob. też: ibidem, s. 120.

281 O możliwości funkcjonowania liberatury w nowych mediach (w tym i o kłopotliwym terminie e-liberatura oraz problemach z klasyfikacją prac, takich jak primum mobile Fajfera czy Koniec świata wedtug Emeryka R. Nowakowskiego) piszę w rozdziale poświęconym relacji literatury totalnej i nowych mediów.

${ }^{282}$ W. Birek, Główne problemy teorii komiksu, s. 285. Punktem wyjścia do wprowadzenia nowego terminu staje się tu (słuszne) zwrócenie przez badacza uwagi na fakt, że elementy takie jak kształt kadrów czy ich wzajemne usytuowanie są w komiksie semantycznie istotne, choć nie do końca dają się zaliczyć do przestrzeni ikonicznej. 
rozwiązaniem byłoby mówienie o jedności pansemantycznej. W ten sposób w samym brzmieniu terminu sygnalizowana byłaby kluczowa kwestia: trwały związek użytych kodów oraz brak ich hierarchizowania.

\subsection{Konwencja jedności ikono-lingwistycznej versus dowolność jedności pansemantycznej, czyli o poetykach normatywnych i postulatywnych lub czytelniczych przechadzkach po (innym) lesie}

Jak widać, intuicja Żuchowskiego była słuszna: twórców liberatury i komiksu łączy sposób projektowania struktury i znaczeń tekstu, zamysł łączenia w jedną nierozerwalną całość elementów przynależnych do tradycyjnie rozdzielanych przestrzeni. Co więcej (również zgodnie z tezami badacza), w przypadku obu tych rodzajów twórczości, ich odbiorca musi być gotowy do podejmowania rzucanych mu wyzwań: zdolny odrzucić klasyczne ścieżki lektury i po lesie (niekoniecznie) fikcji przechadzać się też drogami jeszcze niezapoznanymi, niewytyczonymi, kierując się nie wskazówkami wielowiekowej tradycji, lecz śladami pozostawionymi w konkretnych tekstach. Ów modelowy czytelnik przede wszystkim jest gotów tropić takie nowe szlaki i wydaje się przygotowany na nietypowe rozwiązania, ma oczy i uszy (a może i inne narządy zmysłów) szeroko otwarte.

A jednak: czy projektowani odbiorcy komiksu i liberatury chadzaja naprawdę tymi samym ścieżkami? Z pewnością jedni i drudzy nie czują się nierozerwalnie związani z dobrze zapoznanymi, dawno wytyczonymi szlakami klasycznej, linearnej lektury. Niemniej, zdaje się, że o ile marszruta czytelnika liberatury obejmuje tereny jeszcze nieprzemierzane, przestrzenie lasu nadal dziewicze i zakamarki, w które raczej nie zaglądano, trasę odbiorcy komiksów stanowią ścieżki, owszem, alternatywne w stosunku do głównych szlaków, jednak podobnie jak one już wytyczone, ukształtowane, wyraźnie wyróżniające się w przestrzeni.

W czym tkwi zatem paradoks tego, iż te dwa typy twórczości, oparte - jak wynika z wcześniejszych rozważań - na podobnym sposobie kreacji znaczeń, tworzone dla czytelników, którym niestraszne alternatywne sposoby lektury przez artystów uciekających od klasycznych rozwiązań, w efekcie zdają się sobie wcale nie tak bliskie? Czemu ich odbiorcy, choć mają do aktu (procesu) czytania podobne podejśsie, nie spotykają się - moim zdaniem - na tych samych ścieżkach?

Sedno odpowiedzi na postawione pytania zdaje się tkwić w jednym małym słowie: konwencja. O ile (pansemantycznie nastawieni) twórcy liberatury próbują od niej uciec, o tyle (dążący do uzyskania w swoich dziełach jedności ikono-lingwistycznej) artyści komiksu dążą do jak najpełniejszego jej zrealizowania. Nawet opisywana przez Toussainta (a za nim kolejnych) jedność jest wyznaczoną norma, którą należy spełnić, by utwór można było zaliczyć do gatunku. A jak pisał już wiele lat temu Ryszard Przybylski: 
Komiks posiada niezwykle precyzyjnie wyznaczone reguły każące określonym przedstawieniom przypisywać określone treści. W historycznym doświadczeniu artystyczno-estetycznym reguły te wyznaczają jego semantykę, a także konstruują zasady genologiczne. Wyjście poza ustanowione w określonej praktyce artystycznej porządki gatunku prowadzi do daleko idących zakłóceń, pozwalających wątpić, czy dany typ manipulacji obrazem i słowem jest jeszcze komiksem ${ }^{283}$.

Mówiąc innymi słowy - podstawą komiksowej komunikacji jest konwencja. Warto też dodać, że w ujęciu wielu badaczy to jej ukształtowanie wyznacza narodziny formy ${ }^{284}$. Dla mnie najistotniejsze wydaje się zaś to, iż podstawa jej budowania była kategoria naturalności odbioru. W konsekwencji, choć - jak często się podkreśla - do zrozumienia komiksu konieczna jest nie tyle jakaś wiedza uprzednia, lecz po prostu właśnie znajomość konwencji (rozpoznawania atrybutów pozwalających identyfikować postaci i przedmioty, interpretowania różnic między następującymi po sobie obrazkami, porządku lektury itp. ${ }^{285}$, nie musimy raczej czytać wcześniej żadnych instrukcji obsługi, wielkich poetyk komiksu, by sobie z jego odczytaniem poradzić. Jak twierdził ponoć Mort Walker: „komiksy nie potrzebuja żadnego wprowadzenia dla nikogo" ${ }^{286}$. Znajomość zasad komunikacji literackiej oraz wizualnej - na bazie których ukształtowana jest konwencja komiksowa - w zupełności wystarcza ${ }^{287}$. A jak tłumaczy Szyłak:

${ }^{283}$ R. Przybylski, Świat komiksu, s. 19. W dalszej części wywodu (w nawiązaniu do definicji Couperie’a) badacz dodawał: „Komiks «ukonstytuował» swą własną postać gatunkowa, [...] wymaga stosowania swoistych reguł zgodnie z którymi przypisuje się mu określony sens" (ibidem, s. 22). Warte podkreślenia jest również to, że owe „powszechnie zrozumiałe reguły” (ibidem, s. 22) związane są z nowym typem odbiorcy: ukształtowanym przez kulturę masową. Zdaniem Przybylskiego właśnie związanie komiksu (i jego genezy) z kulturą masową każe mu sięgać po rozpoznawane powszechnie, proste znaki ikoniczne oraz sposoby łączenia fabuły odzwierciedlające najczęściej spotykane schematy.

284 J. Szyłak stwierdzał: „Istnieje zgoda co do tego, że jako osobny gatunek komiks pojawił się pomiędzy rokiem 1894 i 1897, gdyż w tym czasie historyjki obrazkowe, drukowane w prasie, osiagnęły już znaczny stopień konwencjonalizacji, co upodobniało je do siebie nawzajem” (J. Szyłak, Komiks w kulturze ikonicznej..., s. 7).Ten sam badacz zwracał również uwagę na to, że w procesie tym istotne było przekształcenie w stale obecny w komiksie element (tzw. dymki) wykorzystywanych już w XVIII w. przez rysowników owalnych kształtów, w które wpisywano słowa (J. Szyłak, Komiks, s. 15). W polskiej refleksji głosy o konwencjonalności komiksu pojawiały się od samego początku, por. J. Dunin, Prolegomena do „komiksologii”.

285 J. Szyłak, Komiks, s. 13-14.

${ }^{286}$ Mort Walker, Theses Top Cortoonists [cartoonist? - AP] Tell How they Create American Favorite Comics, cyt. za: J. Dunin, Prolegomena do „komiksologii”, s. 11.

287 J. Szyłak, Poetyka komiksu..., s. 13. W literaturze przedmiotu pojawiały się jednak też głosy zgoła przeciwne, mówiące o tym, że ci, którzy nigdy nie zetknęli się z komiksem mają trudności z jego odbiorem, nie wiedza, jak się do niego zabrać (por. Thierry Smoldern, Komiks i prawa półkula, tłum. Krystyna Uchańska, „Komiks-Fantastyka” 1989, nr 2, s. 36-38). Niemniej, wydaje się, że współczesny odbiorca, wychowany już w kulturze audiowizualnej (i niepotrzebujący instruktażu dotyczącego jej odbioru), nie miewa już takich problemów. Zdaniem B. Kurca właśnie umiejętność dekodowania komunikatów audiowizualnych jest tu kluczowa (por. B. Kurc, Komiks..., s. 48), zwracał też na to uwagę przywołany Smoldern, pisząc o „prawdziwych czytelnikach komiksu” (s. 38), czyli tych, którzy od początku wychowywali się w kulturze komiksem przesiąkniętej. Podobnie należy chyba interpretować uwagi Szyłaka. Zaś Mirosław Szwabowicz w pracy Po co nam Superman? Rozmyślania o komiksie, zamieszczonej w Sktadnicy naukowej internetowego 
Tym, co pomaga nam czytać komiksy, jest właśnie wyrazistość i jednoznaczność obrazków, z których się one składają. Patrząc na serię drobnych rysunków zestawionych obok siebie na stronie, rozpoznajemy od razu, że wszystkie pokazują ten sam świat, odczuwamy upływ czasu, jaki tam następuje, i wiemy, co się wydarzyło ${ }^{288}$.

$\mathrm{Na}$ podobne aspekty komiksowej komunikacji zwraca uwagę Scott McCloud, wprowadzając kategorię zamknięcia (closure) ${ }^{289}$, charakteryzująca ludzką umiejętność dopowiadania tego, czego nie widzimy, składania całości z postrzeganych elementów. Właśnie takie podejście pozwala nie tylko dojrzeć spójny świat w schematycznych komiksowych rysunkach, lecz i dostrzec ciągłość akcji w opowieści, dopowiedzieć to, co między kadrami. W istocie jednak mówimy tu właśnie o umiejętności odczytywania konwencji. Jeśli więc zdaniem przywołanego badacza zamknięcie jest rodzajem „komiksowej gramatyki” ${ }^{290}$, i samą konwencję możemy z nią utożsamić.

I tak: z jednej strony spora grupa teoretycznych opracowań komiksologicznych skupia się na próbie opisu wszelkich typowych dla tego zjawiska zabiegów, dążąc tym samym do stworzenia „poetyki” tego gatunku, z drugiej - w większości tekstów podkreśla się, że podstawa kreowania opisywanej formy jest to, by odbiorca miał jak najmniejszy problem ze zdekodowaniem ubranego w słowa i obrazy komunikatu. Co więcej, twórcy komiksu - na drodze konwencjonalizacji właśnie - wypracowali własny, zawsze na pierwszy rzut oka rozpoznawalny (choć też: „otwarty stale na nowa konwencję”) „kod semantyczny" 291, którego główną idea stały się: czytelność i łatwość odbioru. Doskonała kategorię do opisu tej sytuacji proponuje Szyłak, określając podstawową technikę twórców komiksu jako „przerysowywanie” - tworzenie wizerunków łatwo- i szybkorozpoznawalnych, usprawniających odbiór najistotniejszego elementu komunikatu: opowieści ${ }^{292}$. Słusznie też dopatruje się tu badacz analogii między stylem komiksowym a tym, co Roland Barthes

portalu Zeszyty komiksowe (powstałego z myślą o gromadzeniu wszelkich - nie tylko naukowych - dyskusji komiksologicznych, zob.: www. zeszytykomiksowe.org) stwierdzał: „Dla mnie, osoby urodzonej w 1983 r., komiks stanowi integralną część kultury - od zawsze. Nigdy nie potrzebowałem jakiejś definicji czy «instrukcji obsługi», jak odbierać jego przekaz. Kiedy nie umiałem jeszcze sam czytać, rodzice brali mnie na kolana i śledzili obrazki razem ze mna, jednocześnie pełniąc rolę narratorów. Później sam dobierałem gatunki i problematykę" (Mirosław Szwabowicz, Po co nam Superman? Rozmyślania o komiksie, s. 7 [internetowa publikacja pracy licencjackiej z 2005 r.], http://www.zeszytykomiksowe.org/skladnica/szwabowicz2005.pdf, dostęp 25.08.2011). Por. także M. Hopfinger, Audiowizualny kontekst kultury wspótczesnej, [w:] Kultura-komunikacja-literatura. Studia nad XX wiekiem, red. Stefan Żółkiewski, M. Hopfinger, s. 75-96.

288 J. Szyłak, Komiks, s. 22-23. Doskonałym przykładem opartej na uproszczeniach służących czytelności konwencji komiksowej jest wypracowana na początku lat trzydziestych przez Belga Georgesa Remiego (pseudonim Hergé) technika rysunku zwana ligne claire. Więcej o niej zob. B. Kurc, Komiks..., s. 20-21 lub J. Szyłak, Komiks w kulturze ikonicznej..., s. 21.

289 S. McCloud, Understanding Comics... .

290 Ibidem, s. 67.

${ }^{291}$ K. T. Toeplitz, Sztuka komiksu..., s. 108.

292 Jerzy Szyłak, Komiks: świat przerysowany, Gdańsk 1998, zwłaszcza rozdział Sztuka przerysowania (s. 7-8). 
określił (dla literatury) punktem stylu zero ${ }^{293}$ (dodać by można, że podobne sa też cechy kina stylu zerowego).

Czy podobnie jest w przypadku liberatury? Na początku tego podrozdziału odpowiedziałam po części na to pytanie, kategorycznie zastrzegając, że kwestia stosunku do konwencji raczej różnicuje opisywane tu zjawiska. Pozostaje rozwinąc tę kwestię, a także zapytać o to, czy Traktat kartkograficzny czyli rzecz o liberaturze Radosława Nowakowskiego przypomina komiksowe poetyki ${ }^{294}$.

Przede wszystkim, liberaturę raczej trudno określić mianem twórczości konwencjonalnej czy łatwej w odbiorze, nieukrywającej opowiadanych historii, próbującej przekazać je w sposób dostępny dla każdego i odwołujacy się do naturalnego sposobu percepcji. Nieraz, owszem, sięga się tu do wypracowanego już na gruncie tradycji sposobu budowania przekazu (np. tradycji akrostychu w Oka-leczeniu), jednak - inaczej niż w przypadku komiksu - trudno byłoby tu wskazać kanon odwołań. Zasiadając do lektury dzieła liberackiego, nie wiemy, jakiego rodzaju schematy komunikacyjne (i czy w ogóle) zostana przywołane. Często istotnym elementem utworu jest właśnie to, by czytelnik natrudził się, odkrywając sposób budowania komunikatu. Nie zawsze ma tu być łatwo i czytelnie, przede wszystkim zaś: nie powinno być za każdym razem tak samo, gdyż artyści (jak mówi Fajfer) nie mogą dać się więzić konwencji, pozwalać, by ich ograniczała.

I tak, choć Nowakowski wydaje się artystą o dość spójnej poetyce, sięgającej właśnie w obszary relacji słowa i obrazu, wiedza o konwencjach czytania literatury i sztuk wizualnych nie wystarczy nam do zrozumienia wszystkich jego tekstów (jak byłoby - według Szyłaka i innych - w przypadku komiksu). Dość przypomnieć tu tomy Nieopisania świata ujęte w formie leporello czy analogiczną w swej konstrukcji do Nieszczęsnych Johnsona - Nieposkładana teorię sztuki. Podobnie wygląda sprawa z utworami Fajfera i Bazarnik - choć autorzy dość konsekwentnie stosują w swoich dziełach akrostychową technike tworzenia testów niewidzialnych, nie jedyny to przecież „klucz”, jaki czytelnik musi odnaleźć. Trudno raczej powiedzieć, by dla liberatury kategoria czytelności, prostoty odbioru była atrakcyjna.

W Oka-leczeniu - zgodnie z sugestiami Bazarnik przecież: modelowym dziele tego typu twórczości - nie znajdziemy czytelnych i uproszczonych rysunków, raczej też nie od pierwszego spojrzenia będziemy potrafili określić czas i miejsce akcji, wskazać rozmaite zależności personalne czy chronologiczne. Wręcz samo dostrzeżenie rozwoju fabuły nie jest w tym wypadku takie proste. A właśnie oryginalne rozwiązania, stworzone na potrzeby tego określonego tekstu, są tu kluczowe ${ }^{295}$. Liczy się nie czytelność i łatwość odbioru,

${ }^{293}$ J. Szyłak, Komiks w kulturze ikonicznej..., s. 91. Badacz zwraca jednak uwagę, że zestaw cech czy zabiegów pozwalających w pełni opisać poetykę zerowego stylu komiksowego nie jest zbyt wielki.

${ }^{294}$ Dla tych formułowanych obecnie na polskim gruncie wzorcem pozostaje praca Toeplitza (jako pierwsza) oraz liczne (najbardziej aktualne) opracowania Szyłaka.

${ }_{295}$ Por. przypis $66 \mathrm{w}$ rozdziale Liberatura a poezja wizualna. 
lecz wysiłek włożony w lekturę i tropienie kolejnych (nieraz głęboko ukrytych) wskazówek interpretacyjnych. Odejście od konwencji jest tu istota. A sytuacja to skrajnie różna od tej, z jaką mamy do czynienia w wypadku komiksu, w którym chęć zwrócenia uwagi czytelnika przede wszystkim (o ile nie jedynie) na opowiadaną obrazami fabułę prowadzi - jak podsumowuje Szyłak - do:

świadomego oparcia obrazkowego przekazu na skonwencjonalizowanych sposobach portretowania świata i do wykorzystania takich typów wizerunków, które sprzyjaja szybkiemu rozpoznawaniu tego, co zostało na nich przedstawione ${ }^{296}$.

Jednocześnie, choć Traktat kartkograficzny wydaje się poetyka, w której (obok podania definicji liberatury) opisano możliwe zabiegi liberackie związane z poszczególnymi wymiarami dzieła rozumianego jako książka (od pojedynczych czcionek, poprzez przestrzeń poszczególnych stron, aż po rodzaj papieru lub innego materiału wykorzystanego do budowy tomu) - jego charakter jest nieco inny niż przywołanych opracowań komiksologów. Ci ostatni, opisując typowe dla badanej formy chwyty, dążąc do ich pogrupowania, scharakteryzowania w celu jak najpełniejszego opisu typowego komiksu, tworzą poetyki normatywne. Wyznaczają kanon stosowanych zabiegów, definiując tym samym gatunek ${ }^{297}$. Czytając komiksy, spotkamy się z wszystkimi (lub prawie wszystkimi) cechami opisanymi w tych opracowaniach.

Nowakowski, choć podaje właściwie listy sposobów wykorzystywania pisma czy materii książki (zaznaczając, że jego opis ma charakter „otwarty”), podkreśla, że jego traktat (o którego „naukowawym” charakterze pisałam w pierwszej części tej książki) ma nie tyle cokolwiek wyjaśniać, co „otwierać nowe-nie-nowe terytorium" 298 , ma być odpowiedzia na pytanie: „dlaczego te książki sa właśnie takie?”. Tym samym Nowakowski, odsłaniając przed nami morze liberackich możliwości, nie tyle formułuje listę chwytów (cech, zabiegów), których powinniśmy szukać w konkretnych utworach, lecz pokazuje przykłady eksplorowania tego „nowego terytorium". Wydaje się, że najistotniejsza cechą opisywanej przez niego odmiany sztuki słowa (czy jak on to ujmuje - „sztuki uksiążkowiania świata”) jest właśnie to, że będzie ona zaskakiwać coraz to nowymi, nietypowymi rozwiązaniami, dyktowanymi każdorazowo charakterem (nieraz tematem) konkretnej opowieści. Tym samym, otwarty charakter tej poetyki jest jej cechą najistotniejszą. A jak pisze twórca-teoretyk:

296 J. Szyłak, Komiks: świat przerysowany, s. 8.

297 Współcześnie, gdy komiksowa konwencja jest w pełni ukształtowana, a odbiorcy - mówiąc kolokwialnie - „wytresowani”, wystarczają nikłe sygnały trzymania się jej, w konsekwencji czego sam przekaz może być konstruowany mniej uważnie. Czytelnicy (z przyzwyczajenia?) z łatwością doszukują się spójności w pracach, które ta cecha niekoniecznie charakteryzuje. Zjawisko to ciekawie opisuje Jerzy Szyłak, porównując m.in. konsekwentne budowanie spójności przestrzeni u „starych klasyków komiksu” z jej mglistym i niekonsekwentnym sygnalizowaniem spotykanym obecnie (zob. J. Szyłak, Poetyka komiksu..., s. 64-91).

298 R. Nowakowski, Traktat..., s. 70. 
każdy element jest tu znaczący może musi i powinien być znaczący zatem każdy trzeba o znaczenie podejrzewać w każdy zakamarek należy zaglądać nie tracąc z pola widzenia całości wszystkich relacji prostych i skomplikowanych bezpośrednich i tak pośrednich że sprawiających wrażenie nieistniejących ${ }^{299}$.

Trudno zatem przypisać przywołanemu opracowaniu charakter normatywny. Można powiedzieć, że jeżeli jest to rodzaj poetyki, to takiej o charakterze postulatywnym - określającej możliwe terytoria liberackiej eksploracji materii słowa i tekstu, postulującej, by od konwencji odchodzić. Podobny charakter mają również teoretyczne rozważania Bazarnik, która - podając wyznaczniki liberatury - odwołuje się do kognitywistycznych ujęć genologicznych, niedających się tak łatwo wiązać z typowymi normatywnymi ujęciami $^{300}$.

Mówiąc innymi słowy - liberaci wciąż poszukują nowych przestrzeni do kreowania znaczeń, każde kolejne dzieło ma być inne, a artysta próbuje znaleźć sposób mówienia najbardziej adekwatny do tego, o czym pisze. Tym samym - raczej za każdym razem powinien on być nieco inny, twórca często zmuszony jest wykorzystywać zupełnie nowe środki wyrazu, sięgając po wypracowane już sposoby wyłącznie w sytuacjach, gdy to one właśnie będą najlepsze. Zupełnie inaczej jest w przypadku komiksu. Jak podsumowywał ponad dwadzieścia lat temu Przybylski:

Jego możliwości narracyjne nie są bynajmniej ograniczone. Nie wykorzystuje ich jednak w pełni. Nie ma ambicji zmieniać zasad, które skodyfikowane zostały już wcześniej. Nie chce mówić o świecie, ale o jego idealnym obrazie; nie chce odkrywać nowych form „wyrażania”, woli eksploatować te, których skuteczność została już sprawdzona ${ }^{301}$.

Liberat zaś - często szukając sposobów mówienia najpełniej i najprawdziwiej, zawsze zaś możliwie najadekwatniej - nieustannie owych nowych form pożąda, odrzucając te już wypróbowane. Stąd, choć rzeczywiście u postaw tworzenia znaczeń w komiksie i w literaturze totalnej stoja często podobne mechanizmy, sugerowana przez Żuchowskiego bliskość tych zjawisk jest wyłącznie pozorna. Różni je tak na prawdę wszystko.

\subsection{Komiks liberacki? Liberatura komiksowa? A jednak...}

Niemniej, co z pewnością warto zaznaczyć, i w obrębie komiksu znajdziemy przykłady działań, które dają się traktować jako (w mniejszym bądź większym stopniu) liberackie. Z jednej strony Will Eisner w książce Comics and

299 Ibidem.

300 Zob. pierwsza część tej książki.

301 Ryszard K. Przybylski, Stowo i obraz w komiksie, [w:] Pogranicza i korespondencje sztuk, red. Teresa Cieślikowska, Janusz Sławiński, Wrocław 1980, s. 243. 
Sequential Art trafnie pisał o konwencji przenikającej wszelkie poziomy tej sztuki, co zgrabnie podsumował Szyłak w słowach:

\begin{abstract}
Pierwszym z nich [konwencjonalnych środków wykorzystywanych w komiksie - AP] sa dymki, których zastosowanie pozwala na przytoczenie wypowiedzi i myśli postaci. Drugi to kształt ramek: prostokątne, narysowane linią falista, w kształcie chmurki, zygzakowate oraz utworzone z elementów należących do przedstawienia (obramowane drzwi, okno, wejście do jaskini, oko, które patrzy na zdarzenie, lornetka, etc.). Trzecim sa onomatopeje i najrozmaitsze odmiany liternictwa, którymi zapisane zostały teksty słowne: $\mathrm{O}$ ile przy tym jeden rodzaj liter w komiksie może być potraktowany jako nieobciążony dodatkowymi znaczeniami - „przezroczysty”, o tyle, stosując kilka różnych krojów pisma i wielkości napisów, artysta nadaje im walor nośników dodatkowych znaczeń, czyni z nich wizerunki mowy funkcjonujące w obrębie komiksowych kadrów na zasadzie znaków ikonicznych. Kolejny środek to tzw. speed lines - linie, z pomocą których rysownicy komiksów oznaczają ruch, sygnalizuja szybkość, z jaką poruszają się przedmioty i postacie, lub pokazują kierunek przemieszczania się elementów przedstawienia ${ }^{302}$.
\end{abstract}

Z drugiej strony - trzeba w tym kontekście zapytać, czy w pełni pasuje do tego opisu komiks, w którym słowa bohaterki („Archie, mam ci coś do powiedzenia") - skierowane przez kobietę do partnera - ujęte są w dymek w kształcie bociana niosacego w dziobie pakunek ${ }^{303}$ ? Analogicznie - czy tomy komiksów o Asteriksie, w których wypowiedzi Gallów zapisane są czcionką łacińska, Germanów - gotycka, a Egipcjanina ideogramami przypominajacymi hieroglify (Asteriks i legionista, Asteriks $i$ Goci), to właśnie przykłady opisywanego tu wykorzystania różnych krojów pisma, czy może jednak coś więcej ${ }^{304}$ ? Albo: czy unaocznienie ucieczki bohaterki opisywanego przez Wojciecha Birka komiksu Kabuki ${ }^{305}$ w postaci wpisanego w labirynt tekstu ukształtowanego tak, by odtwarzał trasę ucieczki to zwykła „konwencja zapisu komiksowego” (używam tu terminu Toeplitza) ${ }^{306}$ ? Czy może zabieg ten podobny jest w charakterze tym, po które sięga Nowakowski - liberat, który w Ulicy Sienkiewicza $w$ Kielcach cały monolog głównego bohatera ukształtował w graficzny zapis trasy jego wędrówki?

Niezależnie od silnego uwikłania komiksu w konwencję, jak wiele lat temu podkreślał Toeplitz (i uwaga ta wydaje się wciąż aktualna):

W sztuce tej raz po raz pojawiają się zdarzenia, wymykające się ścisłym kategoryzacjom, efekty nieoczekiwane, na których zasadza się młodość i żywotność gatunku ${ }^{307}$.

W efekcie, rodzi się coś w rodzaju „furtki dla liberackości”. Najczęściej sytuacja ta wiąże się z przestrzenią komiksowej typografii (szczególnie zaś

302 J. Szyłak, Poetyka komiksu..., s. 49-50. Zob. też: Will Eisner, Comics and Sequential Art, Florida 1985 (lub dowolne inne wydanie).

303 J. Szyłak, Poetyka komiksu..., s. 116.

304 Por. też K. T. Toeplitz, Sztuka komiksu..., s. 101.

305 W. Birek, Główne problemy teorii komiksu, s. 301.

306 K. T. Toeplitz, Sztuka komiksu..., s. 90.

${ }^{307}$ Ibidem, s. 53. 
z zapisem onomatopei ${ }^{308}$ ), która w samych swoich założeniach (wykorzystywaniu sposobu wizualnego kształtowania znaczeń) bliska jest liberackiej ${ }^{309}$. Jak podsumowywał Szyłak: „W wielu wypadkach kształt i wielkość liter miały znaczenie nie mniejsze niż treść wypowiadanych słów"310. Często, wizualizując tekst, twórcy komiksu sięgają po stały repertuar środków - rozpoznawalny już na pierwszy rzut oka. Powtarzalność tych zabiegów (owocująca konwencjonalnościa) nie pozwala nam raczej mówić o liberackości, mimo iż często wydaja się przypominać te używane przez twórców literatury totalnej.

Nie tylko kształt i charakter, ale i wielkość czy kolor liter pełnią rolę środka wyrazu - pisał Bartosz Kurc. - Ich różnicowanie oddaje różne stany psychiczne postaci. I tak pismo niewielkie, drobne oznaczać może słowa wypowiadane cicho i nieśmiało. Z kolei wielkie litery, często o charakterze ekspresyjnym, sugerują emocje czy podniesiony ton głosu ${ }^{311}$.

Zdarza się jednak, iż w kontekście tych typowych rozwiązań pojawia się jakiśs zabieg niby oparty na analogicznych zasadach, a jednak nieco odbiegajaccy swym charakterem od innych fragmentów utworu. W takich wypadkach pojawia się właśnie pytanie, czy nie wkraczamy przypadkiem na obrzeża liberatury.

Przykład, który pozwoli lepiej zrozumieć tę kwestię znajdziemy w charakteryzowanym przez Toeplitza komiksie Kto się boi Baby Jagi Guido Crepaxa. Zgodnie z komiksowa konwencją przy zapisie onomatopei w przywołanej publikacji stosowane są pewne zasady (np. wielkość, kształt, położenie liter związane są charakterem konkretnych odgłosów), każdorazowo dyktowane zresztą potrzebami poszczególnych fragmentów utworu (np. „torem ruchu” dźwięku - jeśli można tak powiedzieć). Niekiedy jednak drobiazgowość, dbałość o szczegóły, nietypowa raczej dla trzymania się wyznaczonych schematów, przesuwa charakter

308 Ciekawie o typografii komiksu, szczególnie zaś właśnie o onomatopejach pisze Bartosz Kurc. Badacz wyróżnia wśród nich dwa rodzaje: jedynie ilustrujące dźwięk (ich „kształt nie pełni tu konkretnej roli i sprowadzony jest do schematycznej formy” (s. 54)) oraz takie, które sa „ikonicznym uzupełnieniem” (s. 53), dookreślającym opowieść. Kształt typograficzny tych ostatnich jest istotny. Może nie tylko sugerować ruch (dźwięk hamowania wpisany po tegoż torze) czy charakter zdarzenia (,rozedrgane” litery zdarzeń atmosferycznych takich jak grzmoty itp.), lecz i przekazywać ważne informacje, bez których nie mamy szansy zrozumieć świata przedstawionego. Jak podsumowuje badacz - w takich wypadkach mamy do czynienia z przejęciem przez słowo funkcji obrazu. Zob. B. Kurc, Stowo jako obraz, [w:] idem, Komiks..., s. 48-55.

${ }^{309}$ B. Kurc analizuje również typograficzne nadużycia (przepisania zniekształcające sposób zapisu w takim stopniu, że zmienia się również znaczenie tekstu) towarzyszące tłumaczeniu komiksów. Takie analizy bliskie są z pewnością Bazarnik, która - czyniąc punktem wyjścia liberacka refleksję nad książka - również zwraca uwagę na zabiegi edytorów i tłumaczy owocujące - jak to ujmuje - „popsutą przestrzenią” tomu, a w konsekwencji wypaczeniem znaczeń utworu (por. Katarzyna Bazarnik, Popsuta przestrzeń. O odpowiedzialności wydawcy, „Autoportret” 2006, nr 4).

310 J. Szyłak, Poetyka komiksu..., s. 115. Rację ma jednak Szyłak, zauważając, że o ile w przypadku onomatopei często mamy do czynienia ze znaczącym ukształtowaniem zapisu, większość twórców komiksu w innych sytuacjach (np. zapisując wypowiedzi postaci) stara się unikać ikonizacji pisma i podkreślania, że jest ono obrazem mowy.

311 B. Kurc, Komiks..., s. 53. Ten sam badacz zwraca uwagę na to, że równie znaczący może być kształt dymków. 
stosowanych zabiegów od konwencjonalnych ku liberackim. Przykładem zapis dźwięku przesuwanego po prętach balustrady palca Walentyny - bohaterki komiksu. Zgodnie z konwencja - miejsce wpisania liter w kadr (po torze ruch palca), ich wielkość (w odniesieniu do innych onomatopeicznych zapisów - np. głośniejszego i tym samym większego jako napis dźwięku koparki) oddają istotne dla rekonstrukcji akcji informacje. Jednak, jak słusznie zauważa Toeplitz, autor idzie o krok dalej: kiedy palec Walentyny napotyka grubszy pręt - co naturalnie winno zaowocować nieco głośniejszym dźwiękiem - litery znajdujące się obok niego są trochę większe. Trudno jednak zgodzić się, by ta różnica była łatwo słyszalna - tym samym w typowym dla komiksu zapisie nie powinna być raczej uwzględniana (zbytnie nagromadzenie szczegółów może zaciemnić schematycznie prezentowany układ dźwięków głośnych i cichych). Z tych przecież powodów do stylistyki komiksu nie należy raczej np. powiększanie sylab akcentowanych w słowach itp. Ze względu na to, że inne zastosowane zabiegi pozwalają w pełni zrekonstruować informacje o świecie przedstawionym, przypisałabym takiemu zróżnicowaniu wielkości czcionek charakter nieco liberacki. Choć, przyznaję, granica między konwencjonalnością a liberackością jest tu dość płynna.

Nieco inaczej jest w przypadku komiksów La Cathédrale Invisible Alexandro Jodorowsky'ego (scenariusz) i Françoisa Boucqa (rysunki) ${ }^{312}$ czy Elektra. Assassin (scenariusz Frank Miller, rysunki Bill Sienkiewicz) ${ }^{313}$. W pierwszym wypadku liberacko ukształtowana została okładka tomu (w jednym z wydań - z 1992 r.). Na pierwszy rzut oka przedstawia ona ruiny katedry. Jednak czytelnik, który uważniej się przyjrzy, dostrzeże również zarys tejże budowli w stanie nienaruszonym, tytułowa „niewidzialną katedrę” - namalowana na okładce lakierem. Podobnie jak w Oka-leczeniu Fajfera i Bazarnik - to, co niewidzialne pozostaje tu ukryte dla oka nieposzukujacego czytelnika ${ }^{314}$.

Drugi przywołany komiks wydaje się w jeszcze większym stopniu liberacki. Dla oznaczenia jednej z postaci - kandydata na prezydenta (Kena Winda) - we wszystkich miejscach utworu używany jest ten sam element: fotografia bohatera z jednego z początkowych kadrów, w którym Wind pokazywany jest w telewizji. Kolażowe „doklejanie” pochodzacej z tego ujęcia głowy bohatera do każdego innego kadru w komiksie nie jest zgodne ani z konwencja komiksu, ani też z (realistyczna) poetyką tej konkretnej realizacji. Zyskuje dodatkowe znaczenia, wykreowane na potrzeby tego jednego tekstu. Jak zauważa Szyłak:

312 Wykorzystuję informacje podane przez Wojciecha Birka (W. Birek, Główne problemy teorii komiksu, s. 292).

${ }^{313}$ Opieram się tu na analizie przedstawionej przez Jerzego Szyłaka, zob. J. Szyłak, Poetyka komiksu..., s. 52-53.

${ }^{314}$ Nie jedyny to przykład liberackiego kształtowania tomu, w jaki ujęta jest komiksowa publikacja. W recenzji Berlina - miasta gniewu (scenariusz i rysunki Jason Lutes) Przemysław Gulda stwierdzał: „Czytając ten komis, nie sposób nie odnieść wrażenia, jakby przenosiło się w czasie i lądowało w tytułowym Berlinie dziewięć dekad temu. Potęguje to jeszcze sposób wydania tego komiksu: nie dość, że papier sprawia mocno niedzisiejsze wrażenie, to na dodatek rogi albumu sa zaokraglone w sposób charakterystyczny właśnie dla publikacji z epoki” („Co jest grane”, weekendowy dodatek do „Gazety Wyborczej” (Łódź), 26 sierpnia - 1 września 2011, s. 18). Nie udało mi się - niestety - ustalić, czy podobnie wydano oryginalną wersję amerykańskiej powieści graficznej. 
Wizerunek twarzy Winda pozostaje w bezpośrednim związku z osobą, którą w komiksie oznacza, jednocześnie zaś nie przedstawia jej ani w sposób realistyczny, ani groteskowy. On jedynie ją oznacza, w sposób arbitralny stawiając znak równości pomiędzy osobą i jej portretem spreparowanym na użytek publiczny. Jako oznaczenie osoby ów portret spełnia funkcje znaku ikonicznego. Sienkiewicz używa go jednak z tej właśnie przyczyny, że już w świecie przedstawionym został on spreparowany jako znak ikoniczny - image kandydata. Używając, jednocześnie demaskuje jego obłudę - Wind jest intrygantem, oszustem i mordercą. Zdarzenia, w jakich Wind bierze udział, bezustannie podkreślają nieszczerość uśmiechu na twarzy, którą widać na obrazkach. W istocie podkreślają nieuczciwość tej twarzy i związanego z nią znaczenia. Słowem, kontekst, w jakim pojawia się ów znak, bezustannie demaskuje nieprawdziwość jego znaczenia. W ten sposób znak ikoniczny, wyrwany z właściwego kontekstu, zaczyna służyć do ukazania fałszu znaczenia, które komunikuje, i w tym sensie staje się znakiem symbolicznym ${ }^{315}$.

W tym zatem wypadku wykorzystanie wizualności utworu było iście liberackie. Zdecydowanie więc możemy ten komiks umieścić w grupie takich, które - mimo opisywanych wcześniej różnic między omawianymi obszarami sztuki słowa - mają cechy literatury totalnej. Jednocześnie - warto też pamiętać o użyciach komiksu w samej liberaturze - dość przypomnieć przywoływana już Ulicę Sienkiewicza w Kielcach Nowakowskiego, w której widzimy komiksowe dymki symbolizujące rozmawiający tłum (puste, co pozostaje nie bez znaczenia, gdyż słowa wypowiadane przez stojących ludzi nie są istotne dla bohatera, a być może ich też niedosłyszy).

\subsection{Różnice niewidoczne gołym okiem}

A zatem trzeba przyznać, że nawet jeśli w pierwszym momencie mamy ochotę przytaknąć Żuchowskiemu i wskazywać na podobieństwa teorii czy poetyk twórców komiksu i liberatów, nie jest to - jak się zdaje - dobry trop. Rozwijając inspirowana Twainem i Szyłakiem myśl z początku tego rozdziału, trzeba bowiem zauważyć, że literacka i komiksowa układanka rządzą się swoimi prawami - opierają się na konwencji użycia określonych elementów. Zaś ten, kto siada do „puzzli” liberackich wolny jest od nakazów, wskazówek i krótszej czy dłuższej tradycji podobnych modeli. W tym wypadku poszczególne elementy mogą wykorzystywać najrozmaitsze media, a sposób ich łączenia nie wydaje się określony żadnymi konkretnymi zasadami. Kieruje nim wyłącznie semantyczna funkcjonalność.

Wydaje się też, że przedstawione rozważania dotyczące relacji komiks-liberatura potwierdzają wyrażane tu już po wielokroć przekonanie, że wprowadzony w 1999 r. termin jest użyteczny. Po raz kolejny bowiem okazuje się, że nawet kiedy wydaje się, że istnieją już pojęcia służące do opisywania tekstów przynależnych do obrzeży sztuki słowa, do obszarów, w których słowo wchodzi $\mathrm{w}$ relacje $\mathrm{z}$ innymi mediami - nie do końca sa one $\mathrm{z}$ terminem literatura totalna tożsame. Czasem - jak ma to miejsce w przypadku komiksu właśnie

315 J. Szyłak, Poetyka komiksu..., s. 53. 
- mimo pozornych licznych podobieństw opisywanych zjawisk, znacząco się one różnią. A w konsekwencji zaproponowany przez Fajfera termin zyskuje rację bytu.

Co więcej - wydaje się, że przeprowadzona tu argumentacja popiera też moją tezę, iż użyteczniejsze (choć może stylistycznie mniej atrakcyjne) jest poszukiwanie nie tyle liberatury w obrębie literatury (czy i poza jej granicami), co liberackości poszczególnych dzieł. Dzięki takiemu ujęciu zyskujemy terminologię do opisu tak - wydawało by się - paradoksalnych zjawisk jak komiks liberacki.

Pozostając w kontekście komiksowych rozważań i pisząc o szukaniu liberackości w świecie literatury „zmąconej” innymi kodami, można też przywołać Dream of the Rarebit Fiend Winsora McCaya ${ }^{316}$. Tytułowy bohater rusza na polowanie, stwierdzając „gdzieś tutaj muszą być jelenie! Ukryję się i poczekam”. Ku jego zdziwieniu jednak zamiast nich pojawiają się dziwaczne okazy będące hybrydami różnych gatunków ${ }^{317}$. Gdyby w każdym z nich była cząstka jelenia (w komiksie McCaya takie krzyżówki się nie pojawiaja) sytuacja przypominałaby „polowanie na liberaturę”. W tym wypadku bowiem tam, gdzie dostrzegamy podobieństwa, natychmiast pojawia się element obcy, niepasujący do naszej układanki. Dlatego też - powtórzę raz jeszcze - mimo, że w słowniku znajdziemy różne terminy stworzone do opisu dzieł łączacych w sobie literaturę i „coś jeszcze”, wprowadzenie pojęcia liberatura (a lepiej: liberackość) nie jest nadużyciem, wydaje się nie tyle zbędne, co - dla zachowania porządku konieczne.

${ }^{316}$ Reprodukcję tego komiksu z polskim tłumaczeniem tekstu znaleźć można u Szyłaka (J. Szyłak, Poetyka komiksu..., s. 59).

${ }^{317}$ Bohater - jak to zwykle bywa w pracach autora kanonicznej serii Little Nemo in Slumberland - okazuje sie śnić. Ostatni kadr pokazuje służącego budzącego protagonistę, gdy zbliżają się do miejsca, w którym ma odbyć się prawdziwe polowanie. 


\section{Coda. „Garderoba” współczesnych opowieści (wizualnych)}

Jak wielokrotnie już podkreślałam - choć analizowane tu (różne) odmiany wizualizacji tekstu literackiego najczęściej, ale jak się też okazuje nie zawsze słusznie, budza skojarzenia z literatura totalna, połaczenie słowa i obrazu to tylko jeden z zabiegów, po jakie mogą sięgać liberaci. Trzeba też dodać, że współcześni autorzy często nie wystrzegają się takich niewerbalnych wtrętów, co widać zwłaszcza w przypadku powieści ${ }^{318}$. Niemniej, co dla mnie kluczowe, owe dzisiejsze obrazowo-słowne konstrukcje literackie często wykraczają poza ramy klasycznie definiowanej literatury wizualnej, prowokując ku temu, by znaleźć jednak inne: użyteczniejsze, trafniejsze terminy, które pozwolą ujaćc to zjawisko. Choć więc dopełnieniem moich rozważań mogłoby być przyjrzenie się liberaturze na tle innych niż komiks odmian wizualnej prozy, sięgając po jeden zaledwie przykład, chciałabym pokazać, że - mimo iż utwory takie stanowią idealne tło dla rozważań o niej - nie ta część mojego wywodu jest ku temu stosownym miejscem, gdyż pod pozorem wizualności w książkach tych kryje się znacznie więcej.

Kiedy Dawidek Gryglicka pisała o literaturze totalnej, a konkretnie: o liberackich znakach ${ }^{319}$, zauważała, że „liberackie słowo-znak posiada zewnętrzna, zbieżną z wewnętrznym znaczeniem "garderobę», czyli kształt graficzny, którego istota może ujawnić się przez konteksty słów w zdaniu i zdań w tekście" ${ }^{320}$. Pożyczając od niej zgrabną metaforę, powiedziałabym, że w przypadku tekstów, o jakich tu wspominam owa „garderoba” służy przebraniu się książki za coś innego niż to, czym mogłaby się ona wydawać. Dzieła Briana Selznicka ${ }^{321}$ (Wynalazek Hugona Cabreta oraz Wonderstruck) pozornie byłyby idealnym kontekstem dla

${ }^{318}$ Najpierw coraz częściej wizualne „dodatki” stawały się integralnymi elementami opowieści postmodernistów (tu choćby: Thomas Pynchon, Umberto Eco, Italo Calvino czy - w Polsce - Manuela Gretkowska) czy innych „eksperymentatorów” (bo wspominanego już w tej pracy B. S. Johnsona trudno byłoby chyba za postmodernistę uznać), by dziśs - u pisarzy, takich jak m.in. Mark Haddon, Steven Hall, Brian Selznick - już bez większych (również technologicznych) przeszkód stać się naturalnymi wręcz składnikami opowieści (do czego będę jeszcze wracać w kolejnych rozdziałach i - zwłaszcza - zakończeniu tej książki).

319 Ja do tej kategorii będę nawiązywać w kolejnym rozdziale.

${ }^{320}$ Małgorzata Dawidek Gryglicka, Historia tekstu wizualnego. Polska po 1967 roku, Kraków 2012, s. 650.

${ }^{321}$ Więcej pisałam o nich w szkicu Czytajace dzieci Stefana Themersona. Ku nowym (słowo-dźwięko-)obrazom literackim, [w:] Trajektorie obrazów. Strategie wizualne w sztuce wspótczesnej, red. Ryszard W. Kluszczyński, Dagmara Rode [Łódź 2015]. Za zwrócenie mi uwagi na twórczość Selznicka w kontekście liberackości bardzo dziękuję profesorowi Jerzemu Jarniewiczowi. 
moich rozważań o komiksie. Jako historie ujęte w słowa i obrazy (każda składa się z klasycznych zadrukowanych białych kart oraz wielu zawsze dwustronicowych, czarno-białych ilustracji) wydają się powieściami graficznymi, których analizy mogłyby stać się dopełnieniem części poświęconej komiksowi. A jednak publikacje te wyłamują się prostej formule powieści graficznej i literatury wizualnej. Autorskie dookreślenie powieść $w$ słowach $i$ obrazach (taki podtytuł nosza obie z przywołanych książek) kryje w sobie coś więcej niż deklarację, że będziemy mieć do czynienia $\mathrm{z}$ dwumedialną opowieścia. Zakłada bowiem wskazanie mechanizmu „podawania” historii, pewnej technologii literackiej.

Choć wydaje się, że obie przywołane publikacje wykorzystują tę sama strategię, w każdej z książek jest ona tą długo poszukiwana, jedyną i najlepsza (dodatkowo: niedyktowaną żadna konwencja), zdolną ująć (i przekazać) konkretną historię ${ }^{322}$. Trzeba tu zaznaczyć subtelną różnice polegającą na tym, iż w przypadku Wynalazku... między dwa kody rozpisana jest jedna opowieść, podczas gdy w Wonderstruck słowa i obrazy opowiadaja dwie (oddzielone czasowo) narracje, które dopiero w finale okazują się mieć miejsce wspólne. W wypadku tej książki splecenie się opowieści (i ich mediów) oraz związane z nim zachwianie wcześniej wypracowanym podziałem funkcji narracyjnych między dwa kody (do którego czytelnik zdążył się już przyzwyczaić) zespolone są z przyczyną sięgnięcia po taki sposób opowiadania. Przedstawiona historia dotyczy osób głuchych i by przekazać bezgłośny świat, w którym one egzystuja, silniej unaocznić (!) czytelnikom problemy (również komunikacyjne), z jakimi się mierzą ${ }^{323}$ - Selznick wykorzystuje formę, która uderza w zmysł wzroku silniej niż w jakikolwiek inny, niejednokrotnie na różne sposoby z samego języka (i druku bądź pisma) czyniąc też obiekt wizualny ${ }^{324}$. Autor próbuje z książki uczynić medium dla komunikacji wizualnej, czego kwintesencją jest jedna z ostatnich wypowiedzi bohatera: ciag ilustracji przedstawiajacych zdanie wypowiedziane w języku migowym. W przypadku tego utworu nie chodzi o „zwykłą" literaturę wizualna, m.in. dlatego właśnie, iż za zespoleniem w obrębie opowieści słów i obrazów stoi coś więcej niż chęć mówienia jednymi i drugimi: z jednej strony pragnienie eksplorowania medium tej opowieści (jakim sa nie poszczególne jej kody, ale spajająca je w swojej strukturze książka), z drugiej - poszukiwanie formy, która sama sobą przekaże część sensów dzieła ${ }^{325}$.

Podobnie dzieje się w przypadku Wynalazku... . Historia chłopca, odkrywającego tajemnice związane z narodzinami kina i Georgesem Mélièsem, ujęta jest nie tyle w ramy słów i obrazów, lecz w ramy książki - maszyny

${ }^{322}$ Selznick sporo mówi o owych poszukiwaniach w wywiadach. Zob. A. Przybyszewska, $C z y-$ tajace dzieci... .

${ }^{323}$ Jak wyjaśniał sam autor: „Wydawało się całkiem ekscytujące spróbować opowiedzieć historię osoby głuchej w sposób, który w jakimś stopniu mógłby odzwierciedlić jej doświadczenie, czy sposób poruszania się w świecie" (Julie Danielson, My Conversation With Brian Sleznick: On "Wonderstruck”, "Hugo", and the Terror and Joy of Creating Books, http://blaine.org/sevenimpossiblethings/?p=2228 [dostęp 4.08.2013]).

324 Więcej zob. A. Przybyszewska, Czytajace dzieci... .

325 Co akurat bliskie jest strukturom poezji konkretnej. 
do filmowych projekcji. Ilustracje (w których kryją się m.in. kluczowe zwroty akcji) zaprojektowane sa tak, by przekartkowywane dawały nam iluzję seansu kinowego z czasów, w jakich dzieje się akcja opowieści (nie bez znaczenia pozostaje tu fakt, iż przejścia między nimi wykorzystuja typowe filmowe tricki, jak zmiana planu czy perspektywy, zbliżenie, cięcie). I tu zatem, chodzi nie tyle o to, by zwizualizować literaturę, lecz by do opowiadania zatrudnić jej materialną technologię - książkę: uczynić z niej maszynę, która w rękach czytelnika zadziała (rewolucjonizując sam akt lektury).

O tym, że Wynalazek... rozumieć należy wręcz jako urządzenie do projekcji fabuły przeczytać możemy i w samej powieści - już na jej wstępie, w Krótkim wprowadzeniu Profesor H. Alcofrisbas (jak dowiemy się po lekturze całości powieści - dorosłe wcielenie Hugo) wprost zapowiada, że czytanie tej książki powinno przypominać seans kinowy:

Zanim jednak przewrócisz stronę, chcę, abyś sobie wyobraził, że siedzisz w ciemnościach, tak jak w kinie przed rozpoczęciem seansu. Na ekranie wkrótce wzejdzie słońce i kamera zrobi najazd na dworzec kolejowy w centrum miasta. Po chwili zauważysz w tłumie chłopca, a on ruszy przed siebie. Idź za nim, to bowiem jest właśnie Hugo Cabret. Z głową pełną sekretów czeka, aż rozpocznie się jego historia ${ }^{326}$.

Zaś kończąc swą opowieść Hugo - już jako Profesor Alcofrisbas, a zarazem auktorialny narrator - mówi o automacie, który właśnie zbudował, o książce, którą kończymy czytać:

Gdy się go nakręci, umie zrobić coś - czego - jestem pewien - nie potrafi żaden inny automat na świecie. Może Wam opowiedzieć niewiarygodną historię Georges'a Méliès, jego żony, ich chrzestnej córki oraz zegarmistrza, którego syn wyrósł na iluzjonistę.

Skomplikowana maszyneria wewnątrz mojego automatu potrafi stworzyć sto pięćdziesiąt osiem różnych rysunków oraz napisać, litera za litera, całą książkę; dwadzieścia tysięcy trzysta sześćdziesiąt pięć słów.

Tych słów ${ }^{327}$.

I tak - Selznickowi rzeczywiście udało się stworzyć książkę, która stała się wyjątkowa, jedyną w swoim rodzaju maszyną do opowiadania ${ }^{328}$, do wysłowienia i wyobrazowania jednej, konkretnej historii (z nią bowiem jest zrośnięta i dla niej została zaprojektowana). Jednocześnie - wracając do kwestii poruszonych na początku tego rozdziału - autor oddał w ręce czytelników opowieść „przebraną” jedynie za literaturę wizualna, pod ową czarno-białą (acz przykuwająca uwagę) szatą skrywająca literacko-kinowe „atrakcje” idące daleko dalej niż wizualność. Dlatego właśnie nie chcę w tym rozdziale poruszać kwestii współczesnych wizualnych narracji, gdyż w większości wypadków formuła, jaka je teraz określiłam nijak do nich nie przystaje, bo ujmuje za mało.

${ }^{326}$ Brian Selznick, Wynalazek Hugona Cabreta, Warszawa 2008, s. 9.

327 Ibidem, s. 520-521.

${ }^{328}$ A że jest to maszyna iście filmowa - tym ciekawiej wypada drukowana publikacja w konfrontacji z nagrodzonym pięcioma Oskarami Hugonem i jego wynalazkiem Martina Scorsese (2011). Więcej zob. A. Przybyszewska, Czytajace dzieci... . 
Selznick o Wynalazku... powie, że opowieść ta „została zaprojektowana, aby być książka" ${ }^{329}$ i frazę tę można by odnieść do sporej grupy innych tekstów. Czy Przełożona $w$ normie B. S. Johnsona - tom, w którym wprowadzono np. podwójne numerowanie stron ze względu na to, że to samo „miejsce” materialnej opowieści w przypadku każdego z kolejnych bohaterów mówi o tym samym, choć przedstawiając to z nieco innego punktu widzenia ${ }^{330}$ - to tekst wizualny czy raczej właśnie uksiążkowiony? Czy kryjące niewidzialną (ale w pełni zintegrowana z tą od razu dostępna) opowieść nieporozrywane strony Jezus nigdy nie byt aż tak blady Dariusza Orszulewskiego pozwalają objaćc ten utwór formułą literatury wizualnej? Tego typu teksty, eksplorujące medium, w jakim sa podawane odbiorcom (książkę właśnie), stają się z jednej strony przykładami do analiz raczej nie w tym, a w kolejnych rozdziałach (poświęconych liberaturze i kategorii książki czy liberaturze w kontekście najbardziej współczesnych odmian sztuki słowa), z drugiej zaś - idealnymi egzemplifikacjami tez o literaturze w formie książki i - tym samym - użyteczności postulowanego przeze mnie terminu liberackość. Pojęcia nazywajacego to, co tylko w przebraniu tożsame będzie z wizualnością literatury, choć może mieć z nią wiele wspólnego ${ }^{331}$.

Dostrzeżenie tych aspektów pozwala spojrzeć też na sformułowaną przez Fajfera teorię jako na jedna z odpowiedzi na coraz silniej wybrzmiewajacy „zwrot interfejsologiczny w badaniach literackich”. Współcześnie bowiem w wielu ujęciach wyraźnie akcentuje się rolę technologii podawania literackich tekstów (o czym będę pisać w dalszych rozdziałach), a ta polegająca na zespoleniu werbalnego z wizualnym wydaje się jedną z najprostszych $\mathrm{i}-\mathrm{w}$ gruncie rzeczy - wcale nie tak rewolucyjnych. Z pewnością jest też tylko kroplą w morzu kontekstów badania liberackości.

${ }^{329}$ J. Danielson, My Conversation With Brian Selznick... .

${ }^{330}$ Bardzo dobrze widać to na przykładzie strony piątej, na której bohaterowie śpiewają piosenkę.

331 Warto tu może zaznaczyć, iż Dawidek Gryglicka traktuje liberaturę jako jedną z odmian współczesnych tekstów wizualnych (choć w analizach pokazuje, że owa wizualność sięga i architektoniki, materialności książek). Zob. M. Dawidek Gryglicka, Historia tekstu wizualnego... . 


\title{
II. LIBERATURA A EKSPERYMENTY TYPOGRAFICZNE
}

\author{
1. Liberackie znaki, chwyty i struktury
}

\subsection{Platon, Derrida (?) i Nowakowski - zamiast wstępu}

\author{
Litera wcale nie jest, jak tuszy niektóry, \\ czymś dowolnym, co nie ma swej architektury. \\ Cyprian Kamil Norwid, \\ Rzecz o wolności słowa ${ }^{332}$
}

Jakoś tak się utarło, że kiedy mowa o piśmie, trzeba przywołać Platona i historię o tym, jak bóg Teut przybył na dwór króla Tamuza, wychwalając pismo $^{333}$. A kto przejrzał choć podstawową bibliografię tekstów dotyczacych liberatury, wie, że odwołanie do starożytnego filozofa i jego strachu przed pismem nie jest tu bynajmniej rzadkie. Trop ten wyznaczył zresztą sam Fajfer, stwierdzając:

Platon, jak wiadomo, pisma nie lubił [...]. Brak szacunku dla pisma stał się filozoficzną cnota, co znalazło, niestety, odbicie w podejściu teoretyków. Tekst literacki wciąż postrzegany jest jako rodzaj idealnego bytu, którego fizyczny aspekt jest sprawą właściwie bez znaczenia. Najlepszym tego przykładem jest Stownik terminów literackich, zredagowany przez takie autorytety jak Głowiński, Kostkiewiczowa i Sławińscy. To właśnie analiza jego podstawowych haseł [...] doprowadziła mnie do sformułowania idei liberatury jako odpowiedzi na „platoniczny” stosunek do pisma i książki ${ }^{334}$.

Ja chciałabym dokonać jednak liberackiej rewolty i oddać głos wcale nie Platonowi, lecz Nowakowskiemu. Dotychczas traktowałam jego wywody jako inspirujace, wychodząc z założenia, że choć formułuje on swoje tezy często w sposób banalny, wskazuje tropy interpretacyjne czy tory refleksji, które prowadzić moga ku ciekawym konstatacjom. Wydaje się, że jest tak również w odniesieniu do problematyki pisma, alfabetu, liter. Porzucę więc Platona

${ }^{332}$ Cyprian K. Norwid, Rzecz o wolności słowa, [w:] idem, Pisma wszystkie, t. III (Poematy), oprac. Juliusz W. Gomulicki, Warszawa 1971, s. 572.

${ }^{333}$ Platon, Fajdros, tłum. Władysław Witwicki, Warszawa 1958.

${ }^{334}$ Zenon Fajfer, Nie(o)pisanie liberatury, [w:] LCLT, s. 60. Na platoniczną perspektywę literaturoznawstwa zwracał też uwagę m.in. Adam Poprawa (Ankieta „Liberatura - awangarda XXI wieku czy nowe spojrzenie na stare dzieła literackie?, „Ha!art” 2010, nr 30, s.17). 
(nie odwołam się też do Derridy stanowiącego niejako drugie dno tych „klasycznych" odniesień ${ }^{335}$ ) i oddam głos twórcy i teoretykowi, który w Traktacie kartkograficznym..., swoistym almanachu aktywności liberackiej, analizuje poszczególne, dające się w literaturze totalnej eksplorować, poziomy dzieła. Właśnie na stronach tej niewielkiej czerwonej książki litera (znak graficzny czy ogólnie pismo) staje się głównym bohaterem całego rozdziału.

\begin{abstract}
Litera milczy. Litera jest niema - twierdzi Nowakowski - Odebraliśmy jej głos. Zachwyt nad pięknem litery jest tylko zachwytem nad pięknem abstrakcyjnym niczego nie mającym przekazywać. Żadnej dodatkowej informacji. Ani pobocznej ani głównej. Litera ma być pusta. Litera ma nie zawierać żadnej informacji. Tak postanowiliśmy. Tak to sobie wyobrażamy. Tak chcemy żeby było. Chcemy, żeby taka właśnie była litera. Bo litery (więc także i pismo na które się składaja) nie sa po to, by świat opisywać. One są tylko po to, by nasze mówienie utrwalić na jakimś podłożu, ot choćby papierze. I dziwne to i bardzo interesujące, że mimo iż do tego sa przeznaczone, nie robią tego, bowiem my mówimy [...] inaczej - nie całkiem inaczej, lecz trochę inaczej; tylko trochę, ale to wystarczy, by zarzut był poważny. Zarzut ignorowania fizyczności. Bo nie można wymagać od obiektu istniejącego fizycznie, by wyzbył się swej fizyczności, by utracił swoją fizyczność nie przestając istnieć fizycznie. Nie da się opróżnić litery. Można wydać rozkaz dowolnemu układowi kresek lub plamek by niczego nie zawierał (żadnych skojarzeń-odwzorowań-wyobrażeń-przypomnień-napomknień-...) lecz jest to rozkaz niewykonalny. Więc zamiast walczyć z cielesnością (z fizycznością własnego i czyjegoś jestestwa) i tracić niepotrzebnie energię, lepiej byłoby wykorzystać to co nam ta fizyczność może dać, zagospodarować ten ogromny obszar ${ }^{336}$.
\end{abstract}

Postawiony przez liberata postulat, by ów materialny (,fizyczny”) aspekt litery uczynić znaczącym, a nawet sam sposób opisu sytuacji, która ku tej refleksji prowadzi, skłaniaja ku zastanowieniu się nad kwestiami, takimi jak odmienność tekstu zapisanego od wypowiedzianego czy kwestia automatyzacji aktu odbioru (której konsekwencją jest właśnie bagatelizacja wszelkiej - jak określa to Nowakowski - „fizyczności”). Tym samym, wskazuje się na konteksty, które dotychczas nie zostały tu poruszone, a które dopowiedzenia raczej się domagaja.

Choć w pierwszym momencie może się to wydać zbyt daleko sięgającym przypisem, warto - jak sądzę - przypomnieć, kiedy narodziła się teoretyczna refleksja nad wspomnianymi zagadnieniami. Tym samym, trzeba zadać pytanie o moment zwrotu w lingwistycznym myśleniu o znaku (i jego różnych

${ }_{335}$ Przykładem refleksji badawczej prowadzonej w takim duchu są publikacje Anny Kołos. Zob. Anna Kołos, Geneza liberatury. Filozofia, estetyka i polityka pisma, „Ha!art” 2010, nr 30, s. 52-56 oraz eadem, Liberatura czyli „architektura słowa” a przestrzeń dzieła literackiego, „Ha!art” 2009, nr 1-2 (28/27) [dodatek „Liberatura”], s. 18-25. Pierwszy z przywołanych szkiców w błyskotliwy sposób referuje ciążenie postplatońskiej wizji na humanistycznej refleksji. Badaczka sprawnie pokazuje również, jak Jacques Derrida i Jacques Rancíer „potrafią zmniejszyć nieznośny ciężar filozofii spoczywający na literaturoznawstwie” (A. Kołos, Geneza liberatury..., s. 56). Zaś jako przykład bagatelizowania, a wręcz odrzucania wagi kategorii zapisu można podać ujęcie René Welleka i Austina Warrena (zob. m.in. René Wellek, Austin Warren, Teoria literatury, tłum. Maciej Żurowski, Jerzy Krynicki, Ignacy Sieradzki, Warszawa 1976).

${ }^{336}$ R. Nowakowski, Traktat kartkograficzny..., s. 43. O literze jako znaku zob. też Radosław Nowakowski, Utekstowienie znaku, uznakowienie tekstu, [w:] Druga rewolucja ksiażki, red. Violetta Trella, Gdynia 2008, s. 30-33. 
aspektach). Pytając zaś o ten przełom, dobrze pochylić się również nad idącymi z nim w parze artystycznymi realizacjami i dalszymi postulatami teoretycznymi. To z kolei poprowadzi ku zatrzymaniu się na chwilę nad przełomem wieku XIX i XX, nad twórczością awangardowa, nad eksperymentami typograficznymi spod tego znaku czy wreszcie nad formalizmem i strukturalizmem ${ }^{337}$.

Tym samym - odpowiadając na pytanie o różnice i podobieństwa między twórcami eksperymentującymi z typografią a liberatami, będę miała okazję dopowiedzieć przynajmniej część z kwestii, do których poruszenia prowokuja powtarzane przez liberatów uwagi o tym, że teoretycy literatury pomijali w dotychczasowej refleksji kwestię materialności tekstu czy tomu, w którym jest on zamknięty. Słowem - czas postawić pytanie o to, jak ma się liberatura do lingwistycznych i semiotycznych koncepcji znaku, a także do jego rozumień wypracowanych na gruncie formalizmu czy strukturalizmu, do budowanych w obrębie tych metodologii definicji tekstu, struktury czy chwytu literackiego. Bez takiego - pozornie tylko zbyt daleko wybiegajacego - kontekstu trudno mówić o relacji praktyk liberackich i eksperymentów typograficznych.

A co ma do tego Nowakowski? Mówiąc o tym, że litera jest nie do końca spełniającym swe funkcje odzwierciedleniem, odbiciem mowy, czy wskazując na różnice między wysłowieniem a zapisem, liberat zdaje się pokazywać trop saussure’owski. Zaś jego narzekania na to, że wymyśliliśmy sobie, żeby litera była „niema”, że - na drodze skonwencjonalizowania - pragniemy uczynić znak jak najbardziej neutralnym i prześwitującym, przypominają sprzeciw formalistów wobec zautomatyzowanych aktów odbioru. Czy zatem np. nietypowa, nieraz wręcz przeszkadzająca, postać liberackich tekstów ${ }^{338}$ jest po prostu

${ }^{337}$ Nie zamierzam jednak przywłaszczać sobie pierwszeństwa w przyjmowaniu takiej perspektywy. Analogiczny postulat spojrzenia na twórczość eksplorującą semantyczną nośność sposobów zapisu z perspektywy przełomu lingwistycznego oraz refleksji formalistów i strukturalistów proponuje Johanna Drucker w swojej poświęconej eksperymentom typograficznym początku XX w. książce (Johanna Drucker, The Visible Word. Experimental Typography and Modern Art, 1909-1923, Chicago-London 1996; dalej oznaczane jako Drucker z numerami stron). Badaczka traktuje eksperymenty typograficzne silnie mnożące się w pierwszych dziesięcioleciach XX w. na równi z teoretycznymi manifestami, traktatami czy wręcz tekstami krytycznymi (w tym wypowiedziami artystów: Guillaume’a Apollinaire’a, Filippa Tommasa Marinettiego, Aleksieja Kruczonycha czy Wielimira Chlebnikowa, a także Pieta Mondriana i Ezry Pounda). Podstawowym kontekstem krytycznym jest dla niej semiotyka i filozofia języka (de Saussure) z jednej strony i fenomenologia (Husserl) z drugiej. Podkreślając wagę obu tych odniesień, Drucker skupia się głównie na pierwszym (widząc zasadniczą potrzebę stworzenia opartej na językowej refleksji krytycznej ramy do badań nad eksperymentalną typografia). Podkreśla również, że omawiane przez nią eksperymenty typograficzne powstają w kontekście całej ówczesnej kultury, w duchu modernistycznego postrzegania roli sztuki i jej artefaktów, a więc i uważnego namysłu nad materialnościa. Jednocześnie modernistyczne słowo było bardziej uwikłane w relację bycia niż reprezentowania, imitacji czy referencji i to tę właśnie cechę uznaje Drucker za najważniejszą spośród wszystkich, które eksperymenty typograficzne dzielą z literaturą i sztuką pierwszych dziesięcioleci XX w.

${ }^{338}$ Choć nie wszyscy czytelnicy zwracają na to uwagę - warto podkreślić, że nawet przedruk liberackich esejów Fajfera (Liberatura czyli literatura totalna), a zatem w zamierzeniu poważny, naukowy w charakterze tom, opublikowano jako książkę krzywa, kodeks, którego strony są szersze na górze niż na dole. 
realizacją chwytu udziwnienia? Czy nie bez powodu Wiktor Szkłowski zachwycał się tymi samymi zabiegami w Życiu $i$ Myślach JW Pana Tristrama Shandy, co Bazarnik ${ }^{339}$ ?

Zatem - nim przejdę do mówienia o literaturze totalnej w relacji do eksperymentów typograficznych - chciałabym skupić się przez chwilę na spojrzeniu na koncepcję liberacką w kontekście wybranych zagadnień teoretycznych: przełomu w myśleniu o znaku wiązanym z de Saussure'em oraz (niektórych) postulatów formalistów i strukturalistów.

\subsection{Liberatura a kategoria znaku}

Aż do wystapienia de Saussure’a (mam na myśli publikację Kursu językoznawstwa ogólnego) fakt, że tekst jest zapisany, że jest formą materialna, niekoniecznie neutralna, był na gruncie lingwistyki raczej ignorowany, postrzegany jako niewart wspominania o nim. „Pismo, zapis (writing), niezastapiony towarzysz naukowego językoznawstwa, bez którego nie byłoby samego przedmiotu badań, trwało nienazwane i nierozpoznane" ${ }^{440}$ - pisze Johanna Drucker. Zaśs podsumowując dominację monocentrycznej refleksji w dyskursie językoznawczym do czasu de Saussure’a, dodaje:

Lingwistyka nie tylko uprzywilejowała fonemiczne, fonetyczne, akustyczne czy artykulacyjne aspekty języka, lecz uczyniła wszystko, co możliwe, aby przyczynić się do stanu, w którym wizualna podstawa języka pozostawała niedoceniona, nienazwana, mówiąc krótko - niewidoczna. Zmienił to Ferdinand de Saussure ${ }^{341}$.

To zdekonstruowanie jedności lingwistycznej reprezentacji dało fundamenty myśli szwajcarskiego językoznawcy. Trzeba jednak podkreślić, że jej przełomowość można docenić dopiero spoglądajac na nią na tle ówczesnego stanu badań. Pozornie bowiem autor Kursu językoznawstwa ogólnego nie stawiał innych tez niż jego koledzy. Czy podzielał ze współczesnymi negatywny stosunek do pisma? Jak najbardziej. Tyle że - paradoksalnie - jako jedyny wyciągał z tej niechęci wnioski dotyczące samej istoty owego zapisu, nie tylko podkreślając istotność samego faktu jego istnienia, ale i semantyczną odmienność między nim a kodem fonetycznym.

Język i pismo to dwa odrębne systemy znaków - pisał. - Jedyną racją bytu pisma jest to, że jest obrazem języka; przedmiotu językoznawstwa nie określa połączenie wyrazu pisanego i wyrazu mówionego: przedmiotem tym jest wyłącznie wyraz mówiony. Wyraz pisany zlewa się jednak tak ściśle z wyrazem mówionym, którego obraz stanowi, że w końcu uzurpuje

339 Szkłowski pisał o Sternie w 1921 r. w szkicu „Tristram Szendi” Sterna i tieorija romana. Bazarnik wspomina o tym pisarzu nad wyraz często, niemal we wszystkich swoich szkicach. Z kolei o Fajferowskich liberackich analizach dzieł tego twórcy zob.: Zenon Fajfer, Muza liberatury (czyli kto się boi wdowy Wadman), [w:] LCLT, s. 115-122.

340 J. Drucker, s. 13.

${ }^{341}$ Ibidem, s. 16. 
sobie główną rolę; zaczynamy przywiązywać tyleż wagi do przedstawienia znaku głosowego, co do samego znaku. Jest to tak, jak gdybyśmy uważali, że chcąc kogoś poznać, lepiej jest patrzeć na jego fotografię niż na jego twarz ${ }^{342}$.

A zatem badacz, dostrzegając, że zapis może zwracać na siebie uwagę, sprzeciwiał się sytuacji, w której przesłania on język ${ }^{343}$. I tak, choć właśnie od de Saussure’a datować można przełom polegający na tym, że dostrzeżono podwójną artykulację znaku, u niego jeszcze znaczace było związane $\mathrm{z}$ wypowiadaniem słowa, nie z jego zapisem. Signifiant miało u niego charakter wirtualny, niezwiązany z widzialną czy namacalna fizycznością (a jedynie z obrazem akustycznym). To dopiero w późniejszym podejściu semiotycznym typowe będzie traktowanie znaczacego w kategoriach materialności, dopiero tam będzie ono rozumiane jako dająca się zmysłowo postrzegać część znaku. De Saussure rozważa tu jeszcze wyłącznie warstwę dźwiękowa. Niemniej, to ten badacz nauczył nas w ogóle taką dwoistość dostrzegać. Tym samym, to jego teoria daje podwaliny i wyznacza perspektywy dla eksplorowania semantycznych możliwości materialności signifiant oraz - w konsekwencji - budowania teorii wizualnych reprezentacji języka.

Ze względu na tę intrygującą zależność Drucker mówi o swoistej „paradoksalności Saussure'owskiej teorii znaku: o wyjątkowej konstrukcji i naturze znaku - materialnie nieistotnej, lecz w materii bazujacej" ${ }^{344}$. Co ciekawe, nieprzywołująca teorii szwajcarskiego językoznawcy Bazarnik pisze o liberaturze, akcentujac właśnie analogiczne rozbicie słowa - uwzględniajace i jego warstwę brzmieniową (zatem Saussure'owskie signifiant), i materialność mająca równie silny potencjał semantyczny (a zatem signifiant w rozumieniu dyskursu postsaussurowskiego). Z charakterystyki literatury totalnej przedstawionej przez badaczkę w szkicu podsumowującym pierwsze dziesięciolecie liberatury można wnioskować, że zrodziła się ona niejako w odpowiedzi na takie właśnie rozbicie semantyczne słowa. Liberackie spojrzenie na znak byłoby więc patrzeniem na wszelkie jego poziomy, a tym samym jego liberacka eksploracja opierałaby się na wykorzystywaniu tych z nich, których dostrzeżenie było wynikiem odejścia od monolitycznej koncepcji znaku. Bowiem w literaturze totalnej, jak twierdzi Bazarnik, „słowo ujawnia swą dualistyczna naturę: jest równocześnie dźwiękiem i obrazem, materialnym i niematerialnym bytem, idea, która wciąż na nowo poszukuje odpowiedniej formy" ${ }^{345}$. Zatem liberackie słowo wykracza poza pierwotną Saussure’owską koncepcję

${ }^{342}$ Ferdinand de Saussure, Kurs językoznawstwa ogólnego, tłum. Krystyna Kasprzyk, Warszawa 1961, s. 39-40.

${ }^{343}$ Patrząc na historyczny rozwój języka, de Saussure stwierdzał, że w miarę upływu czasu pierwotna adekwatność sytemu fonetycznego i zapisu (widoczna jeszcze w Grecji starożytnej) zanikała i oba systemy coraz bardziej oddalały się od siebie, a ponadto relacje między formami mówionymi a zapisanymi stawały się czysto konwencjonalne.

344 J. Drucker, s. 22. Dalej (s. 27) badaczka ujmie to w słowach: „De Saussure stworzył trudny do rozwikłania paradoks znaku niezależnego od całej materialności i jednocześnie od niej zależnego".

${ }^{345}$ K. Bazarnik, Liberatura czyli o powstawaniu gatunków (literackich), [w:] LCLT, s. 163. 
znaku i wkracza w przestrzeń dyskusji o znaczeniu (elementach znaczących i znaczonych), której perspektywy, owszem, wyznaczyły tezy autora Kursu językoznawstwa ogólnego, jednak podwaliny dali jej kontynuatorzy myśli tego badacza $^{346}$.

Już Louis Hjelmslev, pisząc o planie wyrażania i planie treści (poniekąd analogicznych do terminów Saussure’owskich), podkreślał nierozłączność tych dwóch elementów ${ }^{347}$ oraz olbrzymią nośność semantyczną każdego z nich (ale właśnie w uwikłaniu we wzajemne relacje). Jednak i dla tego duńskiego językoznawcy plan wyrażania również odnosił się przede wszystkim do aspektów dźwiękowych. Niemniej, jego spojrzenie na znak - jeśli rozszerzymy kategorię wyrażenia o cechy inne niż wyłącznie fonetyczne (czy - lepiej - fonologiczne) - tożsame jest z interesującą nas późniejszą refleksja postsaussurowska, a nawet liberacka. Hjelmslev stwierdzał bowiem, że:

Znak jest więc, choć wydaje się to paradoksalne, znakiem pewnej substancji treści i znakiem pewnej substancji wyrażenia. W tym właśnie sensie można powiedzieć, że znak jest znakiem czegoś. Nie widzimy natomiast powodu, żeby nazywać znak tylko znakiem substancji treści, ani (o czym zresztą nikt nie pomyślał) tylko znakiem wyrażenia. Znak jest jednostką dwustronna, o Janusowym obliczu, działającą w dwu kierunkach: „na zewnątrz”, ku substancji wyrażenia, i „do wnętrza”, ku substancji treści ${ }^{348}$.

Można by powiedzieć, że Kurs językoznawstwa ogólnego zaowocował spojrzeniem, które żadnej ze stron tego oblicza nie chciało ignorować. Jednak, czy możemy uznać je za dominujące współcześnie? Nie. Gdyby tak było - zjawiska takie jak liberatura nie byłyby zapewne niczym zaskakujacym ani nawet wartym opisu. Wśród podręcznikowych definicji znaku nadal znajdziemy choćby takie, jak poniższa, autorstwa Urszuli Żegleń:

Charakterystyczną cechą znaku jest jego przezroczystość, to znaczy, że w odczytywaniu funkcji znaku nie zatrzymujemy się na jego stronie fizycznej. Mówiąc inaczej, substrat

${ }^{346}$ O liberackim rozumieniu kategorii znaku (słowa-znaku) zob. też M. Dawidek Gryglicka, Wewnętrzna i zewnętrzna architektura ksiażki..., s. 650-651.

${ }^{347} \mathrm{Na}$ drodze dyskusji z de Saussure’em, eksponujacc ją znacznie silniej: „Wyrażanie i treść są solidarne [...] wobec siebie - pisał - wzajemnie się zakładają w sposób konieczny. Wyrażenie jest wyrażeniem tylko dzięki temu, że jest wyrażeniem określonej treści; treść jest treścią tylko dzięki temu, że jest treścią określonego wyrażenia” (Louis Hjelmslev, Prolegomena do teorii języka, tłum. H. Kurkowska, A. Weinsberg, [w:] Językoznawstwo strukturalne. Wybór tekstów, red. Halina Kurkowska, Adam Weinsberg, Warszawa 1979, s. 75).

${ }^{348}$ L. Hjelmslev, Prolegomena do teorii języka, s. 82-83. Co ciekawe, później eksplorowanie aspektów związanych z planem wyrażania pójdzie tak daleko, że nieraz stanie się dominanta i w efekcie Gérard Genette stwierdzi: „Dostatecznie już długo patrzono na literaturę jako na przekaz bez kodu, czas by spojrzeć na nią przez chwilę jako na kod bez przekazu” (Gérard Genette, Strukturalizm a krytyka literacka, tłum. W. Błońska, „Pamiętnik Literacki” 1974, nr 3, s. 279). Drucker z kolei patrzy na letryzm właśnie jako na kierunek zrodzony z frustracji owocującej „fetyszyzacją materialnego aspektu” pisma oraz angażujący się bardziej w produkcję samych znaków niż literatury (zob. Johanna Drucker, Hypergraphy: A Note on Maurice Lemaître's Roman Hypergraphique, [w:] eadem, Figuring the Word: Essays on Books, Writing and Visual Poetics, New York 1998, s. 82-83). 
materialny znaku nie zatrzymuje na sobie uwagi badacza (interpretatora znaku), lecz odsłania przedmiot reprezentowany przez znak ${ }^{349}$.

W podsumowaniu rozdziału, z którego pochodzi powyższy cytat, badaczka dodaje:

Jeśli jest to tekst, którego odbiorca słucha, to strona brzmieniowa tekstu nie zatrzymuje uwagi odbiorcy, lecz odsłania jego warstwę znaczeniowa. To samo można powiedzieć o tekście czytanym przez odbiorcę, dla którego takim medium quo będzie strona fizyczna tekstu (tym razem kształt wyrażeń). Toteż czasami porównuje się znak formalny do szyby czy okularów, które dzięki swej przezroczystości pozwalają nam widzieć to, co znajdzie się na zewnątrz ${ }^{350}$.

Z drugiej strony, w opozycji do takich sformułowań znajdziemy wywody Umberto Eco kontynuujące myśl Hjelmsleva ${ }^{351}$ i podejmujące $\mathrm{z}$ nią dyskusję. Jeden z czołowych semiotyków współczesności wskazuje na nośnik znaku jako semantycznie relewantny element systemu wyrażania. Uznaje tė̇, że jeśli mowa o tworach estetycznych - o sztuce, a nie o znaku konwencjonalnym, wszelkie operacje dotykające jego materialnych aspektów nie powinny być bagatelizowane, gdyż w tej sferze nawet najmniejsza ingerencja może zaowocować zmiana znaczeń.

Jeśli [...] rozważamy funkcję znakową jako taką - twierdzi Eco - należy uwzględniać nośnik znaku przekazujący dane znaczenie. Ów nośnik znaku urzeczywistnia się za sprawa formowania określonego kanału; innymi słowy, tworzywo, z którego zrobiony jest nośnik znaku, jest kontinuum, z którego forma wyrażenia wykroiła swoje jednostki wyrażania; jednostki te - jeśli nie zostaną umieszczone w obrębie funkcji znakowej - pozostają zwykłymi sygnałami [...] Nazwijmy tę fizyczną postać sygnału materia nośnika znaku.

Analizowane powyżej przykłady doznania estetycznego dowodza, że w przypadku estetycznego nośnika znaku materia odgrywa istotną rolę. Jest tak dlatego, że została ona oddana w sposób semiotycznie interesujący. Inaczej rzecz ujmując, nośnik znaku (jako pewna jednostka wyrażania) może zostać rozpoznany nie tylko jako element relewantny systemu wyrażania, lecz nawet konsystencja materii takiego nośnika znaku staje się polem do dalszych rozczłonkowań. Używając codziennych reguł jakiegoś języka, mogę wypowiadać słowo na wiele sposobów, zmieniać wymowę, rozmaicie podkreślać niektóre sylaby czy zmieniać wzorce intonacyjne, lecz mimo to owo słowo pozostaje takie samo. W dyskursie estetycznym jednak każda swobodna odmiana wprowadzona do „wypowiadania” takiego nośnika znaku ma pewną wartość „formalną”. Oznacza to, że nawet te cechy, które zazwyczaj nie mają związku z kontinuum i które z semiotycznego punktu widzenia nie muszą być rozpatrywane [...], tutaj stają się semiotycznie relewantne. W tekstach estetycznych materia nośnika znaku staje się pewnym przejawem form wyrażania ${ }^{352}$

${ }^{349}$ Urszula M. Żegleń, Wprowadzenie do semiotyki teoretycznej $i$ semiotyki kultury, Toruń 2000, s. 40, podkreślenie moje. W dalszej części książki autorka dodaje, że o znaku takim (transparentnym dla odbiorcy) mówimy, że „stanowi tzw. «medium quo»” (s. 58).

350 U. Żegleń, Wprowadzenie do semiotyki teoretycznej..., s. 59.

351 Eco analizuje teorię chwytu Szkłowskiego jako naruszanie norm w planie wyrażania i treści. Owo wyłamanie się konwencji, jak mówi: „Zmusza do ponownego rozważenia korelacji obu planów, która nie musi już być taka sama, jak korelacja przewidziana przez zwykły kod. W tym sensie tekst staje się samozwrotny: skierowuje uwagę adresata głównie na "swoją własną postać»" (Umberto Eco, Teoria semiotyki, tłum. Maciej Czerwiński, Kraków 2009, s. 279-280).

352 Ibidem, s. 281-282, podkreślenia moje. 
W dalszym wywodzie Eco używa też terminu „materia znacząca”353, przypisujac jej pełną możliwość komunikowania treści. Badacz, aplikując tezy Hjelmsleva do swoich badań i roztrząsając semiotyczne niuanse planu wyrażania i treści, przeformułowuje nieco teorię duńskiego lingwisty strukturalnego i konkluduje: „Dzieło sztuki dokonuje semiotycznego odkupienia swej zasadniczej materii”. Czy tym samym sugeruje, że warstwa materialna tekstu zdołała odzyskać/zyskać swą semantyczną potencjalność, że - innymi słowy - ziściło się marzenie liberatów? Czy nie są analogiczne do słów Eco następujace, sformułowane przez Fajfera:

Substancją literatury jest słowo.

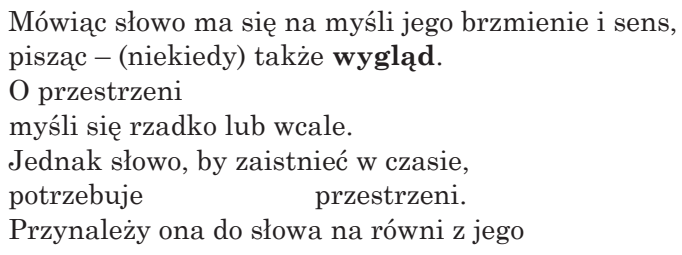

kształtem

dźwiękiem

znaczeniem $^{354}$.

Jak można wytłumaczyć paralelne występowanie tak różnych podejść do kategorii znaku? Sugerowana rozbieżność nie da się przecież prosto wyjaśnić podziałem na inspirowaną myślą de Saussure'a semiologię i postpeirceowska semiotykę, gdyż i u drugiego z wymienionych badaczy reprezentamen - środek przekazu - jest rozumiany właśnie materialnie i tym samym (jak podkreśla też Anna Burzyńska) owa materialna podstawa staje się w jego koncepcji integralną częścią znaku ${ }^{355}$. Co więcej, czyż nie jest tak, że kluczowe winno się tu stać pytanie, czy kwestia istnienia tych różnych ujęć jest w ogóle istotna dla moich rozważań i czy warto poświęcać jej tyle uwagi?

Wracając myślą do de Saussure'a i początku tego rozdziału, mogę - szukając odpowiedzi - stwierdzić, że z pewnością tak. Wyznaczona przez szwajcarskiego badacza droga refleksji językoznawczo-semiotycznej rozwijana jest po dziś dzieńn ${ }^{356}$. Stała się podstawą tych dyskursów, w których znak nie daje się

${ }^{353}$ Ibidem, s. 282.

${ }_{354}$ Z. Fajfer, tiryka, epika, dramat, liberatura, s. 43. Nie zachowuje pełnej formy graficznej oryginału, podkreślenie moje.

${ }^{355}$ Zob. Anna Burzyńska, Michał P. Markowski, Teorie literatury XX wieku. Podręcznik, Kraków 2006, s. 235. W dalszej części książki oznaczam tę pozycję skrótem TLXXW oraz numerem strony.

356 Warto może również przywołać słowa, jakimi Roman Jakobson opisywał nowatorstwo myśli Saussure'owskiej, z żalem stwierdzając: „Wielka to szkoda, że w latach naukowego ożywienia, jakie przyszły po pierwszej wojnie, świeżo wydane dzieło de Saussure’a - «Cours de linguistique générale» - nie mogło zostać skonfrontowane z poglądami Peirce’a. Takie zderzenie koncep- 
sprowadzić li tylko do przekazywanej treści, bądź - innymi słowy - owa treść nie jest przekazywana jedynie na zasadzie arbitralnych konwencji i przez wyłącznie jeden z elementów struktury znaku (poziom treści) ${ }^{357}$. Ujęcie liberackie z pewnością zaś można zaliczyć do tego właśnie nurtu.

Takie rozumienie natury znaku: nie tylko dostrzegające jego co najmniej diadyczną strukturę, lecz i każdemu z jej elementów przypisujące potencję semantyczna, jest - jak najdobitniej zaznaczył Eco - charakterystyczne dla badania przede wszystkim artystycznych realizacji. To w ich przypadku „walka z cielesnościa”, o której mówił Nowakowski, jest bezsensowna. I właśnie na gruncie badań tekstów sztuki pogłębiono teorię de Saussure’a, nadając jego signifiant znaczenie bardziej namacalne, wiążąc je z materialnością czy wreszcie naocznościa, wizualnością znaku ${ }^{358}$. Zaś znak w rozumieniu semiotyki nie-artystycznej, semiotyki dnia codziennego (analizującej znak w funkcji komunikacyjnej) może (a często i powinien) być przezroczysty i oparty na konwencji ${ }^{359}$.

I teoria liberatury, artykułowana przecież od samego początku jako korekta teoretyczno-literacka, mówiąc o tekście, podkreśla jego znakowy charakter na wielu poziomach, traktując jako znak i samą książkę (do czego wrócę w dalszej części wywodu). A zatem, co istotne, rewolucyjny aspekt proponowanej przez Fajfera i Bazarnik perspektywy polega nie na tym, że utwór literacki traktuje się jako znak o charakterze artystycznym (bo w tym nie byłoby nic nowatorskiego), lecz na tym, że wielopoziomowa struktura przenoszaca

cji zarazem i zbieżnych, i rywalizujących zmieniłoby zapewne rozwój językoznawstwa ogólnego i przyspieszyło powstanie semiotyki” (Roman Jakobson, Kilka uwag o Peirce’ie, poszukiwaczu dróg w nauce o języku, tłum. Stefan Amsterdamski, [w:] idem, W poszukiwaniu istoty języka. Wybór pism, t. I, Warszawa 1989, s. 53).

${ }^{357}$ Por. też Christian Vandendorpe, Od papirusu do hipertekstu. Esej o przemianach tekstu i lektury, tłum. Anna Sawisz, Warszawa 2008.

${ }^{358} \mathrm{O}$ przemianach signifiant w refleksji humanistycznej zobacz m.in. Wojciech Kalaga, Mgławice dyskursu: podmiot, tekst, interpretacja, Kraków 2001.

359 Przede wszystkim więc nurt refleksji, który jest tu dla mnie inspirujący, odnosi się właśnie do poczynań artystycznych. Co więcej, zaowocował on zaprzęgnięciem lingwistyki do teorii literatury - dość tu przypomnieć, że Eco również semiotykę postrzega jako dziecko lingwistyki. „Semiotyka [...] staje się niczym innym jak tylko pochodną lingwistyki” - pisze, podkreślając, że dociekanie znaczeń tekstów kultury jest w istocie obcowaniem ze znakami językowymi (U. Eco, Teoria semiotyki, s. 184). Warto też pamiętać o tym, że Roman Jakobson wyraźnie określał poetykę jako część refleksji lingwistycznej, wyznaczając wspólne obszary tych dwóch dziedzin. Poetykę jako namysł nad strukturą językową dzieła należy zdaniem badacza rozpatrywać właśnie jako integralną część lingwistyki (rozumianej jako ogólna wiedza o tej strukturze). W kluczowym artykule Poetyka w świetle językoznawstwa Jakobson dodawał: „Krótko mówiąc, wiele zjawisk poetyckich wchodzi nie tylko w zakres wiedzy o języku, lecz w zakres całej teorii znaków, tj. ogólnej semiotyki” (Roman Jakobson, Poetyka w świetle językoznawstwa, tłum. Krystyna Pomorska, [w:] idem, W poszukiwaniu istoty języka. Wybór pism, t. II, Warszawa 1989, s. 78). O relacji poetyka i literaturoznawstwo a semiotyka pisał też w artykule Język a inne systemy komunikacji (Roman Jakobson, Język a inne systemy komunikacji, tłum. Anna Tanalska, [w:] idem, W poszukiwaniu istoty języka. Wybór pism, t. I, Warszawa 1989, s. 59-74, szczególnie s. 61). Por. też Irena Urbaniak, Romana Jakobsona poetyka w świetle językoznawstwa, „Zagadnienia Rodzajów Literackich” 2002, z. 1-2 (89-90), s. 133-145. 
tekst, jego „opakowanie”, interfejs: sama książka (zwykle postrzegana jako przedmiot nie estetyczny a użytkowy) również jest tu rozpatrywana w takich kategoriach. Dlatego zwrot w teoretycznym myśleniu o znaku jest istotnym kontekstem do rozważań o liberackości.

Dla porządku trzeba tu też dodać, że (jak słusznie podkreśla Drucker) choć teoretycy dostrzegli furtkę, jaką otworzyła refleksja nowej lingwistyki, raczej pomijali majaczącą na horyzoncie ścieżkę. Śmielej wkraczali na nią twórcy. Stąd w przywołanym okresie spotykamy więcej artystycznych realizacji eksplorujących nowe przestrzenie znaku niż roztrząsających tę sytuację teorii. Na fakt ten na naszym rodzimym gruncie już w 1982 r. (w kontekście analiz typograficznego opracowania Sponad Juliana Przybosia dokonanego przez Władysława Strzemińskiego) zwracała uwagę Irena Urbaniak, stwierdzają:

Niekonwencjonalne rozwiązania typograficzne, które pełnić miały funkcję semantyczna. a nie tylko dekoracyjna, stosowali - nie odwołując się do pomocy plastyków - sami poeci. To oni pierwsi - jak zaświadcza historia - wyciagnęli konsekwencje z faktu, iż „słowa drukowane sa widziane, a nie słyszane" (El Lissitzski). To oni na wiele lat przed ogłoszeniem przez włoskich futurystów w 1913 roku „rewolucji typograficznej” odstępowali od zasad drukarstwa tradycyjnego po to, by pewne słowa - słowa o znaczeniu dla tekstu szczególnym - wyeksponować przez wytłuszczenie, spacjowanie, zastosowanie wersalików lub zmianę kroju czcionki (ten cel i sposoby bardzo wyraźne są w twórczości Antoniego Lange i Marii Pawlikowskiej-Jasnorzewskiej), a potem - już bliżej współczesności, pod wpływem hasła „parole in libertá” - by znaleźć odpowiednią formę graficzną dla swoich poetyckich eksperymentów ${ }^{360}$.

Badaczka zwraca też uwagę, że plastycy i literaci nieco inaczej podchodzili do kwestii opracowania typograficznego tekstu. Choć dla jednych i drugich ów kształt graficzny nie miał być wobec pierwotnego tekstu literackiego tautologiczny, dla twórców sztuki słowa istotne było poszerzanie języka poetyckiego, włączanie w jego obręb nowych środków ekspresji, dla plastyków zaś wszelkie podejmowane $\mathrm{w}$ tej przestrzeni działania miały związek $\mathrm{z}$ doskonaleniem techniki drukarskiej i jej - nie dziedzinie literatury - były (w ich mniemaniu) przynależne.

Warto jednak pamiętać, że nie jest tak, że teoretycy zupełnie przemilczeli analizowane tu kwestie. Jeśli dobrze poszukać - okaże się, że nie brak i naukowych dywagacji o przywołanym problemie (choć dobrze pamiętać, iż nieraz mamy do czynienia z teoretycznymi wywodami praktyków sztuki słowa $^{361}$ ). Ponieważ większość z nich pozwala wyakcentować pewne nie zawsze tak łatwo czytelne aspekty teorii liberackiej, na kolejnych stronach proponuje podążyć tym właśnie tropem.

${ }^{360}$ Irena Urbaniak, Analiza zgodności znaczeniowo-graficznej „Sponad” Juliana Przybosia w opracowaniu typograficznym Władysława Strzemińskiego, „Sprawozdania z Czynności i Posiedzeń Naukowych Łódzkiego Towarzystwa Naukowego” 1982, R. XXXVI, 5, s. 1-2.

361 Dość wskazać tu właśnie na duet Przyboś-Strzemiński. 


\subsection{Liberatura, lingwistyka i formalizm albo o lit/beraturze wskrzeszonej}

Rewolucja, jaka zapoczątkował de Saussure, nie ograniczyła się zatem wyłącznie do lingwistyki, a nowe spojrzenie na specyfikę stosunków w obrębie znaku językowego zaowocowało nowym spojrzeniem na język literatury, przede wszystkim na język poetycki. Wpływu ówczesnego językoznawstwa na teorię i praktykę nie sposób przecenićc ${ }^{362}$, zaśs pierwszą szkołą badającą literaturę w oparciu o lingwistykę i artystów eksplorujących nowe przestrzenie znaku był formalizm ${ }^{363}$. Wzajemne zależności czy inspiracje lingwistów, teoretyków i artystów zdają się też poświadczać już same tytuły ogłaszanych wtedy drukiem szkiców, np. Litera jako taka oraz Stowo jako takie Kruczonycha i Chlebnikowa (z 1913 r.) oraz (rok późniejszy) Przyczynek do teorii „stowa jako takiego" $i$,litery jako takiej”Baudouina de Courtenaya ${ }^{364}$.

${ }^{362}$ Wśród wymienianych jako kluczowe postaci-inspiratorów powraca również nazwisko Jana Baudouina de Courtenaya. Jego wpływ jedni doceniają na równi z de Saussure’em (Mayenowa), inni cenią niemal bardziej (Markowski), a jeszcze inni stawiają w hierarchii wpływów nieco niżej niż autora Kursu językoznawstwa ogólnego (Drucker). Z jednej strony z jego szkoły wywodzi się charakteryzujące pierwszy okres formalizmu przekonanie o odrębności języka poetyckiego, w którym słowa zwolnione są z obowiązku wypełniania schematów konwencji (co charakteryzuje mowę codzienna). Z drugiej - przeświadczenie, że ów język daje się badać, analizować, interpretować przy zastosowaniu metod i narzędzi wypracowanych na gruncie językoznawstwa. Pisząc już o strukturalizmie Mayenowa podkreśla też, że w istocie łączono inspirację de Saussure'em i Baudouinem de Courtenayem: „Praskie Koło Lingwistyczne zarówno w zakresie językoznawstwa jak i w zakresie stylistyki staje się w znacznej mierze spadkobiercą strukturalizmu Saussurowskiego przepuszczonego przez medium przemyśleń i osiąnięć radzieckich. Przemyślenia te znaczyły zaś w sferze czysto lingwistycznej włączenie wielu wątków myśli Baudouina de Courtenaya, wątków różnych od myśli Saussurowskiej" (Maria R. Mayenowa, Analiza doktryny stylistycznej praskiego koła, [w:] Praska szkoła strukturalna w latach 1926-1948. Wybór materiatów, red. Maria R. Mayenowa, Warszawa 1966, s. 27).

${ }^{363}$ Ciekawie o narodzinach związku teorii literatury z lingwistyką pisze Ejchenbaum, wskazujący właśnie na formalistów jako tych, od których przełom ten należy wywodzić. Jednocześnie badacz ten wyraźnie podkreśla obustronność omawianej zależności. Wskazując jej źródła, zwraca uwagę na moment, w którym zaczęto zestawiać język tzw. poetycki z praktycznym (co stało się punktem wyjścia badań formalistycznych już od pierwszych publikacji w duchu tego nurtu). „W ten sposób - przekonuje Ejchenbaum - zamiast normalnej dla literaturoznawców orientacji w kierunku historii kultury lub społeczeństwa, psychologii lub estetyki itd., u formalistów wystąpiło charakterystyczne ciążenie ku lingwistyce jako nauce, która ze względu na materiał badań łączyła się z poetyka, ale podchodziła do tego materiału z innym nastawieniem i w innych celach. Z drugiej strony językoznawcy również zainteresowali się metodą formalna, jako że fakty języka poetyckiego, ujawnione przy zestawianiu go z językiem praktycznym, mogły być rozpatrywane w sferze problemów czysto lingwistycznych jako ogólne fakty językowe. Powstało coś na kształt tych stosunków wzajemnej korzyści i demarkacji, jakie istnieją na przykład pomiędzy fizyką i chemią". Niemniej, badacz zwraca uwagę na osłabienie relacji formalizm-lingwistyka w późnym okresie rozwoju nurtu (Boris M. Ejchenbaum, Teoria metody formalnej, [w:] Teoria badań literackich za granica. Antologia, red. Stefania Skwarczyńska, t. II, cz. III, s. 170).

${ }^{364} T L X X W$, s. 114 oraz 127. Por. też Maria R. Mayenowa, Propozycje teoretyczne $w$ zakresie form poetyckich, [w:] Rosyjska szkoła stylistyki, red. Maria R. Mayenowa, Zygmunt Saloni, Warszawa 1970, s. 27. Zaś najpełniejszy chyba w literaturze przedmiotu obraz zależności między 
Formaliści przede wszystkim wyciagnęli wnioski z tego, że forma znaku nie musi być przezroczysta, neutralna, nieznaczaca, a kreowane przez przekaz znaczenie - uwikłane $\mathrm{w}$ arbitralne relacje. $\mathrm{W}$ ich rozumieniu przekaz nie powinien też ograniczać się wyłącznie do tego, co wyczytujemy z poziomu idei ${ }^{365}$. Powstające wtedy (w Rosji) w opozycji do starej poetyki ujęcia, jak np. teoria $z_{a u m u^{366}}$ nastawione były na brzmieniowe wartości słowa i nie było tu jeszcze mowy o jego aspektach wizualnych czy materialnych. Niemniej, faktem jest, że artystów tego czasu (nie tylko poetów, ale i np. plastyków) łączyła - jak ujmuje to Markowski - „wiara w autonomię artystycznego materiału” ${ }^{367}$. Dla poezji było to Chlebnikowowskie samowitoje stowo (samorodne, samowystarczalne słowo $)^{368}$. Z czasem jego eksplorowanie zaczęło sięgać w inne niż wyłącznie fonetyczne przestrzenie (a stąd już bardzo blisko do liberatury).

Słowo to musiało zostać - jak wskazuje manifest Szkłowskiego - „wskrzeszone”. I tu już wyraźniej będzie widać poszukiwane przeze mnie analogie. Dostrzegana przez formalistów martwota słowa (podobnie jak ta opisywana później przez konkretystów ${ }^{369}$ czy liberatów) wynikała z pograżenia się w konwencji, wiązała się z „utratą jego zmysłowej wyczuwalności” ${ }^{370}$, tym, iż stawało się w pełni przezroczyste (i tym samym puste i nijakie):

Słowo poetyckie traci swą przezroczystość i daje się widzieć: oto teza Szkłowskiego [...] pisze Michał Paweł Markowski - Tak jak obraz definiowany jest przez układ plam, linii i wyczuwalną zmysłowo fakturę, tak i utwór poetycki zaczyna być traktowany jako układ słów obliczonych na widzenie ${ }^{371}$.

W tym miejscu można by powrócić do fragmentu Traktatu kartkograficznego przywoływanego na pierwszych stronach tego rozdziału. Wyraźnie bowiem

de Saussure'em, Hjelmslevem, Baudouinem de Courtenayem (a także Kruszewskim) a literaturoznawstwem daje Wojciech Górny w szkicu O stylistyce praskiego koła ([w:] Praska szkoła strukturalna $w$ latach 1926-1948..., s. 6-25). Badacz słusznie podkreśla też, że „samo wiązanie się z językoznawstwem nie byłoby jeszcze dla stylistyki jakimś novum godnym szczególnej uwagi, choć w tym czasie nie należało to do rzeczy oczywistych. Charakterystyczny jest związek z językoznawstwem określonego kierunku, i to związek twórczej wzajemności” (ibidem, s. 7).

${ }^{365}$ Przekonanie o nośności semantycznej samego słowa (,samego w sobie” - jak ujmą to później rosyjscy futuryści) było nad wyraz silne, a zbieżność czasowa z kryzysem symbolizmu włożyła artystom do ust kolejne argumenty. Krytykowano symbolizm za zbytnie odejście od konkretu, od języka jako narzędzia poezji i tworzenie z wierszy tekstów dla wtajemniczonych.

${ }^{366}$ Więcej o zaumie zobacz m.in. TLXXW s. 116 oraz Beata Śniecikowska, Stowo-obrazdźwięk. Literatura i sztuki wizualne w koncepcjach polskiej awangardy 1918-1939, Kraków 2005, s. $154-155,158-160$.

${ }^{367} T L X X W$, s. 116-117. Markowski podkreśla też, że dla plastyków owo usamodzielnienie się warstwy materiałowej oznaczało uwolnienie się od anegdoty, od narracyjności.

${ }^{368} T L X X W$, s. 117. Również Żyrmunski twierdził, że „materiałem poezji są nie obrazy i nie emocje, lecz słowo" (cyt. za: TLXXW, s. 124), co odwołuje nas oczywiście również do formuły autorstwa Mallarmégo, stającego się tym samym patronem już nie tylko konkretystów i liberatów, ale - poniekąd - i formalistów.

${ }^{369} \mathrm{Na}$ bliskość zaumu i poezji konkretnej zwraca uwagę Markowski (TLXXW, s. 116).

370 TLXXW, s. 118.

${ }^{371}$ Ibidem. 
widać, że już formaliści odrzucali negujące cielesność i fizyczność liter czy słów spojrzenie, przeciw któremu buntował się Nowakowski. A przypomnę, że wagę przestrzeni i kształtu słowa zaznaczał także Fajfer ${ }^{372}$.

Szkłowski stawia tezę, iż „dziśs słowa umarły i język stał się podobny do cmentarza”. Gdzie indziej mówi o „zwietrzałych słowach”373 bądź o ich „kamienieniu" (skamielinami mogą być nawet i większe kompozycje słów - całe utwory) ${ }^{374}$. Jego rozpoznanie (połączone z wiarą w możliwość zmiany) opiera się na analizie języka codziennego, na obserwacji automatyzacji naszego obcowania ze słowem ${ }^{375}$. Automatyzacji analogicznej do tej, o której wspominał Nowakowski. Szkłowski stwierdza:

Się ich [słów - AP] nie domawia i nie dosłuchuje w pełni - słowa takie zautomatyzowały się dla nas i nikt nie wyczuwa ich wewnętrznej (obrazowej) i zewnętrznej (dźwiękowej) formy. Nie odczuwamy tego, co zwykłe, nie widzimy, lecz - rozpoznajemy. Nie widzimy ścian naszych mieszkań, trudno nam spostrzec błąd drukarski w korekcie - zwłaszcza gdy chodzi o dobrze nam znany język, gdyż nie możemy się zmusić do tego, by zobaczyć, odczytać, a nie „rozpoznać” znane słowo ${ }^{376}$.

Wracając do Nowakowskiego, można by w tym miejscu postawić pytanie, czy i termin liberatura utworzony nie jest tak, by samym swym graficznym kształtem, owym sterczacym wewnątrz znanego słowa obcym elementem (litera „, b”) ${ }^{377}$, zmuszać nas do odczytań, nie rozpoznań ${ }^{378}$ ? Czy wymierzona przeciw martwocie słowa liberatura nie wychodzi od tych samych co formaliści wniosków? Mówiąc inaczej - czy nie jest ona sprzeciwem wobec skamieniałej formy

${ }_{372}$ Zob. m.in.: Z. Fajfer, tiryet, liberatura, s. 43-49.

${ }^{373}$ Wiktor B. Szkłowski, Wskrzeszenie słowa, tłum. Franciszek Siedlecki, [w:] Rosyjska szkoła stylistyki, red. Maria R. Mayenowa, Zygmund Saloni, Warszawa 1970, s. 57. Tak określa słowa pozbawione formy (na drodze przejścia od języka artystycznego ku codziennemu bądź naukowemu). Warto zaznaczyć, że szkic ten pochodzi z pierwszego okresu formalizmu, w którym nie badano jeszcze prozy. Przejście od poezji ku prozie Szkłowski rozumiał jeszcze jako umartwianie słowa, gdyż słowo niepoetyckie było dlań skonwencjonalizowane. Badaniem prozy w podobnej perspektywie zajmował się m.in. Ejchenbaum, o którym Mayenowa pisze następująco: „założenia jego analizy tkwią w poprzednio scharakteryzowanej teorii języka poetyckiego. W prozie szuka on tych samych zjawisk, których inni szukają w poezji, mianowicie przede wszystkim organizacji prozodyczno-fonicznej” (M. R. Mayenowa, Propozycje teoretyczne w zakresie form poetyckich, s. 46).

374 W. B. Szkłowski, Wskrzeszenie stowa, s. 58, 60.

375 Po części analogiczne wydaje się ujęcie Aleksandra Afanasjewicza Potiebni, który wyróżniając w słowie formę zewnętrzna, wewnętrzną i treść uważał, że słowa, w których treść wiąże się bezpośrednio z dźwiękiem (a więc: o zredukowanej formie wewnętrznej) pozbawione są wartości estetycznej (M. R. Mayenowa, Propozycje teoretyczne $w$ zakresie form poetyckich, s. 20-21). O stosunku Szkłowskiego do Potiebni (m.in. o jego zarzucie nierozróżniania języka i obrazowości poetyckiej od prozatorskiej) zob. Wiktor B. Szkłowski, Sztuka jako chwyt, tłum. Ryszard Łużny, [w:] Teoria badań literackich za granica. Antologia, red. Stefania Skwarczyńska, t. II, cz. III, s. 10-28.

${ }^{376}$ W. B. Szkłowski, Wskrzeszenie słowa, s. 55-56. Więcej o automatyzacji we wszelkich odmianach życia pisze Szkłowski w szkicu Sztuka jako chwyt (s. 15-16).

${ }^{377}$ Dobrze tu pamiętać, że początkowo często zapisywano ten termin z wielkim B w środku wyrazu.

${ }^{378} \mathrm{Na}$ taką genezę terminu zwraca uwagę Bazarnik w szkicu Liberature: a New Literary Genre? (s. 192). 
książki? A że w efekcie powstają tomy o kształtach nieraz i dziwacznych... Cóż, Szkłowski przyznawał, że „kiedy artysta zatęsknił do żywej formy i żywego, a nie martwego słowa, chcąc mu nadać oblicze, przełamał je i wykoślawił”379.

Chęć wskrzeszania słów, zrodzona z namysłu nad automatyzacją naszego postrzegania znaków, miała przywracać literaturze możliwości przekazywania nowego widzenia świata poprzez słowo. Poprzez słowo widziane jako prawdziwe tworzywo literatury. Tym samym - doda Markowski - „forma nie jest [...] zewnętrznym ornamentem lub - jak pisze Żyrmunski - «brzękadłem, które może istnieć lub nie», lecz koniecznym warunkiem odnowionego doświadczenia świata" ${ }^{380}$. Zatem u formalistów, podobnie jak w Fajferowskich manifestach, treść zyskuje swą pełnię wyłącznie w relacji z konkretną („udziwnioną) formą. I to dlatego ta ostatnia z pozycji mniej istotnego, nie zawsze dostrzeganego elementu, awansowała do roli semantycznie relewantnego składnika. Ową zależność nad wyraz trafnie podsumowuje Markowski słowami:

Poezja nie przedstawia rzeczywistości, ale się na nią nastawia czy ją ustawia, co oznacza, że forma poetycka nie jest wtórna wobec niej (jak w tradycyjnym pojęciu formy, w którą ubiera się treść), ale ją na różne sposoby konstytuuje ${ }^{381}$.

Zdaje się, że jest to postulat tożsamy z Fajferowskim stwierdzeniem, że w liberaturze słowa nie tyle są o czymś, co stają się tym czymś, czy z twierdzeniami Bazarnik mówiącymi o ikoniczności diagramatycznej charakteryzującej liberaturę (w której struktury świata mogą być odzwierciedlane poprzez struktury tekstu). O podobnej kwestii mówił Ejchenbaum, zauważając, że „formaliści uwalniali się od [...] pojmowania formy jako osłony, naczynia wypełnionego płynem (treścią)" ${ }^{82}$. Nie muszę chyba dodawać, jak bardzo to zakamuflowane odwołanie do Coleridgeowskiej formuły bliskie jest liberatom.

\subsection{Chwyty lit/berackie - ciąg dalszy formalistycznego wybijania $\mathrm{z}$ automatyzmu lektury}

Przywołany przed chwilą rosyjski badacz podkreślał również, że w istocie terminem ważniejszym, „znośniejszym” i bardziej użytecznym niż forma był w oczach formalistów chwyt. Dlaczego? Ejchenbaum argumentował, że mimo olbrzymiego wysiłku, jaki włożyli oni w pogłębienie znaczenia pojęcia forma,

379 W. B. Szkłowski, Wskrzeszenie słowa, s. 61.

380 TLXXW, s. 119.

381 Ibidem, s. 121.

${ }^{382}$ B. M. Ejchenbaum, Teoria metody formalnej, s. 174. Badacz traktował jednocześnie ten fakt jako zerwanie z „tradycyjną relacją «forma-treść»” (wyróżnienie - moje). Z kolei René Wellek pisał, że „wywody formalistów rosyjskich były częścią buntu przeciw pojmowaniu formy jako pojemnika, w który wlewa się gotową "treść»" (René Wellek, Pojęcie formy $i$ struktury w krytyce XX wieku, tłum. Ignacy Sieradzki, [w:] idem, Pojęcia i problemy nauki o literaturze, tłum. zbior., Warszawa 1979, s. 109). 
nadal nie eksponowało ono (w ich odczuciu) wystarczająco różnicy między językiem poetyckim a praktycznym, co było przecież kluczowe dla omawianej teorii. Zaś kategoria chwytu, który - podobnie jak wskrzeszanie słów - miał czytelnika odwieść od zautomatyzowanej lektury, a sam tekst uniezwyklić (by ten zadziwił odbiorcę), skupiła się właśnie na podkreśleniu możliwości eksploracji tego, co od automatyzacji uwalnia.

Proponuję zatem zatrzymać się na chwilę nad kategorią poetyckiego chwytu udziwnienia. Czy - analogicznie do wcześniej przywoływanych - i to sformułowane na gruncie formalizmu pojęcie wyda się użyteczne, gdy będziemy mówić o tekstach liberackich? Czy można by powiedzieć, że liberaci operuja chwytami? Czy istnieje coś takiego jak chwyt liberacki?

Zestawmy ze sobą przywoływane przez Szkłowskiego (jako egzemplifikacje chwytu udziwnienia) fragmenty opowiadania Tołstoja Bystronogi oraz fragmenty liberackiej hiperfikcji Koniec świata wedtug Emeryka Radosława Nowakowskiego ${ }^{383}$. „Ja” mówiące (stałe i niezmienne dla całego utworu Tołstoja) wyznaje:

przede wszystkim takie, jak: mój, moja, moje. Ludzie stosują te słowa do różnych rzeczy, istot i przedmiotów, a nawet do ziemi, do innych ludzi i do koni. Umawiają się, że o danej rzeczy tylko jeden z nich będzie mówił: moje. I tego, kto zgodnie z ustalonymi regułami owej gry powie o największej ilości rzeczy: to jest moje - uważają za człowieka najszczęśliwszego na świecie. Dlaczego tak sądza, nie wiem. Ale tak już jest. Nieraz próbowałem sobie wytłumaczyć, że mają z tego jakąś bezpośrednią korzyść, ale się okazało, iż podobna teoria nie ma żadnego uzasadnienia.

Na przykład wielu z tych ludzi, którzy mnie nazywali swoim koniem, nie jeździło na mnie, natomiast jeździli na mnie zupełnie inni. Karmili mnie również nie oni, lecz całkiem inni. Dbali o mnie tak samo nie ci, którzy mówili o mnie: „to mój koń”, lecz stajenni, weterynarze i w ogóle całkiem postronni ludzie ${ }^{384}$.

Z kolei wśród wypowiedzi multiplikowanego „ja” w Końcu świata według Emeryka znajdziemy m.in. monologi świni (zob. ilustracja 15) czy domu. Ten ostatni stwierdza:

${ }^{383}$ Odnośnie do tego tekstu zob. m.in. : Joanna Roszak, Mariusz Pisarski, Ja tu a ty tam. Polska powieść hipertekstowa a literacki kanon, [w:] Polska literatura najnowsza-poza kanonem, red. Paulina Kierzek, Łódź 2008, s. 219-239; Xymena Borowiak, Interpretacja bez granic? W hipertekstowym labiryncie „Końca świata wedtug Emeryka” Radosława Nowakowskiego, [w:] Tekst (w) sieci, red. Anna Gumkowska, Warszawa 2009, t. II, s. 190; Emilia Branny, O zwiazkach poezji wizualnej $i$ hipertekstu. Rozważania $w$ świetle „The Aesthetics of Visual Poetry 1914-1928” Williarda Bohna, „Techsty”, nr 5/2008, http://techsty.art.pl/magazyn/magazyn5/artykuly/branny01. html [dostęp 20.07.2009]; Andrzej Pająk, The Polish Way to E-literature from the Baroque to the 21th Century, http://elitineurope.net/node/23 [dostęp 15.11.2009]. Ja szerzej piszę o nim w szkicu Porzadek czy chaos, sieć czy zbieranina, logiczna konstrukcja czy zagmatwany labirynt? Na marginesie hipertekstowej powieści Radostawa Nowakowskiego, [w:] Hiperteksty literackie. Literatura i nowe media, red. Piotr Marecki, Mariusz Pisarski, Kraków 2011. Por. także fragment tej książki poświęcony e-liberaturze.

${ }^{384}$ Cyt. za: W. B. Szkłowski, Sztuka jako chwyt, s. 18-19 (tłum. fragmentu Tołstoja: Jerzy Jędrzejewicz). 
Wychodzi. Znowu wychodzi. A ja się rozpadam. A on ciągle tylko o tym myśli, że ja się rozpadam i zastanawia się co by tu zrobić, żeby ów rozpad powstrzymać i nic nie robi. Zapewne sądzi, że wkrótce i tak winorośl zarośnie mnie całkowicie i nie pozwoli mi się rozpaść. To zastanawianie się tak go pochłania, tyle mu czasu zabiera. To musi być coś doprawdy bardzo zajmującego.... takie rozmyślanie ...... takie zastanawianie się ...... takie wyobrażanie sobie. Bardzo bardzo zajmującego. Całkowicie zajmującego - no bo on nie tyko głowę ma zajęta, ale także i ręce. I nogi też. Brzuch chyba też, bo je niewiele. Gdyby jadł więcej, to myślenie nie mogłoby go tak zajmować, gdyż znaczna jego część byłaby już zajęta i gdzieś te myśli musiałyby się podziać. Pewnie gdzieś musiałyby ulecieć. A jakby uleciały to może by nie wróciły, może by się gdzieś zgubiły [...] Przesadzam z tym rozpadem. Ja tylko powoli i systematycznie niszczeję. Jak wszystko. Niszczeję czy raczej zmieniam się? Raczej zmieniam się. Zmieniam się czy raczej jestem zmieniany? Raczej jestem zmieniany. Kto i co mnie zmienia? Wszyscy i wszystko mnie zmienia. Czyli on też. I ja jego też. Tak. On mnie ciagle zmienia ${ }^{385}$.

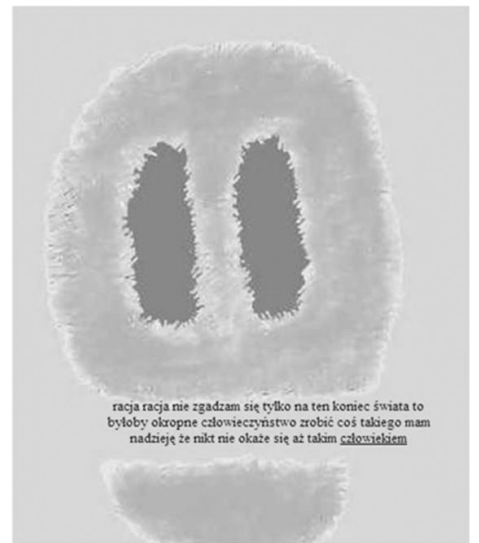

Ilustracja 15. Fragment leksji świnia z Końca świata wedtug Emeryka Radosława Nowakowskiego (zrzut ekranu) (źródło: Radosław Nowakowski, Koniec świata według Emeryka, Bodzentyn 2004, CD)

Jak widać, zastosowano tu podobny zabieg - narracja prowadzona z punktu widzenia bytu innego niż człowiek wskazuje na absurdy zachowań tego ostatniego. Udziwnienie dotyczy więc $\mathrm{w}$ tym wypadku przede wszystkim obrazu, jaki przez utwór jest przywoływany. Sam Szkłowski - dyskutując z teoria Potiebni - podkreślał, że dla wykreowania wrażenia zaskoczenia (i wyrwania tym samym czytelnika $\mathrm{z}$ więzów konwencji) obraz jest nieodzowny. Ma nas zbić z tropu, kazać spojrzeć na coś, co znamy w zupełnie inny sposób. Jak podsumowywał sam Szkłowski:

Celem obrazu jest nie ułatwienie nam zrozumienia przedmiotu, lecz wywołanie specyficznego sposobu percepcji tego przedmiotu, stworzenie jego „widzenia”, a nie „poznaw a n i a" $" 386$.

Tym samym przedmiot niejako wkracza w zupełnie nowy dlań obszar percepcji, komunikat zaś zyskuje nowe jakości semantyczne.

${ }^{385}$ Fragment leksji dom z Końca świata wedtug Emeryka Nowakowskiego.

${ }^{386}$ W. B. Szkłowski, Sztuka jako chwyt, s. 22, podkreślenie moje. 
W wydaniu liberackim jednak owo udziwnienie wydaje się ogarniać dodatkowy poziom tekstu - staje się także udziwnieniem samej formy zapisu, inaczej zatem rozumianego obrazu. Słowa bohaterów Końca świata wedtug Emeryka w większości wybijaja nas z „automatyzmu percepcji” nie tylko tym, o czym mówią (obraz u Szkłowskiego), ale i niekonwencjonalnym ukształtowaniem graficznym: np. filozoficzne w swym charakterze monologi łaki zapisane są na zielonym tle, upstrzone kolorowymi literami niczym kwiatami.

Owe nie-klasycznie utrwalone wyrazy nie pozwalają się nie doczytać, nie dają się domyśleć. Nakazują nam uważnie patrzeć i od-czytywać. Nie pozwalają ignorować tego, co zwykliśmy ignorować, gdyż inaczej - nie dowiemy się rzeczy dla zrozumienia narracji nieodzownych. Jak bowiem - jedynie automatycznie odczytując słowa - wywnioskować z poniższych fragmentów, którędy leciała mucha (zob. ilustracja 16), czy kim jest bohater wypowiadający żółto-zielony monolog (zob. ilustracja 17)?

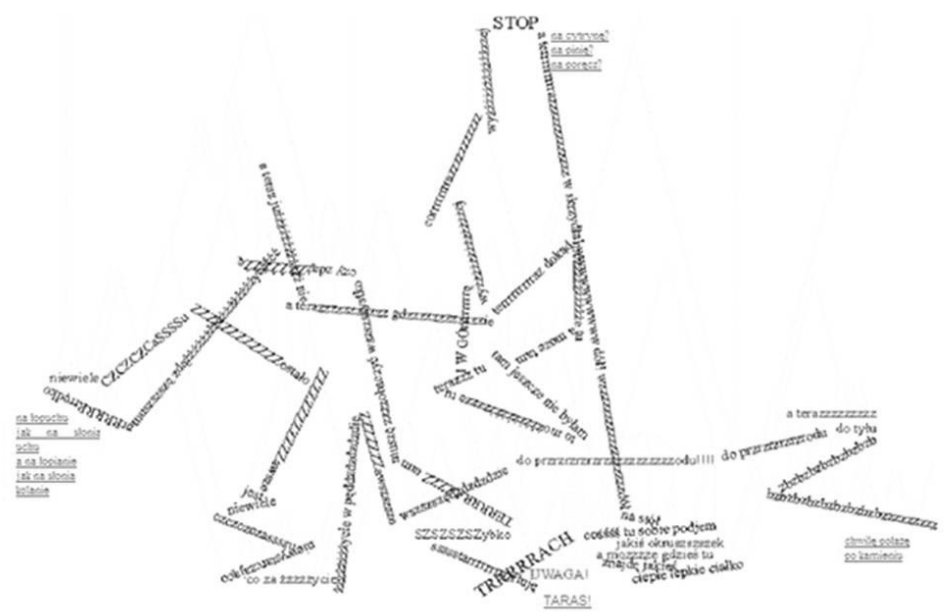

Ilustracja 16. Fragment leksji mucha z Końca świata wedtug Emeryka Radosława Nowakowskiego (zrzut ekranu) (źródło: Radosław Nowakowski, Koniec świata wedtug Emeryka, Bodzentyn 2004, CD)

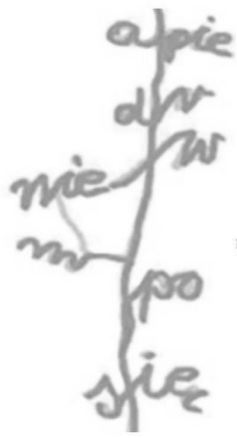

Ilustracja 17. Fragment leksji cytryna z Końca świata wedtug Emeryka Radosława Nowakowskiego (zrzut ekranu) (źródło: Radosław Nowakowski, Koniec świata według Emeryka, Bodzentyn 2004, CD) 
W innym utworze Nowakowskiego, Ulicy Sienkiewicza w Kielcach, z monotonii lektury będzie nas wybijać coraz dziwniejsze zapisywanie monologu bohatera - raz w tej, raz w innej przestrzeni dziewięcioipółmetrowej karty opowieści, to „tłoczac” wyrazy jeden koło drugiego, to znów literami bardzo oddalonymi od siebie bądź poukładanymi w dziwne kształty (o znaczeniu tych zabiegów wspominałam już w rozdziale o liberaturze i literaturze wizualnej). Z kolei we wcześniejszych utworach Nowakowskiego, jak choćby w Kronice Sabiny, czcionka użyta do zapisu monologu nieletniej narratorki odbiegała od przyjętych wzorców (przypominając w tym konkretnym przypadku raczej dziecięce pismo niż klasyczny druk). Trzeba przyznać, że twórczość tego właśnie artysty wydaje się nad wyraz podatna na analizę typograficzna i, tym samym, będzie zapewne powracajaccym punktem odniesienia w tym rozdziale.

Warto dla porządku dodać (czy przypomnieć), iż Szkłowski wielokrotnie podkreślał, że to właśnie artystyczna kreacja nastawiona jest na takie operowanie słowem (w tym także takie jego przestrzenne rozmieszczanie), by przykuwało ono uwagę do samego siebie, by nie stawało się nieme i neutralne.

Wszędzie spotkamy się z tą samą cechą zjawiska artystycznego; z tym, że zostało ono stworzone specjalnie dla percypowania pozbawionego automatyzmu, że jego widzenie było celem twórcy, że jest ono „sztucznie” stworzone tak, iż proces percepcyjny zatrzymuje się na nim i osiaga możliwie znaczne nasilenie i długotrwałośćs ${ }^{387}$.

Podobny wydaje się sposób i sens udziwniania, „uobrazowania” formy książki w liberaturze, jej zwracanie uwagi na samą siebie (swoista fetyszyzacja książkowości, jak ujęła to Pressman).

\subsection{Lit/beracka narracja mówiona/zapisana}

Szkłowski jednak jako główną przestrzeń zastosowań chwytów literackich postrzega poezję, „mowę utrudnioną, „mowę-konstrukcję”, która ma nas uwolnić od konwencji. Proza jest dlań jedynie „mową zwykłą: oszczędna, lekka, prawidłowa" ${ }^{388}$. Badacz, który pokazuje, że i w niej drzemie analogiczny potencjał to Borys Ejchenbaum. Jego analizy opowiadań Gogola wskazuja jeszcze jeden wątek, który zdaje się łączyć liberaturę z formalizmem.

Jeżeli podstawą stylu Gogola jest (jak formułuje to Ejchenbaum ${ }^{389}$ ) narracja mówiona, i - co więcej - jeżeli taki styl opowiadania ma nas prowadzić ku badaniu prozy nastawionemu na dźwiękową warstwę tekstu, to być może w opozycji do tych utworów liberatura - by raz na zawsze uniknąć problemów z tym, czy uwzględnia czy nie uwzględnia eksplorowanie akustycznych aspektów znaku - winna była otrzymać etykietę narracji zapisanej (bądź nawet lepiej: material-

387 Ibidem, s. 26.

388 Ibidem, s. 28.

389 Boris M. Ejchenbaum, Jak jest zrobiony „Płaszcz” Gogola?, tłum. Małgorzata Czermińska, [w:] Rosyjska szkoła stylistyki, red. M. R. Mayenowa, Z. Saloni, Warszawa 1970, s. 491-513. 
nej). Jako taką rozumielibyśmy tę jej odmianę, która właśnie ze swojej warstwy graficznej czerpie dodatkowe profity semantyczne. I tak, jak „charakterystyka akustyczna staje się w mowie Gogola znaczaca, niezależnie od znaczenia logicznego lub rzeczowego" ${ }^{390}$, tak może charakterystyka graficzna (przestrzenna czy - najlepiej - materialna) staje się taka u Fajfera czy innego liberata.

Ze względu na skupienie się na tym, co strukturaliści nazwą później funkcją poetycka, „u Gogola nie ma mowy neutralnej, prostych pojęć psychologicznych lub rzeczowych, połączonych logicznie w zwykłe zdania" ${ }^{391}$. Niknie sjużet, na plan pierwszy wysuwa się język w jego fonetycznym ukształtowaniu. Artysta - jak podsumowuje to Ejchenbaum - „potrafi podać najzwyklejsze słowo w taki sposób, że jego znaczenie logiczne lub rzeczowe blednie, za to obnaża się semantyka dźwiękowa i zwykła nazwa przybiera postać przezwiska" ${ }^{392}$. Ów problem „znaczenia logicznego” będzie pobrzmiewał później i u Mukařovskiego, który pójdzie o krok dalej i zauważy, że wcale nie musi być tak, że w pełni ono zanika, że dzieło sztuki ze swoją dominująca funkcją estetyczną i nakierowaniem na znak, nie wyklucza innych funkcji lecz - wręcz przeciwnie - płynnie między nimi oscyluje. W tym ujęciu nie tylko zostaje do znaku wprowadzony nowy potencjał znaczeniowy, lecz dodaje się go do potencjałów już istniejacych, które choć dotąd istniały, wykluczając się nawzajem - teraz mogą współegzystować. Takie przesunięcie akcentów spotkamy też w liberaturze.

W'sród formalistycznych terminów także i kategoria sjużetu, prozatorskiego (odpowiednika?) chwytu, może się wydać bliska liberatom. „Tak jak chwyt jest świadomą konstrukcją słowna, tak sjużet jest językową konstrukcją fabuły, która nie podporządkowuje się logice przyczynowo-skutkowej" stwierdza Markowski ${ }^{393}$. Zaś Szkłowski, miłośnik wszelakich kompozycyjnych udziwnień, byłby być może modelowym czytelnikiem Oka-leczenia, książki, w której schemat fabularny (raczej w gruncie rzeczy banalny) przesłania oparty o spiętrzone relacje sjużet. Zdecydowanie nie rządzi tą strukturą zasada przyczyna-skutek, wyjaśnień powiązań między poszczególnymi elementami trzeba doszukiwać się w znakowej konstrukcji całego tekstu (przy czym znak jest tu czymś już znacznie więcej niż litera, słowem) ${ }^{394}$.

\subsection{Lit/beracka odczuwalność formy}

Jeśli uważniej wczytać się w przywoływane tezy i postulaty, jasne stanie się, że moje rozważania coraz silniej kierują się w gruncie rzeczy ku strukturalizmowi, który - podejmując dyskusję z jednymi postulatami formalizmu, inne zaś rozwijając - skupiał się przede wszystkim na tych kwestiach, które

\footnotetext{
390 B. M. Ejchenbaum, Jak jest zrobiony „Płaszcz” Gogola?, s. 494.

391 Ibidem, s. 501.

392 Ibidem, s. 500.

393 TLXXW, s. 123.

${ }^{394}$ Zob. bibliografia podana w przypisie 66 rozdziału Liberatura a poezja wizualna.
} 
pozostają kluczowe również dla liberatów. Jednym z istotnych dla moich rozważań o liberaturze problemów, które zaczęto poruszać już w formalizmie, lecz które doczekały się pełniejszego rozwinięcia w strukturalizmie, jest kwestia literackości.

Przede wszystkim - postawiono postulat odpowiedzenia na pytanie, czym w ogóle owa literackość jest, wychodząc z założenia, że to kluczowe dla literaturoznawstwa zagadnienie. Postanowiono opisać esencję literatury. Stawiany przeze mnie postulat szukania definicji liberackości rodzi się z podobnych pobudek - z chęci (jak ujmowali to strukturaliści) nieodwoływania się do wszelkich zaprzyjaźnionych nauk, by pomogły opisać istniejące teksty ${ }^{395}$, lecz zastanowienia się nad istotą sprawy: nad tym, co przesądza o tym, że mówimy, iż tekst jest liberacki.

Formaliści, a w jeszcze większym stopniu strukturaliści, za esencję literatury uznali takie konstruowanie wypowiedzi, by pozbawić ją wszelkiego rodzaju neutralności, konwencjonalności (co służyć ma też odświeżeniu naszego spojrzenia na świat). Podstawą dla takich zabiegów jest zawsze język (czy - jak mówili Kruczonych i Chlebnikow - słowo i litera) sam w sobie, poszczególne wyrazy jako elementy znaczące materialnie/wokalnie/przestrzennie, nie zaś jako neutralne pojemniki na sens (jak ujmuje to Fajfer). Późniejsze formalistyczne badania, obejmujące już nie tylko poezję, ale i prozę, podkreślaja, że warstwa utworu zbudowana w oparciu o eksplorowanie językowego wysłowienia (lexis) jest nieprzekładalna na żaden inny system znaków $^{396}$ (i właśnie ona ma być właściwym przedmiotem badań poetyki). Postulat ten również przypomina twierdzenia odnoszone do liberatury, medialnie nieprzekładalnej ${ }^{397}$, z tym, że w jej przypadku - analogicznie jak w strukturalizmie (o czym za chwilę) - kategoria znaku zostaje jeszcze bardziej rozszerzona, a w konsekwencji przestrzenią artystycznej eksploracji staje się również sama książka. Z automatyzmu percepcji ma nas wybijać również sposób jej ukształtowania.

Za Ejchenbaumem mówi się, że literackość to „odczuwalność formy”. A podobnie można by powiedzieć i o liberackości: forma tekstu liberackiego jest bezsprzecznie odczuwalna, wyzwalając nas tym samym z automatyzmu percepcji. Przywoływane jako jeden z pierwszych punktów charakterystyki formalizmu „stawianie oporu przez formę" (postulowane przez Jakobsona) daje się z kolei porównać z liberacka interaktywnością omawianą przez Bazarnik. Wprowadzając ten wyznacznik literatury totalnej, badaczka zdaje się odnosić

395 Roman Jakobson pisał: „Jak dotąd, ogólnie historycy literatury podobni byli do policji, która mając aresztować daną osobę, zabrałaby na wszelki wypadek wszystkich i wszystko, co znajdowało się w mieszkaniu, ba, nawet osoby, które przypadkowo znalazły się w pobliżu domu na ulicy. Toteż ofiarą historyków literatury padało wszystko - życiowa egzystencja, psychologia, polityka, filozofia. Zamiast wiedzy o literaturze powstał konglomerat pochodnych dyscyplin" (R. Jakobson, Problemy poetyki, s. 39).

396 TLXXW, s. 123.

397 Zob. K. Bazarnik, Liberatura czyli o powstawaniu gatunków (literackich), s. 151-163. 
do formułowanych przez Fajfera pragnień, aby czytelnik walczył z danym tekstem, by utwór wymuszał na nim konkretne działania (stawiał opór wyuczonym technikom percepcji).

\subsection{Lit/berackie miejsca wspólne, czyli o powracających reinterpretacjach}

Zdaje się więc, że nie bez powodu formaliści i liberaci przywołują jako źródła inspiracji tych samych twórców czy podaja analogiczne przykłady tekstów realizujących preferowany przezeń model lit(b)erackości. Jednak moje śledzenie różnego rodzaju analogii nie ma bynajmniej być próbą porównania teorii formalizmu i teorii liberatury (gdyż takie ujęcie domagałoby się znacznie obszerniejszego opracowania). Wskazując na istotne podobieństwa, pragnę przede wszystkim zaznaczyć (podobnie jak czyni to Drucker w odniesieniu do twórczości opartej na eksperymentach typograficznych), że dla jednej i drugiej grupy artystów i teoretyków wspólne jest wyjście od namysłu nad tym, które elementy znaku i - szerzej - komunikatu można eksplorować ${ }^{398}$. Łaczy ich bowiem chęć wybudzenia odbiorcy z czytelniczego marazmu i odkrycia nowych przestrzeni znaczących, jednoczy ich patrzenie na znak w sposób, jakiego nauczył nas de Saussure.

Dość tu przypomnieć, że Szkłowski opisywał Życie i Myśli JW Pana Tristrama Shandy Sterne'a w podobny sposób jak teoretycy liberatury ${ }^{399}$. Zaś Ejchenbaum podkreślał, iż wysunięcie na plan pierwszy kategorii chwytu i motywacji, skupienie się na dotychczas ignorowanej „formie zewnętrznej”, nie tylko samej „treści” ${ }^{400}$, doprowadziło do reinterpretacji znanych tekstów kultury i dostrzeżenia ich dotychczas ignorowanych wartości. Pisał przecież:

Tak właśnie było z Tristramem Shandy Sterne’a. Powieść ta dzięki pracy Szkłowskiego [,Tristram Szendi” Sterna i tieorija romana, osobne wydawnictwo Opojazu z 1921 r. - AP] nie tylko stanowiła ilustrację dla twierdzeń teoretycznych, lecz również sama zyskała nowy sens i na nowo zwróciła na siebie uwagę ${ }^{401}$.

A nie sposób też nie zauważyć, że w ostatnim dziesięcioleciu stała się ona z kolei chętnie i licznie przywoływaną egzemplifikacją twierdzeń liberackich. Ponoć - jak wielokrotnie marzyli publicznie Fajfer i Bazarnik - ma być też wydana w serii Liberatura. Tu zaś można by kontynuować cytat z Ejchenbauma:

398 Przy okazji jednak staram się też podkreślać kolejne argumenty na rzecz tego, iż Fajfer nie miał racji, upierając się, że nikt przed nim nie poruszał kwestii materialności literatury.

399 A nadmienię, że ten właśnie przykład przywołuje też w swoim wywodzie Pressman (J. Pressman, The Aestheric of Bookishness..., s. 466).

${ }^{400}$ Tak charakteryzuje Ejchenbaum „dawną naukę”. Pisze też, że „operowała [ona - AP] jedynie materiałem, rozumiejąc go jako "treść», a całą resztę zaliczając do "formy zewnętrznej», która może zaciekawić tylko amatorów albo w ogóle jest nieciekawa" (B. M. Ejchenbaum, Teoria metody formalnej, s. 181).

${ }_{401}$ B. M. Ejchenbaum, Teoria metody formalnej, s. 182. 
O Sternie zaczęli mówić ci, którzy dotychczas nie widzieli w jego powieści niczego poza nudną gadaniną lub osobliwościami albo też patrzyli na niego ze stanowiska osławionego „sentymentalizmu”, którym Sterne grzeszył w równie małym stopniu, co Gogol „realizmem”402.

Ejchenbaum zaznacza też, że podkreślanie budowy powieści jest świadomie stosowanym przez Sterne’a chwytem: „w jego utworze uświadamianie sobie formy przez jej łamanie stanowi właśnie treść powieści”" ${ }^{403}$. Przywołać by tu można jeszcze samego Sterne’a, który - analogicznie do Szkłowskiego - chciał zerwać z nudna powtarzalnościa. Chciał książek (a owo rozumienie tekstu jako książki czyni go ponoć liberatem) innych, nie wiecznie takich samych:

Powiedzcie mi, mężowie uczeni [...] czyż zawsze będziemy robili nowe książki w ten sposób, $\mathrm{w}$ jaki aptekarze robią nowe mikstury - przelewając z jednego naczynia w drugie? ${ }^{404}$

Snując takie analogie, warto dodać, że (jak podkreśla też Ejchenbaum) wraz z rozwojem i dojrzewaniem doktryny formalistycznej coraz silniej eksplorowano kategorie takie jak materiał ${ }^{405}$. Zamysł artystów nie obejmował już tylko brzmieniowych jakości słów, coraz istotniejsza stawała się ogólna materiałowa charakterystyka znaku, słowa czy, wreszcie, całych zbudowanych zeń struktur. Powoli zyskiwały na wadze kategorie języka poetyckiego i tekstu postrzeganego jako jeden wielki znak. Idąc tropem Jakobsonowskich konstatacji i jego przejścia ku strukturalizmowi, chciałabym poświęcić trochę uwagi także temu nurtowi, by pokazać, że wypracowane na jego gruncie kategorie jeszcze pełniej rozwijają wątki, które dla badania liberatury wydaja się niebanalne ${ }^{406}$.

${ }^{402}$ Ibidem. Warto może też dodać, że podobnie reinterpretowali Sterne'a Genette i Butor (zob. m.in. Od Joyce'a do liberatury, sporo o przedstawionych w The Work of Art Genettowskich interpretacjach Sterne'a pisze też Bazarnik w swoim doktoracie).

${ }_{403}$ B. M. Ejchenbaum, Teoria metody formalnej, s. 182.

${ }^{404}$ Laurence Sterne, Życie i myśli JW Pana Tristrama Shandy, tłum. Krystyna Tarnowska, t. II, Warszawa 1958, s. 7-8.

${ }^{405} \mathrm{Z}$ czasem zaczął on być postrzegany jako „element, który uczestniczy w konstrukcji w zależności od charakteru dominanty formotwórczej” (B. M. Ejchenbaum, Teoria metody formalnej, s. 199). Na niejednolitość materiału sztuki słowa umożliwiającą dominację jednego z elementów zwracał uwage już Jurij Tynianow (zob. B. M. Ejchenbaum, Teoria metody formalnej, s. 190).

${ }^{406}$ Dopowiedzenia wymagałby też stosunek liberatury i formalizmu amerykańskiego. Szczególnie, że wprowadzony przez Johna C. Ransoma termin tekstura stał się tytułem jednej z pierwszych książkowych pozycji poruszających kwestie liberackości (wielokrotnie tu przywoływana TEKST-TURA... Małgorzaty Dawidek Gryglickiej). Trzeba pamiętać, że owa - jak pisze Markowski - „retoryczno-językowa warstwa utworu literackiego”, nieredukowalna do struktury, czyli treści logicznej jest charakterystyczna wyłącznie dla poezji. W rozumieniu Nowych Krytyków wyłącznie przynależny do tego rodzaju utwór postrzegany jest jako autonomiczny słowny artefakt, the verbal icon (słowna ikona/słowny obraz), w którym nie da się oddzielić formy od treści. Jak pisze Cleanth Brooks: „forma i treść zespoliły się tak bardzo, że każda próba oderwania treści, by mówić o niej osobno, to gwałt na wierszu i grozi redukcją «formy» do retorycznej skorupki lub opakowania”. Jednak close reading skupiające się nie tylko na lekturze struktury treści, ale i jej tkanki (tekstury) przynależne jest wyłącznie poezji, gdyż zdaniem amerykańskich formalistów, proza pozbawiona jest tekstury. O ile więc łączy ich z liberatami podejście do organicznej relacji między dwoma poziomami dzieła czy dostrzeżenia słowa jako materialno-językowego budulca tekstu, 


\subsection{Strukturalizm, czyli o liberackim czytaniu de Saussure'a raz jeszcze}

Jeśli próbować by wyznaczać linię rozwojową odnoszącej się m.in. do problemu zapisywania tekstów (i stąd ważnej jako kontekst moich rozważań) refleksji o znaku ${ }^{407}$, której początków dopatrywałam się w teorii de Saussure'a i której ewolucja prowadzi ku myśleniu podobnym liberackiemu - strukturalizm zajmie w niej z pewnościa miejsce szczególne. Kompleksowe porównywanie tych teorii wydaje się dla moich badań raczej mało użyteczne ${ }^{408}$, niemniej, poszukiwanie punktów wspólnych rozmaitych ujęć teoretycznoliterackich pomaga spojrzeć na koncepcję literatury totalnej z szerszej perspektywy i lepiej ocenić jej przydatność. Tym samym, proponowane tu porównania mają też na celu pokazanie korzeni liberackiej refleksji, osadzenie dywagacji Fajfera i Bazarnik w teoretycznoliterackiej tradycji. Kluczową dla mojego wywodu rolę inspiracji de Saussure'em w myśli strukturalistycznej akcentuje Anna Burzyńska ${ }^{409}$, pisząc:

wykluczenie prozy z obszaru tego typu odczytań, odebranie jej wręcz całego poziomu znaczeń zdaje się ich znacząco dzielić (por.: TLXXW; o kategorii tekstury zob. też Pojęcie formy $i$ struktury w krytyce XX wieku, tłum. Ignacy Sieradzki, [w:] René Wellek, Pojęcia i problemy nauki o literaturze, tłum. zbior., Warszawa 1979, s. 106).

${ }^{407}$ Istotne wydaje się tu wskazanie linii rozwojowej i wzajemnych zależności między myślą językoznawców, zarówno Szkoły Genewskiej (de Saussure) oraz Kopenhaskiej (Hjelmslev), jak i Praskiej (także jako kontynuacji myśli formalistycznej; tu przede wszystkim wczesny Jakobson) a literaturoznawczo zorientowaną Praską Szkołą Strukturalną (nie tylko Jakobson, ale i Mukařovský) i poetyką lingwistyczną (teoria „późnego” Jakobsona).

${ }^{408}$ Punktem odniesienia stanie się dla mnie przede wszystkim część nurtu inspirowana badaniami językoznawczymi (a w mniejszym stopniu antropologia). Nie będzie mnie tu zatem interesować (nawet kontekstualnie) późne literaturoznawstwo strukturalne, wszelkie gramatyki literatury zrodzone z inspiracji myślą antropologiczną Claude’a Lévi-Straussa czy gramatyka transformacyjno-generatywną Chomsky'ego; ogólnie rzecz biorąc mało przydatna będzie szkoła narratologiczna i jej okolice (jako skupione na badaniu schematów fabularnych, nie samego tworzywa literatury). O zmianie głównych zainteresowań badawczych i skierowaniu refleksji na tory mniej dla moich rozważań inspirujące pisze Anna Burzyńska: „O ile jednak [...] w koncepcjach Mukařovskiego czy Jakobsona kategorią nadrzędną był znak, a ich wysiłki skierowane były przede wszystkim w stronę uznania dzieła literackiego za fenomen znakowy i możliwości dookreślenia jego specyfiki semiotycznej, o tyle w czasach późniejszych - zwłaszcza na gruncie strukturalizmu francuskiego końca lat sześćdziesiątych i siedemdziesiątych - w centrum zainteresowania znajdzie się już nie sam znak, lecz system znaków. I odpowiednio - najważniejszym zadaniem okaże się wówczas opisanie systemu znaków literackich i kulturowych" (TLXXW, s. 221).

${ }^{409}$ Przywołując jej słowa, pragnę jednak zaznaczyć, że - jak wykazywałam - już na gruncie formalizmu widać pierwsze wpływy szwajcarskiego językoznawcy i pokrewnych mu teorii na myślenie teoretyków i praktyków literatury. Tynianow i Jakobson w 1927 r. pisali: „Uzasadnienie dwóch różnych pojęć - «parole» i «langue» i analiza stosunków pomiędzy nimi (szkoła genewska) były nadzwyczaj płodne dla językoznawstwa. Zasadniczego opracowania na nowo wymaga problem stosunków między tymi dwiema kategoriami (daną normą a indywidualną wypowiedzia) w odniesieniu do literatury" (Jurij Tynianow, Roman Jakobson, Problemy badania literatury i języka, [w:] Teoria badań literackich za granica. Antologia, red. Stefania Skwarczyńska, t. II, cz. III, s. 211). 
De Saussure'owski program teorii języka i językoznawstwa ogólnego stworzy [...] coś w rodzaju światopoglądu badawczego, który na długie lata nada ogólny charakter poszukiwaniom literaturoznawców. Na gruncie wiedzy o literaturze strukturalizm zaowocuje cała serią poetyk strukturalnych - począwszy od przedwojennych dokonań Szkoły Praskiej, do rozmaitych poetyk lat sześćdziesiątych, siedemdziesiątych i osiemdziesiątych (lingwistycznej, generatywnej, poetyk odbioru czy poetyk intertekstualnych). Pierwsi adaptacji poglądów de Saussure’a do nauki o literaturze podejmą się przedstawiciele Praskiej Szkoły Strukturalnej. Będą oni jednak nie tylko wiernie kontynuowali dzieło de Saussure’a, lecz także zmodyfikują jego koncepcję, tak by uczynić ją jeszcze bardziej przydatną do wyrażenia specyfiki literatury i do stworzenia precyzyjnego programu jej badania ${ }^{410}$.

Sam Roman Jakobson zwracał uwagę na kierunek wprowadzanych zmian, podkreślając, że zmierzały one ku uwypukleniu semantycznej nośności obu poziomów znaku i coraz większego eksplorowania nie tylko nośności warstwy znaczącego i znaczonego, ale też ich wzajemnych relacji. Tych ostatnich zaś zdecydowanie nie chciał Jakobson (ani też inni strukturaliści) sprowadzać do arbitralnych związków. Stopniowo wprowadzane przez kontynuatorów de Saussure’a zmiany przywołany badacz opisuje następująco:

Pod sam koniec swej działalności de Saussure przyjął stoicką koncepcję znaku słownego: koncepcję pary złożonej z postrzeganego signifiant i pojmowanego umysłem signifié. Zrozumiał, że te dwa elementy są ściśle ze sobą związane i „wymagają siebie nawzajem”. Uczyl jednak, że związek między signifiant a signifié jest arbitralny i że „wszelki system językowy opiera się na irracjonalnej zasadzie arbitralności znaku”. [...] Motywacja relatywna, gramatyczna, cytowana przez de Saussure’a, dla ograniczenia arbitralności związku między obiema stronami znaku słownego, okazała się stanowczo niewystarczająca. Na tradycyjną wiarę w ,arbitralność znaku słownego”, głoszoną w Kursie, rzucają cień związki wewnętrzne, ikoniczne związki między signifiant a jego signifié, zwłaszcza zaś ścisłe więzi łączące pojęcia gramatyczne z ich wykładnikami fonologicznymi. W ten sposób lingwistyka posaussure’owska rozszerza problem stosunku między signifiant a signifié także na fonologiczną stronę języka, wysuwając na pierwszy plan skomplikowane zagadnienia wzajemnego oddziaływania i rozgraniczenia poziomu fonologicznego i gramatycznego ${ }^{411}$.

Dalszych przesunięć w tej kwestii dokonał, jak już sygnalizowałam, Mukařovský, który pokazał, że wcale nie wyłącznie fonologiczna strona języka może być podstawą semantycznej eksploatacji znaczącego. Badacz ten przede wszystkim - co zaznaczałam wcześniej - dokonał niezwykle istotnego dla moich rozważań przesunięcia kategorii znaczącego ze sfery wirtualności, niematerialności (jak było ono postrzegane u de Saussure’a) w obszar tego, co konkretne. Takie ujęcie zakładało, że signifiant to postrzegalny zmysłowo aspekt znaku ${ }^{412}$.

${ }^{410}$ TLXXW, s. 206.

411 Roman Jakobson, Zwiazki językoznawstwa z innymi naukami, [w:] idem, W poszukiwaniu istoty języka. Wybór pism, t. I, Warszawa 1989, s. 402, podkreślenia moje.

${ }^{412}$ Definicje znaczącego formułowane na gruncie francuskiego strukturalizmu pokazują wyraźnie, jak uprawomocniało się owo oddalające nas od de Saussure’a przejście w dziedzinę konkretności. Znaczące jest tam definiowane jako „zmysłowa część znaku, związana z znaczonym” - podkreśla Johanna Drucker. Dodaje, że staje się ono czysto fizyczne, materialne, niemal dające się dotknąć (J. Drucker, s. 32-33). 
Idąc tym tropem, warto prześledzić, jak czysto akustycznie rozumiane signifiant zaczyna w szkicach Mukařovskiego nabierać charakteru materialnego. Przywołując - kogóż by innego niż - Mallarmégo, badacz pisze:

Znakiem graficznym intonacyjnych właściwości tekstu [bo one, jako przynależące do warstwy fonicznej, są tu centrum zainteresowań - AP] mogą stać się także rozmaite rodzaje druku (kursywa, wersalik), jeśli użyto ich w tym celu w tekście drukowanym normalnie, jak to z upodobaniem praktykowali symboliści. Tegoż znaczenia może nabrać dzielenie tekstu na wersy, jeśli w ten sposób oznaczono podnoszenie się i opadanie intonacji, ewentualnie inne jej właściwości. Mallarmé we wstępie do Un coup de dés mówi wprost o graficznym układzie stronicy jako o „partyturze” ${ }^{413}$.

Co ciekawe, badacz nie wskazuje już takiego analogemu dla tembru głosu - a takie przecież również jest znaczenie grafii u Mallarmégo (nie mówiąc już np. o Oka-leczeniu) ${ }^{414}$.

Podobnie zdają się podchodzić do tych kwestii i liberaci eksplorujący wielorako rozumianą materialność signifiant i zmuszający odbiorcę do badania jego związku z signifié. Oni także nie mogliby zadowolić się stanem opisanym przez Jakobsona, gdyż liberatura to taka literatura, w której strukturalne więzi sięgają relacji signifiant-signifié, zaśs znaczące nie musi być jakością wirtualna, lecz może stać się jak najbardziej namacalne. Sam Jakobson komentował też rosyjski futuryzm jako nurt zasadniczo koncentrujący się na tej nowoodkrytej materialności kodu, języka, słowa ${ }^{415}$. Warto też może dodać, że - jak podkreślał zresztą badacz - oczywista jeszcze dla de Saussure'a linearność signifiant przestała być jako taka postrzegana w momencie pogłębienia badań fonologicznych (rozłożenia fonemów na elementy jednoczesne). A przecież także w liberaturze ową linearność zastępuje się wielokierunkową strukturalnościa.

Co dla mnie ważne, jeśli przyjrzeć się powodom, które skłaniały ku odejściu od formalizmu ku strukturalizmowi - okaże się, że i one są bliskie liberatom. Dość tu przypomnieć, że postulowane przez Romana Jakobsona i Jurija Tynianowa ${ }^{416}$ przejście od pojmowania literatury jako sumy chwytów (ujęcie typowe dla formalizmu) do poszukiwań funkcjonalności całego tego zbioru oraz jego poszczególnych elementów (także dopatrywanie się w nim celowej i sprawnie funkcjonujaccej struktury) bliskie jest ujęciom teoretyków literatury totalnej, dla których - jak najprościej ujmuje to Fajfer - wszystko w tekście musi być „po coś”.

${ }^{413}$ J. Mukařovský, O języku poetyckim, tłum. Wojciech Górny, [w:] Praska szkoła strukturalna w latach 1926-1948. Wybór materiatów, red. Maria R. Mayenowa, Warszawa 1966, zwłaszcza s. 160 .

${ }^{414}$ Wśród jaskółek myśli liberackiej widać u Mukařovskiego również wskazania na potencjalność przekazu zawartego w signifiant (nawet rozumianym wyłącznie jako dźwiękowa warstwa znaku), kiedy pokazuje - za Jakobsonem - jak w twórczości Máchy układ rytmiczny odzwierciedla stosunek do przestrzeni (J. Mukařovský, O języku poetyckim, zwłaszcza s. 195-196).

415 „Wszyscy futuryści rosyjscy są twórcami poezji «samorodnego, samowystarczalnego słowa» jako kanonizowanego odkrytego materiału" - pisał (R. Jakobson, Problemy poetyki, s. 37).

${ }^{416}$ J. Tynianow, R. Jakobson, Problemy badania literatury i języka, s. 210. 
Spośród tez formułowanych przez Praskie Koło Lingwistyczne dla moich badań istotne zdaje się również: zwrócenie uwagi na autoteliczność znaku (podkreślanie osłabienia jego odwołań do sfery pozajęzykowej) oraz na te poziomy systemu języka, które w wypowiedziach nie-poetyckich (nie-artystycznych) moga nie być eksponowane i pozbawiane bywają wtedy nośności semantycznej (najczęściej wspominano tu o warstwie brzmieniowej, jednak analogicznie można dodać tu i warstwę wizualna/materialna $)^{417}$. Ważne wydaje się również ujęcie funkcji estetycznej (Mukařovský) czy poetyckiej (Jakobson) nakierowanej na zwrócenie uwagi na sam znak językowy. Dla strukturalistów jest to już znak rozumiany zupełnie inaczej niż było to przed de Saussure’em, bardzo „po liberacku”. Jak, komentując tezy Koła Praskiego, podsumowuje Maria Renata Mayenowa:

Należy pamiętać, że znak jest konstrukcją dwustronna, łącząca w nierozdzielną jedność stronę fizykalna, zmysłowo dostrzegalny kształt (signans, signifiant) i podporządkowany mu sens, znaczenie (signatum, signifié) ${ }^{418}$.

Przede wszystkim zaś, ów znak jest elementem języka poetyckiego, kategorii kluczowej dla strukturalizmu. Trzeba jednak podkreślić, że punktem wyjścia do skupienia się właśnie na nim są rozważania bliskie myśli Szkłowskiego. Podkreślano bowiem odmienność wspomnianego języka od mowy codziennej, związaną z nietypowym eksplorowaniem znaczeń. Sprzeciwiano się automatyzacji odbioru, czyniąc z owego odrzucenia neutralności samego komunikatu istotę literackości:

\begin{abstract}
Różne płaszczyzny języka poetyckiego (np. fonologia, morfologia itd.) tak ściśle są ze sobą powiązane, że nie można badać jednych z nich bez rozpatrzenia pozostałych, jak to często robili historycy literatury - czytamy w Tezach. - Z tej teorii wynika, że język poetycki dąży do uwydatnienia autonomicznej wartości znaku, że wszystkie płaszczyzny systemu językowego, które w języku porozumiewania się pełnią tylko rolę służebna, uzyskują w języku poetyckim wartość autonomiczną mniej lub bardziej ważką. Środki wyrazu należące do tych płaszczyzn i stosunki zachodzące między tymi środkami, które w języku porozumiewania się zmierzaja do zautomatyzowania się, w języku poetyckim, przeciwnie, zmierzają do aktualizacji ${ }^{419}$.
\end{abstract}

Co więcej, każdorazowo owe zaktualizowane elementy zyskują oryginalna, indywidualna, niepowtarzalną hierarchię. I ją właśnie należy poddawać analizie - oto też struktura dzieła. „Dzieło poetyckie jest strukturą funkcjonalną i różnych jego elementów nie można zrozumieć poza ich związkiem z całościa" ${ }^{420}$ - dodadzą autorzy Tez. O takie rozumienie literatury dopraszaja się też liberaci zachęcający do tworzenia tekstów, w których to, co napotyka czytelnicze oko nie jest neutralne. Proponują oni bowiem lekturę skupiona

${ }^{417}$ Burzyńska mówi tu o „możliwości aktualizacji któregoś z poziomów [języka - AP] (wysunięcia go na pierwszy plan)”, TLXXW, s. 223, zob. też s. 207.

${ }^{418}$ M. R. Mayenowa, Analiza doktryny stylistycznej praskiego koła, s. 34.

419 Tezy praskiego koła (fragment), s. 51.

${ }_{420}$ Ibidem. 
na wszystkim, co jawi się przed zmysłami odbiorcy (i to nie tylko przed wzrokiem, ale przecież choćby i przed dotykiem) - taka, podczas której poszczególne aspekty znaku (jego materialności) mają szansę się zaktualizować.

Również Roman Jakobson, określając funkcję poetycką jako zwrócenie uwagi na sam komunikat (jego strukturę), wskazując na „wysunięcie wyczuwalności znaku”421 jako kluczową jej cechę, sprzeciwiał się automatyzacji odbioru. Definiujacca sztukę słowa (bo nie tylko poezję) funkcja poetycka „w pozostałych aktach językowych występuje” - jak mówi badacz - ,jako element podrzędny, akcesoryjny" ${ }^{422}$. Na gruncie sztuki ${ }^{423}$ nie pozwala ona nie zauważyć samego komunikatu:

Ale w czym się przejawia poetyckość? - w tym, że słowo jest odczuwane jako słowo, a nie tylko jako reprezentant nazwanego przedmiotu lub jako wybuch emocji. W tym, że słowa, ich zestawienia, ich znaczenie, ich zewnętrzna i wewnętrzna forma nie są tylko obojętnym skierowaniem uwagi na rzeczywistość, lecz nabywają własnej wagi i wartości ${ }^{424}$.

Podobne są słowa w liberaturze, literaturze ważącej każdą literę, w której odczuć mamy nie tylko słowo, ale i większe jego struktury - gdyż takim samym komunikatem-znakiem ma być dla nas i forma woluminu.

Nie zamierzam jednak stawiać znaku równości między przywoływanymi teoriami a liberatura. Jej twórcy z pewnością nie zgodzą się na przykład z założeniem (w Tezach Praskiego Koła wypowiedzianym wprost), że nastawiony na fonologię punkt widzenia jest tu uprzywilejowany. Niemniej, już w przywołanym manifeście artykułuje się, że wszelkie aspekty znaku mogą być w tekście literackim aktualizowane: także „elementy akustyczne, motoryczne i graficzne danego języka, których nie wykorzystuje się w systemie fonologicznym tego języka i w jego odpowiedniku graficznym" 425 .

Co więcej, wydaje się nawet, że teoria strukturalistyczna jest „ostrzejsza” niż liberacka, ta ostatnia bowiem dopuszcza sytuacje, w których artysta pracuje w języku wyłącznie symbolicznym, nie eksplorując innych aspektów znaku/struktury tekstu. Z Tez zaś zdaje się wynikać jakby ani artysta, ani krytyk nie mieli prawa pozostać na tym poziomie:

Wskaźnikiem organizującym sztuki, odróżniającym ją od innych struktur semiologicznych, jest skierowanie intencji nie na oznaczanie, lecz na sam znak. Zasadniczą cechą poezji jest skierowanie intencji na wyraz słowny. Znak jest dominantą w systemie artystycznym i gdy

421 R. Jakobson, Poetyka w świetle językoznawstwa, s. 86.

${ }^{422}$ Ibidem.

${ }^{423} \mathrm{~W}$ szkicu Język a inne systemy komunikacji Jakobson wprowadza pojęcie funkcji estetycznej będącej odpowiednikiem poetyckiej w szerszym kontekście. Zob. R. Jakobson, Język a inne systemy komunikacji, s. 68.

${ }^{424}$ Roman Jakobson, Co to jest poezja?, tłum. Maria R. Mayenowa, [w:] idem, W poszukiwaniu istoty języka. Wybór pism, t. II, Warszawa 1989, s. 139.

${ }^{425}$ Tezy praskiego koła (fragment), s. 52-53. Na rolę zapisu i odrębność tekstów pisanych od wypowiedzianych zwraca również uwagę Roman Jakobson (jak sam przyznaje: właśnie z inspiracji fonologów z Praskiego Koła Lingwistycznego). Por. R. Jakobson, Język a inne systemy komunikacji, s. 72 . 
historyk literatury głównym przedmiotem badania czyni nie znak, lecz to, co jest oznaczane, gdy bada ideologię dzieła literackiego jako byt niezależny i autonomiczny, rujnuje hierarchię wartości badanej przez siebie struktury ${ }^{426}$.

Jednakże Tezy... mają charakter manifestu, podobnie jak pierwsze z publikowanych esejów Fajfera, które (jak podkreślałam na początku moich rozważań) cechowało podobne, buńczuczno-mentorskie zacięcie.

\title{
1.9. Nowe nośniki znaczeń i struktura lit/beracka
}

Znaczenie rozwoju lingwistyki dla literaturoznawstwa (akcentując dokładnie te same elementy, które już nieraz tu wskazywałam) podkreślał również Jan Mukařovský, ten ze strukturalistów, który - jak już wielokrotnie wspominałam - dokonał największych przesunięć w dyskursie postsaussure’owskim i którego sposób myślenia najbardziej zbliża się do liberackiego.

Rozwijając fonologię, językoznawstwo otworzyło teorii literatury drogę do badań dźwiękowej strony słownego dzieła sztuki - stwierdzał. - Analizując funkcje językowe, stworzyło nowe możliwości dla badań stylistyki języka poetyckiego; a wreszcie, kładąc nacisk na znakowy charakter języka, umożliwiło rozumienie dzieła artystycznego jako znaku ${ }^{427}$.

Jednak, jak widać też z moich dotychczasowych rozważań, teza taka wymaga rozwinięcia i (w konsekwencji) pojawiają się kolejne kwestie domagajace się poruszenia, co Mukařovský sygnalizuje następującymi słowami:

\begin{abstract}
Powstaje teraz pytanie, jakie składniki dzieła sztuki mogą być nośnikami znaczeń współtworzących jego pełny sens. Nie jest to pytanie zbyteczne, ponieważ dotąd jeszcze nie zostal ostatecznie obalony pogląd, jakoby jedynymi nośnikami sensu dzieła były składniki zwane umownie „treściowymi” w odróżnieniu od „formalnych”. Nosicielami znaczenia, a tym samym i czynnikami współtworzącymi pełny sens dzieła sa jednak (jak założyliśmy to w niniejszym studium) wszelkie dające się wyróżnić składniki ${ }^{428}$.
\end{abstract}

Dalej wymienia jako przykładowe: poszczególne słowa, elementy dźwiękowe, formy gramatyczne, czynniki syntaktyczne (budowę zdań), frazeologię, składniki tematyczne. Liberat zaś (podzielając przecież z badaczem pogląd

${ }^{426}$ Tezy praskiego koła (fragment), s. 55.

${ }^{427}$ Jan Mukařovský, O strukturalizmie, tłum. Józef Mayen, [w:] idem, Wśród znaków i struktur. Wybór szkiców, red. Janusz Sławiński, Warszawa 1970, s. 25, podkreślenie moje. Co ciekawe, w innym szkicu Mukařovský zwraca uwagę na relację odwrotna, podkreślając, że zbliżenie teorii literatury i lingwistyki jest naturalną konsekwencją postrzegania dzieła sztuki jako znaku (Jan Mukařovský, Strukturalizm w estetyce i nauce o literaturze, [w:] Teoria badań literackich za granica. Antologia, red. Stefania Skwarczyńska, t. II, cz. III, Kraków 1986, s. 232).

${ }^{428}$ J. Mukařovský, O strukturalizmie, s. 32, podkreślenie moje. Dalej zaś Mukařovský dodaje: „Wszystkie elementy określane tradycyjnie jako formalne są więc w dziele sztuki nosicielami znaczeń, są cząstkowymi znakami. Ale i przeciwnie, składniki określane z reguły jako treściowe (tematyczne) są w istocie także tylko znakami, które nabierają pełnego znaczenia dopiero w kontekście dzieła” (s. 34). 
o wciąż trwającym bagatelizowaniu roli elementów nie-treściowych) dodałby do tej listy również aspekty graficzne czy - szerzej - materialne. Jeśli przypomnieć współczesną myśli Mukařovskiego twórczość Kruczonycha, Chlebnikowa czy Marinettiego okaże się, że - jak sygnalizowałam wcześniej, przywołując argumenty Drucker - postulaty te bliskie są także intencjom artystów pierwszych dziesięcioleci XX w.

Dalszych argumentów potwierdzających bliskość spojrzenia liberackiego i strukturalistycznego nie trzeba długo szukać. Zdaniem Sławińskiego, proponowane przez Mukařovskiego rozumienie dzieła sztuki jako wysoko-zorganizowanego znaku każe i w nim samym „odróżnić dwie strony: materialny nośnik i znaczenie" ${ }^{229}$. Przy tak postawionej tezie, twierdzenie liberatów, że książka to materialna forma, postać, ucieleśnienie tekstu (a zatem: rodzaj znaku), przybliża ich do strukturalizmu. Rozumiany liberacko tekst to również znak wysoko zorganizowany, sama zaś książka staje się signifiant. Trzeba też przypomnieć, że zdaniem Fajfera sformułowana przezeń teoria w ogóle obalała pojęcia nośnika, tak bardzo stawał się on integralną częścią tekstu, nieoddzielnym elementem znaku ${ }^{430}$.

Jak zauważał Mukařovský, składniki wymienione przezeń jako potencjalnie semantycznie relewantne, „na pierwszy rzut oka obojętne pod względem semantycznym mogą aktywnie ingerować w znaczeniową konstrukcję dzieła" ${ }^{31}$. Wyrwane z kontekstu potrafią wydawać się neutralne, pozornie nie nieść znaczeń. Jednak uwikłane we wzajemne relacje, stanowiąc część tego, co charakteryzujemy terminem dynamicznej struktury, użyte w określony sposób (co Mukařovský nazywa chwytem artystycznym) stają się semantycznie istotne. Dzieło sztuki, rozumiane jako nad wyraz skomplikowany znak przekazywany między nadawca a odbiorca ${ }^{432}$, zbudowane jest właśnie z takich - sygnalizowanych na różnych poziomach tekstu - cząstkowych znaczeń. Zaś wspomniana dynamiczność tej struktury polega również na tym, że każdy taki pojedynczy znak cząstkowy (w miarę uświadamiania go sobie przez odbiorcę) rozbudowuje ja, dopełniajac sens, zmieniając i rozszerzajac znaczenia dotychczas odkryte.

Misterna konstrukcja, jaka jest Oka-leczenie Fajfera i Bazarnik, idealnie daje się opisać właśnie kategorią takiej dynamicznej, wiecznie się dopowiadajacej struktury ${ }^{433}$. Analiza i interpretacja tego utworu ${ }^{434}$, a także tezy Bazarnik dotyczące wyznaczników liberackości uzmysławiają nam, jak bardzo liberaci

${ }^{429}$ Janusz Sławiński, Jan Mukařovski: program estetyki strukturalnej, [w:] Jan Mukařovský, Wśród znaków i struktur. Wybór szkiców, red. Janusz Sławiński, Warszawa 1970, s. 17. Dalej Sławiński dodaje, że „o swoistości poszczególnych sztuk decydują: a) charakter materialnych nośników, z których się korzysta, i sposoby ich organizowania; b) zasady podporządkowywania owym nośnikom pewnych wartości znaczeniowych; c) charakter wyróżnialnych jednostek semantycznych i sposoby konstruowania z nich większych całości sensu”. Sam Mukařovský z kolei zwraca uwagę na możliwość przenikania się sztuk na drodze substytucji tworzyw (J. Mukařovský, O strukturalizmie.).

${ }^{430}$ Zob. Z. Fajfer, Liberatura: hiperksięga w epoce hipertekstu, [w:] LCLT, s. 52 (-8).

431 J. Mukařovský, O strukturalizmie, s. 33.

${ }^{432}$ Ibidem, s. 30.

${ }^{433}$ Zob. też definicja zaproponowana przez Mukařovskiego (J. Mukařovský, Wśród znaków i struktur. Wybór szkiców, s. 26).

${ }^{434}$ Zob. bibliografia podana w przypisie $66 \mathrm{w}$ rozdziale Liberatura a poezja wizualna. 
w istocie domagają się czytania swoich tekstów jako struktur: całości zrodzonych z - jak to określa Mukařovský - „integracji znaczeniowej materiału” ${ }^{335}$. Jeśli struktura ma być „czymś więcej niż tylko całością sumaryczna” ${ }^{436}$ powstałą w wyniku banalnego dodania do siebie składników (nawet jeśli już pójdziemy o krok dalej i przyjmiemy, że składniki te mogą należeć do różnych poziomów znaku), to jest ona też idealnym wręcz kluczem do opisu Oka-leczenia. Co więcej, opisu upragnionego przez jego twórców. Mukařovský stwierdzał:

Strukturalna całość wyznacza każdą ze swych części i na odwrót - każda z owych części wyznacza tę właśnie a nie inną całość ${ }^{437}$.

Bazarnik zaś w tym samym szkicu, w którym podaje definicyjne wyznaczniki gatunku liberackiego, tak pisze o Oka-leczeniu:

Nadając Oka-leczeniu niekonwencjonalny kształt, nie zastanawialiśmy się, jaka forma plastyczno-przestrzenna najlepiej odda nasz koncept, lecz jak powiązać ze sobą trzy odrębne teksty odnoszące się do trzech różnych wydarzeń połączonych ze sobą na ukrytym planie i wzajemnie się determinujących ${ }^{438}$.

Również Fajfer - jakże podobnie jak Mukařovský - stwierdzał:

Musimy być świadomi, że forma zawsze coś komunikuje. Samą swoją struktura, niezależnie od słów. Chodzi więc o to, aby przekaz idący od formy nie był czymś zewnętrznym, czymś przygodnym, ustalonym arbitralnie, lecz wynikał z najgłębszej istoty dzieła ${ }^{439}$.

By dalej dodać w duchu przywoływanych tu wcześniej konstatacji Szkłowskiego:

A jest to bardzo trudne, gdy używamy formy skonwencjonalizowanej - konwencja to często śmierć formy ${ }^{440}$.

Trzeba jednak zauważyć, że choć Fajfer sprzeciwia się podziałom na treść i formę, sam co chwila w nie popada. Paradoks ów zdaje się wynikać właśnie z tego, że ciagle mówi o sumie elementów, że forma może u niego „przylegać do treści, naśladować ja”, lub: „dopełniać, komentować, a nawet jej przeczyć” ${ }^{41}$. Jednak wszelkie te relacje (choć Fajfer nierzadko mówi o nierozdzielności formy i treści) wskazują na ich zależności jako oddzielnych, wzajem się oświetlajacych elementów. Wydaje się zaś, iż nie do końca wyartykułowanym Fajferowskim ideałem byłaby właśnie struktura jako jedność w pełni nierozdzielna, ta, o której Mukařovský dodawał:

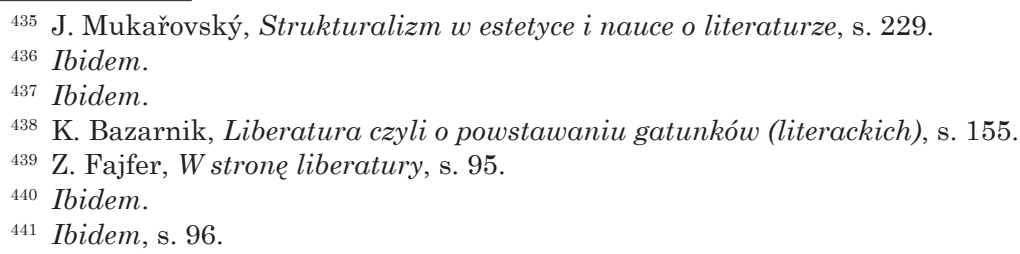


Dalszą zasadniczą cechą struktury jest jej charakter energetyczny i dynamiczny. Energetyczność struktury polega na tym, że każda jednostka składowa spełnia we wspólnej całości określoną funkcję, która przyporządkowuje ją owej całości strukturalnej i z nią wiąże. Wykładnikiem dynamiczności struktury jest z kolei fakt, iż dzięki swemu energetycznemu charakterowi poszczególne funkcje oraz ich wzajemne stosunki ulegają nieustannym przekształceniom. Dlatego właśnie struktura jako całość znajduje się w nieustannym ruchu w odróżnieniu od całości sumarycznej, która w wyniku przemian ulega rozpadowi ${ }^{442}$.

Być może to właśnie w tak rozumianych kategoriach energetyczności i dynamiczności kryje się rozwiązanie zagadki, jak rozumieć liberacką interaktywność i ergodyczność postulowane przez Bazarnik. Badaczka charakteryzuje tymi terminami przecież właśnie potencjalność stawania się, dopełnianie dzieła przez czytelnika w oparciu o przekształcenia struktury pierwotnie mu danej. Szczególnie, że strukturalistyczna kategoria ruchu prowadzi ku Ecowskiemu work in progress, przywoływanemu kontekstualnie również przez Bazarnik ${ }^{443}$.

\subsection{O płynnym przechodzeniu między funkcjami, czyli walka dominanty estetycznej z komunikacyjnością}

Warto podkreślić, iż liberackie budowanie semantyki dzieła przebiega na kilku poziomach znaku - raz jedne, raz inne jego aspekty sa aktualizowane. Liberat, przymierzając się do mówienia słowem, zastanawia się, które z nich (i kiedy) wykorzystać. W konsekwencji, w tego typu twórczości płynnie przechodzi się od jednych do drugich funkcji języka. Nie zawsze przecież liberaci mówia słowem nakierowanym tylko na siebie. Czasem - w pełni świadomie - wybieraja takie, które nastawione jest wyłącznie (bądź w stopniu dominującym) na przekazywanie informacji. Taki stosunek do funkcji słowa również przybliża refleksję liberatów ku teorii Mukařovskiego.

Ten ostatni definiuje język poetycki jako język funkcjonalny, podkreślając, że nie da się go opisać przez jakakkolwiek z cech historycznie zmiennych (takich jak np.: ozdobność, plastyczność czy emocjonalność), a jedynie właśnie poprzez funkcję: oddziaływanie estetyczne ${ }^{444}$. Ona zaś kieruje uwagę odbiorcy

${ }_{442}$ J. Mukařovský, Strukturalizm w estetyce i nauce o literaturze, s. 229

${ }_{443} \mathrm{O}$ kategoriach dzieła $w$ ruchu i modelu do sktadania $\mathrm{w}$ odniesieniu do liberatury pisałam szerzej w pracy magisterskiej (Nie tylko) liberackie modele do sktadania: liberatura, hipertekst, e-liberatura na gruncie polskim.

${ }^{444}$ Janusz Sławiński podkreśla, że tym samym język poetycki jest sprzeciwem wobec automatyzacji: „Jeśli w języku służącym porozumieniu znak odsyła do czegoś, co znajduje się poza nim - do rzeczy czy do przeżycia osoby mówiącej, to w języku poetyckim odwołania takie ulegaja osłabieniu, natomiast na plan pierwszy wysuwa się znak językowy jako taki, w swoim odniesieniu do innych znaków użytych w wypowiedzi. Oderwany od zwykłych zadań i powinności komunikacyjnych ulega on maksymalnej aktualizacji, objawia niedostrzegane w innych kontekstach cechy i walory [...] Działa więc jak gdyby na przekór tendencjom właściwym językowi praktycznemu, którego środki wyrazowe zmierzają do a u to m a t y z a c j i” (J. Sławiński, Jan Mukařouski: program estetyki strukturalnej, s. 7-8, podkreślenie autora). 
na sam znak językowy, co z kolei czyni sztukę odmienną od wszelkich innych typów komunikacji, nastawionych na porozumienie, nie estetyczne oddziaływanie $^{445}$.

W przypadku funkcji poetyckiej języka mamy do czynienia z przesunięciem punktu ciężkości, zmianą akcentów - na plan pierwszy nie wysuwa się tu odniesienie nazwy do świata, lecz jej związek z kontekstem przekazu (,wartość nazwy jest tu określona jedynie przez rolę, którą odgrywa ona w całym układzie znaczeniowym utworu" ${ }^{446}$ ). Funkcja ta stawia w centrum znak i jej podporzadkowane sa - w utworze - wszelkie pozostałe tzw. praktyczne funkcje języka (przedstawiająca, ekspresywna i apelatywna - w ujęciu Bühlera) ${ }^{447}$. Mukařovský zaznacza jednak, że funkcja estetyczna obecna jest w każdej wypowiedzi językowej i że specyfika jej zastosowania w nazwaniu poetyckim polega na przyznaniu jej owej roli dominanty.

Co jednak ważniejsze, zauważa też, że w odniesieniu do skupionego na sobie znaku w języku poetyckim najważniejsze jest to, że może on oscylować między różnymi funkcjami, nie będąc na stałe związany z żadną z nich, ale też - w konsekwencji - nie musi wcale być z żadnej z nich zwolniony. Tym samym, owo skupienie na sobie samym, związanie z funkcją estetyczną nie wyklucza np. tego, że znak ma coś znaczyć, jednakowoż nie dochodzi tu do sytuacji takich, jak w przypadku języka codziennego, gdzie - jak ujmuje to Mukařovský:

logiczne „nastawienie na wyraz” [...] cechuje służebność wyrazu językowego względem logicznego - i w ten sposób kładzie się nacisk tylko na jedną z funkcji znaku językowego i ta izolacja funkcjonalna wyraźnie przejawia się w dążności do oczyszczenia wypowiedzi ze wszystkich wartości pozalogicznych ${ }^{448}$.

W efekcie, możliwe jest - postulowane i upragnione przez liberatów pogłębienie możliwości semantycznych słowa samego w sobie. Przykuwające uwagę do samego siebie, do kodu, materialności, do swojego signifiant zyskuje ono nowe przestrzenie, które można semantycznie eksplorować - co liberatura właśnie stara się czynić. Jeśli więc przypominam, że Mukařovský podkreśla „walkę" i napięcia między dominantą estetyczną a komunikacyjnością cechujące język poetycki, zaznaczając jego wyjątkowość polegająca na nieograniczaniu się do wyłącznie jednej funkcji ${ }^{449}$, to czynię to po to, by uwypuklić, iż podobnie „wielofunkcyjne” jest słowo liberackie. Jednocześnie, jako że twórcy

${ }^{445}$ Genezy takiej zmiany w definiowaniu, opisywaniu języka sztuki (języka poetyckiego) Mukařovský - jak i inni współcześni mu badacze - upatruje właśnie w spojrzeniu zrodzonym z przełomu w językoznawstwie, zaznaczając, że: „w wyniku tego również język poetycki okazał się częścią systemu językowego jako trwała formacja mająca własny regularny rozwój i jako poważny czynnik w rozwoju ludzkiego wypowiadania się językowego w ogólności” (J. Mukařovský, O języku poetyckim, s. 130).

${ }_{446}$ Jan Mukařovský, Nazywanie poetyckie a estetyczna funkcja języka, tłum. J. Mayen, [w:] Jan Mukařovský, Wśród znaków i struktur. Wybór szkiców, s. 233.

${ }^{447}$ Ibidem, s. 239.

448 J. Mukařovský, O języku poetyckim, s. 135.

${ }_{449}$ Ibidem, zwłaszcza s. 136-137. 
literatury totalnej postrzegają poziomy znaku podobnie jak strukturaliści, eksplorują również przestrzeń znaku w rozumieniu najszerszym - całości dzieła: książki. I przecież formułowane przez Bazarnik cechy liberatury w istocie pokazuja, że tych samych zabiegów poszerzenia możliwości znaku dokonuje się na różnych poziomach tekstu - od poszczególnych znaków-liter, poprzez znaki-słowa i znaki-zdania aż do znaków-tomów ${ }^{450}$. Tym samym, spojrzenie na liberaturę z punktu widzenia teorii strukturalistycznej - będące naturalna i logiczną konsekwencją przyglądania się jej w świetle formalizmu - stanowi doskonały wstęp nie tylko do rozważań o literaturze totalnej w kontekście eksperymentów typograficznych (którego naszkicowanie stanowi cel tego rozdziału), ale i do analiz tej odmiany sztuki słowa skupiajacych się na kategorii książki i budowanej przez nią semantyki przekazu (ujęcia, które stanie się dla mnie niezwykle ważne w kolejnych rozdziałach).

\subsection{Tworzywo lit/beratury: słowo zmysłowe}

Wróćmy do łączącego wszystkie przywoływane w tym rozdziale nurty stwierdzenia, że tworzywem literatury jest słowo, konstatacji będącej też punktem wyjścia dla manifestów liberackich. Mukařovský rozumie rolę języka (poetyckiego) w dziele jako funkcję materiału, analogicznego do metalu czy kamienia w rzeźbie lub np. barwy w malarstwie. Gdy uważnie przyjrzeć się jego wywodowi dostrzeżemy w nim jeszcze jedną ścieżkę prowadzącą nas ku myśleniu liberackiemu. Z jednej bowiem strony Mukařovský stwierdza:

Język wchodzi do dzieła sztuki z zewnątrz jako byt podpadający pod zmysły, aby stać się przenośnikiem niematerialnej struktury dzieła artystycznego; on również zostaje w dziele sztuki poddany obróbce, przetworzeniu stosownie do celu ${ }^{451}$.

By za chwilę dodać, że „poezja nie odwołuje się wprost do żadnego zmysłu ludzkiego [...] ale pośrednio do wszystkich" ${ }^{552}$. Co więcej, owo uwikłanie w relacje zmysłowe wydaje się w ujęciu Mukařovskiego zaleta, naddatkiem języka poetyckiego. Dla liberatury zaś owo otwarcie się na materialność, na postrzeganie tekstu literackiego ogólnie zmysłowo (nie zaś wyłącznie przy pomocy zmysłu wzroku i to na drodze tylko i jedynie odczytywania liter i postrzegania odczytywanej wizualności jako semantycznie neutralnej) staje się kluczowe ${ }^{453}$.

${ }^{450}$ Por. komentarze w pierwszej części tej książki.

451 J. Mukařovský, O języku poetyckim, s. 139, podkreślenie moje.

${ }^{452}$ Ibidem, s. 140, podkreślenie moje.

${ }^{453} \mathrm{Na}$ ową wielozmysłowość tkwiąca w samym słowie zwraca również uwagę przywoływana przez Mukařovskiego Marie Majerová, która podkreśla, że poeta myśli „o słowach z ich bogactwem, ich dotykiem, soczystością i zapachem, o wszystkich wreszcie niebezpieczeństwach, które mu gotuje opracowywane tworzywo" [cyt. (z Marie Majerová, Pohled do dílny, Praga 1929, s. 13) za: J. Mukařovský, O języku poetyckim, s. 147]. 
Wypadałoby powrócić do pytania, czy tropienie wszelkich śladów myśli Desaussurowskiej w różnych nurtach teoretycznoliterackich ma sens. Proponując tę wędrówkę, wierzyłam, że tak, zaś Mukařovský zdaje się w pełni ze mną zgadzać:

Odkrycie wewnętrznej budowy znaku językowego dokonane przez de Saussure'a - twierdzi - odróżniło znak językowy zarówno od zwykłych „przedmiotów” akustycznych (dźwięki naturalne itd.), jak i od czystych aktów psychicznych. Otworzyło to nowe drogi nie tylko lingwistyce, ale i przyszłej teorii poezji ${ }^{454}$.

Następnie wskazuje zaś dalej idące wpływy: „lingwistyka dostarczyła wzoru dla analizy całego utworu poetyckiego, nie tylko jego strony językowej" ${ }^{455}$. Mukařovský podkreśla również i to, że choć w istocie prace de Saussure’a były „genialną” - jak mówi „podnietą" ${ }^{456}$, najwartościowsze stały się późniejsze kontynuacje jego myśli i „dopiero ten dalszy rozwój lingwistyki umożliwił przystosowanie metod językoznawczych do rozwiązywania problemów poetyki" ${ }^{457}$. Nie pozostało to - jak już sygnalizowałam - bez znaczenia i dla przestrzeni działań artystycznych. A teoria liberacka, zrodzona z potrzeby znalezienia terminów adekwatnych do opisu wymykajacych się wszelkim klasyfikacjom dzieł Fajfera i Bazarnik, zaproponowana jako odpowiedź na jeden z takich „problemów” nie powinna być rozpatrywana bez uwzględnienia kontekstu naukowych dyskusji oraz artystycznych praktyk początku XX w., będących konsekwencją przełomu tak ważnego i dla niej.

Stąd, nakreśliwszy potrzebne tło ${ }^{458}$, chciałabym przejść do omówienia liberatury w kontekście takich zabiegów twórców, które bazują na graficznej (zatem wizualnej i materialnej) wartości znaków, z których stworzone są literackie komunikaty: przyjrzeć się literaturze totalnej z perspektywy eksperymentów typograficznych. Tu jednak, też od razu na wstępie, również potrzebne będzie jeszcze jedno uzupełnienie...

${ }^{454}$ J. Mukařovský, O języku poetyckim, s. 150.

455 Ibidem, s. 151.

456 Ibidem.

457 Ibidem.

${ }^{458}$ Niezwykle istotne jest jednak dla mnie poczynienie jeszcze jednego zastrzeżenia. Pełna analiza teorii liberackiej w odniesieniu do rozmaitych metodologii mogłaby być przedmiotem niejednej zapewne - osobnej publikacji. Stąd - zdecydowałam się na okrojony wybór takich teorii, na przykładzie których najlepiej można było, moim zdaniem, pokazać kluczowe dla mojego wywodu kwestie. Odrzucenie choćby Derridy tłumaczyć mogę tym, że nie interesowała mnie tu filozofia języka. Jednak wśród nieprzywołanych teoretyków, o których z pewnością warto byłoby tu wspomnieć, pozostaje choćby i Jurij Łotman, którego nawet i sama Struktura tekstu artystycznego również byłaby interesującym kontekstem dla liberackości (por. Jurij Łotman, Struktura tekstu artystycznego, tłum. Anna Tanalska, Warszawa 1984, a także inne prace tego autora). Liczę jednak, że - mimo ograniczeń wynikających z ram tej pracy i ograniczeń czasowych towarzyszących jej pisaniu - udało mi się zarówno wskazać interesujące wątki do (zapewne) dalej jeszcze pogłębianej refleksji, jak i udowodnić, że posądzanie liberatów o pierwszeństwo głoszenia pewnych teorii jest zupełnie nieuzasadnione. 


\section{Liberatura i awangardowa typografia na tle historii druku}

\subsection{Dwie drogi typografii}

Trzeba pamiętać, że istnieje i druga strona medalu teoretycznoliterackich rozważań o materii pisma: sama historia druku. Warto bowiem postawić pytanie, czy rzeczywiście wraz z jego wynalezieniem wymyślono cechującą go neutralność i przezroczystośćc Czy to drukarski kanon nauczył literatów, że pismo to jedynie nieistotny i niewpływający na to, co pisza, nośnik treści? Kiedy zrodziło się przekonanie, że książka to nieważny „pojemnik na treść” ${ }^{559}$ ? Innymi słowy - jaki był kontekst przełomu lingwistycznego, jak postrzegano materię słowa (czyli druk) w tych czasach? Co rzeczywiście było przełomem, a co już niekoniecznie? Czy ówczesne teoretyczne postulaty i (co dla mnie ważniejsze) marzenia twórców mogły zostać zrealizowane?

Co ciekawe (a raczej się o tym zapomina), już od narodzin druku istniały sprzeczne ze sobą tradycje kształtowania pokrytych nim stron. Pierwsza, która wyznaczaja publikacje określone przez Johannę Drucker jako teksty niecharakterystyczne (unmarked text), stała się dominujacca i to jej podporządkowana jest tradycyjnie książka drukowana i literackie słowo. Zgodnie z nią, poszczególne wyrazy pojawiają się na stronie, by mówić wyłącznie swym kształtem lingwistycznym, a fakt ich materialnej obecności na papierze pozostaje niemy, semantycznie transparentny. Pierwowzorem dla tego

459 Skupiając się na typografii, ograniczam się do spojrzenia na dzieje książki drukowanej, pisma utrwalonego za pomocą prasy drukarskiej. Niemniej, równie ciekawa i obfitująca w zaskakujące niespodzianki jest cała historia pisma i książki. Jak podkreśla Anna Świderkówna, i starożytność miała swoją formę komiksu, a kodeks jest wynalazkiem dużo wcześniejszym niż mogłoby się wydawać. Hipotezę, że spojrzenie na liberaturę z perspektywy badania samej książki może być ciekawym tropem badawczym poświadczają zmiany, jakie możemy obserwować we współczesnej refleksji o książce (bibliologii) - przejście od pojmowania jej zadań jako analizowania społecznej funkcji książki (Karol Głombiowski) do badania struktur i właściwości komunikacji wyrażanej poprzez zapis graficzny (Krzysztof Migoń). Warto przypomnieć, że także i dla Bazarnik właśnie badania bibliologiczne były inspiracją (np. Donald Francis McKenzie, który w swoim Bibliography and Sociology of Texts [Cambridge 1999] przekonuje, że kształt książki nie powinien być obojętny dla krytyków, gdyż czytelnik odbiera również przesłanie płynące użycia konkretnego medium przez autora, który to może świadomie uczynić postać książki jedną z przestrzeni oznaczania). Stąd, w jednym z kolejnych rozdziałów rozwijam ten temat. O historii książki zob. m.in. Anna Świderkówna, Maria Nowicka, Ksią̇ka się rozwija, Wrocław 2008; Barbara Bieńkowska, Elżbieta Maruszczak, Ksiażka na przestrzeni dziejów, Warszawa 2005 lub Svend Dahl, Dzieje ksiażki, red. Bronisław Kocowski, tłum. Eugeniusz Garbacik, Tadeusz Zapiór, Helena Devechy, Wrocław 1965 , a także podana w tych pracach bibliografia. 
nurtu są drukowane przez Gutenberga kodeksy biblijne, w których szare strony pokrywały idealnie równe i symetryczne bloki tekstu, co najwyżej z rzadka upiększone pojedynczym inicjałem. Były one jeszcze pozbawione porządkującego tekst układu tytułów, charakterystycznych pierwszych stron itp., który w późniejszych wiekach uzupełnił tradycję owego estetycznie przezroczystego druku. Tak rozumiana edycja tekstu została zaadoptowana przez literaturę, a wyznacznikiem artystycznych utworów drukowanych stała się ich typograficzna neutralność i konwencjonalność. Tekst winien pozostać wizualnie nudny, nieatrakcyjny, by żadne bodźce nie zakłócały percepcji lingwistycznego przekazu.

Dążeniem typografów służących muzie literatury - dodaje Drucker - jest uczynić tekst tak jednolitym, neutralnym, dostępnym i tak uładzonym jak to tylko możliwe $\mathrm{e}^{460}$.

Takie, czysto praktyczne, podejście do powinności drukarza było przez wieki pielęgnowane. Dziś jego pokłosiem są liczne poradniki i podręczniki dla typografów, w których krok po kroku tłumaczy się, jak uczynić książkę możliwie wygodna w lekturze ${ }^{461}$. Podobnie, jeszcze na początku XX w., Eric Gill (jeden z drukarzy angielskich) pisał w swoim opracowaniu zasad typografii (Essay on Typography):

Książka jest przedmiotem do czytania - od tego zaczynamy - i będziemy zakładać, że czytelnik to osoba zarówno wrażliwa, jak i praktyczna. Zatem, pierwszą rzeczą, którą należy zauważyć jest to, że to akt czytania i jego okoliczności determinują kształt książki i rodzaj użytej czcionki; determinuje to akt czytania, nie to, co jest czytane. Dobra czcionka pasuje do każdej książki, a wielkość tej ostatniej jest regulowana nie tym, co jest w niej w środku, lecz przez fakt, czy podczas lektury jest trzymana w dłoni (np. powieść) czy też położona na stole (np. książki historyczne [...] zawierające mapy bądź inne duże ilustracje) czy też na biurku, czy pulpicie (np. książki mszalne) czy trzymana w kieszeni (np. modlitewnik czy słownik podróżny) ${ }^{462}$.

${ }^{460}$ J. Drucker, The Visible Word. Experimental..., s. 95.

${ }^{461}$ Por. np. Robert Chwałowski, Typografia typowej ksiażki, Gliwice 2002. W tego typu wydawnictwach właśnie ta tytułowa tu „typowość” staje się cechą pożądaną. Oryginalny ma być tekst, nie sposób jego wydania.

${ }^{462}$ Cyt. za reprodukcją strony 105 tego traktatu w: Robin Dodd, From Gutenberg to Open Type. An illustrated history of type from the earliest letterforms to the latest digital fonts, Cambridge 2006, s. 118. Podobną w tonie wypowiedź znajdziemy i w polskich opracowaniach. W 1951 r. Jan Muszkowski pisał: „Najbardziej istotną najważniejszą częścią składową książki jest oczywiście jej tekst, i wszystkie inne elementy powinny służyć sprawie jak najpełniejszego uwydatnienia go. Toteż błędem jest w kompozycji książki położenie tak silnego nacisku pod względem graficznym na okładkę, przedmowę, przypisy czy paginę, ażeby przygniatały tekst odsuwając go niejako na plan dalszy. W wydawnictwach naukowych, przeznaczonych dla specjalistów biegłych w przedmiocie dzieła albo dla studiujących, zmuszonych do maksymalnego natężenia uwagi, przyzwyczajeni jesteśmy do większego nieco formatu, do wąskich marginesów, do ściślej zadrukowanej kolumny. Dla utworów literackich wprowadzony jest raczej format mniejszy, poręczny, kolumna zadrukowana luźniej, o większej in t e r li n i i [...] i większej ilości ś w i a tł a" (Jan Muszkowski, Życie ksią̇ki, wyd. 2 rozszerzone, Warszawa 1951, s. 179, podkreślenie autora). 
Analogicznie postrzegała kształt książki Beatrice Warde (publikująca nieraz pod pseudonimem Paul Beaujon), autorka wielokrotnie przedrukowywanego wykładu, który - już choćby z racji samego tytułu: Kryształowy kielich - nie powinien być w moich rozważaniach (w tym właśnie miejscu) pominięty. Ów pochodzący z 1932 r. esej wart jest przywołania tu choćby dlatego, iż badaczka - odwołując się do tak często w historii kultury (ale i w teorii liberackiej) powtarzanej metafory szklanego naczynia, przenoszacego tekst - realizuje ją w sposób skrajnie odmienny niż inni teoretycy przywoływani w moich rozważaniach (dość dodać, iż podtytuł wspomnianego szkicu brzmi: druk powinien być niewidoczny). Warde wykorzystuje ją bowiem do uzasadnienia wizji idealnego drukarstwa rozumianego właśnie jako przygotowywanie tekstów w pełni niecharakterystycznych. Traktuje ona opracowanie typograficzne jako okno wstawiane „pomiędzy czytelnikiem siedzącym w pokoju a krajobrazem na zewnątrz, czyli światem słów autora" ${ }^{463}$. Pożądaną sytuację, rozwiązanie, do którego warto dążyć, badaczka postrzega zaś jako wstawienie okien i szyb tak przezroczystych, by nijak nie zwracały na siebie uwagi (badaczka mówi tu właśnie wprost o „typografii przezroczystej czy też niewidocznej” ${ }^{464}$ ) i z rozrzewnieniem wspomina tak przygotowaną edycję Aleksandra Dumasa ${ }^{465}$. Warde dopuszcza sytuację tzw. „pięknego pisma”, jednak zaznacza, iż kluczowe jest jednak to, by druk nie zwracał zbyt uwagi na siebie, by nie „utrudniał przekazu mentalnego obrazu" 466 .

Sięgając po obraz kryształowego kielicha, teoretyczka używa go do nakreślenia słynnej wśród typografów wizji, w której każdy element tego naczynia odpowiada pewnym aspektom druku. By silniej wybrzmiały sprzeciwy liberatów wobec takiego ujęcia czy inne przywoływane przeze mnie (także w dalszej części książki) głosy, warto przywołać w całości obszerny passus, jakim badaczka rozpoczyna swój wywód.

Wyobraź sobie butelkę wina - zachęca i prowokuje czytelników już w pierwszym zdaniu. - Niech to będzie twój ulubiony gatunek i rocznik, niech wino przyjemnie połyskuje głębokim karmazynem. Na stole stoją dwa kielichy. Jeden ze szczerego złota z kunsztownymi zdobieniami. Drugi z czystego kryształu, cienkiego jak bańka mydlana i tak jak ona przezroczysty. Nalewasz i wypijasz; a ja na tej podstawie stwierdzę, czy jesteś koneserem wina. Jeśli bowiem sam trunek nie dostarcza Ci wrażeń, będziesz chciał mieć poczucie, że pijesz z naczynia wartego tysiące funtów; jeśli zaś należysz do ginącego gatunku miłośników tego napoju bogów, wybierzesz kryształ, gdyż on nie skrywa, lecz ujawnia piękno tego, co zawiera.

${ }^{463}$ Beatrice Warde, Kryształowy kielich, czyli druk powinien być niewidoczny, tłum. Dorota Dziewońska, [w:] Widzieć. Wiedzieć. Wybór najważniejszych tekstów o dizajnie, red. Przemysław Dębrowski, Jacek Mrowczyk, Kraków 2011, s. 43.

${ }^{464}$ Ibidem.

${ }^{465}$ Warde pisze o niej: „Mam w domu książkę, której typografii w ogóle nie pamiętam; gdy o niej myślę, widzę tylko trzech muszkieterów i ich kamratów podczas najróżniejszych potyczek na ulicach Paryża" (B. Warde, Kryształowy kielich..., s. 43).

${ }^{466}$ B. Warde, Kryształowy kielich..., s. 44. Teoretyczka rozwija tę myśl w słowach: „Chodzi o to, że «mentalne» oko patrzy przez pismo, a nie koncentruje się na nim” (ibidem). 
Pozostańmy przy tej rozbudowanej i wonnej metaforze; okazuje się wszak, że niemal wszystkie cechy idealnego kielicha mają swoje analogie w typografii. Jest więc długa nóżka, dzięki której nie pozostawia się śladów palców na czarze. Po co? Żeby nic nie przeszkadzało w dotarciu wzrokiem do płomiennego serca płynu. Czyż analogicznie marginesy książki nie służą temu, by nie zostawiać śladów placów na zadrukowanej stronicy? Dalej: szkło jest bezbarwne albo prawie bezbarwne, ponieważ koneser ocenia wino po części na podstawie koloru i z niechęcią odnosi się do wszystkiego, co mu w tym przeszkadza. W typografii istnieją tysiące sposobów, które śmiało można przyrównać do arogancji i zuchwałości, jaka jest nalanie porto do kieliszków z czerwonego lub zielonego szkła! Kiedy podstawa kielicha sprawia wrażenie zbyt małej, to choćby całość była idealnie wyważona, będziemy się obawiać, że naczynie się wywróci. Tak samo jest z drukiem: zdarza się, że wiersze, choć złożone poprawnie, powodują napięcie związane z obawa, że przeczytamy któryś z nich dwukrotnie lub trzy słowa zleją nam się jedno, itp ${ }^{467}$.

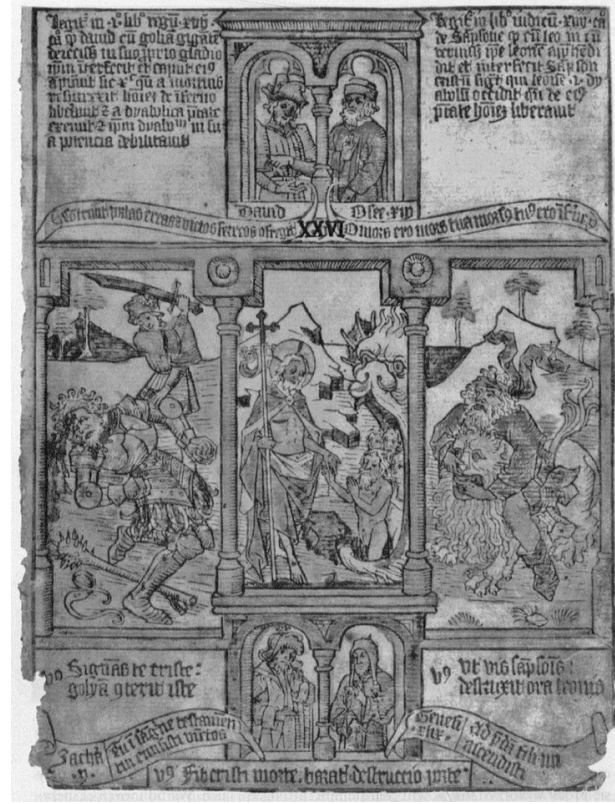

Ilustracja 18. Stronica z książki ksylograficznej z XV w. (Biblia pauperum) (źródło: Barbara Bieńkowska, Elżbieta Maruszczak, Ksiażka na przestrzeni dziejów, Warszawa 2005, s. 58)

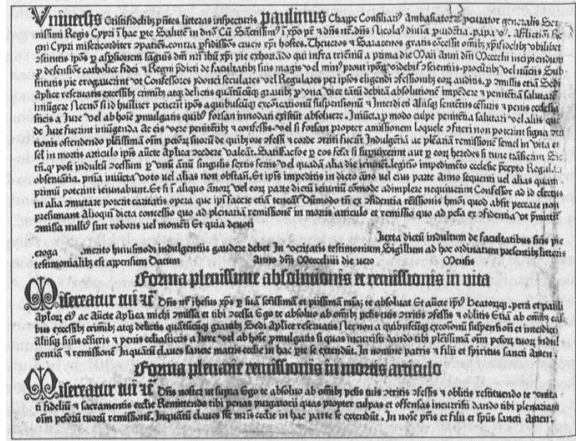

Ilustracja 19. Cypryjski list odpustowy (źródło: Jan Pirożyński, Johannes Gutenberg i poczatki ery druku, Warszawa 2002, s. 66)

Nie możemy jednak zapominać, że od samego początku istniał też nurt zgoła przeciwny wyżej opisanej tradycji, obszar, w którym - można by powiedzieć odrzucano kryształowe kielichy. Albo inaczej: przestrzeń, w której dostrzegano, że bywają teksty, w przypadku których i samo (metaforyczne) naczynie, w jakim się je podaje jest projektowane przez autora, postrzegane jako część komunikatu i w przypadku których - tym samym - przykuwanie uwagi przez taki „kielich” jest częścią procesu oznaczania, nie zaś czymśs, co go zaburza. 
Już w książce ksylograficznej, blokowej (a zatem formie pośredniej między tomem rękopiśmiennym a drukowanym ruchomymi czcionkami) mieliśmy do czynienia $\mathrm{z}$ ogromną różnorodnością rozmaicie rozłożonych $\mathrm{w}$ przestrzeni napisów oraz z wieloma barwnymi ilustracjami. Doskonałym przykładem jest tu Biblia pauperum (por. ilustracja 18). Jednocześnie, sam Gutenberg drukował - obok Biblii - również i inne teksty, których edycja łamała nieraz wszelkie opisane wyżej zasady. Wśród publikacji tych znajdziemy m.in. listy odpustowe $^{468}$ (zob. ilustracja 19), a zasadniczo do grupy tej zaliczymy wszystko to, co „komercyjne”, co miało szansę się sprzedać. Nie bez powodu piszę o tym w takich właśnie kategoriach, gdyż od samego początku druk (właśnie w swojej odmianie mniej uładzonej, typograficznie nieregularnej, celowo przykuwającej wzrok odbiorcy) służył reklamie ${ }^{469}$ (do czego zresztą nie omieszkam tu wrócić). Trafnie podkreśla też Jan Muszkowski, że i reformacja wykorzystywała typografię jako swoisty rodzaj propagandowego oręża w walkach religijnych, sięgając właśnie po szatę graficzną książki, atrakcyjną wizualność druków jako coś, co może skusić wiernych ${ }^{470}$.

Od tak właśnie wydawanych publikacji (głównie druków ulotnych) wywodzi się klasa tekstów określonych przez Drucker jako charakterystyczne (marked text). W nich do hierarchizacji informacji już ojciec drukarstwa używał różnych czcionek (np. w listach odpustowych czcionka służyła do wyróżniania kluczowych zdań), a owa typograficzna różnorodność miała pozwolić „różnym partiom tekstu różnie mówić" ${ }^{471}$. To w tym nurcie - jak podsumowuje Drucker - korzystano z „możliwości, jakie daje reprezentacja typograficzna w zakresie manipulowania poprzez środki wizualne semantyczną wartością tekstu” ${ }^{472}$.

${ }^{468} \mathrm{~W}$ polskiej literaturze przedmiotu o owych listach odpustowych pisze (nie charakteryzując ich jednak) Barbara Bieńkowska (B. Bieńkowska, E. Maruszczak, Ksią̇ka na przestrzeni dziejów). Więcej informacji na ich temat (oraz przykłady) znajdziemy w opracowaniach Jana Pirożyńskiego (Jan Pirożyński, Johannes Gutenberg i poczatki ery druku, Warszawa 2002).

${ }^{469}$ Pirożyński przywołuje (za zagraniczną literatura przedmiotu) przykłady niemieckich reklam księgarskich i wydawniczych (J. Pirożyński, Johannes Gutenberg..., s. 148-149).

470 J. Muszkowski, Życie ksiażki, s. 129.

471 J. Drucker, s. 95.

${ }^{472}$ Tamże. Z kolei Barbara Bieńkowska zwraca uwagę na inną interpretację owej podwójności tradycji druku. Jej wywody pokazuja, jak pierwsze inkunabuły - odwołując się do przyzwyczajeń czytelniczych - próbowały odwzorowywać manuskrypty tak, by zaspokoić ukształtowane już gusta odbiorców. Jednak naśladowanie fantazyjności pism kaligraficznych oraz oryginalnej ornamentyki było dość kłopotliwe i stąd drukarstwo dążyło do stopniowego upraszczania czcionek, rezygnowania z ozdobności i - jak podsumowuje Bieńkowska - wypracowania „stałych kanonów estetyki książki” (s. 75). Ich podstawą stało się właśnie przede wszystkim zharmonizowanie całości oraz ograniczenie różnorodności stosowanych fontów, stonowanie i skonwencjonalizowanie wyglądu poszczególnych kart. Bieńkowska zaznacza jednak, że tak jak jeszcze w XV w. pierwsze druki postrzegane były jako nieudolne naśladownictwo manuskryptów, w XVI w. technika drukarska rozwinęła się na tyle, że i bibliofile zainteresowali się nową postacią książki (pięknej książki) i obok manuskryptów zaczęli kolekcjonować i pięknie wydane publikacje drukowane. Dla tych pasjonatów przygotowywano tomy luksusowe, na wytwornym papierze, pełne ornamentów i zdobień, nieidące w parze z tendencją kanonizowania i upraszczania formy książki. Zob. B. Bieńkowska, E. Maruszczak, Ksią̇̇ka na przestrzeni dziejów, szczególnie s. 67-85. 
Zatem, już od samego początku, od chwili wynalezienia druku, możliwe były szaleńcze typograficzne ekstrawagancje, których świadkami jesteśmy w XX i XXI w. i po które nieraz sięga liberatura. A jednak tradycja ulubiła sobie teksty niecharakterystyczne, przyznała prymat lingwistycznej wadze słowa pisanego (negując jednocześnie jego odmienność od mowy). Tym samym - z ogromnego morza możliwości wybrała nad wyraz ograniczony repertuar środków. W konsekwencji zaś wrażliwość na samo medium, jakim był druk, rozwijała się w jego użytkownikach bardzo wolno, gdyż jedynie poprzez awangardową twórczość (zasadniczo: poprzez nurty zdecydowanie nie-dominujące) uczono, że druk (i sposób zapisu) nie musi być neutralny, przezroczysty i semantycznie obojętny.

Trzeba jednak pamiętać, że przez stulecia rozwijające się czasopiśmiennictwo czy reklama (do której obiecywałam powrócić) to przestrzenie działalności drukarskiej, które czerpały właśnie z drugiej z wymienionych tradycji ${ }^{473}$. Tym samym, gdy pojawiają się dwudziestowieczne awangardowe ekstrawagancje typograficzne, gdy o słowa na wolności walczą futuryści, gdy dziwacznie drukuja dadaiści - wszelkie ich zabiegi nie wykraczają poza arsenał środków już w ówczesnym drukarstwie wykorzystywany ${ }^{474}$. Istotne przesunięcie (które łączy futurystyczną rewolucję z liberatura) to przeniesienie tych wypracowanych środków w inną niż charakterystyczna dla nich, przestrzeń - od drukarstwa użytkowego w obszar sztuki słowa. Paradoksalnie bowiem, to właśnie literatura przez wieki pozostawała obojętna na fakt, iż różni się swą materialnością od mowy ${ }^{475}$.

Robin Dodd w swojej bogato ilustrowanej książce poświęconej historii typografii ${ }^{476}$ podkreśla, jak na początku XIX w. rozwój reklamy przyniósł drukarniom nowych klientów i nowe zapotrzebowania ${ }^{477}$ - okazało się bowiem,

${ }^{473}$ Anna Świderkówna zwraca uwagę na jeszcze jedno ciekawe zjawisko. Tak jak możliwość wizualizowania, uczynienia druku ciekawszym początkowo nie interesowała literatów (i nie chcieli uczyć się jej od innych), tak i kodeksem (jako poręczną formą, dziś kanonicznym kształtem książki literackiej) szybciej zainteresowali się archiwiści niż ci, co zajmowali się literaturą. Zob. A. Świderkówna, M. Nowicka, Ksiażka się rozwija, s. 118-123 (rozdział Narodziny i triumf kodeksu).

${ }^{474}$ Pisząc o łamaniu tabu typograficznego przez dadaistów i futurystów, Drucker podkreśla, że ówczesne drukarstwo - jak je określa - komercyjne (czasopiśmiennictwo, plakat, reklama) operowało już takimi środkami, jak m.in.: użycie zróżnicowanych czcionek, stylów i rozmiarów tekstu w obrębie poszczególnych stron, podział strony na kilka przestrzeni czy stosowanie w obrębie horyzontalnej strony zapisu przebiegającego po okręgu, liniach skośnych i nieregularnych oraz elementów wertykalnych. Por. J. Drucker, s. 96.

${ }^{475} \mathrm{Na}$ fakt, iż typografia dużo wcześniej była gotowa dać możliwości, których pisarze po prostu nie wykorzystali zwracał uwagę też Michel Butor w swoim Sur la page, gdzie czytamy: „Obecne metody, jeśli tylko trochę się je postudiuje, pozwalają realizować w prosty sposób układy, które kiedyś wymagały niesłychanie delikatnej pracy. Wystarczy spojrzeć na gazety, ogłoszenia, podręczniki szkolne, dzieła i wydawnictwa naukowe. Środki oddane do dyspozycji pisarzy są tak wielkie, że nie wolno ich dłużej ignorować. Potrzeba tylko trochę odwagi” (cyt. za: Katarzyna Bazarnik, „Ksiażka jako przedmiot” Michela Butora czyli o liberaturze przed liberatura, [w:] Od Joyce'a do liberatury, s. 176).

${ }^{476}$ R. Dodd, From Gutenberg to Open Type... .

477 O tym, jak rozwój reklamy zaowocował niesłychaną różnorodnością (wcześniej niespotykanych) środków typograficznych ciekawie pisze też Johanna Drucker. Badaczka interesująco analizuje relacje między reklamą a typografią literacką w pierwszej części rozdziału Experimental Typography as a Modern Art Practice, zwracając również uwagę na analogie między typografią futurystów i dadaistów a drukami reklamowymi początków XX w. (J. Drucker, s. 91-104). 
że wszelkie fantazyjne, wielkie, kolorowe, generalnie: przyciąające wzrok czcionki i opracowania typograficzne stają się jednym z podstawowych środków ekspresji w plakacie czy ulotce reklamowej (podobnie jak w gazecie). Zaistniała więc potrzeba przygotowania znacznie większego wyboru czcionek ozdobnych niż te, które w XVIII w. wykorzystywano na stronach tytułowych. Jakkolwiek wiele z opracowanych w XIX w. innowacji miało raczej krótki żywot, ówczesny rozwój drukarstwa był imponujący ${ }^{478}$.

Wydaje się, że praca Dodda: zwykły faktograficzny opis historii druku, prowadzony z perspektywy rozważania losów poszczególnych czcionek, nie mogłaby inspirować badań o charakterze literackim. A jednak dla moich analiz jest nieoceniona pomoca. A wszystko dlatego, że książka angielskiego badacza to właśnie „historia ilustrowana”, pełna zdjęć i reprodukcji, zaś dokonane przez niego zestawienia sa doskonałym zobrazowaniem kwestii, jakie tu poruszam. Z jednej strony Dodd rzeczywiście „wyłącznie” pokazuje, jak poszczególne czcionki rozwijały się w czasie, z drugiej - w konsekwencji przyjęcia takiej właśnie perspektywy - zestawia ze sobą stare i współczesne druki, w których są one wykorzystane. I tak - mimochodem - pokazuje nam przykłady tego, jak płodnym źródłem inspiracji i innowacji mogły być starsze druki użytkowe (o których nie pamiętamy, analizując typografię tekstów literackich). Przykładem - plakaty teatralne z XIX w., których estetyka oparta jest na tym, co niektórzy później i w innych kontekstach określą „typograficzną ekstrawagancją” (zob. ilustracja 20).
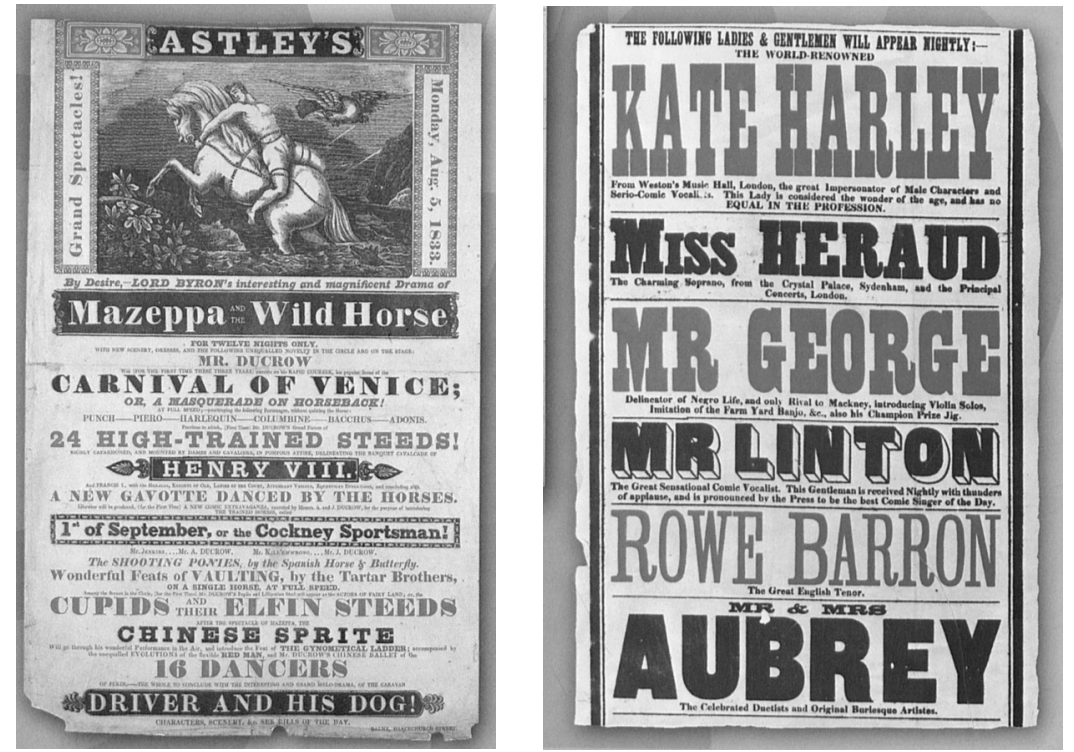

Ilustracja 20. Typowe plakaty teatralne z XIX w. (źródło: Robin Dodd, From Gutenberg to Open Type. An illustrated history of type from the earliest letterforms to the latest digital fonts, Cambridge 2006, s. 66)

${ }_{478}$ R. Dodd, From Gutenberg to Open Type..., szczególnie s. 60-95. 
Równie drukarsko inspirujące i różnorodne bywały ogłoszenia motoryzacyjne. Podobnie, pokazanie współczesnego i starszego o ponad sto lat wykorzystania czcionek Franklin Gothic czy Clarendon doskonale unaocznia, że choć nowomedialna typografia dysponuje różnymi środkami i jest prosta w zastosowaniu, w wielu jednak wypadkach proponowane przez nią rozwiąania nie wykraczaja poza to, co drukarstwo oferowało nam już kilkaset lat wcześniej (zob. ilustracja 21 i 22 ).
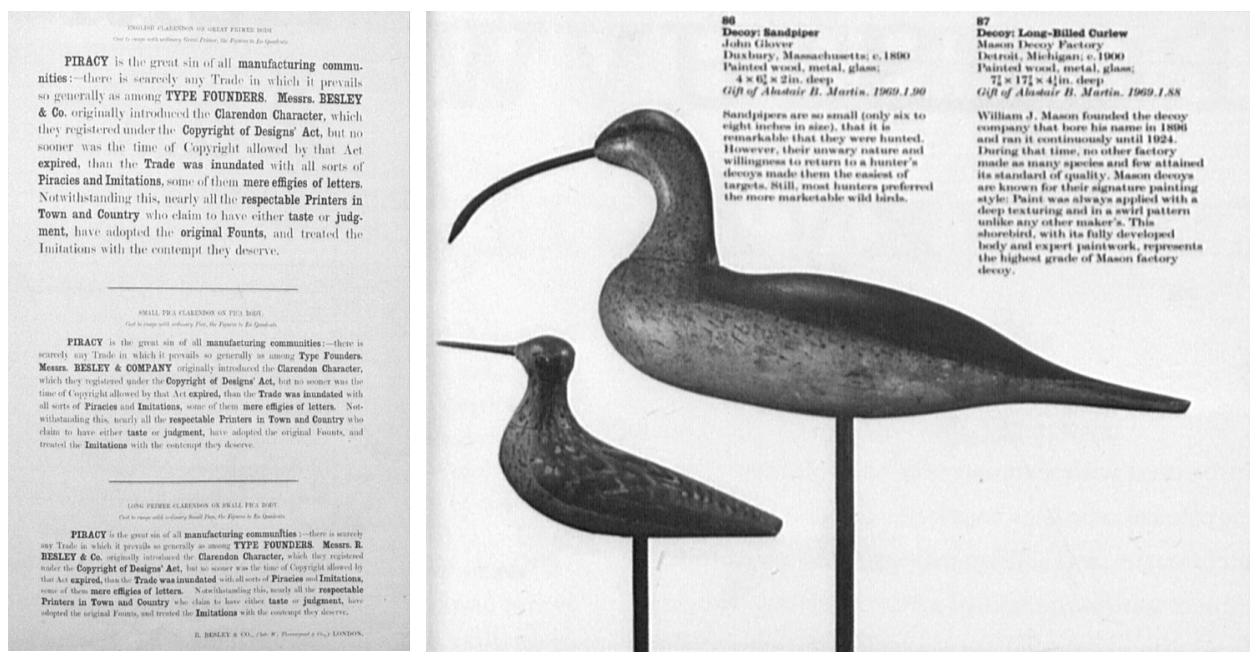

Ilustracja 21. Użycie czcionki Clarendon (zaprojektowanej jako czcionka służąca wyróżnianiu informacji) w XIX w. i współcześnie (źródło: Robin Dodd, From Gutenberg to Open Type. An illustrated history of type from the earliest letterforms to the latest digital fonts, Cambridge 2006, s. 70)
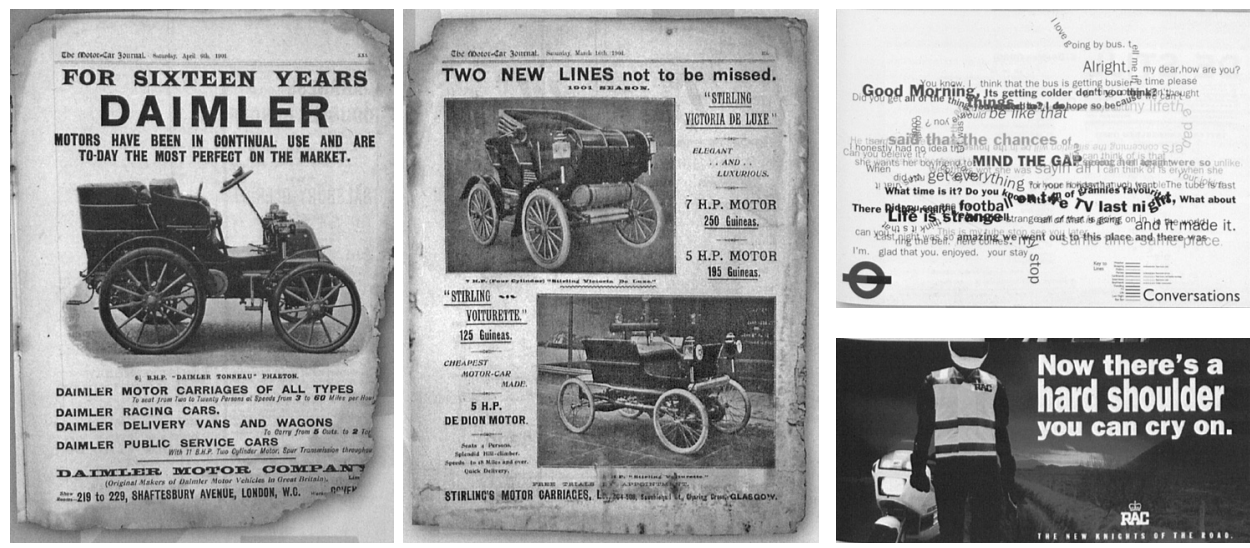

Ilustracja 22. Użycie czcionki Franklin Gothic w motoryzacyjnych ulotkach reklamowych z 1902 r. i współcześnie (źródło: Robin Dodd, From Gutenberg to Open Type. An illustrated history

of type from the earliest letterforms to the latest digital fonts, Cambridge 2006, s. 94-95) 
Typografia literatury awangardowej kształtowała się zatem na tle dyskusji podejmowanych przed drukarzy inspirujących się działalnością Williama Morrisa $^{479}$ i otaczającej go grupy ludzi (wyznaczających nurt myślenia o książce również w kategoriach przedmiotu estetycznego), czerpała też z wszelkiego rodzaju nowinek technicznych. Jej twórcy coraz uważniej też przyglądali się wszelkiego rodzaju drukom użytkowym. Jak zgrabnie formułuje to Dodd, dostrzegli oni (badacz ma tu na myśli futurystów i dadaistów), że „czytanie to również patrzenie" ${ }^{480}$, przy czym - co może nawet istotniejsze - na nasz odbiór tego, co czytamy wpływa to, jak postrzega zmysł wzroku. Rzeczywiście, nowe techniki drukarskie w pełni umożliwiały już odejście od utrwalonych przez tradycję struktur kopiujących antyczne konwencje horyzontalnego układania wersów tekstu i wertykalnego rozmieszczania jego kolumn. Wraz z rozwojem drukarstwa stały się możliwe „słowa na wolności”, gdyż typografowie nie musieli już dłużej poddawać się rygorom pionu i poziomu układu. Tym samym, słowo nie musiało już podporządkowywać się nudnej graficznej rutynie, a przestrzeń stronicy (wraz z wszelkimi swymi kierunkami) została oddana na potrzeby semantyki.

\subsection{Przełom czy chwilowy oddech?}

Czas powrócić do pytania, czy rozpoczynajacy ten rozdział passus poświęcony rewizji kategorii znaku, teoretycznej drodze ku dostrzeżeniu jego materialności i semantycznej potencji w niej drzemiącej nie był zbędny. Podtrzymuję tezę, że nie. Trzeba sobie bowiem uzmysłowić, że początek XX w., to czas, w którym wszelkie wspominane tu innowacje się splatają. Jest to okres, w którym rodziły się literackie awangardowe eksperymenty typograficzne, a zarazem czas teoretycznego namysłu nad kwestia słowa zapisanego. Wtedy też poetyka w istotny sposób inspirowała się językoznawstwem. Z kolejnej strony - to moment, w którym drukarstwo dysponowało już dawno wypracowanymi środkami umożliwiającymi realizację niemal wszelkich typograficznych marzeń. Sądzę, że zarysowanie tak szerokiego kontekstu jest konieczne dla rozstrzygnięcia, czy dwudziestowieczne lub liberackie eksperymenty typograficzne to rzeczywisty przełom. Taka perspektywa wydaje się nieodzowna dla dostrzeżenia pełni problemu.

${ }^{479}$ Odnośnie do Morrisa zob. R. Dodd, From Gutenberg to Open Type..., s. 76-79. Na jego zasługi dla nowego postrzegania materialności i wizualności zadrukowanej strony zwraca też uwagę Johanna Drucker, pisząc, iż: „Morrisowskie podkreślanie związku między technikami produkcji, stylem graficznym oraz kategoriami kulturowej aktywności przyczyniło się do rozwinięcia się strony literackiej aż do oddzielnego rodzaju (genre) o stylu graficznym integralnym z tekstem literackim a nie przypadkowym" (J. Drucker, s. 93). Więcej o tym drukarzu piszę w rozdziale poświęconym relacji liberatury i książki (nie tylko) artystycznej.

${ }^{480}$ R. Dodd, From Gutenberg to Open Type..., s. 97. 
Dziwić powinna - zauważona przez Drucker - rozbieżność polegająca na tym, iż choć na poziomie teorii literaci zdawali się dostrzegać nowe horyzonty literackie, niespecjalnie były one eksplorowane. Teoretyczne konstatacje zostały właściwie bez echa i to w sytuacji, gdy istniały nie tylko techniczne możliwości ku temu, by wyciągnąć z nich wnioski i zacząć inaczej zapisywać teksty literackie, lecz i bogata - w sumie - tradycja eksplorowania semantyki wizualności druku. A jednak typograficzne eksperymenty dwudziestowiecznej awangardy stały się epizodem w historii literatury. Zdawać by się mogło, że po krzykliwym chwilowym zamieszaniu wszystko wróciło do starej, skonwencjonalizowanej normy. Pisze o tym również Janusz Sowiński:

To, co w zamierzeniu niektórych członków awangardy było świadomą prowokacją z czasem przyjęte zostało jako atrybut druku bibliofilskiego, miało wyróżniać wydawnictwo specjalne spośród masowej produkcji [...] Druga dziedzina, w której eksperymenty typograficzne znalazły zastosowanie, było czasopiśmiennictwo.

Natomiast typografia książki w swej masie oparła się wpływom nowej typografii; elementem dominującym pozostało tu zdobnictwo i ilustracja ${ }^{481}$.

Jak na tym tle przedstawia się liberatura? Wydaje się, że dąży do podtrzymania osiagnięć typografii otwartej na swą wizualność w zakresie nie-użytkowej sztuki słowa, do wprowadzenia jej w sferę inną niż bibliofilska. Można by powiedzieć, że jej marzeniem jest masowa produkcja druków nie-masowych (co skądinąd tłumaczy nieraz zawrotne ceny tekstów liberackich). Twórcy literatury totalnej próbują odejść (znów?) od tego „bardziej spokojnego i zrównoważonego układu drukarskiego" ${ }^{482}$, praktyki dominującej, a będącej przecież jedną z dwóch ścieżek typograficznych wskazanych przez Gutenberga. Liberaci nie pozwalają zapomnieć o tym, że istnieje i druga tradycja druku. Że forma tekstu nie musi być semantycznie obojętna i że już Gutenberg jako taką ja projektował. To oni nie przestają się dziwić, że literatura nie chce korzystać z możliwości drzemiących w materialności słowa, że poddaje się zniewoleniu przezroczystości formalnej, oddając drukom użytkowym gros środków ekspresji.

Przeciętny czytelnik czasem wręcz nie wie, co z liberacką książką zrobić, jak zacząć ją czytać. Przywykliśmy bowiem do tego, że forma książki (typograficzna i materialna, a także - o czym będę pisać w jednym z kolejnych rozdziałów - jej klasyczny, kodeksowy kształt) to rzecz niewidoczna, niezauważalna. Tak nas nauczono. A jak słusznie może podkreślają Phil Baines i Andrew Haslam:

481 Janusz Sowiński, Typografia polskiej awangardy, „Studia o Książce” 1989, nr 18, s. 280-281. Badacz zwraca też uwagę na podobne konstatacje ówczesnej krytyki, przywołując słowa Mieczysława Wallisa mówiącego: „nowy ruch na polu drukarstwa i grafiki książki [...] zaznaczył się u nas, jak dotąd, nadzwyczaj słabo [...]. Owa forma dynamiczna i agresywna [...] dzisiaj spospolitowała się i opatrzyła [...]. Dzisiaj pionierzy w dziedzinie grafiki książkowej dążą znowu do bardziej spokojnego i zrównoważonego układu drukarskiego" (cyt. za s. 281, autor zaś za: Mieczysław Wallis, Wydawnictwa artystyczne, „Wiadomości Literackie” 1930, nr 24).

482 J. Sowiński, Typografia polskiej awangardy, s. 281. 
To szczególna anomalia w systemie edukacji, że nauczany przedmiot - język - i system opracowany do jego zapisywania - typografia - sa wykładane w niepowiązanych ze soba uczelniach. Antropologia, lingwistyka, historia języka, języki obce i literatura są wykładane na uniwersytetach, podczas gdy typografii naucza się w akademiach sztuk pięknych. A przecież typografia jest dla języka tym, czym mapy dla geografii, nuty dla muzyki, a algebra dla matematyki. Chyba przedmiot i system jego rejestrowania powinny być analizowane razem? Naszym zdaniem konieczne jest, aby typografowie poznali charakter języka wtedy, kiedy uczą się jego zapisu i technicznych procesów powielania ${ }^{483}$.

Zaś liberatura czy - jak mówi Fajfer - „architektura słowa” to typ literatury, który na druk patrzy raczej podejrzliwie. Albo może inaczej - wręcz przeciwnie, z ogromnym zaciekawieniem ${ }^{484}$. Gdyby liberaci zakładali szkoły, uczyliby pewnie tak, jak wyobrażają to sobie autorzy opracowania Pismo i typografia. Nie potrafiliby oddzielić mówienia o języku od analizowania tego, jak się go zapisuje. Gdy rozważaliby przesłanie dzieła - analizowaliby również jego materię. Bo przecież dla liberatury typografia, sposób kształtowania wizualnej warstwy książki, staje się jednym z elementów tekstu, które domagaja się opracowania. Liberackie „ważenie liter i słów” to także ich (jak najbardziej niemetaforyczne) składanie, to podejmowanie decyzji nie tylko o tym, co (i jak) napisać, lecz i: jak za-pisać. To projektowanie przestrzeni dla słowa lub świadoma (!) rezygnacja z aktualizowania jej potencji semantycznej. Pisanie liberatury to też budowanie tekstu, książki. A - metaforycznie czy dosłownie rozumiane - budownictwo nie może obejść się bez materii. Dlatego tak istotnym punktem w refleksji nad literatura totalną jest namysł nad materialnością języka, poszukiwanie materii słowa ${ }^{485}$.

Książki zawdzięczają nie wszystko myśli, która je poczęła, nie lękam się powiedzieć, że sa one materia, materią szlachetną wykonaną przez ręce umiejętne i mądre, materią obdarzoną życiem przez technikę, która jest sztuką... - pisał Henri Focillon - Żadna ze sztuk nie jest tak bliska architekturze jak drukarstwo. Pierwszą jego zasadą jest tak samo właściwe rozłożenie i zastosowanie materiałów; jak architektura opiera się ono na systemie stosunków stałych, nie znosząc fantastycznych wyskoków. Podobnie jak twórca pałacu rozkłada z rozumnym umiarem na fasadzie światła i cienie i operuje nimi w urządzeniach wewnętrznych na potrzeby życia - tak samo budowniczy książki, rozporządzając dwoma czynnikami przeciwstawnymi: białością papieru i czernią farby, wyznacza każdemu z nich

${ }^{483}$ Phil Baines, Andrew Haslam, Pismo i typografia, tłum. Dorota Dziewońska, Warszawa 2010, s. 10.

${ }^{484}$ Choć, idąc za najbardziej radykalnymi twierdzeniami twórców liberackiej teorii, trzeba wspomnieć, że nie ma też żadnego powodu, by liberatura w ogóle była drukowana. Przecież druk nie jest jedynym medium słowa pisanego. Paradoksalnie, nie chcę tu odnosić się do literatury elektronicznej, lecz przywołać hipertekst wyryty w kamieniu - pracę Pole anielskich szeptów Andrzeja Bednarczyka (do obejrzenia w muzeum sztuki w Orońsku), zob. też ilustracja 4. By przeczytać tekst, czytelnik musi w tym wypadku przespacerować się między kilkudziesięcioma słupami, na bokach których wyryte są poszczególne słowa utworu. Idąc, poszukując, układamy historię, która - o dziwo - składa się w całość.

${ }^{485}$ Innym, równie ważnym zagadnieniem jest kwestia owej budowanej, konstruowanej książki, która stanie się tu przedmiotem oddzielnego rozdziału. Omówienie takie jest o tyle konieczne, iż liberaci od początku zaznaczali, że ich teoria zmusza do zredefiniowania samej już definicji książki oraz że formułowana jest w opozycji do teorii książki artystycznej. 
rolę i stwarza harmonijne ich połączenie. Trafiają się w architekturze wielkie spokojne płaszczyzny, które są jak marginesy. Bywają w układzie książki symetrie i kontrasty jak w budowli ${ }^{486}$.

Jeśli ktoś miałby jeszcze wątpliwości, czy jest sens zestawiać typograficzne eksperymenty pierwszej połowy XX w. z liberatura, niech spojrzy na poemat-znak Dante autorstwa Zenona Fajfera i jedna z prac Herba Lubalina, który od lat $40 \mathrm{XX}$ w. stopniowo zyskiwał miano jednego z najlepszych typografów swoich czasów ${ }^{487}$ (zob. ilustracja 23). Obie podobnie „typograficznie” mówią o jeszcze nienarodzonym dziecku.
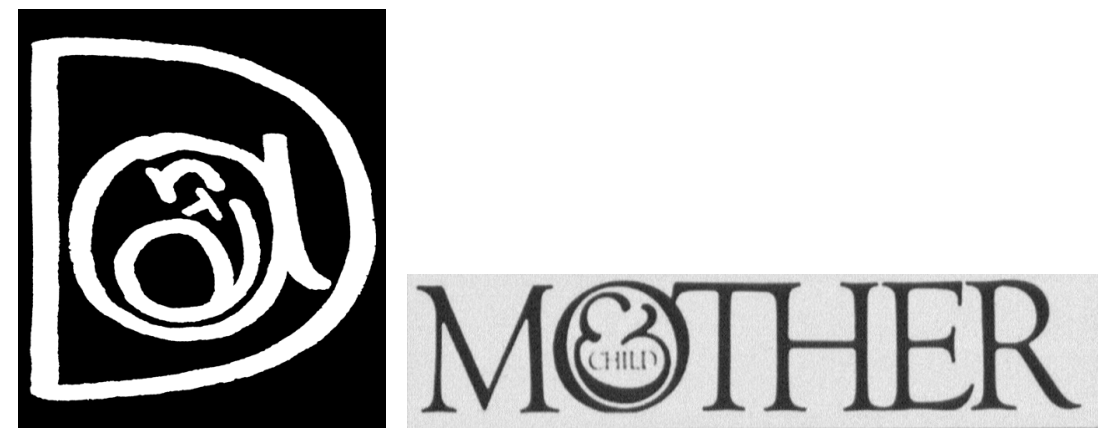

Ilustracja 23. Poemat-znak Dante (embrion) Zenona Fajfera (źródło: zdjęcia własne autora) oraz praca Herba Lubalina z drugiej połowy XX w. (źródło: Robin Dodd, From Gutenberg to Open Type. An illustrated history of type from the earliest letterforms to the latest digital fonts,

Cambridge 2006, s. 149)

Pozostaje jednak pytanie, czemu takie zestawienia miałyby służyć? Jaki jest mój cel, gdy je proponuję? Po pierwsze, zaprezentowany tu kontekst rozważań o (nie tylko literaturoznawczym) dochodzeniu do materialności znaku miał uzmysłowić, jak ważna jest to kwestia i w jak wielu dyskursach powracająca. Nie tylko „po Derridzie” nie można zgodzić się w pełni z de Saussurem ${ }^{488}$. Po drugie, zasygnalizowania wymagała też dotychczas raczej nieporuszana kwestia związków liberatury z formalizmem ${ }^{489}$ i strukturalizmem. Wydaje się, że przyjęcie (choć po części) tych właśnie metodologii podczas analizy liberackich tekstów będzie owocne. Po trzecie, przyjrzenie się temu, jak rozwijał się stosunek do estetyki słowa pisanego i dostrzeżenie, że to literatura najdłużej broniła się przed jego wizualnością pozwoli z pewnością jeszcze lepiej usytuować liberaturę na mapie tych zjawisk sztuki słowa, które czerpią z tego, co mniej tradycyjne, bądź co - jak ujmuje to Piotr Rypson - przynależy do

${ }^{486}$ Henri Facillon, wstęp do Mariusz Audin, Le livre, son architecture, sa technique, Paris 1924 (cyt. za: J. Muszkowski, Życie ksiażki, s. 177-178).

${ }^{487}$ R. Dodd, From Gutenberg to Open Type..., s. 149.

${ }^{488}$ Por. m.in. P. Baines, B. Haslam, Pismo i typografia, szczególnie s. 22-23.

${ }^{489}$ Dopominała się o ich rozważenie m.in. Danuta Ulicka podczas dyskusji w trakcie konferencji Tekst (w) Sieci (Warszawa, grudzień 2008). 
innej tradycji ${ }^{490}$. Interesuje mnie bowiem pokazanie, że - inna niż wszystko inne - liberatura nie wzięła się znikąd, że z jednej strony sięga po to, co już w kulturze się wydarzyło (nie odcinając się wcale od tradycji), z drugiej zaś zakorzeniona jest w swoich czasach. Przełom XX i XXI w., okres powstawania dzieł literatury (i sztuki) nowomedialnej, w której do kategorii materialności znaku, samego tworzywa podchodzi się już zupełnie inaczej (czego pokłosiem są choćby dyskusje o inter-, trans- czy postmedialności sztuki/kultury współczesnej), to też znakomity czas, by mogła pojawić się formułowana przez Fajfera i Bazarnik teoria. Podobnie jak poczatek XX w. był idealnym momentem na narodziny awangardy i teorii spod znaku przełomu lingwistycznego.

Jednocześnie, wszelkie eksperymenty z formą zapisu to takie działania, które po coś z tradycja, konwencją zrywają. O ile nie jest to zwykła „zabawa”, typograficzny żart, najczęściej celem jest tu poszukiwanie nowych przestrzeni do budowania znaczeń. I to właśnie byłoby to, co wszelkiego rodzaju eksperymenty typograficzne łączy $\mathrm{z}$ liberatura. Jednak $\mathrm{w}$ myśl pierwszego i drugiego wyznacznika liberackości podanego przez Bazarnik (,użycie niewerbalnych i typograficznych środków wyrazu oraz przestrzenna organizacja tekstu" ${ }^{491}$, wszystko, co choć po części jest inaczej niż tradycyjnie zapisane, nosi znamiona dzieła liberackiego. Dlatego też - choć nie próbowano nigdzie tych twierdzeń rozwijać - liberaccy mają być futuryści. Dlatego jako liberacki wskazywany (bo trudno powiedzieć: opisywany) jest duet Przyboś-Strzeminski. Jednak, co ciekawe - kiedy zaproszono do Łodzi Fajfera i Bazarnik na konferencję o futuryzmie (Futuryzm. Przyszłość sto lat później, maj 2010 r.), niewiele mieli oni do powiedzenia poza tym, że futuryści byli liberaccy ${ }^{492}$. Czy zatem, rzeczywiście sa to kwestie tak oczywiste? Moim zdaniem - wcale nie. Z jakiegoś powodu liberaci z Krzeszowic niewiele w Łodzi (na temat) mówili.

W dalszej części tego rozdziału chciałabym zestawić liberacką teorię z teorią druku funkcjonalnego oraz ideą słów na wolności. Przywołując Marinettiego (i - w mniejszym stopniu - polskich futurystów) oraz współpracę Przybosia i Strzemińskiego (po wielokroć przez Fajfera i Bazarnik charakteryzowanych jako „prekursorzy liberatury” ${ }^{493}$ ), pragnę pokazać, że „to wszystko wcale nie jest takie proste”. Gdyż ani Marinetti, ani Strzemiński nie byli w dużym stopniu liberaccy. Choć na pierwszy rzut oka widzimy, że „przecież to dziwnie zapisane”, że „ma udziwnioną formę”, że przyciaga wzrok, że eksperymentuje z materia znaku... wcale nie to jest tu najważniejsze. Istota liberatury to przecież to, po co się ów „inny” zapis stosuje (i z czyjej intencji). I tu zaczynają się problemy... Warto pochylić się na chwilę nad tymi zagadnieniami, być może okaże się, że do listy argumentów przemawiajacych za tym, że „liberatura jest

${ }^{490}$ Piotr Rypson, Posłowie, [w:] Dick Higgins, Nowoczesność od czasu postmodernizmu oraz inne eseje, tłum. zbior., Gdańsk 2000, s. 224.

491 K. Bazarnik, Liberatura czyli o powstawaniu gatunków (literackich), s. 160.

492 Przypomnę, iż z podobną sytuacją mieliśmy do czynienia, gdy spotkali się (o ironio, również w Łodzi) z Jerzym Jarniewiczem, by dyskutować o poezji konkretnej. Szerzej piszę o tym w rozdziale poświęconym relacji liberatury i poezji konkretnej.

${ }^{493}$ Zob. m.in. Katarzyna Bazarnik, Zenon Fajfer, Krótka historia liberatury, [w:] LCLT, s. 88. 
potrzebna" (jako termin) wypadnie nam dopisać kolejne, wynikające z różnic między tą ostatnią a działaniami awangardowymi, które w pierwszej chwili wydają się iście liberackie.

Dodam też, że choć kwestii związków liberatury i literatury elektronicznej poświęcam w tej pracy oddzielna część, niemniej chciałabym też już tu zasygnalizować, że porównawcza analiza liberackich środków typograficznych oraz tzw. typografii nowomedialnej (określanej też mianem rozszerzonej czy temporalnej) prowadzić może do ciekawych konstatacji. Stąd zamykający tę część moich rozważań fragment poświęcam właśnie temu zagadnieniu. 


\title{
3. Liberatura a koncepcja druku funkcjonalnego
}

\author{
3.1. Liberatura funkcjonalna albo o równoległym \\ projektowaniu znaczeń (czyli o nie tak prostym \\ związku liberatury z teorią druku funkcjonalnego)
}

Gdyby zastanowić się, czemu Fajfer i Bazarnik tak ochoczo nazywają Przybosia i Strzemińskiego prekursorami liberatury, można by w sumie znaleźć wiele przesłanek ku takiej interpretacji. Wystarczy bowiem przywołać z jednej strony po wielokroć powtarzane tu Fajferowskie sformułowania o tożsamości formy i treści, a z drugiej pochodzące ze szkicu Druk funkcjonalny zdanie Strzemińskiego: „forma [...] jest funkcją treści. Forma wynika z treści” ${ }^{494}$. Równie dobrze można by zacytować list ostatniego z przywołanych do Przybosia, w którym proponował wstępną wersję komunikatu grupy a.r. i o poezji pisał następująco:

Poezja (?? - to już Pana rzecz) (przepraszam za-): wydrukowana i czytana, poezja słów, czcionek i stronicy, a nie śpiewanka-kołysanka, melodeklamacja; poezja drukowana, a nie poezja przechodząca z ust do ust (????) (nie wiem czy to tak, ale przecież Pan może to wyrzucić lub zmienić) $)^{495}$.

Potwierdzeniem przywołanej opinii Fajfera i Bazarnik wydają się też słowa badaczy opisujacych tom Sponad niczym dzieło prawdziwie liberackie. Irena Urbaniak stwierdzała np.:

Przeciwstawiając się bowiem tradycyjnej typografii, Władysław Strzemiński zastosował tu takie rozwiązania graficzne, które nie występują obok tekstu - w postaci ilustracji czy winiety, ale ingerują weń, współdecydując nie tylko o jego walorach wizualnych, lecz także o jego semantyce ${ }^{496}$.

Z kolei Janusz Sowiński, zaznaczając, iż dla poetów awangardowych kwestie typograficzne pozostawały istotne, podkreślał, że (m.in.) Strzemiński postrzegał plastyczną organizację poetyckiego tekstu jako jeden z obowiąków artysty ${ }^{497}$.

\footnotetext{
${ }^{494}$ Władysław Strzemiński, Druk funkcjonalny, [w:] idem, Wybór pism estetycznych, Kraków 2006, s. 91.

${ }^{495}$ Listy Wtadystawa Strzemińskiego do Juliana Przybosia z lat 1929-1933, „Rocznik Historii Sztuki" 1973, t. IX, s. 235. List z 21 lutego 1930 r.

${ }^{496}$ Irena Urbaniak, Analiza zgodności znaczeniowo-graficznej „Sponad” Juliana Przybosia w opracowaniu typograficznym Władysława Strzemińskiego, „Sprawozdania z Czynności i Posiedzeń Naukowych Łódzkiego Towarzystwa Naukowego” 1982, R. XXXVI, 5, s. 1, podkreślenie moje. ${ }^{497}$ Janusz Sowiński, Typografia polskiej awangardy, „Studia o Książce” 1989, nr 18, s. 264.
} 
A jednak, choć nikt nie dyskutował dotąd z tezą postawioną przez pare liberatów z Krzeszowic, warto chyba zastanowić się, czy jest ona w pełni słuszna ${ }^{498}$. Czy druk funkcjonalny i liberatura to zjawiska podobne (może wręcz tożsame), czy też istnieje powód - inny niż ten, że to dwa wymyślone przez różne osoby terminy - dla którego oba te pojęcia funkcjonują równolegle w dyskursie humanistycznym? Czy warto zestawiać je ze sobą?

Z pewnością w świetle moich wcześniejszych rozważań koncepcja Strzemińskiego (silnie inspirowana tezami Tschicholda i wpisująca się w nurt reform typograficznych swoich czasów, a także w całokształt budowanej przez twórcę teorii sztuki ${ }^{499}$ ) wydaje się interesujacca jako sprzeciw wobec dominacji wyłącznie jednej z tradycji druku. Artysta w szkicu Druk funkcjonalny zwraca uwagę na harmonijność, bezbarwność i stonowanie kanonu drukarskiego wyznaczonego przez publikacje renesansowe, od którego jego typografia tak chciała się odróżniać. To zgodnie z tymi odrzucanymi konwencjami - przypomnę - każda karta książki miała być jednobarwna, niezaburzająca monotonii odbioru, co (jak zauważa Strzemiński) osiągano zarówno poprzez „szara perlistość zadrukowanej powierzchni" 500 , jak i dzięki ujednoliceniu kroju czcionek w jej obrębie występujących. Celem nadrzędnym było „ujednostajnienie i złagodzenie wrażeń wzrokowych" ${ }^{01}$ (a więc to, czego wagę podkreślała przywołana w poprzednim rozdziale Warde). Kompozycja była symetryczna, ułożona wzdłuż osi pionowej, zaś - dynamiczne w świetle tej koncepcji - zaznaczanie końców rozdziałów (a czasem i stron) stopniowo zwężajacym się trójkątem (wspominanie jeszcze przez Strzemińskiego) zastępowano z czasem zwykłym ucięciem tekstu ${ }^{502}$.

498 Nieoczywistość tego przyporządkowania sygnalizowała Beata Śniecikowska w dyskusji z liberatami podczas spotkania Liberatura - literatura totalna, które odbyło się w Łodzi w październiku 2008 r. w Kawiarni Literackiej Teatru Nowego w Łodzi. Badaczka sugerowała wtedy, że gdy uważnie przyjrzymy się zależnościom między warstwą wizualną a semantyczną przywoływanych tekstów, możemy dojść do nieco odmiennych wniosków. Jednak dotychczas ten wątek dyskusji o liberaturze nie został rozwinięty.

499 Szerzej o koncepcji druku funkcjonalnego piszą m.in.: Bożena Lewandowska (idem, U źródet grafiki funkcjonalnej w Polsce, [w:] Ze studiów nad geneza plastyki nowoczesnej w Polsce, red. Juliusz Starzyński, Wrocław 1966, s. 192-278) oraz Piotr Rypson (idem, Ksiażki i strony, Warszawa 1992, szczególnie s. 33-52). Omówienie zarówno rozwoju polskiej typografii funkcjonalnej, jak i jej powiązań z analogicznymi nurtami w innych krajach daje tė̇ Janusz Sowiński w przywołanym artykule Typografia polskiej awangardy (s. 263-282). Badacz zwraca uwagę na relacje między polską nową typografią a działalnością rosyjskich konstruktywistów skupionych wokół Kazimierza Malewicza i El Lisickiego oraz grupy UNOWiS, a także Włodzimierza Majakowskiego i środowiska „LEFu” (później „Nowego LEFu”) oraz niemiecką typografią spod znaku wydawnictwa Bauhaus z Laszló Moholy-Nagym i Herbertem Bayerem jako głównymi postaciami. Sowiński zaznacza też w gruncie rzeczy znikomy wpływ Marinettiego i futurystów włoskich na polskich artystów, a także brak związku z czeską nową typografią Karola Teige'a czy eksperymentami węgierskimi (skupionymi wokół czasopisma „Ma”). O rozwoju koncepcji typografii funkcjonalnej u samego Strzemińskiego pisze zaś Andrzej Turowski (Andrzej Turowski, Konstruktywistyczna typografia Wtadystawa Strzemińskiego, „Projekt” 1971, nr 4, s. 19-24).

${ }^{500}$ W. Strzemiński, Druk funkcjonalny, s. 90.

501 Ibidem.

502 Choć w szkicu Strzemińskiego taka sygnalizacja końca rozdziału sugerowana jest jako klasyczna, jedynie w winiecie zastępowana prostym cięciem, trudno w czasach mu współczesnych, 
Wskazując niewielkie zmiany w zakresie tak ustalonej techniki drukarskiej, Strzemiński zauważa, że (niezależnie od epoki) aż do przełomu wieku XIX i XX myślano o drukach na sposób plastyczny. Opracowywanie tekstu było tożsame z jego ozdabianiem, stąd artysta mówi o „druku zdobniczym” 503 , podkreślając, iż przy takim podejściu wszelkie stosowane zabiegi wynikały z chęci „wtłaczania druku w formę rysunkową z góry powziętą" ${ }^{04}$, niemająca żadnego związku z treścią utworu. Wydaje się, iż dominująca harmonijność i stonowanie były kontynuacją renesansowej myśli o sztuce. Zaś przełom wyznaczyły zmiany mające miejsce zarówno w przestrzeni gospodarki, jak i działań artystycznych. To nowe podejście do świata, nowy jego porządek, nowe nań spojrzenie umożliwiły narodziny tzw. drukarstwa funkcjonalnego, którego celem miała być możliwie największa odpowiedniość kształtu typograficznego i przekazywanych treści, zmierzająca do ułatwienia odbioru komunikatu.

Warte podkreślenia jest też to, że Strzemiński, postulując wprowadzenie nowej typografii, nie mówił wcale wyłącznie o literaturze, określając jako cel wprowadzanej formy „rzeczywistą celowość łatwej czytelności druku codziennego (plakat, afisz, okładka książki, ogłoszenie, blankiet firmowy, wizytówka etc.) ${ }^{\prime 505}$. Dopiero w dalszej części jego wywodu pojawia się sformułowana wprost deklaracja, iż opisywany sposób opracowywania tekstów ma być stosowany również w odniesieniu do sztuki słowa. Dla moich rozważań jest to o tyle istotne, iż pozwala pokazać, że i w przypadku tego artysty mamy do czynienia z uwspólnieniem środków ekspresji w drukach użytkowych i artystycznych, ponownym zespoleniem dwóch ścieżek rozwoju typografii, wskazywanych przez Drucker.

Poszukując zaś owych nowych rozwiązań drukarskich, takich, które harmonizowałyby z budową i przesłaniem utworów, Strzemiński sięgał do typografii użytkowej, zdając sobie niejako sprawę z tego, iż w jej obrębie stosowano znacznie więcej środków, które przecież i dla literatury moga być użyteczne (mam tu na myśli właśnie ową ignorowana drugą tradycję Gutenbergowska). W liście do Przybosia z października 1929 r. autor pisał o tym, że potrzebne są mu z drukarni „druczki” o czcionkach większych i też „fantazyjnych", że szuka inspiracji m.in. w katalogach, zaproszeniach ${ }^{506}$. Czy

a już na pewno w dzisiejszych, znaleźć potwierdzenie tej tezy w książkach. Ten „dynamiczny”, bądź co bądź przykuwający wzrok, akcent nie wszedł do kanonu drukarstwa - jak można by powiedzieć - „przezroczystego”.

${ }^{503}$ W. Strzemiński, Druk funkcjonalny, s. 91.

${ }^{504}$ Ibidem.

${ }^{505}$ Ibidem, s. 90-93, s. 91, podkreślenie moje.

${ }^{506}$ Strzemiński zdawał sobie zreszta sprawę z tego, że każda drukarnia ma inny wzornik takich czcionek, dlatego też prosił Przybosia o przesłanie wzorów z tej właśnie drukarni, w której miało być Sponad drukowane. Jak tłumaczył: „Można robić układy tylko wiedzacc, jakie mają czcionki, gdyż inaczej można liczyć na cokolwiek, czego się nie znajdzie i w ten sposób później przerabiać całkowicie. Myślę, ze najlepiej, gdyby drukarnia dała parę książek wydrukowanych u nich, które bym mógł odpowiednio rozszarpać i powyrywać. Może by Pan mógł takie książki z drukarni otrzymać i przesłać" [Listy Wtadystawa Strzemińskiego..., s. 227 (list spomiędzy 1 września a 13 listopada 1929 r.)]. Warto może dodać, że o czcionki z drukarni Strzemiński prosi też przy opracowywaniu Poezji integralnej Brzękowskiego, jak poświadcza list (najprawdopodobniej do Przybosia lub jego żony) z 30 sierpnia 1932 r. 
pod ich wpływem ukształtował swoje opracowanie, o którym napisał poecie: „zdaje się, że znalazłem sposób chwytania poezji w układy graficzne tak, że unaocznia poezje" 507 ?

Jednak pokazując powody, dla których chciałabym zatrzymać się nad kwestią związku druku funkcjonalnego i liberatury, nie muszę chyba kryć, że - sięgając po temat typograficznej działalności Władysława Strzemińskiego - przymierzam się do wyważania (dawno już) otwartych drzwi. Jeżeli obawy o to, cóż można powiedzieć w odniesieniu do zagadnień tak wszechstronnie opisanych towarzyszyły kilka lat temu Beacie Śniecikowskiej, jak ma ich nie podzielać ktoś, kto podejmuje ten temat już po opublikowaniu jej analiz twórczości duetu Strzemiński-Przyboś, rewidujących - choćby z racji przyjęcia odmiennej perspektywy - dotychczasową refleksję na ten temat ${ }^{508}$ ?

Wychodząc z założenia, że bliskie (i potrzebne) jest dla moich rozważań zarówno ujęcie zaproponowane przez przywołaną badaczkę (wyjście od analizy i interpretacji konkretnych wierszy, opis immanentnej poetyki tekstów poprzedzający namysł nad formułowaną przez artystę teoria, a także umieszczenie jego twórczości w szerszym kontekście, porównania z - pozornie - analogicznymi działaniami podejmowanymi przez współczesnych), jak i perspektywa obrana przez jej poprzedników (sytuowanie w centrum badań teorii i szukanie jej potwierdzenia w praktyce), powinnam jednak powtórzyć za Śniecikowską: „Czy warto wracać do kwestii tak wszechstronnie opisanych, czy można dodać tu coś nowego, czy wreszcie analogie występujące w pracach dwu działających w różnych tworzywach konstruktywistów to jeszcze problemy zajmujące dla dzisiejszych odbiorców?’”o9.

I tak, jak badaczkę tłumaczyła chęć przyjęcia nowej perspektywy i wskazania dotychczas niedostrzeganych „istotnych wątków typograficzno-poetyckiej "faktury»" ${ }^{10}$ tomiku Sponad, niech mnie obroni to, że celem moich rozważań również nie jest bynajmniej opis teorii czy praktyki Strzemińskiego, lecz - dotychczas niespotykane $\mathrm{w}$ literaturze przedmiotu - skonfrontowanie ich $\mathrm{z}$ teorią i praktyką liberacką. Pretekstem zaś do proponowanego zestawienia jest pozorna jedynie (jak chciałabym wykazać) zbieżność zdań czołowego polskiego typografa funkcjonalnego i liberata na temat tożsamości formy i treści, powierzchowne wyłącznie podobieństwo twierdzeń o tym, że treść rodzi się (i wynika) z formy.

Kontekstem dla konfrontacji teorii Strzemińskiego i Fajfera sa dla mnie teksty teoretyczne obu autorów oraz (konfrontowane z dziełami liberackimi) wydane w 1930 r. w Cieszynie Sponad Juliana Przybosia jako pierwszy, lecz i - w czym badacze pozostają raczej zgodni - najlepszy tom biblioteki a.r.

${ }^{507}$ Listy Wtadystawa Strzemińskiego..., s. 227 (list z 13 listopada 1929 r.).

${ }^{508}$ Beata Śniecikowska, Dwóch artystów - dwa tworzywa - jedna idea? - o sztuce i teorii sztuki Juliana Przybosia $i$ Wtadystawa Strzemińskiego, [w:] eadem, Stowo-obraz-dźwięk. Literatura i sztuki wizualne w koncepcjach polskiej awangardy 1918-1939, Kraków 2005, s. 175-302.

${ }^{509}$ Ibidem, s. 241.

${ }^{510}$ Ibidem. 


\title{
3.2. Analogie werbalnej i wizualnej kompozycji czy drażniący czytelnika happening typograficzny?
}

\begin{abstract}
Skwapliwość, z jaką Strzemiński konstruował swoją wizję druku funkcjonalnego jako odzwierciedlajaccego poszczególne kompozycyjne cząstki utworów, zrodziła się z inspiracji koncepcją Jana Tschicholda. Dość przypomnieć, że ten ostatni określał „roztrząsanie metody układu” jako nadrzędny i zasadniczy cel nowego drukarstwa ${ }^{511}$. Zaś polski konstruktywista nie tylko w lutym 1930 r. z zachwytem pisał do Przybosia o „wprost rozczulającej [...] solidności i cierpliwości w opracowaniu każdego szczegółu, każdego rozwiąania zagadnienia drukarskiego"512 charakteryzujacej tego reformatora typografii, lecz w czerwcu tego samego roku doprowadził do opublikowania na łamach „Europy” jego szkicu Nowe drukarstwo ${ }^{513}$, a osiem lat później sfinalizował druk skróconego przekładu najważniejszej w dorobku tego teoretyka książki: Druku nowoczesnego ${ }^{514}$. Warto przywołać choć we fragmentach charakterystyke nowych powinności drukarza, jaką podaje Tschichold w tej ostatniej pozycji:
\end{abstract}

każdą poszczególną część kompozycji oddzielamy od innych w sposób widoczny i wyraźny. każda część całości jest przejrzysta i różni się jedna od drugiej. neutralność poszczególnych części jest przez to utrzymana. w dawnym drukarstwie występowały części mniej lub więcej bezkształtne; dziś są już one przejrzyście zarysowane i w jasnej formie ujęte dla oka ${ }^{515}$.

I Strzemiński skrupulatnie takie właśnie części w interpretowanych typograficznie utworach próbował odnaleźć. Jego mierzenie się z twórczościa Juliana Przybosia było poszukiwaniem zasad kierujących kompozycją i budową wierszy, gdyż w jego mniemaniu, dopiero zrozumienie tych podziałów mogło zaowocować dobrym graficznym ułożeniem tekstu. Pisał o tym do poety, tłumacząc jednocześnie, jakie typy (odpowiadające właśnie różnym sposobom wydzielania partii utworów) odkrył w jego twórczości:

511 Jan Tschichold, Nowe drukarstwo, „Europa”, czerwiec 1930, nr 9 [6], s. 272.

512 Listy Wtadystawa Strzemińskiego..., s. 233 (list z 3 lutego 1930 r.).

513 J. Tschichold, Nowe drukarstwo, s. 272-276. Najważniejsze tezy postawione w tym pisanym w Monachium szkicu to uznanie nowego drukarstwa za drukarstwo nowych czasów, ahistoryczne i nienakładające żadnych ograniczeń przy wyborze środków oraz przyznanie, że jego celem miało być jak najbardziej funkcjonalne oddanie treści (co tłumaczy wyzbycie się wszelkiej zbędnej dekoracyjności). Tschichold dodawał, że układ drukarski miał być czytelny, a barwę należało wykorzystywać jako ważny środek oddziaływania.

514 Jan Tschichold, Druk nowoczesny, tłum. Alfred Frank, red. Władysław Strzemiński, Łódź 1938, bez paginacji stron. Pozycja ta przynosi charakterystykę stosowanych w nowym drukarstwie środków, zaś za najważniejsze kwestie poruszane przez autora można uznać: wagę asymetrii układów, sugestię uciekania od natłoku i przeładowania, konieczność stosowania kontrastów (kształtów grup tekstu czy ich kolorów), a także zalecenie łączenia interpretacji semantyki tekstu z dbałością o jego kształt estetyczny. Strzemiński stosuje się do wszystkich tych postulatów, owocem namysłu nad ostatnim z wymienionych jest zaproponowanie zmiany kolejności stron w tomiku Sponad, tak by nie sassiadowały ze sobą wiersze źle obok siebie wyglądające (zob. Listy Wtadystawa Strzemińskiego..., s. 234 - list z 1930 r.).

515 J. Tschichold, Druk nowoczesny. 
Potrafiłem ocenić wiersze dopiero robiąc układy. Znalazłem typy: 1) ciagły (Krajobraz, Ziemniaki, pokój), 2) członowany (Strofy), 3) bijacy słowami o rozmaitej sile (Murarze, Deszcz), 4) wieloplanowe ( $Z$ blyskawic, Florian). W niektórych miałem duże trudności, bo musiałem je zrozumieć nie na poziomie czytelnika, lecz tak jak je Pan rozumiał pisząc. Najgorzej było z Florianem, którego miałem zamiar Panu odesłać, prosząc o należyte wytłumaczenie, ale w ostatniej chwili zrozumiałem, że jest trzyplanowy ${ }^{516}$.

Jak widać, każdy z wyróżnionych typów wyznacza inną zasadę kierującą późniejszym podziałem tekstu na czastki graficzne (lub właśnie sugerująca brak konieczności wprowadzania takich podziałów) ${ }^{517}$. Strzemiński był na tyle przekonany o słuszności swoich interpretacji i - co ważniejsze - o ich znaczeniu dla tekstów, że w późniejszym o niespełna miesiąc liście do poety dodawał, że bez proponowanych przezeń układów nie da się dostrzec walorów, jakie niesie w sobie poezja Przybosia, że - bez wyróżnień typograficznych ich bogactwo i nowatorstwo jest raczej niedostrzegalne ${ }^{518}$. Stąd ośmielam się przypuszczać, że polski konstruktywista oceniał swoje działania jako raczej oddajace przysługę wierszom poety ${ }^{519}$.

A jednak Jerzy Kwiatkowski - komentując dokonane przez Strzemińskiego opracowanie Sponad - zarzucał artyście, że oddał tomikowi „nienajlepsza przysługę" ${ }^{20}$, że zwolnił czytelnika z obowiązku interpretacji, ujednoznaczniając ją i podając odbiorcy - można by rzec - jak namalowaną. Co więcej, jak dodaje autor: „grafik stworzył mu natomiast dodatkową przeszkodę do

${ }^{516}$ Listy Wtadystawa Strzemińskiego..., s. 228 (list z 30 listopada 1929 r.).

517 Andrzej Turowski następujaco charakteryzuje sposoby graficznego opracowania konkretnych grup wierszy: „Wierszom «ciagłym» odpowiadał stosunkowo jednolity układ graficzny, bez wyraźniejszego różnicowania czcionki, o złagodzonych kontrastach linii i równomiernym rozłożeniu wielkości kształtów. "Członowane» podporządkował artysta grupom graficznym rozmieszczonym w kilku strefach o zmiennych akcentach. W «bijących słowami o rozmaitej sile» - poszczególne wyrazy zostały uwypuklone zwiększoną skalą. "Wieloplanowe» - łączyły teksty w bloki, wyraźnie oddzielone, lecz równoważone walorami plastycznymi” (A. Turowski, Konstruktywistyczna typografia Wtadystawa Strzemińskiego, s. 23).

${ }_{518}$ Listy Wtadystawa Strzemińskiego..., s. 230 (list z grudnia 1929 r.).

519 Jak poświadcza korespondencja z Przybosiem, Strzemiński zdawał sobie jednak sprawę z raczej negatywnego odbioru publikacji. W liście z 26 kwietnia 1930 r. czytamy: „W Warszawie ludzie rozmaici, z którymi się spotykałem, na ogół sa źli na «Z ponad» i zależnie od swego usposobienia napadają albo na Pana, albo na mnie (że Pan jest zły poeta i że ja musiałem opracować [wiersze] kogo innego, np. Iłłakowiczówny), że w Pana wierszach nie ma muzyki, że ja przez układy zrobiłem muzykę w Pana wierszach, że rozbiłem zdanie, że słowo wyjęte ze zdania terytorialnie lub przez krój czcionek traci sens, że tylko w związku i innymi słowami, że trudno czytać małe litery obok dużych, że Pan nie przestrzega zasady strofalnej, że tylko stara deklamacja uwzględnia cieniowanie każdego wyrazu, a teraz się deklamuje całościami [...] Książka jest im [w Departamencie Sztuki AP] kością w gardle, że modernizm nie umarł, nie jest sprzedpokojowiony" [Listy Wtadystawa Strzemińskiego..., s. 240 (list z 26 kwietnia 1930 r.)]. Jednak, jak słusznie zauważa Śniecikowska, wśród zebranych w tomiku wierszy przeważały takie, które sprawnie realizowały założenia teoretyczne koncepcji druku funkcjonalnego i które oceniać można jak najbardziej pozytywnie: „Najliczniejsza grupa to układy współgrajace z kompozycją wewnętrzną wierszy, «chwytajace» najważniejsze cechy konstrukcyjne tekstu i w czytelny sposób odwzorowujące je na stronie. Kompozycje tego rodzaju pomagają w lekturze, wydobywają walory dzieła literackiego, nie sa uzurpacją plastyki w stosunku do utworu literackiego" (B. Śniecikowska, Stowo-obraz-dźwięk..., s. 245].

${ }^{520}$ Jerzy Kwiatkowski, Świat poetycki Juliana Przybosia, Warszawa 1972, s. 107. 
przezwyciężenia: różnorodność czcionek, skomplikowany układ typograficzny - utrudniaja mianowicie lekturę, rozpraszają uwagę, kierujac ją ku literom, odciagają od znaczeń" 521 . Jak powiedziałaby Warde, zaoferował odbiorcom złoty kielich miast kryształowego. Pomijajac już kwestię toczonych przez lata dyskusji o słuszności bądź niesłuszności dokonanych przez Strzemińskiego ingerencji w tekst, trzeba przyznać, że - szczególnie w świetle wcześniej przywołanej korespondencji - raczej nie takie były jego intencje.

U Strzemińskiego rozbijanie partii tekstu i czynienie zeń (na drodze przekształceń przestrzennych zapisu) form graficzno-obrazowych miało mieć związek z budową utworu, z jego semantyka. Miało czytelnikowi pomóc, nie przeszkadzać. Celem stawało się uwypuklenie znaczeń tekstu, przy czym chodziło tu nie o (raczej tautologiczne) podkreślenie, lecz wzmocnienie akcentów powiąane $\mathrm{z}$ dopowiadaniem, dopełnianiem znaczeń. Takie podkreślenia, istotnie, utrudniały pójście inną czytelniczą ścieżką niż ta zaprojektowana przez Strzemińskiego-interpretatora. Kwiatkowski mówi wprost: „proces, który powinien - w sposób subiektywnie zróżnicowany - odbywać się podczas lektury w psychice każdego czytelnika, został tu - raz na zawsze - ujednoznaczniony i spetryfikowany" ${ }^{22}$. Wyjaśnienia, rozwinięcia wymagają jednak dwie kwestie. Po pierwsze: czy stawiany przez Kwiatkowskiego zarzut można (na zasadzie sugerowanych wcześniej analogii) odnieść również i do liberatury (którą przecież niektórzy określali właśnie i happeningiem typograficznym). Po drugie, rozważając, na ile słuszne są zarzuty Kwiatkowskiego - stajemy przed problemem tego, czym w istocie sa typograficzne opracowania Strzemińskiego.

Zaczynając od pierwszej kwestii, trzeba zaznaczyć, że liberaci nieraz, owszem, chca drażnić czytelnika, stawiać przed nim przeszkody budowane z liter czy słów. Jednak owo „drażnienie oka” ma dość specyficzny charakter. Określone elementy warstwy zapisu utworu zwracają na siebie uwagę w chwili, gdy właśnie im trzeba się przyjrzeć, gdy znaczenia tekstu rodzą się z owej nieprzezroczystości materiału. Jeśli udziwnione litery w Ulicy Sienkiewicza $w$ Kielcach Nowakowskiego wpadaja na siebie, to dlatego, że forma ich zapisu oddaje charakter ruchu bohatera, jeśli zapisane sa w dziwnych kierunkach i czytelnik musi się namęczyć, by je odczytać - jak w przypadku (przywoływanej już) leksji „mucha” w Końcu świata wedtug Emeryka tegoż autora - to właśnie dlatego, że tym razem same ten tor ruchu przedstawiaja. Jeśli - jak jest w poematach-znakach zamieszczonych w Oka-leczeniu Fajfera i Bazarnik - litery przeradzaja się w obraz, to właśnie dlatego, że jego zespolenie z obrazem jest istotne. Jak pokazują interpretacje Oka-leczenia, fakt, że dwa różne, nazwijmy je roboczo, słowo-rysunki (odpowiadajace fabularnie dwóm różnym częściom utworu) sa zbudowane $\mathrm{z}$ tych samych liter, pozostaje nie bez znaczenia $^{523}$. Właśnie na poziomie typografii przekazanych jest tu wiele znaczeń, których nie da się odczytać ani z samego obrazu, ani z samych słów, ani nawet

\footnotetext{
521 Ibidem.

522 Ibidem.

${ }^{523}$ Por. bibliografia podana w przypisie $66 \mathrm{w}$ rozdziale Liberatura a poezja wizualna.
} 
z ich połączenia wyjętego z kontekstu całego tomu. Zaś pierwszym krokiem prowadzacym ku interpretacji jest właśnie to, że drażnią one wzrok czytelnika. Nie dostrzegam też w tekstach liberackich niczego, co ograniczałoby interpretację, petryfikowało jej proces, ujednoznaczniało.

Wydaje się również, iż w przypadku tomu Sponad intencja Strzemińskiego była jednak inna niż sugeruje Kwiatkowski. Tak jak - w duchu tez Tschicholda - nie stosował on zbyt wielu środków graficznych i jego (pozbawione zbędnej dekoracyjności) układy opierały się na kontrastach i asymetrii, tak i nie miały odbiorcy przeszkadzać, lecz właśnie czynić przesłanie tekstu bardziej czytelnym. Miały być funkcjonalne, a nie przykuwać uwage do samych siebie. Jeśli stało się inaczej, to może warto zastanowić się dlaczego.

\subsection{Typograficzna interpretacja contra dzieło totalne}

I tu, trzeba powrócić do drugiego z sygnalizowanych przeze mnie problemów i przyznać wprost, iż w myśli Strzemińskiego drukarstwo jest rodzajem interpretacji tekstu. To dlatego artysta i teoretyk dopomina się o nowe potrzebne zecerowi umiejętności: nie ma on być już wyłącznie tym, kto - wykorzystując swą wiedzę z zakresu edycji tekstu oraz talent plastyczny - opracowuje graficznie i przestrzennie otrzymany tekst. Powinien stać się również jego interpretatorem $^{524}$. Jeśli proponowana przez drukarza forma ma - jak chce Strzemiński - odpowiadać treści, a postać graficzna odzwierciedlać strukturę utworu, ten, kto ją opracowuje musi ową literacką budowę dostrzec i zinterpretowaćc5. By wyróżnić części tekstu, które mają ze sobą wchodzić w relacje przestrzenne, graficzne, trzeba wiedzieć, jakie są owe analogiczne relacje w zakresie semantyki. Stąd Strzemiński wspomina o konieczności „dokładnego zrozumienia” tekstu przez zecera ${ }^{526}$. Co więcej, jak mówi wprost twórca teorii unizmu:

Jak każda interpretacja utworu literackiego nie daje kompozycja drukarska jednego tylko rozwiązania graficznego. Wynik zależy od tego, jakie części tekstu chcemy podkreślić, a jakie uważamy za drugo- i trzeciorzędowe. Dlatego przy akcentowaniu innych składników tekstu kompozycja będzie wyglądała inaczej ${ }^{527}$.

${ }^{524}$ O swojej koncepcji pisał Strzemiński: „Tekst uporządkowany na zasadzie największej czytelności organizujemy w rytm oka czytającego [...] Drukarstwo funkcjonalne wymaga [...] opanowania zdobyczy nowoczesnej plastyki konstrukcyjnej i umiejętności zwartego obrazowania i zagęszczania treści wynikających z poezji nowoczesnej” [cyt. za: Andrzej Turowski, Komentarz do korespondencji Wtadystawa Strzemińskiego, „Rocznik Historii Sztuki” 1973, t. IX, s. 277, ten zaś za: Koło Artystów Grafików Reklamowych, IV wystawa, Warszawa 1936 (maj) IPS.].

${ }^{525}$ Strzemiński mówi o takim działaniu m.in. następującymi słowy: „W drukarstwie funkcjonalnym każda z grup tekstu powinna współdziałać z zawartą w niej treścią, wyrażać ja. Wydobycie z niej jej charakteru emocjonalnego możemy uzyskać właśnie przez zastosowanie rozmaitych typów i wielkości czcionek" (W. Strzemiński, Druk funkcjonalny, s. 92). I tu wyraźnie podkreślony jest interpretacyjny charakter działań typograficznych.

${ }^{526}$ W. Strzemiński, Druk funkcjonalny, s. 91.

${ }^{527}$ Ibidem. 
Czy i w przypadku dzieła liberackiego możemy mówić o kilku możliwych jego postaciach? Czy jego kształt zależny jest od interpretacji? W jakim stopniu? Zanim odpowiem na te pytania, chciałabym zatrzymać się jednak jeszcze przez chwilę nad procesem interpretacji dokonywanym przez Strzemińskiego. Śniecikowska w swoich badaniach wyróżnia wśród wierszy składających się na tom Sponad spora grupę tekstów, w których opracowanie typograficzne rzeczywiście współgra z semantyką utworu. Dokonane przez badaczkę analizy w pełni pokazuja, że Strzemiński - w tym wypadku - konsekwentnie stosuje zaproponowany przez siebie w Druku funkcjonalnym sposób edycji tekstu. Przygotowane przezeń opracowanie typograficzne jest w pełni „poprawne”, funkcjonalne, czyli: klarowne, przejrzyste, jednoznaczne i w pełni związane z treścia, odpowiadające jej. Uważnej lekturze i interpretacji towarzyszyło podzielenie tekstu na człony semantyczne, najczęściej zgodne z podziałem na gramatyczne części zdań, bądź układ wersowy czy stroficzny. Ułatwianie czytelnikowi lektury, które zarzucał Strzemińskiemu Kwiatkowski (i na które wskazywała też Śniecikowska) polega tu właśnie na bardzo wyraźnym rozczłonowaniu tekstu: nie tylko wskazaniu poszczególnych jego fragmentów, lecz i uwydatnieniu relacji między nimi. Rzeczywiście, jest to zabieg ujednoznaczniający i choć niebędący w sprzeczności z treścią utworu, nieraz pozbawiający go niedopowiedzeń, niejasności wymagajacych interpretacji ${ }^{528}$. W przypadku tych wierszy ich kształt graficzny nie tylko nie jest na bakier z sensami w nich przekazywanymi, lecz skłania ku mówieniu o pełnej odpowiedniości konstrukcyjnej warstwy werbalnej i typograficznej. Jednak pozostaje pytanie: czy owa odpowiedniość jest też liberacka?

Poszukując na nie odpowiedzi, można by - wyprzedzając nieco tok wywodu - powiedzieć, że stosunek druku funkcjonalnego do liberatury jest mniej więcej taki, jak tej ostatniej do książki artystycznej. Co jednak ważne, idzie tu o taką postać tej ostatniej, której twórcy liberaccy sprzeciwiali się i którą usilnie - już od samych początków - chcieli od swojej działalności odróżnić. Jakie jej stawiali zarzuty? Z ich punktu widzenia grzechem takich książek była nieprawdziwa jedność formy i treści, kusząca tautologiczność. Artysta poszukiwał tekstu literackiego i - interpretując go - nadawał mu możliwie piękną/adekwatną/estetycznie satysfakcjonującą formę. Wiązała się ona często z przesłaniem tekstu, niemniej, pozostawała wtórną wobec niego typograficzna (jak określałam to już wcześniej w tym rozdziale) czy szerzej - woluminowa - ilustracja. Kluczowe wydaje się tu to, że owa ilustracja (której stawia się zarzut tautologiczności, niesamodzielności) tworzona jest znacznie później

${ }^{528}$ Najłatwiej dostrzec to na przykładzie utworów określanych przez Strzemińskiego jako wieloplanowe, w których czytelnik nie musi już samodzielnie przyporządkowywać wydarzeń do odpowiednich płaszczyzn czasowo-przestrzennych (ani nawet domyślać się, że powinien coś takiego uczynić), gdyż od razu owe różne plany malują się przed nim jako odmienne wizualnie. Warto tu może też przywołać dyskusję Śniecikowskiej z dokonaną przez Strzemińskiego interpretacja Floriana. Badaczka - podobnie jak i inni krytycy, a przypuszczalnie również i sam Przyboś - widzi w tym utworze zaledwie dwa plany czasowe, autor opracowania typograficznego dostrzega zaś trzy (Por. B. Śniecikowska, Stowo-obraz-dźwięk..., s. 266-267). 
niż sam tekst, niejako w odpowiedzi na niego. A owo rozsunięcie czasowe projektowania znaczeń może też - co w przypadku liberatury pozostaje kwestia niebanalna - owocować właśnie tym, że sensy budowane w warstwie wizualnej będą nie tyle potęgować czy wzmacniać znaczenia werbalne, lecz zaczna je przesłaniać, czasami wręcz im przecząc. Wydaje się też, iż i krytyka Kwiatkowskiego wymierzona jest w scharakteryzowaną tu sytuację.

Skupienie się na tych pracach Strzemińskiego, o których Śniecikowska i Wysłouch pisza, że wypaczają sensy poezji Przybosia, pozwoli głębiej przeanalizować tę kwestię i dokładniej zrozumieć, czemu dla liberatury tak istotna jest nie tyle współpraca edytora/typografa tekstu i artysty-literata (bo tej przecież w trakcie pracy nad Sponad - jak poświadcza korespondencja obu twórców - nie brakowało), lecz właśnie jednoczesność projektowania znaczeń werbalnych i materialnych. Tym samym - jasne staną się różnice między ujęciem „literatury funkcjonalnej” i totalnej. Zreszta w przypadku tej ostatniej niemożliwe jest, by warstwa wizualna przesłaniała werbalna, by wypaczała jej sensy, gdyż obie - wspólnie - je współtworzą.

O liberackości Ulicy Sienkiewicza $w$ Kielcach przesądza właśnie to, że nie była ona tekstem monologu bohatera wtórnie opracowanym typograficznie, nie znajdziemy go nigdzie jako utworu „samodzielnego”. Wyjątkowość tej - odważmy się nazwać rzecz po imieniu - książki, nie wynika też z tego, iż ten, kto wybierał i kto układał (w przestrzeni) jej słowa to ta sama osoba. Wcale nie tożsamość typografa/drukarza i literata jest tu kluczowa ${ }^{529}$. Specyfika rodzi się z jednoczesności projektowania znaczeń - z tego, że przyjmując, iż bohater będzie biegł, myśli się o tym, jak materialnie, typograficznie to pokazać. Że szukajac słów do opisania toru jego ruchu, ciągłej zmiany miejsca zajmowanego przezeń w przestrzeni, czasem sięga się po słowa, czasem zaś ów ruch (będący przecież elementem literackiej fikcji) przedstawia się w inny sposób: wizualny, operujący nie tyle słowem, co jego (bądź innych znaków) materią. U Nowakowskiego pełna rekonstrukcja fabuły i świata przedstawionego jest możliwa dopiero po odczytaniu wszystkich kodów i znaków tworzących przekaz. Same zaimki „ten”, „tamten”, „tędy”, „tamtędy” nic nie znacza, jednak w połączeniu z fragmentami obrazów czy umieszczone w odpowiednim miejscu kartki nabierają sensów. Podobnie, zamiast pisać o grupie osób toczących nieistotne dla bohatera (i niedosłyszane przez niego) rozmowy, Nowakowski schematycznie zaznacza ich obecność $\mathrm{w}$ świecie przedstawionym pustymi dymkami. W konstruowanej rzeczywistości literackiej są to postacie zdecydowanie epizodyczne. O ile w ogóle możemy mówić o ich roli w fabule, to polega ona li tylko na tym, że zajmuja miejsce w przestrzeni świata kreowanego przez twórcę. I może lepiej właśnie poświęcić im - dla zamarkowania ich bezsłownej egzystencji - odrobinę tejże przestrzeni, nie samych słów.

${ }^{529}$ A warto też pamiętać, że Nowakowski osobę pełniącą obie te funkcję nazywa często ksiażkarzem - tym, co robi książki, gdyż dla tego artysty i teoretyka liberatura to, najprościej mówiąc, właśnie robienie ksiązek. 
Choć tekst Nowakowskiego dla niektórych może wyglądać jak jedna wielka ilustracja, nie ma z takową nic wspólnego. Choć skrzy się kolorami, choć słowa są w nim fantazyjnie zapisane, choć mamy tu do czynienia z „koncertem na czcionki i linie", a nawet i na rysunki, wszystko to, co widzimy, powinno do nas przemawiać, przekazywać nam sensy. Nie spotkamy tam żadnej literackiej treści, z którą kształt jej zapisu idealnie by - jak postuluje Strzemiński - harmonizował. Nie znajdziemy bowiem niczego, co owa niezwykła typografia miałaby oddawać, podkreślać czy ujednoznaczniać. Koronnym argumentem niechże będzie i to, że nawet samo miejsce akcji dzieła Nowakowskiego nie jest opisane słowem. Co informuje nas, że bohater spaceruje po deptaku Kielc? Jak przekazana jest informacja, że wyruszył z dworca i przeszedł się główna ulicą miasta, by - tą samą drogą - nań powrócić? Nie ma tu słów, adresów, opisów miejsc. W zamian oferuje się czytelnikowi idealną wizualno-typograficzną reprodukcję wspomnianej przestrzeni. Co ciekawe - nie tak wyraźna, gdy bohater nie zwraca na nią uwagi (nie wszystkie budynki odmalowane sa równie starannie), ale też wchodzącą i w najciemniejsze zakamarki podwórek, gdy tam właśnie podąża spacerowicz ${ }^{530}$.

Śniecikowska analizowała, jak w Sponad miejsce przestrzeni strony, w którym umieszczono poszczególne fragmenty utworu współgra z jakościami semantycznymi tekstu. Pokazywała, jak zaprojektowane relacje przestrzenne oddaja znaczenia, idealnie harmonizujac z przekazem. Doceniała poprawność i oryginalność takiego „funkcjonalnego” zapisu. Czy podobnie jest u Nowakowskiego? Zapisanie słów krzyczącej z okna kobiety na wysokości tegoż okna jest zdecydowanie funkcjonalne. Bo w liberaturze każdy szczegół jest sfunkcjonalizowany. Jednak - podkreślę raz jeszcze - jest on taki od samego początku, gdyż przypisano mu konkretną rolę w kreowanym świecie znaków, a uniwersum to jest ewidentnie nie tylko werbalne. W tekście nie ma przecież żadnej sugestii słownej naprowadzającej nas na trop tego, że kobieta znajduje się we wnętrzu budynku, na którymś tam piętrze i, że - wychylając się przez okno - kieruje swą wypowiedź do osób znajdujacych się poza domem. Nie ma takich informacji, które, analizując (wtórnie) można by podkreślić takim, a nie innym układem typograficznym. Tak musiałoby być u Strzemińskiego, gdyż tam mielibyśmy do czynienia z - rozgrywającą się na poziomie struktur - konstrukcyjną jednością kompozycji, jak słusznie zauważa Andrzej Turowski ${ }^{531}$. W liberaturze zaś kompozycja i struktura jest jedna, od początku projektowana jako zespół znaczeń tworzonych na styku kodów.

Niemal wszyscy, którzy zajmowali się Sponad przywoływali list Strzemińskiego do Przybosia z 27 czerwca 1929 r., w którym prosi on poetę o ponowne przejrzenie $20 \mathrm{~kg}$, z których typograficznym ułożeniem twórca unizmu nie mógł sobie poradzić. Uznał więc, że tekst musi być literacko niedopracowany pod względem kompozycyjnym i (warunkowo) zwrócił go artyście do poprawy.

${ }^{530}$ Kiedy bohater wchodzi w jedną z bram, tekst przenosi się na drugą stronę karty, równiė̇ „kryjąc się” w bramie. Słowa bohatera wędrują tam, gdzie on.

531 A. Turowski, Konstruktywistyczna typografia Władystawa Strzemińskiego, s. 23. 
Trudno byłoby wyobrazić sobie postawienie takiego zarzutu liberatowi. Podobnie jak nie dałoby się adresować do twórców literatury totalnej słów krytyki, jakie spotkały Strzemińskiego za graficzne ułożenie niektórych wierszy Przybosia. Śniecikowska zauważa, że w przypadku utworu Gwiazdy zaproponowany przez artystę układ przestrzenny stawia pod znakiem zapytania kolejność strof. W konsekwencji, nie tylko nie ułatwia lektury wiersza, lecz ją utrudnia, nie ujednoznacznia, lecz wprowadza do tekstu niepożądaną wieloznaczność. W efekcie - czyni z poezji Przybosia inną poezję. Czy można wyobrazić sobie analogiczna sytuację w odniesieniu do liberatury?

Liberatowi nie sposób postawić zarzutu nieodpowiedniości formy i treści, nie da się w obrębie utworów należących do literatury totalnej wyróżnić tych, które sa źle ułożone, w których forma nie współgra z przekazem. Dlatego nie możemy przeprowadzić krytyki liberackiej analogicznej do tej, jaka prowadziły Wysłouch czy Śniecikowska w odniesieniu do działań Strzemińskiego. Obie badaczki podkreślały nieraz, że w przypadku wierszy, w których mamy do czynienia z zaburzeniami semantycznymi wprowadzanymi przez typografię, Strzemiński nie pilnował już tak precyzyjnie podziału na czastki konstrukcyjne, wprowadzał w obręb stanowiących jedną całość partii tekstu różne czcionki, sugerując większą komplikację struktury niż to potrzebne i sprowadzając tym samym czytelnika na manowce. Kiedy indziej zaś dokonywane przezeń podziały prowadziły ku zatraceniu istniejących $\mathrm{w}$ wierszu innych powiąań między elementami (np. Wieczór) bądź wypaczały jego ogólny charakter. Śniecikowska zauważa, że opracowany przez Strzemińskiego Świt traci wiele ze swej delikatności i subtelności ${ }^{532}$, zaś Wysłouch - zaznaczająca, że typograficznej pracy artysty nie da się ocenić jednoznacznie - pisze o $W$ budowie:

Taki zapis przeradza się w odsemantyzowaną kompozycję typograficzna, w której jednostką staje się wyraz i w której ginie zupełnie podział na wersy (nie mówiąc już o strofach). Można zapytać, co w takiej sytuacji dzieje się z rymami i z metafora? ${ }^{533}$

Śniecikowska kontynuuje ten wątek, podkreślając, że opracowanie Strzemińskiego to - co dla mnie kluczowe - ilustracja. Badaczka dodaje:

Gry grafią okazywały się na tyle pasjonujące, że niejednokrotnie na drugi plan schodził sam tekst literacki czy raczej - oddajmy sprawiedliwość kompozycjom Strzemińskiego tekst literacki jako całość. Plastyk skupiał się na fragmencie, starał się „zilustrować” (w możliwie najbardziej oszczędny sposób, poprzez sam sposób zapisu) dany związek wyrazowy czy nawet jedno słowo. Całość kompozycji stawała się wówczas często graficzną mozaika, korowodem czcionek-kształtów tracących łączność z semantyką całości złożonego z nich tekstu ${ }^{534}$.

Liberat nie „gra grafią”. Nie może stracić łączności z semantyką tekstu, opracowujac go graficznie czy materialnie, bo owa grafia i materia rzeczona semantykę współtworza. Twórca literatury totalnej może napisać nawet i bez-

${ }_{532}$ B. Śniecikowska, Stowo-obraz-dźwięk..., s. 260.

533 Seweryna Wysłouch, Literatura a sztuki wizualne, Warszawa 1994, s. 58.

534 B. Śniecikowska, Stowo-obraz-dźwięk..., s. 275. 
nadziejny tekst, dzieło niespójne, nie może jednak źle typograficznie (wtórnie) zinterpretować treści, nie może wypaczyć sensów na drodze ich - późniejszego wobec literackiego pierwowzoru - wzmacniania i ujednoznaczniania. Może, owszem, oddać w ręce czytelników - jak ują to Kwiatkowski w odniesieniu do Sponad - „koncert gry czcionkami” ${ }^{335}$, jednak owa typograficzna ekstrawagancja winna być wtedy postrzegana jako jeden z użytych środków literackiej ekspresji. Ocenie może podlegać jedynie jej funkcjonalność w całej strukturze, nie jest bowiem typem - udanej i chwytającej sensy dzieła bądź nie - ilustracji.

\subsection{To samo?... A jednak zupełnie inaczej...}

Coraz wyraźniej chyba widać różnice, jakie rysują się między proponowanymi przez Strzemińskiego rozwiązaniami a teorią liberacka. Przede wszystkim, w tej ostatniej, nie możemy mówić o kilku graficznych postaciach tekstu, które obrazuja różne interpretacje. Liberatura nie jest interpretacja tekstu, jest nim samym. I - w konsekwencji - jej graficzna forma jest ostateczna, niezmienna ${ }^{536}$.

Niebagatelna jest też kwestia występowania (bądź nie) pozornie mało istotnego rozsunięcia $\mathrm{w}$ czasie prac autora tekstu i tego, kto zajmuje się opracowaniem jego postaci graficznej. Nie jest, oczywiście, tak, iż liberatura w pełni takie rozsunięcie temporalne wyklucza. Jednak - w myśl teorii Strzemińskiego - sam utwór (odmiennie niż w przypadku literatury totalnej) projektowany jest w oparciu o wyłącznie klasyczne literackie środki. Warstwa materialna, typografia tekstu nie jest uwzględniana przez autora w momencie kreacji jako element mogacy współtworzyć semantykę dzieła. Znaczenia, jakie rodzą się w wyniku jej późniejszego opracowania, są więc w swej istocie niejako wtórne. Tym samym, po pierwsze, mają raczej charakter dopowiedzeń, wzmocnień (nie rekonfigurując semantyki tekstu), po drugie ich celem ma być jej ujednoznacznienie. Funkcjonalność, jakiej pożąda Strzemiński to też czytelność i jasność przekazu. Z jednej strony dąży się tu do usunięcia wszelkiej zbędnej ozdobności (niepotrzebnie przyciagającej uwagę widza, zakłócającej odbiór), z drugiej - do ujednoznacznienia wypowiedzi. W konsekwencji, znikają wszelkie literackie niedopowiedzenia, a jednokierunkowy tor lektury staje się dominujący.

W liberaturze, owe „dodatkowe” znaczenia od razu sa częścią projektowanej całości. Tym samym, trudno tu w ogóle mówić o jakimś pierwowzorze literackim - od razu mamy do czynienia z dziełem - jak określa to Fajfer - totalnym.

${ }^{535}$ J. Kwiatkowski, Świat poetycki Juliana Przybosia, s. 107.

${ }^{536}$ Oczywiście, może ulegać zmianom, dopracowywaniu w taki sposób, jak dzieje się to czasami z „klasycznymi” tekstami literatury, które mają swoje kolejne, zmienione wydania. W moich analizach śledzę takie różnice w przypadku Oka-leczenia, które doczekało się właśnie dwóch różniących się między sobą wydań (zob. bibliografia podana w przypisie $66 \mathrm{w}$ rozdziale Liberatura a poezja wizualna). 
Właśnie ta jednoczesność projektowania znaczeń owocuje ich pełnym zespoleniem i - w przypadku dobrego dzieła - brakiem tautologizmów. Oba procesy - pisanie jako tworzenie i zapisywanie jako kreacja - sa zintegrowane. Połaczenie w jednej osobie autora, typografa, introligatora jest tu o tyle istotne, że pytania o oddanie sensów poprzez typografię nie są tu zadawane post factum. Jak podkreślał już w pierwszych swoich tekstach Fajfer, problem kształtu tekstu i książki rodzi się w tym samym momencie, w którym artysta zastanawia się nad fabułą i konstrukcją bohaterów ${ }^{537}$. Tym samym, związane z różnymi mediami środki są angażowane do tworzenia znaczeń równolegle. Stąd, dzieło liberackie może być dziełem totalnym, w pełni integralnym. Dlatego też nie możemy oddzielić w nim warstwy stricte literackiej od innych - wszystkie razem $\mathrm{w}$ istocie tworzą jedna, idealnie zespoloną strukturę: strukturę liberacka.

Co więcej - trzeba też podkreślić, że wśród tekstów liberackich nie brak i takich, które wcale nie stronią od wieloznaczności, a przede wszystkim od: wielokierunkowości projektowanej lektury. Nierzadko przecież (u Nowakowskiego, u Fajfera i Bazarnik czy u „prekursorów”, takich jak: Johnson, Federman, Joyce) zabiegi liberackie, nieraz właśnie owe typograficzno-graficzne „ekstrawagancje”, służyć mają ukazaniu symultaniczności świata, ujęciu niemożliwej do objęcia mnogości perspektyw, nakładania się płaszczyzn itp. Funkcjonalność liberacka - o ile można by o takiej mówić - to też bycie na usługach pokazywania, przedstawiania czy odtwarzania struktur niepowtarzalnych, to (być może nawet i nieraz mimetyczne) naśladowanie tego, co skomplikowane, niejednoznaczne, niedopowiedziane i niedające się rozwikłać. Nie musi więc mieć nic wspólnego z tym, czego pragną Strzemiński: z klarownością jasnością, prostotą i jednoznacznościa.

Mówiąc innymi słowy - to, co proponuje autor Druku funkcjonalnego to swoistego rodzaju typograficzna ilustracja tekstu ${ }^{538}$, jego interpretacja, która zawsze - nawet gdy opracowywana jest na drodze konsultacji i dyskusji z autorem, jak miało to miejsce w przypadku Sponad Przybosia - pozostanie dodatkiem do właściwego tekstu literackiego. Jak w przypadku przywołanego tomu z 1930 r., może ona wywoływać liczne dyskusje poruszające słuszność zaproponowanego ujęcia. Liberatura ilustracją nigdy nie będzie. Stąd - nie sądzę, by warto było mówić o Strzemińskim i Przybosiu jako liberatach.

${ }^{537} \mathrm{~W}$ założycielskim manifeście liberatury Fajfer, przypomnę, pytał: „Czy kształt okładki, kształt i kierunek pisma, format, kolor i liczba stron, słów a może nawet liter nie powinny być przedmiotem refleksji twórcy jak każdy inny element jego dzieła, wymagajacy od niego nie mniejszej inwencji niż dobieranie rymów czy konstruowanie fabuły?" (Zenon Fajfer, Liberatura. Aneks do słownika terminów literackich, [w:] LCLT, s. 25).

${ }^{538}$ O ilustracji i jej typach zob. m.in. Seweryna Wysłouch, Tekst $i$ ilustracja, [w:] eadem, Literatura a sztuki wizualne, Warszawa 1994, s. 99-138 oraz Janina Wiercińska, Sztuka i obraz, Warszawa 1986 (szczególnie rozdział Obraz i słowo, s. 29-46). 


\title{
4. Liberatura a typografia futurystyczna
}

\author{
4.1. Kilka wstępnych zastrzeżeń
}

\author{
Liberatura... to [...] ksiażka na wolności \\ Zenon Fajfer ${ }^{339}$
}

Kolejny eksperymentujący z typografią artysta, którego bezdyskusyjnie okrzyknięto protoliberatem, to Filippo Tommaso Marinetti ${ }^{540}$. Zastanawiajac się nad słusznością szukania paralel między jego słowami na wolności a teorią liberacka, można przywołać dwa zdania, którymi Tadeusz Miczka - autor poświęconej włoskiemu futuryzmowi książki Czas przyszły niedokonany - rozpoczyna rozdział dotyczący wyzwolonej sztuki słowa:

Futurystom nie wystarczał stary włoski słownik rodzajów i gatunków literackich. Poszukiwali nowych literackich sytuacji komunikacyjnych, przekraczając granice poezji, dramatu i epiki oraz przekształcając formuły estetyczne tradycyjnych gatunków $w^{541}$.

539 Zenon Fajfer, Pięć sylab w poszukiwaniu definicji, [w:] LCLT, s. 133.

${ }^{540} \mathrm{~W}$ dostępnym na stronie www.liberatura.pl szkicu Katarzyny Bazarnik i Zenona Fajfera dotyczącym historii liberatury (w części zatytułowanej 1909-1969: od futuryzmu do ksią̇ki artystycznej) czytamy: „W twórczości przełamującej konwencjonalny układ tekstu celowali zwłaszcza futuryści: ojciec zainicjowanego w 1909 roku ruchu - włoski poeta, piszący także po francusku, Filippo Tommaso Marinetti (1876-1944) i jego liczni naśladowcy, powiewający na swych «jednodniówkowych» sztandarach wypisanymi w różnych językach parole in libertà - «słowami na wolności» (taki tytuł nosił manifest Marinettiego z 1913 roku, postulujący oswobodzenie literatury z rygorów składni języka i konwencjonalnego składu drukarskiego). Do najbardziej reprezentatywnych przykładów realizacji tej idei należy tom poezji samego Marinettiego Zang Tumb Tumb (1914), w którym wyzwolona z wszelkich ograniczeń (z wyjątkiem kodeksowej budowy książki) typografię uznać można za pełnoprawny środek wyrazu, a samą książkę za jeden z oryginalniejszych przejawów liberatury tamtych czasów - liberatury rozumianej także w szerszym sensie, jako twórczości rozsadzającej ramy społecznych ograniczeń i ustalonego porządku” (http://www.liberatura. pl/1909-19690czyli-od-futuryzmu-do-ksiazki-artystycznej.html, dostęp z dn. 13.06.2011r., podkreślenia autorów). W wersji książkowej opublikowana jest starsza wersja tego samego szkicu ([w:] LCLT), w której futuryści jako prekursorzy liberatury byli wyłącznie wzmiankowani, bez przywoływania Marinettiego (s. 88). Por. też m.in. Wojciech Kalaga, Liberatura: stowo, ikona, przestrzeń, [w:] LCLT.

${ }_{541}$ Tadeusz Miczka, Czas przyszty niedokonany. O włoskiej sztuce futurystycznej, Katowice 1994, s.76. 
Nie domagali się, co prawda, określania ich twórczości mianem czwartego rodzaju literackiego ${ }^{542}$, niemniej sprzeciwiali się dotychczasowej formule języka poetyckiego. Futurystyczne słowa to słowa na wolności, zaś samo brzmienie tego sloganu przywołuje jedna z etymologii terminu liberatura. W ujęciu Fajfera ta ostatnia to - przypomnę - właśnie sztuka słowa oswobodzona, niespętana normami czy konwencjami, literatura wolna: „od” czytelniczych i pisarskich przyzwyczajeń, a także „do” przekraczania wyznaczanych przez nie granic.

Niemniej, podążajac tym tropem, muszę zaczać od kilku wyjaśnień. Po pierwsze - futuryzm włoski, jakkolwiek był w Europie pierwszy, nie był jednak jedyny. Czemu zatem koncentruję się na tej jego odmianie i - co więcej skupiam zasadniczo wyłącznie na teoretyczno-artystycznej działalności głównego założyciela ruchu: Marinettiego? Można powiedzieć, że przyczyna jest czysto pragmatyczna: zbadanie relacji między liberaturą a futuryzmem w jego wszelkich (nawet wyłącznie europejskich) wariantach spokojnie mogłoby stać się przedmiotem osobnego opracowania. Jednak nie kierowały mną wyłącznie takie względy praktyczne.

Przede wszystkim, teoria parole in libertà i włoska odmiana futuryzmu, jak twierdzi Alan Bartram: najbardziej nieprzebierajacego w środkach awangardowego ruchu swoich czasów ${ }^{543}$, odegrała na tyle istotną rolę, że nie tylko wpłynęła na całą sztukę współczesną ${ }^{544}$, lecz i po dziś dzień - zdaniem tego

${ }^{542}$ Choć swoiste dyskusje czy dialogi z genologia - o czym (w kontekście polskiego futuryzmu) pisze Grzegorz Gazda - nie były im zupełnie obce. Zaznaczając, iż na nurt ten należy patrzeć jako na ścieranie się dwóch tendencji - „działalności futurystycznej” (a więc tego, z czym związane są manifesty, wszelkiego typu ulotki, wydarzenia, sam sposób bycia), konsekwencji „poetyki skandalu i nonsensu” (s. 236) oraz konkretnych utworów, samej „poezji” (s. 236), badacz zauważa w nim podwójną tendencję genologiczna. Prowadzi go ku tej obserwacji fakt, iż o ile w pojedynczych utworach futuryści stosują klasyczne terminy genologiczne (ballada, hymn, oda, bajka, kolęda etc.), o tyle poszukując terminów zbiorczych dla całych tomów wierszy, sięgają po neologizmy (futuryzje, futurogramy, futureski etc.). Jak podsumowuje teoretyk: „Pierwszy zespół nazw jest sygnałem świadomości gatunkowej nadawców odwołujących się do świadomości odbiorców. Natomiast semantyka zespołu drugiego realizuje się poprzez opozycję: poezje - futuryzje (tradycja - nowatorstwo). Ów drugi ciąg nazw byłby więc wynikiem tendencji, którą nazwalibyśmy działaniem futurystycznym, sfera zewnętrzną tego ruchu, tendencji, która nie doprowadziła aż do takich wewnętrznych przekształceń w strukturze gatunków, aby poza tymi nazwami doszukiwać się odpowiadających im przedmiotów genologicznych" [Grzegorz Gazda, O gatunkach polskiej poezji futurystycznej, Warszawa 1972 (odbitka autorska z tomu $4 Z$ polskich studiów slawistycznych. Seria 4. Nauka o literaturze), s. 236-237]. O stosunku futurystów włoskich do tradycji gatunków literackich pisze Miczka (T. Miczka, Czas przyszty niedokonany..., szczególnie rozdział Stowa na wolności, s. 76-85). Por też: Józef Heistein, Gatunki (formy) literackie, [w:] idem, Wprowadzenie do literaturoznawstwa porównawczego. Literatura awangardowa w świetle badań porównawczych, Wrocław 1990, s. 116-122.

${ }_{543}$ Alan Bartram, Futurist Typography and the Liberated Text, London 2005, s. 7 (dalej oznaczane jako A. Bartram wraz z numerem stron).

${ }^{544}$ Miczka pisał: „Parole in libertà» były pierwszym wielkim odkryciem futurystycznym i dokonały prawdziwego przełomu nie tylko w dwudziestowiecznej poezji, ale jak słusznie zauważył Francesco Flora, słowa uwolnione od gramatyki i logiki zmieniły cała sztukę współczesną" (T. Miczka, Czas przyszły niedokonany..., s. 78). Także Janusz Sławiński zauważał, że Marinetti w zakresie typograficznego opracowywania tekstów wpłynął „również na niefuturystyczne tendencje poetyckie" [Janusz Sławiński, Koncepcja języka poetyckiego awangardy krakowskiej, Kraków 1998, s. 85 (przypis 14)]. 
zajmujacego się futurystyczną typografią badacza - odbija się echem w sposobie graficznego opracowywania tekstów (graphic design) ${ }^{545}$. Na tle innych współczesnych nurtów włoski futuryzm wyróżniało właśnie większe przywiązywanie wagi do samego sposobu przekazywania utworów, do kształtowania materialności tekstów, do typografii traktowanej jako środek ekspresji. Jak podsumowuje Bartram:

\begin{abstract}
Kiedy włoski futuryzm próbował pogłębić znaczenie słowa, rozwijając nowe podejście do druku, rosyjski futuryzm - bardziej malarski w swym charakterze - uwolnił wizualny aspekt poezji od istniejących ograniczeń na drodze wzmocnienia jej emocjonalnego przekazu poprzez silnie zintegrowane z tekstem ilustracje. Programem dadaistów, dla odmiany, było podkreślenie brzmienia słów, nawet brzmień poszczególnych liter lub cyfr przy pomocy zarówno wizualnych, jak i brzmieniowych środków. Jednak wypracowali oni swój zespół chwytów wizualnych z wykorzystaniem szerokiego wachlarza możliwości innowacji typograficznych wprowadzonych przez włoskich futurystów ${ }^{546}$.
\end{abstract}

Już choćby dlatego to właśnie ci ostatni wydali mi się najlepszym kontekstem do mówienia o liberaturze ${ }^{547}$. Tym bardziej, że sam Marinetti zajął się kwestią sposobu drukowania tekstów również teoretycznie, czyniąc rewolucję typograficzna elementem swojego programu literackiego, a przede wszystkim - środkiem do tworzenia nowego języka literatury. I w tym rozdziale to właśnie ten ostatni aspekt stanowić będzie centrum moich zainteresowań.

Porównywanie futuryzmu jako takiego (a więc nurtu kulturowego obejmującego wszelkie dziedziny życia i sztuki, obfitującego w manifesty dotyczące wszelkich sfer działalności człowieka ${ }^{548}$ ) z liberaturą (której teoretycy nie tworzyli żadnych ideologii, nie proponowali nowego spojrzenia na świat

\footnotetext{
545 A. Bartram, s. 7.

${ }^{546}$ Ibidem, s. 8.
}

${ }^{547}$ Choć wiele interesujących problemów rodzi też choćby relacja liberatury i rosyjskiego futuryzmu, który od typograficznych eksperymentów wcale nie ucieka. O spojrzeniu na typografię i kształt książki w rosyjskim futuryzmie zob. m.in.: Johanna Drucker, Zdanevich: Inachievable Essentialism and Zum Typography, [w:] eadem, The Visible Word. Experimental Typography and Modern Art, 1909-1923, Chicago-London 1996; Alan Bartram, Artist-poets in Russsia: illustration + words, [w:] idem, Futurist typography...; Marjorie Perloff, The Word Set Free: Text and Image in the Russian Futurist Book, [w:] eadem, The Futurist Moment. Avant-Garde, Avant Guerre, and the Language of Ruptures, Chicago 1986. O rosyjskim futuryzmie zob. m.in: Florian Nieuważny, Futuryzm, [w:] Literatura rosyjska, t. II, red. Marian Jakóbiec, Warszawa 1971; Zbigniew Barański, Futuryzm w Rosji, [w:] Futuryzm i jego warianty w literaturze europejskiej, red. Józef Heistein, Wrocław 1977; Grzegorz Gazda, Od ego poezji do „Nowego LEF-u”. Futuryzm $w$ Rosji, [w:] idem, Futuryzm w Polsce, Wrocław 1974 oraz liczne hasła [w:] Stownik kierunków $i$ grup literackich $X X$ wieku (m.in.: egofuturyzm, kubofuturyzm), pokrótce pisze o nim też Artur Hutnikiewicz (podrozdział Futuryzm w Rosji w szkicu Futuryzm, [w:] idem, Od czystej formy do literatury faktu. Gtówne teorie i programy literackie XX stulecie, Warszawa 1974).

${ }_{548}$ Zob. m.in. Christa Baumgarth, Futuryzm, tłum. Jerzy Tasarski, Warszawa 1987; T. Miczka, Czas przyszły niedokonany...; Futuryzm i jego warianty w literaturze europejskiej, red. Józef Heistein; Grzegorz Gazda, hasło 'futuryzm', [w:] Słownik europejskich kierunków i grup literackich XX wieku, wyd. 2, Warszawa 2009; Artur Hutnikiewicz, Futuryzm, [w:] idem, Od czystej formy do literatury faktu...; M. Perloff, The Futurist Moment... oraz International Futurism In Arts and Literature, red. Günter Berghaus, Berlin-New York 2000. 
czy życie, lecz jedynie na konwencje literackie dotyczące języka sztuki słowa i jej nośników) byłoby - delikatnie mówiąc - ujęciem zbyt szerokim, donikąd nieprowadzącym. Jednak zestawienie formułowanych na gruncie tych nurtów tez dotyczących możliwości ekspresji w dziele literackim, sposobu pojmowania roli nośnika w tworzeniu literackiej semiozy czy - generalnie - potencji semantycznej typografii, może już prowadzić do ciekawych wniosków. Być może też pozwoli lepiej zrozumieć, czym ma być analizowana w tej pracy liberackość dzieła, a także czym miałaby się ona różnić od innych formułowanych w XX w. ujęć wizualności literatury. Dlatego właśnie nie tylko ograniczam się do włoskiego futuryzmu (a nawet jedynie jego literackiej odmiany), lecz wręcz wyłącznie do tego wąskiego fragmentu tej ostatniej, który odnosi się do kwestii języka sztuki słowa, przede wszystkim zaś typografii ${ }^{549}$.

Osobnego wyjaśnienia wymaga również kwestia tego, czemu nie zajmuję się polskim futuryzmem. Odrzucenie tego kontekstu może się wydawać dziwne, gdy przypomnimy sobie pochodzace z manifestu Prymitywiści do narodów świata $i$ do Polski sformułowania: „SŁOWA mają wagę, dźwięk, barwę, swój rysunek, ZAJMUJA MIEJSCE W PRZESTRZENI"550. Toż to iście liberacka deklaracja!551 Jednak, czy istotnie powinniśmy dać się ponieść wrażeniu bliskości tych postulatów z tezami twórców literatury totalnej? Czy, rzeczywiście, „robienie” książek przez Nowakowskiego, a także pragnienie Fajfera, by autor był odpowiedzialny również za kształt materialny swojego dzieła są bliskie tezie głoszonej w punkcie IX przywołanego tu fragmentu manifestu (,poeta winien być zarazem zecerem i introligatorem swej książki” $\left.{ }_{552}\right)$ ? Kiedy uważnie wczytamy się w jego słowa, okaże się, że niekoniecznie, gdyż formie (prowokujacej, przyciagającej uwagę) jest tu dany prymat nad treścią (,główne wartości książki - to format i druk jej po nich dopiero - treść" $\left.{ }_{553}\right)$. Zaś postulowany tu wizualnie atrakcyjny kształt tekstu (w dalszej części manifestu zastapiony jego deklamowaniem, „krzyczeniem” przy pomocy innych, silniej oddziałujących na odbiorcę mediów) jest tu elementem prowokacji, próbą - typowego dla futurystów - zwrócenia na siebie uwagi poprzez skandal.

Sprawa nie jest jednak wcale prosta, gdyż wśród licznych futurystycznych deklaracji teoretycznych znajdziemy i takie, które silnie akcentują niero-

${ }^{549}$ W pełni zgadzając się z opiniami takimi jak ta wyrażona przez Michaela Webstera, który podkreśla, że przecież „futurystyczna rewolucja typograficzna jest zaledwie częścią dużo rozleglejszego ataku na «literackośc»», gramatykę i składnię, a także słowo samo w sobie, któremu narzucono powinność zachowywania się niczym przedmiot a nie znak" (Michael Webster, The Avant-Garde Poem: Marinetti, [w:] idem, Reading Visual Poetry after Futurism. Marinetti, Apollinaire, Schwitters, Cummings, New York 1995, s. 25.

${ }_{550}$ Anatol Stern, Aleksander Wat, Prymitywiści do narodów świata i do Polski, [w:] Antologia polskiego futuryzmu i Nowej Sztuki, oprac. Zbigniew Jarosiński, Wrocław 1978, s. 5.

${ }^{551}$ Jako taką odczytywałam je jeszcze pisząc pracę magisterską (por. (Nie tylko) liberackie modele do sktadania: liberatura, hipertekst, e-liberatura na gruncie polskim, praca ukończona pod kierunkiem prof. Grzegorza Gazdy w UŁ), nadal interpretuja je tak Fajfer i Bazarnik (por. szkic 1909-1969: od futuryzmu do ksiqżki artystycznej przywołany w przypisie 2).

552 A. Stern, A. Wat, Prymitywiści do narodów świata..., s. 6.

${ }^{553}$ Ibidem. 
zerwalny zwiąek formy (materialnej, konkretnej i jak najbardziej fizycznej) utworu z przesłaniem, jakie on niesie ${ }^{554}$. Kwestia książki jako adekwatnego bądź nie nośnika dla idei (kodeksu nieraz rozumianego jako partytura dzieła) powraca tu po wielokroć (ja zaś zajmę się nią w dalszej części rozdziału).

Być może więc, warto byłoby zająć się nie tyle Marinettim, co porównać dokonania Fajfera i pokrewnych mu ideowo artystów z rodzimymi realizacjami futurystycznymi. Nie przeczę, iż w kwestii tej można z pewnością jeszcze wiele dodać, niemniej, moim wyborem kierował również fakt (konsekwentnie podkreślany przez badaczy), iż - z nielicznymi wyjątkami - polska odmiana nurtu silniej eksplorowała brzmieniową niż wizualną wartość słowa. Jak zauważa Paweł Majerski:

Futuryści polscy nie podążyli w kierunku radykalnych projektów włoskich prekursorów. Wprawdzie wyczuleni na graficzny aspekt tekstu nie budowali z uwolnionych słów „tablic synoptycznych” (jak Marinetti w Zang Tumb Tumb), lecz zaproponowali inne - znów jednak nieliczne - innowacje edytorskie. Były one realizowane na trzy możliwe sposoby, tzn. w postaci grafiki organicznie związanej z zapisanym tekstem (Czyżewski), grafiki w przestrzeni strony towarzyszacej wierszowo (Ziemia na lewo Jasieńskiego i Sterna w opracowaniu Mieczysława Szczuki), wreszcie kompozycji integralnej, w której tekst staje się dziełem literacko plastycznym (książkowa edycja Europy) ${ }^{555}$.

$\mathrm{Na}$ raczej nikłe w naszej tradycji futurystyczne eksplorowanie wizualności tekstu literackiego zwracał też przed laty uwagę Grzegorz Gazda, stwierdzając, że:

Dwudziestowieczna koegzystencja poezji i plastyki przebiegała w Polsce torami słabiej ujawnionymi. Mówić tu trzeba jedynie o twórczości T. Czyżewskiego ${ }^{556}$.

Późniejsze badania pokazuja, że nie jest to jedyny artysta, którego warto $\mathrm{w}$ tym kontekście przywoływaćs57, niemniej - w odniesieniu do polskiego

${ }_{554} \mathrm{~Np}$. Bruno Jasieński deklaruje: „Dzieło sztuki uważamy za żecz dokonana, konkretną i fizyczną. Kształt jego uwarunkowany jest śćiśle wewnętszną potszebą. Jako takie odpowiada ona za śebie całym kompleksem śił go składającyh, zawdźęczając kturym tak a ńe inaczej - tj. z wewnętsznym pszymusem skoordynowane sa jego poszczegulne częśći w stosunku do śebie i do całośći” (Bruno Jasieński, Mańfest w sprawie poezji futurystycznej, [w:] Antologia polskiego futuryzmu i Nowej Sztuki, s. 18-19).

${ }_{555}$ Paweł Majerski, Anarchia i formuty. Problemy twórczości poetyckiej Anatola Sterna, Katowice 2001, s. 33, podkreślenie moje. Badacz już na samym początku swojej książki zwraca też uwagę, że w liryce Sterna dostrzec można dwie tendencje: stosowanie wiersza rymowanego i rytmizowanego oraz wiersza wolnego. Ta druga, jak ujmuje to autor, owocuje tym, że „wartość prymarną zyskuje graficznie wyróżnione słowo" (s. 20).

556 G. Gazda, Futuryzm w Polsce, s. 99.

${ }_{557}$ Por. choćby B. Śniecikowska, Stowo-obraz-dźwięk... i obszerna bibliografia tam podana. Oczywiście trzeba zaznaczyć, że znaczna część tej pracy poświęcona jest właśnie twórczości Czyżewskiego. Z kolei Paweł Majerski stawia ciekawe tezy odnośnie do twórczości Anatola Sterna - szczególnie interesujący w świetle moich rozważań wydaje się rozdział jego książki, w którym zwraca uwagę na relację między twórczością Sterna a Marinettiego oraz poezją konkretną (Paweł Majerski, Wiersze alfabetyczne, [w:] idem, Anarchia $i$ formuty... lub przedruk [w:] idem, Odmiany awangardy, Katowice 2001). 
futuryzmu - konstatacja, że brzmieniowa warstwa słowa była silniej eksplorowana niż jego aspekty wizualne pozostaje aktualna ${ }^{558}$. Rzeczywiście też znacząco wyróżnia się twórczość Tytusa Czyżewskiego, o którym - na ponad dziesięć lat przed ogłoszeniem pierwszych manifestów liberackich - Alicja Baluch (w pełni przekonana, że jego twórczość jest przeznaczona „do czytania i oglądania” $\left.{ }^{559}\right)^{560}$ pisała:

\begin{abstract}
Wszystkie całościowe edycje utworów poetyckich, dramatycznych czy poematów Czyżewskiego, muszą być traktowane przez odbiorców jako rzeczy widzialne, wzrokowe. Umieszczone w nich ilustracje czy rysunkowe przerywniki, różnego rodzaju przedstawienia obrazowe, oznaki, symbole, cała organizacja typograficzna i wygląd obwoluty, a więc wszystkie formy graficzne występują tu w różnych funkcjach wobec tekstu i innych elementów książki. Na przykład już sam układ graficzny pierwszego teatralnego obrazka Czyżewskiego „Śmierć Fauna” [...] jest znaczacy: kojarzy się z Wyspiańskim poprzez waskie karty, z podwójną kreską u dołu i u góry stronicy i przez stylizowany - na wzór secesyjnych ornamentów kwiatek - ozdobnik strony tytułowej ${ }^{561}$.
\end{abstract}

Czy zatem twórczość Czyżewskiego nie byłaby doskonałym materiałem do analiz liberackich?

Niemniej, interesują mnie miejsca wspólne tzw. literatury totalnej i futuryzmu (czy postulowanej na jego gruncie typografii) i moim celem jest sformułowanie wniosków o naturze raczej ogólnej, generalizującej. Trudno byłoby czynić ich podstawą twórczość jednego artysty, wyróżniającego się zresztą na tle pozostałych przedstawicieli nurtu. Dlatego też polscy pisarze (m.in. Jasieński, którego realizacje bywają równie liberackie jak te Czyżewskiego) pozostaną w tym rozdziale z rzadka przywoływanym kontekstem, zaś głównym punktem odniesienia będzie dla mnie - pozwalająca formułować wnioski o charakterze bardziej uniwersalnym - teoria i praktyka Marinettiego fundująca założenia interesujacej mnie nowej typografii (podchwytywana również przez jego licznych „wyznawców”).

Dotychczas w polskim literaturoznawstwie sięgano po literackie manifesty tego artysty, by mówić o futurystycznej onomatopei i ten obszar związków polskiego futuryzmu z jego włoskim odpowiednikiem wydaje się już dość szeroko opisany ${ }^{562}$. Jednak tezy Marinettiego dotyczące typografii - jak próbowa-

${ }^{558}$ Przekonują o tym również opisy kształtu typograficznego futurystycznych publikacji, jakie daje Bożena Lewandowska (Bożena Lewandowska, U źródeł grafiki funkcjonalnej w Polsce, [w:] Ze studiów nad genezq plastyki nowoczesnej w Polsce, red. Juliusz Starzyński, Wrocław 1966, szczególnie s. 212-221).

559 Alicja Baluch, Wizualność poezji Tytusa Czyżewskiego, „Rocznik Naukowo-Dydaktyczny WSP w Krakowie” 1986, z. 101 (Prace historycznoliterackie X), s. 100.

${ }^{560}$ Prace Czyżewskiego określa badaczka jako „dzieła słowo plastyczne” (s. 100). Z wyróżnionych przez nią czterech rodzajów odwołań wizualnych typowych dla artysty czysto literacki jest ostatni, oparty na współistnieniu pierwiastków pikturalnych i werbalnych, w wyniku którego powstaje „swego rodzaju typ poezji wizualnej” (ibidem, s. 99).

561 Ibidem, s. 100.

${ }^{562}$ Beata Śniecikowska, „Nuż w uhu”? Koncepcje dźwięku w poezji polskiego futuryzmu, Wrocław 2008 oraz obszerna bibliografia tam podana. Zob. też Paweł Majerski, O języku (w) poezji Anatola Sterna, [w:] idem, Anarchia i formuty... (lub analogiczny fragment: „Widzenie rzeczy”. O języku (w) poezji Anatola Sterna, [w:] idem, Odmiany awangardy, s. 29-57). Warto tu przytoczyć fragment pod- 
łam podkreślić: z racji braku takiej potrzeby - nie były raczej dogłębniej analizowane. Niech więc postawienie pytania o ich liberacki (bądź nie) charakter stanie się okazją do przybliżenia ich czytelnikom.

\subsection{Futurystyczna literackość i rewolucja typograficzna}

Jaką wizję literatury przynoszą zatem futurystyczne manifesty? Co mówią o jej języku, sposobie typograficznego kształtowania druków, semantycznej potencji znaku ${ }^{563}$ ? Zasadniczo, w założycielskim manifeście futuryzmu z $1909 \mathrm{r}$. nie wspomina się jeszcze ani o przywoływanych już to słowach na wolności, ani też o - interesującej mnie najbardziej - nowej typografii ${ }^{564}$. Kwestie te rozwijane są właściwie wyłącznie w trzech (nietłumaczonych w całości na język polski) szkicach Marinettiego ${ }^{565}$ : Manifeście technicznym literatury futurystycznej z 11 maja 1912 r. (wraz z trzy miesiące późniejszym Suplementem do tegoż manifestu z 11 sierpnia tego roku) ${ }^{566}$, eseju Likwidacja składni. Wyobraźnia bez

sumowania, jakie daje Śniecikowska, wskazujący wyraźnie, jakie kierunki obierała dotychczasowa refleksja nad relacjami polskiego i włoskiego futuryzmu: „Związki polskiego futuryzmu z twórczością Marinettiego okazały się w dużej mierze powierzchowne. Stosunkowo często w analizowanych wierszach pojawiały się konstrukcje, które opisać można jako pogłosy Marinettowskiej koncepcji «Słów na wolności». Nie były to jednak nigdy realizacje «ortodoksyjnie» wierne postulatom Włocha. Co ciekawe, w tekstach polskich futurystów rolę czynnika substytuującego związki syntaktyczne spełniała często - kunsztowniej i bardziej różnorodnie «rozgrywana» niż w utworach autora "Zang Tumb Tuuum» - organizacja naddana warstwy dźwiękowej” (B. Śniecikowska, „Nuż w uhu”?..., s. 522).

${ }^{563}$ Chciałabym raz jeszcze podkreślić, że z futurystycznych tez odnoszących się do literatury wybieram i przywołuję wyłacznie te postulaty, które (w mniej lub bardziej widoczny na początku sposób) wpływają na sposób typograficznego opracowania utworów. Pełny ogląd literackiego programu futurystów dają prace przywoływane w przypisach w tym rozdziale.

${ }^{564}$ Zob. Filippo T. Marinetti, Akt założycielski i manifest futuryzmu (1909), tłum. Marcin Czerwiński, [w:] Artyści o sztuce. Od van Gogha do Picassa, wybór i oprac. Elżbieta Grabska, Hanna Morawska, Warszawa 1969.

${ }^{565}$ Większość tytułów podaję tu w tłumaczeniu Haliny Kralowej (za: Halina Kralowa, Zmierzch i maszyna. Poezja poczatku XX stulecia, [w:] Historia literatury wtoskiej XX wieku, red. Joanna Ugniewska, Warszawa 2001, s. 53). Najpełniejszą w polskiej literaturze przedmiotu charakterystykę tez przedstawionych w tych szkicach daje J. Heistein w szkicu Futuryzm we Włoszech, [w:] Futuryzm i jego warianty w literaturze europejskiej (szczególnie s. 32-35). Zob. też omówienie literackich manifestów u Kralowej (H. Kralowa, Zmierzch i maszyna..., szczególnie s. 53-55 lub ten sam fragment w rozdziale Poezja w poczatku XX stulecia, [w:] Historia literatury włoskiej, red. Halina Kralowa, Piotr Salwa, Joanna Ugniewska, Krzysztof Żaboklicki, t. II, Warszawa 2002, s. 242-243). Wiele ciekawych uwag do manifestów Marinettiego (oraz praktycznych realizacji głoszonych w nich haseł) znajdziemy też w: Józef Heistein, W kręu poetyk awangardy, [w:] idem, Wprowadzenie do literaturoznawstwa porównawczego... . Por. też G. Gazda, Stownik europejskich kierunków i grup literackich XX wieku, zwłaszcza s. 165-167.

${ }_{566}$ Filippo T. Marinetti, Manifesto tecnico della Letteratura futurista oraz Supplemento al Manifesto tecnico della Letteratura futurysta, [w:] idem, Zang tumb tumb, Milano 1914. Korzystałam równiė̇ z angielskiego tłumaczenia: Technical Manifesto of Futurist Literature, tłum. R. W. Flint, [w:] Filippo T. Marinetti, Selected writings, tłum. R. W. Flint, Arthur A. Coppotelli, red. R. W. Flint, London 1972, s. 84-89. 
drutu. Stowa wyzwolone z 1913 r. ${ }^{567}$ oraz (raczej nieprzywoływanym w polskiej literaturze przedmiotu) tekstem Geometryczny $i$ mechaniczny splendor oraz wrażliwość numeryczna ${ }^{568}$ opublikowanym 18 marca 1914 r. ${ }^{569}$

Teoretyczne wypowiedzi futurystów przynosiły tezę, iż literatura potrzebowała nowych środków językowo-stylistycznych, gdyż - jak konkluduje Józef Heistein - „dawne odpowiadały przestarzałej psychologii i przebrzmiałemu liryzmowi człowieka" ${ }^{570}$. Trzeba było zerwać z nudna tradycją i znaleźć formy adekwatne do opisu dynamicznej, zmieniającej się rzeczywistości.

Przeszłość przeżyła się, głosili futuryści - stwierdza Halina Kralowa - należy ją odrzucić i zniszczyć, świat poszedł do przodu, wkroczył w erę wielkiego rozwoju technicznego i nie może oglądać się ciągle wstecz. Nowe jest piękne. W imię nowego należy odciąć się definitywnie od przeszłości. Trzeba wreszcie zbudować nową moralność i nową sztukę ${ }^{571}$.

W stwierdzeniach tych futuryści niewiele różnili się od innych współczesnych im twórców. O nowy kształt sztuki dopominali się artyści wszelkich narodowości, należący do różnych prądów kulturowych czy literackich. W większości z tych postulatów pojawiała się konstatacja, iż rozwój technologiczny, wszelkie nowości, które przyniósł wiek XX przekreślają dotychczasową tradycję i kształtują nowego odbiorcę ${ }^{572}$. Ten, mając już dostęp choćby do telegrafu czy kinematografu, będąc przyzwyczajanym do coraz większej ilości bodźców wizualnych, stopniowo zaczynał poszukiwać w sztuce innych jakości ${ }^{573}$. Sytu-

${ }_{567}$ Filippo T. Marinetti, Distruzione della sintassi. Immaginazione senza fili. Parole in libertá, [w:] idem, Zang tumb tumb. Korzystałam również z angielskiego tłumaczenia: Filippo T. Marinetti, Destruction of syntax - Imagination without Strings - words-in-freedom (1913), tłum. R. W. Flint, [w:] The Book of the Book. Some Works \& Projections about the Book \& Writing, red. Jerome Rothenberg, S. Clay, New York 2000 (tłumaczenie to pomija rozdziały: Morte dell'Io letterario. - Materia e vita molecolare, Aggettivo semaforico. - Aggettivo-faro o aggettivo-atmosfera, Verbo all'infinito oraz Onomantopee e segni matematici).

${ }^{568}$ Korzystałam z angielskiego przekładu eseju (Geometrical and Mechanical Splendor and the Numerical Sensibility, tłum. R. W. Flint, [w:] F. T. Marinetti, Selected writings, s. 97-103). Tekst ten - jako ostatni z literackich manifestów Marinettiego - przywołuje Michael Webster (M. Webster, The Avant-Garde Poem: Marinetti, s. 25). W polskiej krytyce spotkamy też inne tłumaczenie tytułu: Wspaniałość geometryczna i mechaniczna oraz wrażliwość numeryczna (G. Gazda, Stownik europejskich kierunków i grup literackich XX wieku, s. 162).

${ }^{569}$ Nieistotny (jako niemający większego znaczenia dla dalszych losów futurystycznej typografii) jest dla mnie manifest Il manifesto dell'alfabeto a sorpresa z $1916 \mathrm{r}$.

570 J. Heistein, Futuryzm we Wtoszech, s. 32. Ponadto, do nowych sposobów literackiej kreacji inspirują też nowe środki przekazu (np. telegraf), na co zwracał w literaturze przedmiotu uwagę nie tylko Heistein, ale i inni badacze.

${ }^{571}$ H. Kralowa, Zmierzch i maszyna..., [w:] Historia literatury wtoskiej XX wieku, s. 52 lub [w:] Historia literatury wtoskiej, t. II, s. 239.

572 O wpływie poszczególnych mediów i ich rozwoju na kulturę por. m.in.: Walter J. Ong, Oralność i piśmienność. Stowo poddane technologii, tłum. Józef Japola, Lublin 1992; Paul Levinson, Miękkie ostrze, czyli historia i przyszłość rewolucji informacyjnej, tłum. Hanna Jankowska, Warszawa 2006; Tomasz Goban-Klas. Cywilizacja medialna. Geneza, ewolucja, eksplozja, Warszawa 2005; Maryla Hopfinger, Doświadczenia audiowizualne. O mediach w kulturze wspótczesnej, Warszawa 2003.

${ }^{573} \mathrm{~Np}$. francuski poeta, Nicolas Beauduin (który podobnie jak Marinetti dążył do znalezienia literackiej formy zdolnej uchwycić symultaniczność zdarzeń) stwierdzał: „Wiersz wolny odpo- 
acja ta zmuszała do stawiania pytań o nową estetykę, na gruncie literatury owocujących m.in. refleksją nad językiem poetyckim.

Futuryści widzieli dwa zasadnicze sposoby odświeżenia tego języka: budowanie literatury ze stów na wolności oraz poddanie się - jak określił to sam Marinetti - lirycznej obsesji materii (l'ossessione lirica della materia) ${ }^{574}$. Wysuwali hasła oswobodzenia słów z kajdan gramatyki, zerwania z klasyczna syntaksa czy odrzucenia interpunkcji i używania znaków matematycznych na równi z literami (jako alternatywnego - lepszego niż przestarzała i skonwencjonalizowana składnia - sposobu ukazywania relacji łacczacych elementy wypowiedzi). Takie nowe podejście miało „przywrócić ekspresji artystycznej pełnię bezpośredniości”"575, stwierdzał Artur Hutnikiewicz. Marinetti przekreślił też koniugację, postulował, by ograniczyć użycie przymiotników na rzecz rzeczowników. Te ostatnie - jako najbliższe temu, co nazywaja - miały być dla twórców najważniejsze, pozwalając im osiąnąć futurystyczny ideał literatury, w której granica między słowem a rzeczą stanie się niemal niedostrzegalna ${ }^{576}$. Co więcej, wszelkie inne niż rzeczownik części mowy - jak podsumowuje Hutnikiewicz - „hamują dynamizm aktu twórczego" ${ }^{577}$, a futurystom zależało przecież na ujmowaniu dynamizmu (świata i materii). Christa Baumgarth następującymi słowy podsumowuje ich wizję:

Odziedziczoną po antyku składnię należy znieść, a język rozłożyć z powrotem na poszczególne części składowe. Wszystkie spójniki, wszystkie przymiotniki o charakterze określającym i komentującym powinny odpaść. Elementy języka - rzeczowniki, czasowniki w bezokoliczniku lub wręcz głoski trzeba zestawić na nowo, zgodnie z zasadą, która odpowiada nowoczesnemu sposobowi odczuwania, a opiera się na skojarzeniach myślowych [...] w rezultacie język przestawał już być logicznym przebiegiem myśli, lecz jedynie następstwem uczuć i obrazów ${ }^{578}$.

wiadał znakomicie nieścisłej i muzycznej wrażliwości symbolistów, wyrażaniu stanów duchowych i oddawaniu płynności [...] Lecz dzisiaj wydaje nam się już przestarzałym. A w każdym razie nadaje się mało do wyrażenia gwałtownego "paroksyzmu» świata nowoczesnego. W istocie swej jest zbyt muzyczny, jest stworzony dla rozkoszy ucha. Tymczasem pokolenie obecne (mówię o jego żywiołach najbardziej zaawansowanych) jest czysto wizualne, zamiłowane w symetrji plastycznej, w porządku i w konstrukcji. Jest to pokolenie kinematografu. Ponadto nie na darmo byliśmy świadkami okresu analitycznego, a potem okresu konstrukcyjnego kubizmu" (Nicolas Beauduin, O potrzebie nowej techniki poetyckiej. Poemat synoptyczny, wieloplanowy [nie podano tłumacza], „Zwrotnica” 1923, nr 4, s. 108). Por. też G. Gazda, hasło 'paroksyzm', [w:] Stownik europejskich kierunków i grup literackich XX wieku, s. 470.

${ }^{574} \mathrm{O}$ futurystycznej fascynacji materią zob. F. T. Marinetti, Manifesto tecnico della letteratura futurista, a także m.in. A. Hutnikiewicz, „Liryczna obsesja materii”, fragment rozdziału Futuryzm, [w:] idem, Od czystej formy do literatury faktu..., s. 106-107 oraz Tadeusz Peiper, Futuryzm (analiza i krytyka), „Zwrotnica” 1923, nr 6, s. 162-172 (szczególnie fragment pt. Materijalizm poetycki).

575 A. Hutnikiewicz, Futuryzm, s. 111.

576 Tadeusz Peiper podkreślał, że „skoro chodzi o oddanie materji w sposób jak najbardziej czysty, jak najbardziej wierny; skoro chodzi o takie jej oddanie które byłoby zlaniem się słowa z rzeczą i do pewnego stopnia wniknięciem w wszechświat, Marinetti sądzi, że literatura może tego dokonać jedynie drogą zniszczenia dotychczasowej składni gramatycznej” (T. Peiper, Futuryzm (analiza i krytyka), s. 166-167).

577 A. Hutnikiewicz, Od czystej formy do literatury faktu..., s. 111.

${ }^{578}$ Ch. Baumgarth, Futuryzm, s. 247-248. 
Nad wyraz trafnie (i akcentując kluczowe dla mnie kwestie) referuje ten element teorii Marinettiego również Janusz Sławiński:

\begin{abstract}
Postulat „słów na wolności” pozostawał w ścisłym związku z całym kompleksem założeń, określających zadania twórczości artystycznej w kategoriach walki z ukształtowanymi w tradycji systemami wartości kulturalnych, konwenansami, schematami porozumiewania się i utrwalonymi społecznie przyzwyczajeniami poznawczymi. Składnia - głosił wódź włoskiego futuryzmu, a z nim jego wyznawcy, również polscy - to jedno z takich utwierdzonych przyzwyczajen, które są całkowicie dowolne i działają na zasadzie inercji, uniemożliwiając człowiekowi bezpośredni kontakt z życiem. Zakłamuje ona świat materialny, ponieważ ustala statyczne relacje między zjawiskami, które sa dynamiczne i zmienne. Dzięki syntaksie człowiek ma złudzenie, że przebywa w świecie uporządkowanym i zhierarchizowanym, co nie pozwala mu na współżycie z rzeczywistym potokiem zdarzeń i paraliżuje jego własną wobec nich aktywność. Powinnością poezji jest burzyć to złudzenie poprzez wytrącanie słów ze związków syntaktycznych, poprzez dawanie im maksimum samodzielności, poprzez ciagła dezorganizację kontekstu zdaniowego ${ }^{579}$.
\end{abstract}

Sam Marinetti pytał w swoim manifeście o to, jak mówimy porwani przez żywioł zdarzeń. Czy usytuowani w samym centrum rewolucji czy trzęsienia ziemi składamy piękne, okragłe zdania? Nie - odpowiadał. W takiej sytuacji człowiek „będzie pogardzał subtelnościami i niuansami języka"580. Literatura (liryka) to owoc naszych konfrontacji z życiem, z wydarzeniami i - by je opisać lub oddać wywoływane przezeń emocje - poeta nie może ograniczać swej wyobraźni konwencja, zapatrywać się na utrwalone w tradycji powiązania słów. W codziennej komunikacji w takich momentach wystarczają nam półgesty i półsłówka, ginie składnia, a słowa wymykają się regułom i konwencjom. Marinetti uznaje, że nie powinny im się poddawać również wtedy, gdy są zapisane. Zbędne wydawało się artyście też, by krępowała je tradycyjna interpunkcja i ortografia ${ }^{581}$. Wolne od utartych obrazów i sposobów ich zestawiania, niepoddane rygorom klasycznego zapisu, miały być niezwykle nośnym semantycznie materiałem sztuki słowa, zdolnym przekazać obraz świata. Tak Marinetti postrzegał swe słynne słowa na wolności, które układać miał poeta o fantazji bez drutów (taczników) ${ }^{582}$. Pisał o nich:

579 J. Sławiński, Koncepcja języka poetyckiego awangardy krakowskiej, s. 83-84.

${ }^{580}$ F. T. Marinetti, Distruzione della sintassi..., s. 10 lub F. T. Marinetti, Destruction of syntax..., s. 180 .

${ }_{581}$ Zob. fragment Ortografia libera espressiva, [w:] F. T. Marinetti, Distruzione della sintassi..., s. 29-32 lub Free Expressive orthography, [w:] F. T. Marinetti, Destruction of syntax..., s. 184-185. Warto też na marginesie choć zaznaczyć, że we wstępie do swojego manifestu Marinetti tłumaczy się też, czemu - choć sam propaguje nową typografię, brak interpunkcji i słowa na wolności - formułuje swe manifesty w sposób tradycyjny. Wyjaśnia, że proponowane w technicznym manifeście literatury „rewolucje” odnosić się miały wyłącznie do sztuki słowa, nie zaś do wszelkich tekstów pisanych. A jako że teksty teoretyczne muszą być przede wszystkim jasne i klarowne stąd i sam pomysłodawca rewolucji typograficznej wraca do tego, co klasyczne.

${ }_{582}$ Miczka podkreślał trudność przetłumaczenia sformułowania immaginazione senza fili. Podając oba dostępne polskim czytelnikom rodzime odpowiedniki słowa fili [tacznik za Józefem Heisteinem oraz drut za Joanną Ugniewską (a raczej może Haliną Kralowa)], badacz stwierdza, że każdy z nich trafnie oddaje intuicję Marinettiego. Zob. T. Miczka, Czas przyszły niedokonany..., s. 74, przypis 14. Gazda tłumaczy tę frazę jako Nieograniczona wyobraźnia, co - choć oddaje zamiar autorski - nie przenosi, jak sądzę, wszelkich znaczeń: ginie sugestia, że ograniczenie jest tu spętaniem. 
Poetę i publiczność łączy relacja, jaką spotkamy między dwójką starych przyjaciół. Mogą się zrozumieć przy pomocy półsłówek, gestów, spojrzeń. Dlatego wyobraźnia poetycka musi łączyć odległe rzeczy bez żadnych łaczacych je drutów, dzięki prawdziwie wolnym słowom ${ }^{583}$

Drugim elementem tradycji, w który wymierzona była skoncentrowana na sztuce słowa futurystyczna rewolucja, stały się: podmiot liryczny oraz tematyka poezji. Kategorycznie zastapiono liryczne ,ja” i psychologizm przywołana już tu liryczna obsesja materii. Już nie człowiek miał być centrum wszechświata, przedmiotem i podmiotem poezji. Hutnikiewicz, pisząc o tym programowym odejściu od literackiej psychologii, zauważał:

Literatura europejska od wielu stuleci pasjonowała się [...] uprawianiem swoistego rodzaju wiwisekcji i anatomii na duszy ludzkiej [...] Futuryści uznali, że poezja nie ma już nic w tym zakresie do powiedzenia i - że to w końcu jest nudne. „Precz z psychologiczną fantastyką - nawoływał któryś z niezliczonych manifestów futurystycznych. - Precz z metafizycznym niepokojem. Precz z ujeżdżaną od dwudziestu wieków przez romantyków, symbolistów i ekspresjonistów nie istniejącą szkapą metafizyki”. W miejsce człowieka jako prawie wyłącznego dotąd tematu literatury, wobec którego wszystko inne było tylko pretekstem i dodatkiem, futuryści wprowadzili materię jako jedyny motyw godny poezji. Nie duchowe doświadczenie człowieka, lecz fizyczne życie materii - oto, co może prawdziwie i istotnie pasjonować nowoczesnego artystę ${ }^{584}$.

Pochodzący głównie z Manifestu technicznego literatury futurystycznej postulat skupienia się na materii przekładał się na wizję specyficznej budowy obrazu poetyckiego. Nie dość, że liryczne „ja” i wszelki psychologiczny indywidualizm (zdaniem futurystów - jak głosi Marinetti w 11 punkcie swojego Manifestu technicznego literatury futurystycznej - zużyty) należy zastapić owa liryczna obsesja materii, to jeszcze literacki obraz tejże ma być budowany tak, by na pierwszy plan wysuwały się jej konkretne (materialne) właściwości: zapach, ciężar i - przede wszystkim - ruch. W konsekwencji - jak słusznie zauważa Tadeusz Miczka - jednym z charakterystycznych dla włoskich futurystów zabiegów była ikonizacja języka, czy - dokładniej - znaku werbalnego. Wiązała się ona właśnie z istotnym wysunięciem na plan pierwszy właściwości materiałowych samego znaku, a także znalezieniem formy ukształtowania tejże materii najbliższej w swej strukturze obrazowi, jaki ma ona przekazać. Tym samym, jak pisał polski badacz:

Obraz literacki upodabniał się do ikony, w której, jak wiadomo, łatwiej zaciera się granica pomiędzy planem treści a planem wyrażania. Futurysta komunikując właściwości rzeczy, materializował semantykę znaku werbalnego, eksponował tworzywo, które podsuwała mu twórcza intuicja. Organizował materię językową zgodnie z zasadą adequatio intellectus ad rem. W praktyce proces ikonizacji przybierał niekiedy formy skrajne. Zapis graficzny niejednokrotnie nadawał wyraźnie plastyczny kształt obrazowi literackiemu, a układ przestrzenny liter, sylab i wyrazów naśladował ruchy materii ${ }^{585}$.

${ }^{583}$ F. T. Marinetti, Distruzione della sintassi..., s. 11-12 lub F. T. Marinetti, Destruction of syntax..., s. 181 .

${ }^{584}$ A. Hutnikiewicz, Od czystej formy do literatury faktu..., s. 106-107.

${ }_{585}$ T. Miczka, Czas przyszły niedokonany..., s. 72. 
Istotna stała się konkretność owej materialności, wiązana z cecha, którą w jednym ze swoich manifestów Marinetti nazwał „dotykowością ${ }^{586}$. Zdaniem włoskiego artysty sama materia językowa winna zyskać namacalność równą tej, którą odznacza się komunikacja poprzez dotyk ${ }^{587}$. Można by posunąć się do stwierdzenia, że odpowiednikiem owego dotyku w przypadku literatury było muskanie ucha słowem, co tłumaczyłoby przedkładanie przez futurystów recytacji tekstów nad ich „dystrybucję” w formie książkowej588.

\subsection{Futurystyczna liberackość?}

Tu dochodzimy do istotnego punktu moich rozważań. Zreferowane pokrótce powyżej postulaty futurystów zdają się mieć przecież niewiele wspólnego z myśleniem liberackim. Jakże więc zaowocowały podejściem do materii literatury, w którym dopatrujemy się tych podobieństw? Liberaci ani nie chca zrywać z klasycznym sposobem budowania zdań, co najwyżej - sprzeciwiaja się tradycyjnej konstrukcji książki, na którą się one składają. Nie pożądają też przesunięcia punktu zainteresowania literatury z człowieka na materię. Nie narzucają żadnych tematów, ideologii. Ich krytyka dotychczas używanego języka poetyckiego (jeśli można o takiej w ogóle mówić) odnosi się do nieaktywowania wszelkich jego możliwości, nie nakazuje zmian tak drastycznych (i jednostronnych), jak manifesty futurystów. Liberaci nie mają też nic przeciwko usankcjonowanej normami ortografii czy interpunkcji. Bliskość obu teorii zdaje się podkreślać wyłącznie chęć wprowadzania jakichkolwiek innowacji typograficznych oraz ikonizacja znaku werbalnego, na którą zwrócił uwage Miczka. Trzeba jednak dodać, że pojawiający się w jego książce wątek refleksji nie jest dominujaccym w literaturze przedmiotu, a sam badacz równolegle do opisów tego, jak futuryści dokonywali konkretyzacji znaku językowego, eksplorujac jego materialność, stawia tezę, iż słowa na wolności realizowały się w pełni w tych przestrzeniach, w których nie musiały być zapisane ${ }^{589}$.

Tu trzeba wrócić do postulatów Marinettiego. Charakteryzując swe słowa na wolności, podkreślał on, że nowej składni winna towarzyszyć i nowa typografia, nowy sposób drukowania, w którym różnorodność czcionek i oryginalne spacjowanie już na poziomie wizualnego odbioru tekstu uzmysłowi czytelniko-

${ }^{586}$ Manifest Il tattilismo (Dotykowość) z 1924 r. Korzystałam z angielskiego przekładu Tactilism, [w:] F. T. Marinetti, Selected Writings, s. 109-112.

${ }^{587}$ T. Miczka, Czas przyszły niedokonany..., s. 74. W tym kontekście warto przywołać też o kilkadziesiąt lat późniejsze „wiersze dotykowe” Ladislava Nováka.

${ }^{588}$ Do kwestii tej powrócę w dalszej części rozdziału.

589 Dowodem podsumowanie futurystycznych działań teatralnych, jakie daje badacz: „Wydaje się, że w miarę upływu czasu futuryści coraz bardziej, aczkolwiek nie całkiem konsekwentnie, usuwali dramat ze sztuki literackiej, opowiadając się za jego teatrologiczną koncepcją. Słowa na wolności znajdowały najpełniejszą konkretyzację w «obrazach i dźwiękach na wolności». Potwierdzają to przypuszczenie hasła zawarte w następnych manifestach teatralnych" (T. Miczka, Czas przyszty niedokonany..., s. 99]. 
wi wage poszczególnych słów lub unaoczni relacje między elementami (zatem w pewnym stopniu ową odrzuconą składnię zastapi). Podobnie o semantycznej wadze czcionki mówił też Fajfer (choć nie wspominał o możliwości zastępowania nią tradycyjnej składni):

\begin{abstract}
Zdecydowana większość pisarzy w ogóle nie zastanawia się nad krojem pisma, którym ma być drukowane ich dzieło, a przecież jest to jedna z części składowych ich utworu. To tak jakby kompozytor wymyślił melodię, natomiast odpowiedź na jakim instrumencie ma być ona zagrana, zostawił dyrygentowi czy muzykom. Jest to zabieg czasem stosowany we współczesnej muzyce, ale autor kompozycji ma wtedy pełna świadomość idących za tym konsekwencji (zaproszenie instrumentalistów do współtworzenia). Pisarz natomiast, ignorując zupełnie te kwestie i zostawiając je wyłącznie w gestii wydawcy, nie robi tego z powodu wyznawanych przez siebie koncepcji estetycznych, lecz dlatego, że ten problem po prostu dla niego nie istnieje. Daje tym samym dowód pewnej elementarnej „głuchoty”, gdyż czcionka, którą drukuje się jego tekst, jest jak barwa dźwięku w muzyce ${ }^{590}$.
\end{abstract}

Marinetti, co dla mnie nawet i ważniejsze, stwierdzał tė̇, że zaproponowana przezeń rewolucja ma „zdwoić ekspresywną siłę słowa”"591 oraz, że jest ona formułowana nie tylko przeciw klasycznej typografii, lecz i w opozycji do dotychczasowej formy książki (będącej przecież głównym obiektem ataków liberatów).

Książka winna być futurystyczną ekspresją futurystycznej myśli - twierdził. - I nie tylko tym. Moja rewolucja jest wymierzona w tak zwaną harmonię strony, która jest przeciwna strumieniom i odpływom, skokom i wybuchom stylu biegnącego poprzez stronę. Tym samym - tłumaczy dalej - na jednej stronie będziemy używać trzech lub czterech kolorów atramentu lub nawet dwudziestu różnych czcionek, jeśli będzie to potrzebne ${ }^{592}$.

Jak zaznaczał, wymierzona nawet przeciw Mallarméańskiej (sic!) ${ }^{593}$ estetyce (poszukujaccej rzadkich słów, eleganckiej, sugestywnej, delikatnej i wyszukanej) nowa typografia miała nie być statyczna, a pisane przy jej pomocy słowa stawały się „wolne, dynamiczne i niczym torpedy” 594 , zyskując tym samym możliwość przekazania fascynacji prędkościa, tak charakterystycznej dla futuryzmu. Marinetti, jak mówił, nie chciał sugerować odbiorcy idei, podsuwać mu wyszukanych obrazów (co zarzucał właśnie Mallarmemu), odrzucał grację i elegancję w komunikacji z czytelnikiem. Chciał swe słowa i przekazywane przezeń emocje, wrażenia, idee „brutalnie chwycić i cisnać nimi w twarz

590 Z. Fajfer, Liberatura. Aneks do stownika terminów literackich, s. 24.

${ }^{591}$ F. T. Marinetti, Distruzione della sintassi..., s. 25 lub F. T. Marinetti, Destruction of syntax..., s. 183.

${ }^{592}$ Ibidem.

${ }^{593} \mathrm{O}$ wadze Mallarmégo dla zmian w podejściu do wizualnych aspektów sztuki słowa zob. rozdział poświęcony relacji liberatury i literatury wizualnej.

${ }^{594}$ F. T. Marinetti, Distruzione della sintassi..., s. 26 lub F. T. Marinetti, Destruction of syntax..., s. 183. Z kolei na naszym rodzimym gruncie Bruno Jasieński opisywał futurystyczne słowo jako „kapslę” (jak czytamy w przypisie: „spłonkę, mały pojemnik z materiałem wybuchowym o wielkiej pobudliwości, którego detonacja powoduje wybuch całego ładunku"). B. Jasieński, Futuryzm polski (bilans), [w:] Antologia polskiego futuryzmu..., s. 56. 
czytelnika" ${ }^{595}$, co szło w parze z futurystyczną wizją świata, światopoglądem, stosunkiem do kultury, tradycji etc. Stąd formy, po jakie sięgał, były tak dynamiczne, wyłamujące się konwencjom, krzykliwe właśnie w swej odmienności. Zawsze jednak miały możliwie najpełniej odpowiadać swym charakterem (i możliwościami jakie daja) temu, co artysta chciał przekazać. Zdwajanie mocy słowa było uczeniem go nie tyle mówienia, co wręcz krzyczenia swą materia.

A zatem - właśnie odpowiedniość zastosowanej formy do przekazywanej treści, poszukiwanie formy typograficznej czy materialnej, która najtrafniej oddałaby charakter komunikatu, sama sobą go współtworzyła, jest tu kluczowa. I ona - a konkretnie świadome odrzucanie konwencji na rzecz tego, co lepiej współgra z idea - jest liberacka. Istotny jest tu namysł nad tym, czy środki, jakimi dysponuje twórca, są adekwatne do treści, jakie chce przekazać. Każdy artysta w akcie kreacji dokonuje, rzecz jasna, takich wyborów. Jednak dla pisarzy, których utwory badam, istotna jest refleksja wolna (liber) od ograniczeń tradycji, otwarta na przekraczanie wytyczonych przez nią granic. Obejmuje ona również i pytanie o to, czy wypracowane przez tysiąclecia formy podawcze, sposoby komunikacji czy gatunki literackie, jakie artysta ma do wyboru, sa zawsze najlepsze, czy nie warto - może nawet i dla każdego tekstu, za każdym razem od początku - tworzyć nowych struktur, zrodzonych z potrzeb (i na potrzeby) tego właśnie jednego, wyjątkowego w swojej jednostkowości utworu. Liberackie podejście charakteryzować się będzie tym, że tradycja przestaje tu być jakimkolwiek ograniczeniem, choć nie jest też całościowo zanegowana. O ile futuryści odrzucali ją w pełni, uważając, że formy, jakie wypracowano na jej gruncie, nie są w stanie oddać obrazu świata i - zasadniczo - należałoby odkryć nowe, liberaci nie przecza, że (w niektórych sytuacjach) te dotychczas stosowane mogą być nad wyraz użyteczne. Dopominają się jednak, by uważnie rozważyć dostępne (i niedostępne) możliwości i wybrać te najlepsze.

Pisarz - nawoływał już w swoim pierwszym manifeście Fajfer - powinien za każdym razem od nowa budować przestrzeń swego dzieła, a każde z jego dzieł powinno mieć swoją własna, odrębną strukturę. Niech będzie to nawet tradycyjny wolumen, byle tylko stanowił z treścia książki integralną całość 596 .

Źródło analogii futurystyczno-liberackich tkwi zatem w przyczynie odrzucania zastanych form podawczych tekstu. Podczas gdy liberaci pytali o to, czy nie należy równie uważnie jak schematu fabularnego projektować układu książki, futuryści zastanawiali się, czy - spośród dostępnych im mediów - spętane konwencją sposoby druku to najlepszy środek, po jaki mogą sięgnać. I nieraz refleksja prowadziła ich nawet i ku odrzuceniu formy książki.

Warto chyba zaznaczyć, że jeszcze wyraźniej niż u Marinettiego widać to u polskich twórców (i dlatego obiecywałam jednak do nich wrócić). Bruno Jasieński twierdził wprost:

${ }^{595}$ F. T. Marinetti, Distruzione della sintassi..., s. 26 lub F. T. Marinetti, Destruction of syntax..., s. 183 .

${ }_{596}$ Z. Fajfer, Liberatura. Aneks do stownika terminów literackich, s. 27. 
Pszekreślamy kśążkę jako formę dalszego dostarczańa poezji odbiorcom. Poezja, jako sztuka operująca wartośćami akustycznymi, może być oddawana jedyńe słowem. Kśążka odgrywać może co najwyżej rolę nut, na podstawie kturyh pewna kategoria ludźi wyjątkowo uzdolńonych (wirtuozuw) może odbudować całość pierwotną. Z hwilą wynalezieńa telefonografu, tj. połączeńa fonografu z telefonem, kśążka jako pomost pomiędzy twurcą a publicznośćą okaże śę de reszty ńeużyteczną i zbędną ${ }^{597}$.

I tu właśnie dochodzimy do istoty problemu. Przyczyna futurystycznego odrzucania konwencji, odchodzenia od tradycyjnej formy książki tkwiła w jej nieadekwatności do przekazywanych treści. W takim kontekście można futurystyczne akcje odczytywać jako liberacje. Kiedy Fajfer postulował, by artysta rozważył formę klasyczna, konwencjonalną jako jedną z możliwych i - mając świadomość jej plusów i minusów - podejmował decyzję, czy warto po nią sięgnąć - wskazywał drogę, jaką wcześniej kroczyli już futuryści.

U podstaw ich pragnienia zmiany kanału komunikacji tkwił zaś nie tylko odmienny od dotychczasowego charakter uprawianej twórczości, lecz i - poniekąd na niego oddziałująca - jakość nowego odbiorcy, ukształtowanego - jak już wspominałam - w świecie rozwiniętych technologii przekazu. O takim czytelniku, a także o „pełnym odnowieniu ludzkiej wrażliwości, którym zaowocowały wielkie odkrycia naukowe" ${ }^{598}$ pisał Marinetti w swojej Likwidacji składni, podkreślając ogromny wpływ nowych środków komunikacji (m.in. telefonu, telegrafu, samolotu czy gazety) na psychikę współczesnego człowieka ${ }^{599}$. Michael

${ }^{597}$ B. Jasieński, Mańifest $w$ sprawie poezji futurystycznej, [w:] Antologia polskiego futury$z m u \ldots$, s. 21. Ciekawym nawiązaniem do futurystycznej idei innego rozpowszechniania literatury wydaje się praca grupy Twożywo wykorzystująca wiersz Marsz Jasieńskiego. W kontekście wyłaniającej się z manifestów wizji książki animacja ta staje się intrygującym przykładem remediacji (nie wyłącznie: adaptacji), nie daje się odczytywać wyłącznie jako remake polegający na dodaniu do słów poety adekwatnego dźwięku i obrazu. Por. też Ula Pawlicka o adaptacji „Marszu” Jasieńskiego wg grupy Twożywo, http://www.techsty.art.pl/magazyn/magazyn7/rec/marsz_jasienskiego. html [dostęp 29.09.2011].

598 F. T. Marinetti, Distruzione della sintassi..., s. 2 lub F. T. Marinetti, Destruction of syn$\operatorname{tax} \ldots$, s. 178 .

${ }_{599} \mathrm{Na}$ rodzimym gruncie przeczytamy o tym m.in. w Mańifeście w sprawie natyhmiastowej futuryzacji żyća: Artyśći na ulicę! - nawołuje w nim Bruno Jasieński - „Sztuka gńeżdżąca śę w kilkuset, a nawet kilkutyśęcznoosobowyh salah koncertowyh, pałacah sztuki itp. jest śmiesznym anemicznym dziwolagiem, pońeważ korzysta z ńej 1/100000000 wszystkih ludz. Człowiek wspułczesny ńe ma czasu na hodzeńe na koncerty i wystawy, 3/4 ludźi ńe ma po temu możnośći. Dlatego sztukę muszą znajdować wszędźe: Latające poezokoncerty w poćąah, tramwajah, jadłodajńah, fabrykah, kawiarńah, na placah, dworcah, w hallah, pasażah, parkah, z balkonuw domuw itd. itd. itd. o każdej poże dńa i nocy” (Bruno Jasieński, Do narodu polskiego. Mańifest w sprawie natyhmiastowej futuryzacji żyća, [w:] Antologia polskiego futuryzmu..., s. 11). To, że futuryści nowy sposób dotarcia do odbiorcy, nawiązywania artystycznej komunikacji silnie wiązali właśnie z rozwojem techniki podkreśla też Helena Zaworska. „Futuryści polscy rozumieli już doskonale, że technika nie jest ich wrogiem, lecz sprzymierzeńcem w nawiązywaniu kontaktu z prawdziwie masowym odbiorca, że jest to jedna z najistotniejszych nowych szans sztuki XX-wiecznej” - twierdzi badaczka. - „Chcieli oczywiście tę szanse wykorzystać, proponowali organizowanie wielkich, tłumnych przedstawień ludowych, masowych spotkań poetyckich, zabaw przypominających tradycje XVII-wiecznych festynów [...] Czynili wokół swojej sztuki wiele hałasu, demonstrowali publicznie ekscentryczność zachowania, na wieczorach poetyckich starali się nawiązać kontakt z publicznościa poprzez wywołanie szoku budzącego zainteresowanie. Marzyli istotnie o tym, by bawić całe tłumy” [Helena Zaworska, 
Webster podkreśla, że twórca dostrzegał w owych mediach „natychmiastowość podobną tej, której oczekiwał od swoich słów na wolności”"600.

Referując teorię liberatury podkreślałam, że raczej nie bez powodu zrodziła się ona właśnie na przełomie XX i XXI w., w dobie nowych mediów, sztuki (i literatury) elektronicznej, czasu raczej v-userów i interaktorów niż czytelników. Kwestia materialności dzieła literackiego i - co za tym idzie - badania nośności semantycznej medium, w jakim jest tworzone, stała się w tym czasie kwestia niebagatelna ${ }^{601}$. Namysł nad tymi kategoriami w odniesieniu do dzieł mniej wirtualnych (najczęściej - acz niekoniecznie - papierowych) zaowocował refleksją liberacką i próbą wypracowania nowej szkoły (?) analizy i interpretacji tekstu ${ }^{602}$. Bez mała sto lat wcześniej podobna sytuacja zrodziła rewolucję futurystyczna (i jej liryczna obsesję materii) ${ }^{603}$. Twórcy tego ostatniego nurtu nie patrzyli obojętnie na nowości technologiczne zmieniające świat na ich oczach. Nie czynili ich też jedynie tematem (czy podmiotem) swoich utworów, lecz sięgali po nie w swoich poszukiwaniach lepszej drogi ekspresji słowa.

Pamiętając, że futuryści to ci, co swe wiersze nie tyle deklamuja, co krzyczą $^{604}$, trzeba przyznać, że konsekwentnie tropili wśród dostępnych im środków takie, które ów krzyk najlepiej wyrażą. Ich poszukiwania traktować można jako liberackie, gdyż eksplorują również przestrzeń samego medium. Sięgaja w konsekwencji między innymi w raczej niewykorzystywaną dotąd przestrzeń słowa: namacalną formę jego zapisu. Zwracają uwagę na druk, który tradycyjnie postrzegany był - jak frapujacco ujmuje to Alan Bartram - jako „medium krnąbrne, niepoddające się łatwej obróbce" (normally intractable medium) ${ }^{605}$. Futuryści wykorzystali je do tworzenia semantyki utworów. Z tym, że typografia nie tylko tu naświetlała, intensyfikowała i wyjaśniała znaczenia tekstu (czy wzmacniała efekt użytych słów poprzez nadanie im kształtu wizualnego)

Futurystyczne koncepcje sztuki dla mas, „Pamiętnik Literacki” 1967, nr 3, s. 87]. O przemianach technicznych, naukowych czy mentalnych, które stały się podwalinami futuryzmu jako prądu kulturalnego (o „filozoficznym zapleczu” nurtu - jak ujmuje to Tomasz Burek) zob. też: Tomasz Burek, Futuryzm, [w:] Lektury i problemy, wybór i oprac. Janusz Maciejewski, Warszawa 1976.

${ }_{600}$ M. Webster, The Avant-Garde Poem: Marinetti, s. 23.

601 Por. zwłaszcza ostatnie rozdziały tej książki.

602 Warto tu może przywołać analizę 21 liter Zenona Fajfera, autorstwa Łukasza Jeżyka. Badacz odczytuje ten utwór właśnie jako liberacką refleksję nad medialnością literatury. Zob. Łukasz Jeżyk, Widzieć, wierzyć, wiedzieć. „dwadzieścia jeden liter” Zenona Fajfera, [w:] LCLT lub wcześniejsza wersja tego tekstu Widzieć - wierzyć - wiedzieć. Zenona Fajfera podejrzenia i spojrzenia [w:] Między językiem a wizualnościa, red. Magdalena Bednarek, Maciej Junkiert, Joanna Klausa-Wartacz, Poznań 2008.

${ }^{603}$ Zauważywszy takie pokrewieństwo nurtów, warto podkreślić, że w obu przypadkach mamy też do czynienia z teorią formułowaną przez praktyków, z manifestami artystów.

${ }^{604}$ O futurystycznej „poetyce skandalu” i „epatowaniu czytelnika” (za Sternem) jako jednej z podstawowych form futuryzacji życia pisze m.in. Edward Balcerzan (Zob. Edward Balcerzan, Wstęp, [w:] Bruno Jasieński, Utwory poetyckie, manifesty, szkice, Kraków 1972). Z kolei na przyczyny takich działań trafnie wskazuje, charakteryzując włoski futuryzm, Halina Kralowa: „hasła futurystów były świadomie prowokacyjne i obrazoburcze: to także należało do reklamy" (H. Kralowa, Zmierzch i maszyna..., s. 52). Por. też G. Gazda, Legenda polskiego futuryzmu, [w:] idem, Futuryzm w Polsce.

605 A. Bartram, s. 7. 
- jej rola urastała do rangi nieusuwalnego składnika semiozy. Dlatego właśnie - zauważa Bartram - radykalne idee typograficzne odegrały tak istotną rolę w futurystycznej rewolucji. Dlatego również - dodam - czynią ją pokrewna „rewolucji” liberackiej.

Przywołany badacz zaznacza tė̇, że włoskim futurystom brakowało podstawowej wiedzy o typografii, jednak - co ważne w kontekście dzisiejszego operowania przez nas możliwościami oferowanymi przez ogólną dostępność nowych mediów i komputerowego składu tekstu - podkreśla też, że „umiejętność korzystania z komputera jeszcze nikogo nie uczyniła typografem”606, że jest ona niczym $\mathrm{w}$ porównaniu $\mathrm{z}$ wyobraźnią czy wizualna wrażliwościa, jakie cechowały Marinettiego. To one - a nie wiedza o składzie tekstu - leża $\mathrm{u}$ podstaw wprowadzanych przezeń typograficznych innowacji. Trzeba téz zaznaczyć, że u włoskiego artysty owa wrażliwość kieruje również doborem słów, stąd w wielu z jego utworów dostrzeżemy analogie między zabiegami zastosowanymi na poziomie tradycyjnie rozumianego języka poetyckiego a tymi związanymi ze sposobem jego zapisu (na co będę jeszcze zwracać uwagę, analizując poszczególne utwory „papieża futuryzmu”, szczególnie Carta sincrona). Podobnie „wrażliwi” na materię słowa i tekstu sa liberaci.

Zdaniem Bartrama, Marinettiemu wymienione wyżej cechy pozwoliły tworzyć jedyną w swoim rodzaju poezję, którą badacz określa wręcz mianem „nowego sposobu komunikacji” (a new mode of communication) ${ }^{607}$. Być może, jako taki należałoby traktować i liberaturę ${ }^{608}$. Dodam, iż opisując prace włoskich futurystów, Bartram podkreśla z jednej strony ich zakorzenienie w literackości, z drugiej - dążenie do stworzenia nowego języka sztuki słowa, dwie cechy jakże bliskie liberatom. Do obu bowiem zjawisk możemy odnieść słowa tego badacza:

[Teksty te - AP] nie sa zwykłymi ćwiczeniami typograficznych form. Są wierszami i jako takie próbują kreować nowy, bardziej intensywny i ekspresywny język komunikacji, ani nie literacki, ani nie graficzny, lecz będący syntezą tych dwóch. Stworzone przez poetów, wszystkie elementy, słowa i forma reprezentacji, są nierozdzielne. Forma jest częścią treści, zaś treść kreuje formę $e^{609}$.

Zatem - zarówno u liberatów, jak i u futurystów - dziwny, niecodzienny, odmienny od klasycznego zapis, owo łamanie obowiązujących kanonów maja służyć tworzeniu nowego rodzaju tekstów, w których informacja przekazywana będzie poprzez różne poziomy znaku, poprzez różne media. Sądzę, że rzeczywiście słuszna jest intuicja Bartrama, iż wręcz należałoby taki sposób pisania określić mianem nowego sposobu komunikacji. Bo istotnie, przekracza on granice wyznaczone przez konwencję projektowania, wytwarzania i czytania ksiazzek, co zarówno liberaci, jak i futuryści ujmują w kategoriach „uwalniania słów”.

\footnotetext{
${ }^{606}$ Ibidem, s. 8 .

607 Ibidem.

${ }^{608}$ Hipotezę tę rozwijam w dalszej części książki.

609 A. Bartram, s. 8.
} 
W przypadku twórczości przedstawicieli obu tych nurtów artysta od samego początku projektuje utwór tak, by wykorzystać odnalezione „dodatkowe możliwości”, jakie oferuje mu medium, rozpisuje i kreuje znaczenia, uwzględniając jego specyfikę. Stąd, zjawiska te sa sobie bliższe niż liberatura i druk funkcjonalny. Wszystkie trzy łączy intencja - chęć wzmocnienia ekspresji słowa, poszerzenia języka poetyckiego, znalezienia dodatkowej możliwości tworzenia znaczeń. Jednak w przypadku liberatury i futuryzmu inicjatywa podejmowania prób pozyskiwania nowych środków wyrazu leży zawsze po stronie twórcy, a nie - jak miało to miejsce w przypadku druku funkcjonalnego - odczytującego i interpretującego utwór typografa. Poszukiwania nowych rozwiązań prowadzone przez twórców literatury totalnej i artystów spod znaku Marinettiego koncentrują się też na badaniu właściwości medium, jakim dysponują (a także na samym jego wyborze). I w końcu - zarówno w przypadku futurystów, jak i liberatów - namysł nad nim prowadzi do zmian w tradycyjnej formie książki (lub w ogóle do jej odrzucenia).

W konsekwencji, choć wydaje się, że futuryzm z liberaturą łączy niewiele, analogie sięgają jednak w tym wypadku dość daleko. Czemu? To, co przybliża do siebie zestawiane tu nurty to istotny namysł nad samym procesem literackiej komunikacji. Choć więc wspólne postulaty daje się zamknąć w dwóch zaledwie sformułowaniach (w szansie na wzmocnienie ekspresji słowa na drodze eksploracji sposobu jego graficznego czy materialnego przedstawienia oraz w refleksji nad adekwatnością formy książki jako nośnika prezentowanych idei), ich podłożem jest podobny stosunek do istoty literackiego przekazu, refleksja poszukująca nowych przestrzeni pogłębienia semantyki słowa.

\subsection{Bliżej futurystyczno-liberackiej praktyki: tablice synoptyczne i symultaniczność liberacka}

Choć - bezsprzecznie - tej części mojej książki przyświeca idea poszukiwania analogii w teoretycznych postulatach, nie chciałabym jednak rezygnować tu z analiz i interpretacji. Szczególnie, że sugerowane pokrewieństwo charakterystyk pisarstwa futurystycznego i liberackiego, na które wskazuję - dające się w ogromnym uproszczeniu zamknać w formule aktualizowania wizualności tekstu - najpełniej jest widoczne, kiedy odniesiemy się również do twórczości teoretyków. Dopiero analizując konkretne utwory Marinettiego, można pokazać, jak bardzo ich kształt typograficzny bywa związany z treścią i (co ważniejsze) jak jest - w jej obrębie - sfunkcjonalizowany. Tym samym, jeszcze wyraźniej widać, że - podobne jak w tekstach liberackich - i u włoskiego artysty owe „drukarskie ekstrawagancje” dyktowane sa potrzebami tekstu i ściśle związane z jego poetyka, nie mają nic wspólnego z zabawą. Kilka interpretacji, jakie chciałabym tu zaprezentować, pozwoli, mam nadzieję, pokazać, na czym w praktyce miało polegać postulowane przez włoskiego teoretyka zdwajanie mocy słowa poprzez jego typograficzne opracowanie. Jednocześnie, porównując stosowane przez Ma- 
rinettiego zabiegi z tymi, po które sięgają liberaci, uda mi się zapewne jeszcze lepiej zobrazować podobieństwa łączące te dwa typy twórczości.

Jedna z literackich propozycji futurystów, która nad wyraz bliska jest liberaturze, sa z pewnościa tablice synoptyczne wartości lirycznych, które miały umożliwiać odbiorcom równoległą percepcję kilku zjawisk ${ }^{610}$. Zrodziły się z rozważań o kategorii liryzmu multilinearnego (multilinear liricism), pozwalającego osiągnąć w dziele literackim pełnię symultaniczności. A trzeba tu pamiętać, iż - zdaniem futurystów - człowiek współczesny postrzegał otaczająca go rzeczywistość jako natłok nakładających się na siebie bodźców, stąd forma literacka pozwalajacca oddać ową wielowątkowość świata i jego percepcji była przez nich nad wyraz pożądana. Zaś w porządkowaniu (hierarchizowaniu) strumieni wrażeń przypisanych do różnych zmysłów (bodźców wizualnych, ale też i np. węchowych) miała tu pomóc typografia, gdyż to właśnie sposób zapisu z jednej strony sugerował równoległość doznań (analogiczne wersy w grupach wersów), z drugiej - ich gradację (np. poprzez wielkość poszczególnych czcionek). Grafia pomagała również orientować się w tak skomplikowanej multilinearnej strukturze, porządkując ją (np. na drodze konsekwentnego związania konkretnych czcionek z określonymi strumieniami wrażeń) ${ }^{611}$.

Liberackim (epickim) odpowiednikiem takiego zapisu byłyby fragmenty utworów Bryana Stanleya Johnsona, Raymonda Federmana, Jamesa Joyce’a, a także stronice Arwa Stanisława Czycza (zob. ilustracja 24). Choć trzeba pamiętać - iż mimo wydania tego ostatniego tekstu w serii Liberatura, jego literackość jest dość dyskusyjna ${ }^{612}$. Zaś w Oka-leczeniu Katarzyny Bazarnik i Zenona Fajfera cała konstrukcja książki podporządkowana jest obrazowaniu

${ }^{610}$ Zob. J. Heistein, Futuryzm we Wtoszech.

611 Zob. F. T. Marinetti, Distruzione della sintassi..., s. 27-29 lub F. T. Marinetti, Destruction of syntax..., s. 184. Poszukiwanie techniki zdolnej oddać dziejące się równolegle wydarzenia nieobce było też polskim futurystom. Maria Tarnogórska pisała o symultaniczności jako wyznaczniku rodzimego poematu futurystycznego, wyróżniając 2 typy stosowanego przez futurystów symultanizmu: zewnętrzny (z dominantą epicka) będący techniką przedstawienia rzeczywistości oraz wewnętrzny (z dominantą liryczna) rozumiany jako technika przedstawienia strumienia świadomości. Trzeba też podkreślić, iż Tarnogórska jest wrażliwa na stosowane przez artystów - jak sama je określa - „chwyty typograficzne” (s. 160), zwracając uwagę na rolę grafii tekstu w konstruowaniu symultaniczności nie tylko w twórczości Czyżewskiego, ale i w rozmaitych innych utworach (np. w Sterna Zdobyciu Paryża czy tegoż rozmowie kochanków z romansu peru). Zob. Maria Tarnogórska, Formuła symultaniczna. O poemacie futurystycznym, [w:] eadem, Poemat międzywojenny. Studium z poetyki historycznej gatunku, Wrocław 1997. O adekwatności techniki symultanicznej (jako pozwalającej widzieć więcej i szybciej) do współczesności pisał też Władysław Strzemiński, stwierdzając m.in.: „Uwielokrotniona komplikacja życia współczesnego zmusza do chwytania kilku rozmaitych wrażeń, widzenia więcej i szybciej. Stąd postulat futurystów, że tylko to widzenie świata odpowiada rzeczywistości współczesnej, które łączy jednoczesnością wszystkie zjawiska otaczające człowieka" (Władysław Strzemiński, Sztuka nowoczesna w Polsce, [w:] idem, Wybór pism estetycznych, red. Grzegorz Sztabiński, Kraków 2006, s. 104).

${ }^{612}$ Pisałam o tej kwestii w szkicu Sprzedać legendę. Jak zachwyca i rozczarowuje „Arw” Stanisława Czycza, „TECHSTY”, nr 4/2008 [http://techsty.art.pl/magazyn4/recenzje/przybyszewska01.html; czasopismo internetowe posiadające ISSN: 1898-4843]. Por. także Katarzyna Bazarnik, Zenon Fajfer, „Arw” z perspektywy liberatury (kilka słów od redaktorów serii), [w:] Stanisław Czycz, Arw, oprac. Dorota Niedziałkowska, Dariusz Pachocki, Kraków 2007. 
symultaniczności, a także innych zależności czasowych ${ }^{613}$. Wśród innych - nieprzywoływanych dotychczas w kontekście liberatury - rodzimych przykładów możemy też wymienić Dwudziestu czterech kochanków Perdity Loost Jana Brzękowskiego, powieści, w której (właśnie niczym u Joyce’a czy Johnsona) stronica została podzielona na dwie części, by oddać w nich równoległe myśli kochanków (Perdity i Jeana) ${ }^{614}$. W tym kontekście można też wspomnieć Ziele na kraterze Melchiora Wańkowicza, na którego kartach równolegle biegną myśli bohatera o charakterze wspomnieniowym (sprowokowane wiadomością o śmierci brata) i wygłaszany przezeń odczyt ${ }^{615}$.
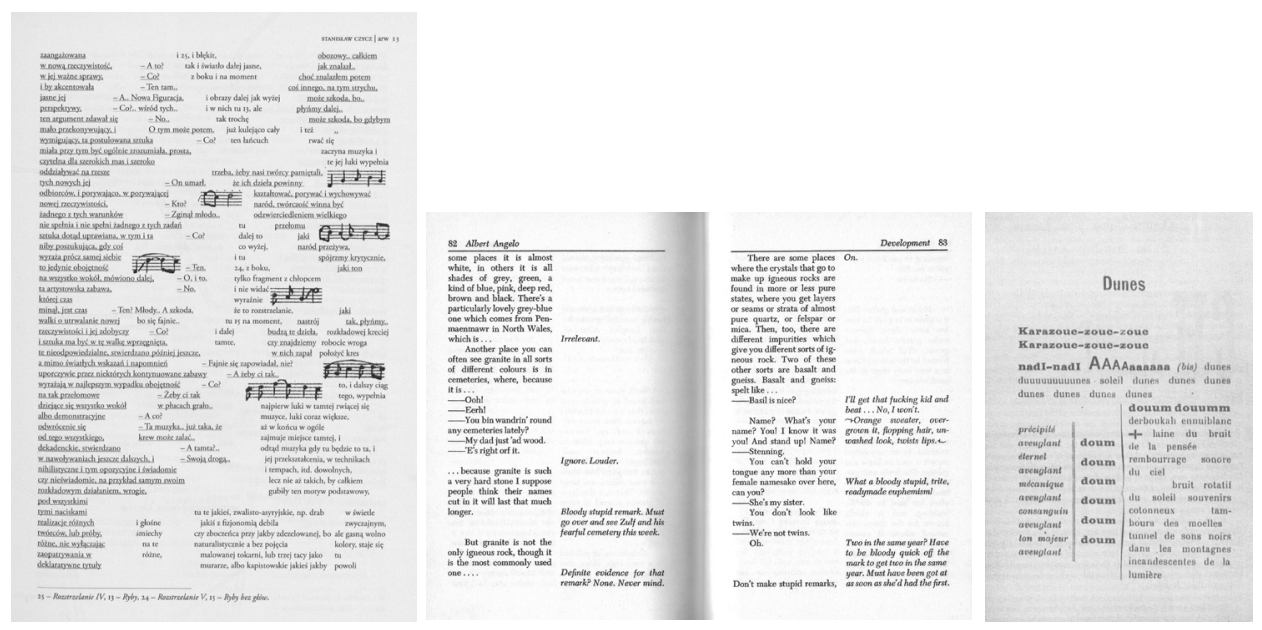

Ilustracja 24. Od lewej - Arw Stanisława Czycza, Albert Angelo Bryana S. Johnsona (źródło: zdjęcia własne); Dunes Filippo T. Marinettiego (źródło: Johanna Drucker, The Visible Word. Experimental Typography and Modern Art, 1909-1923, Chicago-London 1996, s. 122)

Przykładem utworu, w którym Marinetti korzysta z takiej techniki pisarskiej są Dunes (zob. ilustracja 24), które Giovanni Lista określił dojrzałą formą stów na wolności $i^{616}$. Co ważne - tak naprawdę utwór ten nie ma w swo-

${ }^{613}$ Szczególnie istotna i warta przywołania jest tu zastosowana przez autorów technika emanacyjna pozwalająca w jeden tekst wpisać inne. W tych ostatnich (określanych przez Fajfera i Bazarnik jako niewidzialne), dających się zbudować z pierwszych liter słów użytych w utworze opisane są (również poniekąd „niewidzialne” - bo niedostrzegane przez wszystkich) zdarzenia rozgrywające się paralelnie z tymi przedstawionymi w tekście głównym. Por. też przypis 66 w rozdziale Liberatura i poezja wizualna.

614 Por. Seweryna Wysłouch, Problematyka symultanizmu w prozie, Poznań 1981, szczególnie s. 61-62. Zob. też: Jan Brzękowski, Dwudziestu czterech kochanków Perdity Loost, Londyn 1961 (s. 133-134).

${ }^{615}$ Melchior Wańkowicz, Ziele na kraterze, Warszawa 1957, s. 472-474. Tekst ten również przywołuję za wskazaniem Seweryny Wysłouch. Warto może - za badaczką - zwrócić uwagę na fakt, że w polskiej tradycji taki rodzaj zapisu częściej służy raczej oddaniu równoległości myśli niż samych wydarzeń.

616 J. Drucker, s. 129. 
jej organizacji nic obrazowego ${ }^{617}$. Rozbicie słów na kolumny, a także rozmieszczenie ich w różnych przestrzeniach strony ma ewokować nie tyle wizualne skojarzenia, co pomóc uporządkować strumienie bodźców zgodnie z zasadami organizacji opisanymi przez Marinettiego w jego manifeście: poszczególne wyróżnione całości to strumienie wrażeń węchowych, wizualnych czy dźwiękowych. Z analogicznym (wcale nie: estetycznie wizualnym) uporządkowaniem przestrzennym słów mamy do czynienia w przywołanym już tu liberackim (?) Arwie. W obu przypadkach zastosowana organizacja tekstu ma podkreślać symultaniczność odbioru bodźców. Zatem, rzeczywiście, celem wykorzystania oryginalnej typografii jest „uwolnienie słów”, wyzwolenie ich z kajdan syntaksy i linearności, które sprzeczne są z natura świata i jego odbioru (jak dodałby Marinetti). To ostatnie warto podkreślić, gdyż właśnie takie przekonanie zaowocowało w tym wypadku poszukiwaniem nowych form literackich, zdolnych taki nielinearnie poukładany świat przedstawić. Tym samym, inny niż klasyczny sposób zapisu jest tu nie tyle eksperymentem, lecz podporządkowanym prezentowanej wizji świata (i ją obrazujaccym) środkiem poetyckim.

Wśród liberackich dzieł na pewno warto tu również przywołać - jako cechujacy się podobnym sfunkcjonalizowaniem układu tekstu - Koniec świata wedtug Emeryka Nowakowskiego, w którym zastosowana struktura hipertekstowa oraz liberacka typografia maja pomóc w wykreowaniu obrazu świata portretowanego $\mathrm{z}$ wielu odmiennych perspektyw. I tam nie-klasyczna forma prezentacji tekstu wynika z potrzeby przedstawienia zdarzeń rozgrywajacych się równolegle. Jednocześnie, pozwala ona podkreślić, że często te same sytuacje (w przypadku tego utworu proces przenoszenia rzeźby pielgrzyma na szczyt góry, co - zgodnie z legenda - miało sprowokować koniec świata) postrzegane sa zupełnie inaczej przez różne osoby (w Końcu świata... znajdziemy bohaterów, którzy wobec zdarzenia konstytuującego warstwę fabularną sa obojętni i takich, którzy są w nie ogromnie zaangażowani) ${ }^{618}$.

W Dunes, podobnie jak w przywołanych utworach zaliczanych do literatury totalnej, typograficzne „dziwactwa” nie mają bawić oka czytelnika, nie sa ozdoba, lecz wynikają z przekazywanych treści, nie tylko podkreślając pewne sensy dzieł, lecz i samemu je przenosząc. Michael Webster słusznie podkreśla, że dla Marinettiego zastosowane innowacje typograficzne (w tym i tablice synoptyczne) nie miały być celem samym w sobie, lecz stawały się istotne jako środki do pogłębienia siły ekspresji słowa ${ }^{619}$.

Nie dawały się też do końca skodyfikować, gdyż to sensy (i potrzeby) danego utworu rodziły konkretne sposoby kształtowania tekstu. Nikt nie wybierał tu formy ze zbioru gotowych możliwości, lecz była ona konstruowana na potrzeby tekstu, równolegle z nim. Podobnie i w liberaturze nie stworzymy kanonu liberackich środków stylistycznych, gdyż w przypadku każdego utworu

617 Ibidem

618 Szerzej pisałam o tym w szkicu Porzadek czy chaos, sieć czy zbieranina, logiczna konstrukcja czy zagmatwany labirynt? Na marginesie hipertekstowej powieści Radosława Nowakowskiego. Porównaj też bibliografia podana w przypisie 383 rozdziału Liberackie znaki, chwyty $i$ struktury.

${ }_{619}$ M. Webster, The Avant-Garde Poem: Marinetti, s. 29. 
forma jest tym, co rodzi się wraz z pomysłem treści. Określać można wyłącznie pewne ramy teoretyczne naświetlające potencjalne możliwości (co czyni i Marinetti, i - m.in. - Bazarnik ${ }^{620}$ ).

\subsection{Zniewolone słowa na wolności}

Oczywiście nie każdy utwór Marinettiego powstał z wykorzystaniem tablic synoptycznych. Co więcej, zdaje się, że też nie wszystkie dzieła artysty podporządkowują się formułowanym przezeń charakterystykom słów na wolności. Zaś wśród tekstów odautorsko (bo w podtytule) określonych jako te ostatnie znajdziemy i utwory, które zdają się przekreślać sugerowane podobieństwa między typograficznie opracowanymi pracami futurystów a liberatura. Trafimy bowiem na wiersze, w których graficzne ukształtowanie nie dodaje żadnych sensów, a jedynie (wtórnie) podkreśla to, co wyrażone słowem. Trudno, rzeczywiście, podtrzymywać w takich wypadkach tezę o bliskości liberatury i futuryzmu, szczególnie mając w pamięci słowa Fajfera ostro sprzeciwiającego się wszelkim słowno-wizualnym tautologiom ${ }^{621}$. Niemniej, by jeszcze wyraźniej wybrzmiały pokrewieństwa, których szukam - i o takich utworach warto wspomnieć. Szczególnie, że są one często przywoływane, gdy mowa o futurystycznych eksperymentach z typografią (z racji swojej - bądź co bądź - odbiegajacej od klasycznej, formy wizualnej).

Przykładem takiego tekstu jest Bataille à neuf étages (1916, zob. ilustracja 25), utwór, w którym Marinetti sam uwięził swoje - tym razem wcale niewyzwolone - słowa w ograniczającej je wizualności. Symultaniczność działań wojennych ujęta jest tu w ramy obrazowego schematu. Zajmujący całą stronę utwór ${ }^{622}$ to opis walk toczących się 25 października 1915 r. na Monte Altissimo. Przestrzeń kartki i - tym samym - przestrzeń tekstu kształtuje schematyczny zarys szczytów górskich, doliny i jeziora, uzupełniony etykietowym w charakterze, przypominajacym nieco informacje podawane na mapach, zapisem wysokości. Każdej z nich - niczym na wykresie - przyporządkowany jest fragment tekstu charakteryzujacy ową przestrzeń.

${ }^{620}$ Przypomnę, że za najbardziej aktualny opis takich możliwości pozostających w zasięgu liberatów należałoby traktować wyznaczniki liberatury podane przez Bazarnik w szkicu Liberatura czyli o powstawianiu gatunków (literackich). Podobny charakter mają również wcześniejsze publikacje: Traktat kartkograficzny... Radosława Nowakowskiego (aspirujacy do spisu liberackich środków) oraz szkic Christiana A. Dumaisa Would You Like To Save Your Game Now? The Replayability Of Liberture (,Systems. Journal of Transdisciplinary System Science” 2008, nr 1-2; polski przekład ukazał się dwa lata później na łamach „Ha!artu”: Christian A. Dumais, Wielogrywalność liberatury. Czy chciałbyś zapisać stan gry?, tłum. Joanna Pyra, „Ha!art” 2010, nr 30).

${ }^{621}$ Por. uwagi o kaligramach w rozdziale poświęconym relacji liberatury i poezji wizualnej.

${ }^{622}$ Korzystałam z wersji opublikowanej w: F. T. Marinetti, Les mots en liberté futuristes, Milano 1919. Nieco różniące się (brzmieniem tytułu i jego typograficznym kształtem) reprodukcje tej pracy podają też w swoich książkach Drucker (s. 132, za wydaniem z 1916 r., Rzym) oraz Bartram (s. 31, za wydaniem z 1919 r., Milano). 
Johanna Drucker ocenia Bataille à neuf étages negatywnie, uznając, że w porównaniu z wcześniejszymi utworami Marinettiego - temu akurat brak dynamizmu i dramatyczności.

Elementy graficzne tego tekstu - dodaje - zdają się dawać złe wyobrażenie podtytułu Słowa na wolności, jako że kompozycja jest sztywnym uporządkowaniem elementów typograficznych zgodnie z ustalonym obrazkowym schematem, którego konceptualną bazą była jedna z najbardziej sztywno skodyfikowanych form: diagram sekcyjny. W pewnym stopniu elementy wizualne i werbalne duplikują się wzajemnie - konkluduje Drucker. - Na przykład: umieszczenie elementów na odpowiednich wysokościach było niepotrzebnie wtórnie przedstawione poprzez oznaczenie tych poziomów ${ }^{623}$
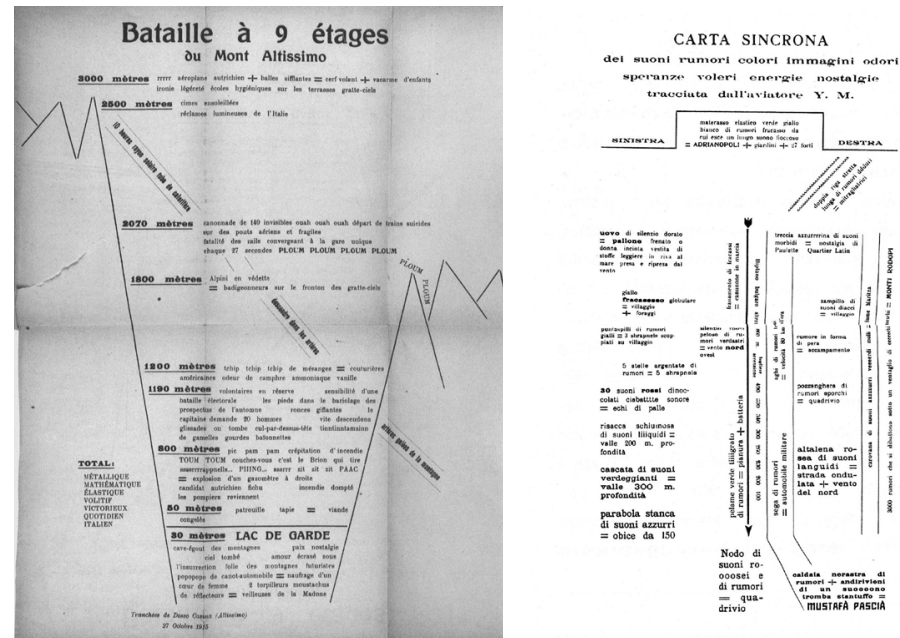

Ilustracja 25. Od lewej - Filippo T. Marinettiego Bataille à 9 étages (źródło: Alan Bartram, Futurist Typography and the Liberated Text, London 2005, s. 31) oraz Carta Sincrona (źródło: Michael Webster, Reading Visual Poetry after Futurism. Marinetti, Apollinaire, Schwitters, Cummings,

New York 1995, il. 4)

Interpretacja Drucker i tezy stawiane przez badaczkę wydają się słuszne. Rzeczywiście - zamknięte w wizualności zrodzonej z realizacji schematu słowa nie tylko stają się semantyczne nijakim wizualnym duplikatem zawartych w utworze znaczeń, lecz i traca (zamiast zyskiwać) wiele ze swych możliwości. Uwięzione w diagramie nie sa już ani słowami wieloznacznymi, ani (wbrew

${ }^{623}$ J. Drucker, s. 134. Tak surowa ocena wynika przypuszczalnie z wagi, jaką Drucker przywiązuje do przełamania przez Marinettiego (wywodzonej od Mallarmégo) poetyki słowa umieszczonego (i mówiącego) w przestrzeni. Jej zdaniem dojrzała i właściwa postać słów na wolności w dużej mierze właśnie poprzez swój kształt typograficzny nie odsyła nas swoim obrazem do czegoś z zewnątrz, nie przywołuje mimetycznie rzeczywistości. Jej domeną jest zwrócenie uwagi na sam dyskurs (i kreowanie zeń nowej rzeczywistości), nie zwykła (choćby nawet i oparta na kilku tworzywach) reprezentacja. Jak pokazywałam, podobnie dzieje się w poezji konkretnej (która tworzy światy, a nie je odtwarza). 
tytułowi) - wolnymi ${ }^{624}$. Rysunkowe zarysy szczytów dublują określone w tytule miejsce akcji (Mont Altissimo), zaś rozmieszczenie słów w przestrzeni w pełni odpowiada określonym konkretnymi liczbami wysokościom (3000 m, 2500 m, 2070 m, 1800 m, 1200 m, 1190 m, 800 m, 50 m, 30 m). Graficzne wyróżnienie tych ostatnich jeszcze bardziej uwidacznia ową zależność: określenie wysokości staje się rodzajem tytułu dla następującego po nim fragmentu (a samą ilość wyróżnionych w ten sposób poziomów również możemy wyczytać z tytułu utworu). Nawet do odgadnięcia usytuowania jeziora nie jest nam w rzeczywistości wcale potrzebne graficzne ukształtowanie tekstu czy jego zwizualizowanie. Wydaje się bowiem, iż bardziej komunikatywny niż symboliczna kreska sugerująca taflę wody jest znajdujący się tuż pod nią (i obok określenia wysokości) napis „Lac de Garde” (franc. jezioro Garda), określajacy miejsce akcji.

W efekcie, pozbawiony graficznego ukształtowania tekst nie straciłby nic ze swych znaczeń - nadal dałby się czytać jako linearnie prowadzona narracja opisująca kolejne przestrzenie. Szczególnie, że jedyny wers zapisany inaczej niż poziomo - „10 heures rayon solaire tube de calorifère descendre dans les artères artères gelées de la montagne" ${ }^{625}$ - ewidentnie wiąże się z treścią fragmentu, przy którym się zaczyna, zaś jego skośna wędrówka przez kartę dubluje jedynie - wyrażoną słowami - trasę ruchu. Trudno tu też mówić o odchodzeniu od usankcjonowanych tradycją zestawień, o „wyobraźni bez drutów" - wpisanie w diagram wymusza wręcz konkretne artystyczne posunięcia czy obrazy, zniewalając i ograniczając wyobraźnię poety (a - w konsekwencji - także i odbiorcy) zamiast ją oswobadzać.

Choć więc Bataille à neuf étages jest często przywoływane, by ilustrować hasła słów na wolności, nie najlepszy to raczej przykład. Co więcej, ze względu na swoją semantycznie pustą tautologiczność, nie jest też utworem liberackim. Jednak fakt ten nie przekreśla też badanej bliskości charakteryzowanych w tym rozdziale nurtów ${ }^{626}$.

${ }^{624}$ Jakkolwiek nie wszystkie publikacje utworu mają w tytule dodatek Mots en liberté - reprodukowana przez Drucker edycja rzymska z 1916 r. zawiera to sformułowanie, powielona przez Bartrama edycja z 1919 r. (Milano) już nie. Nie ma go również w wersji publikowanej w Les mots en liberté futuristes.

${ }^{625} \mathrm{~W}$ literalnym tłumaczeniu z francuskiego: „10 godzin promień słoneczny przewód ciepłonośny schodzić z tętnic tętnic zlodowaciałych góry”.

${ }^{626}$ Szukając analogicznych tautologii wśród innych przywoływanych w tym rozdziale kontekstów, można przypomnieć publikowany na łamach „Zwrotnicy” wiersz Bruna Jasieńskiego Morze, w którym ukształtowaniu poszczególnych wersów w falujące linie trudno przypisać inne funkcje niż wizualne podkreślenie głównego bohatera utworu - fal na tytułowym morzu (Bruno Jasieński, Morze, „Zwrotnica” 1923, nr 4, s. 114). Z drugiej strony odnieść można się do opracowanego przez Strzemińskiego wiersza Wóz Przybosia, w którym typograf zdublował frazę „oddechy: konie parowe/ zamiast słów użyję wozu" takim graficznym ukształtowaniem tekstu, że wóz rzeczywiście jawi się oczom czytelnika. Beata Śniecikowska odczytuje przywołane opracowanie jako nawiązanie do poezji wizualnej i zwraca uwagę na uatrakcyjnienie odbioru czytelniczego będące zasługą Strzemińskiego (B. Śniecikowska, Stowo-obraz-dźwięk..., s. 254). Z mojej perspektywy uwypuklenia wymaga jednak fakt, iż jest to wyłącznie tautologiczne podkreślenie sensów wyraźnie w tekście poetyckim wyartykułowanych, dodane - jak zaznaczałam we fragmencie poświęconym kwestii druku funkcjonalnego - post factum przez interpretatora. Sam autor wiersza użył tu słowa, nie znaku ikonicznego. 


\subsection{Ku nowym - liberackim i futurystycznym - sposobom komunikacji}

Wrócę zatem do innych utworów Marinettiego, do przykładów, które pozwolą tę bliskość unaocznić. Nie tak trudno znaleźć w dorobku tego przedstawiciela włoskiego futuryzmu teksty, które - sięgając po środki wizualne - nie popadaja w schematy i znacznie przekraczają nie tylko zasady i konwencje, lecz i spotykane sposoby ich łamania. W Zang Tumb Tumb chaos czcionek, ich pęd na stronie, czy też typograficzne pokawałkowanie słów, ma odzwierciedlać właściwy temat utworu, oddawać charakter walk. Materiał słowny ma być jak to ujmuje Drucker - zmanipulowany tak, by stać się „imitacją dźwięków i obrazów zadymionego cierpiącego królestwa militarnej bitwy" ${ }^{627}$. W przypadku większości utworów zebranych w tym tomie kształt słów i stron zdecydowanie nie był projektowany w celu kreowania tautologicznych w stosunku do treści obrazów, lecz po to, by ową treść uzupełniać.

Pójdźmy zatem tropem takich właśnie tekstów, by zastanowić się, na ile bliskie są one liberaturze. Mając w pamięci tablicę synoptyczną Bataille à neuf étages, dobrze zestawić ją choćby z pochodzacym z tomu Zang Tumb Tumb innym, pozornie bardzo podobnym utworem w tej samej formie - z Carta sincrona (Mapa synchroniczna, zob. ilustracja 25$)^{628}$. Tekst obrazuje nam to, co widzi pilot po prawej i lewej stronie lecacego w dół samolotu. Kierunek ruchu oznaczony jest pionową strzałą biegnąca z góry karty, obok której zapisane są wysokości, na jakich pojazd się znajduje. Nie możemy jednak tak łatwo postawić w stosunku do tego utworu tych samych zarzutów, co wobec Bataille à neuf étages. W przypadku Carta sincrona poziom (miejsce) zapisanych słów nie odpowiada wyraźnie określonym liczbami wysokościom - relacja ta jest bardziej symbolicznie wizualna niż typowo diagramatyczna. Istotniejsze wydaje się zaznaczenie kierunku zmiany (a być może i jej tempa) niż dokładne przyporządkowanie poszczególnych fragmentów wypowiedzi do określających położenie liczb.

Co więcej - poszczególne urywki zapisane są czcionkami o różnych wielkościach, co pozostaje nie bez znaczenia dla interpretacji ${ }^{629}$. Istotą tego utworu nie jest bowiem jedynie wskazanie zdarzeń paralelnych, ukazanie symultaniczności zjawisk, lecz również zobrazowanie natężenia dźwięków dochodzących do podmiotu. Im bliżej ich źródła znajduje się samolot, tym większe są

627 J. Drucker, s. 131.

${ }^{628}$ Filippo T. Marinetti, Carta sincrona dei suoni rumori colori immagini odori speranze voleri energie nostalgie tracciata dell' aviatore Y. M., [w:] idem, Zang tumb tumb, Milano 1914, wkładka publikowana między stronami 65 a 67; reprodukcję pracy podaje w swojej książce Webster (strony nienumerowane, il. 4), w nieco gorszej jakości można ją również znaleźć w pracy J. Heisteina, Wprowadzenie do literaturoznawstwa porównawczego..., s. 103.

${ }^{629} \mathrm{Z}$ kolei w Bataille à neuf étages rozmiary czcionek pomiędzy poszczególnymi dziewięcioma poziomami akcji nie były w ogóle różnicowane, tak jakby pragmatyczna czytelność diagramu była najważniejsza. 
litery słów je opisujących ${ }^{630}$. Nie jedyny to też poziom tekstu, na którym Marinetti wiąże obraz z dźwiękiem. Analogia ta kieruje niejednokrotnie również zestawieniami słów, metaforami (?) tworzonymi i zapisanymi zgodnie z zasadami słów na wolności, np.: „hałas w kształcie gruszki = obozowisko” (rumore en forma di pera = accampaniamento) $\mathrm{czy}, 5$ gwiazd posrebrzanych hałasem $=$ 5 szrapneli" ( 5 stelle argentate di rumori $=5$ shrapnels $)^{631}$.

Jak widać, zarówno ukształtowanie przestrzenne, jak i rodzaj użytych elementów graficznych, czy rozmiary poszczególnych liter nie są tu zwykłą konsekwencją schematu wizualnego imitujacego rzeczywistość (widzianą z dwóch stron lecacego samolotu). Zaangażowanie typografii utworu do kreowania znaczeń (wzmagania ekspresji słowa - jak mówił Marinetti) idzie tu o krok dalej, współgra też (rodzajem użytych zestawień) ze sposobem budowania poetyckich obrazów. Utwór ten wydaje się doskonale ukazywać wielopoziomowość teorii „papieża włoskiego futuryzmu”. Zarówno oswobadzanie słów z więzów tradycyjnej składni, jak i troska o ich typograficzny kształt sa tu elementem kompleksowej wizji języka sztuki słowa. W pełni wybrzmiewają dopiero odczytane nie jako „eksperymentalne dodatki”, „futurystyczne wybryki”, lecz jako integralne części utworu, w którym już brzmienie tytułu eksponuje nastawienie na symultaniczność odbioru bodźców oraz synestezyjność. Stąd - być może wbrew pierwszym wrażeniom - nie mamy tu wcale do czynienia $\mathrm{z}$ realizacja jakiegoś wizualnego schematu, diagramu. Warto przypomnieć, że i Józef Heistein, choć uznawał Zang tumb tumb za nieczytelne, podkreślał, że utwory składające się na tom pokazuja, jak spójnie łączą się postulaty Marinettiego związane z konstrukcja stylistyczno-składniową tekstu z tymi odnoszonymi do jego typografii:

Porzucenie zasad składni, korzystanie ze związków słów rozproszonych, bez łączników w postaci tradycyjnych części zdania: orzeczeń, dopełnień, bez interpunkcji itp. miało u futurystów włoskich określony cel: nadanie utworom rytmu maszyn, świata puszczonego w ruch przez technikę, ukazanie deformacji obrazu dzięki szybkiej zmianie punktu obserwacji przedmiotu (np. [w carta sincrona - AP] z samolotu poruszającego się z szybkością $200 \mathrm{~km} / g o d z$. sic!), a także odzwierciedlenie szybkości zmian i symultaniczności zdarzeń i ich percepcji ${ }^{632}$.

Trzeba przyznać, że w twórczości Marinettiego (podobnie jak i w liberaturze) zdarzały się fragmenty nawiązujace swym wyglądem do konwencji poezji wizualnej, wierszy-obrazów ${ }^{633}$. Sam artysta nazywał je auto-ilustracjami ${ }^{634}$,

${ }_{630}$ Zob. M. Webster, The Avant-Garde Poem: Marinetti, s. 30-31.

${ }^{631}$ Dla tego obrazu istotne jest też, jakiego rodzaju pociskiem jest szrapnel. W Stowniku wyrazów obcych PWN (oprac. Lidia Wiśniakowska, Warszawa 2004) czytamy o nim: ,pocisk artyleryjski wypełniony kulkami, zaopatrzony w ładunek wybuchowy i zapalnik czasowy, dzięki któremu rozpryskuje się w dowolnym miejscu na torze swego lotu” (s. 912). Porównanie do gwiazd wiąże się zapewne bardziej ze sposobem wybuchu tego pocisku niż z jego wyglądem, szczególnie, iż to, co widzi lotnik to zapewne właśnie wybuchy, mieniące się niczym gwiazdy albo sztuczne ognie.

632 J. Heistein, Wprowadzenie do literaturoznawstwa porównawczego..., s. 124.

${ }^{633}$ W liberaturze do konwencji tej nawiązuje m.in. cały kształt typograficzny Ulicy Sienkiewicza $w$ Kielcach Nowakowskiego czy poematy-znaki oraz teksty-znaki w Oka-leczeniu Fajfera i Bazarnik.

${ }_{634}$ M. Webster, The Avant-Garde Poem: Marinetti, s. 32. 
podkreślając ich tautologiczność i samozwrotność. Jednak nie były to w większości przypadków użycia tak ograniczające, jak w analizowanym wcześniej Bataille à neuf étages. Najczęściej ich (nieraz pozorna) wizualna prostota była w utworze (w niebanalny już sposób) sfunkcjonalizowana, a obraz stawał się czymś więcej niż ilustracją. Podobnie wprzęgnięty w semiozę tekstu jest on w liberaturze, czego najlepszym dowodem Oka-leczenie $e^{635}$.
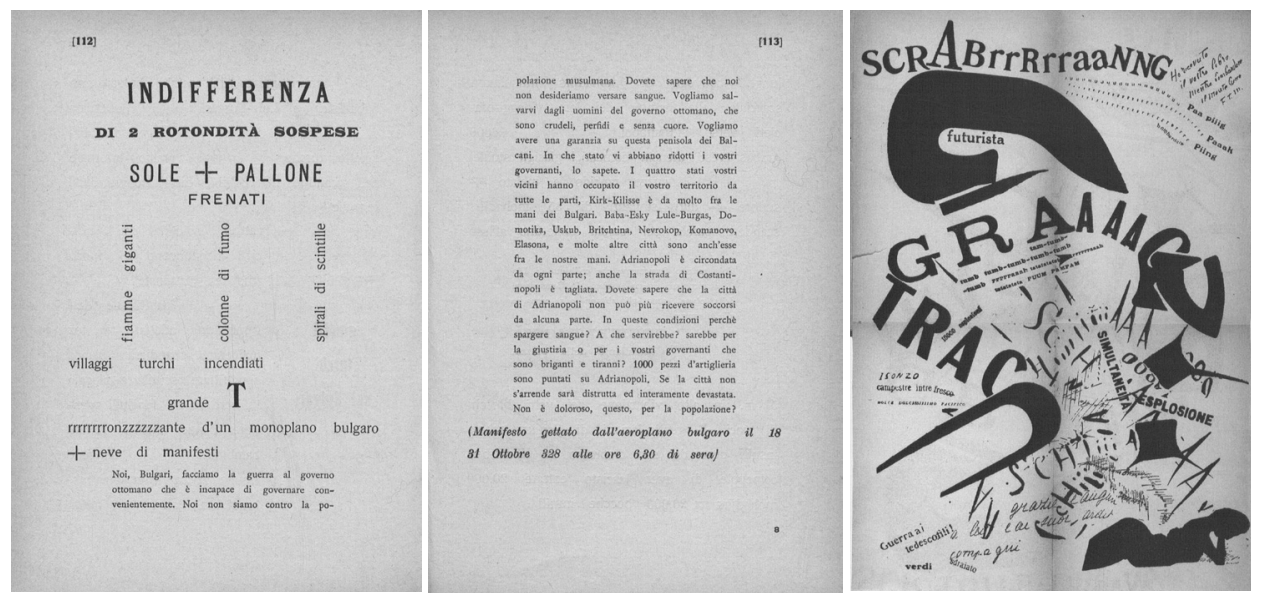

Ilustracja 26. Od lewej - Filippo T. Marinettiego Indiferenza (źródło: Filippo T. Marinetti, Zang, tumb, tumb, Milano 1914, s. 112-113) oraz Le soir, couchée dans son lit, elle relisait la lettre de son artilleur au front (źródło: Alan Bartram, Futurist Typography and the Liberated Text, London 2005, s. 30)

Zabiegi takie bardzo dobrze widać również na przykładzie innego jeszcze (także często przywoływanego jako przykład słów na wolności) tekstu Marinettiego: Indifferenza (Obojętność, zob. ilustracja 26) ${ }^{636}$. Jeżeli spojrzeć na pierwszą część utworu, rzeczywiście, dostrzeżemy pewną ikoniczność. U góry strony: unoszace się (w bezruchu) ponad płonącą turecką wioską dwie „okrągłości" (rotonditá) - słońce i balon (zapisane zgodnie z zasadami słów na wolności jako „sole + pallone”); poniżej - zapisane pionowo, co podkreśla kierunek ruchu - „gigantyczne płomienie” (fiamme giganti), „kolumny dymu” (colonne di fumo) i „spirale iskier” (spirali de scintille) unoszące się z obszaru pożaru; pod nimi - wyznaczające źródło dymu „płonace wioski tureckie” (villaggi turchi incendiati, tym razem słowa, zgodnie z rzeczywistym przestrzennym usytuowaniem wiosek, zapisane są horyzontalnie).

Różnica między tym fragmentem a przywoływanym wcześniej Bataille à neuf étages nie polega jednak ani na większej różnorodności typów i rozmiarów czcionek czy zróżnicowaniu kierunków zapisu, ani też na próbie mimetycznego

${ }^{635}$ Zob. przypis $66 \mathrm{w}$ rozdziale Liberatura i poezja wizualna.

${ }^{636}$ F. T. Marinetti, Zang tumb tumb, Milano 1914, s. 112-113. Pracę tę reprodukują (niestety - pomijając jej istotny fragment, istotny dla mojej interpretacji) również Webster oraz Drucker. 
oddania kształtu rzeczywistości bez nawiązywania do żadnego gotowego schematu, diagramu ${ }^{637}$. Poniżej frazy „wioski tureckie płonące” następuje dalszy ciąg utworu. Czytamy w nim o „wielkim T” (obrazującym nadlatujący samolot), z którego rozrzucane są ulotki z manifestem (stąd też - spleciona z samolotem znakiem „+” - metafora „śnieg manifestów”: neve di manifesti) i - jeśli przyjać sugerowaną logikę mimetycznego wizualnego odbicia rzeczywistości w przestrzennym układzie tekstu na karcie - musielibyśmy założyć, że samolot wylatuje spod wioski, a śnieg pada w górę. A (nawet w futurystycznym świecie) raczej tak nie jest.

Trzeba zauważyć, że Marinetti nakłada kolejna płaszczyznę przestrzenną na tę już w wierszu wykreowana. Wykracza poza zwykłą ikoniczność, zestawiając ze sobą fragmenty utworu operujące mimetycznością wizualna, lecz niedające się zgodnie z sugerowanymi przez nią zasadami połączyć w logiczna całość. A jak odnieść jedne do drugich? Sądzę, że w przypadku tego tekstu również mamy do czynienia z opisem zjawisk symultanicznych, a sekwencyjne ich następowanie jest tylko ułuda, jaką owocują nasze przyzwyczajenia czytelnicze (przekładane i na lekturę tekstów wizualnych). Paralelnie występujące w rzeczywistości obrazy połączone są u Marinettiego uwolnioną wizualna syntaksa ${ }^{638}$. Także słowa zwizualizowane to u ojca futuryzmu słowa na wolności. Pojawiający się w utworze samolot przynależy przecież do tej samej przestrzeni co słońce czy balon. Co więcej - w przeciwieństwie do owych „zatrzymanych" (frenati), statycznych obiektów - jest też elementem dynamicznym, który przecina prostopadle płaszczyznę pierwszego obrazu. „Umieszczony” na dole strony ma szanse przelecieć przez nią (co tożsame będzie z przelotem nad płonaccymi wioskami).

Jeżeli odczytamy śnieg manifestów jako ulotki rozrzucane z samolotu, przedrukowany na koniec utworu tekst tegoż manifestu (,ciagnący się” za symbolizującym samolot - wyróżnionym „T") wyda się logicznym wizualnym ucieleśnieniem tych wysypujących się z przemieszczającego się pojazdu druków. Śledząc analogie futurystyczno-liberackie, muszę też podkreślić tu wage umieszczenia całej treści manifestu (wyróżniającego się na tle innych fragmentów utworu czcionka), uczynienia zeń materialnego tekstu w innym tekście. Nie: opisywanie, lecz właśnie rzeczywiste umieszczanie przywoływanych przedmiotów w utworze to iście liberacki zabieg, którego przykłady znajdziemy i w książkach bez wątpliwości zaliczanych do literatury totalnej, jak i tych

${ }^{637} \mathrm{Na}$ marginesie warto też zaznaczyć, że i takie korzystanie z gotowych wzorów i opieranie na nich konstrukcji utworu nie musi prowadzić do tautologii. Jedna z wydanych w serii Liberatura powieści - Prospekt emisyjny Krzysztofa Bartnickiego (Kraków 2010) - wykorzystuje formę (właśnie wizualna) tytułowego prospektu (rodzaj druku giełdowego). W tym wypadku zabieg ten nie tylko nie prowadzi do tautologii, lecz zastosowany kształt tomu jest też ścí́le podyktowany fabułą utworu i w jego obrębie sfunkcjonalizowany.

${ }^{638}$ Michael Webster podkreśla, że Marinetti w latach czterdziestych (w manifeście La tecnica della nova poesia z 1937 r.) rozróżniał już tablice słów na wolności (tavole parolibre) od samych słów na wolności. Wydaje się, że opisywane tu zabiegi charakterystyczne są raczej dla pierwszych z wyróżnionych. Zob. M. Webster, The Avant-Garde Poem: Marinetti. 
bardziej klasycznych, które - stanowiąc kanon sztuki słowa - mają również i swoje liberackie aspekty ${ }^{639}$.

Jak widać - wszelkie zabiegi typograficzne czy wizualizacje tekstu, jakie zostały tu zastosowane, nie sa wobec niego wtórne, i (co zawsze w takiej sytuacji jest najprostszym sprawdzianem wagi obrazowego ukształtowania) utwór zapisany inaczej (klasycznie, linearnie) straciłby przynajmniej część ze swych znaczeń. Wykorzystane nowe środki ekspresji - zgodnie z zamiarem Marinettiego - służą w tym wypadku wzmocnieniu siły słowa. Dążenie do ich poszukiwania i projektowanie utworów je angażujących łączy zaś futuryzm z liberatura.

By zobaczyć, jak najpełniej realizują się postulaty Marinettiego, warto przywołać też doceniany przez wielu badaczy utwór Le soir, couchée dans son lit, elle relisait la lettre de son artilleur au front (W nocy, leżac $w$ tóżku czyta list od swojego strzelca będacego na froncie, zob. ilustracja 26) z 1917 r. Zdaniem Drucker to jeden z przykładów dzieł artysty, w których słowa staja się rzeczywiście w pełni (a nie wyłącznie przypadkowo) wizualne. Odwołujacc się do przywoływanych już spostrzeżeń Bartrama, można by dodać, że mamy w nim też do czynienia z nowym sposobem komunikacji, poszukiwanym przez futurystów (ale - przy zastrzeżeniu, że jest to komunikacja literacka - również i liberatów).

Rzeczywiście, słowa tego tekstu znaczą na kilka różnych sposobów i na rozmaitych poziomach. Przede wszystkim: te z tytułu - w sposób najbardziej tradycyjny, konwencjonalny określają bohaterów, których dotyczą wydarzenia, na których koncentruje się utwór (kobieta czytająca list oraz artylerzysta, który go napisał), a także czas (wieczór) i miejsce akcji (sypialnia kobiety). Wymienione elementy w połaczeniu z wizualnym znakiem bohaterki (czarny zarys postaci w prawym dolnym rogu karty) pozwalają nam zrekonstruować ramę wydarzeń.

Część z pozostałych słów pochodzi ze wspomnianego w tytule listu i - dzięki formie zapisu - daje się podwójnie interpretować. Z jednej strony znacza one jako konkretne fragmenty korespondencji, z drugiej: pojedyncze litery, kawałki bądź ciagi słów i oryginalnie zapisane onomatopeje są rozmieszczone na stronie w taki sposób, by przyciagały wzrok - by je nie tylko czytać, ale i widzieć, postrzegać, oglądać. W konsekwencji podglądamy je też tak, jak podglądamy (jako widzowie-czytelnicy-podglądacze) bohaterkę usytuowana przed naszymi oczami niczym na filmowym ekranie ${ }^{640}$.

${ }^{639} \mathrm{~W}$ tomiku poetyckim Andrzeja Bednarczyka Światynia kamienia znajdziemy prawdziwy kamień, w Muzie z zaścianka Honoriusza Balzaka - strony odnalezionej przez bohaterów powieści, a Umberto Eco (w Tajemniczym płomieniu królowej Loany) uczyni fragmentem swojej narracji różnego rodzaju elementy wizualne (podobnie „reprodukował” odnajdowane znaki Thomas Pynchon w 49 idzie pod młotek). Tego typu zabiegi często spotykane są również we współczesnej literaturze popularnej - zob. np. Mark Haddon, Dziwny przypadek psa nocna porq.

${ }^{640}$ Interpretację w duchu voyeryzmu sugeruje Drucker. Por. Laura Mulvey, Przyjemność wzrokowa a kino narracyjne, [w:] Panorama wspótczesnej myśli filmowej, tłum. Jolanta Mach, red. Alicja Helman, Kraków 1992. 
Jednocześnie, w słowach utworu odbijają się doświadczenia strzelca, autora tekstu w tekście: chaos, niemożność odnalezienia sensu i porządku, ciagłe wybijanie z rytmu, natłok wrażeń. Jego doznania przekładają się w tym wypadku jednak nie tylko na klasycznie rozumianą treść utworu (trudno byłoby zreszta takową wskazać), ale właśnie na sposób jej zapisu. Nie czytamy w liście o wybuchach na froncie, lecz widzimy eksplozję liter, fajerwerki i wystrzały słów. Michael Webster dopatruje się w tej pracy wręcz takiego graficznego zakomponowania niektórych wyrazów, by ich poszczególne litery przypomniały odłamki ${ }^{641}$. Podkreśla tė̇, że w miejscu największego nagromadzenia „obrazkowych” wybuchów znajdziemy też słowo „eksplozja” (esplosione), co ważne dla mniej przyzwyczajonego do odbioru ,aż” tak wizualnej sztuki słowa czytelnika ${ }^{642}$.

Zatem, w obrębie jednego komunikatu uruchomionych zostało tu kilka różnych kanałów przekazu informacji, sposobów reprezentacji i oznaczania. Co więcej, są one zespolone ze sobą tak silnie, iż w istocie stają się nierozdzielne, a sens przekazu budowany jest w oparciu o nie wszystkie. Nie da się go odczytać, ignorując jeden z aspektów, wyłącznie czytając bądź wyłącznie oglądając. Jeżeli Marinetti poszukiwał sposobu pogłębienia ekspresji słowa, jeśli pragnął słów bijaccych w czytelnika niczym torpedy - tu właśnie zdołał wszystko to osiagnacc. Utwór „zrobiony jest” ze słów, które opowiadają całym swoim jestestwem, choć nie zawsze dają się... przeczytać.

Nie trzeba szukać daleko liberackiego przykładu, w którym będziemy mieć do czynienia z analogicznym wykpieniem (dawno już przecież skrytykowanych) tez Lessinga ${ }^{64}$, z nowym sposobem budowania literackiego komunikatu. Odbiorcy przywoływanej już kilkakrotnie Ulicy Sienkiewicza w Kielcach Nowakowskiego ${ }^{644}$ towarzyszy identyczna niemożność oddzielenia tego, co się czyta,

${ }^{641}$ Zob. M. Webster, The Avant-Garde Poem: Marinetti, s. 34.

${ }^{642}$ Webster $\mathrm{w}$ swoich analizach wskazuje też na większą niż się pierwotnie wydaje ilość aktualizowanych jako miejsca akcji przestrzeni (ja sygnalizowałam wyłącznie jedną: pokój bohaterki). Ku takiej konstatacji prowadzi go (przekonująca) analiza wplecionych w tekst fragmentów pisanych odręcznym pismem. Zdaniem badacza znajdujący się w prawym górnym rogu karty skrawek tekstu to list od artylerzysty, zaś ten usytuowany na dole strony (w którym przekazywane są pozdrowienia dla towarzyszy) Webster odczytuje jako odpowiedź kobiety - co pozwala mu wyznaczyć również drugi plan akcji: miejsce, w którym ten list jest odczytywany (front). Zob. M. Webster, The Avant-Garde Poem: Marinetti, s. 35.

${ }^{643}$ Dla przyjętej przeze mnie perspektywy istotne sa związane z tym tematem uwagi Seweryny Wysłouch ze szkicu Ut pictura poesis - stara formuta i nowe problemy ([w:] Ut pictura poesis, ed. Marek Skwara, Seweryna Wysłouch, Gdańsk 2006). Przypomnę, że przywołana badaczka nie tylko pokazuje, jak w XX i XXI w. powracał Horacjański sposób myślenia o sztuce, lecz i wskazuje na elementy kultury współczesnej (m.in. nowe media) oraz zmiany w refleksji humanistycznej owocujące próbą znalezienia nowych sposobów mówienia o nowej sztuce. Konsekwencją tychże poszukiwań jest właśnie odwrót od nurtu Lessingowskiego. Por. też m.in. Gotthold E. Lessing, Laokoon, czyli o granicach malarstwa i poezji, tłum. Henryk Zymon-Dębicki, [w:] idem, Dzieła wybrane, t. III, Warszawa 1959; Seweryna Wysłouch, Rewolucja Lessingowska, [w:] eadem, Literatura a sztuki wizualne, Warszawa 1994; Henryk Markiewicz, Obrazowość a ikoniczność literatury, [w:] idem, Wymiary dzieła literackiego, Kraków 1984.

${ }^{644}$ R. Nowakowski, Ulica Sienkiewicza w Kielcach, Kielce 2003. Trzeba dodać, iż utwór ten zrealizowany jest też nieco odmienną techniką - w przeciwieństwie do tekstu Marinettiego znajdziemy w nim barwne czcionki; jednocześnie nie mamy w nim do czynienia z techniką kolażowa (charakterystyczną dla Le soir... oraz innych wierszy plakatowych). 
od tego, jak owo coś jest zapisane. I w tym utworze, do pełnego zrozumienia sytuacji bohatera, który kroczy deptakiem w Kielcach, potrzebne jest nie tylko (nie wyłącznie) wczytanie się w słowa jego monologu, lecz i w to, jak są one zapisane. Ten, kto będzie próbował zaniechać ową drugą czytelniczą (!) powinność, nie otrzyma wszelkich potrzebnych do rekonstrukcji wydarzeń informacji.

U Nowakowskiego - przypomnę - kierunek tekstu wyznacza tor ruchu bohatera (a w konsekwencji bez śledzenia kierunku zapisu i miejsca słów w przestrzeni książki - bo trudno w wypadku tego dziesięcioipółmetrowego tekstu mówić o stronicy - nie zrozumiemy, do czego odnoszą się liczne zaimki wskazujące). Kształt czcionki może nam zaś wyjaśnić, w jakim tempie bohater się przemieszcza: kiedy biegnie, słowa zdają się biec wraz z nim - litery sa rozciagnięte i jakby napisane w pośpiechu, kiedy gwałtownie zwalnia - znaki „wpadają na siebie”. Gdy spacerujący zatrzymuje się, jego myśli układaja się w kaligram cienia budynku, przed którym stanął, na poziomie werbalnym wskazując na treść jego przemyśleń, na poziomie wizualnym - na ich czasoprzestrzenny kontekst. Nie trzeba już chyba dodawać, jak kolorystyka tekstu dopełnia tu informacji o świecie zewnętrznym itp. (zob. ilustracja 1$)^{645}$.

Podsumowujacc, w przywołanych tu utworach znacznie przekroczono tradycję literackiego drukarstwa, sięgając po środki, których nie przekreślił Gutenberg (choć może nie wszystkie były dlań osiagalne), a które z pola typografii literackiej wyrugowało nasze czytelnicze przyzwyczajenie, konwencja, ustalone schematy. W tekstach tych materialność samego zapisu jest semantycznie wykorzystana i nie tylko uzupełnia treść przekazu, lecz - jak powiedzieliby liberaci - tworzy go w równym stopniu, co warstwa werbalna. Zarówno do dzieł literatury totalnej, jak i do sprawnie realizujacych hasła słów na wolności i nowej typografii utworów futurystycznych możemy odnieść zdania, którymi Drucker podsumowuje swoje rozważania o Marinettim:

Znaczenie słów rodzi się w równym stopniu z ich pozycji, relacji (jako elementów wizualnych) z innymi takimi elementami oraz ich ruchu jako serii znaków przebiegajacych przez stronę, jak i z wartości semantycznej. Ich zróżnicowane lingwistyczne działanie nie może być izolowane od ich fenomenologicznej obecności na stronie: jedno i drugie jest na usługach produkcji znaczeńn ${ }^{646}$.

${ }^{645}$ Przywoławszy Ulicę Sienkiewicza $w$ Kielcach, powinnam też przypomnieć tu jeszcze jednego włoskiego futurystę - Alda Palazzeschiego i jego Przechadzkę (La passeggiata). Utwór ten zaczynają słowa propozycji przechadzki („Może pójdziemy?/Owszem, chodźmy”), kończy zaś sugestia jej zakończenia (,Może wrócimy?/Owszem, wracajmy”), zaś całą zasadniczą jego część stanowa spisane napisy z wszelkich szyldów widocznych na ścianach budynków, koło których przechodzili bohaterowie. Palazzeschi niespecjalnie eksperymentuje tu z typografia - napisy z szyldów nie sa zróżnicowane graficznie, jedynie ich ciag ujęty jest w znak cudzysłowu (por. Alda Palazzeschi, $L a$ paseggiata, [w:] idem, Poesie 1904-1914, Firenze 1925), niemniej przyświeca mu podobna idea, co Nowakowskiemu. Żadna z edycji utworu, które udało mi się zweryfikować nie była bardziej urozmaicona typograficznie. Nie znalazłam też w literaturze przedmiotu informacji sugerujących, by było inaczej. Polskie tłumaczenie (za którym też podaję cytaty) dostępne jest w tomie: Chora fontanna (wiersze futurystów włoskich), przekład i esej wstępny Jalu Kurek, Kraków 1977.

${ }^{646}$ J. Drucker, s. 137. Dalej badaczka doda: „Są wizualnymi obrazami języka, których pełna wartość rodzi się z aspektów ich reprezentacji o naturze graficznej: formy, pozycji, odpowiedniego 
W ujęciu Marinettiego, a także według liberatów, potencja semantyczna komunikatu może być pogłębiona na drodze eksploracji wszelkich warstw jego znaków. Znaczace staje się tu (na wiele sposobów) równie ważne, jak znaczone. Artysta zaś zyskuje nowy obszar wyborów, wahań i (słusznych bądź nie) decyzji do podejmowania. Jeśli sama forma słów (a nie tylko ich wybór i sposób - czysto lingwistycznego, gramatyczno-stylistycznego powiązania) może znaczyć, przed autorem pojawia się nowa przestrzeń, w której musi się zacząć poruszać i dokonywać świadomych wyborów. Jej odrzucenie jest postrzegane negatywnie zarówno przez futurystów, jak i liberatów. Pierwsi, widzą w nim bezwolne skłanianie się ku starej, nic już niewartej tradycji (przeciw której na każdym poziomie się buntuja), ci drudzy w dotychczasowej „normie” widza lenistwo i umywanie rąk od odpowiedzialności ${ }^{647}$. Dla pierwszych - dotychczasowe formy literackie nie nadają się już do opisu świata, dla drugich zaś - poszukiwanie kształtu książki najlepiej współgrającego z jej sensami jest jedna z głównych powinności literata.

kierunku i orientacji na stronie itd. Pokazują dramatyczną oczywistość, że język może istnieć $\mathrm{w}$ formie wizualnej i że ową wizualną postacią języka można manipulować poprzez znaczace. To nie oznaczane jest tym, co determinuje formę wizualną; raczej to znaczenie jest osiagane poprzez sposób ekspresji, który czyni je dostępnym, istniejącym. Typograficzne, wizualne oddanie języka jest tym, co - w tym wypadku - odpowiada definicji znaczqcego jako "namacalnej części znaku»" (ibidem, s. 139). Drucker tłumaczy tė̇, że znaczenie osiagane jest tu na drodze rozszerzania semantyki znaczonego poprzez to, co wnosi znaczace (ibidem).

${ }_{647}$ Warto jednak pamiętać, że naprawdę i przed Fajferem wielu było takich, którzy o medialności swoich tekstów myśleli, wśród nich i John Barth, piszący w Nocie autora do Zagubionego w labiryncie śmiechu (tłum. Monika Adamczyk-Garbowska, Warszawa 1991) niczym futurysta i liberat zarazem: „podczas gdy niektóre z tych opowiadań powstały specjalnie z myśla o druku, z innymi tak nie było. Imie jego Ambroży i List wyłowiony z morza, napisane najwcześniej, traktują przekaz drukarski jako rzecz oczywista, ale nie tracą też nic ani nie zyskują przy recytacji. Z kolei Petycja, Zagubiony w labiryncie śmiechu, Życio-opowieść i Anonimiada straciłyby częściowo sens w formie innej niż drukowana; Podróż po nocnym morzu została pomyślana albo dla druku, albo dla nagranego głosu autora, nie zaś dla żywego czy nieautorskiego głosu; Glosolalalia nie mają sensu, jeśli nie są słuchane na żywo lub w nagraniu, w wykonaniu głosów męskich i żeńskich, lub też czytane w taki sposób, jak gdyby tak właśnie się ich słuchało; Echo jest przeznaczone dla monofonicznego autorskiego nagrania na płycie lub taśmie; Autobiografia dla monofonicznej taśmy i widzialnego, ale milczącego autora. Menelajada, choć przypomina nagrany monolog autorski, to jednak dla jasności wymaga oka czytelnika i można powiedzieć, że została napisana dla "drukowanego głosu». Tytuł zyskuje odmienne, ale równie istotne znaczenia w różnych środkach przekazu: druku, monofonicznie nagranym głosie autorskim, takimż stereofonicznym w dialogu z samym soba, głosie autorskim na żywo, takimż na żywo w dialogu w takimż monofonicznym wyżej wspomnianym oraz takimż na żywo rozmawiającym ze stereofonicznym itd., osobiście przeze mnie preferowanym: «wykonywano» go we wszystkich wariantach. Opowieść ramowa jest jedno-, dwu- lub trójwymiarowa, w zależności od tego, za co uzna się wstęgę Möbiusa” (s. 11-12). Owa medialna autocharakterystyka nie byłaby dla mnie tak istotna, gdyby w Siedmiu dodatkowych uwagach autora Barth (broniąc się przed zarzutem pretensjonalności, jaki postawiono przytoczonej Nocie) stwierdzał, że „idea przewodnia jest bezpretensjonalna i polega na przekształceniu możliwie wielu aspektów tej fikcji - struktury, narracyjnego punktu widzenia, środków prezentacji, w niektórych przypadkach procesu kompozycji i/lub recytacji, jak również czytania i słuchania - w istotne pod względem dramatycznym konkretne ujęcia tematu” (s. 13, podkreślenia moje). Aż dziw, że duet Zenkasi nie ogłosił jeszcze Bartha jednym z czołowych protoliberatów... 
Bliskość tekstów liberackich i futurystycznych, którą obrazowałam przeprowadzonymi analizami, jest konsekwencją łączącego twórców przynależnych do tych nurtów spojrzenia na literacką komunikację, sposób kształtowania wypowiedzi (na poziomie języka artystycznego oraz wykorzystywanego medium). Dlatego właśnie - jak podkreślałam, podsumowując część poświęconą porównaniu teoretycznych ujęć - mimo pozornie niewielkich zbieżności na poziomie refleksji o literaturze (i świecie), na poziomie artystycznych realizacji znajdziemy między liberatami a futurystami sporo analogii. A spotkamy je w tekstach operujaccych futurystyczną typografia - dlatego w samym już tytule rozdziału zaznaczałam, że interesuje mnie właśnie ona, nie zaś futuryzm jako taki. Bo to za jej pośrednictwem, zgodnie z wyrażonym przez Marinettiego pragnieniem zdwojenia mocy ekspresyjnej słowa, aktualizuje się jego dodatkowe przestrzenie, czyni książkę czy kartę, na której zapisany jest utwór, czymś więcej niż podkładką czy pojemnikiem na sens (treść) ${ }^{648}$.

\subsection{Zamiast zakończenia: liberacko-futurystyczne nic wcielone}

Choć zastrzegałam się, że nie pokuszę się o analizowanie związków polskiego futuryzmu z liberatura, na koniec chciałabym przewrotnie przywołać jednak jeden, nad wyraz krótki, utwór Bruna Jasieńskiego. Lapidarność wiersza, nad którym chciałabym się na chwilę zatrzymać, może być mylacca. Choć bezsprzecznie krótki - okazuje się jednak nie tak prosty w analizie. Dodam, że liberaturę i futuryzm (w rozmaitych jego eksplorujących typografię odmianach) łączy również częste stawianie wyzwań czytelnikom, prowokowanie ich do lektury niecodziennej, angażującej nieraz i inne zmysły niż te, do których używania jesteśmy przyzwyczajeni. W konsekwencji, krytycy literaccy postawieni przed takimi utworami nieraz nie wiedzą, czy odważyć się na lekturę, jaką dyktuje nam sam tekst, czy też lepiej może nie opuszczać z góry upatrzonej pozycji wprawionego w analizach znawcy, nie zbaczać z wytyczonych przez tradycję ścieżek interpretacyjnych.

${ }^{648}$ Powinnam też wytłumaczyć, czemu nie przywołałam w swoich rozważaniach późniejszych prac Marinettiego, szczególnie wierszy plakatowych (silnie przecież eksponujących wizualność i materialność tekstu, opartych na zabiegach zachęcających wręcz bardziej do patrzenia nań niczym na obrazy niż czytania). Liberacko nastawionego czytelnika owe słowno-wizualne kompozycje artysty rozczarowuja. Dla mnie istotny zaś jest nie sam fakt owego rozczarowania, lecz jego przyczyna, tłumacząca moją decyzję. Drucker, uznająca kolażowe Une Assemblée tumultueuse (ang. Tumultuous Assembly) Marinettiego za punkt dojścia jego słów na wolności, przyznaje, że przekroczone sa już w nich granice, poza które nie należało wychodzić. W tekstach tych, jak twierdzi, ,język jest już niemal bez znaczenia” (J. Drucker, s. 138), a zatem - co dla mnie istotne - prace te tracą już swój literacki charakter. Nie mówia, nie opisują (różnymi kanałami komunikacji), lecz wyłącznie przedstawiają. Nie mogą więc być ani w tym rozdziale (ani też w całym moim wywodzie) punktem odniesienia - jako twory nienależące do obszaru sztuki słowa, której liberatura (z definicji) jest częścią. 
Poczyniwszy te uwagi, pozwolę sobie przypomnieć 80. stronę tomu But $w$ butonierce Bruna Jasieńskiego (zob. ilustracja 27) ${ }^{649}$. Raz jeszcze przywołam tė̇ stwierdzenie Fajfera, iż liberackie słowa nie są o czymś, lecz same się tym czymś stają. Czemu znów to podkreślam? Otóż na wspomnianej stronie kwadratowego tomiku Jasieńskiego znajdziemy tytuł utworu: Nic. Po nim zaś następuje... nic innego tylko rzeczone „nic”, pusta, biała strona. A zatem - nic zmaterializowane, niczym słowa Oka-leczenia ${ }^{650}$, niczym konkretne słowo Dróżdża. O owymi „nic” między innymi tekstami pisał Balcerzan: „Sprawa jest w gruncie rzeczy poważna"651. Badacz ten próbował też - właśnie poważnie - ów utwór interpretować, doszukując się tu odniesień do ówczesnego systemu politycznego, do pozostawiajacych białe plamy na wierszach działań cenzury. Sam jednak stwierdzał zaraz: „I jednocześnie pomysł z «nicem» jest przecież niepoważny, czysto zabawowy. Trudno traktować serio postulat uznania tego rodzaju "niców» za "utwory» podległe nowym, faktycznym regułom gatunkowym!"'652

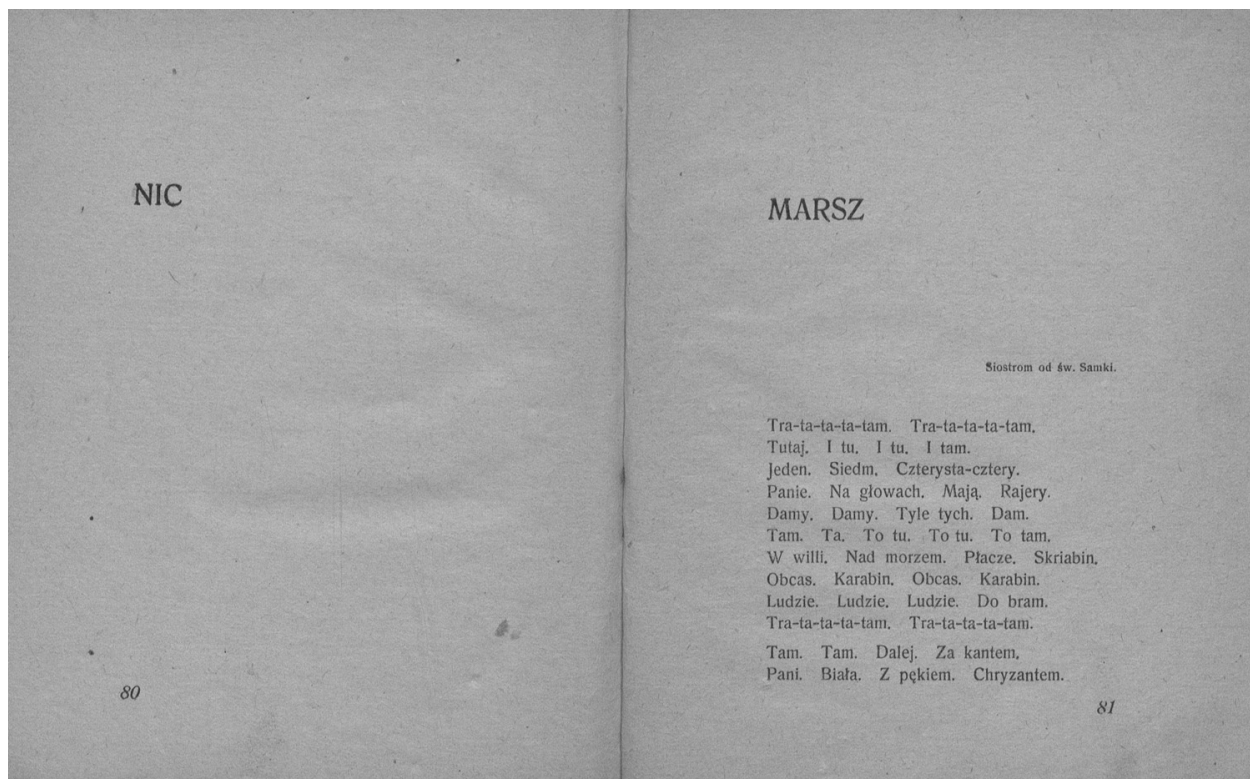

Ilustracja 27. Bruno Jasieński, But w butonierce, s. 80-81 (źródło: Bruno Jasieński, But w butonierce, Warszawa 1921, zdjęcia własne ze zbiorów CIMELIA Biblioteki Uniwersytetu Łódzkiego)

${ }^{649}$ Bruno Jasieński, But w butonierce. Stron dziewięćdziesiat sześć, Warszawa 1921, s. 80 .

${ }^{650}$ Zob. przypis $66 \mathrm{w}$ rozdziale Libertura i poezja wizualna.

${ }^{651}$ E. Balcerzan, Wstep, s. LXII.

${ }^{652}$ Ibidem, s. LXIII. 
Tu zaś rodzi się pytanie: ale dlaczego? Dlaczego mówienie nicością o nicości, brakiem o braku, nieobecnościa słowa o jego niebycie miałoby być niepoważne? Nie zamierzam tu dyskutować znów z liberacką kategoria gatunku i rodzaju, stąd pominę wątek odrębności genologicznej takich literackich tworów, niemniej, czemu nie potraktować tego utworu w pełni poważnie, dosłownie i z literackim zacięciem?

Szczególnie, że przywołany Balcerzan, w tym samym wstępie do wyboru wierszy, manifestów i szkiców Jasieńskiego (nota bene, samego Nic niezawierającego) podkreślał, jak istotna dla rozumienia poetyki futurystów jest kategoria materialności. Pisał i o tym, jak „kult materii [...] przechodził w kult materiału pracy twórczej" ${ }^{653}$, jak rozwijał się w owych majacych swą "wagę, barwę, dźwięk i miejsce w przestrzeni”654 futurystycznych słowach. Taka poezja - dodawał Balcerzan - „jest materialna”655. I Marinetti zwracał uwagę na fakt, że rzeczywistość, która miała być przedmiotem nowej sztuki to rzeczywistość materii, jej barw, dźwięków i przynależnej jej przestrzeni. Twierdził tė̇ przecież, że taką samą materią należało o tej rzeczywistości mówić. Pozostaje więc postawić pytanie: czymże mówić o „nicu”, jak nie... niczym? Być może więc, przywołany w dialogu z Balcerzanem wiersz Jasieńskiego jest jedną z lepszych realizacji haseł Marinettiego na gruncie polskim. A że jest to realizacja o charakterze stricte liberackim...

Warto przywołać w tym miejscu również legendarna, zaginioną jednodniówkę futurystów To sa niebieskie pięty, które należy pomalować, o której pisali Piotr Rypson ${ }^{656}$ i Bożena Lewandowska ${ }^{657}$. Artyści, wpisując interakcję z odbiorca w formę dzieła, zostawili czytelnikowi tytułowe pięty do pokolorowania. Podobnie, nieco wcześniej w historii literatury, uczynił Laurence Sterne w Życiu $i$ myślach JW Pana Tristrama Shandy, kiedy w rozdziale XXXVIII drugiego tomu pozostawił pustą ramę portretu kuszącej wdowy Wadman i zaczepnie zwrócił się do czytelnika:

Aby stworzyć sobie właściwe o niej pojęcie, zażądaj atramentu i pióra; a oto papier. Teraz siądź, panie, i narysuj ją wedle własnego upodobania - tak podobną do twojej kochanki, jak tylko zdołasz, tak niepodobną do twej żony, jak pozwoli ci na to sumienie. Mnie tam wszystko jedno - bylebyśs własną zadowolił fantazję ${ }^{658}$.

${ }^{653}$ Ibidem.

${ }^{654}$ A. Stern, A. Wat, Prymitywiści do narodów świata i do Polski, s. 5.

655 E. Balcerzan, Wstep, s. LXIII.

${ }_{656}$ Piotr Rypson, Ksią̇ki i strony, Warszawa 1992 , s. 20.

${ }^{657}$ B. Lewandowska, U źródet grafiki funkcjonalnej $w$ Polsce, s. 214. Lewandowska podaje tytuł jednodniówki w brzmieniu: To sq niebieskie pięty, które trzeba pomalować. Przy okazji warto wspomnieć, że badaczka w Bucie w butonierce nie dostrzega pod względem typograficznym nic (!) nadzwyczajnego (s. 217).

${ }^{658}$ Laurence Sterne, Życie i myśli JW Pana Tristrama Shandy, tłum. Krystyna Tarnowska, Warszawa 2001, s. 511. 
Dla liberatów taka interakcja z czytelnikiem urosła do rangi jednego z wyznaczników liberackości ${ }^{659}$, nie muszę chyba też przypominać, że Sterne to jeden z czołowych - zdaniem Fajfera i Bazarnik - protoliberatów. Zakładajac, że i mój czytelnik na różnego rodzaju liberackie aspekty dzieła jest wrażliwy, być może mogłabym skwitować ostatnie kilkadziesiąt stron pustym miejscem opatrzonym wskazówka, by wpisał tu - w ramach podsumowania - cechy łaczące futuryzm i liberaturę. Ile zaś miejsca powinnam zostawić? Do wypisania dwóch lub trzech punktów ${ }^{660}$ wystarczyłoby pewnie niewiele, jednak - zważywszy na wagę tych analogii, na to, że leżą u podstaw poetyki obu nurtów, że obejmują namysł nad ideą pisania, nad samym sposobem literackiej komunikacji - lepiej zostawić chyba więcej miejsca. Niech i tym razem przestrzeń tekstu dopowie, co należy.

${ }_{559}$ Por. K. Bazarnik, Liberatura czyli o powstawaniu gatunków (literackich), szczególnie s. 160 .

660 Trzech, jeśli zaliczyć do nich również wspomniane nastawienie na interakcję z odbiorca. 


\section{Liberatura a typografia nowomedialna}

Czy będziecie się dziwić, że spóźniłam się do kina tego wieczoru, gdy wam powiem, $\dot{z}$ zobaczyłam dwie litery $A$ z powykrecanymi nogami, spacerujace ramie $w$ ramie $z$ ta charakterystyczna dla członków zespołu cyrkowego pewnościa siebie? Ujrzałam czcionki szeryfowe ściśnięte razem, jakby ubrane $w$ baletki, tak iż dostownie stapaty „sur les points” [...] po czterdziestu stuleciach istnienia sita rzeczy „statycznego” Alfabetu zobaczyłam, co jego elementy moga wyprawiać $w$ czwartym wymiarze Czasu, w „płynnym” ruchu. Nic dziwnego, że to mnie zelektryzowało.

Beatrice Warde, Alphabet ${ }^{661}$

\section{1. „Nowa”(?) typografia „nowej”(?) literatury}

Relacja liberatury i literatury nowomedialnej będzie jeszcze w tej książce tematem oddzielnego rozdziału - rozdziału kluczowego dla mnie, gdyż pozwoli on pokazać, że nowe media oczekują operowania takim rodzajem komunikatów, o jaki liberatura musiała się dopominać. Dla (świadomych) twórców związanych z sztuką elektroniczna, eksplorowanie materii przekazu jest - można by powiedzieć - norma. Zapowiadając, że do zagadnień tych powrócę, chciałabym przywołać bardzo waski nurt rozważań dotyczących e-literatury - przyjrzeć się zagadnieniom związanej z nią typografii, zastanowić się nad tym, co dają literaturze możliwości kształtowania tekstu przynoszone jej przez nowe medium, w którym zaczęła się już zadomawiać662. Uwagi te traktować należy jako rekonesans, niewielka codę do rozdziału o relacji liberatury i eksperymentów typograficznych, zwłaszcza, że wiele z sygnalizowanych tu problemów powróci na dalszych stronach tej książki.

${ }^{661}$ Cyt. za: Marshall McLuhan, Zrozumieć media. Przedtużenia człowieka, tłum. Natalia Szczucka, Warszawa 2004, s. 234.

${ }^{662}$ Potrzebę zajęcia się tematem typografii w kontekście jej nowomedialnych użyć postulował m.in. Maciej Dutko (na przykładzie Internetu) w artykule Typografia Internetu - problemy badawcze, zamieszczonym w pracy zbiorowej Oblicza kultury ksiażki. Prace i studia z bibliologii i informacji naukowej (red. Małgorzata Komza, Krzysztof Migoń, Marta Skalska-Zlat, Anna Żbikowska-Migoń, Wrocław 2005, s. 141-150). Dla swoich badań proponuje on jednak odmienną niż moja perspektywę. Jedynym punktem odniesienia są dla niego „tradycyjne” techniki typograficzne, które ja przyjmuję tylko za jeden z dotychczas zrodzonych nurtów. Tym samym badacz dopatruje się w sieciowej typografii przełomu, ja - zestawiając ją z typografią liberacką czy innymi nie-klasycznymi jej postaciami - traktuję ją jako kontynuację pewnej odmiany tradycji. 
Kontekstem dla moich rozważań będą z jednej strony artykuły badaczy z amerykańskich środowisk naukowych (Davida Smalla, Jasona Lewisa, Alexa Weyersa oraz Yin Yin Wonga) - autorów oprogramowań pomagających wprowadzić to, co określają oni terminami rozszerzonej bądź temporalnej typografii (ang. extended typography, temporal typography), z drugiej: prace taką typografią się posługujące (cykl Strings Dana Wabera). Zestawiając przywołane teorie i działania artystyczne z postulatami liberatów i utworami przez nich tworzonymi oraz spoglądając na nie w kontekście innych rozważań o piśmie (i sposobach jego utrwalania) przedstawionych w tym rozdziale, chciałabym spróbować pokazać taką „nową” typografię jako kontynuację wcześniejszych nurtów.

Nie analizując tu szczegółowo, czym jest e-literatura ${ }^{663}$, chciałabym podkreślić, że podobnie jak liberatura i ona wydaje się przede wszystkim takim działaniem artystycznym, które za jedno (nie zawsze przecież jedyne) ze swoich tworzyw uznaje słowo. Warto pamiętać, że w konsekwencji ogólnokulturowych przemian funkcja literatury nie uległa drastycznej zmianie i raczej nadal ma ona oddziaływać na ludzi tym, co werbalne. Przekształceniu uległo głównie to, jak (pod względem technicznym) ten werbalny element, słowo „wygląda" i jak jest przekazywane. Tu warto od razu zaznaczyć, iż w przestrzeni cyfrowej już ze względu na stosunek do materii komunikatu wyraźnie dają się wyróżnić dwa skrajne nurty.

Różnicę między nimi najłatwiej wyjaśnić, odnosząc się do literatury funkcjonującej w Internecie i (historycznego już) podziału, jaki dla tej przestrzeni sztuki słowa zaproponował Piotr Marecki: literatury w sieci i literatury sieci ${ }^{664}$. Pierwsza $\mathrm{z}$ nich to literatura niejako adaptowana do Internetu, ale mogaca funkcjonować równie dobrze w wersji klasycznej - książkowej. Zaliczyć tu trzeba wszystkie oficjalne i nieoficjalne projekty internetowych bibliotek, w których znajdziemy dzieła bardziej i mniej znanych artystów. Z drugiej strony, w obręb tego właśnie nurtu wpisuje się działalność takich portali jak np. interaktywny serwis poetycki „Nieszuflada” ${ }^{665}$, a więc takie miejsca w sieci, gdzie można przeczytać teksty często dotychczas nieopublikowane w wersji książkowej. Ów brak klasycznej publikacji oczywiście może (acz nie musi) być świadomą decyzja autorska. Charakteryzując ten obszar występowania literatury, trzeba zaznaczyć, iż różnice między postacią tekstów internetowych i ich wydań książkowych (realnie istniejących lub niejako wirtualnych, w wypadku dzieł dotychczas niepublikowanych) najczęściej są tylko i wyłącznie natury technicznej.

${ }^{663}$ Kwestię tę rozwijam w rozdziale poświęconym jej relacji z liberatura.

${ }_{664}$ Piotr Marecki, Liternet, [w:] Liternet. Literatura i internet, red. Piotr Marecki, s. 5-21 (zwłaszcza s. 6-7).

${ }^{665}$ www.nieszuflada.pl [dostęp 20.10.2007]. W Stowie wstępnym umieszczonym na tej stronie czytamy: „Oto nieszuflada. Nieszuflada tym różni się od przeciętnej, oklepanej do znudzenia w swej użyteczności szuflady, że nie można w niej nic odłożyć. Oto jest miejsce dla tych, którzy nie chca już swoich wierszy odkładać do szuflad, dla tych, którzy wiersze do szuflad nieodłożone chca przeczytać i dla tych, którzy nie odkładając już do szuflad swoich wierszy, chcą komentować wiersze tych, którzy ich do szuflad nie odłożyli, lecz odłożyli nie do szuflad, czyli w NIESZUFLADZIE”. 
Tego typu utwory będa, oczywiście, miały postać cyfrowa, a także wszystkie te cechy, które charakteryzują (czy moga charakteryzować) twory/teksty (czy jak powie Manovich: obiekty) nowomedialne ${ }^{666}$. Zostana jednak zapisane/napisane dokładnie tak, jak te, które czytamy (,analogowo”) na co dzień. Jednocześnie, choć korzystając z udogodnień komputera, dużo łatwiej nadać tekstom inny niż najbardziej typowy kształt (m.in. poprzez operowanie barwa czcionek i tła), w obrębie nurtu, o którym mówimy, zabiegi tego typu - jeśli w ogóle są wykorzystywane - mają raczej charakter dekoracyjny. Sensy w żaden sposób nie zmieniają się tu w zależności od tego, w jakim medium czytamy. Typografia tego typu w ogóle nie będzie mnie interesować. Niemniej, już samo zastanowienie się nad nią prowadzi ku ciekawszym - i istotnym dla moich badań - konstatacjom.

Ograniczenie działań „upiększających” owe „przedrukowywane” w Internecie teksty (w ogóle lub do najprostszych form takich jak np. zmiana koloru czcionki) wskazuje na istotny problem, z którym borykać się będą teoretycy nowej typografii. Wcale nie tak łatwo zaprojektować słowo, które nie przestanie być czytelne, gdy zacznie się ruszać czy nie spowolni działania programu, gdy zbyt wiele algorytmów będzie się doń odnosiło. Mówiąc wprost: nie wystarczy, by słowo wkroczyło na nowe terytorium. Ów nowy obszar trzeba tė̇ opanować (technologicznie). W części owej dopiero poznawanej przestrzeni literackiej z powodów - powiedzmy - właśnie technologicznych, na początku często wręcz ogranicza się nieklasyczne rozwiązania towarzyszące prezentacji tekstu (a więc np. pozornie tak łatwo stosowane na stronach HTML różnicowanie czcionek). Twórcy przywołanej już tu Nieszuflady tłumaczą to w następujący sposób:

Naszym pierwotnym zamiarem było udostępnienie Autorom WIERSZY i FORUM możliwości twórczego wykorzystania HTML w celu tworzenia wpisów o dowolnym kolorze i wielkości czcionki... Niestety, wymaga to pewnej wprawy w stosowaniu tzw. znaczników, których błędne użycie powoduje uszkodzenie tworzonej dynamicznie strony z nowym wpisem.

Wystarczy źle wpisać zakończenie znacznika, aby sformatowanym tekstem była pisana CA£A strona, włącznie $\mathrm{z}$ wpisami osób poniżej. Błędne zastosowanie innych znaczników może spowodować jeszcze gorsze zamieszanie. Tak więc - z przyczyn funkcjonalnych - mechanizm wpisów analizuje przekazany tekst i wpisane znaczniki HTML zapisuje jako tekst zwykły, nie mający wpływu na funkcjonalny kod strony, zmianę kolorów, czcionki itp. ${ }^{667}$

Drugą grupę, którą w zawężonym do obszaru Internetu spektrum badań nazwać można za Mareckim literatura sieci, stanowią teksty tworzone w nowym medium i w nim właśnie zakorzenione, świadomie wykorzystujące

${ }_{666}$ Por. Lev Manovich, Język nowych mediów, przeł. Piotr Cypryański, Warszawa 2006. Badacz wyróżnia pięć cech takich obiektów, z których dwie pierwsze sa obligatoryjne, pozostałe (wynikające $\mathrm{z}$ nich) mają charakter fakultatywny. Przypomnę, że są to: reprezentacja numeryczna, modularność (fraktalna struktura), automatyzacja, wariacyjność, transkodowanie.

${ }^{667}$ www.nieszuflada.pl [dostęp 20.10.2007]. Warto pamiętać, że technologicznie bardziej rozwinięty Zachód, od dziesięcioleci „uczący się” e-literatury, wyszedł już raczej z fazy ograniczania nowomedialnych atrakcji, śmiało eksplorując coraz to nowsze przestrzenie technologiczne dla sztuki słowa. 
jego możliwości: literatura, której nie da się „adaptować”, „przepisać” jako klasycznej książki, nie uroniwszy nic z jej sensów. Związana jest ona z cyfrowym światem i - tym samym - możliwościami, jakie słowu oferują nowe technologie. W tym obszarze właśnie wypracowano (i nadal się wypracowuje) techniki pozwalające rozszerzyć możliwości, jakie daje słowu sama typografia, z tą przestrzenią związane są projekty nowych sposobów zapisywania, o jakich będę tu pisać668.

Jak już podkreślałam, wydaje się, że stojąca po drugiej stronie szklanego ekranu, „na nowo”, inaczej zapisana literatura może być w naturalny i niebudzacy zdziwienia sposób niemal bardziej liberacka niż sama liberatura. Ma bowiem pełne prawo korzystać z tego, co wizualne, co intermedialne, co grające z przestrzenią tekstu. Odwołujac się do tego, jak Piotr Rypson komentował teorię Higginsa, można powiedzieć, iż to era komputerów i Internetu pozwoliła rozwinąc się tym nurtom literatury, które dotychczas płynęły cichutko gdzieś poboczem $^{669}$.

Potwierdzeniem takiego stanu rzeczy (a jednocześnie jego skutkiem) są projekty badawcze (najogólniej rzecz ujmując - informatyczne), skupiające się na tym, by stworzyć taki rodzaj oprogramowania, który pozwoli swobodnie korzystać z tego, co oferują słowu pisanemu nowe media. Przywoływani przeze mnie na początku tego szkicu naukowcy postulują wprowadzenie nowego rodzaju zapisu również po to, by sprostać oczekiwaniom odbiorcy żyjącego w XXI w. Wychodzą z założenia, iż tekst w mediach wcześniejszych traktowany był jako obiekt statyczny, a dodatkowo zawsze sprowadzany zaledwie do dwu wymiarów. Stąd prawdziwa przestrzenność pojawi się dopiero na tym etapie rozwoju literatury, na którym zawrze ona pakt z nowymi mediami, tu bowiem zostanie uruchomiony wymiar trzeci ${ }^{670}$. Referując podstawowe tezy teoretyków i praktyków nowej typografii, chciałabym pokazać kluczowe dla ich rozważań postawy teoretyczne oraz przywołać problemy, które sygnalizują w swoich opracowaniach. Pozwoli to uzmysłowić, że droga literatury zapisanej przy pomocy takiej typografii to szlak dopiero przecierany, na którym wiele musi się jeszcze zdarzyć.

Yin Yin Wong, przyglądając się zmianom mentalnym towarzyszacym wprowadzeniu nowych mediów, zauważa, że ich szerokie rozpowszechnienie

668 Sięgam do opracowań z lat dziewięćdziesiątych, jednak i obecnie w starciach literatury i nowych mediów wybrzmiewają podobne problemy. Pod wieloma względami problematyczne jest jeszcze np. operowanie słowem w przestrzeni virtual reality. Por. np. Katherine N. Hayles, Electronic Literature. New Horizons for the Literary, Notre Dame 2008 oraz Monika Górska-Olesińska, Pisanie jaskiniowe (cave writing), „Autoportret” 2011, nr 1, s. 92-97.

${ }^{669}$ Badacz stwierdzał: „Higgins lokuje współczesną twórczość eksperymentalną w obrębie starszych, niekiedy niezwykle znaczących i bogatych tradycji. W owym wskazaniu na twórczość eksperymentalną jako na swego rodzaju kulturowy «constans» zdaje się jawić niemal wywrotowa intencja umocowania owych nurtów jako innych tradycji właśnie. Gdy rozprawiał więc o «tradycyjnych gatunkach» i «tradycyjnej estetyce», Higgins zwykł pytać o jakich tradycjach w istocie jest mowa" ([w:] P. Rypson, Postowie, [w:] D. Higgins, Nowoczesność od czasu postmodernizmu..., s. 224).

${ }^{670} \mathrm{Na}$ różnice między typograficznymi eksperymentami w duchu awangardy a typografia nowomedialną zwracała też uwagę Górska-Olesińska w szkicu Elektroniczne uwolnienie słowa. W środowisku poematów cyfrowych, [w:] Materia sztuki, red. Michał Ostrowicki, Kraków 2010. 
przyczynia się do zmiany samego sposobu postrzegania typografii ${ }^{671}$. W nowych mediach powstają oczywiście także teksty - jak to określa Wong - „typograficznie powściagliwe” (ang. typographically constrained) ${ }^{672}$, jednak w większości sytuacji:

media elektroniczne rozszerzają potencjał ekspresji poprzez umożliwienie formom typograficznym dynamicznej zmiany rozmiaru, koloru czy pozycji zgodnie z ekspresją pisarza lub interakcją czytelnika w czasie rzeczywistym ${ }^{673}$.

Stąd pomysł typografii temporalnej (ang. temporal typography), traktującej wizualną stronę tekstu jako umożliwiającą rozszerzenie spektrum informacji, jakie może on z sobą nieść. Komunikat wykorzystujący taki sposób notacji (o ile w ogóle możemy tu jeszcze mówić o „notacji”) to coś więcej niż tylko zwykły, zapisany tekst. Może poprzez swój typograficzny kształt przekazywać emocje, ton głosu (te aspekty aktywizowały już różne awangardowe typografie), ale także dynamicznie zmieniać się w czasie, co również bywa wykorzystane do tworzenia znaczeń ${ }^{674}$. W rozważaniach Wonga kluczowe są właśnie: dynamiczna forma tekstu, rytm jego prezentacji oraz sam ruch.

Skupiajacy się na podobnych kwestiach Jason Lewis oraz Alex Weyers, autorzy ActiveText, czyli - jak sami twierdza - „metody tworzenia dynamicznych i interaktywnych tekstów"675, określają grupę przekazów, w zakresie których ich projekt może być wykorzystany i (co dla mnie bardzo istotne) wymieniają wśród nich literaturę (badacze stosują tu określenie fiction and poetry writing). Autorzy ci również podkreślaja, iż aplikacje służące do tworzenia tekstów dotychczas traktowały sam tekst jako medium statyczne i właśnie to podejście należy zmienić:

Twierdzimy, iż tekst jest medium dynamicznym. Z tego założenia wyprowadzamy metodę ActiveText, która traktuje tekst jednocześnie jako ciąg znaków i obraz. Tekstowi temu mogą być przypisane zachowania na różnych poziomach jego ziarnistości. Dynamiczne zachowania mogą być zaznaczane w czasie rzeczywistym. Użytkownik może płynnie przechodzić od komponowania tekstu do dodawania dynamiczności i interaktywności oraz z powrotem $^{676}$.

${ }^{671}$ Yin Y. Wong, Temporal Typography. A Proposal to Enrich Written Expression, [w:] Conference companion on Human factor in computing systems: common ground, Vancouver 1996, s. 408 (dalej oznaczane jako Y. Y. Wong z numerem strony).

${ }_{672}$ Y. Y. Wong jako przykład podaje tu e-maile.

673 Y. Y. Wong, s. 408.

${ }^{674}$ Wong stwierdza: „Proponuję «typografię temporalną» jako obszar badawczy, w którym zatrudnia się dynamikę i wizualność tekstu [ich dynamiczne i wizualne ujęcie] jako przedłużenia języka pisanego [...] Projekt ten proponuje podejście przekraczające tradycyjną typografię, traktując tekst dynamicznie, również jako związany z czasem".

675 Jason Lewis, Alex Weyers, ActiveText: A Method for Creating Dynamic and Interactive Texts, [w:] Symposium in User Interface Software and Technology Proceeding in the 12th annual ACM symposium on User interface software and technology, Asheville 1999, s. 131 (dalej oznaczane jako J. Lewis, A. Weyers z numerem strony).

${ }^{676}$ J. Lewis, A. Weyers, s. 131. 
Z kolei David Small, chyba jako jedyny z przywoływanych tu przeze mnie badaczy, podkreśla, iż „media elektroniczne początkowo próbowały naśladować te, które zastępowały"677, na co wielokrotnie zwracali (za Bolterem) uwagę zajmujacy się remediacja ${ }^{678}$. Przede wszystkim, jednak i on zauważa, że wykorzystując możliwości, jakie daje nowe medium (trójwymiarowość, udogodnienia graficzne), możemy „odkrywać nowe sposoby traktowania tekstu”679. Small wprowadza nawet (za Muriel Cooper) określenie pejzaż informacji (ang. information landscape), by opisać rodzaj przestrzeni tekstowej, z jaką możemy mieć do czynienia w nowych mediach, przestrzeni:

w której informacja „wisi” jak konstelacje, a czytelnik „przelatuje” z miejsca na miejsce i gdzie sama ta podróż może być tak znacząca, jak i jej cel ${ }^{680}$.

Small podkreśla, że niezbędnym warunkiem użyteczności wizualizacji jest łatwość nawigowania przez tekst oraz to, by pozostawał on przy tym dla nas czytelny. A podsumowując swoją działalność praktyczna, wyróżnia kilka najbardziej dokuczliwych problemów: grupę niedogodności związanych z przenoszeniem do przestrzeni trójwymiarowej obiektów pierwotnie projektowanych w dwu wymiarach (dotyczy to np. liter), trudności związane z różnicami wielkości poszczególnych elementów, a także komplikacje wynikające z konieczności takiego zaprojektowania tekstu, by dowolny ruch nie zmieniał drastycznie jego czytelności ${ }^{681}$.

Jakie zatem perspektywy otwiera przed sztuką słowa typografia, która próbują stosować przywołani przeze mnie badacze? Jaka może być zapisywana przy jej pomocy literatura? Zdaniem Smalla - nawet „kusząca i wygodna” (ang. inviting and comfortable) ${ }^{682}$. A przede wszystkim - uzmysławiajacca

${ }_{677}$ David Small, Navigating large bodies of text, http://research.ibm.com/journal/sj/353/sectiond/small.txt [dostęp 20.10.2007]).

678 Np. Maciej Maryl mówiący wprost o „elektronicznych inkunabułach” (Maciej Maryl, Reprint i hipermedialność - dwa kierunki rozwoju literatury ucyfrowionej, [w:] Tekst (w) sieci, red. Anna Gumkowska, t. 2, Warszawa 2009, s. 85). Por. też: Dorota Sikora, Remediacja - cyfrowa adaptacja dziet literackich, [w:] e-polonistyka 2, red. Aleksandra Dziak, Sławomir J. Żurek, Lublin 2009, s. 53-62 oraz część tej pracy poświęcona relacji liberatury i literatury nowomedialnej.

${ }^{679}$ D. Small, Navigating large bodies of text.

${ }^{680}$ Ibidem. W gruncie rzeczy o takich właśnie „pejzażach” pisze Górska-Olesińska, analizując wiersze-środowiska (zob. eadem, Elektorniczne uwolnienie słowa...).

${ }^{681}$ Warto zwrócić uwagę, że akurat wiele projektów Smalla wiąże się z przenoszeniem tekstów staromedialnych w obszar cyfrowy. Nie mamy tu jednak do czynienia z rodzajem ucyfrowienia, o jakim pisałam w odniesieniu do polskiej literatury w sieci, lecz z taką odmianą remediacji, w obrębie której próbuje się wykorzystać własności nowego medium do uczynienia tekstu przejrzystszym, lepiej dostępnym, wygodniej podanym. Przykładem projekt Virtual Shakespeare, w którym Small próbował zebrać wszystkie dzieła tego dramatopisarza w obrębie jednego tekstu medialnego (nadając im nowy kształt typograficzny). Skutkiem remediacyjnej zmiany miało być uczynienie struktury Szekspirowskich utworów bardziej czytelną. W tym celu Small rozróżnił poszczególne osoby dramatu (czy ich wypowiedzi) odmiennymi kolorami, didaskalia, dialogi, komentarze itp. - rozmaitymi czcionkami, zaś sceny, akty i poszczególne dzieła - kształtując przestrzeń tekstu. Dla znaczeń tekstu nie wniosło to nic, choć, być może, dla niektórych uczyniło lekturę dramatów nieco łatwiejsza.

${ }^{682}$ D. Small, Navigating large bodies of text. Warto zwrócić uwagę na to, jak nietypowych dla opisu literatury słów badacz tu używa. 
odbiorcom, że istnieją alternatywne formy lektury, dowodząca, iż (nawet nie odrzucajac tradycji) można próbować spojrzeć na tekst literacki w nieco odmienny sposób i inaczej go przeczytaćc63. Tym samym, e-literatura może wydawać się liberacka, przyszło nam bowiem żyć w czasach, w których wysoki stopień płynności granic między sztukami nie pozwala już ograniczać literatury do sztuki jedynie słowa, chyba że pamiętając, iż współcześnie owo słowo może być zapisane w najdziwniejszy sposób, a forma dzieła - by przywołać argumentację Fajfera - to coś znacznie więcej niż sposób ułożenia słów i zdań ${ }^{684}$.

Zapowiadajac niejako rozdział o relacji liberatury i nowych mediów jako jeszcze jeden kontekst, chciałabym przywołać tu konstatacje Jaya Davida Boltera odnoszace się do tego, jak w nowych mediach pojmowany jest stosunek słowa i obrazu. Nie jest to w tym rozdziale bezzasadne, gdyż nowomedialna typografia wykorzystuje właśnie wizualność słowa, nieraz traktując je jak obraz. Jedna z konkluzji możliwych do wyprowadzenia z Bolterowskiego wywodu jest taka, iż wszelkie elementy: werbalne, wizualne, akustyczne zostaja w tekście nowomedialnym zrównane w swym statusie ${ }^{685}$. W konsekwencji - możliwe jest tworzenie komunikatów, w których reguły składniowe odnosić się będą do łączenia elementów klasycznie przypisywanych do różnych porządków. W dalszej części rozdziału pokażę, że z sytuacją taką będziemy mieć do czynienia i w pracach elektronicznych sięgających niemal wyłącznie po typografię.

Zwracając uwagę na wizualność tego, co można znaleźć w Internecie, Bolter przywołuje kategorię retoryki graficznej (graphic rhetoric), której narodziny łączy z początkami dwudziestego stulecia ${ }^{686}$. Jego zdaniem to właśnie ona będzie dominująca dla wszystkiego, co związane z www, ponieważ w języku

${ }^{683}$ Wątki nowych sposobów lektury rozwijam m.in. w szkicach: Po(d)żeranie tekstu. Wstęp do rozważań o czytaniu kinetycznym ([w:] e-polonistyka 3, red. Aleksandra Dziak, Lublin [w druku]), O niektórych strategiach otwarcia na czytelnika $w$ wybranych przykładach literatury nowomedialnej (rekonesans) (Teksty kultury uczestnictwa, red. Andrzej Dąrówka, Maciej Maryl, Aleksandra Wójtowicz, Warszawa [w druku]) oraz Ku literaturze grywalnej (kilka uwag wstepnych) („Przegląd Kulturoznawczy" 2014, nr 2).

${ }^{684}$ Sygnalizowane tu zaledwie istotne kwestie rozwijać będę w rozdziale poświęconym relacji liberatury i literatury nowomedialnej.

${ }^{685}$ Wątek zrównania statusu słowa i obrazu, zamieniania się przez nie funkcjami często powraca w refleksji nowomedialnej. Warto przywołać tu również słowa Bazarnik, która w jednym z wywiadów stwierdzała, że w Oka-leczeniu: „słowa stają się obrazami, a obrazy literami i słowami. Jedno przechodzi nieustannie w drugie" [Ile stron ma liberatura? Z Katarzyna Bazarnik i Zenonem Fajferem rozmawia Adam Poprawa, „Conrad”, dodatek tematyczny do „Tygodnika Powszechnego" 2010, nr 44 (z 31 października), s. 5]. Podobnie, o przechodzeniu pisania w rysowanie pisał - przypomnę - Nowakowski.

686 Jay D. Bolter, Writing Space. Computers, Hypertext, and the Remediation of Print, edition 2, Mahwah 2001, s. 70. Pracując nad tym rozdziałem, nie miałam jeszcze do dyspozycji polskiego tłumaczenia przywoływanego tu rozdziału książki Boltera (opublikowanego w tomie Ekrany piśmienności. O przyjemnościach tekstu w epoce nowych mediów, red. Andrzej Gwóźdź, Warszawa 2008) ani pełnego tłumaczenia przywoływanej książki (David J. Bolter, Przestrzeń pisma. Komputery, hiperteksty i remediacja, tłum. Aleksandra Małecka, Michał Tabaczyński, Kraków 2014). Ponieważ większość fragmentów, w których powołuję się na Boltera pisałam przed wydaniem tych publikacji, pozwoliłam sobie pozostawić cytowane fragmenty we własnym tłumaczeniu oraz odsyłać do oryginalnej pozycji. 
programowania stron internetowych status operacyjny tekstu i obrazu jest taki sam ${ }^{687}$. O podobnym równouprawnieniu możemy - moim zdaniem - mówić w przypadku liberatury, a tym samym poszerzyć granice czasowe, jakie dla retoryki graficznej wyznaczył Bolter.

Porównując teksty drukowane z elektronicznymi, badacz zauważa, że do czasów powstania hipermediów, „słowo i obraz zwykle przypisane były do innej przestrzeni, zarówno w rozumieniu wizualnym, jak i technologicznym" 688 , a to, co obrazowe, zawsze podlegało syntagmatycznemu porządkowi słowa pisanego. Przyczyn owej hegemonii badacz upatruje m.in. w tym, iż przywołane sfery tekstu wytwarzano przy użyciu innych środków (rządziła nimi „inna przestrzeń technologiczna") ${ }^{689}$. Jego zdaniem, kontrola (słowocentrycznego) dyskursu, jaka mieli pisarze związani z drukiem ${ }^{690}$, wynikała nie tyle z łatwo dostrzegalnej w tekście przewagi ilościowej elementów werbalnych nad wizualnymi, ile raczej z tego, w jaki sposób słowo otacza obraz i nadzoruje odbiór ${ }^{691}$. Zaś w nowych mediach twórcy „redefiniują równowagę pomiędzy słowem a obrazem" ${ }^{692}$. Sięgaja też po wizualność (a także akustyczność), by „zapewnić bardziej autentyczne czy bezpośrednie doświadczenie niż to, które oferują wyłącznie słowa"693.

Definiująca właściwością pisma obrazkowego - stwierdza Bolter - jest jego zdolność do jednoczenia dwóch skrajnie odmiennych przestrzeni. Tradycyjne pismo obrazkowe wchłania „czysty” element wizualny, aby opowiedzieć historię, zrelacjonować fakty lub dać ostrzeżenie. Wraz z elektronicznym pismem obrazkowym, hipermedia ponownie kształtuja zapis fonetyczny na drodze umocnienia statusu elementów wizualnych ${ }^{694}$.

Wchłonięcie, o jakim mówi tu badacz, zakłada jeszcze wspominany układ hierarchiczny, w którym słowu przypisana jest funkcja dominująca. W nowych mediach umocnienie roli obrazu prowadzi do sytuacji, w której - jak mówi

\section{${ }^{687}$ Ibidem.}

${ }^{688}$ Ibidem, s. 48. W Ekranach piśmienności-s. 121.

689 Ibidem.

690 Analizując współczesną typografię oraz graficzne ukształtowanie druku (m.in. w oparciu o współczesne czasopiśmiennictwo), Bolter zaznacza jednak, że „tekst werbalny nie cieszy się już swą dawną hegemonią ani też czyste obrazy nie zastępują tekstu” (s. 52), a także podkreśla, iż obecnie twórcy, balansując między paradygmatami wyznaczanymi przez stare i nowe media, mają szeroki wybór [(,od przezroczystości do hipermedialności i od czystego tekstu do czystej obrazowości” (s. 52)].

691 Ibidem, s. 49

${ }^{692}$ Ibidem, s. 58.

${ }^{693}$ Ibidem. Większość badaczy podkreśla związaną z tym przemianę samej kategorii znaku. Ewa Szczęsna zaznacza, iż często prowadzi to w efekcie do zacierania relacji między znaczącym a znaczonym (Ewa Szczęsna, Poetyka w świecie domen cyfrowych, „Teksty Drugie” 2006, nr 4, szczególnie s. 220-221). Z kolei Ryszard Kluszczyński zwraca uwagę na przejście znaku w przestrzeni wirtualnej od ikonicznego ku indeksowemu i analizuje konsekwencje tego faktu (zob. Ryszard W. Kluszczyński, Światy możliwe - światy wirtualne - światy sztuki. Fragmenty teorii doświadczenia rzeczywistości wirtualnej, [w:] Estetyka wirtualności, red. Michał Ostrowicki, Kraków 2005, s. 15-25).

694 J. D. Bolter, Writing Space..., s. 64. W Ekranach piśmienności-s. 141. 
Bolter - oba sposoby przekazu stapiają się w obrębie tekstu tak bardzo, iż „ani pisarz, ani czytelnik nie wiedzą już, gdzie kończy się przestrzeń piktoralna, a zaczyna werbalna" ${ }^{95}$. Brak wtedy jakiejkolwiek hierarchii. Owo nierozerwalne zespolenie, którego antycypację w historii słowa pisanego Bolter dostrzega jedynie $\mathrm{w}$ średniowiecznych iluminowanych manuskryptach ${ }^{696}$, to nic innego niż powiązanie podkreślane przez Higginsa w odniesieniu do intermediów ${ }^{697}$ i Fajfera definiującego liberaturę ${ }^{698}$.

\subsection{Bliżej praktyki: nowomedialna opowieść słowa}

By pełniej zobrazować potencjalne pokrewieństwo liberatury i tekstów nowomedialnych warto przywołać tu kilka przykładów utworów stworzonych i pomyślanych jako teksty nowomedialne (nie remediacje dzieł już istniejacych), które korzystają z osiagnięć nowej, rozszerzonej (extended) typografii. Tu chciałabym odwołać się do dzieł zebranych w Electronic Literature Collection Volume One ${ }^{699}$, wybierając z całej kolekcji wyróżniający się na jej tle zbiór tekstów Dana Wabera zatytułowany Strings. Pochodzące z 1999 r. króciutkie utwory sa, moim zdaniem, doskonałym przykładem tego, jak możliwości nowego medium moga być wykorzystywane dla budowania dzieł literackich o nowych jakościach. Przywołanie tego zbioru wydaje się interesujące również dlatego, iż pod względem wizualnym jest on nad wyraz ascetyczny. Waber operuje wyłącznie bielą ekranu i czernią pisma (odwołując się tym samym do tradycji druku), w gruncie rzeczy niemal wcale nie zatrudnia do tworzenia znaczeń w Strings elementów wizualnych (w ogóle zaś nie sięga po dźwiękowe). Niemniej - wykorzystując własności nowomedialnej typografii, nad którymi pracowali m.in. przywołani przeze mnie badacze - znacząco pogłębia potencję semantyczną owych czarnych liter na białym tle.

Każdy z utworów zbudowany jest z kilku zaledwie wyrazów. Jednak dzięki temu, iż sam sposób ich zapisania wzbogacony jest o dynamiczny ruch $\mathrm{w}$ (dwuwymiarowej) przestrzeni, owe jedno, dwa czy trzy słowa wystarczaja

695 Ibidem, s. 66.

696 Teza ta wydaje się ciekawym tropem interpretacyjnym dla pracy Illuminated Manuscript Davida Smalla, łączącej kategorię literatury elektronicznej właśnie z dawnymi księgami iluminowanymi. O pracy tej więcej pisałam w szkicu Którędy do literatury nowomedialnej?, „Fragile” 2008, nr 2.

${ }^{697}$ W 1981 r. badacz zaznacza, że w mixed media rozróżnienie użytych technik jest niezwykle łatwe, podczas gdy „w intermediach element wizualny (obraz) jest pojęciowo stopiony ze słowami” (D. Higgins, Intermedia, s. 128-129).

${ }^{698}$ Zdaniem Fajfera liberatura jest „rodzajem, którego cechą konstytutywną byłaby nierozerwalna więź tekstu ze sferą pozawerbalną książki” (Z. Fajfer, W stronę liberatury, s. 93). Przypomnę, że w mojej interpretacji tez liberatów, jeśli słowo miałoby w literaturze totalnej pełnić funkcję dominująca, to wyłącznie w takim sensie, iż jest jedynym z elementów, który musi się pojawić.

${ }^{699} \mathrm{http}$ ///collection.eliterature.org (od $2011 \mathrm{r}$. dostępny jest również drugi tom tej kolekcji). Przywoływany tu wybór tekstów elektronicznych wydany został także na płycie DVD, dołączonej do przywoływanej już tu publikacji Hayles (Electronic literature...). 
do opowiedzenia całej historii. Praca Argument (Sprzeczka? Polemika?) ${ }^{700}$ (zob. ilustracja 28) - podobnie jak pozostałe utwory - opiera się na ruchu falującej czarnej linii, która symbolizuje zapis na papierze (stąd białe tło). Linia ta najpierw dynamicznie, a potem coraz łagodniej przetacza się z jednej strony na druga, by na koniec na chwilę uspokoić się i zastygnąc w bezruchu. W chwilach kulminacyjnych na jej końcach (które wyglądają niczym ciagnięte przez dwóch niewidzialnych aktorów), pojawiają się słowa „yes” (tak) i „no” (nie).

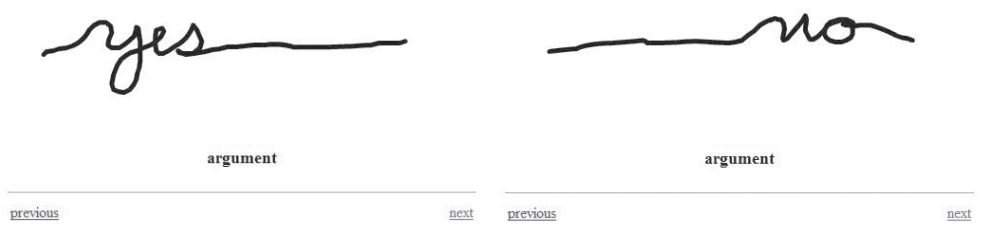

Ilustracja 28. Dan Waber, Argument (zrzuty ekranowe) (źródło: Internet: http://vispo.com/guests/ DanWaber/argument.html)

Choć bazę słowną tego tekstu stanowią zaledwie dwa krótkie wyrazy, dzięki wprowadzeniu rytmicznego ruchu typograficznego sa one zdolne stworzyć narrację - opowiedzieć (swoją forma) o konflikcie. Jakkolwiek tłumaczyć tytuł pracy (Kłótnia, Spór, Polemika, Sprzeczka), odsyła on do konfrontacji poglądów. Stanowiąca semantyczne centrum przeciwstawność zobrazowana jest poprzez wizualne zaktualizowanie dwóch stron ekranu, zaś dynamiczny ruch tekstu pozwala zinterpretować emocje towarzyszace wydarzeniu. W moim odczytaniu są one kontrolowane i względnie uładzone, dlatego skłaniałabym się ku tytułowi Polemika (uzasadnionym, jeśli położyć nacisk na równowagę wymiany zdań) lub Sprzeczka (ze względu na niewielkie zaangażowanie emocjonalne rozmówców ${ }^{701}$. Podsumowując - w tym wypadku zaledwie dwa krótkie (ale za to nowomedialne) słowa są zdolne przekazać swym nieosiagalnym w innych mediach kształtem emocje, jakie towarzyszyły wymianie zdań, oddać cała skomplikowaną sytuację. Ponadto - niczym w liberaturze - tekst przepisany inaczej (np. jako dialog złożony z powtarzanych „tak” i „nie”) straciłby wiele ze swych znaczeń, byłby opowieścią nie tylko inna, ale i semantycznie okaleczona.

Warto tu przypomnieć, iż Jay David Bolter odbierał tekstowi wizualnemu potencję narracyjna ${ }^{702} \mathrm{i}$ uważał, że to dopowiedzenia werbalne odpowiadają w takich sytuacjach za logikę i chronologię wywodu. Jednak w przypadku przywołanego utworu porządek czasowy budowany jest właśnie przez oparty na animacji (a zatem dynamiczny) element wizualny. W Argument łatwo

\footnotetext{
${ }^{700} \mathrm{http}: / /$ collection.eliterature.org/1/works/waber_strings/argument.html

701 Tytuł Kłótnia idealnie zaś przystaje do pracy Wabera Argument 2.

702 J. D. Bolter, Writing Space..., s. 59.
} 
odczytać słowa w kolejności warunkującej zrozumienie przebiegu akcji i wynika to nawet z ruchu wyrazów, nie zaś z ich konwencjonalnego ułożenia przestrzennego. Dodam, że - jak pokazuja analizy Oka-leczenia Fajfera i Bazarnik - i w przypadku liberatury potencją narracyjną operują przeróżne, niekoniecznie werbalne, sfery tekstu ${ }^{703}$.

Wśród należących do omawianego cyklu utworów znajdują się i takie, które sprawnie łączą wizualizację zapisu z samym obrazem (jednak obrazem bardzo prostym, estetyką swą nieodbiegającym od całości utworu). Powiedziałabym więcej - Strings przynosi też przykłady równorzędności elementu wizualnego ze słowem w budowaniu syntagmy. Dzieje się tak choćby w pracy Arms (Ramiona) ${ }^{704}$ (zob. ilustracja 29) mówiącej m.in. o tym, jaką radość i spokój można czerpać z bliskości z drugim człowiekiem. Początkowo widzimy na ekranie kształtowane - linią podobna jak we wcześniej przywołanych przykładach - słowa: „your arms” (twoje ramiona), następnie zapis uspokaja się, łagodnieje i powoli zamyka się, ograniczając się do kształtu delikatnego okręgu, przy czym dwa końce linii - niczym dwie dłonie - nie łączą się idealnie. Gdy owe (dopowiedzmy) ikonicznie przedstawione ramiona wykonaja ruch symbolizujący utulenie kogoś z jednej i drugiej strony (koło się obróci), linia powoli się rozplata i zdecydowanie spokojniej niż przed kojącym przytuleniem układa się w kolejne słowo: „me” (mnie).
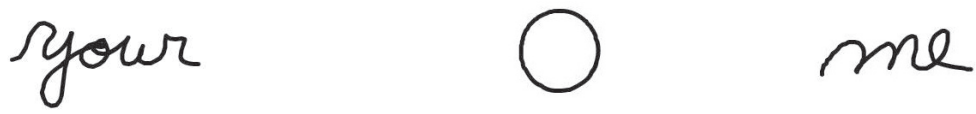

Ilustracja 29. Dan Waber, Arms (zrzuty ekranowe) (źródło: Internet: http://vispo.com/guests/DanWaber/arms.htm)

Jak widać, symboliczny obraz dzięki dynamicznemu ruchowi w pełni zastapił słowo „hug” (przytulić), zachowując jednak takie cechy czasownika jak rekcja itd. Następujące po nim dopełnienie „me” (mnie) jest zarówno konieczne, jak i czytelne. Trzeba też dodać, że „normalny” czasownik nazywa czynność, odsyła do niej, tutaj zaś verbum po prostu działa ${ }^{705}$. Tego typu zabiegi sa, oczywiście, możliwe również na gruncie literatury niemającej nic wspólnego

${ }^{703}$ Podobną strukturę ma też praca Argument 2 (Sprzeczka 2? Kłótnia?), w której analogiczne słowa wyrzucane są z dwóch krańców ekranu, potem pojawiają się coraz mniej agresywnie, by w końcu „dojść do kompromisu”. W pracy tej pojawia się bowiem też „trzeci bohater” - słowo „maybe” (może) będące tym, które wyłania się z przestrzeni pomiędzy „yes” i „no” i w efekcie doprowadza do załagodzenia sporu. Zob. http://collection.eliterature.org/1/works/waber_strings/ argument2.html

${ }^{704} \mathrm{http} / / /$ collection.eliterature.org/1/works/waber_strings/arms.html

705 Jeśli odsyła do czegokolwiek, to do opisu tego działania. 
z nowymi mediami - w różnie rozumianej literaturze wizualnej (dość przypomnieć analizowane wcześniej utwory Nieradzkiego) czy w (obejmującej większy wachlarz możliwości) liberaturze.

W „starych” mediach pozbawione sa jednak raczej tego, co daje możliwość rozszerzenia (i stąd właśnie określenie extended) sposobu zapisu o wykorzystanie ruchu i to ruchu rozgrywajacego się w czasie (stąd temporal). A - jak widać - znaczna część historii opowiadanych przez przywołane w ostatnich akapitach teksty Wabera przekazana jest właśnie dzięki wykorzystaniu tych nowych dla literackiego zapisu możliwości. Jednak - co dla mnie kluczowe sam sposób ujmowania narracji jest tu podobny jak w liberaturze. Sensy wynikają nie z neutralnie zapisanego słowa, ani też nie z (odczytywanych niezależnie od niego) innych elementów dodanych do tekstu. Rodzą się z zespolenia tych przestrzeni semantycznych. Waberowskie słowo odarte ze swego ruchu w przestrzeni, dynamiki itp. nie byłoby już opowieścia, stałoby się nieme i nic nieznaczace. Opowieść bowiem w tym wypadku rodzi się z eksplorowania swego medium, którym jest nie tylko słowo, lecz słowo w konkretny (istotny) sposób ukształtowane (zapisane). Podobnie, jak w dziełach liberatów - i u Wabera nie da się go zapisać inaczej, gdyż uśmiercimy w ten sposób sens.

Jak widać, zasygnalizowane tu zaledwie pokrewieństwo liberatów i artystów nowych mediów w podejściu do samego procesu budowania znaczeń jest nad wyraz ciekawym tropem interpretacyjnym. Niech szkicowo tu nakreślone możliwości pogłębiania analizy podobieństw (ale i różnic) liberatury i literatury nowomedialnej zapowiedza, że do kwestii tych w dalszej części książki jeszcze powrócę. Nie mogłoby być inaczej, gdyż - jak widać - takie porównania kieruja nas ku nad wyraz ciekawemu obszarowi badawczych poszukiwań. Sformułowane $\mathrm{w}$ tym krótkim rozdziale wnioski traktuję jako konieczne dopełnienie uwag o relacji liberackiego podejścia do dzieła i różnorakich typograficznych eksperymentów. Nie uważam jednak otwartej tu dyskusji za zamkniętą i - raz jeszcze podkreślę - wracać będę do niej w dalszej części wywodu.

Dodam tu jeszcze tylko, że jeśli rozdział ten rozpoczynały uwagi o tym, że nowego podejścia do typografii światowa (a za nią i polska) e-literatura dopiero się uczy, że musi rozpoznać nowe terytorium, warto spojrzeć na prezentowane tu rozważania z perspektywy czasu i wskazać interesujace kierunki rozwoju, jakie podejmowane są najbardziej aktualnie ${ }^{706}$. Szeroko dyskutowane i nagradzane w chwili kończenia prac nad redakcją tej książki sa bowiem utwory eksplorujace nie tyle dynamiczne i temporalne aspekty typografii, ale jej jeszcze głębszą sensualność - np. taktylność wiążąca kształt tekstu z projektowanym doświadczeniem lektury angażującej ciało odbiorców, wykorzystującym fizyczną interakcję. Nowatorskie projekty takie jak cykl P.o.E.M.M. Poetry for Exci-

${ }^{706}$ Moment zbierania materiałów do tego rozdziału oraz ostatecznej publikacji książki dzieli kilka lat, które - jak zwykle w przypadku prężnie rozwijanych technologii - przyniosło już wiele zmian i innowacji. Doskonałym uzupełnieniem byłyby tu np. rozpoczęte ostatnio przez Górska-Olesińską badania nad, jak to określiła, „żywymi literami”, których pierwsze wyniki badaczka prezentowała w październiku 2014 r. na seminarium Maszyny kruszenia słowa w Częstochowie. 
table [Mobile] Media Jasona Lewisa i Bruno Nadeau ${ }^{707}$ z czytelniczego gestu dotykania czcionek (liter, słów) czynia istotny (ponadto: nieodzowny, konieczny) element samego czytania. W konsekwencji, w pracach tego typu (jako kolejny przykład można tu przywołać He Liked Thick Word Soup Ariela Malki ${ }^{708}$, wpisany w ramy rozwijanej od 2001 r. koncepcji chronotextu ${ }^{709}$ ) dawne snucie opowieści przez barda zastępowane jest naszym - czytelniczym, zmysłowym, palcami dłoni prowadzonym rozwijaniem kłębka narracji. Układamy ja - ale układamy dosłownie, cieleśnie (gdyż litery reaguja na nasz dotyk, a historia objawia się na naszych oczach tylko pod warunkiem, że wejdziemy z nią w interakcję). Choć analizy tego typu zjawisk w znacznym stopniu przekraczaja ramy tego opracowania, warto je tu choć odnotować jako liberackie (zwłaszcza w kontekście rozdziałów zamykających tę książkę). Bowiem, jak już zaznaczałam (i do czego wrócę w rozdziale poświęconym relacjom liberatury i literatury elektronicznej), w obszarze nowomedialnej sztuki słowa znaczenia projektowane są na styku kodów, a wirtualna materialność słów traktowana jest jako naturalny element wpływający na znaczenie komunikatu. Jest materialnościa o charakterze liberackim, a wrażliwe na dotyk słowa są nań i semantycznie czułe. Tak projektowana typografia może zaś być widziana jako spełniony sen liberatów.

${ }^{707}$ Zob. http://www.poemm.net. Podtytuł projektu wyjaśnia, iż jego autorom chodzi o eksplorowanie przestrzeni typograficznej (i literackiej) mediów mobilnych wrażliwych/czułych na dotyk. ${ }_{708}$ Zob. http://chronotext.com/WordSoup [dostęp 30.06.2014].

${ }^{709}$ Zob. www.chronotext.org. 



\section{LIBERATURA A KSIĄŻKA}

\section{Literatura totalna $w$ perspektywie sztuki książki, czyli o liberaturze i (nie tylko) książce artystycznej}

\subsection{Podwójna opozycja}

Poszukiwanie niezwyktych treści nigdy nie było tak inspirujace. Bo wszystkie ksiażki do nas mówia, ale nie wszystkie catymi soba...

Cyprian Maciejewski ${ }^{710}$

Narodziny terminu liberatura wiążą się - jak pisałam - z krakowską $W y$ stawa Ksiażek Niekonwencjonalnych, która miała miejsce w czerwcu 1999 r. Wydawać by się mogło, że literatura totalna debiutowała w towarzystwie doborowym: wśród tomów zaskakujących swoim kształtem, książek wyłamujących się z (wydawniczych) schematów. Pojawiła się w otoczeniu dzieł twórców, którzy nie mają w zwyczaju respektować ustalonych konwencji i którzy - podobnie jak liberaci (czego dowiedzieć się można było z prezentowanych wtedy - jeszcze przed publikacja na łamach „Dekady Literackiej” - tez Fajfera) - nie postrzegają książki (jej materialnego kształtu) jako formy neutralnej i semantycznie niemej. A jednak... Bazarnik kategorycznie zaznaczała, iż mimo że często na pierwszy rzut oka mogą się wydać podobne, zrównywanie liberatury z tym, co określane bywa mianem książki artystycznej, pięknej książki czy sztuki książki to „identyfikacja nieuprawniona”711.

Trzeba powiedzieć więcej - od samego początku Fajfer i Bazarnik sytuowali liberaturę w opozycji do dwóch postaci książki: nie tylko jej artystycznej, ale i konwencjonalnej odmiany. Dlaczego? Mówiąc najkrócej - pierwsza zawiniła tym, że zbyt małą wagę przywiązuje się w niej do literackości, druga natomiast grzeszy bagatelizowaniem materialności. Obu zaś - zdaniem

${ }^{710}$ Druga rewolucja ksiażki, red. Violetta Trella, Gdynia 2008, tylna okładka (pozycję te dalej oznaczam jako DRK wraz z numerem stron).

711 K. Bazarnik, Liberatura: ikoniczne oka-leczenie literatury, s. 25. 
krzeszowickich liberatów - daleko do ideału Księgi, do którego zbliża się literatura totalna ${ }^{712}$. Analizy relacji między tymi trzema pojęciami nie mogłoby zabraknać w moich rozważaniach. Czas odpowiedzieć na pytanie: czym tak bardzo różni się książka artystyczna od liberackiej, skoro i podobne sa na pierwszy rzut oka, i obie rodzą się ze sprzeciwu wobec konwencjonalnej formy książki? Co takiego jest też w tej ostatniej, że nie zadowala niektórych twórców i skłania ich ku poszukiwaniu nowych środków wyrazu?

Już na początku chciałabym zaznaczyć, że w odniesieniu do kwestii książki artystycznej główni teoretycy liberatury skrupulatnie opracowali temat „różnic i podobieństw”. Istotne wydaje mi się jednak nie tylko zreferowanie ich tez, lecz również wskazanie ewolucji tych poglądów, a także zanalizowanie przyczyn różnych myślowych zwrotów. Dlatego punktem wyjścia są dla mnie uwagi formułowane przez twórców w pierwszych szkicach (określam je jako pierwszą fazę refleksji), zaś punktem dojścia korekty, rozwinięcia i uzupełnienia zawarte w esejach pisanych podczas realizacji projektu Kolekcja POLSKA KSIAZŻKA ARTYSTYCZNA Z PRZEEOMU XX I XXI WIEKU ${ }^{713}$ (określone przeze mnie jako faza druga).

\subsection{Zgodny głos sprzeciwu i dwa różne rozwiązania}

Skąd w ogóle wziął się sprzeciw wobec książki konwencjonalnej, którego pokłosiem sa książki artystyczne i liberackie? Tak zwana „zwykła” książka na drodze wielowiekowego rozwoju ${ }^{714}$ przybierała kształty coraz to poręczniejsze, łatwiejsze w produkcji i rozpowszechnianiu. Stworzona właśnie po to, by ułatwić przekazywanie idei - dążyła do tego, by stać się nośnikiem jak najbardziej poręcznym. Jak zwraca uwagę Robert Escarpit, o ile wynalazek pisma pomógł zwalczyć ograniczenia czasu (pozwalając utrwalić idee), wymyślenie książki - jako sposobu utrwalenia tegoż pisma - pozwoliło pokonać ograniczenia prze-

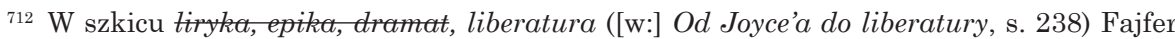
stwierdzał: „Liberatura to być może nic innego, jak pisanie Księgi, której nie udało się stworzyć Mallarmému”. O bliskości teorii francuskiego artysty i liberackiego rozumienia kategorii książki zob. równiez: Zenon Fajfer, Katarzyna Bazarnik, Dwa rzuty kośćmi czyli szczególna i ogólna teoria liberatury.

${ }_{713}$ Szkice: Katarzyna Bazarnik, Kilka uwag o liberaturze i ksiażce artystycznej (2009) oraz Zenon Fajfer, Jak liberatura redefiniuje ksiażkę artystyczna. Oba teksty przed publikacją udostępnili mi autorzy i za ich zgodą je wykorzystuję. Obszerne fragmenty szkicu Fajfera zostały też opublikowane w LCLT (s. 134-140). Trudno rozpatrywać te artykuły w oderwaniu od siebie, jako że Fajfer sam powołuje się na tekst Bazarnik. Stąd, referując tezy autorów, odwołuję się do obu esejów. Informację o tym, że teksty są przyjęte do planowanej publikacji można znaleźć na stronie http://www.kolekcja.bookart.pl/strony/lista\%20_artykulow/ [dostęp 20.09.2011].

${ }^{714}$ Poszczególne fazy przemiany kształtu książki, dzięki którym od pierwszych zwojów, poprzez kolejne formy kodeksów doszliśmy aż do popularnej, taniej formy książki masowej, sprawnie opisuje Robert Escarpit (zob. Robert Escarpit, Zarys historyczny, [w:] idem, Rewolucja ksia $\dot{z} k i$, Warszawa 1969, s. 13-31). Odnośnie do historii książki zob. też rozdział o związkach liberatury z typografią i drukiem (oraz podana tam bibliografia). 
strzeni, dając idei pełne prawo krążenia wśród ludzi, oferując jej całkowicie transportowalny nośnik ${ }^{715}$. Jak podsumowuje badacz: „książka, przynajmniej w teorii, pozwoliła [...] zwracać się do całej ludzkości”"16.

Tym samym, rzeczywiście, musiała mieć formę możliwie najbardziej wygodna i przezroczysta. Po wynalezieniu druku, wkroczyła na ten etap swojego rozwoju, w którym - jak ujmuje to Anna Olszewska - „przestaje być skarbem, staje się narzędziem"717. Powstające książki zyskują formę coraz bardziej ujednolicona, zaś przemiany, jakim podlegaja, prowadzą ku coraz większemu sfunkcjonalizowaniu. Trzeba jednak pamiętać, że nie są to (zwłaszcza od momentu ustalenia kodeksowej formy) przeobrażenia drastyczne. Jak zwraca uwagę Janusz Dunin, ważna na tej drodze jest ponadczasowa czytelność konwencji: utrwalony przez wieki kształt książki pozostaje czytelny dla odbiorców i - oswajani od początku edukacji z klasyczna, ukształtowaną przez długą tradycję formą - nie napotykają oni na trudności w lekturze.

Potrafimy bez dodatkowych instrukcji sięgnąć po książkę z przed lat. Nie przeżywamy związanego z nią szoku przyszłości, jaki uniemożliwia wielu już w pełni ukształtowanym ludziom korzystanie z różnych nowinek technicznych ${ }^{718}$.

Nie muszę chyba dodawać, że zupełnie inaczej jest w przypadku liberatury czy książki artystycznej, gdzie takich wskazówek czasem wręcz potrzebujemy.

Przypomnę, że za kluczowe w rozwoju kodeksów takich pomocniczych wyjaśnień niewymagających, uznaje się też tzw. dwie rewolucje, które przeszła książka w XX w. Pierwsza z nich była związana z technicznym postępem poligrafii, druga zaś z rozwojem technologii nowomedialnych (nowych technik informacyjnych) ${ }^{719}$. To dzięki nim książka stawała się coraz wygodniejszym, nieprzyciagającym niepotrzebnie uwagi odbiorcy pojemnikiem na tekst. Jak podsumowuje Escarpit: „epoka nasza [...] przywraca książce jej prawdziwe znaczenie, które polega na tym, by była ona nie pomnikiem, lecz środkiem przekazu"720. Nie jest dziełem sztuki, lecz wręcz - jak zgrabnie formułuje to przywołany badacz - „maszyną do czytania”"21.

715 Por. R. Escarpit, Rewolucja ksiażki, s. 14-15.

${ }^{716}$ Ibidem, s. 15.

717 Anna Olszewska, Ksią̇̇a konwencjonalna i ksiażka artystyczna, „Plastyka i Wychowanie" 1999, nr 5, s. 44.

718 Janusz Dunin, Ksiażka na miarę człowieka, Łódź 1989, s. 12.

719 Por. Andrzej Kłossowski, Ze spotkania z Umberto Eco, [w:] Sztuka ksiażki. Współczesna polska sztuka ksiażki. Ksiażka artystyczna (katalog, edycja VI), Warszawa 2000. Sformułowanie rewolucja ksiażki pochodzi oczywiście od tytułu pracy Escarpita. Pogłębienie jego refleksji w kontekście współczesnego rozwoju technik informacyjnych zaowocowało kategorią tzw. drugiej rewolucji ksiażki, która to z kolei stała się tytułem kolejnego opracowania: poświęconej współczesnym problemom ksiażek pozycji Druga rewolucja ksiażki zredagowanej przez Violettę Trellę, jako tom zbierający referaty wygłoszone na ogólnopolskiej interdyscyplinarnej konferencji naukowej, towarzyszącej wystawie Druga rewolucja ksiażki w Gdyni (7-25 stycznia 2008). W tomie tym pojawia się zresztą szkic Bazarnik dotyczący liberatury (K. Bazarnik, Liberatura, czyli literatura w formie ksiażki, s. 20-27).

${ }^{720}$ R. Escarpit, Rewolucja ksiażki, s. 10 .

721 Ibidem, s. 13. 
I właśnie w opozycji do tak ukształtowanej formy książki zrodziła się (wcześniej niż pomysł na liberaturę) idea książki artystycznej. Jak pisze Piotr Rypson, tego typu utwory sa „,zęścią swoistej rewolty przeciwko produkcji masowej, sprowadzającej książkę rzeczywiście do funkcji pojemnika tekstu"722. Sprzeciw artystów wobec postrzegania materii książki jako nieznaczącej, niekomunikującej i nieestetycznej rzeczywiście przypomina, jak łatwo zauważyć, głosy liberatów. Jedni i drudzy bowiem nie zgadzali się na to, by traktować książki wyłącznie jako wygodne nośniki idei. Żądali, by zaczać dostrzegać także i same woluminy. Stąd wydawać by się mogło, że i na poziomie rozważań teoretycznych zjawiska te sa pokrewne (o ile nie identyczne).

Niemniej, jak pisałam, zdaniem twórców i teoretyków literatury totalnej przynajmniej w początkowej fazie refleksji - mimo wspólnego punktu wyjścia, niewiele je łączy. Dlaczego? Andrzej Kłoskowski, opisując narodziny książki artystycznej, stwierdzał:

W latach sześćdziesiątych XX w., jako owoc awangardowych ruchów, pojawiła się książka, „która sama w sobie jest dziełem, a nie środkiem upowszechniania dzieła” (Anne Moeglin-Delcroix). - Dodawał jednak - Nośnik przekazu stał się więc dla artystów celem samym w sobie, który - w ostateczności - może się obyć bez tekstu. [...] W tej zazwyczaj niepowtarzalnej postaci książka jest spokrewniona z rzeźbą, a atrakcyjny jej kształt dostarcza tylko artyście formy i pretekstu oraz - ale już nie zawsze - materiału ${ }^{723}$.

Choć więc twórcy obu grup sprzeciwiali się temu samemu, wybierali inne rozwiązania końcowe. Mówiąc najprościej: liberaci pragnęli, by do wartości, jakie miała książka (rozumiana jako utwór literacki), dodać te, które przynosi jej forma. Dla twórców książki artystycznej idee, jakie niesie w sobie zawarty w tomie tekst artystyczny, mogły być zupełnie nieistotne. Oni pożądali zmiany zdecydowanie bardziej drastycznej - z jednej skrajności ku drugiej: od tekstu w nieistotnym opakowaniu ku artystycznie cennemu opakowaniu dla nieistotnych treści. Stąd w ich pracach może w ogóle brakować słów, nie muszą być czytane. Dlatego też lepszym miejscem dla takich dzieł wydaje się sala wystawiennicza, półka w galerii czy muzeum, nie zaś „zwykła” biblioteczka, a tym bardziej zapełniony książkami regał literaturoznawcy, człowieka który miałby pełne prawo czuć się w tym wypadku zwolniony z obowiązku czytania. Regał ten - przypomnę - jest jednak doskonałym miejscem dla dzieł liberackich, które o lekturę się dopominają i których twórcy po wielokroć podkreślaja, że tworzą literaturę. Opisuje ten problem również Bazarnik:

${ }_{722}$ Piotr Rypson, Ksiażki i strony. Polska ksią̇̇ka awangardowa i artystyczna 1919-1992, Warszawa 1992, s. 62.

${ }^{723}$ A. Kłossowski, Ze spotkania z Umberto Eco, s. 22-23; cyt. za: Nauka o ksiażce. Antologia tekstów, red. Dariusz Kuźmina, Marek Tobera, Warszawa 2006, s. 233. Rafał Jakubowicz podkreśla, że nowe spojrzenie na książkę, dostrzeżenie w niej interesującego dla artysty obiektu wiązało się z narodzinami sztuki konceptualnej. Zob. Rafał Jakubowicz, Sztuka ksią̇ki. Odsłona trzecia, „Exit” 2000, nr 4, s. 2352-2357, dostępny również na stronie: http://free.art.pl/wilmanski/ teksty/5_pl.htm [dostęp 26.09.2011]. 
Mówiąc o książce artystycznej, myślimy zasadniczo o sferze sztuk plastycznych, wizualnych czy przestrzennych. Jak zauważyła Alicja Kępińska, książka postrzegana jest tutaj jako „obiekt sam w sobie, jako rzecz autoreferencyjna”, a nie „jako pojemnik dla określonych treści”, dodajmy: wyrażonych za pomocą tekstu [...]. Obiekt tego typu, choć często wygląda jak wolumin, choć może składać się z kartek i okładek, nie jest utworem literackim. Nie jest, jak to się potocznie określa, książką - książką do czytania (w tradycyjnym znaczeniu tego słowa: jako śledzenia dyskursu), „zawierająca tekst słowny utrwalony w znakach graficznych i służącą przekazywaniu i rozpowszechnianiu wszelkiego rodzaju powiadomień".

Kontekst galerii sprawia, że odbiorca postrzega owe „książkopodobne” obiekty zasadniczo jako dzieła sztuki wizualnej, a więc przedmioty służące przede wszystkim do oglądania $^{724}$.

Zatem - należałoby przy okazji wskazać na jeszcze jedną sugerowaną przez liberatów cechę różnicującą zestawiane tu zjawiska: deklarowaną przynależność artystyczną twórcy utworu. Jeśli postrzega siebie jako plastyka, trudno by podchodził do tekstu będącego elementem jego dzieła niczym literat. Jeśli przedstawia się jako ten ostatni, zainteresowanie formą tworzonego tekstu czyni go liberatem ${ }^{725}$.

Takie obserwacje można uznać za wyjściowe do mówienia o związach liberatury i książki artystycznej. Zasadniczym trzonem pierwszej fazy rozważań Fajfera i Bazarnik na ten temat było uznanie, że wspomniane zjawiska różnicuje rodzaj relacji między samą książka a zawartym w niej tekstem. W liberaturze - jako sztuce słowa - jest on elementem niezbędnym i, co więcej: dyktuje kształt książki. Tym samym - jak ujmuje to Bazarnik - wszelkie odstępstwa od „normy” (konwencjonalnego kształtu tomu) maja „przyczyny literackie"726. Zatem, jeśli liberatura to dzieło w postaci książki-przedmiotu, to jest to jednak przedmiot do czytania. Zaś w przypadku książki artystycznej to z kolei książka (rozumiana właśnie jako: przedmiot, obiekt, idea) jest nadrzędna, tekst wręcz nie jest konieczny. Taki układ akcentów, zdaniem liberatów, wiąże się zaś z tym, że omawiana forma przynależy do obszaru sztuki książki ${ }^{727}$, a tym samym do działu sztuk wizualnych (bądź też jego pogranicza z przestrzenia

${ }^{724}$ Katarzyna Bazarnik, Liberatura, czyli literatura $w$ formie ksiażki, [w:] DRK, s. 24. Przywołany szkic należałoby zaliczyć już do drugiej fazy rozważań, niemniej kwestie, do których odwołuje się cytowany tu fragment, powtarzane były na obu etapach dyskusji.

${ }^{725}$ Zob. też ibidem.

${ }^{726}$ Katarzyna Bazarnik, Krótkie wprowadzenie do liberatury, s. 134. W innym szkicu badaczka podkreśla, że tekst jest „PRE-TEKSTEM dla kształtu i typografii książki”, że jej forma od niego zależy i z niego wynika (K. Bazarnik, Liberatura, czyli literatura $w$ formie ksiażki, s. 25). Nie zgadzam się jednak z wyrażonym w tym szkicu sądem Bazarnik, że owo decydowanie o kształcie książki czyni tekst składnikiem nadrzędnym wobec innych. W książce będącej efektem końcowym, wszystkie elementy sa, moim zdaniem, równie ważne, wzajemnie się dopełniają i określaja. Sądzę również, że tym, co warunkuje kształt materialny liberackiej książki jest bardziej idea w tekście zapisana niż sam ten tekst (sformułowanie „tekst” zakłada już jakąś jego konkretną materialność).

${ }_{727}$ Termin ten jest bardzo nieprecyzyjny, w dalszej części rozdziału wskazuję na możliwe rozumienia i konsekwencje, jakie wynikają z przyjęcia każdego z nich. Tu pozwolę sobie pozostawić go bez szerszego komentarza, gdyż na etapie formułowania teorii liberatury, który tu przywołuję, tak właśnie traktowali go Fajfer i Bazarnik. 
literacka $)^{728}$. Stąd Fajfer i Bazarnik dopatrują się istoty poszukiwanej różnicy właśnie w - jak to nazywaja - „stosunku do tekstu”:

W książce artystycznej tekst podporządkowany jest książce, w liberaturze książka podporządkowana jest tekstowi. W obu sytuacjach dziełem jest książka, lecz stosunek do tekstu sprawia, że w pierwszym przypadku mamy do czynienia z rodzajem bliższym rzeźbie (książka-obiekt), w którym słowo jest nie tylko jednym z wielu równoważnych elementów dzieła, w drugim natomiast z literaturą anektującą do swojego terytorium fizyczny obszar książki ${ }^{729}$.

Mówiąc innymi słowy, w omawianym tu pierwszym etapie formułowania teorii literatury totalnej, (liberacki) problem z książką artystyczną polegał na tym, że często nie jest ona stworzona po to, by ją czytać. I nie mam tu na myśli bynajmniej tego, że może być zwyczajnie niewygodna w lekturze (za duża, trudna do utrzymania w dłoni czy nawet samego otwarcia, niekształtna itp.) - co nie zawsze przecież odróżniałoby ją od nieraz nad wyraz nieporęcznych czy skomplikowanych w obsłudze tomów literatury totalnej - lecz to, że jej autorzy projektuja ja jako dzieło sztuki: przedmiot, obiekt, coś do wizualnej (bądź - jeśli pozwolą na to warunki - również taktylnej) kontemplacji. Takie utwory rządzą się własnymi prawami i stanowią jak tłumaczy Piotr Rypson, „rozdział osobny w [...] książkowym świecie”. Jak trafnie podsumowuje badacz, „książka - służąc sama sobie - staje się w tym wypadku też sama dla siebie pretekstem" ${ }^{330}$. Doskonale opisuje to zagadnienie również Dorota Folga-Januszewska, stwierdzając:

Tradycyjna nowożytna książka, to przedmiot złożony ze zszytych kart, mający początek i koniec, okładkę przednią i tylną. Taka książka służy poecie i pisarzowi, uczonemu i innym uczonym, ona tylko niesie, a nie stanowi. Od tej usłużnej użyteczności odcina się książka artystyczna, tworzona jest by być, a nie przekazywać, by soba zastanawiać, a może nawet zachwycać. Bez względu na to, czy charakteryzuje się wyrafinowaną estetyka, czy jest siermiężna i szorstka, czy jest tworzeniem, czy niszczeniem, ambicją jej twórcy jest stworzyć dzieło dla niego samego, nie zaś dla kogoś, kto chciałby swoją myśl ubrać w graficzną formę. Tym zapewne książka artystyczna różni się od książki pięknie ilustrowanej i pięknie projektowanej. W tej ostatniej - w tradycyjnym połączeniu ilustracji i formy książkowej tkwi najwyższa postać służebności wobec treści.

${ }^{728}$ Bazarnik stwierdza, że książka artystyczna ,jest zjawiskiem bliższym sztukom plastycznym niż literaturze (może z wyjątkiem tak zwanych «bookworks», znajdujących się dokładnie na styku obu dziedzin)" (K. Bazarnik, Dlaczego od Joyce'a do liberatury (zamiast wstepu), [w:] Od Joyce'a do liberatury, s. V). Warto jednak podkreślić, że ani Clive Phillpot, do którego się tu Bazarnik odwołuje, przywołując termin bookworks, ani Piotr Rypson (za którym go przywołuje) nie sytuują owej formy na styku sztuk plastycznych i literatury, lecz sztuki i formy książkowej. Wrócę jeszcze do tego problemu w dalszej części rozdziału. Por. też: Clive Phillpot, Books book objects bookworks artists' books, „Artforum” 1982, nr 9, s. 77-79 oraz P. Rypson, Ksiażki i strony..., s. 8.

${ }^{729}$ Z. Fajfer, Nie(o)pisanie liberatury, s. 61. Niechętnie o kategorii książki artystycznej jako terminie wskazującym na domenę sztuk plastycznych wypowiadał się też Nowakowski (por. Traktat kartkograficzny..., s. 113). Artysta-teoretyk zwracał też uwagę na to, że jego książki są w większym niż książka artystyczna stopniu nastawione na czytanie (R. Nowakowski, Dlaczego moje ksiażki sq takie jakie sa, s. 230-231)

${ }_{730}$ Piotr Rypson, Sztuka ksiażki, http://free.art.pl/wilmanski/teksty/17_pl.htm [dostęp 20.08.2011]. 
Książka artystyczna jest samolubem, jak każde dzieło sztuki niestosowanej. Jest treścią samą w sobie [...] Sama siebie ilustruje i o sobie opowiada, stając się symbolem ${ }^{731}$.

I rzeczywiście, choć liberaturę i książkę artystyczną łączy fakt, że ich tworzywem nie muszą być wyłącznie kartki papieru i pismo, lecz dowolny wybrany przez autora material ${ }^{732}$, różni je to, do czego mają służyć swemu odbiorcy. Stąd liberaci, zamiast organizować kolejne wystawy książek niekonwencjonalnych, założyli Czytelnię Liberatury, pragnąc stworzyć właściwa przestrzeń odbiorczą dla swoich dzieł ${ }^{733}$. Jeśli teoretycy zjawiska decydują się na pokazanie podczas różnego rodzaju spotkań utworów stanowiących przykłady literatury totalnej, starają się (w miarę możliwości) dbać także i o to, by prezentacja ta nie przybrała charakteru „wystawki”, na której nie będzie można nawet dotknąć pokazywanych książek.

Przykładowo - w trakcie przygotowań do spotkania w Kawiarni Literackiej Teatru Nowego w Łodzi ${ }^{734}$ prosili, aby najważniejsze z przywiezionych przez nich pozycji udostępnione były w taki sposób, by zachęcić przybyłych do czytania, nie wyłącznie do oglądania z daleka. Przychodzący powinni mieć ochotę usiaśś i poczytać, nie: stanać i popatrzeć. Zgodnie z pomysłem Fajfera i Bazarnik pojedyncze egzemplarze miały być ułożone na stolikach, przy których powinno też znajdować się wygodne krzesło. Co więcej, ten, kto chciałby się w nim zagłębić w lekturze miał móc nawet - w razie potrzeby - zapalić specjalnie w tym celu przygotowaną lampkę. W przypadku książek artystycznych, zabiegi takie byłyby potrzebne tylko, jeśli urosłyby do rangi fragmentu autorskiego projektu dzieła. Normalnie, wystarczyłby w ich przypadku kawałek przestrzeni odpowiedniej do wyeksponowania przedmiotu ${ }^{735}$. Dla nich nie trzeba aranżować przestrzeni - powiedzmy - czytelniczej. Jak zauważał Janusz Dunin po latach obcowania z księgami różnego rodzaju:

731 Dorota Folga-Januszewska, Ksiażka ilustrowana czy ksiażka artystyczna?, [w:] Wspótczesna polska sztuka ksiażki, Warszawa 1998, s. 8-9 (cyt. za: Nauka o ksiażce. Antologia tekstów, s. 231). Warto podkreślić, że badaczka wskazuje na różnice między terminami, które Bazarnik traktuje - na tym etapie refleksji - jako synonimy. Sugerowane przez Folgę-Januszewską rozróżnienia użyteczne będą w dalszych moich rozważaniach (choć nie pokuszę się o skrupulatne rekonstruowanie wszystkich związanych z tematem książki artystycznej i sztuki książki terminów, gdyż zadanie to - wcale zresztą nie takie łatwe - przekracza znacznie zakres tej pracy). Ciekawie o samozwrotności (jak inaczej można by określić owo „samolubstwo”) książki artystycznej pisze też Johanna Drucker analizująca ją na poziomie zarówno pojedynczych elementów (wykorzystanie konwencji aranżacji strony czy odwołania do typowego układu wizualnego), jak i ogólnej idei książki jako całości (konkretnego układu elementów, określonej struktury) czy - jeszcze szerzej procesu jej produkcji-kreacji. Zob. Johanna Drucker, Self-Reflexity in Book Form, [w:] eadem, The Century of Artists’ Books, New York 2004, s. 161-196.

732 Por. A. Olszewska, Ksiażka konwencjonalna i ksiażka artystyczna, s. 48.

${ }^{733}$ O Czytelni Liberatury pisałam w pierwszej części tej książki.

${ }^{734}$ Spotkanie odbyło się w październiku 2008 r. i miałam przyjemność je prowadzić. Uczestniczyłam również w jego przygotowywaniu, stąd czerpię przywołane informacje.

${ }^{735}$ Zainteresowanych problemem eksponowania książki (nie tylko artystycznej) warto odesłać do szkicu Małgorzaty Komzy Muzea sztuki ksią̇ki, [w:] Sztuka ksią̇ki. Historia-teoria-praktyka, red. eadem, Wrocław 2003, s. 255-268. 
Jako bibliolog zajmujący się różnymi rodzajami publikacji interesowałem się również drukami artystycznymi i eksperymentalnymi o wielkich walorach estetycznych, należącymi do wielkiej sztuki [...]. Ale jako badacz czytelnictwa wiedziałem, że nie są one w istocie przeznaczone do czytania, stanowią pomniki postawione na cześć ich twórców, aby trwały na półkach bibliotek i w gablotach muzeów ${ }^{736}$.

Można by zatem powiedzieć, że - wbrew pozorom - literatura totalna i książka artystyczna są nie tyle podobne, co właśnie diametralnie różne. Jedne do czytania - drugie do oglądania. Jedne - samolubne, wsobne, pokazujące tylko swą formę, drugie - prezentujące (oprócz niej) także swe wnętrze, otwarte na czytelniczą interakcję. Liberaci skrupulatnie wypunktowują różnice. Ale czy teoretyczne deklaracje artystów książki również poprowadziłyby nas w kierunku rozdzielania tych typów sztuki?

\subsection{O artystycznym i liberackim „robieniu książek”}

Postawione pytanie nie jest bezzasadne, gdyż okazuje się, że manifesty twórców książki artystycznej mogą trochę skomplikować sprawę. Nieuważnie (lub fragmentarycznie) przeczytane zdają się sugerować istotne podobieństwa omawianych zjawisk. Podobnie jak jednym okiem obejrzane (i wyłącznie obejrzane) książki liberackie i artystyczne wydają się należeć do tego samego obszaru sztuki. By unaocznić, w czym tkwi problem, chciałabym przywołać Ulisesa Carrióna i fragmenty jego Nowej sztuki robienia ksiażek publikowanej w Second Thoughts ${ }^{737}$. Prześledzenie punktów zbieżnych i spornych między jego wywodem a myślą polskich liberatów pozwoli, jak sądzę, nie tylko uchwycić istotę owego pozornego podobieństwa, ale i naświetlić jeszcze jeden aspekt porównania dwóch interesujących mnie tu form sztuki ${ }^{738}$.

Inspirujacy do rozważań i zestawień jest już sam tytuł przywołanej pracy. Jeśli mamy w pamięci Traktat kartkograficzny... Nowakowskiego, wydawać by się mogło, że zarówno twórca książek artystycznych, jak i liberat „robią książki”. A jednak okazuje się, że nic bardziej mylnego. I być może niebezzasadnie Fajfer uragał na formułowaną przez Nowakowskiego definicję liberatury i tłumaczył, że powtarzana w przywołanym Traktacie... fraza „liberatura to robienie książek" jest zgrabna, jednak niekoniecznie w pełni trafna ${ }^{739}$. Pod-

${ }^{736}$ Jacek Ladorucki, Pozostawałem $w$ kręgu ksiażki... Rozmowy z profesorem Januszem Duninem o bibliologii, medioznawstwie i zwyczajnym życiu, Łódź 2007, s. 55.

${ }^{737}$ Korzystam z polskiego przekładu fragmentów: Ulises Carrión, Nowa sztuka robienia ksiażek. Z wystawy w Galerii „Remont”, „Linia. Jednodniówka warszawskiego środowiska studenckiego", luty-marzec 1977, s. 8-10 (w cytatach nie zachowuję układu typograficznego).

${ }^{738}$ Przywołując Carrióna, mam świadomość, że w kontekście książki artystycznej - zważywszy na mnogość jej ujęć - trudno byłoby wybrać teoretyka reprezentatywnego. Stąd staram się być ostrożna przy uogólnianiu wyciagniętych z porównania wniosków.

${ }^{739}$ Zob. Zenon Fajfer, Jak liberatura redefiniuje ksiażkę artystycznq. Uwagi na marginesie projektu „Kolekcja POLSKA KSIĄŻKA ARTYSTYCZNA PRZEEOMU XX I XXI WIEKU” (fragment), [w:] LCLT, s. 134-140. 
kreślał, że proponowane przez autora cyklu Nieopisanie świata podejście każe patrzeć na liberaturę niczym na ideę tworzenia książki jako czegoś niemal zewnętrznego w stosunku do tekstu, który ma ona zawierać. Tym samym - jak zauważa Fajfer - literatura totalna stawałaby się synonimem sztuki książki ${ }^{740}$ i okazywałaby się niepotrzebna.

Nie chodziło mi o sztukę „robienia książki” [...] - wyznaje artysta-teoretyk - Myślę, że jest to istotne na obszarze książki artystycznej, ale nie w liberaturze. Liberatura bowiem, ujmując rzecz metaforycznie i dosłownie zarazem, to sztuka PISANIA KSIĄŻKI. Pisania czyli wymyślania. Nie tylko samego tekstu, ale właśnie książki ${ }^{741}$.

I tu zdaje się tkwić istota problemu. Dla liberatów pojęcia książki i tekstu są nierozerwalnie ze sobą związane, tak jak tekst literacki z materia, na której jest utrwalony. Nie można powiedzieć prosto, że literat pisze teksty, zaś liberat robi książki (jak zdaje się sugerować Nowakowski). On - jak mówi Fajfer - książki pisze. A z kolei u Ulisesa Carrióna przeczytamy:

Pisarz w przeciwieństwie do ogólnego mniemania, nie pisze książek. Pisarz pisze teksty. Fakt, że tekst jest zawarty w książce wynika jedynie z rozmiarów takiego tekstu, lub w przypadku szeregu krótkich tekstów (np. wierszy), z ich liczby.

*

Tekst literacki (proza) zawarty w książce ignoruje fakt, że książka jest autonomiczną sekwencją czaso-przestrzenną [...]

Początkowo książki istniały jako pojemniki na teksty (literackie) [...]

Książka może być dowolnym pojemnikiem tekstu, którego struktura nie jest logicznie związana z książką: takie są książki z księgarń i bibliotek. Książka może istnieć również jako autonomiczna i samowystarczalna forma, może ona zawierać tekst, który podkreśla tę formę, tekst który jest organiczną częścią tej formy: tu właśnie zaczyna się nowa sztuka robienia książek.

*

W starej sztuce pisarz pisze teksty. W nowej sztuce pisarz robi książki ${ }^{742}$.

Czy zatem jednak „robienie książek” nie może być bliskie liberaturze? Innymi słowy - czy Carrión nie mówi o podobnych kwestiach, co twórcy literatury totalnej? W odniesieniu do obu typów dzieł kategoria tomu jako „nośnika” przestaje być zasadna. Książka nie służy tu wyłącznie przenoszeniu znaczeń, sama zyskuje głos (co zresztą współcześnie, w erze dyskursu postmcluhanowskiego nie powinno dziwić). A, jak mówił Fajfer, i w liberaturze:

${ }^{740}$ To jeden z momentów, w których w dyskursie Fajfera i Bazarnik pojawiają się istotne dla moich dalszych rozważań nieścisłości terminologiczne. O ile bowiem w dotychczas przywoływanych fragmentach sztuka książki rozumiana była jako synonimiczne określenie książki artystycznej (lub termin o nieco szerszym, lecz podobnym zasięgu), tu traktowana jest jako sposób artystycznego opracowania tekstu, funkcjonalnego jego opracowania, stąd bliska rozumieniu, jakie znajdziemy u Wolii Nikołajewicza Lachowa w jego Szkicach z teorii sztuki ksiażki (tłum. Bożena Chrzanowska-Sokołowska, Krystyna Gieda, Małgorzata Komza, Grażyna Talar, Wrocław 1978, zob. szczególnie s. 13-15).

${ }^{741}$ Z. Fajfer, Jak liberatura redefiniuje ksiażkę artystyczna..., s. 137.

${ }^{742}$ U. Carrión, Nowa sztuka robienia ksiażek..., s. 8 (podkreślenie autora). 
Pojęcie nośnika właściwie straciło sens. Książka (liber) jest częścią dzieła, jej fizyczny kształt i budowa stanowi jego integralną częśśc ${ }^{743}$.

Jednak wbrew pozornym zbieżnościom, musimy pamiętać, że kiedy książka jest „robiona”, tak jak rozumie to Carrión i twórcy mu podobni, słowo przestaje (lub może przestać) w niej znaczyć. Może zginąć, bo nie jest już istotne. Stąd, choć z przywołanymi powyżej tezami Carrióna liberat by się zgodził, nie przytaknałby dalszym konstatacjom meksykańskiego artysty. Ten bowiem wyraźnie stwierdza, że tekst jest wyłącznie jednym z elementów książki i to wcale nie najważniejszym. A dla liberatów dyktuje on przecież jej kształt, co więcej - jest, przypomnę, nieodzowny.

Dla Carrióna słowa zawarte w książce nie muszą być napisane przez jej autora, moga być wypowiedzią cudza, użytą tu wyłącznie jako materiał (do dalszego opracowania), gdyż - jak zapewne zwróciliby uwagę liberaci - nie jest on literatem, lecz artystą sztuk wizualnych. Jednak, czy problem tkwi w tym, że twórca, o jakim mówi Carrión, „pisze mało lub nie pisze wcale” ${ }^{\text {"44 }}$ ? Nie kluczowy jest fakt, że to, co pozostaje napisane niekoniecznie jest istotne. Najważniejsza w ujęciu proponowanym przez autora Nowej sztuki robienia ksia$\dot{z} e k$ jest książka jako materialna struktura i to ona powinna być przedmiotem namysłu odbiorcy. Dla liberatów dopełnia ona treści książki, na równi z tekstem je współtworzy - dla twórców książki artystycznej może je przesłaniać.

Zatem, gdy uważniej przeczytać manifest Carrióna, znów okaże się, że choć jedni i drudzy dostrzegają w książce przedmiot, wyciagają z tej obserwacji inne wnioski. Bazarnik podkreśla, że ważna jest świadomość, iż kwestia budowy i wyglądu owego przedmiotu „nie jest bez znaczenia dla przekazywanych treści” ${ }^{\prime 25}$, Carrión zaś wychodzi z założenia, że celem odbiorcy ma być tego przedmiotu zauważenie. W konsekwencji, jak stwierdza, nowych książek nie trzeba już jak trzeba było dawniej i jak należy w przypadku liberatury - czytać w całości:

W nowej sztuce często NIE trzeba przeczytać całej książki. Czytanie można przerwać w momencie zrozumienia całkowitej struktury książki ${ }^{746}$.

Ze względu więc na stosunek do tekstu (pozwolę sobie użyć sformułowania Bazarnik) czytanie „nowych ksiażek” jest zupełnie inne niż czytanie liberatury. Tylko to drugie jest czytaniem literackim. I choć formułowane przez teoretyków książki artystycznej postulaty mogą się wydawać nawet i bardzo bliskie liberaturze (choćby właśnie mówić też o nowym rodzaju czytania), różnica między nimi wydaje się jednak ogromna.

Zatem teoria, podobnie jak praktyka, łudzi nas podobieństwami i bliskościa które są wyłącznie pozorne. Choć przyznać trzeba (i warto mieć w pamięci), że gdy śledzimy niektóre wypowiedzi różnice te wydają się niezauważalne.

\footnotetext{
${ }^{743}$ Z. Fajfer, Liberatura: hiperksiega w epoce hipertekstu, s. -8 (paginacja ujemna).

${ }^{744}$ U. Carrión, Nowa sztuka robienia ksiażek..., s. 9.

${ }^{745}$ K. Bazarnik, Dlaczego od Joyce'a do liberatury (zamiast wstepu), s. V.

${ }^{746}$ U. Carrión, Nowa sztuka robienia ksiażek..., s. 10.
} 
W przypadku ostatniego fragmentu manifestu Carrióna, który chciałabym przywołać, nie widać ich przecież wcale:

Aby czytać starą sztukę wystarczy znać alfabet - stwierdza, niczym prawdziwy liberat, ów meksykański artysta książki. - Aby czytać nową sztukę należy rozumieć książkę jako strukturę, identyfikując jej elementy i rozumiejąc ich funkcję. W starej sztuce wszystkie książki czyta się w ten sam sposób. W nowej sztuce każda książka wymaga odmiennego sposobu czytania ${ }^{747}$.

Jak wygląda „inne” czytanie liberatury? Można powiedzieć, że jego istota wynika nie tylko z tego, że w tym wypadku kształt książki dodaje znaczenia do znaczeń tekstu (takie ujęcie byłoby pewnym uproszczeniem), lecz z tego, iż pełnia tych znaczeń rozpisana jest między przestrzenia tekstu i jego formy, których - by zrozumieć komunikat - nie możemy rozdzielać. Za każdym razem jest to więc lektura inna, gdyż trzeba odkrywać nowe sposoby czytania, właściwe tej konkretnej strukturze, którą mamy w ręku. Zgoła odmienne to mimo wszystko od sytuacji książki artystycznej. W jej przypadku nie musimy mieć do czynienia z relacją treści przekazywanych przez różne kody, gdyż właściwy komunikat sformułowany jest w języku sztuk wizualnych i może zupełnie przesłaniać to, co przekazane słowem (choć i tu za każdym razem będziemy szukać odpowiedniego sposobu lektury). Dlatego te książki można, zgodnie z wskazaniem Carrióna, czytać inaczej - nie doczytując. I, paradoksalnie, będzie to lektura poprawna. A w liberaturze, jak mówi Bazarnik:

Chodzi [...] o świadome wykorzystanie materialności litery, słowa, zdania i przestrzeni książki, o umiejętne użycie innych elementów graficznych lub rezygnację z nich, o integralność tekstu i obrazu, który nie tyle ilustruje, co komentuje i uzupełnia tekst [...] Słowem, chodzi o to, że wszystkie składniki książki są - w mniejszym lub większym stopniu - znaczące, a warstwa graficzna staje się nie mniej istotna niż fonetyczna - obie współtworza warstwę semantyczną utworu ${ }^{748}$.

I w tym wypadku też żadnej z nich nie można niedoczytać. Zatem liberatura i książka artystyczna to zdecydowanie nie to samo.

\subsection{Odnaleziona przestrzeń wspólna}

Prześledziliśmy tok rozumowania charakterystyczny dla pierwszej fazy refleksji nad związkami liberatury i książki artystycznej. Mówiąc najkrócej i podsumowując dotychczasowe ustalenia: wspólny punkt wyjścia, jakim jest odrzucenie pojmowania książki jako wyłącznie funkcjonalnego nośnika tekstu literackiego, nie poprowadził artystów obu frakcji ku podobnym rozwiązaniom ani w obszarze praktyk, ani teoretycznych dywagacji. Choć więc mylą nas nieraz niektóre sformułowania artystów książki (sugerujące, że mają na myśli to

\footnotetext{
747 Ibidem.

${ }^{748}$ K. Bazarnik, Dlaczego od Joyce'a do liberatury (zamiast wstepu), s. VI.
} 
samo, co i twórcy literatury totalnej) czy dziwny, niekonwencjonalny wygląd wybranych utworów liberackich (prowokujacy do tego, by najpierw się im poprzyglądać, a dopiero potem zastanowić, czy nie należałoby jednak i przeczytać), wypadałoby - zgodnie z intencją Fajfera i Bazarnik, zjawiska te wyraźnie oddzielać. Jedne bowiem przynależą do sfery literatury, drugie - do obszaru sztuk wizualnych. I raczej - jak wynikałoby z rozważań czołowych polskich liberatów - nie należy doszukiwać się miejsc wspólnych.

Niemniej, 21 września 2011 r. na łamach internetowego wydania „Gazety Wyborczej” można było przeczytać o amerykańskich peregrynacjach Fajfera, Bazarnik i (najważniejszej w tej historii) samej liberatury. Artykuł, który doczekał się też licznych internetowych przedruków ${ }^{749}$, mówił o życzliwym przyjęciu całej trójki na Brooklyn Book Festival, definiując liberaturę jako... „nowy rodzaj literacki, łączaccy w sobie elementy poezji i sztuki książki”. Trzeba tu dodać, że sformułowanie to nie jest dziennikarskim nadużyciem czy nadinterpretacja, lecz dosłownym tłumaczeniem tekstu, który dużo wcześniej pojawił się na stronie nowojorskiego Instytutu Kultury Polskiej (www.polishculture-nyc.org) ${ }^{750}$. Fajfer i Bazarnik kilka dni wcześniej z dumą odsyłali zresztą do tych informacji grono znajomych miłośników liberatury, przesyłając w mejlowych pozdrowieniach z USA link kierujący na tę właśnie stronę ${ }^{751}$.

Wydaje się, że oto natrafiamy na ciężki orzech do zgryzienia. Jak liberatura, która - jak wynikałoby z dotychczasowych ustaleń - nie ma z książka artystyczną i sztuką książki nic wspólnego ${ }^{752}$, może być połączeniem tej ostatniej z poezją? Jak Fajfer i Bazarnik moga się też z tego cieszyć, jeśli irytowało ich „wrzucanie” tych pojęć do jednego worka? Czy przypadkiem nie jest tak, że łatwo krytykować Nowakowskiego, gdy triumfuje on na kolejnych wystawach książek artystycznych, trudniej zaś odmówić, gdy znajomi artyści książki (i teoretycy zjawiska) proponuja, by samemu na takich wystawach być gwiazdą?

Sądzę, że za wcześnie jeszcze na ocenianie, czy promowanie liberatury bądź jako sztuki książki, bądź jako literatury jest zwykłym chwytem marketingowym (i poszukiwaniem najszerszego grona odbiorców) ${ }^{753}$. Natomiast

${ }^{749}$ M.in. na serwisie Wirtualna Polska [http://ksiazki.wp.pl/tytul,Liberatura-ZenonaFajfera-i-Katarzyny-Bazarnik-w-Nowym-Jorku,wid,18360,wiadomosc.html?ticaid=1d137] [dostęp 23.09.2011]. Podobny news już 17 września opublikowano na Polskim Portalu Kultury [http:// news.o.pl/2011/09/17/liberatura-nowy-jork/] [dostęp 23.09.2011].

${ }^{750}$ Informacje o „amerykańskim tournée” (to również określenie ze wspomnianych materiałów) znaleźć można pod adresem: http://www.polishculture-nyc.org/?eventId=1870 [dostęp 23.09.2011]. Zaś oryginalna wersja przywołanej definicji liberatury brzmi: „a genre of literature that combines poetry with the art of the book".

751 Powołuję się tu na e-mail, jaki - jako jedna z całej grupy osób - otrzymałam 18 września 2011 r. Dla ścisłości zaznaczę, iż jego autorzy mówią o przywoływanych przeze mnie materiałach jako o informacji „przygotowanej przez Polski Instytut Kultury w Nowym Jorku” [poprawna nazwa tej instytucji to: Instytut Kultury Polskiej]. Nijak nie zaznaczają jednak, by cokolwiek w niej było niezgodne $\mathrm{z}$ ich intencjami.

752 Przypomnę, że w dotychczas cytowanych szkicach pojęcia te liberaci - szczególnie Bazarnik - traktowali jako bardzo bliskie, momentami wręcz synonimiczne.

${ }^{753}$ Można by przecież zapytać wprost: co się lepiej sprzedaje: „zwykłe” niezwykłe książki czy te artystyczne? Zaś przysłowiową wisienką na torcie byłoby wyznanie, że jako osoba zajmująca 
muszę zaznaczyć, że to zdecydowanie nie tak, że Fajferowi i Bazarnik złożono interesująca propozycję i ci od razu zmienili strategię. Już od kilku lat w ich szkicach marginalnie sygnalizowane było przekonanie, że istnieją i takie przestrzenie książki artystycznej, które moga z liberatura czy literatura mieć coś wspólnego. Myśl ta powróciła we wspominanych na początku rozdziału, pisanych już z perspektywy dziesięciu lat, tekstach autorów. Jej rozwinięcie było konsekwencją uważniejszego przyjrzenia się kategorii książki artystycznej, samej sztuki książki, doprecyzowanie tych wcześniej - trzeba przyznać - raczej nonszalancko używanych przez Fajfera i Bazarnik określeń. Takie podejście do tematu wyznacza drugą fazę liberackiej refleksji o relacji literatury totalnej i książki artystycznej. Wystawy i prelekcje w USA, obok przywołanych szkiców, wydają się ukoronowaniem tego etapu rozważań. Być może, potrzeba było dekady, która dzieli pierwsze i ostatnie dotyczące tematu wypowiedzi teoretyczne „rodziców” literatury totalnej, aby idea liberatury na tyle okrzepła, by nie trzeba było stawiać bardzo wyraźnych granic, by móc zaczać mówić o pewnych pograniczach. Albo czas ten potrzebny był, by nabrać dystansu i wyraźniej zobaczyć pewne kwestie.

Już w 2008 r. Bazarnik pisała o pewnej grupie tekstów przekraczających równolegle granice sztuk plastycznych i sztuki słowa:

I to jest właśnie ta sfera, gdzie liberatura i sztuka książki spotykają się, zakreślając pewien wspólny obszar - gdzie obie dziedziny przenikają się, rzucając wyzwanie badaczom oraz odbiorcom-widzom i odbiorcom-czytelnikom ${ }^{754}$.

Zaś Fajfer wskazywał, że do owego wspólnego obszaru przynależy np. twórczość Nowakowskiego. „Teraz widzę to znacznie wyraźniej niż przed kilku laty”755 - wyznawał. Powodem dostrzeżenia owej „części wspólnej”756 był właśnie, jak się zdaje, uważniejszy namysł nad samą kategorią książki artystycznej. Z pewnością inspirujące było spojrzenie na nią w szerszej perspektywie, jako na jeden z rodzajów sztuki książki. Tym samym, jak zaznaczałam, doprecyzowaniu w dyskursie Fajfera i Bazarnik uległy pojęcia, o których problematycznej niejasności pisałam już wcześniej. I nagle okazało się, że książka artystyczna i sztuka książki to nie to samo. Każdą z nich trzeba było na nowo - w kontekście liberatury - zdefiniować.

Wnioski prowadziły właśnie ku uznaniu, że liberatura jest odmianą sztuki książki (albo przynajmniej jako taka może być rozumiana), oczywiście przy odpowiednim rozumieniu tej ostatniej. Choć - trzeba dodać - w żaden sposób nie wyklucza to jej równoległego bycia literaturą. Taka - znacznie szersza

się Oka-leczeniem jeszcze przed jego publikacją w Ha!artowskiej serii, zakupiłam (oczywiście za kwotę znacznie przekraczającą obecną cenę Oka-leczenia) jeden z dziewięciu prototypowych egzemplarzy książki, „sprzątając go sprzed nosa” jednemu z amerykańskich kolekcjonerów książek artystycznych (takiej informacji udzielili mi w 2005 r. autorzy).

${ }^{754}$ K. Bazarnik, Liberatura, czyli literatura $w$ formie ksiażki, s. 26.

755 Z. Fajfer, Jak liberatura redefiniuje ksiażkę artystyczna..., s. 137.

756 Ibidem. 
- perspektywa patronuje drugiej fali refleksji o związkach liberatury i książki artystycznej, rozważań, które - w konsekwencji - nie tylko odnajdują nowy kontekst dla istnienia literatury totalnej (i mówienia o niej), zatem wyznaczaja i nowy krag odbiorców, lecz i czyniąjej teorię inspiracją do doprecyzowania terminów już istniejących. Liberatura - zdaniem Fajfera - redefiniuje bowiem książkę artystyczna. Wskazawszy aktualniejsze filary interesujacego mnie w tym rozdziale wątku myśli polskich liberatów, pozostaje podążyć wskazanym przez nich torem refleksji: zastanowić się, jak dotychczas wyglądało w polskiej humanistyce opisywanie przywoływanych pojęć i na ile odświeżyła ten stan teoria liberacka.

\subsection{Od książki artystycznej do sztuki książki}

Na wstępie trzeba zaznaczyć, że w gruncie rzeczy w Polsce każde poszukiwanie charakterystyki książki artystycznej zadowalającej większą grupę badaczy kończy się fiaskiem. Różnorodność przyjmowanych podczas jej opisywania perspektyw (owocująca zresztą nikłą wymianą zdań między poszczególnymi środowiskami), brak forum dyskusji o charakterze naukowym, trudna dostępność tekstów dotyczących zagadnienia - to tylko niektóre z powodów trudności w odnalezieniu satysfakcjonującej definicji. Monika Polak uznaje jej zbudowanie za zadanie karkołomne $e^{757}$, podkreślając, że jedna z przyczyn braku takiego opracowania w Polsce jest „pułapka waskiej klasyfikacji, odsuwająca wszystkie nietypowe postacie książek na bliżej nieokreślone peryferie"758. Zwracając uwagę na to, że zagranica problem doczekał się już w miarę satysfakcjonujących omówieńn ${ }^{759}$, o rodzimych badaniach Polak pisze:

Specyficzną polską bolączką jest jednak brak obiegu sztuki książki. Nie istnieje fizycznie miejsce bieżącego gromadzenia cennych obiektów, jak również informacji. Częściowo tę lukę zapełnia prywatne Muzeum Książki Artystycznej w Łodzi, prowadzone przez Jadwigę i Janusza Tryznów, posiadające własną bibliotekę dzieł, katalogów, wydawnictw poświęconych książkom oraz publikacji na ich temat. Jednakże do książek artystycznych [...] jak i do szczątkowych opracowań wciąż docierać trzeba przez sieć znajomych, artystów, poprzez kwerendy w piwnicach bibliotek lub muzeów, skrawki informacji zamieszczane w Internecie i inne - sobie tylko znane sposoby. Regularnie odbywające się w Warszawie wystawy sztuki książki czy też zielonogórskie warsztaty książki artystycznej [...], jak również cykliczna poznańska wystawa „Książka i co dalej” oraz wiele tyleż interesujących co efemerycznych inicjatyw pozostaje bez refleksji teoretycznej, dopóki sami artyści lub koordynatorzy wystaw tego nie zrobia. Nawet jeśli refleksje takowe się pojawiaja - nie znajduja podatnego gruntu, archiwum lub forum. Toteż informacje na ten temat ulegają rozproszeniu, zamieszczane sa sporadycznie w magazynach poświęconych kulturze i sztuce współczesnej, na łamach pism o znaczeniu dydaktycznym (np. Plastyka $i$ Wychowanie $)^{760}$.

${ }^{757}$ Monika Polak, Nie do czytania - dywagacje wokót definicji ksiażki artystycznej, [w:] DRK, s. 35.

${ }^{758}$ Ibidem, s. 37.

${ }^{759}$ W USA dzięki Johannie Drucker, Dickowi Higginsowi oraz Clive'owi Phillpotowi, we Francji dzięki Ann Moeglin-Delcroix. Zob. M. Polak, Nie do czytania-dywagacje wokót definicji ksiażki artystycznej, s. 37.

${ }^{760}$ Ibidem, s. 38-39. 
Jak zatem pisze się (i pisało się) u nas o książce artystycznej? Spośród rodzimych opracowań wyróżnia się pozycja Książi $i$ strony Piotra Rypsona ${ }^{761}$. Niemniej, zaproponowane przez badacza ujęcie jest bardzo szerokie, zaś wytyczone przezeń granice pojęcia ksiażka artystyczna dość niejasne. Z pewnością jednak perspektywa, jaką proponuje, propozycja objęcia terminem (jak sam mówi: „umownym”) wszelkich dwudziestowiecznych eksperymentów z przestrzenia zapisu, tekstu czy łaczenia tekstu i obrazu, zainspirowała wielu polskich myślicieli ${ }^{762}$. Odzwierciedla jednak zasadniczy problem rodzimej myśli o książce artystycznej, na który zwracała uwagę też Polak: brak precyzyjnej klasyfikacji. W konsekwencji, często utożsamiamy książkę artystyczną z tym, co bywa nazywane sztuką książki (przypomnę, że w szkicu Liberatura: ikoniczne oka-leczenie literatury Bazarnik wymiennie używa określeń „,sztuka książki”, „piękna książka” i „książka artystyczna”, a zresztą również w cytowanym przed chwila fragmencie artykułu Polak terminy te stosowane sa raczej jako synonimy).

Ta zaś, jak podkreśla choćby Rypson właśnie, to pojęcie jeszcze szersze, właściwie rodzaj terminu-worka obejmującego niemalże „cała problematykę estetyczna, związaną z tym, czym książka jest i była - i stać się może na przestrzeni dziejów"763. Jednak, właśnie ze względu na to, że centrum zainteresowania jest w nim książka, ważne wydaje się określenie relacji liberatury do tworów wpisywanych w ten obszar sztuki. Przy tak szerokiej jej definicji, literatura totalna daje się bowiem rozpatrywać jako jedna $\mathrm{z}$ jej form ${ }^{764}$. Być

${ }^{761}$ Piotr Rypson, Ksią̇ki i strony. Polska ksiażka awangardowa $i$ artystyczna $w$ XX wie$k u$. Pozycja ta - jak większość opracowań książki artystycznej - jest niestety trudno dostępna. W obiegu funkcjonuje również nieco wcześniejsze wydanie (z którego korzystałam i z którego pochodzą wszelkie cytaty w tej pracy): Piotr Rypson, Ksią̇ki i strony. Polska ksiażka awangardowa $i$ artystyczna 1919-1992, Warszawa 1992. Na ile udało mi się ustalić, pomiędzy wydaniami nie ma znaczących różnic w zakresie fragmentów, na które się powołuję.

${ }^{762}$ Por. P. Rypson, Książi i strony..., s. 7-8. Analogiczne ujęcie, wpisujące w obszar książki artystycznej działania europejskiej awangardy XX w., znajdziemy m.in. w myśli Tomasza Wilmańskiego (zob. np. Tomasz Wilmański, Ksiażka i co dalej, [w:] DRK, s. 50-60). Odnośnie do związków książki artystycznej i awangardy początków XX w. zob. także: Johanna Drucker, Artists’ Book \& the Early 20-th Century Avant-Garde, [w:] eadem, The Century of Artists'Books, s. 45-67.

${ }^{763}$ Piotr Rypson, Sztuka ksiażki, [w:] Sztuka ksiażki. Ksiażki artystyczne, Warszawa 1996, s. 1, cyt. za: Nauka o ksiqżce. Antologia tekstów, s. 229 (tekst dostępny jest również na stronie: http://free.art.pl/wilmanski/teksty/17_pl.htm [dostęp 26.09.2011]). O tym, że sztuka książki to termin wciąż niedopracowany, wymagający uściślenia (gdyż zainteresowanie dziedziną wyprzedziło jej pełne zdefiniowanie) na polskim gruncie przekonująco pisze też Andrzej Bednarczyk, którego ujęcie bliskie jest zresztą przywoływanej przez mnie w dalszej części rozdziału propozycji Richarda Kostelanetza. Obaj badacze zwracają uwage na ciekawe pogranicza omawianego obszaru sztuki, nie wykluczając tym samym i „romansu” z literaturą. Bednarczyk mówi wręcz i o lekturze dzieł artystów książki (zob. Andrzej Bednarczyk [bez tytułu], http://www.bookart.pl/pl/o_sztuce_ksiazki_andrzej_bednarczyk.html [dostęp 24.09.2011]). Na niedookreśloność terminu (oraz jego niedefiniowalną relację z książką artystyczna) zwraca też uwagę Rafał Jakubowski w przywoływanym już szkicu Sztuka ksiązki. Ten ostatni podkreśla również, że zasadniczo jest to nurt sztuki mniej dostrzegany przez krytykę, zatem - podobnie jak liberatura - plasujący się niejako na obrzeżach.

${ }^{764}$ Szeroką panoramę terminów opisujących rozmaite fenomeny zaliczane do sztuki książki jako podtypy książki artystycznej bądź też zjawiska od niej odrębne (od livre d'artiste po e-artist's book, a także: anti-book, non-book czy magazine art) prezentuje Duncan Chappell w szkicu Typologising the artist's book, „Art Libraries Journal” 2003, nr 4, s. 12-20; szkic dostępny jest również 
może byłaby to wręcz najwłaściwsza perspektywa, a taki zwrot pozwoliłby dostrzec nowe badawcze horyzonty. Do wniosków tych doszli też z czasem liberaci. W przywoływanym już szkicu Bazarnik (Kilka uwag o liberaturze i ksiażce artystycznej), który - jak zaznaczałam - traktować należałoby jako najbardziej aktualne ujęcie problemu, badaczka umieszcza liberaturę właśnie w obszarze sztuki książki i określa ją jako: „Taki jej podzbiór, w którym innowacyjne kształtowanie materialności książki wprzęgnięte jest w służbę literaturze" "765.

Warto więc chyba podażyć tym tropem i spróbować scharakteryzować relacje między wszystkimi tymi trzema terminami (liberatura, książka artystyczną oraz sztuką książki). Interesujące wydaje się też prześledzenie przyczyn omawianej zmiany perspektywy. Jak w ogóle do dywagacji o literaturze totalnej i książce artystycznej wkradł się termin „sztuka książki” (i to w konkretnym jego rozumieniu)?

\subsection{Od Clive'a Phillpota do Richarda Kostelanetza}

Przede wszystkim trzeba zauważyć, że o ile głównym inspiratorem pierwszego etapu opisywanej tu refleksji był Clive Phillpot, drugiemu patronuje Richard Kostelanetz. I, rzecz jasna, nie bez znaczenia pozostaje to, jak wiele tych myślicieli dzieli. Zasadniczo, zmiana w podejściu do kategorii książki artystycznej i sztuki książki u Fajfera i Bazarnik wydaje się naznaczona przejściem od rozumienia tych terminów u pierwszego z badaczy ku ich pojmowaniu u drugiego.

Często przywoływany w polskiej krytyce Phillpot, autor podziału książek artystycznych na: zwykłe książki (just books), książki-dzieła (bookworks) oraz obiekty książkowe (book objects) ${ }^{766}$ w szkicu, z którego przywołana systematyzacja pochodzi, stwierdzał, że dość enigmatycznie mianem książki artystycznej określa się wszystko to, co przynależy do obszaru sztuki (ale dodać trzeba, że ma tu na myśli sztuki wizualne) i jakkolwiek przypomina książkę ${ }^{767}$. Jednocześnie zauważał, że popularność terminu wiąże się przypuszczalnie z tym, że daje on możliwość wyraźnego odróżnienia omawianych artefaktów od estetycznej produkcji książek ${ }^{768}$ oraz równolegle wskazania na to, iż ci, którzy je tworzą to arty-

pod adresem: http://www.arts.ucsb.edu/faculty/reese/artist\%20books/chappell_typologising.pdf [dostęp 18.09.2011]. Jako że systematyzacje tych form sztuki i próba ich opisu jest zadaniem znacznie przekraczajacym ramy tej książki, zainteresowanych odsyłam do wspomnianego opracowania oraz bogatej bibliografii, jaka zawiera.

${ }^{765}$ K. Bazarnik, Kilka uwag o liberaturze i ksiażce artystycznej.

766 C. Phillpot, Books book objects bookworks artists' books, s. 77. Polskiemu odbiorcy podział ten przyswoił Piotr Rypson (Ksiażki i strony..., s. 8), za nim przywołuje go Bazarnik (m.in. w: Liberatura: ikoniczne oka-leczenie literatury, s. 25) oraz Polak (Nie do czytania-dywagacje wokót definicji ksiażki artystycznej, s. 40). Z kolei Tomasz Wilmański jako jedyny przypomina, że Phillpot w swojej systematyzacji stosował również podział ze względu na ilość publikowanych egzemplarzy (multiple/unique) - zob. Tomasz Wilmański, Ksiqżka i co dalej, s. 53.

767 C. Phillpot, Books book objects bookworks artists' books, s. 77.

${ }^{768}$ C. Phillpot używa tu określeń: „art-of-the-book” oraz „art-book industry”. 
ści sztuk wizualnych. Podkreślając (w innym artykule), że przez ostatnie dziesięciolecia to właściwie wyłącznie oni przyczynili się w znaczący sposób do rozwoju refleksji o materialnym kształcie książki ${ }^{769}$, Phillpot proponuje właściwie ujęcie, w którym termin książka artystyczna, rzeczywiście, nie obejmuje niemal niczego, co byłoby literatura. Nie powinien więc dziwić sprzeciw Bazarnik wobec utożsamiania czy nawet łączenia tego pojęcia z liberatura. Warto pamiętać, że zaproponowany przez amerykańskiego badacza wykres omawiający opisywany schemat kategorii literatury w ogóle nie uwzględnia, jako że Phillpot skupia się na obszarze książki (czy „formy książkowej” jak ujmuje to Rypson ${ }^{770}$ ) i sztuki ${ }^{771}$. Zaś - jak zauważa w drugim z przywoływanych tu przeze mnie szkiców - wszelkie dzieła pisarzy, którzy nie bagatelizują formy książki mogą być wpisane w obszar sztuki książki, „sztuki związanej z formą książki”772. Tę ostatnią ujmuje zatem jako termin szerszy, bardziej pojemny, zdolny być może objać i to, co liberackie.

Zaś Richard Kostelanetz (wspomniany już tu jako ten, który uznał teorię liberatury za koncept „użyteczny”"773) charakteryzuje ową sztukę książki w sposób rzeczywiście bardzo bliski liberatom. W szkicu Book $\operatorname{art}^{774}$ pisze o wyrobnikach książki (jak dałoby się w wolnym tłumaczeniu oddać określenie book $h a c k^{775}$ ), przeciwstawiając ich jej artystom (book artists). Pierwsi to ci, którzy - poddając się konwencjom medium - produkuja (bo chyba trudno w tym wypadku mówić o tworzeniu) tomy w żaden sposób niezwracajace na siebie uwagi, o stronach podobnych jedna do drugiej, „łatwoczytalne”, odpowiadajace czytelniczym oczekiwaniom, wpisujące się w pełni w konwencje, spełniajace wszelkie „normy”. Ich dzieła nie mają się w żaden sposób wyróżniać, nie powinny też zwracać na siebie uwagi. Wyrobnikami książki (i literatury) wydają się chyba również z punktu widzenia liberatów.

Druga grupa opisywana przez Kostelanetza to, bliżsi twórcom literatury totalnej, prawdziwi artyści książki. Oni zadają sobie pytanie, czym może stać się sama książka. Poszukują nowych środków wyrazu, próbują od spełniania oczekiwań przejść ku zaskakiwaniu. Kostelanetz określa ich mianem prawdziwych

769 C. Phillpot, Artists’ Booklets, „Printed Matter” Catalog 1986/1987 [http://www.printedmatter.org/researchroom/essays/booklets.cfm (dostęp 28.08.2011)]. Phillpot, pisząc swój esej w latach osiemdziesiątych, mówił o ostatnim dwudziestopięcioleciu.

770 P. Rypson, Ksiażki i strony..., s. 8.

771 Stąd pewną nadinterpretacją jest przekonanie Polak, że „«zwykłe książki» są najbliższe literaturze, «książki-dzieła» - sztuce, a «obiekty książkowe» - innym dziedzinom” (M. Polak, op. cit., s. 40), gdyż interpretując myśl Phillpota, trzeba zauważyć, że pierwsze przynależą do obszaru książki (nie: literatury!) tradycyjnej (jak zresztą podkreśla Rypson), drugie: do pogranicza tego obszaru z przestrzenią sztuki, trzecie - wpisują się zaś po prostu w zakres sztuki. Niemniej, uwaga o bliskości „zwykłych książek” do literatury dałaby się „obronić gdyby” funkcjonowała wyłącznie jako odautorska interpretacja teorii badacza. Pozostałe konstatacje autorki wydają się jednak nadużyciem.

772 C. Phillpot, Artists' Booklets (tłum. moje). Bazarnik tłumaczy frazę, ,art dependent upon the book form” jako „sztukę wyrażającą się w formie książki” (K. Bazarnik, Liberatura: ikoniczne oka-leczenie literatury, s. 25).

${ }^{773}$ Zob. pierwsza część tej książki.

774 Richard Kostelanetz, Book art, artykuł dostępny na autorskiej stronie Kostelanetza, http://www.richardkostelanetz.com/examples/bookart2.html [dostęp 20.11.2011].

775 Angielskie słowo huck to pejoratywne określenie pisarza. 
artystów, w porównaniu z którymi pierwsi z przezeń charakteryzowanych mogą być co najwyżej zwykłymi malarzami (ścian). To ich twórczość mamy też prawo określać (honorowym, jak stwierdza badacz) mianem sztuki książki, czyli - jak podsumowuje autor - książek, które sa prawdziwymi dziełami sztuki, pozostając nadal książkami. Takich, które przekraczają zarówno kategorię projektowania książek (book design), jak i ich pisania (literary art).

Kostelanetz proponuje wręcz (co dla moich rozważań istotne), by terminem sztuka ksią̇̇i zastapić mylące pojęcie ksią̇̇ka artystyczna (podkreślające - jak tłumaczy - samym brzmieniem terminu nie tyle charakter opisywanego dzieła, co profesję jego twórcy). Umożliwi to wreszcie charakteryzowanie własności samego dzieła, gdyż - jak dodaje - „nieważne kto je zrobił”776, ważne, jaka przybrało postać, jaki kształt: istotne, że jest książka. Tym samym, owym „nieważne kto” pozwala, by mówić o utworach innej niż plastyczna (wizualna) proweniencji. A jako że główną kategorią czyni książkę, niemalże wprost zaprasza liberatów do dyskusji. Wydaje się, że przyjęcie takiej perspektywy pozwala wyjść z impasu inspirowanego lektura Phillpota odgradzania się od książki artystycznej, i dostrzec, że wśród artystów ją tworzących, znajdą się i tacy, którym idea liberatury będzie nad wyraz bliska.

\subsection{Między sztuką, książką i literaturą}

Najważniejszą konsekwencją takiej myślowej rewolty jest uwzględnienie w dywagacjach o liberaturze i (niekonwencjonalnej) książce nie dwóch (książki i sztuki), lecz trzech płaszczyzn, które mogą mieć obszary wspólne: książki (czy formy książkowej), sztuki i literatury. Stąd liberatura zaczyna się jawić jako rodzaj twórczości łączący wszystkie te trzy przestrzenie. I choć nie wybrzmiewa to jednak jeszcze w sformułowaniach jej teoretyków, niemniej, w prosty sposób daje się z ich myśli wyprowadzić.

Mówienie o liberaturze w kontekście sztuki książki, zaowocowało, jako łatwo się domyśleć, próbami ujęcia jej w klasyfikacjach tej ostatniej. Pierwsza daje przywoływany już tu szkic Polak, którego autorka proponuje schemat podziału obszaru sztuki książki ${ }^{777}$ uwzględniający jej relacje z innymi dziedzinami sztuki. Jak sama wyznaje, model powstał z inspiracji dyskusjami na gdyńskiej konferencji Druga rewolucja ksiązki, w rozmowach z innymi referentami. Bazarnik, która we wspomnianych dyskusjach również uczestniczyła, „pożycza” schemat od młodej badaczki i - nieco go poprawiając i rozbudowując - wykorzystuje do zobrazowania problemu w szkicu Kilka uwag o liberaturze $i$ ksiażce artystycznej ${ }^{778}$. Choć intencja poprawienia, skorygowania propozycji

${ }_{776}$ R. Kostelanetz, Book art.

777 Por. M. Polak, Nie do czytania - dywagacje wokót definicji ksiażki artystycznej, s. 36 (schemat) oraz 41 (jego omówienie).

778 Zob. schemat zatytułowany Zasięg sztuki ksią̇ki i jej relacje z innymi dziedzinami sztuki, schemat Katarzyny Bazarnik, [w:] K. Bazarnik, Kilka uwag o liberaturze i ksiażce artystycznej. 
młodszej badaczki wydaje się słuszna ${ }^{779}$, również model Bazarnik nie obroni się w pełni przed krytyką ${ }^{780}$.

Paradoksalnie, nie zamierzam „czepiać się” szczegółów, ani poprawiać zaproponowanego przez Bazarnik schematu. Ośrodkiem moich zainteresowań jest liberackość dzieła literackiego, a zatem mniej są dla mnie istotne inne dziedziny sztuki niż literatura. Stąd, rzeczywiście skomplikowane, zależności między nimi a sztuką książki nie będą tu przedmiotem refleksji. Jednocześnie, celem tego rozdziału jest opisanie relacji liberatury i książki (artystycznej i tzw. zwykłej), więc - tym samym - tym, co mnie najbardziej interesuje jest stosunek tych pojęć do siebie (w kontekście literackości). I w takim zakresie sformułowany przez liberatke model będzie dla mnie punktem wyjścia do dalszych rozważań. Kwestię innych (koniecznych) korekt pozostawiam do podjęcia.

Przede wszystkim, pozbawiony odniesień do innych dziedzin, model Bazarnik opisywałby właśnie zależności pomiędzy liberatura, literatura, sztuka książki i książką artystyczna. Ta ostatnia byłaby podzbiorem sztuki książki. Zaś literatura nakładałaby się na pozostałe przestrzenie w taki sposób, że istniałby obszar wspólny dla wszystkich trzech oraz taki, w którym jej zakres pokrywałby się wyłącznie ze sztuką książki. Część tego wspólnego obszaru zajmowałaby właśnie liberatura, która - tym samym - zyskałaby i niewielkie wspólne pole z książką artystyczna. Taką uproszczoną wersję zaproponowanego przez Bazarnik schematu pokazuje poniższy wykres:

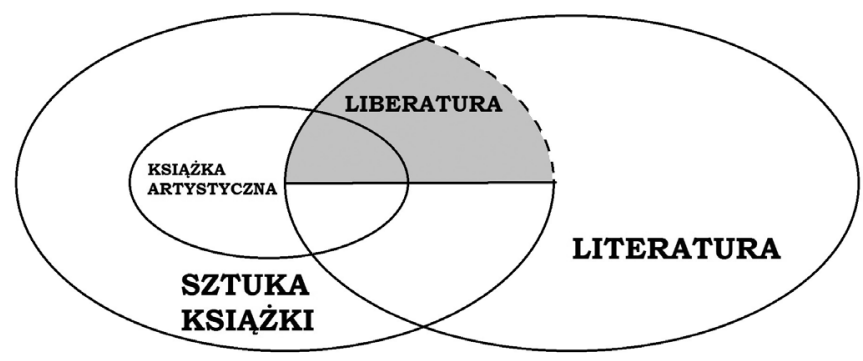

Wykres 1. Uproszczony schemat zasięgu sztuki książki wg Katarzyny Bazarnik (źródło: oprac. Agnieszka Przybyszewska)

${ }^{779} \mathrm{~W}$ zaproponowanym przez Polak modelu wiele jest niejasności i nieścisłości, np. poemat kinetyczny Fajfera umieszcza autorka - według sformułowanego przez nią opisu - „na przecięciu liBeratury i cyfrowych postaci książek” (s. 41), którego wizualizacja schematu nie zawiera.

${ }^{780}$ Choć trzeba przyznać, że - jak też Bazarnik sama podkreśla - relacje, które próbuje ująć są skomplikowane. Silnie inspirowane schematem Polak usytuowanie muzyki czy techniki (jako dziedziny sztuki?!) z dala od liberatury wydaje się problematyczne, gdzie bowiem umieścić nowomedialne, a - zdaniem Fajfera (i Bazarnik!) - liberackie, teksty takie jak kinetyczne Ars Poetica? Jeżeli to, co ma związek z inną niż druk technologią (dźwięk) i muzyką ma nie mieć nic wspólnego z tym, co liberackie - gdzie zaliczyć Koniec świata według Emeryka Nowakowskiego, w którym wykorzystany został dźwięk? 
Mankamentem tego modelu jest wyraźna granica, która oddziela liberaturę od drugiej części nienazwanego w moim „przerysowaniu” schematu Bazarnik wspólnego obszaru sztuki książki i literatury. Oryginalnie znajdowała się tam książka bibliofilska oraz (w części obejmującej również książkę artystyczna) drukarstwo artystyczne ${ }^{781}$. Przyczyny takiego a nie innego jej wyznaczenia sa niejasne. Bez odpowiedzi pozostaje również pytanie o to, czemu granica między liberatura a literatura oznaczona jest przez Bazarnik - jako jedyna - linią przerywaną. Proponowałabym, jak mówiłam, potraktować ten schemat jako punkt wyjścia, zmodyfikować go tak, by objął jeszcze więcej interesujących kwestii.

Po pierwsze, sądzę, że warto byłoby zaznaczyć na nim - wracając myślą do rozpoczynającego chyba modę na tego typu modele Phillpota - że nie wszystko, co z książką związane musi mieć wymiar sztuki. Tym samym proponowałabym wrócić do postulowanego przez tego badacza uwzględnienia w modelu zarówno obszaru „książki”, jak i „sztuki”. Doprecyzowania jednak wymagałyby oba te terminy, które dla wygody proponowałabym zostawić w takiej formie, jaka przyjęła się - po Phillpocie - w refleksji bibliologicznej. Jako książkę rozumiem więc wszystko to, co z jej formą związane, zatem w tym obszarze plasowałoby się również drukarstwo traktowane jako produkcja książki, pozbawiona estetyczno-artystycznego wymiaru. Sztukę rozumiałabym tu możliwie najszerzej, mając świadomość, że wydzielając w niej różne podzbiory, takie jak „sztuki wizualne”, „muzyka” czy inne, musielibyśmy uwzględnić również różnorakie ich pogranicza. Dzięki takiemu ujęciu do pojęć, których relacje opisuje schemat, można zaliczyć i „literaturę”. Znów tłumacząc się tym, że interesuje mnie bardzo konkretny zakres sztuki, jedynie tę jej odmianę proponowałabym wyróżnić na schemacie. Zatem, poza liberaturą i książką artystyczna, moje ujęcie uwzględniałoby następujące podzbiory: książka, sztuka, literatura.

W konsekwencji, w zaproponowanej modyfikacji modelu część wspólna zbiorów „sztuka” i „książka” stanowiłaby obszar określany jako „sztuka książki” (rozumiana zatem w duchu Kostelanetza). Jego fragment, na który nachodziłaby i „literatura” (jako podzbiór „sztuki”) - a zatem obszar, w którym nakładają się na siebie trzy z interesujących mnie kategorie: książka, sztuka i literatura - to właśnie „liberatura”. Może ona mieć również wspólną część z podzbiorem sztuki książki: „książką artystyczną”. Wykres 2 przedstawia wizualizację powyższego opisu.

Sądzę, iż zaproponowany model najlepiej oddaje aktualny stan teoretycznej refleksji o relacjach książki artystycznej, sztuki książki, liberatury i literatury. Takie ujęcie wydaje się też dobrym punktem wyjścia do dalszego rozbudowywania: choćby dodania obszaru sztuk plastycznych jako podzbioru

${ }^{781}$ Co ciekawe, Bazarnik, poprawiając model Polak, usuwała podzbiory takie jak „zdobnictwo” czy „introligatorstwo”, podkreślając, że są to kategorie z innego porządku niż pozostałe, które odsyłają do rodzaju książek. Jednak, czy dodany przez liberatkę zbiór „drukarstwo artystyczne” nie ma przypadkiem takiego właśnie charakteru? 
„Sztuki”, mającego swoją część wspólną i z literaturą (w zakresie ilustracji), i z książka artystyczna (w zakresie jej twórczego plastycznego opracowania), ale i z liberatura. Podobnie, przywoływana tu wcześniej „technika” (lub może lepiej: „nowe media”) mogłyby zaistnieć w obrębie tego schematu jako obszar o części wspólnej ze sztuka, jej konkretnymi podzbiorami (ze sztukami wizualnymi - czego przykładem może być sztuka interaktywna, z literatura - gdzie mielibyśmy do czynienia z jej elektroniczną odmiana, z książką artystyczną - gdzie sytuowałyby się jej cyfrowe postacie, a nawet i z liberatura - i tu mogłyby się wpisać dzieła takie, jak Koniec świata według Emeryka). Takie uzupełnienia chętnie pozostawię jednak (jak już wspominałam) tym, którzy zajmować będą się relacją omawianych pojęć do innych niż literacka przestrzeni. Temat to nad wyraz ciekawy, lecz jak słusznie podkreślała Bazarnik - niełatwy do opisania. Przede wszystkim zaś - zasadniczo wykraczajaccy poza ramy tego opracowania.

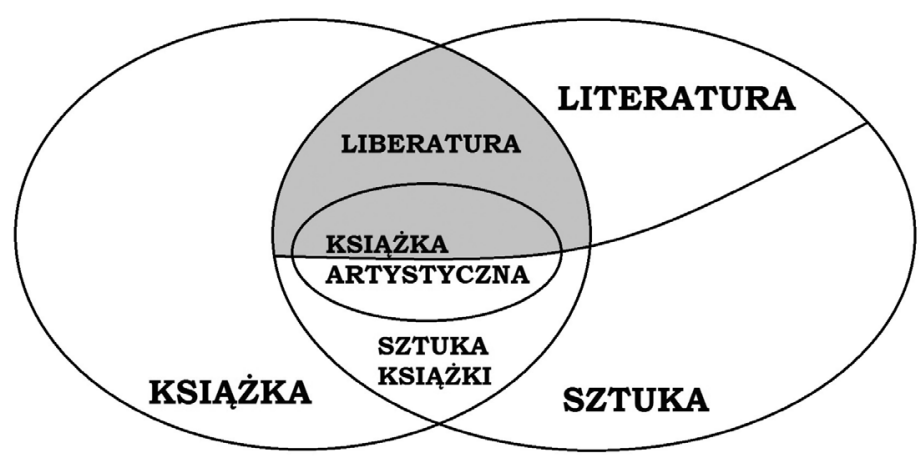

Wykres 2. Schemat ujmujący relacje między książką artystyczną, liberaturą, sztuką książki, książka, literaturą i sztuką (źródło: oprac. Agnieszka Przybyszewska)

Ponowne umieszczenie w omawianym modelu kategorii sztuki pozwala również spojrzeć na samą książkę artystyczną właśnie jako jej odmianę. Tym samym, pełniej wybrzmiewa słuszna chyba konstatacja Johanny Drucker, iż coraz silniej oddzielając się od inspirujących jej powstanie dziedzin sztuki, książka artystyczna przeobraziła się w oddzielna, typowa dla współczesności formę artystycznego wyrazu, oddzielny rodzaj sztuki ${ }^{782}$. A jak zauważa przywołana badaczka, sama forma książki stała się w XX w. inspirująca dla artystów rozmaitych profesji. Zatem i tych, którzy parają się sztuką słowa. Przywołanie tej myśli wydaje mi się istotne o tyle, że liberatura coraz częściej bywa opisywana jako „uwikłana w książkę” odpowiedź na sztukę współczesna, jako współczesna sztuka (słowa) w formie - nie innej, a właśnie - książki.

${ }^{782}$ J. Drucker, The Century of Artists'Books, s. 1 oraz 362. 


\subsection{Redefiniujący walor liberatury}

Na koniec warto powrócić do kwestii samej książki artystycznej. Jak sytuuje się ona w opisywanym układzie? Przywołana Drucker, choć odsyła do innych opracowań analizujących literackie „romanse” z formą tekstu i czyni meritum swoich rozważań książkę artystyczną jako formę sztuk wizualnych, dostrzega, że niektóre jej postaci pozwalają dostrzec również możliwość funkcjonowania takich publikacji jako utworów literackich ${ }^{783}$. Choć - w ujęciu przywołanej badaczki, podobnie jak w moim, Bazarnik i Fajfera - jest to sytuacja graniczna. Ostatni z przywołanych mówił o tym, że za właściwą formę książki artystycznej należałoby uznać:

W pełni autorskie dzieło sztuki wizualnej bądź konceptualnej, wyrażone w formie książki lub w postaci nawiąującej do książkowej symboliki, pozbawione jednak istotnego komponentu literackiego ${ }^{784}$.

Podobnie jak Drucker, uznając, iż książka artystyczna ma być dziełem pomyślanym od początku do końca przez jej autora ${ }^{785}$, Fajfer postulował też, by oryginalne edytorskie adaptacje cudzych tekstów literackich traktować bardziej jako inną odmianę sztuki książki. Zaś interesujące nas pogranicze - jak mówi „dzieła dotychczas definiowane jako książki artystyczne, a zawierające [...] literacki (również w pełni autorski) komponent" 786 przesunąć w obszar liberatury, co pozwoli przywrócić je czytelnikom i krytykom.

Zaproponowane modele pozwalaja zatem nie tylko zobaczyć, jak plasuje się liberatura na tle sztuki książki i w jakiej jest relacji z książką artystyczna, lecz i ułatwiają zrozumienie problemu, który Fajfer uczynił wręcz tytułowym zagadnieniem swojego poświęconego liberaturze i książce artystycznej szkicu. Jak pierwsza redefiniuje tę drugą? - pytał przecież. Zwracałam już uwagę, iż powodem początkowego wyraźnego rozdzielania przestrzeni liberackiej i tej dotyczącej książki artystycznej było związanie tej drugiej wyłącznie ze sztukami wizualnymi, przeznaczenie tych dzieł do oglądania, kontemplowania, nie lektury.

${ }^{783}$ Ibidem, s. 10. Bazarnik przywołany przeze mnie fragment interpretuje zgoła odmiennie, zarzucając Drucker pełne wyłączanie z obszaru dyskusji książek o literackiej proweniencji. Wydaje mi się jednak, że choć zasadniczo amerykańska badaczka opisuje książkę artystyczna jako rodzaj sztuki wizualnej, silnie akcentuje jego rozmaite relacje z literatura (odsyłając do innych opracowań). Dość przypomnieć obszerne fragmenty pracy, jakie poświęca książkowym eksperymentom symbolistów, dadaistów, surrealistów oraz nazwiska (bliskie przecież i liberatom), które w jej pracy padają po wielokroć: jak choćby Marinetti czy Mallarmé. Wskazując na artystów patrzących na książkę jako formę zapraszającą do dalszych poszukiwań „a nie tylko narzędzie reprodukujące” (s. 9), Drucker otwiera, moim zdaniem, a nie zamyka pole do dyskusji.

784 Z. Fajfer, Jak liberatura redefiniuje ksiażkę artystyczna..., s. 140.

785 Zob. J. Drucker, The Century of Artists'Books, s. 2.

${ }^{786}$ Z. Fajfer, Jak liberatura redefiniuje ksiażkę artystyczna..., s. 140. 
Jednak, jak pokazują schematy Polak, Bazarnik i mój - w obrębie książki artystycznej może istnieć też obszar, w którym spotyka się ona z literaturą. Pozostając i dziełami sztuki, i książkami, niektóre z utworów tworzonych przez artystów książki są też dziełami do czytania - należałoby uzupełnić wywód Kostelanetza. Fajfer i Bazarnik stwierdzaja, że teoria liberatury pozwala przywrócić je czytelnikom i literaturoznawcom, gdyż liberaci - walczaccy o to, by ich dzieła czytać, nie oglądać - wymuszają niejako konieczność ponownego rozejrzenia się po obszarze sztuki książki i sprawdzenia, czy aby i inne znajdujące się tam twory nie proszą o lekturę. Jak stwierdza Bazarnik:

Póki jednak nie uświadomimy sobie istnienia liberatury, książki te pozostaną nierozpoznane jako dzieła literackie, zamknięte w gablotach i niedostępne dla przeciętnego czytelnika. Lub też będą wydawane niezgodnie z intencją autorów, docierając do czytelnika w stanie zdeformowanym, pozbawione istotnych sensów ${ }^{787}$.

Zaś pisząc w szkicu Kilka uwag o liberaturze $i$ ksiażce artystycznej o odbywającej się w Bristolu konferencji Traditional and emerging formats of artists' books: Where do we go from here?, na której byli razem z Fajferem w lipcu 2009 r., teoretyczka-artystka wyznawała:

choć początkowo [byliśmy - AP] sceptyczni, szybko odnaleźliśmy wspólny język z obecnymi tam poetami, artystami, kuratorami, drukarzami, introligatorami, profesorami i bibliotekarzami. Sarah i Tom [Sara Bodman oraz Tom Sowden - organizatorzy konferencji - AP] dobrze wiedzieli, że wśród nich spotkamy i takich, których również uwiera etykietka twórców „książki artystycznej” i którzy z zadowoleniem rozpoznają się jako twórcy liberatury.

Bazarnik dodaje też, że niektórzy wysłali później egzemplarze swoich książek do Czytelni Liberatury. Zatem, podkreślenie przez teoretyków literatury totalnej, że w dziwnej, nieubogo komunikującej sobą książce ${ }^{788}$ i tekst może być istotny jako część komunikatu, że należy go przeczytać, zaowocowało tym, że niektóre dzieła zaliczane do książek artystycznych mogły zacząć mówić do odbiorcy: „obejrzyj mnie, ale i przeczytaj, w końcu jestem książka”. W ramach sugerowanych przez liberatów „porządków terminologicznych” przeniosły się z kategorii książek artystycznych - czyli „nie-do-czytania” (za Polak) - do zbioru dzieł liberackich: „dziwnych-acz-do-uważnej-lektury”.

Podsumowujac, teoretycy literatury totalnej przeszli od myślenia o liberaturze i książce artystycznej jako dwóch zupełnie przeciwstawnych formach sztuki, ku refleksji dostrzegającej pewne cechy wspólne i pozwalającej wskazywać dzieła z pogranicza tych dziedzin. Szczególnie istotne w tej myślowej rewolcie było uznanie kontekstu sztuki książki jako właściwego dla rozpatrywania obu form. Okazało się, że oba terminy są potrzebne, gdyż nazywają odmienne fenomeny, a tym samym, po raz kolejny, koncept liberatury obronił się jako nie na darmo wprowadzony do humanistycznego słownika. Jednocześnie stał się użyteczny w nowym wymiarze - pozwalając doprecyzować istniejące

\footnotetext{
${ }^{787}$ K. Bazarnik, Liberatura, czyli literatura $w$ formie ksiązki, s. 26.

788 Por. druga część tego rozdziału.
} 
już definicje. Warto tu przypomnieć, że już pierwsze manifesty Fajfera mówiły o takim redefiniujacym charakterze literatury totalnej, zaś wśród terminów, które należałoby na nowo przemyśleć, pojawiła się i kategoria (zwykłej) książki. Czas zatem zastanowić się, czy, rzeczywiście, i ja teoria literatury totalnej redefiniuje. Poszukiwania odpowiedzi warto zaś zacząć od przyjęcia szerszej jeszcze niż dotychczas perspektywy: perspektywy całej nauki o książce, bibliologii (której - note bene - sztuka książki jest częścia). W kolejnym rozdziale z tego właśnie punktu widzenia spróbuję przyjrzeć się relacji liberatury i (tzw. zwykłej) książki. 


\section{Literatura totalna $w$ perspektywie bibliologii (i nie tylko), czyli o liberaturze i „zwykłej" książce}

\subsection{Nowe (?) kompleksowe spojrzenie na książkę}

Jak widać, kontekst sztuki książki pozwolił nieco uporządkować refleksję liberacką. Pamiętając, że kategoria materialnego nośnika tekstu wydaje się podstawa całej teorii literatury totalnej, warto chyba rozszerzyć jeszcze spektrum odniesień i spróbować przyjrzeć się relacji książki liberackiej i „zwykłej” książki (wobec której też ma ona być niejako w opozycji) z perspektywy całej nauki o książce ${ }^{789}$. Być może w obszarze bibliologii znajdą się tropy, ujęcia, definicje, które wydadzą się pomocne w opisie liberatury. Szczególnie, że najlepszy to chyba merytorycznie kontekst do dywagowania o samej książce. A jak w polskiej nauce wygląda dyskurs jej poświęcony?

Przywoływana już Polak, stwierdzając, że w rodzimej refleksji humanistycznej brak miejsca na namysł nad książką artystyczna, zauważała, że naszym „grzechem” jest odrzucenie kompleksowego podejścia do samej książki. Badaczka podkreślała, że z jednej strony bibliologowie „«rozkładają» dostępne im książki na czynniki pierwsze"790, dając właśnie podstawy nauce o książce, z drugiej: teoretycy literatury (ale przecież i jej historycy, a także krytycy literaccy) zajmują się wyabstrahowaną z woluminów treścia. Z trzeciej wreszcie: znajdzie się i grupa badaczy, których interesuje okołoksiążkowy marketing (nakład, sposób dystrybucji etc. $)^{791}$. Tym, co w efekcie umyka jest złożoność, kompleksowość problemu. Książka staje się niejako bytem podwójnym: albo idealnym, niemal niematerialnym tekstem literackim, albo przedmiotem bez większego przesłania, niejako pozbawionym treści (choć ją przenoszącym). Zdaje się, że krytyka takiego podejścia stoi również za liberackimi próbami zredefiniowania książki.

${ }^{789}$ Zdefiniowanie tej dziedziny wcale nie jest jednak sprawą prosta. Por. hasło "nauka o książce', [w:] Encyklopedia wiedzy o ksiażce, red. Aleksander Birkenmajer, Bronisław Kocowski, Jan Trzynadlowski, Wrocław 1971, s. 1588-1592. Przystępny opis historii tej nauki wraz z uporządkowaniem problematycznych zależności między jej poddziedzinami przedstawia Krzysztof Migoń w książce $Z$ dziejów nauki o ksiażce (Wrocław 1979). Bardziej zwięzłe opracowanie zagadnienia znajdziemy w rozdziale Powstanie i ewolucja nauki o ksiażce w pracy tego badacza Nauka o ksiqżce wśród innych nauk społecznych (Wrocław 1976, s. 7-46). Porządkujące i użyteczne ujęcie daje także Karol Głombiowski w rozdziale Czym jest nauka o ksiqżce w pracy Ksiqżka w procesie komunikacji społecznej (Wrocław 1980, s. 5-12).

${ }^{790}$ M. Polak, Nie do czytania - dywagacje wokót definicji ksiażki artystycznej, s. 35.

${ }^{791}$ Warto jednak zaznaczyć, że i ten obszar badań często zalicza się do nauki o książce, por. hasło 'nauka o książce', [w:] Encyklopedia wiedzy o ksiażce. 
Czy jednak rzeczywiście problem opisanego „podziału obowiązów” pomiędzy poszczególnymi dziedzinami nauki nie został nigdy dostrzeżony? Czy ci, którzy naukowo zajmują się książką zawsze dokonują tak wyraźnych rozróżnień?

Warto przypomnieć, iż początkowo nauka o ksiażce była znacznie silniej związana z literaturoznawstwem, dopiero z czasem dziedziny te tak wyraźnie się rozdzieliły ${ }^{792}$. Jednocześnie już $\mathrm{w}$ latach siedemdziesiątych m.in. Marcin Czerwiński zauważał podobne co Polak problemy: wytykał, że dla nie-filologicznych badań nad książką charakterystyczne wydaje się skupienie się na jej materialności przy równoczesnym ujmowaniu w nawias jej treści, zawartości ideowej. I rzeczywiście, w Encyklopedii wiedzy o ksiażce wyczytamy, że z punktu widzenia nauki o tej ostatniej, pisarstwo nie jest procesem twórczym, lecz aktem kształtowania tekstu ${ }^{793}$. Z kolei literaturoznawcy - zdaniem Czerwińskiego - rzeczywiście odcinają się zupełnie od tych „materialnych” kwestii, w konsekwencji czego dla nich - jak mówi badacz - „rozprzestrzenianie się utworu w społeczeństwie ma [...] postać wędrówki pewnego rodzaju bytu idealnego"794.

Czerwiński dostrzegł jednak także zwrot w myśleniu o literaturze i książkach, mówił o nowych horyzontach, jakie otwierała tu socjologia kultury. Dodać można, iż w gruncie rzeczy ważny jest tu wpływ zarówno socjologii ogólnej, jak i rozmaitych jej poddziedzin, nie tylko tej wymienionej przez badacza $^{795}$. Ów nowy nurt refleksji objawiać miał się:

W postaci prób ścisłego powiąania ze sobą tych dwu sposobów podejścia do fenomenu książki, które ukształtowały się historycznie: podejścia doń w kategoriach „rzeczy” oraz tego, które koncentruje się na „utworze”, „rzecz” pozostawiając na stronie ${ }^{796}$.

${ }^{792}$ K. Głombiowski, Ksiażka w procesie komunikacji społecznej, s. 7. Na fakt początkowego powiązania nauki o książce z nauką o literaturze zwraca też uwagę Krzysztof Migoń (idem, $\mathrm{Na}$ uka o ksiażce. Zarys problematyki, Wrocław 1984, s. 223).

${ }^{793}$ Encyklopedia wiedzy o ksią̇ce, s. 1588. Warto też przywołać w tym miejscu Wolę Nikołajewicza Lachowa, który definiował książkę (m.in.) jako „formę organizacji komunikatu pisanego” (s. 6), lecz podkreślał, że w zakresie jego dziedziny przesłanie, jej literacka zawartość nie są przedmiotem refleksji. O „ideologicznej stronie książki, niezwykle ważnej ze stanowiska społecznego” pisał, że „jest istotą nie książki (w naszym pojęciu), lecz tekstu lub obrazu, tzn. samej informacji semantycznej. Dlatego tę grupę związków należy rozpatrywać w innej płaszczyźnie (tekst - czytelnik, ilustracja - widz)” - tłumaczył (Wola N. Lachow, Szkice z teorii sztuki ksiażki, s. 8).

${ }^{794}$ Marcin Czerwiński, System ksiqżki, Warszawa 1976, s. 6. Dalej badacz pisze o „tradycyjnie filologicznej wyłączności w ujmowaniu «utworu» ze względu na jego immanentne cechy, jako pewnego umownego bytu idealnego" (s. 7).

${ }^{795}$ Karol Głombiowski, O dwóch tendencjach badań bibliologicznych, „Studia o Książce” 1981, t. 11, s. 3. Ciekawie (i podając obszerną bibliografię) o związkach nauki o książce z socjologia, ale i wszelkimi innymi naukami humanistycznymi pisze też Krzysztof Migoń w: Nauka o ksiqżce w zespole nauk humanistycznych, [w:] idem, Nauka o ksiązce. Zarys problematyki, s. 222-303. Szczególnie istotny dla moich rozważań wydaje się fragment poświęcony związkom z nauką o literaturze, s. 223-258. Por. także wcześniejszy szkic autora Stan i perspektywy wspótdziałania nauki o ksiażce z innymi naukami, [w:] idem, Nauka o ksiażce wśród innych nauk społecznych, s. 111-151.

${ }^{796}$ M. Czerwiński, System ksiażki, s. 7. Niemniej, pojawiały się i głosy zwracające uwagę na to, że ujęcie socjologiczne może też z kolei odcinać się od samej literackości, zob. Maria Corti, Literatura i komunikacja, tłum. Joanna Ugniewska, „Teksty” 1980, nr 1, s. 133-144 (zwłaszcza część Próba opisu socjologicznego, s. 139-142). 
Czemu właśnie socjologia miała się przyczynić do przełomu w myśleniu o sztuce słowa? Przede wszystkim dlatego, że wyznaczyła nowe pole odniesień - teorię komunikacji. W efekcie i sama książka (jako element procesu przekazywania znaczeń) stawała się interesującym obiektem badań. Bliższa literaturoznawstwu stać się musiała (medioznawcza w swej naturze, i „skażona McLuhanem") refleksja nad rolą i charakterem samego nośnika przekazu, za jaki zaczęto kodeksy postrzegać ${ }^{797}$. To zaś owocowało właśnie połączeniem obu podejść do wytworów sztuki słowa, próbą kompleksowego ujęcia, o które dopominała się Polak. Jednocześnie (co może nawet istotniejsze), jak podkreśla Głombiowski: o ile dla socjologii wpływ narzędzia i sytuacji przekazu na proces recepcji jest zagadnieniem istotnym i przepracowanym, jednak nie kluczowym, o tyle „dla problematyki procesu komunikacyjnego książki jest [...] zagadnieniem centralnym" ${ }^{98}$. Czy takie spojrzenie na książkę nie powinno zadowolić liberatów? Przecież, jak wyjaśnia Głombiowski, dla bibliologów:

Przekaz uczestniczy w procesie odbioru zarówno w swej treści, jak w jej materialnej postaci. Stąd sprawą największej wagi w analizie zjawisk książki wydaje się być zrozumienie dialektycznej jedności treści i formy książki ${ }^{799}$.

Pamiętając, że szeroko pojęta teoria komunikacji jednoczy dwa ujęcia: szkołę procesu komunikacyjnego i szkołę semiotyczna ${ }^{800}$, nie sposób nie zwrócić uwagi na semiotyczne inspiracje w myśleniu o książce. Przywołana nauka pozwala z kolei traktować ja jako komunikat naturalnie wielokodowy ${ }^{801}$ i strukturę: całość złożoną z tych różnokodowych elementów, których wzajemne związki sa kluczowe i - jako że mamy do czynienia z czymś więcej niż zwykłą sumą elementów - określają funkcję całości ${ }^{802}$. Jak wyraźnie wypunktowuje Teodor Zbierski:

Wychodząc z semiotycznego punktu widzenia, mogliśmy scalić problematykę książki - „rzeczy” i książki - „utworu”. Książka dzięki swej strukturze nie jest tylko „opakowaniem” jakiejś idei, ale jest w pełni, we wszystkich elementach przedmiotem znaczącym, umożliwiającym pełnienie określonych funkcji ${ }^{803}$.

${ }^{797}$ Również Janusz Dunin, w prowadzonych już w XXI w. rozmowach z Jackiem Ladurockim (J. Ladorucki, Pozostawałem w kręgu ksiażki...), podkreśla, jak ważny jest współcześnie dla księgoznawstwa ów medioznawczy punkt widzenia. W wypowiedziach tego badacza wyraźnie też widać, iż - niejako wskutek takiego właśnie podejścia - w centrum zainteresowań badaczy książki znajdują się kwestie kluczowe dla liberatów. Jak wyjaśnia Dunin: „Tak jak retoryka zajmuje się komunikatem mówionym, teoria sztuki - obrazem, teatrologia - widowiskami, tak księgoznawstwo - komunikatem pisanym i graficznym, utrwalonym w druku" (s. 49). Traktuje zatem tekst literacki jako coś więcej niż tylko słowa, zdania, rozdziały. Przyjmuje też inny punkt widzenia niż klasyczne literaturoznawstwo, utożsamiające - jak już zaznaczałam - w większości sytuacji utwór wyłącznie z przywoływanym ,bytem idealnym”, bezcielesnym.

798 K. Głombiowski, O dwóch tendencjach badań bibliologicznych, s. 6.

799 Ibidem, s. 8.

800 John Fiske, Wprowadzenie do badań nad komunikowaniem, tłum. Lech Tkaczyk, Wrocław 2008, s. 16.

801 Teodor Zbierski, Semiotyka ksiażki, Wrocław 1978, s. 33.

802 Ibidem, s. 24-25. Nie muszę chyba podkreślać, jak silnie wybrzmiewają tu też echa wniosków, jakie formułowałam, analizując liberaturę w kontekście teorii formalizmu i strukturalizmu. ${ }^{803}$ Ibidem, s. 62. 
Znaczenie semiotyki dla refleksji o książce podkreślał (zresztą dwa lata wcześniej niż Zbierski) i przywołany już tu Czerwiński, mówiąc, iż w jej perspektywie właśnie możliwe jest mówienie o książce jako kanale przekazu. I on dodawał, że:

W [...] perspektywie semiotyki, przedmiot taki jaki książka (właśnie: przedmiot) ożywa, nie jest „opakowaniem” idei o niejasnym do niej stosunku. Uwydatnia się i uszczegółowia sens przedmiotu znaczącego, pełny sens zapisu. „Utwór”, idea literacka, zakorzenia się z kolei w konkretnych zapisach ${ }^{804}$.

W konsekwencji takiego zwrotu w myśleniu, współcześnie książka rozumiana jest (przynajmniej z punktu widzenia bibliologii) właśnie jako nie-neutralne narzędzie przekazu i większości prób zbudowania jej definicji towarzyszy wykorzystanie modelu komunikacji społecznej ${ }^{805}$. Nie sposób nie zauważyć bliskości tego ujęcia z myślą liberacka. Dla twórców literatury totalnej przecież właśnie owa „materialna postać” oraz „dialektyczna jedność formy i treści” sa kluczowe. I to jej teoretycy protestuja przeciw nazywaniu ksiazzek opakowaniami na słowa. Pozostaje zatem pytanie: czemu Fajfer sprzeciwiał się współczesnemu rozumieniu książki, czemu już pierwsze jego manifesty przynosiły postulat zredefiniowania tej kategorii?

\subsection{Redefinicja książki czy komunikacji?}

Przede wszystkim, raz jeszcze podkreślić trzeba, że książka - wbrew pozorom - wcale nie jest obiektem do zdefiniowania łatwym ${ }^{806}$. Choć Duninowie w Stowniczku bibliofila wieńczącym Philobiblon polski stwierdzali: „książka co to jest, każdy widzi” "807, badacze są raczej zgodni co do tego, że spójnie opisać to, co się widzi, już wcale w tym wypadku nie jest tak łatwo. Niektórzy - jak Krzysztof Migoń - uznają wręcz, że książki (za względu na otwarty charakter tego pojęcia) po prostu nie da się do końca zdefiniować ${ }^{008}$. Trzeba też zauważyć, że sprzeciw wobec rozumienia książki, jaki przynoszą pierwsze manifesty Fajfera, to w gruncie rzeczy odrzucenie potocznego jej rozumienia. Wyraźnie widać już, że gdy zajrzymy do innych niż przywołane przez liberata słowni-

${ }^{804}$ M. Czerwiński, System ksiażki, s. 9.

805 Radosław Cybulski, Ksiażka wspótczesna. Wydawcy-rynek-odbiorcy, Warszawa 1986, s. 47 oraz 92 .

${ }^{806}$ Przystępny opis rozmaitych ujęć znaleźć można w książce Migonia Nauka o książe. Zarys problematyki w rozdziale Ksiażka jako przedmiot badań bibliologicznych (s. 6-26). Por. też K. Głombiowski, Czym jest ksiażka, [w:] idem, Ksiażka w procesie komunikacji społecznej, s. 20-26.

${ }^{807}$ Cecylia i Janusz Duninowie, Philobiblon polski, Wrocław 1983, s. 280.

808 K. Migoń, Nauka o ksiqżce wśród innych nauk społecznych, s. 50. Na problemy z definicja książki zwracali tė̇ uwagę właściwie wszyscy przywoływani w tym rozdziale badacze. I Escarpit na pierwszych stronach Rewolucji ksią̇ki stwierdzał wprost: „Jak wszystko, co żyje, książka nie da się ująć w jednoznaczną definicję. W każdym razie nigdy jeszcze nie udało się nikomu zdefiniować jej w sposób całkowity i trwały” (R. Escarpit, Rewolucja ksiązki, s. 13). 
ków i opracowań - okaże się, że książka to coś więcej niż tylko kodeks, zszyte karty, „opakowanie tekstu”. A zresztą Fajfer - warto podkreślić - przywołuje Słownik terminów literackich, a więc poszukuje definicji książki formułowanej przez filologów, więc - jak wypada się zgodzić w kontekście dotychczasowych ustaleń - tych, którzy materię książki, rzeczywiście, najczęściej bagatelizuja.

Ale nawet w krytykowanej przez Fajfera definicji podkreśla się przecież, że książka ma służyć komunikacji. Cytowany przez liberata słownik mówi wszak o przedmiocie „służącym przekazywaniu i rozpowszechnianiu wszelkiego typu powiadomień" 809 . Wydawać by się więc mogło, iż właściwy zarzut powinien dotyczyć nie tyle samej definicji książki, lecz tego, jak rozumiana jest (lit/beracka czy książkowa) komunikacja. Właściwie zadane pytania odnieść trzeba zatem do tego, co rzeczywiście przenosi w niej znaczenia, co naprawdę uczestniczy w akcie komunikacji. I choć samego pojęcia „komunikacja” Fajfer akurat nie używa, w istocie zdaje się dopytywać o takie właśnie kwestie. W tym też obszarze warto kontynuować badawcze poszukiwania.

Prowadzi to właśnie ku nauce o książce, gdyż - jak słusznie zauważa Radosław Cybulski - i „księgoznawcy doceniaja problematykę organizacji materii, jako istotna dla przebiegu komunikacji społecznej" ${ }^{810}$, i oni dopominali się o dostrzeżenie w książce innych niż same słowa elementów znaczących. O specyfice komunikacji poprzez papierowe woluminy stanowi według nich też to wszystko, co związane z owych tomów materią. Jakże bliskie Fajferowskiemu jest ujęcie Głombiowskiego, który dostrzegał, że:

Książka jest całościa, złożoną z treści piśmienniczych, funkcji i formy książkowej. Tworzywem książki jest tekst i materia fizyczna książki. Ale o tym, jak książka spełnia swoja funkcję narzędzia przekazu, decyduje sposób organizacji materii, inaczej sztuka książki ${ }^{811}$.

Jednak czy takie spojrzenie zmieści się w kategoriach komunikacji literackiej? Innymi słowy: czy tworzywem (kodem, medium) w rozumieniu literaturoznawców może być owa fizyczna materia książki? Czy zmieści się ona w budowanych z punktu widzenia nauki o literaturze modelach komunikacyjnych? Czyż nie o to właśnie pytają w gruncie rzeczy liberaci?

\subsection{Książkowa komunikacja}

Jednak już samo mówienie o komunikacji literackiej przysparza problemów. Choć „literacki komunikacjonizm” stał się u nas popularny (jak ujmują to Aleksandra Okopień-Sławińska czy Henryk Markiewicz) już w latach

809 Teresa Kostkiewiczowa, hasło 'książka', [w:] Słownik terminów literackich, red. Janusz Sławiński, Wrocław 2008, s. 266. W dalszej części hasła, niecytowanej już przez Fajfera, wprost wyrażone jest przekonanie, że książka jest narzędziem komunikacji (,będąc materialnym środkiem utrwalania i przekazywania myśli, służy komunikowaniu się ludzi”).

${ }^{810}$ R. Cybulski, Ksią̇̇ka wspótczesna..., s. 46.

811 K. Głombiowski, $O$ dwóch tendencjach badań bibliologicznych, s. 11, podkreślenie moje. 
osiemdziesiątych, aktualna zostaje nadal konstatacja przywołanej badaczki, iż „mimo potęgi mody problematyka komunikacyjna nie została jeszcze dostatecznie przemyślana" ${ }^{12}$. Próba opisania „liberackiego komunikacjonizmu” zmusza zaś do zauważenia w tej refleksji bardzo konkretnych niedomyśleń. Przede wszystkim - za punkt wyjścia przyjmuje się tu tezę, iż utwór literacki jest „wypowiedzia językową szczególnego rodzaju”"13, że charakter dzieła jest „znakowy i językowy" 14 . Mówiąc wprost: przyjmuje się, że jego tworzywem jest język i nic więcej (przeciw czemu właśnie burzył się Fajfer) ${ }^{815}$.

Choć więc polska refleksja o literackiej komunikacji (czy komunikacyjnej teorii dzieła literackiego) rozwinęła się w różnych kierunkach, króluje tu skupienie się na relacjach nadawczo-odbiorczych (mnożeniu ich poziomów), zaś zdecydowanie brak tu namysłu nad samym zaprzężonym w ową komunikację komunikatem ${ }^{816}$. I być go nie może, gdyż podstawą formułowanych teorii jest jego konkretna wizja. Jednocześnie badania skupiające się na odbiorze dzieł literackich (przez Sławińskiego uznane za dominujący nurt refleksji ${ }^{817}$ ) nie analizuja raczej roli mediów przenoszacych komunikat czy też jego samego. Stąd we wszystkich tych ujęciach nie wspomina się raczej o książce ani o jej materialnych właściwościach, o możliwości uczynienia jej istotną w akcie komunikacji. Taki zaś model byłby raczej potrzebny, by w ramach komunikacji literackiej ująć i tę liberacka ${ }^{818}$. Gdy spojrzymy na dzieło liberackie nie da się bowiem przyznać racji Okopień-Sławińskiej, która kończąc szkic Teoria wypowiedzi jako podstawa komunikacyjnej teorii dzieła literackiego pisała:

812 Fraza ta kończyła pierwszy akapit publikowanego po raz pierwszy na łamach „Pamiętnika Literackiego" (1988, z. 1, s. 165-181) szkicu Okopień-Sławińskiej Teoria wypowiedzi jako podstawa komunikacyjnej teorii dzieła literackiego. W przedrukach tego tekstu (jako Zakończenie) w kolejnych (począwszy od drugiego) wydaniach Semantyki wypowiedzi poetyckiej (Preliminaria) (Kraków 1998, 2001) pozostaje - co chyba znaczące - niezmieniona.

${ }^{813}$ Aleksandra Okopień-Sławińska, Semantyka wypowiedzi poetyckiej (Preliminaria), wyd. 2, Kraków 1998, s. 231.

814 Ibidem.

815 Por. ibidem, a także Janusz Lalewicz, Komunikacja językowa i literatura, Wrocław 1975.

816 Odnośnie do relacji nadawczo-odbiorczych zob. Aleksandra Okopień-Sławińska, Relacje osobowe w komunikacji literackiej, [w:] Semantyka wypowiedzi poetyckiej (Preliminaria), s. 100 116 oraz eadem, Semantyka ,ja” literackiego”(,Ja” tekstowe wobec ,ja” twórcy), ibidem, s 117-135. O pragmatycznych aspektach komunikacji literackiej pisze też Kazimierz Bartoszyński w szkicu O integracji badań nad tzw. komunikacja literacka, [w:] idem, Powieść w świecie literackości. Szkice, Warszawa 1991, s. 231-255.

817 Janusz Sławiński, hasło 'komunikacja literacka', [w:] Słownik terminów literackich..., s. 256.

${ }^{818}$ Warto jednak odnotować tu artykuł Macieja Maryla opublikowany w 2010 r. na łamach „Pamiętnika Literackiego”, wskazujący na sygnalizowane tu przeze mnie problemy i - za badaczami takimi jak skupiająca się na elektronicznej sztuce słowa Hayles czy socjologami literatury pokroju Escarpita - w przekonujący sposób wprowadzający kategorie książki jako „interfejsu” do literaturoznawczego dyskursu. Przyjęta przez badacza perspektywa jest mi bliska, zaś wiele tez przezeń formułowanych zbieżnych z wnioskami, do których sama doszłam (co poświadczaja zarówno wcześniejsze, jak i kolejne rozdziały tej książki). Wspólnotę inspiracji dla naszych badań widać będzie szczególnie w ostatniej części tej publikacji. Zob. Maciej Maryl, Technologie literatury. Wpływ nośnika na formę i funkcje przekazów literackich, „Pamiętnik Literacki”, nr 2/2010. 
Roztrząsając poszczególne kwestie, mówiłam o wypowiedzi, nie zaś o utworze literackim, mimo to wywody moje ostatecznie utwór literacki miały na względzie. Utwór bowiem uważam za szczególnego rodzaju wypowiedź, a jego teorię zakorzeniam w teorii wypowiedzi. Dzięki temu odniesieniu widzę możliwość objaśnienia komunikacyjnych mechanizmów dzieła we wszystkich jego wymiarach, od elementarnych właściwości znaczeniowych poczynając, a na funkcjonowaniu w obrębie życia społecznego kończąc ${ }^{819}$.

Wymiarów dzieła liberackiego jest być może więcej niż przewidziała badaczka. Na pewno jednym z nich jest książka. Warto zatem poszukać takich ujęć komunikacji, które uwzględnią tę kategorię. Nie jest tu moim celem zgłębianie różnorodności proponowanych $\mathrm{w}$ tym zakresie modeli ${ }^{820}$. Za punkt wyjścia wystarcza mi zaobserwowanie, że koncentrujące się wokół literatury bądź - szerzej - komunikacji językowej propozycje (nietraktujące książki jako elementu istotnego), najczęściej posługują się modelem linearnym (zatem wywiedzionym z propozycji Shannona i Weavera), dającym się w dużym uproszczeniu sprowadzić do relacji nadawca-komunikat-odbiorca, wzbogaconym o (uprzestrzenniająca go) propozycję Jakobsona: uwzględnienie również takich elementów, jak kontekst, kontakt i kod ${ }^{821}$. Druga wyjściowa konstatacja jest taka, iż w formułowanych (najczęściej przez teoretyków sztuki książki czy semiotyków) modelach komunikacji książkowej wyróżniany jest po prostu jakby dodatkowy poziom, dotyczący wtórnego opracowania tekstu autorskiego przez edytorów i redaktorów, mówiąc innymi słowy - komunikacja ta maluje się jako bardziej złożona niż „klasyczny” układ, w którym zwykliśmy wyróżniać nadawcę, odbiorcę i komunikat. Wydawać by się mogło, że liberackie ujęcie zakładałoby takie samo uzupełnienie istniejacych modeli. Hipotetycznie zatem schemat zdolny opisać literature totalna przyjmowałby za podstawę opis komunikacji literackiej, poszerzajac go jednak o uzupełnienia wniesione $\mathrm{z}$ modeli tworzonych dla komunikacji książkowej. By sprawdzić, czy jest tak rzeczywiście, chciałabym przyjrzeć się przykładom tak poszerzonych modeli formułowanym przez Janusza Lalewicza (bliższego klasycznym ujęciom komunikacji czysto literackiej) oraz Teodora Zbierskiego (bliższego ujęciu nauki o książce). Czy propozycje tych badaczy mogłyby być użyteczne przy opisie liberatury?

\subsection{Propozycja Janusza Lalewicza}

Lalewicz rozbudowuje klasyczny schemat, niejako go podwajając. Przede wszystkim, badacz traktuje literacką komunikację dość wąsko - uznając, że „ponieważ utwór literacki to przede wszystkim komunikat słowny [...], sposób

819 A. Okopień-Sławińska, Semantyka wypowiedzi poetyckiej (Preliminaria), s. 246.

${ }^{820}$ Klarowny opis najważniejszych propozycji zarówno szkoły procesu komunikacyjnego, jak i semiotycznej znaleźć można w pracy Fiske’a Wprowadzenie do badań nad komunikowaniem.

${ }^{821}$ Por. Roman Jakobson, Poetyka w świetle językoznawstwa, tłum. Krystyna Pomorska, [w:] Teorie literatury XX wieku. Antologia, red. Anna Burzyńska, Michał P. Markowski, Kraków 2006, s. 243-253 oraz John Fiske, Wprowadzenie do badań nad komunikowaniem, s. 21-40 oraz 54-56. 
pojmowania literatury jest sprzężony ściśle ze sposobem rozumienia komunikacji językowej" ${ }^{22}$. Jednocześnie, uznaje tworzenie tekstu, który ma być potem ujęty w formę książki, za działanie należące do „prekomunikacyjnej fazy produkcji książki” ${ }^{823}$, przyjmując, że właściwy proces książkowej (z kolei) komunikacji zaczyna się z chwilą wydania dzieła. W efekcie dostrzega więc jakby dwa (rozdzielne) rodzaje komunikacji: językowa - literacka, związaną z komunikatem, którym jest sam tekst artystyczny (przenoszony przez przedmiot, jakim jest książka lub przez inny środek przekazu) oraz tę związaną z konkretnym kanałem dystrybucji tego tekstu.

Jak więc widać, stanowisko tego badacza wydaje się nie do końca bliskie liberackiemu, jednocześnie też bardziej skrajne niż inspirujące moje rozważania ujęcia Głombiowskiego, Zbierskiego czy Escarpita. Przede wszystkim, choć Lalewicz dostrzega, że wybór książki jako środka przekazu jest istotny i wiąże się z konkretnymi konsekwencjami, mimo chwilowych ustępstw ku refleksji inspirowanej McLuhanem, zdaje się traktować sam wolumin jako nieistotny nośnik. Tekst widzi jako „towar” ${ }^{24}$, zaś sam materialny tom jako jego „opakowanie" 825 . Patrzy zatem na literacką komunikację w sposób, którego liberaci nie chcieli zaakceptować.

To, co napisane - stwierdza, - dociera do czytelnika poprzez książkę. Lektura, w której dokonuje się komunikowanie, to interpretacja tekstu, ale kupuje się, przechowuje i czyta książkę, tj. przedmiot, który ten tekst zawiera. [...] Książka jest środkiem przekazu tekstu, ale zarazem jest przedmiotem związanym z całą machiną rozpowszechniania, której funkcjonowanie wykracza znacznie poza same operacje komunikacyjne. [...] Kupując książkę, nie kupuję tekstu, lecz cały ten przedmiot, który Escarpit nazywa „maszyną do czytania” wraz ze wszystkimi jego aspektami. Nie kupuję tekstu ani nawet jednego zapisu tekstu, jest on bowiem powielony, lecz jedynie dostęp do tekstu, możliwość lektury. Jednocześnie dany mi jest przedmiot, który tę potencjalną lekturę zawiera, który jest niejako jej opakowaniem ${ }^{826}$.

A taka właśnie charakterystyka literackiej komunikacji (czy właściwie sprzeciw wobec niej) stała się punktem wyjścia do sformułowania teorii liberatury.

Lalewicz sam z czasem dostrzegł, że w cytowanej tu pracy (Komunikacja językowa i literatura) - koncentrując się przede wszystkim na komunikacji językowej, za której szczególny przypadek uznał właśnie literaturę - marginalnie (i jak sam później stwierdzi: „ogólnikowo” ${ }^{827}$ ) traktował jeszcze rolę medium, jakim jest książka (poświęcając tej kwestii zaledwie niespełna dziesięciostronicowy rozdział ${ }^{828}$ ). Rozwinięcie sygnalizowanych tam problemów przynosi jednak późniejszy artykuł Proces i aparat komunikacji literackiej ${ }^{829}$.

\footnotetext{
822 J. Lalewicz, Komunikacja językowa i literatura, s. 5-6.

823 Ibidem, s. 129.

${ }^{824}$ Ibidem, s. 132.

825 Ibidem.

${ }^{826}$ Ibidem.

827 J. Lalewicz, Proces i aparat komunikacji literackiej, „Teksty” 1978, nr 1, s. 20.

828 J. Lalewicz, Ksiażka, [w:] idem, Komunikacja językowa i literatura, s. 125-133.

829 J. Lalewicz, Proces $i$ aparat komunikacji literackiej, s. 17-36.
} 
Czy większe skupienie się na kategorii medium literatury poprowadzi ku tezom mniej niepokojaccym liberatów? Czy zaproponowany tam model - uwzględniający samą książkę - będzie użyteczny do opisu komunikacji liberackiej?

W przywołanym szkicu badacz przyjmuje za punkt wyjścia fakt, iż w myśleniu o literaturze dokonał się (charakteryzowany tu wcześniej przeze mnie) zwrot i zaczęto rozpatrywać ją właśnie jako „szczególnego rodzaju zjawisko komunikacyjne" ${ }^{30}$. Zwraca jednak uwagę, że w przypadku komunikacji literackiej stosowanie schematu nadawca-komunikat-odbiorca więcej wnosi nieporozumień niż wyjaśnia ${ }^{831}$. Krytykuje również wszelkie sposoby rozbudowywania takiego ujęcia o elementy związane z produkcją książki, podkreślając, że wszelkie te propozycje łączy błędne przekonanie, iż komunikacja literacka daje się scharakteryzować na wzór tej opartej na dialogu ${ }^{832}$.

Odwołując się do teorii Pierre'a Schaeffera oraz Roberta Escarpita ${ }^{833}$, Lalewicz konstruuje klarowny model komunikacji literackiej uwzględniający kategorię książki. Daje się w nim wyróżnić dwie płaszczyzny: semiotyczno-kulturową (związaną z czytelnikiem, tekstem i jego autorem) oraz rzeczowo-ekonomiczną (obejmujaccą kwestie obiegu, rozpowszechniania, konsumpcji książek). Jak podkreśla badacz, nie można „traktować sekwencji: «pisanie-czytanie» jako «jednego, nieprzerwanego» ciąu operacji, tworzącego "całość» procesu operacyjnego" ${ }^{334}$. Jakie sa zatem inspiracje Lalewicza?

Cytowany przezeń Schaeffer wyróżniał dwie strony komunikacji: płaszczyznę przekazu oraz płaszczyznę sytuacji, z tą drugą wiążąc elementy, takie jak kwestie wydania, produkcji czy konsumpcji dzieła. Podkreślał też, że zupełnie inna jest rola autora czy czytelnika w każdym z tych układów, oraz że tak naprawdę nie ma między nimi bezpośredniej relacji (co ma odróżniać komunikację literacka jako zapośredniczona przez materialne medium od tych jej odmian, które były prawdziwie dialogowe i dawały się opisać linearnymi schematami). Tym samym, konieczne wydawało się oddzielenie dwóch aspektów, czy - jak ujmuje to francuski teoretyk - płaszczyzn aktu komunikacji.

${ }^{830}$ Ibidem, s. 17. O „włączeniu literatury w ramy klasycznego obiegu komunikacyjnego” pisał również Karol Głombiowski (K. Głombiowski, Ksią̇ka w procesie komunikacji społecznej, s. 13).

${ }^{831}$ Pogląd ten Lalewicz sygnalizował już we wcześniejszej pracy. Zob. J. Lalewicz, Komunikacja językowa i literatura, s. 128-129.

${ }^{832}$ A już w przywoływanej wcześniej pracy traktował literacką komunikację jako „nader specyficzną” (s. 8), wręcz - jak mówił - „z pewnego punktu widzenia nienormalną” (s. 8) i stwierdzał: „analiza przekazu drukowanego czy radiowego wymaga uwzględnienia czynników pragmatycznych zupełnie innego typu niż analiza rozmowy czy przemówienia” (J. Lalewicz, Proces $i$ aparat komunikacji literackiej, s. 9).

${ }^{833}$ Klarowne omówienia ich teorii badacz podaje w swoim artykule na s. 20-30. Por. też Robert Escarpit, Literatura a społeczeństwo, tłum. Janusz Lalewicz, [w:] Współczesna teoria badań literackich za granica. Antologia, oprac. Henryk Markiewicz, t. III, s. 137 (zwłaszcza część Czynnik socjologiczny $w$ literaturze, s. 125-134).

834 J. Lalewicz, Proces $i$ aparat komunikacji literackiej, s. 32. Badacz już w 1975 r. zauważał, że autor jest, owszem, nadawcą tekstu, jednak nie: książki; tę bowiem w proces komunikacji jako nadawca wprowadza wydawnictwo (J. Lalewicz, Komunikacja językowa i literatura, s. 128). Z kolei opisywane przeze mnie w dalszej części rozdziału ujęcie zaproponowane przez Zbierskiego w Semiotyce ksią̇ki zdaje się prowadzić do rozumienia negowanego przez Lalewicza. 
Escarpit z kolei proponuje, by rozpatrywać literaturę i jako „proces” (a zatem to, co związane z semantyką tekstu, z jego tworzeniem i lektura), i jako „aparat" (a zatem to, co określimy jako produkcję, rynek i konsumpcję) ${ }^{835}$, co pokrywa się z wyróżnianymi przez Schaeffera płaszczyznami.

Najistotniejsze w obu teoriach (i inspirujące model zaproponowany przez Lalewicza) jest właśnie to rozbicie na dwie przestrzenie relacji, dwie przestrzenie komunikacyjne. Jak podkreśla polski badacz:

\footnotetext{
Mówiąc o literaturze rozumianej jako proces, rozpatrujemy [...] pewien twór językowy tekst - i operacje językowe czy komunikacyjne w sensie ścisłym. Mówiąc o aparacie literatury natomiast, zajmujemy się zjawiskami socjoekonomicznymi. Innymi słowy - dodaje - komunikacja literacka rozpatrywana jest z jednej strony w kategoriach jednostkowych zjawisk semiotycznych czy komunikacyjnych, z drugiej zaś w kategoriach socjologicznych i ekonomicznych zarazem ${ }^{836}$.
}

Mówiąc jeszcze inaczej - biorąc książkę, sięgamy jako konsumenci po pewien produkt. Musimy zaistnieć na płaszczyźnie aparatu, by móc zagłębić się w lekturę, stać się czytelnikiem. Lalewicz wyciąga z tej sytuacji jednak dalsze wnioski. Uznaje, że charakteryzowaną komunikację warunkują i czynniki techniczne, materiałowe, związane z kwestią projektowania, produkcji, dystrybucji i konsumpcji książki, i - z drugiej strony - czynniki kulturowe ściśle związane z tekstem. Pierwsze z wymienionych jednak, jak wyraźnie zaznacza, „oddziałują na producenta, dystrybutora i konsumentów, natomiast nie dotyczą bezpośrednio tekstu i operacji na tekście" ${ }^{837}$. Z tym zaś liberaci na pewno się nie zgodzą. Zaś rozbicie komunikacji literacko-książkowej na część uwikłaną w relacje $\mathrm{z}$ semantyką utworu i drugą (zupełnie od niej niezależna), związaną wyłącznie z jego „opakowaniem”, wydaje się zupełnie sprzeczne z postulowana przez twórców i teoretyków literatury totalnej teorią roli owego „pojemnika na treśćc w procesie tworzenia znaczeń.

Liberaci bowiem chca, byśmy znacznie wcześniej weszli w rolę czytelnika. Pragna, by to, co u Lalewicza w ogóle nie dotyczy tekstu, poddane zostało interpretacji podczas jego lektury. Oczywiście, kupując książkę liberacka, możemy być jeszcze konsumentami; nie jest moim celem rozważanie tu słuszności takiego rozbicia. Istotne jest jednak to, w którym momencie wkraczamy w przestrzeń znaczeń, w obszar semiotyki, a nie ekonomii. Wydaje się, iż „liberacki problem" z charakteryzowana tu propozycją wynika z tego, iż teoretycy literatury totalnej nie mogą się zgodzić na wyróżnianie dwóch płaszczyzn komunikacji, a już na pewno nie na rozdzielanie komunikatów z nich płynących. Jeśli w liberaturze i kształt, i treść książki mają znaczyć i tworzyć spójny komunikat, w którym dopiero paralelna percepcja wszystkich składowych elementów pozwoli go odczytać, nie możemy tylko jednego z tych obszarów wiązać z semiotyka. Komunikat liberacki jest po prostu szerszą kategoria,

\footnotetext{
${ }^{835}$ Por. także R. Escarpit, Literatura a społeczeństwo.

836 J. Lalewicz, Proces $i$ aparat komunikacji literackiej, s. 28.

837 Ibidem, s. 33.
} 
obejmujaccą i to, co Lalewicz wiązał z płaszczyzną znaczeń (tekstu) i to, co dlań było związane z ekonomią. Obszary te zatem należałoby nie tyle skrupulatnie rozdzielać, co właśnie uspójniać.

Wydaje się więc, że liberaci poszukują jednak modelu, który choć rozbuduje ujęcie klasyczne o kategorię książki, nie będzie samego aktu komunikacji rozwarstwiał. Wydaje się, że bardziej satysfakcjonujący (czy użyteczny) byłby tu jednak schemat nawiązujący do (uznanego przez Lalewicza za błędny i upraszczajacy w odniesieniu do komunikacji literackiej) układu linearnego. Powracam zatem do pytania, jak miałaby wyglądać widziana oczami liberatów książkowa komunikacja, gdyż - jak widać - zaproponowany model nie posłuży tu pomoca.

\subsection{Propozycja Teodora Zbierskiego}

Proponuję przyjrzeć się dla odmiany ujęciu zaproponowanemu przez Teodora Zbierskiego w jego Semiotyce ksiażki ${ }^{838}$. Badacz ten, inaczej niż Lalewicz, nie rozdziela płaszczyzn komunikacji, jednoczy to, co przekazywane „tekstem” (słowem) z tym, co „mówi” książka. Tym samym, uspójnia to, co tamten skrupulatnie rozdzielał i tworzy model nawiązujący do ujęcia linearnego, traktujacego pisanie i czytanie jako elementy jednego układu. Czy zaproponowane przez badacza poszerzenie schematu nadawca-komunikat-odbiorca bliższe będzie liberatom?

Również Zbierski uznaje, że uproszczeniem jest patrzenie na książkowa komunikację jako na przekazanie przez autora komunikatu (w formie książki) do odbiorcy, gdyż „w rzeczywistości droga od autora do odbiorcy-czytelnika jest bardziej złożona”, a składa się na nią „złożony proces tworzenia książki, dystrybucji i udostępniania książki czytelnikom" ${ }^{839}$. Do analizy opisywanych relacji badacz posługuje się zapożyczoną od Tadeusza Wójcika teorią kooperatoryki i wprowadza pojęcie kooperatora komunikowania dla scharakteryzowania wszelkich elementów współuczestniczących w procesie tworzenia komunikatu (inaczej właśnie: kooperujacych). Wśród nich pojawiają się edytorzy (gdyż autorski komunikat zanim trafi do czytelnika - który jest tu celem ostatecznym autora - trafia w ręce tych, którzy zajmują się jego edycja ${ }^{840}$, ale też m.in. redaktorzy techniczni czy poligrafowie (gdyż książka jest też „produktem” i musi przejść przez poszczególne etapy samego „procesu produkcji”).

${ }^{838}$ Prezentowane przez autora wizualizacje i ich opisy wydają się wskazywać na Jakobsonowską inspirację. Zob. T. Zbierski, Semiotyka ksia $\dot{z} k i$, s. 8 oraz 12.

839 T. Zbierski, Semiotyka ksiażki, s. 9. Por. też ibidem, s. 10-23. O roli wszelkiego rodzaju instytucji związanych z dystrybucją i produkcją książek pisze także Janusz Lalewicz. I ten badacz nie zgadza się, by owe instytucje traktować jako kanał komunikatu, postrzegając takie ujęcie jako uproszczenie. Zob. J. Lalewicz, Komunikacja językowa i literatura, zwłaszcza rozdział Ksiażka (s. 125-133), szczególnie zaś s. 128-129.

${ }^{840}$ T. Zbierski uznaje, że edytor jest „użytkownikiem produkcyjnym produktu autora” (s. 14), niejako celem pośrednim. 
Zbierski zwraca uwagę na to, że w przypadku interesującego mnie rodzaju komunikacji sytuacja jest na tyle skomplikowana, że w rzeczywistości mamy do czynienia z kooperatorem pasmowym: tworzenie książki to cały łańcuch złożonych procesów wytwórczych. Autor jest tu wyłącznie elementem początkowym (producentem pośrednim), czytelnik zaś - elementem końcowym. W stadiach przejściowych kluczowe zaś stają się właśnie postaci: edytora, poligrafa, dystrybutora i wszystkie te elementy są niezbędne do zaistnienia pełnej komunikacji. Mówiąc innymi słowy: na opisywany łańcuch składa się szereg kooperatorów prostych, związanych zarówno z procesem tworzenia, jak i utrwalania oraz dystrybucji książki. A jak podsumowuje Zbierski:

Użytkownik kooperatora poprzedniego jest zarazem producentem pośrednim, twórcą ksią̇̇ki oraz użytkownikiem części ekwiwalentu. Kolejnymi produktami w tym łańcuchu są: komunikat autorski [tekst autorski], komunikat edytorski [tekst opracowany redakcyjnie], komunikat poligraficzny [tekst autorski opracowany redakcyjnie, wydrukowany] i książka [komunikat poligraficzny oprawiony introligatorsko] ${ }^{841}$.

Czy jest sens rozbierania tego procesu na czynniki pierwsze, czy wyszczególnione tu zabiegi są rzeczywiście na tyle istotne, by warto było je wyróżniać, opisując komunikację? I wreszcie - czy przywołany tu przeze mnie kontekst ma jakikolwiek związek z teorią liberacką? Choć mogłoby się wydawać, że niekoniecznie - wystarczy przytoczyć jeszcze jedną uwagę Zbierskiego, by stało się jasne, jak ogromna jest waga wypunktowanych tu kwestii i zrozumieć, czemu w ogóle po cytowane opracowanie sięgam.

Rolę edytora pojmuje się na ogół jako technikę wydawania książek oraz dostarczania ich odbiorcy - stwierdza badacz. Natychmiast jednak dodaje - W rzeczywistości edytor jest partnerem twórcy książki, jest współodpowiedzialny za treść i funkcjonowanie wspólnego utworu $^{842}$.

Tu trzeba jednak przypomnieć, że liberaci bynajmniej nie chcieli dzielić się autorstwem ani z edytorami, ani też z drukarzami czy wydawcami (ogólnie mówiąc: z podwykonawcami). Z ich punktu widzenia wcale nie powinno być też tak, że miejsce w łańcuchu książkowej komunikacji wpływa na to, jak postrzegamy strukturę książki i jakie funkcje przypisujemy jej poszczególnym elementom ${ }^{843}$. To nie tak, że „dla autora podstawową sprawa jest tekst, jego warstwa językowa jako wyraz podanej treści i idei, którym ona służy" ${ }^{444}$, redaktor skupia się na logice i merytorycznej poprawności tekstu, redaktor techniczny na najlepszym sposobie ujęcia tegoż w formę książki przy użyciu dostępnych środków poligraficznych ${ }^{845}$. Twórcy literatury total-

\footnotetext{
841 T. Zbierski, Semiotyka ksiażki, s. 22.

${ }^{842}$ Ibidem, s. 16, podkreślenie moje.

${ }^{843}$ R. Cybulski, Ksią̇̇a wspótczesna..., s. 53.

${ }^{844}$ Ibidem.

845 Ibidem.
} 
nej nie mogą się zgodzić z taką wizja, gdyż wtedy właśnie musieliby dzielić się autorstwem ${ }^{846}$.

Mówiąc innymi słowy: liberaci pragna, by autor komunikatu nie był wyłacznie autorem tego, co Zbierski określa mianem tekstu/komunikatu autorskiego, lecz zapanował (a przynajmniej miał świadomość, że może zapanować) nad całościa procesu budowania i przekazywania znaczeń. Można by powiedzieć, że twórcy literatury totalnej dążą do jeszcze większego niż przywołany badacz ujednolicenia procesu (lit/berackiej i książkowej) komunikacji: ograniczenia elementów współodpowiedzialnych za budowanie znaczeń, a zatem poniekąd - odrzucenia kategorii koordynatu. Niemniej, za istotne dla przekazu uznaja przecież elementy komunikatu przez ten koordynat formułowane. Liberaci nie chcą się autorstwem dzielić - lecz, przypomnę, wcale nie pragna też wyręczać edytorów czy redaktorów w ich pracy. Jednak ich zdaniem, ten, kto komunikuje się przez książkę, winien mieć świadomość tego, z jakiego rodzaju komunikacji korzysta i świadomie swe przekazy formułować. Tym samym - powinien mieć wpływ na ich kształt ostateczny, przejacc - w zakresie tych kwestii, które istotnie wpływają na znaczenie całej książki - obowiązi tych, którzy na koordynat się składaja. Mówiąc najprościej: liberat do produkcji winien oddawać produkt w pełni semantycznie ukształtowany.

Choć więc i Fajfer czy Bazarnik postrzegają książke jako „całość mówiaca”, przyjęta przez nich perspektywa nie do końca daje się utożsamić z tą proponowaną przez „,semiotyków książki”. Wydaje się to nieco paradoksalne, gdyż prezentowane ujęcia zdecydowanie łączy właśnie chęć wyodrębnienia w procesie tworzenia literackiego komunikatu (jakim jest książka) obszaru zagospodarowanego przez przypisywanie znaczeń samemu medium. Zbliża liberatów i badaczy takich jak Zbierski również traktowanie całej ujętej w wolumin wypowiedzi jako komunikatu (a zatem - niezgodne z założeniami Lalewicza - uspójnienie procesu komunikacji zakładajace, iż pełnia przekazu kreowana jest równolegle w dwóch opisywanych płaszczyznach oraz odżegnywanie się od ich rozdzielania).

\subsection{Komunikacja liberacka}

Podsumowując, trzeba przyznać, że żaden z przywołanych modeli nie jest zdolny ująć istoty literackiej komunikacji poprzez książkę, komunikacji liberackiej. Niemniej, każdy z nich wnosi elementy, które mogą być użyteczne przy próbie stworzenia takowego.

Liberaci nie mogliby zgodzić się na proponowane przez Lalewicza rozbicie procesu przekazu znaczeń na dwie płaszczyzny. Jednak, gdy przesunać nieco granicę wprowadzonego przez badacza podziału - wcześniej wkroczyć w obszar

${ }^{846}$ Warto tu też zaznaczyć, że z pokrewnych - w gruncie rzeczy - powodów w jednym z poprzednich rozdziałów dopominałam się o dostrzeżenie nieliberackości koncepcji druku funkcjonalnego. 
semantyki - propozycja nie musiałaby być tak konsekwentnie odrzucana. Szczególnie, że przecież nie wszystko to, co dotyczy „aparatu” czy „płaszczyzny sytuacji” interesuje liberatów. Jeżeli z obszaru tego wykluczyć elementy związane ze znaczeniami utworu, pozostawić tylko to, co rzeczywiście z produkcja czy dystrybucją książki związane, otrzymamy uzupełniający właściwy model komunikacji lit/berackiej schemat, obejmujący komunikację poprzez książkę (traktowaną w tej płaszczyźnie wyłącznie jako dystrybuowany, konsumowany przedmiot).

Podobnie, nie chcąc dzielić się autorstwem swojego dzieła, liberaci odrzuciliby model proponowany przez Zbierskiego. Niemniej, gdyby w jego obrębie poszerzyć kategorię obowiązków autorskich tak, by autor odpowiedzialny był nie wyłącznie za to, co Zbierski określa mianem tekstu autorskiego, lecz za całą semantykę utworu w formie książki (innymi słowy: przejął kontrolę nad tymi elementami dzieła, które są dlań semantycznie istotne, zwalniając tym samym z części obowiązów innych członków koordynatu i pozostawiając w ich kompetencji tylko to, co nie zmieni już wymowy utworu) - i ta propozycja mogłaby być inspirująca.

Jak sygnalizowałam już wcześniej, zasadniczy problem ze znalezieniem czy skonstruowaniem modelu zdolnego ujać interesujace mnie kwestie tkwi w dotychczasowym spojrzeniu na literacka komunikację (a do takiej zaliczyć trzeba i tę liberacka). Być może więc, zamiast próbować dodać do istniejących schematów kategorię książki, szukając inspiracji w myśli o niej samej, należałoby tak zredefiniować pojęcia tworzące zastane struktury, by dało się je zastosować i w nowym kontekście. Innymi słowy, proponuję, by zamiast poszukiwać nowych modeli, spróbować podjać (krytycznie doprecyzowujacc) te wątki refleksji nad komunikacjonizmem, które w literaturoznawczym ujęciu przyjęte zostały jako niekwestionowalna podstawa. A inspiracji do ich rozwinięcia można szukać choćby właśnie w przywołanych tu modelach.

Po pierwsze więc należałoby zastanowić się nad samą kategorią komunikatu (określanego - przypomnę - również przekazem, bądź - co już niekoniecznie użyteczne w kontekście literaturoznawczym - informacja). Proponuję, by nie poprzestawać na konstatacji, iż komunikatem literackim musi być komunikat wyłącznie językowy (jak ujmują to Okopień-Sławińska, Lalewicz i inni ${ }^{847}$ ), lecz odnieść się do szerszej definicji. Istotne wydaje mi się przede wszystkim, by nie określać a priori kodu i medium komunikatu ${ }^{848}$. Walery Pisarek charakteryzuje interesujące mnie pojęcie jako „treści intelektualne

${ }^{847}$ Rację ma Fajfer, wytykając, iż hasło ‘dzieło literackie’ w Słowniku terminów literackich rozpoczyna fraza ,językowy twór sensowny (wypowiedź)” (s. 116), wykluczająca zrazu wszelkie nie-językowe elementy tegoż komunikatu. Co więcej, Sławiński próbuje odróżniać utwór literacki od innych „typów przekazów słownych” (s. 116), umieszczając dzieło literackie w ściśle określonym kontekście, poza który niejako nie wolno mu wykraczać. Wprost też określa jego tworzywo jako wyłącznie język (s. 117). Por. J. Sławiński, hasło ‘dzieło literackie’, [w:] Słownik terminów literackich..., s. 116-117.

${ }^{848}$ Jako że i one wpływają na jego semantykę, jak przekonuje nas choćby Marshall McLuhan. 
i emocjonalne przenoszone między nadawcą a odbiorcą" ${ }^{849}$, co - jak widać - nie predestynuje żadnego z mediów, kodów do owej funkcji przekazywania.

W uproszczeniu można by powiedzieć, że w dotychczasowych ujęciach komunikacji literackiej zakładało się, że kodem jest język, zaś medium (środkiem reprezentacyjnym ${ }^{850}$ ) książka, która wyłącznie przenosi ów komunikat. Nim samym miał z kolei być utwór literacki (czyli właśnie wyrażony w języku). W proponowanym tu ujęciu komunikacji liberackiej należałoby wyjść z założenia, że komunikatem jest utwór liberacki, zatem utwór literacki w konkretnym medialnym (książkowym) ukształtowaniu. W konsekwencji jako kod trzeba tu rozumieć nie wyłacznie język, lecz i materię książki, jako że medium staje się tu nie tylko prze-nośnikiem, ale i nośnikiem znaczeń. W obu zaś przypadkach nadawca komunikatu jest autor, niemniej zakres jego obowiązków i kompetencji (m.in. operowania kodami) bywa różnie rozumiany.

Jak zaznaczał Pisarek, choć „zwykle treść w przekazie (jak i w znaku) jest ważniejsza niż forma”, ta ostatnia nie jest bez znaczenia, a wręcz „każda zmiana formy wypowiedzi rzutuje na jej treść"851. W przypadku liberatury z racji szerszego rozumienia kodu i komunikatu - to, co w literaturze traktowane może być jako semantycznie nieistotna materialna postać (forma), wręcz przesunięte jest w obszar treści (przekazu). Nie tylko więc na nią rzutuje, co ją współtworzy. Dlatego właśnie, postulowane przeze mnie korekty opisanych ujęć wydają się istotne. Nie sposób bowiem - przyjmując dotychczas stosowane założenia - objać schematem komunikacji literackiej to, co nam przekazuja w swoich dziełach liberaci. Umyka nam część komunikatu, „kawałek” treści.

Mówiąc inaczej: należałoby zauważyć, że już pierwsze Fajferowskie manifesty przynosiły sprzeciw nie tyle wobec rozumienia formy książki czy postrzegania tworzywa literatury, lecz wobec rozumienia całego procesu literackiej komunikacji. Postawienie pytania o - używając innego niż Fajfer określenia - kod sztuki słowa prowadzić miało ku refleksji nad (ignorowanym, zdaniem literaturoznawców semantycznie niemym) środkiem przekazu (medium, jakim jest książka) i samą kategoria przekazywanego komunikatu. Istota sformułowania „liberatura to literatura w formie książki” (najprostszej, jak mówi Bazarnik, definicji liberatury ${ }^{852}$ ) wydaje się właśnie zwrócenie uwagi na fakt, że jest ona specyficznym rodzajem literackiej komunikacji. Takim, w którym nieco inaczej powinny być rozumiane: tworzywo, kanał i środek przekazu, co w konsekwencji wpływa i na rozumienie samego przekazu. Liberatura to - jak widać - komunikacja poprzez książkę. Mieszcząca się w obszarze literatury, więc - jak chca Lalewicz czy Okopień-Sławińska - oparta na słowie i języku. Jednak, jako komunikacja liberacka: poza słowo i język wychodząca ${ }^{853}$.

\footnotetext{
849 Walery Pisarek, Wstep do nauki o komunikowaniu, Warszawa 2008, s. 20.

850 J. Fiske, Wprowadzenie do badań nad komunikowaniem, s. 35.

851 W. Pisarek, Wstęp do nauki o komunikowaniu, s. 27.

${ }^{852}$ Tytuł szkicu Bazarnik publikowanego w Drugiej rewolucji ksia $\dot{z} k i$ to przecież właśnie Liberatura, czyli literatura $w$ formie ksiażki.

${ }^{853}$ Takie szerokie rozumienie liberackiej komunikacji proponuje też Nowakowski (por. R. Nowakowski, Dlaczego moje ksiażki sq takie jakie sq, s. 218).
} 
Wydaje się, że nieco podobnie na ową komunikację patrzą też bibliolodzy, których ujęcia stanowiły silną inspirację tej części moich rozważań. I oni dostrzegają w książce nie tylko tekst, ale i jej kompozycję wydawniczą czy typograficzna, rozmiar, wage, kształt, rodzaj użytych kart. O wszystkich tych składowych Głombiowski mówił:

Wszystkie elementy [...] „fizyki” książki składają się [...] na całość, która oddziaływa na świadomość odbiorcy wespół z tekstem, jako że tworzy z nim wspólnie całość organicznie skomponowana ${ }^{854}$.

Liberatura ową „fizykę” książki zaprzęga w tekstową semiozę, czyni ją składnikiem komunikacji, mówiąc wprost: włącza w komunikat. A jako że jego nadawca jest autor - oczywiste staje się, że odpowiada on i za znaczenia w ten sposób tworzone. Tym samym, liberackość to włączanie do literackiej komunikacji również tego, co komunikowane przez medium, nieredundantne jego eksplorowanie (innym słowy: odejście od konwencjonalnego traktowania nośnika).

\title{
2.7. Bratnie nauki albo o noszeniu i prze-noszeniu tekstów
}

\begin{abstract}
Stwierdzić musimy za McLuhanem, że choć z jednej strony struktura utworu piśmienniczego z natury rzeczy determinuje układ graficzny jego tekstu, to $z$ drugiej - właśnie narzędzie przekazu ksiażkowego jest zdolne oddziaływać w odwrotnym kierunku na strukturę utworu poetyckiego.
\end{abstract}

Karol Głombiowski

Przede wszystkim więc - trzeba zaznaczyć, że (współczesna) bibliologia, za której właściwy przedmiot uznać należy funkcję komunikacyjną książki ${ }^{855}$, staje się przyjazną dla mówienia o liberaturze perspektywa ${ }^{856}$. W „skażonej McLuhanem” myśli o książce - podobnie jak w „skażonej Fajferem” refleksji liberackiej - przyznaje się, że wybór „ekspresji książkowej” (za Głombiowskim) nie może pozostać bez znaczenia, że ma swoje istotne konsekwencje, poetyka dzieła ma zaś związek z narzędziem przekazu ${ }^{857}$. Jak podkreśla przywołany bibliolog:

${ }^{854}$ K. Głombiowski, Ksiażka w procesie komunikacji społecznej, s. 139.

855 Ibidem, s. 11, również cały rozdział Czym jest nauka o ksiażce?, s. 5-12. W artykule O dwóch tendencjach badań bibliologicznych Głombiowski definiuje zaś naukę o książce jako „termin umowny na oznaczenie całokształtu problematyki, związanej z funkcjonowaniem procesu komunikacyjnego książki [...] jako narzędzia utrwalania i upowszechniania treści piśmienniczych" (K. Głombiowski, $O$ dwóch tendencjach badań bibliologicznych, s. 3).

${ }^{856}$ Również wspominany przeze mnie zwrot Bazarnik ku myśli McGanna wydaje się potwierdzać ten stan rzeczy (porównaj przypis 169 w części Definiowanie liberatury).

857 K. Głombiowski, Ksiażka w procesie komunikacji społecznej, s. 24. 
Poza zagadnieniem komunikatywności wpisanej przez pisarza w samo dzieło musimy wziąc pod uwagę również komunikatywność właściwą materialnemu narzędziu przekazu ${ }^{858}$.

Głombiowski, próbując zdefiniować książkę, wymieniał jako jej elementy konstytutywne (czy konstrukcyjne) nie tylko tekst, ale i: pismo, tworzywo materialne, format, realizację plastyczną i dodawał:

Rodzaj pisma - w rękopisach, kształt czcionki - w drukach, układ kolumny tekstu, iluminacja i miniatura w książce rękopiśmiennej, artystyczne techniki ilustracyjne w książce drukowanej, wreszcie oprawa - oto istotne elementy plastycznego ukształtowania książki. Sztuka inscenizacji tekstu za pomoca technicznych i artystycznych środków, właściwych książe tworzy atmosferę sprzyjająca oddziaływaniu testu i sprawia, że ulotne słowo poety czy uczonego zyskuje zgodnie z pragnieniem twórcy byt substancjalny w materii książkowej, byt niezniszczalny, związany z materialną egzystencją książki ${ }^{859}$.

Z momentem owej inscenizacji zaczyna się właśnie życie dzieła literackiego w formie książki. Gdy zaś jej twórca rozumie znaczenie owych zabiegów, gdy nie traktuje budowanego przez siebie komunikatu jako tekstu autorskiego (w ujęciu Zbierskiego), wypowiedzi, która potem przez innych zostanie poddana obróbce, by stać się komunikatem książkowy, lecz sam próbuje taki właśnie komunikat stworzyć (nie odbierając pracy edytorom, poligrafom czy redaktorom, lecz ją projektując, planując, aranżując) - wtedy możemy mówić o liberaturze.

Różnicy między przedstawicielami „bratnich nauk”: nauki o książce i o liberaturze, można by jednak dopatrzeć się w tym, jak wielki potencjał widzą oni w tym medium (najcześsciej) zbudowanym z papierowych, zszytych i oprawionych kart. Głombiowski, traktując książkę jako jeden ze sposobów przekazywania tekstu literackiego i porównując ją z innymi mediami (radiem, filmem, telewizja, estradą literacka), zaznaczał, że:

Surowość środków ekspresji książkowej, oderwanie jej od wszelkiej realności i konkretu, sprawia, że realizacja książkowa utworu piśmienniczego jest neutralna, niezindywidualizowana i doskonale „przezroczysta” ${ }^{\circ 60}$.

Podkreślał również, iż książkowa ekspresja ,jest uboga w swoich środkach utrwalania i przekazywania"861. Wydaje się jednak, że nie bez znaczenia pozostaje tu fakt, iż czytelnicze reakcje na medium sa wynikiem zakorzenienia w konwencji. Brak przywiazywania wagi do semantyki książki jako medium jest więc sprzężony z przyzwyczajeniem do takiego, a nie innego jej kształ$\mathrm{tu}^{862}$. Liberatura zaś próbuje zerwać $\mathrm{z}$ tymi przyzwyczajeniami, wyznacza takie

858 Ibidem, s. 22.

${ }^{859}$ Ibidem.

${ }^{860}$ Ibidem, s. 153. W innym rozdziale badacz, analizując książkową komunikację jako utrwalanie i przekazywanie tekstu dzieła w wierzytelnej i pełnej postaci, zauważa, że „przekaz książkowy jest w zasadzie przezroczysty" (s. 167).

861 K. Głombiowski, Ksią̇ka w procesie komunikacji społecznej, s. 153.

862 Ibidem, s. 138. 
podejście do tekstu literackiego, w którym owe nikłe możliwości ekspresji książkowej zostają w istotny (ale często: zaskakujący, oryginalny, wyłamujaccy się schematom) sposób poszerzone. Jednak - co kluczowe - tym, kto po nie sięga jest sam autor, zatem w konsekwencji odbiorca nie ma do czynienia ze zinterpretowanym, opracowanym utworem (jak miałoby to miejsce w przypadku wykorzystania innych przywoływanych przez Głombiowskiego mediów czy typografii dynamicznej, otwartej, funkcjonalnej - o czym również pisał), lecz pełniejszym odautorskim komunikatem. Dla liberatów bowiem książkowa ekspresja nie jest bynajmniej uboga.

Za to z pewnościa sama książka jest w niej nieodzowna. Stąd nauce o książce blisko do „nauki o liberaturze”, literaturze w formie książki, sztuce słowa komunikującej poprzez Księgę. Warto dodać, że wnioski o nikłej semantycznej potencji omawianego medium prowadzą Głombiowskiego ku stwierdzeniu, iż książka nie może funkcjonować bez jakiejkolwiek postaci tekstu ${ }^{863}$. Liberatura zaś (która tekstem - i to literackim - jest ex definitione) nie może się obyć właśnie bez książki. Gubiąc swój nośnik, traci bowiem część swych znaczeń.

Jednocześnie jednak, poszerzając (w stosunku do ujęć bibliologów), zakres semantycznej potencji samej książki, przekracza ustalone normy komunikacji, próbuje się komunikować niejako wbrew przyjętym, powiedzmy też wprost - skonwencjonalizowanym - zasadom. Dlatego to bibliolodzy, kiedy patrzą na historię literatury podobnym co liberaci okiem ${ }^{864}$, napotykają pewne problemy. Głombiowski (sięgający aż do antyku w swoich wędrówkach przez historię sztuki słowa), zajmując się kwestiami zwrotu w myśleniu o typografii, stwierdzał wyraźnie, że kategoria przestrzeni samego tekstu - której ignorowanie zarzucał przecież Fajfer literaturoznawcom - nie jest zupełnie obca artystom różnych epok i (formułując tezy pokrewne tym, które prezentowałam, omawiając relację liberatury i literatury wizualnej) pisał:

863 Ibidem, s. 154.

${ }^{864}$ I nie trzeba, jak widać, wcale przywoływać tu - za Bazarnik - anglojęzycznych badaczy; wystarczy porządnie rozejrzeć się w rodzimej myśli bibliologicznej. Por. m.in. Karol Głombiowski, O dwóch tendencjach kształtowania kompozycji graficznej, [w:] idem, Ksiażka w procesie komunikacji społecznej, s. 73-108. Badacz, charakteryzując dynamiczną konwencję typograficzna, przywołuje artystów, o których zawsze wspominają i liberaci, zaznacza, że w analizowanych przypadkach graficzne ukształtowanie jest istotnym elementem struktury utworu (s. 88). O Mallarmém Głombiowski pisze przecież, iż „korzystał z graficznych środków wyrazu dla wydobycia z tworzywa językowego określonych wartości znaczeniowych” (s. 89). A jak dodaje, „zdaniem [...] poety każdy składnik utworu jest zdeterminowany przez swoje miejsce w dynamicznej kompozycji graficznej książki. Tak więc środek przekazu wyraźnie determinuje wewnętrzną strukturę przekazywanego utworu" (s. 89). Istotne wydaje się też podkreślenie, że Głombiowski mówi tu o semantycznie istotnej typografii utworu „nadanej tekstowi przez autora” (s. 89). Iście liberacka jest też fraza zamykająca passus poświęcony Mallarmému: „Należy tylko poddać się swobodnemu oddziaływaniu fizycznej materii książki, aby w pełni doznać magicznego piękna poetyckiego słowa” (s. 91). Nie muszę chyba dodawać, że kolejne akapity dotyczą Apollinaire’a czy futurystów. 
Dość wymienić tzw. carmina figurata w starożytnym Rzymie i w siedemnastowiecznej Europie, wiersze typu akrostychu i raków, wiersze-dywany, wiersze-widoczki. W żadnym jednak wypadku twórczość ta nie wychodziła poza granice żartu czy zabawy, w której nie wahali się wziąć udziału nawet najwięksi. Tymczasem w eksperymentach Mallarmégo, poematach-przedmiotach Reverdy'ego, kaligrafach Apollinaire'a ukształtowanie graficzne wersu staje się elementem strukturalnym utworu poetyckiego, w poezji konkretnej zaś przestrzeń typograficzna autonomizuje się i staje się elementem wręcz kreacyjnym ${ }^{865}$.

Jednocześnie jednak pytał, czy wymienione rodzaje twórczości to jeszcze literatura, czy przywoływane przez niego kaligramy, wiersze konkretne, utwory wpisujące się w nurt spacjalizmu to jeszcze poezja. Wydaje się, że satysfakcjonująca byłaby tu odpowiedź: tak, liberacka. Gdzie zatem tkwi problem? Głombiowski przypominał, że przecież dla literatury (tu Fajfer zacierałby ręce) ,jedynym tworzywem [...] jest słowo, jego materialnym wspornikiem zaś - pismo" $\$ 66$. To ostatnie zaś powinno utrwalić utwór i umożliwić jego rozpowszechnienie. W rozumieniu literatów samo w sobie jest nieme, pozostaje środkiem przekazu rozumianym jako prze-nośnik znaczeń. Jednak „skażony mcLuhanowską myślą" badacz zajmujący się książką z punktu widzenia księgoznawstwa, bibliologii, zacznie się zastanawiać nad owym nośnikiem i zapyta, czy może on tylko przenosić, przekazywać sensy, czy też sam ich nie nosi. Myśląc o nim, zastanowi się też nad medium, jakim jest książka owym pismem wypełniona. Zapyta, czy sama w sobie nie jest znacząca. Stąd niedaleko już do wniosku, że w niektórych przypadkach „zarówno słowo, jak i pismo zmuszono do zdrady ich misji, odrywajac jedno i drugie od ich podstawowych funkcji społecznych" ${ }^{867}$, że zyskały one inne obowiązki. Że - innymi słowy - w obrębie literatury (utworów prze-noszonych przez książki) znajdziemy teksty liberackie (utwory noszone przez książki, dzieła, w wypadku których te ostatnie też coś od siebie mówią, komunikuja, przekazuja). Niech wybrzmi tu „liberacka” myśl Głombiowskiego, który uznawał, że znaczenie utworu powstaje w złożonej grze jego elementów, do których zaliczał i to, co w klasycznych ujęciach nieme:

\begin{abstract}
Inicjatywy symbolistów i futurystów, zmierzające w kierunku spotęgowania ekspresji tekstu językowego za pomocą środków ekspresji książkowej, uświadomiły nam ponownie poznana już prawdę: tekst utworu posiada określone znaczenie nie tylko w swojej warstwie językowo-brzmieniowej, lecz także w fizycznej materii narzędzia przekazu, w strukturze typograficznej, odpowiadającej strukturze tekstu językowego ${ }^{868}$.
\end{abstract}

Wracając do rozpoczynającego rozważania o związku bibliologii i liberatury zarzutu Polak, wypadałoby zapytać raz jeszcze, czy na pewno we współczesnej myśli o książce nie ma miejsca na refleksję o jej artystycznej odmianie. W świetle prezentowanych tu ustaleń, należałoby nawet to pytanie rozszerzyć, poszukując również przestrzeni do dyskusji o liberaturze. I przyznać trzeba,

\footnotetext{
${ }^{865}$ K. Głombiowski, Ksiażka w procesie komunikacji społecznej, s. 95.

866 Ibidem, s. 96.

867 Ibidem.

${ }^{868}$ Ibidem, s. 94
} 
że w nauce o książce jest miejsce i dla takich utworów, w których środek przekazu autonomizuje się na tyle, że sam tekst staje się nieistotny (książka artystyczna) i takich, w których to tekst autonomizuje się na tyle, iż środek przekazu staje się niemy (książka w tradycyjnym kształcie), oraz takich, w których między ekspresją medium a funkcją komunikacyjną tekstu panuje równowaga i (co równie ważne) zgoda owocujące ich wzajemnym uzupełnianiem się, wspólnym budowaniem komunikatu. Innymi słowy - w takiej refleksji (w dyskursie niekoniecznie bagatelizującym książkę jako taka) jest miejsce i na liberaturę. Ta ostatnia dałaby się opisać także jako poszukiwane kompleksowe podejście do książki czy dzieła sztuki słowa. Dodałabym jednak, że zawsze to tekst dyktuje metodologię i że nie każde dzieło takiego spojrzenia potrzebuje. Szukanie liberackości zaś wydaje się tropieniem tych utworów, które właśnie o takie kompleksowe podejście się dopominają.

\subsection{Bookishness, technotext i liberackość}

Zarysowawszy tak szerokie tło, chciałabym na chwilę powrócić do dyskursu literaturoznawczego i przywołać cytowaną na początku tej książki Jessicę Pressman i jej - formułowana na gruncie literaturoznawstwa, nie bibliologii przecież - koncepcję estetyki ksią̇̇kowości (aesthetic of bookishness) ${ }^{869}$. Przypomnę, że tę ostatnią badaczka definiuje jako widoczną w powieściach publikowanych od początku XXI w. strategię, polegająca na fetyszyzowaniu ich materialnej formy ${ }^{870}$ i zwracaniu uwagi na jej multimedialne możliwości (w niczym nieustępujące potencjałowi nowomedialnej komunikacji) ${ }^{871}$. Pressman traktuje ją także jako naturalną i oczywistą odpowiedź literatury drukowanej na współczesną konfigurację medialną.

Z kilku powodów nie sposób tej teorii tu właśnie nie przywołać. Po pierwsze - postulowana przez Pressman perspektywa z jednej strony niezwykle bliska jest liberackiej. Po drugie - pozwala pokazać, że współczesność (o której w finale tej książki wprost już napiszę, że „skażona” jest liberackością ${ }^{872}$ ) to czas, w którym - jak już sugerowałam w zakończeniu rozdziału o liberaturze i literaturze wizualnej - forma książki stała się znacznie bardziej pojemna niż bywała dawniej. Choć w gruncie rzeczy - bo w kontekście całości mojego wy-

869 Teoria formułowana w ramach wciąż rozwijanego projektu BOOKISHNESS: The Afterlife of Books in 21st-Century American Literary Culture, analizującego reakcje powieści na współczesną konfigurację medialną (i związany z nią strach o przyszłość pozbawiona materialnych kodeksów i papieru), przejawiające się w fetyszyzowaniu materialnej (książkowej) formy literatury zarówno na poziomie poruszanych tematów i kreowanych obrazów, jak i proponowanych form tekstów (zob. http://www.jessicapressman.com/current-research, dostęp 20.09.2013).

870 Jessica Pressman, The Aesthetic of Bookishness in Twenty-First-Century Literature, „Michigan Quarterly Review", fall 2009, s. 466.

871 Ibidem, s. 465.

${ }^{872}$ Zob. fragment zatytułowany Liberackość nasza wspótczesna. 
wodu można już to wprost powiedzieć - przywrócono jej po prostu potencjał, który drzemał w niej od zawsze, choć wydaje się, że - przynajmniej w obrębie głównego nurtu - na pewien czas zapadł wręcz w głęboki sen zimowy (zatem dzieje książki i czytania, jak losy druku toczą się dwiema co najmniej drogami).

Książka jest, i zawsze była, technologia sztuki słowa, sposobem podania literackiego komunikatu, co dla bibliologów nigdy nie pozostawało kwestią dyskusyjną i stąd ten właśnie rozdział jest doskonałym miejscem, by to wprost wyartykułować. Dlatego też liberatura, rozumiana jako literatura w formie książ$\mathrm{ki}^{873}$, nie jest w gruncie rzeczy niczym nadzwyczajnym - taki może się wydawać niektórym jedynie kształt, jaki współcześnie potrafi ona przybrać. Ale - jak słusznie podkreśla też Pressman (i wszyscy teoretycy, którzy są dla mnie inspiracja) - nie ma w tym nic nowego, gdyż „estetyka książkowości jest tak stara jak sama forma książki" ${ }^{74}$, choć nie zawsze była tak - co tu ukrywać - popularna.

Istotna zmiana wiąże się z tym, że sam kodeks coraz częściej nie jawi się już twórcom jako wyłącznie owo (przez wieki, jak pokazywał Escarpit, wypracowywane) przezroczyste, wygodne i użyteczne urządzenie do prze-noszenia tekstów, ale właśnie jako „materialny obiekt, a nawet maszyna do czytania” ${ }^{775}$, jak podsumowuje Pressman, mówiąc wprost o „książce jako technologii czytania (reading technology)" ${ }^{776}$. Badaczka podkreśla tym samym to, co ja - podobnie jak choćby współpracująca z nią (i silnie ją inspirująca) Hayles, do której wywodów będę nawiązywać w kolejnym rozdziale - zamykam w sformułowaniu, iż interfejs sztuki słowa może, ale wcale nie musi, być przezroczysty ${ }^{877}$. Zwrócenie uwagi na to, że pojawienie się nowych mediów i - co za tym idzie nowych interfejsów dla (wszelkiego typu) tekstów i komunikacji, zaowocowało sytuacja, w której coraz oczywistszym okazuje się, iż tradycyjna forma książki stała się tylko jednym z możliwych sposobów podania tekstu literackiego to trzeci z powodów, dla których o teorii Pressman nie mogłam nie wspomnieć, kończąc ten rozdział i przechodząc do kolejnego.

Dzielę z nią bowiem artykułowane od pierwszych stron tej książki przekonanie, że najwłaściwszym kontekstem dla rozpatrywania współczesnego kształtu drukowanej sztuki słowa jest jej elektroniczna odmiana, bowiem pozostają one w ciagłym dialogu, wzajemnie na siebie wpływajacc ${ }^{878}$. Zgadzam

${ }^{873}$ Poza tą cytowaną już, definicją Bazarnik warto tu może przywołać również tytuł kolejnego ważnego dla moich rozważań opracowania, które ukazało się już po zamknięciu moich prac badawczych: The Novel as Book. Textual Materiality in Contemporary Fiction in English Grzegorza Maziarczyka (Lublin 2013), silnie, jak się wydaje, inspirowanego tekstami Pressman właśnie.

874 J. Pressman, The Aesthetic of Bookishness..., s. 466.

875 Ibidem, s. 467.

876 Ibidem.

877 Spośród kluczowych konstatacji Hayles trzeba tu przywołać tę mówiąca, iż druk to też medium (które nie pozostaje dla komunikatu neutralne) „a nie przezroczysty interfejs” (Katherine N. Hayles, Writing Machines, London-Cambridge 2002, s. 43).

${ }^{878}$ Pressman jednak silniej akcentuje powtarzanie w e-literaturze form „tradycyjnych”, związanych z materialnością (jak pismo odręczne), mnie zaś bardziej interesują nowe jakości aktu lektury oferowane przez nowe media (pozwalające czytaniu nadać charakter wielozmysłowy, uczynić zeń performance i event), zachęcające tym samym i literaturę drukowaną do poszukiwań w tym zakresie. 
się też z diagnozą Pressman, iż istnieją pewne (jak ujmuje to badaczka) literackie „potrzeby” i „pragnienia”"779, którym właśnie materialna, analogowa forma najlepiej może odpowiedzieć. Podzielam z nią też przeświadczenie, że konfrontacja z nowymi platformami literackiej komunikacji może książce jako technologii się przysłużyć - gdyż w odpowiedzi rozwija się ona, a ci, którzy po nią sięgaja, eksplorują coraz to nowsze przestrzenie analogowego medium.

Bo o tym, że nic nie stoi na przeszkodzie, by w jego ramach osiagnąć wszystko to, co oferuje elektronika, pisała już w 2002 r. (w silnie autobiograficznie zabarwionym tomie Writing Machines) Katherine Hayles ${ }^{880}$. Lekcja wyniesiona przez nią ze spotkania z książkami artystycznymi czy - jak słuszniej byłoby w tym rozdziale powiedzieć - sztuką książki (bo chodzi tu o teksty, których Fajfer i Bazarnik, zwłaszcza po 2011 r., nie wykluczyliby już z obszaru liberackości) zaowocowała sformułowaniem przez badaczkę teorii (realizowanego w dowolnym medium) technotekstu (technotext). Jak przekonywała wtedy badaczka:

Kiedy dzieło literackie testuje wpisaną weń technologię, dzięki której powstało, aktywizuje połączenie pomiędzy światem wyobrażonym a materialnym aparatem ucieleśniającym tę kreację w postaci fizycznej obecności. Oczywiście, nie wszystkie dzieła literackie decydują się na ten gest, ale nawet w stosunku do tych, które tego nie robia, gotowa jestem twierdzić, że fizyczna forma literackiego artefaktu wptywa na to, co stowa (i inne komponenty semiotyczne) znacza. Dzieła literackie, które wzmacniaja, pogłębiają czy tematyzują połączenie między sobą jako materialnym artefaktem a wyobrażoną dziedziną werbalnych/semiotycznych znaczących [...] otwierają drogę ku ściślejszemu połączeniu literatury jako sztuki słowa z jej materialną formą. By nazwać takie prace, proponuję termin „technotekst”, łączący technologię pozwalającą wyprodukować tekst z jego werbalną konstrukcją ${ }^{881}$.

Samej zaś kategorii materialności Hayles z powodzeniem używa, mówiąc również o tekstach pozornie nie-materialnych właśnie - elektronicznych. Wiażąc ją z interfejsem, pokazuje, jak - niezależnie od tego, w jakim medium (czy mediach) rozgrywa się komunikacja - jej częścią może stać się i to, co przekazuje sam interfejs, użyta technologia. Jak więc widać - z konfrontacji analogowej i elektronicznej literatury i (co w tym rozdziale warto podkreślić) ze spotkania z książkami odmiennymi niż te najbardziej tradycyjne - i za Oceanem zrodziła się teoria analogiczna do polskiej propozycji ${ }^{882}$. Nic w tym chyba dziwnego, gdyż - jak będę jeszcze przekonywać w tej książce - współczesna konfiguracja medialna (podobnie jak ta z początku poprzedniego stulecia, na co zwracałam uwagę, pisząc o historii druku) w naturalny sposób zaowocować musiała i nowa jakością artystycznych realizacji (na które przygotowała nas zarówno awangarda, jak i - nie tylko postmodernistyczne - eksperymenty drugiej połowy XX w., które po części dałoby się objać kategoriami grafemizmu i intermedialności, do których jeszcze wrócę), i teoriami próbujacymi się z nimi zmierzyć.

\footnotetext{
879 J. Pressman, The Aesthetic of Bookishness...

880 Zob. przypis 9.

881 K. Hayles, Writing Machines, s. 25-26.

882 Choć warto podkreślić, że esej Fajfera jest o trzy lata wcześniejszy niż publikacja Hayles.
} 
Dodam, że proponowane przeze mnie ujęcie - wprowadzenie ponadmedialnej kategorii liberackości, pojęcia aspektu liberackiego (lepiej, jak sądzę, radzących sobie z problemem dzieł liberackich w kontekście e-literatury niż oryginalne terminy Fajfera czy Bazarnik, co postaram się pokazać) - na tle jawnie i wprost nawiązujących do Espena Aarsetha propozycji Hayles i Pressman wydaje mi się wygodniejsze. Mniej stechnicyzowane niż pierwsza z teorii (acz od problemów technologii sztuki słowa nieuciekające) staje się użyteczniejsze dla literaturoznawcy, zaś dzięki wyjściu poza formę (i gatunek) powieści (a takie ograniczenie wprowadza Pressman) ma szerszy zakres. Również sam językowy kształt terminu wydaje się poręczniejszy (polsko-łacińska formuła oddaje znacznie więcej znaczeń niż, nawiązujące do tego samego źródła, anglosaskie pojęcie proponowane przez Pressman) ${ }^{883}$.

Zatem, odwołując się coraz częściej do McLuhana i medioznawczych kontekstów, zmierzam również do przyjrzenia się liberaturze w kontekście nowych mediów. Silnie eksponowany już w tym rozdziale namysł nad semantyczną potencją nośnika literackiego tekstu powinien poprowadzić ku szukaniu takich ujęć literatury, w których już nie tylko język - słowo pisane - jest jej tworzywem. Jako że dla elektronicznej jej odmiany kwestie wielokodowości komunikatów sa - można by rzec - chlebem powszednim, a utwory doń zaliczane nie dają się rozpatrywać bez interpretowania ich medialnych własności - chciałabym zastanowić się w kolejnym rozdziale nad relacją między ową najnowszą (bądź lepiej: najbardziej nowoczesna) odmianą sztuki słowa a - związaną z tradycyjną książka, zatem ewidentnie staromedialną - liberatura. Najnowsze badania Pressman, które zaowocowały zarówno tomem Digital Modernism, Making It New in New Media ${ }^{884}$, jak i przywoływanym już wystapieniem na ostatniej (2014) konferencji ELO, również wyraźnie ida w tym właśnie kierunku.

Zapowiem też, że interesować mnie będzie również pojawiająca się w dyskusjach kategoria e-liberatury i, tym samym, kwestia możliwości zaistnienia liberatury w świecie wirtualnym (zatem na swój sposób: bezksiążkowym). Dywagacje te zaś poprowadzą mnie również ku pytaniu o to, jak patrzeć na liberaturę w kontekście pytań o śmierć książki. Wydaje mi się, że warto kwestie te zapowiedzieć w tym właśnie miejscu, gdyż będą one również dopełnieniem rozważań o liberaturze i kategorii książki.

${ }^{883}$ Pozwala również na tworzenie dalszych wygodnych terminów, jak choćby liberackość (w kontrze do literackości).

${ }_{884}$ Nowy Jork 2014. 



\section{LIBERATURA A LITERATURA ELEKTRONICZNA}

\section{Od galaktyki Gutenberga ku galaktyce Turinga}

\subsection{Dziwny przypadek Mallarmégo i Joyce’a}

„Dzięki ci, Mallarmé!” - pisał w jednym ze swoich szkiców Jean-Paul Fargier. Co takiego uczynił francuski pisarz, przywoływany tu już niejednokrotnie jako autor jednej z ważniejszych pozycji, wydanych dotychczas w serii Liberatura, że zasłużył na wdzięczność teoretyka sztuki wideo? Jego rodak kwituje to następująco:

Oto i Rzut kośćmi. Słynny rzut kości... Którego nikt nie przeczytał naprawdę [...]. Oto on... Mam go przed oczami, trzymam go w rękach... Rzucający się w oczy podział na strony... Kilka substancji... Kilka czcionek... Podwójna strona wykorzystana jako pojedyncza... Kompozycja, która przyznaje główną rolę bieli... Słowa rytmizują przestrzeń, dzielą ja, rzeźbia skręcają w bryły... Ależ to jest obraz cyfrowy! Obraz cyfrowy sięga do Mallarmégo! Obraz cyfrowy zrodził się z rzutu kości ${ }^{885}$ !

Co ciekawe, to właśnie wśród tekstów medioznawczych możemy znaleźć wiele cennych z punktu widzenia przyjętej tu perspektywy analiz twórczości autora Popołudnia fauna, który swoim Demonem analogii dał teoretykom sztuk wizualnych przyczynek do takich odwołań. W efekcie, w tym samym roku co manifest Fajfera, zostaje opublikowany tekst Andrzeja Gwoździa (wygłoszony wcześniej, w 1998 r., na konferencji w Białowieży), w którym polski teoretyk pojmuje pisanie Mallarmégo nie jako „gest semantyczny”, lecz jako „gest topograficzny”, akcentując, iż sposób organizacji przestrzeni tekstu wydaje się u tego twórcy co najmniej równie istotny (o ile nie bardziej) jak arbitralne relacje między znakiem a jego znaczeniem. Zapoczątkowany przez artystę nurt badacz ujmuje zaś jako rodzaj rewolucji iście liberackiej w swej istocie - jako bunt przeciwko klasycznej koncepcji woluminu, walkę o wolność strony:

${ }^{885}$ Jean-Paul Fargier, Anioł obrazu cyfrowego. Czy Mallarmé wymyślit wideo?, tłum. Iwona Ostaszewska, [w:] Pejzaże audiowizualne..., red. Andrzej Gwóźdź, Kraków 1997, s. 324-325, wyróżnienie autora. 
Rzut kośćmi - pisze - to nie tylko rewolucja samego porządku wprowadzania pisma, to także rewolta przeciwko płaszczyźnie jako fundamentowi bytowemu książki, który nie chce być wyłącznie tafla dla pisma, rewolta znamionująca kryzys uniwersum tekstowego jako uniwersum linearności w ogóle. W owej - jak powiada Ważyk - „składni na płaszczyźnie” chodzi bowiem o emancypację pisma z medium książki na rzecz awansu powierzchni ${ }^{886}$.

Czyż nie takiej rewolucji oczekiwał Fajfer, mówiąc o książce „rozumianej już nie jako zewnętrzny wobec dzieła, obojętny futerał na słowa, lecz tegoż dzieła integralny składnik"887 czy nie o niej myślała Bazarnik, doprecyzowując słowa męża ${ }^{888 ?}$ Choć autorzy Oka-leczenia wskazują na bardzo odległe korzenie takiego pojmowania istoty tekstu, Gwóźdź - nie jako jedyny zresztą - dostrzega w nim przejście od McLuhanowskiej galaktyki Gutenberga ${ }^{889} \mathrm{ku}$ Bolterowskiej galaktyce Turinga ${ }^{890}$, upatrując w nim początków - jak to określa - „«tkania» przy pomocy pisma powierzchni [...], pisania nie «w służbie linijki», ale «w służbie powierzchni», jak powiada Flusser"

Mallarmé, któremu nie wszyscy mówiący o posttypografii tak ochoczo przypisywali palmę pierwszeństwa (bo już choćby u samego Onga, od którego zapożyczam owo określenie, francuski twórca jest „znacznie późniejszy”"892 niż choćby George Herbert czy Lawrence Sterne), to nie jedyny pisarz, którego „przywłaszczyli sobie” teoretycy mediów ${ }^{893}$. Drugim, przywoływanym chyba równie często, jest James Joyce ze swoim Finnegans Wake, które - niejednokrotnie analizowane przez Bazarnik w kontekście formułowanej przez nia i Fajfera teorii ${ }^{894}$ - również, zgodnie z obietnicami redaktorów, ukazało się w liberackiej serii.

Dyskurs hybrydalny - twierdzi Krzysztof Loska, który dostrzegał prekursorów nowego spojrzenia na tekst również wśród modernistów - łączący w sobie różne teksty, dokonujący syntezy rozmaitych form medialnych, pojawił się bowiem na wiele lat przed nastaniem techniki cyfrowej. Tekstem-kluczem, tekstem-matryca, pozwalającym zrozumieć przemiany spo-

${ }^{886}$ Andrzej Gwóźdź, Spektakle pisma w stadium monitorowym filmu, [w:] Stowo w kulturze mediów, red. Zbigniew Suszczyński, Białystok 1999, s. 112.

887 Z. Fajfer, W strone liberatury, s. 94.

${ }^{888}$ K. Bazarnik, Liberature: a New Literary Genre?, s. 192.

889 Marshall McLuhan, Galaktyka Gutenberga, tłum. Ewa Różalska, [w:] idem, Wybór tekstów, Poznań 2001.

${ }^{890}$ David J. Bolter, Człowiek Turinga: kultura Zachodu w wieku komputera, tłum. Tomasz Goban-Klas, Warszawa 1990.

891 A. Gwóźdź, Spektakle pisma w stadium monitorowym filmu, s. 115.

${ }^{892}$ Walter J. Ong, Oralność i piśmienność. Słowo poddane technologii, tłum. Józef Japola, Lublin 1992, s. 174.

${ }^{893}$ Owo pożyczanie bywa zwielokrotnione i czytelnik musi zastanowić się, czy przywołuje się tylko samego Mallarmégo czy też i odniesienie do niego. Przykładem szkic Piotra Zawojskiego „Soft Cinema” Lva Manovicha i Andreasa Kratky'ego. „Język nowych mediów” w praktyce, „Kwartalnik filmowy” 2007, nr 60 (tekst dostępny również na stronie autora, http://www.zawojski.com/2008/06/07/soft-cinema-lva-manovicha-i-andreasa-krakty\%E2\%80\%99ego-jezyk-nowychmediow-w-praktyce/ [dostęp 30.09.2011]).

${ }^{894}$ Zob. Od Joyce'a do liberatury oraz Katarzyna Bazarnik, Globalne spojrzenie na „Finnegans Wake”, [w:] Wokót Jamesa Joyce’a: szkice monograficzne, Kraków 1998 i eadem, Joyce \& Liberature, Praga 2011. 
wodowane ingerencją nowych technologii elektronicznych w obszar tradycyjnych sztuk, nie musi wcale być twórczość filmowa Greenawaya czy Rybczyńskiego ani dzieła projektantów instalacji multimedialnych czy artystów związanych z wideo-artem; może to być książka: książka-hybryda, książka-monstrum, którą jest Finnegans Wake Joyce’a, ukazująca nowe oblicze świata podporządkowane technologii telekomunikacji [...] W przestrzeni Finnegans Wake dokonało się zjednoczenie składników wizualnych, audialnych, kinetycznych, taktycznych. Książka Joyce’a jest zapowiedzią nowej tekstualności [...] Otrzymujemy oto szczególna zapowiedź przełomu, który dokona się pół wieku po napisaniu Finnegans Wake za sprawa nowych technologii elektronicznych ${ }^{895}$.

Co sprawia, że ci, którzy próbują opisać to, co na ekranie, przywołuja pisarzy, bez których nie sposób mówić o literaturze totalnej? Czyż nie jest zastanawiające, iż to liberatura właśnie staje się niemym kontekstem takich rozważań? Należałoby zatem nie tylko postawić pytanie o to, co łączy ją z literatura wizualna, poezja konkretna czy komiksem lub książką artystyczna, lecz rozszerzyć spektrum badanych zjawisk na to, co elektroniczne, uzupełniając tym samym refleksję o związki liberatury z nowymi mediami. Czy przestrzenia odniesień powinien być w tym wypadku obraz cyfrowy? W pewnym stopniu tak, gdyż będzie mnie interesowała ta część zjawisk nowomedialnych (cyfrowych zatem), w której do głosu dochodzi opracowane artystycznie słowo. Podążając za wskazanym tropem joyceowsko-mallarméańskim skieruję się więc ku innym nieco ścieżkom niż przywoływani tu badacze, szukając wśród tego, co elektroniczne literatury i przyjmując jednocześnie - w przeciwieństwie do nich - perspektywę diachroniczna. Tym samym, spróbuję mówić nie tyle o (pozbawionej demona) analogii, co o kontynuacji tradycji, wpisując się w nurt badań archeologii mediów.

Jednocześnie, „nowa” literatura, do której się odniosę, nie będzie wyłącznie tą hipertekstowa, nielinearna, o której wspominał Gwóźdź czy Zawojski. Jak bowiem zaznacza Loss Pequeño Glazier (bliski mi ze względu na konsekwentnie podtrzymywaną przezeń tezę, iż najwłaściwszym kontekstem dla badań literatury elektronicznej jest twórczość jak najbardziej „papierowa”: mianowicie wszelkiego rodzaju teksty o charakterze awangardowym), humanistyczna refleksja nad słowem w nowych mediach (refleksja wciąż świeża, z dnia na dzień korygowana, uzupełniana) nie obroniła się przed różnego rodzaju uproszczeniami i stereotypizacjami. Wśród nich jednym z ważniejszych

${ }^{895}$ Krzysztof Loska, Joyce i McLuhan: słowo w epoce technologii elektronicznej, [w:] Stowo w kulturze mediów, s. 95-96, 97 i 98. Warto tu też przypomnieć, że i sam McLuhan pisał o autorze Ulissesa (ale też i o innych artystach) właśnie jako prekursorach nowomedialnego myślenia o twórczości: „Książka wydawana drukiem zachęcała artystów do zredukowania - tak dalece, jak to możliwe - wszystkich form wyrazu do pojedynczej opisowej i narracyjnej płaszczyzny słowa drukowanego. Nadejście elektronicznych środków przekazu od razu wyzwoliło sztukę z tego kaftana bezpieczeństwa i przyczyniło się do powstania świata Paula Kleego, Picassa, Braque’a, Eisensteina, braci Marx oraz Jamesa Joyce'a” (Marshall McLuhan, Zrozumieć media. Przedtużenia człowieka, tłum. N. Szczucka, Warszawa 2004, s. 97). W wypowiedziach autora Galaktyki Gutenberga Joyce pojawia się zresztą niejednokrotnie (określany np. jako twórca wykorzystujący typografię do tworzenia nowej sztuki - ibidem, s. 235); w szkicach McLuhana pada też nazwisko Mallarmégo. 
było popadanie (przez chwilę) w skrajność mówienia wyłącznie o twórczości prozatorskiej, tak jakby poezji „zamknięto przed nosem drzwi” do tego, co elektroniczne. Dziwne to podejście, szczególnie gdy zauważymy, że liryka znacznie szybciej niż epika zareagowała na możliwości, jakie dają sztuce słowa komputery. Chris T. Funkhouser podkreśla już w pierwszym zdaniu wstępu do Prehistoric Digital Poetry, że mówiąc o nowym typie literatury, jakim jest poezja dygitalna (digital poetry), będzie zajmował się artystami, którzy zaczęli eksperymentować z komputerami już pod koniec lat $50^{896}$.

Co jednak dla mnie ważniejsze - polska refleksja o słowach zapisanych w przestrzeni wirtualnej popełniała grzech znacznie gorszy: gloryfikowała nie tylko prozę, lecz jej konkretną elektroniczną odmianę gatunkowa. Bowiem nasi badacze e-literatury (skupieni wokół krakowskiego środowiska ha!artowskiego) przez lata rozprawiali głównie (i niemal wyłacznie) o nielinearnym(?) hipertekście, o nowatorskiej(?) hiperfikcji, o genialnych(?) powieściach hipertekstowych. Czy mieli rację? Z jednej strony tak, gdyż nie da się zaprzeczyć, że linkowa struktura stanowi podstawę sporej grupy tekstów elektronicznych. Jednak jest to zaledwie podzbiór pewnej całości i posługując się wyłącznie tym kryterium, tracimy wiele z pola widzenia. Co więcej - typ hipertekstu, który

896 Chris T. Funkhouser, Prehistoric Digital Poetry. An Archeology of Forms, 1959-1995,Tuscaloosa 2007, s. 1. W polskiej refleksji również dominował nurt prozatorskocentrycznych rozważań o literaturze nowomedialnej (taki termin - jako najszerszy - uważam za najbardziej adekwatny do mówienia o wszelkich odmianach literatury elektronicznej, por. Agnieszka Przybyszewska, Którędy do literatury nowomedialnej?, „Fragile” 2008, nr 2). Niemniej, dyskusje ostatnich lat przynoszą również zwrot ku badaniom innych obszarów e-literatury, w tym i poezji - za szczególnie ważne można tu uznać opracowania Moniki Górskiej-Olesińskiej (zob. m.in. Monika Górska-Olesińska, Elektroniczne uwolnienie słowa. W środowisku poematów cyfrowych, [w:], Materia sztuki, red. Michał Ostrowicki, Kraków 2010; eadem, Playable poetry i gry komputerowe. Krytyczne negocjacje, [w:] Olbrzym w cieniu. Gry wideo w kulturze audiowizualnej, red. A. Pitrus, Kraków 2012; eadem, Wiersze Turinga?, [w:], Język@multimedia 3. Dialog-konflikt, red. Agnieszka Dytman-Stasieńko, Jan Stasieńko, Wrocław 2012; eadem, Poetry@science? - „slippingglimpse” Stephanie Strickland, Cynthii Lawson Jaramillo i Paula Ryana, [w:] Liberatura, e-literatura i... Remiksy, remediacje, redefinicje, red. Monika Górska-Olesińska, Opole 2012; eadem, Animacje słowa. Poematy kinetyczne, „Este” 2010, nr 1; eadem, Tekstowe instrumenty do gier z pamięcia. Czas i pamięć $w$ literaturze elektronicznej, „Kultura Popularna” 2010, nr 3-4 (29-30); eadem, Pisanie jaskiniowe, „Autoportret” 2011, nr 1 (33)). Przywołana badaczka należy, moim zdaniem, do osób kierujących polską refleksję o związkach literatury i nowych mediów ku naprawdę interesującym (i wartym dalszego namysłu) zjawiskom, nie - mało już aktualnym - rozważaniom o tym, że Internet umożliwił pisanie tekstów „bardziej kolorowych” i olinkowanych (dość przywołać tu dla porównania artykuł Witolda Sadowskiego Wiersz w sieci ([w:] Tekst (w) sieci, t. 2, red. Anna Gumkowska, Warszawa 2009, s. 21-31)). O poezji elektronicznej pisała również Emilia Branny-Jankowska (Obietnice poezji elektronicznej, „Dekada Literacka” 2010, nr 1/2, a także Impresje z e-poetry 2009, „Techsty” 2009, nr 6, http://techsty.art.pl/magazyn/magazyn6/e-poetry01.html [dostęp 30.09.2011]) czy Anna Wendorff (Anna Wendorff, Nowa poetyka i nowe przestrzenie awangardowe w poezji elektronicznej Ladislao Pabla Györiego. Poezja wirtualna i cyfrowa Argentyny lat 80. XX wieku, [w:] Od liberatury do e-literatury, red. Monika Górska-Olesińska, Eugeniusz Wilk; por. też: eadem, Vanguardias Poéticas en el Arte Digital en Latinoamérica, Caracas 2010). Istotnym świadectwem przełomu w polskiej refleksji e-literaturoznawczej o poezji było też opublikowanie książki Urszuli Pawlickiej (Polska) poezja cybernetyczna. Konteksty i charakterystyka (Kraków 2012). 
interesował $\mathrm{w}$ tym okresie polskich badaczy, to zaledwie jeden z podtypów owego podzbioru (na co zwraca uwagę Katherine Hayles, szkicując historię tej formy literackiej ${ }^{897}$ ). Trzeba jednak dodać, że powoli zaczęły się też pojawiać głosy dostrzegające wśród tekstów elektronicznych i inne formy gatunkowe (i mam tu na myśli nie tylko blogi, których popularność jako przedmiotu badań równa jest niemal tej, jaką szczyci się hipertekst).

Porównania literatury elektronicznej i liberatury zaczynam od porządków terminologicznych i wyjaśnienia, czym tak naprawdę zamierzam się zajmować w tym rozdziale, by właśnie uprzedzić, że o hipertekście będę tu mówić wyjątkowo mało. Nie chcę bowiem narzekać niczym Glazier, który z żalem zauważał, że choć mówi się o poezji nowych mediów (New Media Poetries), tytułuje się własną książkę Poetyka Dygitalna (Digital Poetics) to i tak zostaje sie „chłopcem od hipertekstu” (the hypertext guy). Ja (niechcaca zostać „dziewczynka od porównywania dziwacznych książek i olinkowanych powieści" - bo nie one będa dla mnie głównym punktem odniesienia) świadomie odcinam się raczej od większości polskich dyskusji o literaturze elektronicznej (konkretnie: ich pierwszej fazy). Aczkolwiek, nie da się pewnie wykluczyć, że przymierze zawarte z badaczami, takimi jak m.in. Hayles, Glazier, McGann, Funkhouser czy Aarseth nie okaże się równie zgubne, co przyjęta przez moich rodaków perspektywa ${ }^{898}$.

\subsection{Hipertekstowa dygitalna e-cyber-literatura 2.0 w dobie remediacji}

Trzeba podkreślić, że ostatnie lata są najlepszym świadectwem tego, iż wiele w polskiej „e-refleksji” się zmienia ${ }^{899}$. Wcześniejsze, nieraz buńczuczne, sądy poddawane są autokorektom, zaczyna się stopniowo rozszerzać spektrum badanych zjawisk, a organizowane konferencje ${ }^{900}$ sa najlepszym przykładem

897 Katherine N. Hayles, Electronic Literature. New Horizons for the Literacy, Notre Dame 2008 (tłumaczenie pierwszego rozdziału tej pracy, dającego panoramę gatunków literatury elektronicznej oraz jej definicję, polski czytelnik może od 2011 r. znaleźć w magazynie „Techsty”, $\mathrm{nr}$ 7: http://techsty.art.pl/magazyn/magazyn7/literatura_elektroniczna_czym_jest_1.html [dostęp 30.09.2011]; pracując nad tym rozdziałem nie miałam jeszcze możliwości korzystania z tego udogodnienia, stąd też cytaty z pracy Hayles podaję - o ile nie zaznaczam inaczej - w tłumaczeniu własnym).

${ }^{898}$ Warto może dodać, że Glazier wprost mówi też o wykluczaniu w obrębie humanistycznej refleksji o elektronice kontekstów nieanglojęzycznych.

${ }^{899}$ Opublikowany w chwili kończenia ostatnich prac redakcyjnych nad tą książka szkic Urszuli Pawlickiej Literatura elektroniczna. Stan badań w Polsce (,Teksty Drugie”, nr 3/2014) potwierdza te zmiany oraz uzmysławia, że w konsekwencji rozwoju tej refleksji możemy już mówić o pewnych nurtach czy szkołach polskiego e-literaturoznawstwa.

${ }_{900}$ Wystapienia związane z problemem literatury w świecie nowych mediów (najczęściej oscylujące wokół następujących tematów: hipertekst, blog, życie literackie w sieci, możliwości udostępniania literatury w Sieci) pojawiają się przy okazji rozmaitych konferencji (nie wyłącznie literaturoznawczych). W'́ród ważnych, koncentrujących się przede wszystkim na związkach sztuki słowa i nowych mediów warto z pewnością przywołać: niejako rozpoczynające ten cykl dwie sesje 
rodzenia się świadomości tego, iż być może najwłaściwsza, a z pewnością najwygodniejsza, perspektywą do badania nowej tekstualności jest spojrzenie interdyscyplinarne ${ }^{901}$.

Konsekwencją tych przemian wydaje się też powolne wkraczanie polskich badaczy na arenę międzynarodowa. Szlaki przecierały teksty Mariusza Pisarskiego, Andrzeja Pajaka i Emilii Branny-Jankowskiej publikowane w „Cybertext Yearbook” w 2010 r. (początkowo numer ten - redagowany przez Markku Eskelinena i Raine Koskimaa - projektowany był jako monograficzny, poświęcony polskiej e-literaturze, w efekcie jednak uzupełniono go czterema artykułami dotyczacymi innych kwestii). Kolejne warte odnotowania fakty to czynny udział (z referatami oraz prezentacjami artystycznymi) Polaków na najważniejszych światowych konferencjach dotyczących e-literatury: przede wszystkim w 2011 r. na konferencji ACM Hypertext (wystapienie Pisarskiego zostało tam nominowane do nagrody Teda Nelsona), na biennale e-Poetry (Londyn 2013), a także na konferencjach ELO w 2013 i 2014 r. (w Paryżu i Milwaukee). Co dla mnie niezwykle istotne na obu ostatnich konferencjach pojawił się watek liberacki, a zaproponowane przez polskich teoretyków terminy doskonale

literaturoznawczo-medioznawcze poświęcone związkom literatury i Internetu pod hasłem liternet (Kraków, kwiecień 2002 oraz maj 2003), lublińskie konferencje e-polonistyka (listopad 2007), e-polonistyka 2 (grudzień 2009) oraz e-polonistyka 3 (kwiecień 2013), które choć obejmują również kwestie związane z wkroczeniem nowych mediów w obszar humanistycznej dydaktyki (dość przypomnieć, że organizowane są przez Katedrę Dydaktyki Literatury i Języka Polskiego w Instytucie Filologii Polskiej Katolickiego Uniwersytetu Lubelskiego), stały się miejscem istotnych dyskusji, interdyscyplinarną konferencję Tekst $(w)$ sieci (Warszawa, grudzień 2008) zorganizowaną przez Zakład Teorii Literatury i Poetyki Instytutu Literatury Polskiej Wydziału Polonistyki Uniwersytetu Warszawskiego oraz portal internetowy Gazeta.pl oraz dwie edycje interdyscyplinarnej konferencji Od liberatury do e-literatury (Kamień Śląski, listopad 2009 oraz maj 2011) organizowanej przez Katedrę Teatru, Filmu i Nowych Mediów Instytutu Filologii Polskiej Uniwersytetu Opolskiego. Wymienionym dyskusjom towarzyszyły publikacje pokonferencyjne (już dostępne bądź też właśnie do druku przygotowywane). Wspomnieć można też o organizowanej przez Instytut Humanistyczny Państwowej Wyższej Szkoły Zawodowej w Gorzowie Wielkopolskim konferencji Literatura $w$ mediach. Media w literaturze (Rogi, marzec 2010 oraz druga edycja - październik 2011), której zakres tematyczny jednak mniej pokrywa się z interesującymi mnie tu zagadnieniami, oraz sesję studencko-doktorancką Przestrzenie literatury. Wizje, rewizje, kontynuacje (Poznań, maj 2009), na której pojawiło się kilka interesujących referatów dotyczących literatury w świecie nowych mediów (część tekstów publikowana była tė̇ na łamach internetowego czasopisma „Perspektywy Kulturoznawcze”). Sporo referatów w mniejszym lub większym stopniu nawiązujących do tematyki e-literackiej (w szerszym kontekście) pojawiło się też na konferencjach: Literatura i konwergencja (Łódź, maj 2012) oraz Teksty kultury uczestnictwa (Warszawa, październik 2013). A że o literaturze nowomedialnej mówi się coraz częściej (a równolegle przybywa rodzimych przykładów do analiz), nie sposób tu wymienić wszystkich konferencji, na których ostatnimi czasy te tematy bywają poruszane.

901 Warto pamiętać, że (także polskie) badania np. języka Internetu zaczęły się jeszcze w XX w. I tak w polskiej humanistyce pierwsze głosy o związkach mediów (w tym i Internetu) z literaturą rodziły się w kontekście namysłu nad językiem czy komunikacją w kontekście kultury audiowizualnej (przykładem N@wigacje słowa. Strategie werbalne w przekazach audiowizualnych Eugeniusza Wilka, Kraków 2000). Związki literatury i Internetu badano także z punktu widzenia Sieci jako potencjalnej wielkiej biblioteki (można mówić o bibliologicznej perspektywie badania Internetu). 
wpisały się w najbardziej aktualne dyskusje (dość dodać, że jednym z prelegentów w Milwaukee była sama Pressman).

Warto odnotować w tym miejscu również dwie publikacje, które wydaja się domykać pierwszy, a otwierać kolejny (już nie prekursorski) etap rodzimej refleksji e-literackiej. Z jednej strony w 2012 r. ukazała się wspomniana juz książka Urszuli Pawlickiej (Polska) poezja cybernetyczna ${ }^{902}$, wprowadzajaca powiew świeżości, przybliżająca wiele zebranych w Electronic Literature Collection prac i sprawnie sytuująca na tym tle polska poezję elektroniczną ${ }^{903}$; z drugiej - kolejny rok przyniósł długo oczekiwaną monografię Mariusza Pisarskiego Xanadu. Hipertekstowe przemiany prozy ${ }^{904}$, domykająca (w godny podziwu sposób) dotychczasową polska refleksję o hipertekście ${ }^{905}$.

Jednak próbując uporządkować historię polskiego dyskursu e-literackiego, trzeba tu wspomnieć też o dwóch znacznie starszych publikacjach, które niejako ufundowały rodzimą refleksję o związkach literatury (nie języka, słowa, ale właśnie literatury) z Internetem, czy (następnie) szerzej - nowymi mediami. Mam na myśli zredagowane przez Piotra Mareckiego książki liternet. literatura i internet (Kraków 2002) oraz Liternet.pl (Kraków 2003), które wyznaczyły kierunek pionierskiej rodzimej refleksji o sztuce słowa i nowych mediach (a w drugiej z wymienionych pozycji znalazł się również - lekko zmieniony - przedruk szkicu Fajfera Liberatura: hiperksiega w epoce hipertekstu, w którym po raz pierwszy chyba pojawiła się propozycja zestawiania tych dwóch typów twórczości). Trzeba tu jednak zwrócić uwagę na to, że utożsamianie kategorii liternetu z literaturą elektroniczną nie jest do końca prawomocne. Zaproponowany w 2002 r. termin odnosić miał się do (wieloaspektowych) związków literatury z Internetem ${ }^{906}$, jest zatem pojęciem o zarazem węższym, jak i szerszym zakresie znaczeniowym. Niemniej, wyznaczone w przywołanych publikacjach spektrum zainteresowań: powieść hipertekstowa, blog (literacki, ale i nie tylko), życie literackie w sieci stało się na długie lata kanonem poruszanych tematów podobnie jak zasugerowane tam metodologie (np. traktowanie hipertekstu jako ucieleśnienia poststrukturalistycznego rozumienia tekstu). I rzeczywiście, nadal gros szkiców polskich badaczy skupia się na tak właśnie pojętej problematyce ${ }^{907}$.

902 Zob. przypis 896.

${ }^{903}$ Choć badaczka nie ustrzegła się pewnych uproszczeń (czy uchybień merytorycznych), nie sposób nie docenić roli owej - jak by na to nie patrzeć - pionierskiej i przełomowej pracy.

${ }_{904}$ Kraków 2013.

${ }^{905}$ Nie bez znaczenia dla umiędzynarodowiania polskiej refleksji e-literackiej pozostają też popularyzujące polskich e-artystów darmowe anglojęzyczne chapbooki udostępniane na stronach ha!artu.

906 Zob. Piotr Marecki, hasło 'liternet', [w:] Tekstylia bis. Stownik młodej polskiej kultury, red. Piotr Marecki, Kraków 2006. O dyskusyjnym autorstwie tego określenia patrz też Bardziej opicki od Fecebooka. O Liternecie.pl rozmowa pqczkujaca, „Techsty” 2011, nr 7 (http://www.techsty.art.pl/magazyn/magazyn7/wywiad_z_leszkiem_onakiem.html [dostęp 30.09.2011]).

${ }^{907}$ Dobry to moment by przywołać opublikowane w Polsce zbiory tekstów dotyczących kwestii e-literackich (po części są to publikacje związane z konferencjami, które wymieniałam wcześniej). Za ważne (z powodów „historycznych” bądź rzeczywiście merytorycznych) uznałabym 
Niemniej, rozszerzają oni spektrum badań, mówiąc już nie tylko o literaturze w kontekście Internetu, lecz szerzej - nowych mediów, a co najważniejsze, posługując się terminami takimi jak choćby (widniejąca w tytule rozdziału ostatniej książki Maryli Hopfinger ${ }^{908}$ ) literatura elektroniczna (której zakres - jak zaznaczałam - znacznie przekracza ramy globalnej Sieci: zreszta do sieciowej odmiany e-literatury zaliczyć wypada inne formy niż wyłącznie hipertekst czy blog) ${ }^{909}$. Znamienna jest dyskusja Anny Łebkowskiej, Krzysztofa Uniłowskiego i Krystyny Wilkoszewskiej, której zapis otwiera pierwszy numer „Dekady Literackiej” z 2010 r. ${ }^{910}$ Trzeba tu podkreślić, że choć tę rozmowę redakcyjna zatytułowano Literatura a nowe media, nie wspomina się w niej właściwie o zjawiskach innych niż te, które omawiały publikacje spod patronatu krakowskiego „Ha!artu”. Dlaczego? Być może sugestia odpowiedzi tkwi w szczerym wyznaniu Krystyny Wilkoszewskiej, która, opowiadając o ob-

przede wszystkim: Stowo w kulturze mediów, red. Zbigniew Suszczyński, Białystok 1999; liternet. literatura $i$ internet, red. Piotr Marecki, Kraków 2002; Liternet.pl, red. Piotr Marecki, Kraków 2003; Joanna Wrycza, Galaktyka języka internetu, Gdynia 2008 (z zastrzeżeniem, że nie tylko o literaturze tam mowa); e-polonistyka, red. Aleksandra Dziak, Sławomir J. Żurek, Lublin 2009; Tekst (w) sieci (tom 1 Tekst. Język. Gatunki, red. Danuta Ulicka, tom 2 Literatura. Społeczeństwo. Komunikacja, red. A. Gumkowska), Warszawa 2009; Hiperteksty literackie. Literatura i nowe media, red. Piotr Marecki, Mariusz Pisarski, Kraków 2011; Od liberatury do e-literatury, red. Monika Górska-Olesińska, Eugeniusz Wilk, Opole 2011; e-polonistyka 2, red. Aleksandra Dziak, Sławomir J. Żurek, Lublin 2012; Liberatura, e-literatura i... Remiksy, remediacje, redefinicje, red. Monika Górska-Olesińska, Opole 2012; Małgorzata Janusiewicz, Literatura doby Internetu. Interaktywność i multimedialność tekstu, Kraków 2013. Sądzę, że publikacje te są lepszym źródłem odniesień niż - skądinąd słusznie nad wyraz rzadko bądź wręcz wcale nieprzywoływane - prace, takie jak choćby: Dzieło literackie w Sieci. Pomysty, hipotezy i interpretacje z pogranicza wiedzy o literaturze, kultury masowej $i$ wspótczesnych technologii Marka Adamca (Gdańsk 2004) czy Ku ciału post-ludzkiemu... poezja polska po 1989 roku wobec nowych mediów i nowej rzeczywistości Bogusławy Bodzioch-Bryły (Kraków 2006). Warto też zaznaczyć, że w 2008 r. ukazała się pozycja Ekrany piśmienności. O przyjemnościach teksu w epoce nowych mediów (red. Andrzej Gwóźdź, Warszawa 2008), zbierająca tłumaczenia wielu ważnych w rozważaniach o nowomedialnych kontekstach literatury szkiców (m.in. często przywoływany rozdział książki Davida J. Boltera Writing Space. Computers, hypertext, and the Remediation of Print zatytułowany: The breakout of the visual - Eksplozja obrazów, tłum. J. Mach), zaś rok 2014 przyniósł tłumaczenie całej książki Boltera (Przestrzeń pisma. Komputery, hipertekst i remediacja druku, tłum. Aleksandra Małecka, Michał Tabaczyński, Kraków 2014). W tym samym roku ukazała się również polska edycja kolejnej kanonicznej dla e-literaturoznawstwa pozycji: Cybertekstu Espena Aarsetha (Espen J. Aarseth, Cybertekst. Perspektywy literatury elektronicznej, tłum. Dorota Sikora, Mariusz Pisarski, Paweł Schreiber, Michał Tabaczyński, Kraków 2014).

${ }_{908}$ Maryla Hopfinger, Literatura i media. Po 1989 roku, Warszawa 2010.

909 Trzeba też zwrócić uwagę na mnogość terminów, jakimi określana bywa ta „nowa” odmiana literatury, co starałam się podkreślić tytułem tego podrozdziału. Za najwłaściwsze (ale i też najbardziej pojemne) uznaję określenie literatura elektroniczna, w rozumieniu przywoływanej Hayles. W swoich rozważaniach synonimicznie używałam również terminu literatura nowomedialna jako podkreślającego wyraźnie związek nie tylko i wyłącznie z Internetem (warto pamiętać, że w krytyce funkcjonuje również skrót e-literatura - właśnie od literatury elektronicznej - a w polskiej refleksji wszelkie przedrostki „e-” prowadzą ku utożsamianiu kontekstu z siecia). Por. mój szkic Którędy do literatury nowomedialnej?

${ }^{910}$ Literatura a nowe media. Rozmowa redakcyjna $z$ udziałem Anny Łebkowskiej, Krzysztofa Uniłowskiego, Krystyny Wilkoszewskiej, „Dekada Literacka” 2010, nr 1/2, s. 6-23. 
cowaniu z instalacja interaktywną w muzeum sztuki w Karlsruhe, wyznała: „tylko że ja w ogóle nie umiem tego odnieść do literatury”11.

I właśnie - u nas, w gruncie rzeczy, dopiero zaczynają pobrzmiewać głosy o tym, że literatura elektroniczna to nie tylko blogi i hiperteksty, a jednocześnie zaczynamy przyswajać sobie refleksję nad sposobami badania owej „nowej” literatury. Wspominałam o autokorektach, jakich dokonuja ci, którzy rozpoczynali omawianą tu dyskusję w polskiej humanistyce, stąd nie sposób nie przywołać tu wystapienia Mariusza Pisarskiego podczas pierwszej lublińskiej konferencji e-polonistyka (listopad 2007 r.) ${ }^{912}$. Młody badacz, redaktor równie kanonicznej jak oba tomy liternetu „pozycji”: wortalu www.techsty.pl, na którym dostępny jest również magazyn pod tym tytułem ${ }^{913}$, wskazywał na różne „grzechy” (czy jak mówi: „pułapki metodologiczne”) pierwszej fazy polskiej refleksji o literaturze elektronicznej (takiego terminu używa wymiennie z tytułowym określeniem „literatura cyfrowa”), wyznając jednocześnie, że i on sam w nie wpadał. Samokrytyce towarzyszył postulat, by - mówiąc o dziełach literatury elektronicznej - sięgać i do metodologii literaturoznawczej, i do medioznawczej, by w badanych tekstach dostrzec nie tylko ich literackość, ale i cyfrowość oraz wywiedzione z niej jakości. Pisarski sugeruje też, by inni badacze - jak i on sam - prześledzili swoje prace pod kątem „niedowidzeń warstw tekstu cyfrowego".

Na pierwszy rzut oka wydawać by się mogło, że podobny ton autokorekty, refleksji po czasie ma szkic Andrzeja Pająka Litteratura cybernetica, czyli burza w szklance wody ${ }^{914}$. Niemniej, choć wypowiedź ta jest znacznie bardziej stonowana niż wcześniejsze wystapienia autora, nadal daje przede wszystkim raczej świadectwo nieświadomości istnienia innych niż hiperteksty form literatury elektronicznej ${ }^{915}$, choć - tu trzeba się zgodzić - na te Pająk wreszcie przestaje patrzeć niczym na ziemię obiecana. W kontekście nowszych niż refleksja nad hiperfikcją opracowań marzenia o nowych możliwościach literatury związanych choćby z „połączeniem tejże [...] z rzeczywistością” nie są bynajmniej - jak uważa Pająk - niemożliwe do zrealizowania ${ }^{916}$. Niemniej, w szkicu tym autor artykułuje wprost niezwykle ważną dla rozważań o polskiej literaturze

911 Ibidem, s. 12 . Z krótkiego opisu, jaki daje badaczka, śmiem wnioskować, że chodziło o pracę Portrait no. 1 Luca Courchesne'a.

${ }_{912}$ Zob. Mariusz Pisarski, Pułapki metodologiczne w badaniach nad literatura cyfrowa, [w:] e-polonistyka, s. 77-87.

${ }^{913}$ Czasopismo posiadajace nr ISSN.

914 „Dekada Literacka” 2010, nr 1/2, s. 33-37.

915 Por. Andrzej Pająk, Litteratura cybernetica, czyli burza w szklance wody, „Dekada Literacka” 2010, nr 1/2, s. 34. Por. też: Maryla Hopfinger, Sytuacja mediów: zmiana kultury?, [w:] eadem, Literatura i media... (zwłaszcza podrozdział Polskie realia, s. 46-53).

${ }^{916}$ Dość przywołać literackie instalacje interaktywne typu Beyond Pages (Masakiego Fujihaty) czy Text Rain (Camille Utterback i Romy'ego Achituva). Pisząc o autokorektach powinnam zaznaczyć, że komentując kilkakrotnie drugą z przywołanych prac byłam przekonana, że jej autorami są dwie kobiety [por. moje szkice: Którędy do literatury nowomedialnej? oraz W pudetku i na wadze - o przestrzeni śmierci i przestrzeni tekstu w utworach Bryana S. Johnsona oraz Zenona Fajfera i Katarzyny Bazarnik ([w:] red. Izabela Grzelak, Tomasz Jermalonek, Łódź 2007)]. 
cyfrowej kwestię: niezbyt mamy o czym mówić. Niewiele tego typu tekstów się u nas pojawia (jak podsumowuje Pająk: „mniej niż 30 pozycji, jakie powstały przez ostatnie 14 lat”17) i wciąż za mało znamy technologie, w których można taką literaturę tworzyć.

Przyczyn niezbyt imponującego stanu polskiej e-literatury nie należy upatrywać w jej niszowości, ale raczej w opóźnieniu Polski w dostępie do nowoczesnych technologii, które było efektem polityki rządów komunistycznych - tłumaczy badacz. - Zaryzykowałbym twierdzenie, że nasz kraj ominęła „epoka Story Space” (1987) i zamiast tego wkroczyliśmy od razu w „epokę blogów” (ok. 1999). W dużej mierze polska e-literatura powstawała w czasach, kiedy zarówno komputery, jak i dostęp do Sieci były znacznie mniej powszechne i być może dlatego te działania nie trafiały na podatny grunt ${ }^{918}$.

Tłumaczyłoby to po części, dlaczego w środowiskach polonistycznych niewiele mówi się o literaturze elektronicznej.

W tak zarysowanym kontekście przywołany tu już rozdział Literatury $i$ mediów. Po 1989 roku Maryli Hopfinger jest idealnym wręcz udokumentowaniem stanu, w którym w chwili publikacji tej książki znajdowała się rodzima refleksja o e-literaturze. Badaczka, dogłębnie analizując w swoich wcześniejszych pracach przemiany postaci słowa w kulturze audiowizualnej (oraz w obszarze dopiero rodzącej się audiowizualności), badając nie tylko jego relację z innymi mediami, lecz i przemiany kultury w powiązaniu z kształtowaniem się nowych mediów (w szerokim rozumieniu terminu), dała też rzeczowy fundament refleksji nad formą literatury w dobie nowych mediów (również w ich wąskim rozumieniu) ${ }^{919}$. Jednocześnie Hopfinger, próbując scharakteryzować kolejny etap przeobrażeń literatury (jakim jest właśnie jej elektroniczna odmiana), z jednej strony popada w pułapkę mówienia tylko o spektrum zjawisk zakreślonym przez publikacje Mareckiego z początku XXI w., z drugiej - można powiedzieć - odrabia zadaną przez Pisarskiego pracę domowa.

Choć - pisząc w 1993 r. o happeningu i literaturze - stwierdzała, że ta ostatnia „zakłada pośredni charakter sytuacji komunikacyjnej”, a jej dzieła mają charakter zamkniętych, gotowych całości, „na które poza [...] autorem nikt nie ma większego wpływu"920, elektronicznej odmianie sztuki słowa przyznaje

917 A. Pająk, Litteratura cybernetica..., s. 33.

918 Ibidem.

919 Por. Maryla Hopfinger, W laboratorium sztuki XX wieku. O roli słowa i obrazu, Warszawa 1993; eadem, Kultura audiowizualna u progu XXI wieku, Warszawa 1997; eadem, Doświadczenia audiowizualne. O mediach w kulturze współczesnej, Warszawa 2003. Dla moich rozważań istotne są też opisane przez badaczkę jeszcze w latach osiemdziesiątych dwa modele współobecności słowa i obrazu (zob. eadem, Stowo i obraz w kulturze wspótczesnej, „Kultura i Społeczeństwo” 1986, z. 1), które - jak stwierdza w późniejszych tekstach - współczesny kształt kultury nieco podważa. Model statyczny komplikuja, jak twierdzi Hopfinger, działania o charakterze intermedialnym, dynamicznym - techniki komputerowe (M. Hopfinger, Kultura audiowizualna u progu XXI wieku, s. 96-97 oraz Doświadczenia audiowizualne. O mediach w kulturze współczesnej, s. 151-152).

${ }_{920}$ M. Hopfinger, W laboratorium sztuki XX wieku..., s. 85. 
już charakter struktury bardziej otwartej, dynamicznej ${ }^{921}$. Co ważniejsze, mówi o potrzebie nowych kompetencji czytelniczych (odbiorca tego typu sztuki musi nie tylko umieć czytać, lecz i posługiwać się technologiami, które mu to czytanie umożliwia, innymi słowy: interfejsem bardziej złożonym niż jego „preelektroniczna" odmiana, jaka jest/była klasyczna postać książki) ${ }^{922}$ czy zniesieniu różnic między słowem, dźwiękiem i obrazem, a także ich hierarchii obowiązujących w starych mediach ${ }^{923}$. Hopfinger dość krytycznie podchodzi też do bogato (na tle innych) opracowanego w polskiej refleksji nurtu rozważań o protohipertekstowości, słusznie zauważając, że wskazując na podobieństwa struktur, należy pamiętać o tym, co je dzieli: o „odmienności technologicznej”, która „generuje zasadnicze różnice materii semiotycznej i kontekstu komunikacyjnego"924. Choć więc badaczka nie daje pełnej panoramy literatury elektronicznej, choć niezgodnie z prawda uznaje, że tekst literacki w Internecie musi być opary na strukturze hipertekstowej (dość tu przywołać niemające z nią nic wspólnego utwory tworzone jako animacje flashowe $)^{925}$, praca Hopfinger pokazuje, że i bardziej aktualne aspekty światowej refleksji o literaturze w nowych mediach sa w Polsce powoli przyswajane, choć - raz jeszcze powtórzę - nie mamy ich jeszcze do czego odnosić ${ }^{926}$.

${ }^{921}$ Warto jednak dodać, iż Hopfinger nie zmierza już w stronę metodologicznej pułapki uśmiercania autora i nowej aktywności czytelniczej (wynikającej z dynamiczności struktury tekstów nowomedialnych), nie wiąże z odebraniem autorowi prawa do własnego tekstu, lecz z obowiązkiem zaprojektowania jego całości (modelu, z którego czytelnik dalej będzie tworzył konkretne odsłony testu - z których wszystkie zostały przez autora zaprojektowane). Por. M. Hopfinger, Literatura i media..., s. 180. Tezy Hopfinger związane z przemianami samej istoty aktu komunikacji i roli, jaka pełnią w nim poszczególne media, warte są przywołania tu, szczególnie zważywszy na kontekst liberackiej (re)interpretacji aktu literackiej komunikacji, o czym pisałam w rozdziale poświęconym relacji liberatury i książki oraz (w nieco mniejszym stopniu), odwołując się do futuryzmu.

${ }_{922}$ M. Hopfinger, Literatura i media..., s. 179. Por. też Dorota Sikora, (Hiper)przestrzeń tekstu - o Storyspace, najstynniejszym programie do tworzenia literatury hipertekstowej, „Techsty”, nr 6 (2009) oraz eadem, Muza połaczeń. O Word Circuits Connection Muse-zestawie narzędzi do tworzenia poezji i prozy sieciowej, „Techsty” 2008, nr 5, www.techsty.art.pl [dostęp 30.09.2011]. Niemniej, warto w tym kontekście pamiętać o tym, że twórcy tekstów nowomedialnych eksplorują często równolegle naturalność elektronicznych interfejsów, jak i ich ludyczny charakter (por. Marcin Składanek, Funology - homo ludens $i$ homo faber $w$ projektowaniu interakcji, „Dyskurs. Pismo Naukowo-Artystyczne ASP we Wrocławiu" 2012, nr 13/14).

${ }^{923}$ M. Hopfinger, Literatura i media..., s. 181. Por. też David J. Bolter, Eksplozja obrazów, [w:] Ekrany piśmienności... (lub - dla szerszego kontekstu cała książka, z której pochodzi ten rozdział: idem, Przestrzeń pisma...).

${ }_{924}$ M. Hopfinger, Literatura i media..., s. 127, por. także s. 174-175.

${ }_{925} \mathrm{~W}$ przywołanym rozdziale czytamy, że „tekst w środowisku cyfrowym staje się hipertekstem” (s. 175), a nawet, że „w środowisku Internetu cechy hipertekstu sa obligatoryjne, stały się konieczną oczywistościa”" (s. 178). Tak więc, choć Hopfinger dostrzega medialną odmienność literatury powstającej w tym środowisku, mówi o nowych czytelniczych kompetencjach, nie zawsze jednak konsekwentnie pamięta i o tym, że również wybór konkretnego narzędzia do tworzenia tekstu jest istotny - i że nie zawsze musi to być narzędzie operujące hiperłączami.

${ }^{926}$ Ciekawe sa jednak - w pełni zreszta zgodne z duchem prac Hopfinger - spostrzeżenia Moniki Górskiej-Olesińskiej, analizującej elektroniczną poezję czy literaturę tworzoną w technologii CAVE w kontekście twórczości choćby Stanisława Dróżdża. Por. M. Górska-Olesińska, Ukryte wymiary pojęciokształtów, [w:] Od liberatury do e-literatury; eadem, Pisanie jaskiniowe (cave writing) oraz eadem, Tekstowe instrumenty do gier z pamięcia. 
Stąd, pewnym kontekstem dla moich rozważań mogłyby być (i sa) nieliczne publikacje ${ }^{927}$ wskazujące większe bogactwo form literatury elektronicznej ${ }^{928}$. Sądzę jednak, że - wyjaśniwszy, iż mój zwrot ku opracowaniom zagranicznym nie jest wynikiem zachłyśnięcia się ich nowością czy nieznajomości rodzimego stanu badań - mogę (i powinnam) dla charakterystyki liberatury na tle wykorzystującej słowo twórczości nowomedialnej odwoływać się do najszerszych znanych mi ujęć. Zwłaszcza, że i najbardziej aktualna polska refleksja e-literaturoznawcza do nich się odnosi. Jednocześnie, takie ujęcie wpisuje się w - słuszne, jak sądzę - tendencje umiędzynarodowiania polskiego e-literaturoznawstwa. Ponadto, jak zapowiadałam już na początku tej książki, analizowana przeze mnie kategoria liberackości wydaje się doskonale trafiać w dyskutowane na świecie luki w ujęciu współczesnej kondycji sztuki słowa, idealnie wpisywać w debaty dotyczące (interesujacej mnie w tym rozdziale) wspólnej (analogowej i elektronicznej) przestrzeni literackiej. Tym samym, pozwolę, by - mimo wszystko - moim rozważaniom w tej części książki patronowała raczej Hayles niż Hopfinger. Szczególnie, że do bezsprzecznie inspirujacych mój wywód konstatacji tej ostatniej przyjdzie mi jeszcze wrócić w dalszej części tego rozdziału. książki.

927 Publikowane, dodam, w większości już w momencie, gdy kończyłam pracę nad tą częścią

${ }_{928}$ Jak przywoływane już tu eseje Górskiej-Olesińskiej (m.in. Pisanie jaskiniowe (cave writing) czy Elektroniczne uwolnienie stowa...), Wendorff (Nowa poetyka i nowe przestrzenie awangardowe w poezji elektronicznej Ladislao Pabla Györiego...) czy Anny Nacher (,Alternative reality narrative" - granice tekstu, [w:] Od liberatury do e-literatury), w pewnym stopniu też analizy Janusiewicz (Literatura doby Internetu...). 


\section{Daleko czy jednak blisko? O tym, co lączy liberatów i e-literatów}

\subsection{Niemieszczące się $\mathrm{w}$ biblioteczkach literackie dziwolągi, które trzeba czytać inaczej}

Opisujac wybrane prace literatury elektronicznej, Katherine Hayles stwierdza, że ustanawiają one literaturę jako doświadczenie odczuwane zupełnie inaczej niż dotychczas, niezwiązane już z trwale zapisaną stroną tekstu, lecz poszerzone o wielozmysłowe odczuwanie (fullbody experience) ${ }^{929}$. Charakteryzując i komentujac Screen, prace oparta na technologii interaktywnej jaskini CAVE, badaczka - zgadzając się z Ritą Raley odnośnie do zaistniałej w takiej sytuacji konieczności zweryfikowania kategorii lektury - stwierdza, że:

Czytanie staje się kinestetycznym [...] i żywym doświadczeniem, angażującym nie tylko umysłową aktywność dekodowania, lecz również cielesne interakcje ze słowami postrzeganymi jako poruszające się w przestrzeni obiekty ${ }^{930}$.

Przypomnę, że Hayles swoimi charakterystykami obejmuje szeroka gamę tekstów przynależnych do literatury elektronicznej, z ogromnym bogactwem form gatunkowych, jakie ona oferuje. Tym samym - jak już zaznaczałam przywołuję jej tezy nie tylko w odniesieniu do form najczęściej komentowanych w polskiej krytyce (hipertekstów, blogów czy tzw. code works), lecz odwołując się do całej e-literackiej genologii ${ }^{931}$. Owej różnorodności nie sposób ignorować, szczególnie zważywszy na to, iż formy takie jak hipertekst rodziły się w pierwszym okresie rozwoju e-literatury ${ }^{932}$, zapoczątkowując szereg

${ }_{929}$ K. N. Hayles, Electronic Literature..., s. 13.

${ }_{930}$ Ibidem. Ciekawym kontekstem dla tej konstatacji wydaje się opublikowany już w $1999 \mathrm{r}$. szkic Estetyka dotyku Krystyny Wilkoszewskiej ([w:] Stowo w kulturze mediów), w którym badaczka zwracała uwagę na - związany z nowymi mediami - powrót kategorii dotyku do rozważań estetycznych (po okresie koncentrowania się na zmysłach wzroku i słuchu).

${ }^{931}$ Ciekawą i wartą uwagi jej charakterystykę dał również - kilkanaście lat wcześniej niż Hayles - George Landow. Zob. George P. Landow, Twenty minutes into the future, or how are we moving beyond the book?, [w:] The Future of the Book, ed. Geoffrey Nunberg, Belgium 1996.

${ }^{932}$ K. N. Hayles, Electronic Literature... Warto tu podkreślić również za badaczka, że „pionierskie" (jak mówi) prace Landowa czy Boltera na tym etapie rozwoju literatury elektronicznej były ważne, istotne, z perspektywy czasu jednak nieco się zdezaktualizowały. Warto o tym pamiętać w kontekście polskiej recepcji teorii hipertekstu, w której ci właśnie badacze królowali przez długi czas. Ciekawie o hipertekście jako dość archaicznej formie pisze też Eskelinen: „teoria hipertekstu nastawiona była na zrobienie wokół siebie szumu (nieszczęśliwie rozdzielając tekstualność cyfrową czy elektroniczną od drukowanej), jakkolwiek wydawać by się to mogło konieczne 
zmian w literackości, których owoce dostrzeżemy, dopiero spoglądając na późniejsze, znacznie dalej idące w modyfikacjach klasycznych układów, formy. W większości przypadków to właśnie teksty oparte na innych niż hipertekstowa strukturach, przekonały część badaczy o konieczności znalezienia nowego określenia dla tak realizowanej sztuki słowa.

Jako przejawy omawianych poszukiwań traktować należy zwrot od mówienia o literaturze ku traktowaniu (za Ongiem) o piśmienności (literacy ${ }^{933}$ ), a później jeszcze ku temu, co Gregory L. Ulmer - w pełni już wpisując się w dyskurs nowomedialny - określił mianem electracy ${ }^{934}$. Przypominajacc wyznanie Józefa Japoli tłumaczącego Onga, w którym przyznaje on, że „prostota, oczywistość i elegancja angielskiego tytułu tej książi - «Orality and Literacy» - dorównuje chyba tylko nieporęczności i niezgrabności jej polskiego odpowiednika: "oralność i piśmienność»" 935 , ten ostatni termin wolałabym tymczasowo zachować w jego oryginalnym brzmieniu. Trzeba dostrzec, że wszystkie te określenia zrodziły się z potrzeby zredefiniowania kategorii lektury i dzieła literackiego wynikłego z nowej sytuacji, w jakiej znalazła się literatura.

Nie jest to pierwszy raz, kiedy teoretycy (czy twórcy bądź teoretycy-twórcy) domagają się ponownego zdefiniowania literatury, literackości czy tė̇ zauważenia konieczności zmiany naszego pojmowania aktu czytania ${ }^{936}$. Postulaty takie z reguły towarzyszą wszelkim działaniom awangardowym (dość przypomnieć choćby Raymonda Federmana ${ }^{937}$ czy analizowana tu wcześniej poezję konkretna). Zaznaczajacc, że wcale nie chciałabym się skupić na niemainstreamowych eksperymentach, pragnę przywołać w tym miejscu również stanowisko Loss Pequeño Glaziera, który twierdzi, że najlepiej traktować literaturę elektroniczną właśnie jako kontynuację eksperymentalnej literatury drukowanej ${ }^{938}$.

w którymś momencie naszej najnowszej historii, jednak nadal zbyt wiele jej odwołań i twierdzeń jest temu poświęconych. Taka strategia była zrozumiała, ponieważ hipertekst jest dużo bliżej przeciętnej drukowanej tekstualności niż większość innych podzbiorów cybertekstu” (Markku Eskelinen, Teoria cybertekstu a badania literackie. Podręcznik użytkownika, tłum. Dorota Sikora, Grzegorz Mielcarek, „Techsty” 2006, nr 2, http://www.techsty.art.pl/magazyn2/artykuly/eskelinen_cybertekst5.html [dostęp 20.11.09]). Por. tė̇ Mariusz Pisarski, Xanadu. Hipertekstowe przemiany prozy, Kraków 2013.

${ }_{933} \mathrm{~W}$ tłumaczeniu sugeruję się polskim przekładem pracy W. J. Onga Orality and literacy: the technologizing of the word.

${ }_{934}$ Gregory L. Ulmer, Internet Invention: From Literacy to Electracy, Nowy York 2002 (tam czytamy: „Electracy is to digital media what literacy is to print”). Po raz pierwszy Ulmer zastosował ten termin w wydanej w 1989 r. Teletheory.

935 Józef Japola, Od ttumacza, [w:] W. J. Ong, Oralność i piśmienność..., s. 13.

${ }^{936} \mathrm{~W}$ kontekście e-literatury na nowe strategie lektury zwracały też uwagę m.in. Stephanie Strickland i Cyntia Lawson, pisząc o „doświadczeniu czytania eksplorującego” (experience of exploratory reading) i społecznościowym charakterze niektórych aktów e-lektury (zob. Stephanie Strickland, Cyntia Lawson, Vniverse, [w:] New Media Poetics. Contexts, Technotexts, and Theories, ed. Adelaide Morris, Thomas Swiss, London 2006). Por. też mój szkic Po(d)żeranie tekstu. Wstep do rozważań o czytaniu kinetycznym, [w:] e-polonistyka 3, red. Aleksandra Dziak, Lublin (w druku).

${ }^{937}$ Raymond Federman, Surfikcja - cztery propozycje $w$ formie wstepu, tłum. Jarosław Anders, [w:] Nowa proza amerykańska, oprac. Zbigniew Lewicki, Warszawa 1983.

${ }_{938}$ Loss P. Glazier, Digital Poetics. The Making of E-Poetries, Tuscaloosa 2002. 
Również teoretycy badanej przeze mnie liberatury niejednokrotnie podkreślali, że terminy, jakimi operuje współczesna humanistyka, wydają się zupełnie nieadekwatne w odniesieniu do kształtu dzisiejszej książki, możliwości, jakie stoja przed literaturą czy potencjalnych sposobów jej czytania ${ }^{939}$. Zaś teksty zaliczane do liberatury, podobnie jak te opisywane przez Hayles czy innych krytyków e-literatury, stawiaja pod znakiem zapytania klasyczne rozumienie aktu lektury. Przypomnę: nie są to książki, które da się „normalnie” otworzyć (Z. Fajfer, Spod), ich czytanie niejednokrotnie wymusza na nas przemieszczanie się w przestrzeni (A. Bednarczyk, Pole anielskich szeptów), a czasem nawet czas, jaki musimy na takie lekturowe spacery poświęcić wydaje się istotny w interpretacji (R. Nowakowski, Ulica Sienkiewicza w Kielcach). Książki liberackie potrafią rozsypać się w dłoniach, nawet gdy pozornie przypominają klasyczny kodeks (B. S. Johnson, Nieszczęśni), a gdy już sa kodeksem - to nie zawsze pojedynczym, a na dodatek część tekstu musimy sami rekonstruować, gdyż pozostaje on niewidzialny (Z. Fajfer, K. Bazarnik, Oka-leczenie). Tym samym, moje rozważania o liberackości (liberacy?) moga być postrzegane jako składowa przywołanego dyskursu o „innych” piśmiennościach.

Jaki jest cel proponowanego tu zestawienia ze sobą literatury totalnej i elektronicznej nie jako marginalizowanych odmian literatury, z racji swoich „dziwactw” spychanych do getta literackich dziwolagów, lecz właśnie jako takich odmian sztuki słowa, które w XXI w. nie tylko już żądają swojego miejsca w literackim kanonie, lecz również zmuszają nas do przedefiniowania od dawna już nieweryfikowanych kategorii, takich jak choćby samo pojęcie literatury? Wydaje się, że przed owymi dziwadłami nie sposób już uciec i trzeba zacząć próbować je opisywać. Być może dobrym punktem wyjścia jest właśnie postawienie pytania o to, co powoduje, że zarówno e-literatura, jak i liberatura prowokują do innego spojrzenia na kategorie tekstu literackiego, aktu czytania czy samej literackości, pytania o to, co łączy te dwie formy literackie. Wydawać by się mogło, że da się zauważyć podobne podejście do tekstu prezentowane przez działajacych w obrębie tych nurtów twórców i być może dostrzeżenie tego faktu pozwoliłoby określić wspólne perspektywy badawcze dla omawianych zjawisk i znaleźć tym samym wygodny sposób ich krytycznego opisu.

\subsection{Espen Aarseth i liberatura}

W 1997 r. Espen Aarseth, poszukując terminologii zdolnej opisać każdy tekst (niezależnie od tego, w jakim medium będzie on realizowany), również domagał się porządków terminologicznych.

${ }^{939}$ Ale przypomnę też, że o konieczności redefinicji kategorii tekstu (w tym: także literackiego) w dobie kultury multimedialnej pisała również - jak już podkreślałam - Seweryna Wysłouch (zob. eadem, Nowa genologia - rewizje i interpretacje, s. 106). 
Olbrzymim problemem w ostatnich dyskusjach o medium komputerowym jest brak rygorystycznej terminologii - stwierdzał, by dalej postulować taka, która - nie byłaby zakorzeniona w komputerowej retoryce (por. „hipertekst”, „,interaktywny”, „wirtualny” itd.) lecz oparta na dostrzegalnych różnicach w relacjach między tekstem a jego czytelnikiem (użytkownikiem) ${ }^{940}$

Formułując swoją teorię dążącą do opisania każdego rodzaju tekstu, badacz zwracał uwagę również na rażący brak takiej jego definicji, która dałaby się zastosować w odniesieniu do tworów różnomedialnych i która zarazem nie domagałaby się ciagłej aktualizacji. Zaproponowane przez Aarsetha pojęcie cybertekstu, charakteryzujące tekst jako maszynę przekształcająca tekstony (ciagi znaków $\mathrm{w}$ takiej postaci, $\mathrm{w}$ jakiej istnieją w tekście) w skryptony (ciagi znaków w takiej postaci, w jakiej jawią się one odbiorcy), zrodziło się jako próba znalezienia owej brakującej definicji ${ }^{941}$. A z wywodu badacza dla moich rozważań kluczowe wydaje się założenie leżące u podstaw tak formułowanego ujęcia. Jak bowiem mówi Aarseth, jeśli tekstem jest „każdy przedmiot o prymarnej funkcji przekazywania werbalnej informacji” ${ }^{442}$, to trzeba zwrócić uwagę na dwie jego cechy charakterystyczne: po pierwsze tekst nie może działać niezależnie od jakiegoś materialnego medium (co nie pozostaje bez wpływu na jego funkcjonowanie), po drugie zaś - nie jest on tożsamy z samą tylko informacja, jaką przenosi ${ }^{943}$.

Jednocześnie Aarseth podkreśla, że aby dostrzec wagę znaczenia kategorii medium, czy - jak dokładniej to określa, co dla mnie niezwykle ważne - jego materialności (the materiality of the medium $)^{944}$, musimy zdać sobie sprawę z tego, że to wcale nie zastosowanie odmiennych nośników warunkuje inny charakter tekstów, a dychotomia dzieł (umownie je nazwijmy) staroi nowomedialnych nie sprowadza się do opozycji druk-elektronika ${ }^{945}$. Jedną z podstaw zaproponowanej przez badacza typologii tekstualności sa przecież „zauważalne różnice $\mathrm{w}$ relacjach między tekstem a czytelnikiem (użytkownikiem)"946. Przywołana funkcja odbiorcy to ostatnia z siedmiu wymienionych przez Aarsetha zmiennych pozwalających opisać mechanizmy przekształcania tekstonów w skryptony ${ }^{947}$, a tym samym możliwych postaci/typów tekstów.

940 Espen J. Aarseth, Cybertext. Perspectives on Ergodic Literature, Baltimore-London 1997, s. 59; pozycję tę dalej oznaczam jako E. J. Aarseth wraz z numerem stron.

${ }_{941}$ Więcej o teorii cybertekstu zob. np. Katarzyna Prajzner, Cybertekst. Tekst jako mechanizm, [w:] eadem, Tekst jako świat i jako gra. Modele narracyjności w kulturze wspótczesnej, Łódź 2009; eadem, Cybertekst. Nowa perspektywa postrzegania tekstualności, [w:] Język @ multimedia, red. Agnieszka Dytman-Stasieńko, Jan Stasieńko, Wrocław 2005 lub Dorota Sikora, Tekst jako maszyna. Wprowadzenie do mechaniki hipertekstu, [w:] Tekst (w) sieci, red. Anna Gumkowska, t. 2, Warszawa 2009.

${ }_{942}$ E. J. Aarseth, s. 62.

${ }_{943}$ Ibidem.

${ }^{944}$ Ibidem, s. 59.

${ }_{945}$ Ibidem.

${ }_{946}$ Ibidem.

${ }_{947}$ Pozostałe to: 1. dynamizm (dynamics), 2. zdeterminowanie (determinability), 3. krótkotrwałość (transiency), 4. perspektywa (perspective), 5. dostęp (access), 6. powiązania (linking). Więcej zob. m.in. K. Prajzner, Cybertekst. Nowa perspektywa postrzegania tekstualności lub dowolna inna pozycja z podanych w przypisie 941. 
Trzeba zaznaczyć, że uwzględniając wszystkie z wskazanych przez badacza wyznaczników, otrzymamy 576 możliwości. Jak podkreśla Markku Eskelinen, „każdy tekst (od «I Ching» do MUD-ów) może być sklasyfikowany w oparciu o to, jak funkcjonuje jego medium" ${ }^{448}$. Nie sposób nie zgodzić się również z Katarzyną Prajzner twierdząca, że „wyróżnione przez Aarsetha zmienne [...] pozwalają precyzyjnie wyróżnić konkretne typy tekstów”949. Ponieważ z tego samego powodu łatwo nam wskazać na podobieństwa między poszczególnymi grupami utworów, warto spróbować przyjąć zaproponowaną przez Aarsetha perspektywę i zestawić ze sobą przykładowy tekst liberacki i e-literacki, by zobaczyć, czy bardzo się od siebie różnią ${ }^{950}$. W przypadku Oka-leczenia Fajfera i Bazarnik oraz Końca świata wedtug Emeryka Nowakowskiego taka charakterystyka porównawcza daje następujące rezultaty:

Tabela 1: Zestawienie cech Oka-leczenia i Końca świata wedtug Emeryka wg typologii E. Aarsetha

\begin{tabular}{|c|c|c|}
\hline & Oka-leczenie & Koniec świata wedtug Emeryka \\
\hline 1. & Statyczny & Statyczny \\
\hline 2. & Niezdeterminowany & Niezdeterminowany \\
\hline 3. & Niebędący krótkotrwałym & Niebędący krótkotrwałym \\
\hline 4. & Perspektywa bezosobowa & Perspektywa bezosobowa \\
\hline 5. & O ograniczonym dostępie ${ }^{a}$ & O ograniczonym dostępie ${ }^{b}$ \\
\hline 6. & 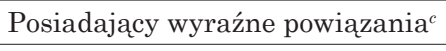 & Posiadający wyraźne powiązania \\
\hline 7. & $\begin{array}{l}\text { F. interpretacyjna } \\
\text { F. eksploracyjna } \\
\text { F. konfiguracyjna }\end{array}$ & $\begin{array}{l}\text { F. interpretacyjna } \\
\text { F. eksploracyjna } \\
\text { F. konfiguracyjna }\end{array}$ \\
\hline
\end{tabular}

Objaśnienia:

${ }^{a}$ Kwestia ta jest problematyczna. Z jednej strony czytelnik ma dostęp do wszystkich partii tekstu, jednak „dostępność” partii niewidzialnych polega na tym, że może (ale nie musi) włożyć wysiłek w ich rekonstrukcję i dopiero wtedy będzie miał dane wszystkie partie tekstu. Ponieważ nie wszystkie teksty w różnym stopniu są dostępne „od zaraz”, skłaniam się bardziej ku opcji ograniczonego dostępu.

${ }^{b}$ Występuja, nieliczne co prawda, linki warunkowe.

${ }^{c}$ I w tym przypadku sytuacja nie jest do końca klarowna. Dostrzeżenie zależności między poszczególnymi partiami Oka-leczenia wymaga wnikliwej analizy, jednak wszystkie ślady tych powiązań dane są w tekście.

Źródło: oprac. Agnieszka Przybyszewska.

${ }_{948}$ M. Eskelinen, Teoria cybertekstu a badania literackie... .

949 K. Prajzner, Cybertekst..., s. 63.

${ }^{950}$ O liberaturze jako o literaturze ergodycznej pisał również Andrzej Pająk w szkicu The Polish way to e-literature. From the Baroque to the 21sth Century (zob. szczególnie s. 26-31). Tekst ten przygotowywany był na konferencję Electronic Literature in Europe, która odbyła się w Bergen we wrześniu 2008 r. (samo wystapienie autora zostało odwołane, tekst jest jednak opublikowany). Szkic (publikacja elektroniczna) dostępny jest pod adresem: http://elitineurope.net/node/23 [dostęp 15.11.09]. W 2011 r. jego fragment (niezawierający jednak interesujacych mnie tu odniesień do liberatury) opublikowany został po polsku w Od liberatury do e-literatury (A. Pajak, Na tropie dziwnych ksiażek. Polska droga do e-literatury (od baroku do XXI wieku)). Tej samej tematyki dotyczyła także praca magisterska autora: Polska droga do e-literatury. Od baroku do XXI wieku, ukończona w 2009 r. w Uniwersytecie Warszawskim pod kierunkiem profesora J. Lichańskiego. 
Oczywiście, wybrany przeze mnie przykład można uznać za nieco kontrowersyjny. Liberackie korzenie hipertekstowej powieści Nowakowskiego czynią ją w naturalny sposób podobną do dowolnego tekstu liberackiego. Jednak w przypadku zestawienia innych utworów, wyniki prezentują się podobnie (ja zaś chciałam oprzeć się na rodzimych i dostępnych szerszemu gronu odbiorców dziełach). Charakteryzowana przez Prajzner przy pomocy tych samych zmiennych web fiction Shelley Jackson (My Body) jest tekstem: dynamicznym, niezdeterminowanym, niebędącym krótkotrwałym, o perspektywie bezosobowej i swobodnym dostępie, posiadajacym wyraźne powiązania. Jednocześnie - zgodnie z ustaleniami badaczki - i w tym wypadku funkcje, jakie przyjmuje czytelnik to: interpretacyjna, eksploracyjna oraz konfiguracyjna ${ }^{951}$.

Trzeba zaznaczyć, że tym, czego poszukujemy nie jest pełna identyczność charakterystyki tekstów, lecz podobieństwa. A w większości przypadków zarówno liberatura, jak i e-literatura różnią się od sporej grupy (papierowych, drukowanych) tekstów klasycznych (bo od awangardowych już nie zawsze) tym, że odbiorca podejmuje więcej niż jedną - interpretacyjna - funkcję wobec tekstu. Rzadko kiedy utwór przynależny do jednej z tych dwóch grup da się scharakteryzować, tak jak - używajacc Aarsethowskiej klasyfikacji - opisał „zwykłe teksty” (Aarsethowskie ordinary texts) Eskelinen: statyczne, nieprzechodne, zdeterminowane, bezosobowe, o dostępie swobodnym, wyłacznie interpretacyjne i bez linków. Przywołany krytyk norweskiej teorii stwierdza też:

Teoria Aarseth’a kładzie nacisk na znacząco pomijane w badaniach i marginalizowane obszary wiedzy literackiej [...]: materialność tekstu i funkcjonalne różnice w tekstualnych mediach. Istniejący obszar tekstualności jest wtedy poszerzony i dynamicznie przegrupowany [...] a tym samym poprzednio dominujące formy przepisywane są z powrotem do znacznie zmienionego pola badawczego - i to jako podzbiory cybertekstów ${ }^{952}$.

W takim kontekście, logiczna wydaje się chyba przyjęta na początku tego rozdziału strategia niewykluczania e-literatury i liberatury z obszaru tekstualności, lecz takiego definiowania tej ostatniej, by teksty te znalazły się w jej obrębie. Z jednej bowiem strony Aarsethowskie ujęcie wydaje się wyjątkowo użyteczne do opisu tych „nowszych” jej przejawów (jak choćby hiperfikcji, literatury wcielonej w instalacje interaktywne czy - nie zawsze kojarzonych z kategoria tekstu - gier) i niezbyt ciekawe do charakterystyki tego, co badacz określa mianem „zwykłego tekstu" (ordinary text). Z drugiej jednak pokazuje, że teksty, na bazie których tworzyliśmy nasze dotychczasowe wyobrażenie tekstualności, to twory właśnie nad wyraz - w świetle proponowanych tu kategorii opisu - „zwykłe” (Aarsethowskie ordinary): statyczne i „medialnie powściagliwe” (jak można by powiedzieć, parafrazując Wongowskie określenie „typograficznie powściagliwy”953). Eskelinen

951 K. Prajzner, Cybertekst. Nowa perspektywa..., s. 65.

${ }^{952}$ M. Eskelinen, Teoria cybertekstu a badania literackie... .

${ }^{953}$ Yin Y. Wong, Temporal Typography. A Proposal to Enrich Written Expression, [w:] Conference companion on Human factor in computing systems: common groud, Vancouver 1996, s. 408. Zob. też rozdział poświęcony liberaturze i typografii. 
przypisuje im wykorzystywanie 2 do 3 procent zarysowanych przez teorię cybertekstu możliwości ${ }^{954}$.

Być może nie powinno zatem dziwić, iż dotychczasowe literaturoznawstwo mogło spokojnie ignorować kwestię tekstowej materialności i medialności - wydaje się, że, rzeczywiście, istotne wydawały się one wyłącznie dla pewnej peryferyjnej, awangardowej czy eksperymentalnej grupy tekstów, której historia sięga starożytności, tworząc jednak - wielokrotnie już tu przywoływana - „inną tradycję" ${ }^{955}$, której nurt swobodnie płynie obrzeżami literackiego kanonu ${ }^{956}$. I (na co zwracała uwagę też choćby Hayles) z tych samych powodów „wyjątkami raczej niż regułą" ${ }^{557}$ mogły dotąd pozostawać i teorie akcentujące takie jakości sztuki słowa. Jednak w obliczu nowych mediów i powstajacych w nich utworów spojrzenie takie wydaje się skażone pewnymi - jak określa to Liv Hausken - „niedowidzeniami metodologicznymi”, z których najistotniejsze dla moich rozważań wydaje się „niedowidzenie medium” (ang. medium blindness) ${ }^{958}$.

Jednocześnie, to nie użycie, upraszczając, starego (druk) czy nowego (elektronika) medium jest tu tym, co przesądza o - używając już Aarsethowskiej terminologii - ergodyczności literatury ${ }^{959}$. Decydujące jest właśnie eksplorowanie potencjału drzemiącego w medium i, związane z tym, zaktualizowanie roli odbiorcy. Przywołany badacz, charakteryzując własną koncepcję, już na pierwszych stronach swojej książki zaznaczał, że zrodziła się ona z przekonania, że kluczowe jest dostrzeżenie znaczenia medium jako w pełni integralnego składnika tekstu, wyraźnie domagającego się zinterpretowania. Jednocześnie, podkreślając wielokrotnie, że cyberteksty wcale nie muszą być elektroniczne i wyliczając ich papierowe przykłady (wśród których królują teksty stale przywoływane przez Fajfera i Bazarnik: od Sterna po Queneau), Aarseth mówił o książkach z - można by rzec - liberackim zacięciem i zamiłowaniem, dostrzegając w papierowych kodeksach to, co wielu ich użytkownikom tak łatwo umyka z pola widzenia. Inspirujący mnie badacz nie wieszczył też bynajmniej śmierci literatury drukowanej.

Niektórych czytelników - tłumaczył - może dziwić, że nadal używam słowa ksiażka, jednak wiele z cybertekstów, które powinniśmy omówić to właśnie książki - wydrukowane, oprawione i sprzedawane w najbardziej tradycyjny sposób. Trzeba dostrzec, że format kodeksu jest jednym z najbardziej elastycznych i potężnych nośników informacji, jakie dotąd wynaleziono, nośnikiem o niewykorzystanym jeszcze potencjale, nadal gotowym na zmiany. Nie przypuszczam, by w najbliższym czasie miał wyjść z mody ${ }^{960}$.

${ }_{954}$ M. Eskelinen, Cybertekst a badania literackie... .

${ }_{955}$ Piotr Rypson, Posłowie, [w:] Dick Higgins, Nowoczesność od czasu postmodernizmu oraz inne eseje, tłum. zbior., Gdańsk 2000, s. 224.

${ }^{956}$ Jednocześnie, sądzę, że proponowane tu ujęcie pozwala zrozumieć czemu awangarda jest - jak sugeruje m.in. przywoływany Glazier - doskonałym wręcz kontekstem do badania literatury elektronicznej.

${ }^{957}$ K. N. Hayles, Writing Machines, s. 19.

${ }_{958}$ Zob. Liv Hausken, Textual Theory and Blind Spots in Media Studies, [w:] Narrative Across Media. The Languages of Storytelling, ed. Marie-Laure Ryan, University of Nebraska Press, Linkoln 2004 (cyt. za: M. Pisarski, Pułapki metodologiczne..., s. 84).

${ }^{959} \mathrm{~W}$ ujęciu tego badacza ergodyczne są teksty oczekujące od użytkowników podjęcia innych niż wyłącznie interpretacyjna funkcji.

960 E. J. Aarseth, s. 8-9. 
Tym, co pozwala mówić o liberaturze w kontekście cybertekstu, a wręcz rzekłabym - prowokuje ku takiemu ujęciu jest to, że testuje się w niej eksplorowana właśnie medialna materialność samego tekstu. Co więcej - literatura totalna doprasza się takiego modelowego czytelnika, który nie zadowoli się jedynie funkcją interpretacyjna, który będzie chciał na rozmaite sposoby eksplorować tekst, doświadczać go, rozgryzać, jak powiedziałby Aarseth - odbiorcy, który pragnie uruchomić tekst jako maszynę. Jak można interpretować słowa Bazarnik z 2009 r. ${ }^{961}$ - czytelnik ten nie powinien obawiać się interakcji z tekstem. A jak dopełnia tę konstatację uzupełnienie konferencyjnej wypowiedzi w publikacji z 2011 r.: nie straszna mu też ergodyczność. Liberatura bowiem jest przykładem literatury ergodycznej. Jako że kategoria ta prowadzi i ku rozważeniu rozumienia tekstu jako maszyny, wrócę jeszcze w moich rozważaniach do tego, jak z owa maszyna czytelnik ma sobie radzić, innymi (z nowomedialnego dyskursu zapożyczonymi) słowy: spróbuję scharakteryzować liberackie interfejsy.

W tym miejscu jednak przypomnę tylko, że Aarsethowska teoria - podobnie jak liberatura - również miała być odpowiedzią na przywołane tu wcześniej „niesłuszne wykluczenia” z obszaru literackości ${ }^{962}$. Obie teorie wiążą się także z przywołanymi na początku tego podrozdziału postulatami ponownego, szerszego, właściwszego zdefiniowania otaczającej nas tekstualności. Jeśli zarówno liberatura, jak i literatura elektroniczna wydają się domagać tego rodzaju definicji, warto może zastanowić się, dlaczego te właśnie, zrodzone pod koniec XX w., lecz majacce swe antycypacje na długo wcześniej, formy tekstowe prowokują nas do takich poszukiwań. Co takiego stało się w sztuce (bądź w samej sztuce słowa), że potrzeba ta stała się tak nagląca?

\subsection{Medialnie niema literatura czy medialnie niedowidzące analizy?}

W tym momencie wypada powrócić do przywoływanych już tu twierdzeń o medialnej niemocie klasycznej literatury. Przez wiele wieków powstajace teksty nie prowokowały do zastanawiania się nad faktem, że zapisane sa na jakimś materiale ani nad tym, czy ów nośnik ma jakiekolwiek właściwości (poza kwestią większej lub mniejszej trwałości). Czy jednak rzeczywiście nigdy o tym nie myślano? Pomijam już to, iż z całą pewnością wyrazem takiego zainteresowania był sięgający starożytności nurt literatury wizualnej, który doczekał się zresztą swoich teoretycznych kodyfikacji, z których pierwsza przyniósł wiek XVI w postaci poetyki Scaligera ${ }^{963}$. Nie będę powtarzać refe-

${ }^{961}$ Wypowiedziane na konferencji Od liberatury do e-literatury.

${ }_{962}$ Bazarnik - jak już wskazywałam - charakteryzowała przecież teorię liberacką jako jedyną (albo przynajmniej jedną z bardzo nielicznych), która pozwala „stawić czoła szczególnemu pisarstwu Blake'a czy Johnsona" (K. Bazarnik, Some Aspects of Spatiality...).

${ }_{963} \mathrm{Z}$ takich samych inspiracji powstawały prace chyba wszystkich dotychczas przeze mnie przypominanych artystów czy nurtów. 
rowanych przez Bazarnik teoretycznych refleksji Butora czy McKenziego ${ }^{964}$ (by podać tylko kilka przykładów) ani nie oddam tym razem głosu Federmanowi. Równie dobrze bowiem można w tym miejscu przywołać nasze rodzime, teoretyczne i wcale nie takie nowe kategorie, jak: Balbusowski „graficzny inwariant tekstu literackiego"965, omawiana przez Grzegorza Gazdę „architektonika graficzna poetyckiego utworu drukowanego"966 czy wart może pełnego zacytowania w tym miejscu postulat Stefanii Skwarczyńskiej:

Otóż skoro mowa o języku pisanym - stwierdzała badaczka w latach siedemdziesiątych - nie sposób abstrahować od jego istotnej właściwości, jaką stanowi fakt g r a fi c z n e g o utrwalania sformułowanych w nim wypowiedzeń (odręcznie czy typograficznie) na powierzchni pewnego quantum różnego rodzaju materiału pisanego (dziś najczęściej arkusz papieru, ale wchodzi tu w grę - nie tylko dla czasów dawnych - m.in. płyta kamienna czy metalowa). Tym samym jednak w pole widzenia twórców języka pisanego wchodzi kategoria przestrzeni, a dla ich odbiorcy kategoria percepcji wizualnej [...] Ten nieodłączny od tekstu w języku pisanym aspekt jego plastyczny otwiera przed poetą rozległe możliwości twórczej eksploatacji, tak silnie aktywizowane w poezji XX w. [...] Jeśli poprzednio korzystała z nich poezja raczej sporadycznie a nauka o literaturze przemilczała te efekty lub zaliczała je do dziwactw [...] to chyba dlatego, że nie dostrzegano istotności tego aspektu, a więc i jego obecności w każdym tworze języka pisanego ${ }^{967}$.

Nieco wcześniej niż Skwarczyńska i Henryk Markiewicz zwracał uwagę, że (krytykowane przez liberatów) Ingardenowskie traktowanie dzieła odejmuje mu pewne, nieraz istotne, wartości semantyczne ${ }^{968}$. Stwierdzał przecież:

Dyskusyjne jest potraktowanie znaków graficznych jako pośredniego tylko, przedmiotowego fundamentu istnienia dzieła, który jednak w stosunku do samego dzieła i jego konkretyzacji jest transcendentny. Ingarden nie docenia chyba roli czynnika „napisowego”, a przecenia rolę czynnika brzmieniowego. [...] Ponadto w zapisie dzieła literackiego znajdują się niekiedy pewne momenty „semantycznie obciążone”, a brzmieniowo nieprzekazywalne, jak np. zastosowanie dużych i małych liter, stylizacyjne odstępstwa od obowiązującej ortografii, cudzysłowy, spacje i kursywy (nie bez znaczenia np. dla wierszy Norwida), tzw. „rymy wzrokowe”, nie mówiąc już o takich sztuczkach, jak akrostychy czy carmina figurata ${ }^{969}$.

${ }_{964}$ Zob. K. Bazarnik, Some Aspects of Spatiality... . Por. także pierwsza część tej książki.

${ }_{965}$ Stanisław Balbus, Graficzny inwariant tekstu literackiego, [w:] O języku literatury, red. Józef Bubak, Aleksander Wilkoń, Katowice 1981.

966 Grzegorz Gazda, Architektonika graficzna poetyckiego utworu drukowanego, [w:] Literatura $i$ metodologia, red. Jan Trzynadlowski, Wrocław 1970.

${ }_{967}$ Stefania Skwarczyńska, O paru zagadnieniach poetyki nie podjętych przez badania języka poezji (literatury), [w:] Z zagadnień języka artystycznego, red. Józef Bubak, Aleksander Wilkoń, Kraków 1977, s. 12-13, wyróżnienie autorki.

968 Liberackie dyskusje z Ingardenowską koncepcją dzieła poświadczają dotychczas - przypomnę - dwa wspominane już w tej pracy szkice opublikowane w Materii Sztuki pod redakcja Ostrowickiego (Materialność jako wyznacznik gatunkowy liberatury Bazarnik oraz Fajferowski Od liberatury do tekstu niewidzialnego (autoportret $z$ Ingardenem $w$ tle). Warto dodać, że Fajfer w swoim szkicu sam wskazuje na Markiewicza, jednak przywołuje go jako - jak stwierdza - „wyjątek” (Z. Fajfer, Od liberatury do tekstu niewidzialnego..., s. 121).

${ }_{969}$ Henryk Markiewicz, Sposób istnienia $i$ budowa dzieła literackiego, [w:] idem, Główne problemy wiedzy o literaturze, Kraków 1965, s. 72. 
Z nowszych propozycji warto może dodać tu jeszcze Witolda Sadowskiego i jego rozumienie architektoniki wiersza, „tekstu graficznego”970, o którym (w tym samym roku co Fajfer o liberaturze!) pisał:

Tekst graficzny wychodzi od linearności, dąży jednak wyraźnie do struktury przestrzennej, rozgrywając się na płaszczyźnie i kierując poszukiwania w stronę trzeciego wymiaru. Nie staje się przez to dziełem malarskim, gdyż przestrzeń funkcjonuje w nim jako pamięć tekstu, jako usytuowanie dla liter. Przestrzeń nie zaprzecza jego warstwie semantycznej, ani jej nie podważa. Odróżniamy więc termin „tekst graficzny” od pojęć:

- kolaż (który polega na wspólistnieniu sztuk)

- emblematyk[a?] (która zestawia ze sobą dwie sztuki)

- poezja konkretna (która prowadzi do zakwestionowania tekstu)

- poezja wizualna (która włącza obraz jako znak struktury tekstowej)

Tekst graficzny jest pojęciem w pełni literackim ${ }^{971}$.

Równie zasadne byłoby tu przywołanie terminu przekaz (czy tekst) grafemiczny, którym posłużyła się Maryla Hopfinger w książce Doświadczenia audiowizualne. $O$ mediach $w$ kulturze współczesnej ${ }^{972}$. Jednak, jako że do tej kategorii chciałabym jeszcze powrócić w dalszej części rozdziału, tu pozwolę sobie jedynie zasygnalizować tę kwestię.

Czy racje ma zatem Mariusz Pisarski, twierdząc, że dopiero komputer (nie zaś wcześniejsze wynalazki) „przypomniały nam” o materialności tekstu ${ }^{973}$ ? Odpowiedzieć można mu nie tylko rozmaitymi przypominanymi przeze mnie w tej pracy teoriami (których w samym XX w. spotkamy - jaki widać - niemało), ale i postawioną w 1976 r. przez Marcina Czerwińskiego tezą o tym, że książka jest kanałem przekazu ${ }^{974}$. Wychodząc z perspektywy socjologii piśmienności, badacz dochodzi do podobnych co Fajfer i Bazarnik wniosków. Wskazuje na charakterystyczne dla nowych (ówcześnie) czasów „znaki synkretyczne”, w obrębie których nie sposób oddzielić słowa od obrazu. W opartych na nich „tworach znaczacych" (jak określa to badacz) ${ }^{975}$ wyabstrahowanie samego tekstu tworzy - jak postulował Fajfer w odniesieniu do liberatury - przekazy „semantycznie kalekie" ${ }^{976}$. W ujęciu Czerwińskiego kontekstem dla zmiany statusu słowa pisanego i książkowego kodeksu są przemiany medialne daleko wyprzedzające te, na które wskazuje Pisarski. Autor Systemu ksiażki o wiele wcześniej niż ten ostatni, zaznaczał, że to dwudziestowieczna inwazja wizualności „zaatakowała pismo na jego własnym terenie, oddając je w służbę pewnego typu znaków złożonych i tworzac nowe dziedziny druku"977. Dla nich materialność znaku (i wizualność zrodzona ze specyfiki medium, jakim jest druk) nie pozostaje przezroczysta, nieznacząca czy - jak chciałby Pisarski - niedostrzeżona i niewykorzystana.

${ }_{970}$ Zob. Witold Sadowski, Wiersz wolny jako tekst graficzny, Kraków 2004.

971 Witold Sadowski, Tekst graficzny Białoszewskiego, Warszawa 1999, s. 17.

${ }^{972}$ M. Hopfinger, Doświadczenia audiowizualne..., s. 172-173.

973 M. Pisarski, Pułapki metodologiczne..., s. 78.

${ }_{974}$ Marcin Czerwiński, System ksiażki, Warszawa 1976.

975 Ibidem, s. 59.

976 Ibidem.

977 Ibidem, s. 18. Por. też D. J. Bolter, Writing Space... oraz przywoływane prace Hopfinger. 
Na koniec należałoby również przywołać raz jeszcze Glaziera, któremu dość nietaktownie przerwałam w połowie słowa. W istocie bowiem ten twórca-teoretyk ni]e tylko wskazywał na awangardowe korzenie e-literatury, lecz również określał ją jako „eksperymentalną praktykę bazującą na m a t e r i a lności me di u m”978. Zamiast przywoływać którykolwiek z tekstów Fajfera czy Bazarnik, w których różnie (raz mniej, raz bardziej precyzyjnie) powtarzają oni tezy o książkach jako nie-przezroczystych futerałach na słowa, można raz jeszcze sięgnąć do wypowiedzi tego twórcy i teoretyka:

Czy poezja (lub proza) - pyta on - traktuje język jako przezroczysty nośnik znaczeń? [Tekst - AP] jest realizowany poprzez eksplorowanie materialnych elementów pisma w konkretnym medium. Innym słowy, z punktu widzenia innowacyjnych praktyk, „literatura” nie jest boskim napojem pitym z kryształowego kielicha. Jest walką z owym kielichem unaoczniająca kwestie problematyczne - jego gładkość, temperaturę, sposób w jaki samo pojęcie płynu zmienia się wskutek umieszczenia go $\mathrm{w}$ kielichu ${ }^{979}$.

Glazier konkluduje, dodając, że jeśli walka między przezroczystością tekstu a jego materialnością miewała znaczenie w przypadku słowa drukowanego, w przypadku literatury elektronicznej jest kwestią dużo większej wagi ${ }^{980}$. Podobnie jak - uzupełnijmy - w przypadku liberatury.

Dla literaturoznawcy, który dotychczas wykorzystywał analizę formy dzieła rozumiana jako interpretowanie struktury, konstrukcji czy kompozycji utworu, a raczej jedynie w przypadku poezji zastanawiał się nad właściwościami kodu (mowy wiązanej), teksty przynależne do nowej tekstualności, istotnie, stawiają nowe wyzwania. Wyraźniej mówią bowiem nie tylko samym znakiem, lecz i jego materialnościa, ich (dosłowna) forma (często już niewiele mająca wspólnego z kodeksem) doprasza się zauważania i zinterpretowania. Gdy mówimy o liberaturze i literaturze elektronicznej (ale i o działaniach awangardowych, najszerzej rzecz ujmujacc - za Hopfinger czy Higginsem - intermedialnych), przykładów nie trzeba daleko szukać. Zaś ich odpowiednie zestawienie pozwala uwypuklić podobieństwa łączące te formy pisania (myślenia o pisaniu).

Nieszczęśni Bryana Stanleya Johnsona (pisarza - jak twierdzi Bazarnik - „modelowo liberackiego” ${ }^{981}$ ) oraz Screen zespołu badaczy, wśród których spotykamy m.in. Roberta Coovera ${ }^{982}$, to prace traktujace (m.in.) o zapominaniu. $\mathrm{W}$ przypadku pierwszego, jeszcze papierowego, utworu dla charakterystyki

978 K. N. Hayles, Electronic Literature..., s. 18, podkreślenie moje.

979 L. P. Glazier, Digital Poetics..., s. 171.

${ }_{980}$ Ibidem.

981 Katarzyna Bazarnik, „Nieszczęśni” B. S. Johnsona. Liberacka gra z przypadkiem. Stowo od tłumaczki i redaktorki serii, [w:] Bryan S. Johnson, Nieszczęśni, tłum. Katarzyna Bazarnik, Kraków 2008.

${ }_{982}$ Cały skład zespołu stanowili: Noah Wardrip-Fruin, Josh Carroll, Robert Coover, Shawn Greenlee i Andrew McClain. Odnośnie do tej pracy zobacz Katherine Hayles, Electronic Literature..., s. 13-15, http://www.techsty.art.pl/hipertekst/cyberprzestrzen/screen.htm [dostęp 20.11.09], a także przywoływane już artykuły Górskiej-Olesińskiej Pisanie jaskiniowe... oraz Tekstowe instrumenty... . 
mechanizmu pracy pamięci nie bez znaczenia pozostaje jego materialna forma - niezszyty kodeks (ma formę luźnych składek, z których tylko pierwsza i ostatnia sa oznaczone) czy graficzne luki w zapisie tekstu ${ }^{983}$. Druga praca to samo obrazuje dzięki chaotycznej, niedajacej się opanować wędrówce słów po ścianach interaktywnej jaskini. Oba teksty pokazują (udosłowniaja, uwidaczniaja) rozpadanie się historii tkwiących w naszej pamięci. Jednak, zrealizowane w różnych mediach, wykorzystują do tego inne zabiegi.

Apollinairowski Deszcz i Text Rain autorstwa Camille Utterback i Romy'ego Achituva można przywołać jako kolejny przykład. W przypadku francuskiego kaligramu, wiersz o deszczu przyjmuje jego graficzną formę (co - jak wskazywałam - nie jest „,bardzo” liberackie). Drugi z utworów oferuje odbiorcy dosłowny (tytułowy) deszcz słów, z którego wyłania się opowieść o dotyku i cielesności. Czytelnik-użytkownik doświadcza takiego kontaktu z samym tekstem $^{984}$. Oczywiście, przywołany duet warto byłoby rozbudować do triady, przypominając jeszcze o Deszczu jesiennym Staffa, eksplorującym z kolei brzmieniową warstwę słowa (co akurat niespecjalnie - w przeciwieństwie do pozostałych przywołanych sytuacji - sprzeciwia się „normom”).

Przykłady można mnożyć. Nie jest jednak tu moim celem analizowanie kamiennych hipertekstów (Pole anielskich szeptów Andrzeja Bednarczyka) czy pokazywanie analogii między instalacjami zrodzonymi $\mathrm{w}$ duchu poezji konkretnej (Między Stanisława Dróżdża) a najnowszymi tekstami e-literatury (przywołany już Screen). Choć analizy te są kuszace, przekraczaja ramy tego opracowania. Pielęgnując własne rodzące się pomysły interpretacyjne i śledząc cudze prace ${ }^{985}$, muszę jednak bezsprzecznie przyznać jedno: takie interpretacje są możliwe. Przywołane teksty to nie niedające się zrozumieć dziwolagi, lecz dzieła wpisujące się w - na nowo zdefiniowana - tekstualność. I jako do niej przynależne, poddają się w pełni literackiej analizie i interpretacji. Jednak - analizie i interpretacji już, przywołując raz jeszcze Hausken, nie medialnie niedowidzacej.

A trzeba też przypomnieć, że na takie niedowidzenia zwracała uwage już dawno temu również Hayles. W przywoływanej kilkakrotnie w tej książce publi-

${ }^{983}$ Por. Krystyna Stamirowska, B. S. Johnson's Novels: A paradigm of Truth, Kraków 2006, s. 102-118. Więcej o tym utworze piszę w przywoływanym już szkicu W pudełku $i$ na wadze o przestrzeni śmierci i przestrzeni tekstu... .

${ }_{984}$ Warto jednak pamiętać, że ta praca jest swoistego rodzaju remediacja, nie autorskim literackim tekstem duetu Utterback-Achituv. Twórcy wykorzystali bowiem utwór poetycki Evan Zimroth Talk, You (z tomu: Dead, Dinner or Naked), mówiący o bliskości dwojga ludzi odkrywanej podczas konwersacji, budowanej poprzez wymianę słów. Podkreślany jest także cielesny jej aspekt (,at your turning, each part/of my body turns to verb” - z chwila gdy się odwracasz, każda część mojego ciała/przemienia się w czasownik), co zostaje w intrygujący sposób podkreślone na drodze uczynienia z utworu instalacji interaktywnej, na której odbiorców spada tytułowy deszcz liter. A trzeba też dodać, że ten właśnie tytuł nadali już artyści medialni, nie poetka. O interpretacji owej nowomedialnej gry z cielesnością języka i tekstu szerzej pisałam w szkicach Którędy do literatury nowomedialnej... (s. 15) oraz Po(d)żeranie tekstu... .

985 Sugerowane tu porównanie Między i Screenu podjęła np. Monika Górska-Olesińska (Pisanie jaskiniowe...). 
kacji Writing Machines, zdając raport ze swojego dojrzewania do dostrzeżenia bliskości tekstów elektronicznych z pewną grupa jak najbardziej analogowych literackich działań, relacjonując swoje kwerendy wśród książkowych „dziwolagów": książek artystycznych zgromadzonych m.in. w Museum of Modern Art w Nowym Jorku, badaczka pisała o tym, że literatura błędnie była postrzegana przez większość teoretyków jako byt intencjonalnie niematerialny, swym kształtem innym niż werbalny niczego niekomunikującym ${ }^{986}$. W istocie tom, w którym Hayles formułuje swą teorię technotekstu jest świadectwem dojrzewania do odrzucenia wizji jakoby „fikcyjne i narracyjne światy były w całości produktami wyłącznie wyobraźni" ${ }^{87}$ i też jedynie do niej powinny się odwoływać. Jest próbą pokazania, że - podobnie jak elektroniczne - materialne i świadome swej materialności literackie artefakty są doskonałymi interfejsami dla sztuki słowa (i takiego przecież terminu sama Hayles używa). I jak (podobnie jak Aarseth) podkreśla - potencjalne możliwości tych interfejsów sa przeogromne, a już na pewno porównywalne z tym, które oferuje literaturze elektronika ${ }^{988}$. Stąd porównawcze charakterystyki różnomedialnych technotekstów (żartobliwie i metaforycznie określanych przeze mnie literackimi dziwolagami) są jak najbardziej uzasadnione. Mają też już swoją tradycję w literaturze przedmiotu.

Wskazując na bliskość literatury totalnej i elektronicznej (jawnie wiażącą się z podkreślanym przez część badaczy pokrewieństwem tej ostatniej z pewnym obszarem starej, analogowej sztuki słowa), niebezpiecznie zbliżam się jednak też do problematycznej kwestii: czy liberatura może mieć swoja wersję elektroniczną (wirtualna, cyfrowa)? I czym miałaby się ona różnić od literatury elektronicznej? Zważywszy na fakt, że w krytyce funkcjonuje termin e-liberatura, wydawać by się mogło, że pytanie jest poniekąd bzdurne. Niemniej, okazuje się, że absurdalna jest raczej odpowiedź, jakiej należałoby nań udzielić.

${ }^{986}$ K. N. Hayles, Writing Machines, s. 19.

987 Ibidem.

988 W kolejnej części rozwijać będę właśnie ową interfejsologiczną perspektywę badań nad lit/berackością (bliską ujęciom Lori Emerson czy Alexandra Gallowaya). 



\section{Czy (i jak) można mówić o e-liberaturze?}

\subsection{Rozgryzanie definicji - geneza problemu ${ }^{989}$}

Rozważając problematyczną kategorię e-liberatury, należy wskazać co najmniej dwóch sprawców terminologicznego „zamieszania”: Radosława Nowakowskiego i Mariusza Pisarskiego. Pierwszy stworzył niebagatelny tekst, który wymykał się próbom opisu, by w konsekwencji sprowokować do okrzyknięcia go e-liberaturą. Drugi właśnie tak o Końcu świata wedtug Emeryka powiedział. W 2003 r., mierząc się z "hasarapańska powieścia hipertekstowa”" pisał o niej jako o być może wytyczającej kierunek polskiej hiperfikcji, dodając, że „Emeryk» jest przy okazji unikatowa jak dotąd fuzją pomiędzy liberaturą a medium elektronicznym" ${ }^{990}$. Wydaje się, iż istotne było również dopowiedzenie podkreślające, że na takie połączenie - przynajmniej ówcześnie - liberaci nie patrzyli przychylnym okiem. W listopadzie 2004 r. w Łodzi (na konferencji poświęconej młodej polskiej literaturze ${ }^{991}$ ) badacz używał już w tym miejscu określenia e-liberatura, w wydanej kilka lat później, po części związanej z ową konferencja, publikacji ${ }^{992}$ termin ten użyty został nawet w tytule jednego z podrozdziałów („Emeryk”. E-liberatura ${ }^{993}$ ). Szkicując (wspólnie z współautorką artykułu - Joanną Roszak) panoramę polskich hipertekstów,

989 Tym razem oddaję w ręce czytelników fragment rozdziału „rozdarty sam w sobie”, przychodzi mi bowiem dyskutować z własnymi tezami, weryfikować sądy już wygłaszane. Co więcej - powinnam też uprzedzić tych, którzy sprowokowani tytułowym pytaniem, będą spodziewali się udzielenia nań wystarczającej, pełnej i logicznej odpowiedzi: przedstawione tu sądy niekoniecznie spełnia, jak sądzę, te oczekiwania. Stawiam bowiem więcej pytań niż daję odpowiedzi i być może - jak czynili to Janusz Ankudowicz i Grażyna Straus zastanawiając się w 1997 r. nad przyszłością Galaktyki Gutenberga - należało zasugerować to już w samym tytule (Janusz Ankudowicz, Grażyna Straus, Ksiażki i ludzie na przełomie stuleci (więcej pytań niż odpowiedzi), [w:] Kultura i sztuka u progu XXI wieku, red. Sław Krzemień-Ojak [i in.], Białystok 1997). W moim odczuciu, przedstawione tu rozważania mają charakter bardziej zarysowania problemu niż (udanej) próby rozwiązania go. Wydają się raczej raportem z napotkanych na badawczej drodze trudności, niemniej - jak mam nadzieję pokazać - to właśnie wskazanie owych problemów i kwestii spornych wydaje się (w tym akurat wypadku) najważniejsze.

${ }_{990}$ Mariusz Pisarski, Kartografowie i kompilatorzy. Pót żartem, pót serio o praktyce $i$ teorii hiperfikcji w Polsce, [w:] Liternet.pl, red. Piotr Marecki, Kraków 2003, s. 23, podkreślenie moje.

991 Mam tu na myśli Ogólnopolską Konferencję Naukową dla studentów, doktorantów i młodych pracowników naukowych Polska literatura najnowsza - poza kanonem, która odbyła się w Łodzi w dniach 17-18 listopada 2004 r.

992 Polska literatura najnowsza - poza kanonem, red. Paulina Kierzek, Łódź 2008.

993 Joanna Roszak, Mariusz Pisarski, Ja tu a ty tam. Polska powieść hipertekstowa a literacki kanon, [w:] Polska literatura najnowsza... . 
Pisarski ponownie zaznacza wyjątkowość utworu Nowakowskiego994. Wtedy to padają słowa:

Kluczem do osobności Emeryka jest liberatura: niszowy, pozakanoniczny nurt literacki, który Nowakowski współtworzył i przede wszystkim na tym polu realizuje się artystycznie. Emeryk to e-liberatura ${ }^{995}$.

Co dalej? Zaproponowana formuła przylgnęła do Emeryka i niejednokrotnie pojawia się w dyskusjach o tym tekście. Piszą tak o nim ci, którzy po utwór sięgaja, nie sposób bowiem analizować go, marginalizując znaczenie wszystkich tych elementów, które wywieść się da z papierowej (bądź realizowanej w innym, lecz nie-elektronicznym medium) liberatury. Co ciekawe, nawet gdy termin nie jest artykułowany wprost, wyłania się niejako spomiędzy linii zapisu prowadzonych rozważań, gdyż wskazując na wpisywanie się Emeryka w nurt powieści hipertekstowych i liberackich zarazem, krytyka sygnalizuje jednocześnie, iż w istocie rodzi się on na styku tych dwóch przestrzeni literatury (co - jak wskazywałam - czynił na samym początku Pisarski).

W efekcie, dostrzegając coraz liczniejsze użycia pojęcia, pracując nad hasłem liberatura do materiałów do Stownika rodzajów i gatunków literackich, przygotowałam również krótki tekst dotyczący jej elektronicznej odmiany. Hasło, opublikowane w 2007 r. ${ }^{996}$, dawało następująca charakterystykę zjawiska:

E-LIBERATURA [...] - termin zaproponowany przez Mariusza Pisarskiego na określenie Końca świata wedtug Emeryka Radosława Nowakowskiego (2004). Pojęcie ma opisywać LIBERATURĘ (zob.) funkcjonującą w Internecie. Ponieważ dla tego typu twórczości relacja między użytym medium a znaczeniem utworu jest niezwykle ważna, istota e-liberatury nie tkwi w przenoszeniu tekstów liberackich do Sieci (bo byłoby to niemożliwe), lecz na tworzeniu takiej liberatury, dla której wirtualna przestrzeń w jakiej została ukształtowana staje się elementem konstytutywnym. Dzieł e-liberackich nie dałoby się zrealizować w innych mediach, a każda próba takiego przetworzenia zniekształcałaby sensy utworu równie mocno jak zmiana przestrzenno-materialno-graficznej struktury tekstu liberackiego. Podobnie jak nie każde dzieło literackie wzbogacone o aspekty wizualne staje się liberatura, tak i nie każdy tekst artystyczny, który funkcjonuje w Internecie i zawiera animację, rysunki czy połączenia między poszczególnymi leksjami, zyska miano e-liberatury (nie jest nią np. Blok Sławomira Shuty, choć wykorzystuje większość z wymienionych tu elementów). W obrębie polskiego liternetu dotychczas tylko Koniec świata według Emeryka w pełni wpisuje się w kategorię e-liberatury ${ }^{997}$.

Co więcej - głosy dotyczące e-liberackości Końca świata wedtug Emeryka nie zamilkły, a niezwykle w nie owocny wydaje się rok 2008, w którym nota bene opublikowany został tekst Roszak i Pisarskiego. I tak: w tymże roku Xymena

994 „To utwór nieznajdujący swojego odpowiednika w świecie literackich hipertekstów” (s. 228) - stwierdzają autorzy szkicu, mając na myśli światowa, nie tylko rodzimą twórczość e-literacka.

995 Ibidem, s. 229, podkreślanie moje.

996 „Zagadnienia Rodzajów Literackich”, z. 1-2/2007, s. 247. Nowa (zmieniona) wersja hasła została opublikowana w: Stownik rodzajów i gatunków literackich.

997 Ibidem. 
Borowiak stwierdza, że „aranżacje przestrzenne Nowakowskiego kreują wizję literatury totalnej [a więc liberatury - AP] możliwą do realizacji właśnie w przekazie cyfrowym" ${ }^{998}$. W tym samym czasie Andrzej Pają, referując poza granicami kraju historię polskiej e-literatury - szukając tekstów reprezentatywnych dla naszej rodzimej e-fikcji - wskazuje na Emeryka. Podkreśla jednak, iż jest to dzieło nie tylko cyfrowe, ale i liberackie. Zaś szukając korzeni twórczości nowomedialnej oraz ciekawych kontekstów do jej analiz, badacz jako taki przywołuje właśnie sformułowana przez Fajfera teorię. Jednocześnie odnosi się również do zaproponowanego przez Pisarskiego terminu ${ }^{999}$. Wtedy też ukazuje się w sieci artykuł Emilii Branny, która choć wprost mówi o pokrewieństwie Emeryka z poezją konkretna (co daje się zresztą doskonale wytłumaczyć przyjęta przez interpretatorke perspektywą badawczą i nieustannym dialogiem z Bohnem, który do takiejże poezji się odnosił), zdaje się w istocie wskazywać na - parafrazując słowa badaczki - interesujące połączenie hipertekstowości z dorobkiem liberatury ${ }^{1000}$.

By zamknać ową historyczną wyliczankę trzeba jeszcze przywołać słowa Katarzyny Bazarnik, wypowiedziane 23 listopada 2009 r. w Kamieniu Śląskim, podczas konferencji Od liberatury do e-literatury. Krakowska badaczka, podkreślając - jak to ujęła - „paradoksalny” charakter terminu e-liberatura, zdefiniowała ją jako:

takie e-teksty, które wykorzystuja specyfikę elektronicznego medium i cyberprzestrzeni w taki sposób, że nie da się ich przełożyć na inny nośnik (na przykład wydrukować) bez istotnego przekształcania znaczeń, utwory operujące dodatkowo elementami niewerbalnymi, takimi jak grafika, dźwięk czy ruch ${ }^{1001}$.

Nie muszę chyba dodawać na jaki tekst - jako przykład - Bazarnik się powołuje...

Sformułowana przez badaczkę definicja, choć niezwykle bliska tej proponowanej przeze mnie, wprowadza istotna korektę. Poprawia bowiem pewna nieścisłość, na którą sama niejednokrotnie zwracałam uwagę, a której i ja się poddałam. Jak podkreślałam, o ile, gdy rodziła się polska refleksja o e-literaturze, ów (modny ówcześnie) przedrostek „e-” najczęściej stosowany był

${ }_{998}$ Xymena Borowiak, Interpretacja bez granic? W hipertekstowym labiryncie „Końca świata wedtug Emeryka” Radosława Nowakowskiego”, [w:] Tekst (w) sieci, s. 190, podkreślenia moje. Tekst wygłaszany był w grudniu 2008 r. podczas warszawskiej konferencji Tekst [w] sieci.

${ }_{999}$ A. Pajak, The Polish Way to E-literature from the Baroque to the 21th Century.

1000 Emilia Branny, O zwiazkach poezji wizualnej i hipertekstu. Rozważania w świetle „The Aesthetics of Visual Poetry 1914-1928” Williarda Bohna, „Techsty” 2008, nr 5, http://techsty.art. pl/magazyn/magazyn5/ artykuly/branny01.html [dostęp 20.07.09], podkreślenie moje. Formułowane przez Branny zdania doskonale nadają się do charakterystyki liberackości tekstu Nowakowskiego. Pisze ona: „Występujące tam [w Emeryku - AP] trzy systemy znakowe, wizualny, werbalny i mechaniczny, tworzą misterną konstrukcję. Interpretacja z uwzględnieniem tylko jednego z tych systemów jest niemożliwa. Sens obrazu mediuje ze znaczeniem i działaniem słowa, wytwarzając interaktywny świat przedstawiony oraz narracje”".

1001 K. Bazarnik, Liberatura czyli o powstawaniu gatunków (literackich), s. 162 (tekst oparty na przywołanym wystapieniu). 
w odniesieniu do tego, co znaleźć można w Internecie, dziś już konsekwentnie termin e-literatura definiuje się jako literaturę elektroniczna (nie: sieciowa, bo to - jak już wyjaśniałam - termin dużo węższy). Stąd, nawet w kontekście Emeryka (funkcjonującego przecież nie tylko w swojej internetowej wersji), trzeba wyjść poza ramy tego, co w Sieci, obejmując badawczym spojrzeniem wszelkie odmiany tego rodzaju twórczości.

Chwila zadumy nad terminem przynosi jednak jeszcze jedną refleksje i problem niedający się już tak łatwo rozwikłać. E-liberatura bezsprzecznie musi być liberacka. Jednak w wielu dotychczasowych ujęciach to książka, czy - szerzej - pewien materialny fundament będący bazą dla tekstu urastał do rangi elementu w niej nieodzownego i nie-neutralnego. Dla Nowakowskiego i Fajfera liberatura to przecież „myślenie książką”. I dla Bazarnik właśnie kategoria owego materialnego tomu i przynależnej mu przestrzeni, książki rozumianej w duchu Butorowskim, pojmowanej jako coś więcej niż konwencjonalne, nic-nie-znaczące opakowanie dla tekstu, stała się kluczowa. Jak owa materialną warstwę tekstu przenieść w przestrzeń wirtualna, z wszelkiej materialności wyzutą?

\subsection{W poszukiwaniu wirtualnych kodeksów i elektronicznej lit/berackości}

By odpowiedzieć na postawione pytanie (i odnaleźć wirtualno-materialna Księgę), warto porzucić na chwilę tok wywodu i przenieść się do Wrocławia w roku 2005. Tam, podczas wystawy Inna Ksiażka (towarzyszacej XI Biennale Sztuki Mediów WRO 05) Masaki Fujihata zaprezentował swoją powstała w 1995 r. pracę Beyond Pages ${ }^{1002}$. Wejdźmy do niewielkiego pokoju. Umieszczono tam pulpit z wirtualną księgą. Można powiedzieć, że jest to książka ilustrowana - obok słów znajdują się w niej podpisane obrazy (np. wizualnemu przedstawieniu owocu towarzyszy również słowo: „jabłko”). „Wykorzystanie” dowolnego elementu ikonicznego wywołuje różnego rodzaju sygnały dochodzące do nas ze świata rzeczywistego - dotknijmy lampy na kartce powieści, a spowoduje to jej zapalenie się w przestrzeni, w której się znajdujemy; „skosztujmy" jabłka, a dobiegna nas dźwięki gryzienia i przeżuwania. Świat powieściowy zaczyna się tu nakładać ze światem rzeczywistym, przestrzeń książki przekracza stronice kodeksu i wydaje się, że kategoria teleobecności staje się użyteczna podczas rozmowy o odbiorze dzieła literackiego.

Z pewnościa mamy tu do czynienia z książka, której - jak domniemywali niektórzy - mieliśmy nie znaleźć wśród tego, co elektroniczne. Czy jednak jest to księga literacka? A nawet więcej - czy nosi znamiona liberackości, by mogła wybawić z impasu rozmów o jednym tekście i stać się kolejną egzemplifikacją

1002 Tzw. środowisko interaktywne; z kolekcji Zentrum für Kunst und Medientechnologie ZKM, Karlsruhe, Niemcy. 
e-liberatury? Praca Fujihaty porusza kwestię wielomedialności, pokazując, iż czytanie książek może łączyć się z wykorzystaniem większej ilości zmysłów. Bowiem współczesna księga nie musi wymagać od czytelnika wyobrażania sobie świata przedstawionego; może mu go po prostu przedstawić. Może zwolnić go z obowiązku przenoszenia się w inny świat, inny wymiar - bo może mu tenże inny świat sprowadzić do jego „tu i teraz”. Beyond pages zwraca uwage na to, że czytajac zawsze jesteśmy „tu i teraz”, gdzie jest nam - jako czytelnikom - zimno/ciepło, wygodnie/źle oraz „tam i wtedy”, gdzie zimno/ciepło jest bohaterom opowieści; pokazuje jednocześnie, iż obie te przestrzenie mogą się na siebie nałożyć, a lektura będzie wtedy angażować więcej zmysłów. Oczywiście trudno już tu mówić o czytelniku, a nawet (jeśli uwzględnić tu szerszą kategorię odbiorcy sztuki) o widzu/odbiorcy/użytkowniku. Z połączenia statycznej formuły „odbiorca” i wskazującej na większą interakcję „użytkownik” rodzi się kategoria inter-aktora, a potem $v$-usera, czyli viewer-user (używam tu terminu Rogali).

A zatem - księga nie doprowadziła nas wcale do... księgi. Ani - tym bardziej - do literatury czy liberatury. Przywołana praca nie spełnia podstawowego postulatu, jaki stawia się tej ostatniej (a w konsekwencji i jej elektronicznej odmianie): nie przynależy do samej sztuki słowa. Wpisuje się za to w cały nurt tekstów sztuki elektronicznej (interaktywnej), które, choć staja się ważnymi głosami w dyskusji nad kształtem książki/literatury XXI w. ${ }^{1003}$, same się jednak do tej ostatniej nie zaliczaja. Często można by określić je mianem metacommentary art za Errki Huhtamo czy sztuki metainteraktywnej za Maciejem Ożogiem ${ }^{1004}$. Wydaje się też, że tego typu prace są „problematyczne” dla e-liberatury w takim samym stopniu, jak książka artystyczna dla „klasycznej” literatury totalnej (przynajmniej w pierwszej fazie refleksji o niej).

Warto może więc zarzucić poszukiwanie Księgi i wyjść od tego, że tak jak liberatura jest rodzajem literatury, tak e-liberatura winna być rodzajem e-literatury. Zatem to w obrębie tej ostatniej trzeba by prowadzić poszukiwania. Warto przypomnieć, że równolegle z pierwszymi tezami o istnieniu e-liberatury pojawiło się również przywoływane już tu rozróżnienie na literaturę Sieci i literaturę w Sieci ${ }^{1005}$. Rozszerzenie tych kategorii, konieczne gdy mówimy o e-literaturze, uzmysławia, że niekoniecznie warto (poszukując

1003 Jednym z wielu innych przykładów mógłby tu być Illuminated Manuscript Davida Smalla (zob. http://www.davidsmall.com/portfolio/illuminated-manuscript). Da się również wskazać takie prace, w których tekst jest tylko elementem struktury i znaczy jako tekst (typ przekazu), sam w sobie zaś nie zachowuje znaczeń (Christa Sommerer, Laurent Mignonneau, Life Writer). Są też i teksty graniczne - jak choćby Legible City Jeffrey'a Shawa, w którym tekst daje się odczytać, a nawet poddać interpretacji, jednak z racji zaprojektowanego sposobu odbioru w rzeczywistości raczej rzadko jest tak naprawdę czytany. Warto też pamiętać, iż w tej mającej trzy odsłony pracy wyłącznie jedna (Manhattan) sięga do prawdziwie literackich narracji, dwie pozostałe jako teksty wykorzystują dokumenty historyczne. Nieco więcej o części z tych prac pisałam w szkicu $P o(d)$ żeranie tekstu. Wstep do rozważań o czytaniu kinetycznym.

1004 Odnośnie do obu terminów zob.: Maciej Ożóg, Krytyczny wymiar sztuki interaktywnej,

[w:] Estetyka wirtualności, red. Michał Ostrowicki, Kraków 2005, s. 195-210.

1005 Zob. m.in. Liternet. Literatura i Internet. 
e-liberatury czy e-liberackości) odnosić się do tekstów po prostu „przepisanych" do nowego medium. Bo przecież Katherine Hayles na samym początku swojej książki poświęconej literaturze elektronicznej charakteryzuje ją następujacymi słowy:

Literatura elektroniczna, pomyślana zasadniczo jako wykluczająca literaturę drukowana, która została zdygitalizowana, jest - w przeciwieństwie do tej właśnie - digitalnie zrodzona, jest pierwszą generacją obiektów digitalnych stworzonych przy użyciu komputera i (najczęściej) przeznaczonych do czytania właśnie przy jego pomocy ${ }^{1006}$.

A i kolejne strony czy rozdziały książki badaczki coraz silniej potwierdzaja wizję e-literatury, jako sztuki słowa zrodzonej w medium elektronicznym, nierozerwalnie z nim związanym, wykorzystującym wszelkie jego możliwości, niedającym się przenieść do żadnego innego ${ }^{1007}$.

I w tym momencie trzeba zadać pytanie: gdzie zatem tkwi różnica między e-literatura a e-liberaturą? Obawiam się, że to jedno z tych pytań, na które nie dam odpowiedzi. A nie mogę jej udzielić, gdyż różnicy takiej nie potrafię dostrzec.

\subsection{Wątpliwość, która podważa wszystko?}

Warto może odnotować jeszcze jeden historyczny moment w dziejach e-liberatury. W trzecim, pochodzącym z 2007 r. numerze „Techstów” pojawił się dział e-liberatura. Umieszczono w nim dwa teksty, co pozornie powinno poszerzyć spektrum omawianych zjawisk i pozwolić wyjść jednak poza mówienie o samym Emeryku. Pierwszy z przywołanych tam utworów to Ars Poetica Fajfera, drugi to Bluzgator Bis Pawła Kozłowskiego. Ten ostatni Pisarski określa jako „jeden z pierwszych literackich tekstów generatywnych na skromnej polskiej scenie literatury cyfrowej”"1008. I mówiąc krótko - nic w nim liberackiego. Tekst Fajfera stawiać może więcej pytań. Wpisując się w pełni w nurt e-literatury, a konkretnie w jego oparta na flashowej animacji odmianę, oddala się jednak od liberatury. Autor, chcąc uzyskać zamierzony przez siebie efekt: m.in. odebrać odbiorcy możliwość ingerowania w tekst, swobodnego doń dostępu, uzyskać konkretne tempo odsłon (emanacji) poszczególnych tekstów, sięgnął po idealnie pozwalające to osiagnąć na-

${ }^{1006}$ K. N. Hayles, Electronic literature..., s. 3, podkreślenie moje.

1007 Odcinając się od tego, co drukowane, Hayles podkreśla też „hybrydyczny charakter” e-literatury oraz zwraca uwagę na - jakże bliskie liberatom - problemy związane z tym, iż przy tak specyficznym opracowaniu tekstu, autorstwem wypada nam się często dzielić z tymi, którzy opanowali lepiej niż my konkretne oprogramowanie.

1008 http://techsty.art.pl/magazyn3/bluzgator_bis.html. Pająk jako drugi i jedyny dotychczas uznaje Esemesy z dnia na dzień. Ksiażkę dla wszystkich i dla nikogo Marka Bulanowskiego z 2007 r. (A. Pajak, The Polish way to e-literature...). 
rzędzie $^{1009}$. Z różnych możliwości (i oprogramowań), jakie dało mu medium elektroniczne, wykorzystał w pełni to, co było potrzebne, tworząc tekst - jak powiedziałaby Hayles - „digital born”, niedający się wydrukować czy zrealizować inaczej. Stworzył e-literaturę. Czy liberacką? Nie sądzę. Wykorzystanie w medium cyfrowym techniki emanacyjnej typowej dla reprezentujaccych literaturę totalną tekstów Fajfera nie uprawnia nas jeszcze do mówienia o e-liberaturze.

Powróćmy na chwilę do sygnalizowanego już w tym szkicu i przywoływanego wcześniej przez Pisarskiego i Roszak problemu braku materialności, braku kodeksu, który miał utrudnić mówienie o e-liberaturze ${ }^{1010}$. Dwójka badaczy zaznacza, że utwór Nowakowskiego może stać się głosem w dyskusji o literaturze totalnej, że zdaje się postulować inną jej wizję niż ta formułowana przez Fajfera ${ }^{1011}$.

Także w środowisku hipertekstowym - podsumowuja - „przestrzeń zawierająca słowa” nie jest [nie musi być - AP] neutralna. Emeryk, będąc próbą kolonizacji interaktywnego ekranu przez liberaturę, istniejąca najpełniej na materialnych nośnikach (papier, drewno, itp.), potęguje powszechnie znany już proces: słowo na ekranie, w przeciwieństwie do słowa na kartce papieru, zachęca do patrzenia na, a nie do patrzenia poprzez tekst.

Nie tylko wynika z tego - jak postuluja badacze - sprzeciw wobec Fajferowskiego ujęcia, lecz powraca problem medialności. Nie sposób - jak próbowałam już to pokazywać - nie dostrzec wagi tej kategorii dla liberatury. Jak już sygnalizowałam - z dotychczas publikowanych tekstów Fajfera i Bazarnik daje się wyprowadzić teorię liberatury ujmująca ją jako literaturę jawnie eksplorująca swoją medialność. Nie sposób nie poprzeć tych tez słowami Bazarnik, która w swoim wystapieniu na konferencji Od liberatury do e-literatury do dotychczas postulowanych cech liberatury dodała właśnie tę, która określiła jako medium specific, zakorzenienie w medium (osobiście preferuję właśnie to ujecie, nie terminologię, jaką badaczka zastosowała w późniejszej publikacji).

Przy tak prowadzonych rozważaniach powraca również poruszana w poprzednim rozdziale kwestia tego, że teksty nowomedialne mogą (acz nie musza) być równie (a czasem i bardziej) liberackie niż sama liberatura ${ }^{1012}$. W wielu przypadkach mechanizmy budowania znaczeń w liberaturze i w e-literaturze

1009 Por. głosy w dyskusji Od „Oka-leczenia” do liberatury prowadzonej w styczniu $2010 \mathrm{r}$. w krakowskim Bunkrze Sztuki (zapis rozmowy dostępny w: „Ha!art” 2010, nr 30, s. 5-14).

1010 Por.: „Nie tak łatwo [...] wyjąć tekst i zanurzyć w wirtualnej przestrzeni, gdyż w utworze liberackim przestrzeni zawierającej słowa nie cechuje neutralność. Autor kreuje ją zarówno poprzez nieprzezroczysty tekst, jak i budowę samej książki, która [...] może przybrać dowolny wygląd" (J. Roszak, M. Pisarski, Ja tu a ty tam..., s. 229).

1011 Warto tu przypomnieć, że Nowakowski jest również autorem Traktatu kartkograficznego czyli rzeczy o liberaturze. Jednocześnie trzeba jednak podkreślić nienaukowy charakter tej pracy, na co zwracałam już uwagę w pierwszej części tej pracy

1012 Zob. też Agnieszka Przybyszewska, Nowa? Wizualna? Architektoniczna? Przestrzenna? Kilka słów o tym co może literatura $w$ dobie Internetu, [w:] e-polonistyka, red. Aleksandra Dziak, Sławomir J. Żurek, Lublin 2009. 
są podobne. Możliwości, jakie dają tekstom nowe media, często czynią te zabiegi prostszymi, jednak równolegle odbiorca tekstów elektronicznych jest na nie bardziej łasy (a tym samym i lepiej z nimi obyty). Wśród refleksji medioznawczej (szczególnie tej wpisujacej się w nurt archeologii mediów) nie brak prac, które uzasadniają taką sytuację. Przywoływanie ich nie jest jednak moim celem, czyniono to już wielokrotnie. Współczesność, w której nastapiło (lub ciagle następuje) przejście od ery druku (która w znaczny sposób zmieniła przecież charakter naszego postrzegania i wyznaczyła też początek dzisiejszej refleksji nad materialnością zapisu) ku nowym mediom, ku nowym typom ekranów, to znów czas rewidowania naszego sposobu postrzegania, czas w którym nie sposób już zapominać, że „medium is the message", że nie pozostaje dla formułowanego weń przekazu obojętne. Czy jednak prowadzi nas to ku e-liberaturze? Tu pokuszę się o odpowiedź, że nie, niekoniecznie.

Zasugerowane ujęcie zmusza również do postawienia pytania o możliwości, czy perspektywy badawcze. Jeśli mówienie o e-liberaturze wydaje się jednoznaczne z mówieniem o literaturze elektronicznej i termin ten w istocie wydaje się zbędny, czy sensowne jest wyznaczanie wspólnych perspektyw badawczych dla liberatury i literatury elektronicznej? Tym samym - czy sensowne jest np. ujmowanie obu tych rodzajów twórczości w perspektywie Aarsethowskiej teorii cybertekstu, mówienie o liberaturze w kategoriach tekstu ergodycznego? W świetle postawionych przed chwila tez, paradoksalnie, okazuje się, że jednak tak. Liberatura, tworzona w innych niż elektroniczne mediach niejako podskórnie przeczuwa, jakie możliwości szykują się dla przyszłej sztuki słowa. Roman Chymkowski zauważył kiedyś, że:

Z perspektywy historycznej wiemy dziś, że pewne formy gatunkowe wypowiedzi słownej, w tym również artystycznoliterackiej, zaistniały lub wręcz mogły zaistnieć dopiero z chwila rozpowszechniania się odpowiednich mediów; tak było m.in. z powieścia, której geneza wiąże się z narodzinami kultury druku ${ }^{1013}$.

Być może, potrzebne były nowe media, by zaistniała literatura, która naturalnie i bez większych trudności wykorzystywać będzie to wszystko, po co dotychczas sięgali raczej wyłącznie liberaci. Wynika z tego jednak również, że definiowanie liberatury właśnie na gruncie innych niż elektroniczne mediów wydaje się sensowniejsze. Wprowadzenie terminu e-liberatura nie tylko niczego nie wyjaśnia, lecz również każe się zastanowić nad sensownością pojęcia liberatura, które w takim otoczeniu traci swoją wyrazistość. Zdaje się więc, że na swój sposób rację miała Bazarnik, twierdząc, że potrzebne było wieszczenie śmierci książki, byśmy zwrócili uwagę na ów materialny nośnik i by mogła zaistnieć liberatura ${ }^{1014}$.

1013 Roman Chymkowski, Literatura na morzu i w sieci, czyli kim chce być czytelnik e-ksiażek, [w:] Liternet. literatura i internet, red. Piotr Marecki, Kraków 2002, s. 81.

1014 Por. K. Bazarnik, Liberatura czyli o powstawaniu gatunków (literackich), s. 156. 


\section{4. (Jednak obecna) konkluzja}

Być może jest po prostu tak, że liberatura nie tylko zmusza nas do zastanowienia się nad konwencjami typograficznymi, w które niezauważalnie się wplątaliśmy i nie tylko każe nam rewidować nasze pojęcie tekstu literackiego czy samej literatury, literackości oraz literackiej komunikacji. Wydaje się, że podważa tym samym - z konwencji przecież właśnie zrodzone - przekonanie, że konkretne formy literackie rodzą się w konkretnych mediach i owe granice trudne sa do przekroczenia. Może nie bez powodu w jej właśnie obrębie powstał zarówno hipertekst kamienny (Pole anielskich szeptów Andrzeja Bednarczy$\mathrm{ka}^{1015}$ ), jak i „prawdziwy”. Obu - tu chyba nie sposób się nie zgodzić - nie odmówimy liberackości. Być może jednak Emeryk jest przypadkiem jednostkowym czy granicznym. Być może poza dotychczas wskazywanymi perspektywami interpretacyjnymi należy poszukać w nim również głosu o medialnych możliwościach liberatury ${ }^{1016}$. Być może jest to jedyny tekst e-liberacki, stworzony po to, by pokazać, że medium liberatury może być każde medium, nawet to, w którym właściwie nie powinna ona istnieć. Czym zatem byłby w takiej perspektywie Emeryk? Wyjątkiem potwierdzającym regułę? Pułapką dla teoretyków?

Podsumowując - od dobrych kilku lat toczy się dyskusja o e-liberaturze. Stworzyliśmy owo pojęcie. Definiowaliśmy termin. Posługiwaliśmy się nim i posługujemy się nadal ${ }^{1017}$. Tylko, że w istocie opisuje on - choć, nie przeczę,

1015 Ciekawą pracą na pograniczu książki artystycznej, instalacji, liberatury i hipertekstu wydaje się również w tym kontekście Libro $2 N$ Radosława Nowakowskiego, zrealizowane w przestrzeni fabryki (zob. Radosław Nowakowski, powieść w przestrzeń i... o uksiażkowieniu fabryki, „Autoportret” 2006, nr 4, s. 14-17). Warto przywołać w tym miejscu również Krótka historię przypadku Małgorzaty Dawidek Gryglickiej, olinkowany sznurkiem i żyłką hipertekst rozpisany na kartkach w przestrzeni pokoju, który Pisarski określił „pionierskim dziełem liberackim i ergodycznym” (Marcin Pisarski, Podróż do wnętrza ksiá̇ki, „Ha!art” 2010, nr 30, s. 159).

1016 Łukasz Jeżyk jako liberacką dyskusję o medialności interpretuje również dwadzieścia jeden liter Zenona Fajfera (Łukasz Jeżyk, Widzieć - wierzyć - wiedzieć. Zenona Fajfera podejrzenia i spojrzenia, [w:] Między językiem a wizualnościa, red. Magdalena Bednarek, Maciej Junkiert, Joanna Klausa-Wartacz, Poznań 2008). Warto może dodać, że w tym szkicu badacz określa samego Fajfera mianem „czołowego teoretyka, a także przedstawiciela liberatury i e-liberatury” (s. 129), podkreślenie moje. Nie sposób zresztą nie zauważyć, że całokształt twórczości Fajfera - z uwzględnieniem nie tylko przywołanych tu tomów, ale i np. Piety - daje się czytać jako dyskurs o medialności sztuki słowa, świadectwo autorskiego poszukiwania najwłaściwszego medium. Tym samym, być może nieco paradoksalnie, dla monograficznego opisu dorobku artysty znacznie wygodniejsza i użyteczniejsza wydaje się proponowana przeze mnie kategoria liberackości (pozwalająca na ujęcie transmedialne) niż (wymuszające medialne podziały i związane z tym różnego rodzaju uproszczenia) terminy liberatura czy e-liberatura.

1017 W 2014 r. bowiem Pisarski, pisząc o udostępnionej w „Techstach” elektronicznej wersji Powiek, zaznaczy, że „rozpoczęty przed dekadą równoległy do głównej twórczości Fajfera nurt e-liberatury doczekał się godnej i - zdaje się - granicznej kontynuacji” (Marcin Pisarski, Na kozetce (e-)liberatury. O „Powiekach” Zenona Fajfera, „Techsty” 2014, nr 9, http://techsty.art.pl/m9/ rec_m_pisarski_powieki.html [dostęp 25.07.2014]. Moim jednak zdaniem Powieki są jedynie kolejnym dowodem zarówno na transmedialność twórczości samego Fajfera (kluczowe jest tu i to, że - zawierający w sobie też płytę - tomik poetycki, który rozpatrywany jako całość powinien tu 
genialnie - jeden wyłącznie tekst. Choć w odniesieniu do Końca świata według Emeryka owo pojęcie wydaje się konieczne, nieodzowne, potrzebne i użyteczne, w przypadku innych tekstów jest bezsensowne, wewnętrznie sprzeczne, puste i po prostu zbędne. Czy istnieje e-liberatura? Nie. Czy stworzyliśmy terminologicznego potwora? Być może. Na pocieszenie pozostaje nam jednak Emeryk, który jest na wskroś e-liberacki.

być raczej głównym punktem odniesienia, dzieje się niejako na kilku medialnych platformach), jak i na to, że proponowany przeze mnie termin liberacki-pozwalający mówić nie tylko o tekstach różno-, ale i transmedialnych - jest znacznie użyteczniejszy niż ograniczające pojęcia jak liberatura czy (jak próbowałam pokazać - dodatkowo problematyczna) e-liberatura. Warto też podkreślić, że Fajfer sam często zaznacza, że jego dorobek jest spójna, ewoluującą całościa, stąd zdecydowanie nie określiłby żadnych ze swoich utworów jako „nurtu równoległego do głównej twórczości”. 
CZĘŚŚ III

\section{CZYTANIE LIBERATURY KONKLUZJE}





\section{Liberatura - przekaz grafemiczny w postmedialnym świecie konwergencji}

\subsection{W dialogu z Seweryną Wysłouch i Marylą Hopfinger}

Przyjrzawszy się rozmaitym potencjalnie liberackim obszarom sztuki słowa, dobrze byłoby dojść do (być może pozwalających wreszcie sprawnie zdefiniować literaturę totalna) wniosków, konkluzji. Przede wszystkim, czas zapytać o to, czy poszukiwania liberackości na przestrzeni dziejów okazały się owocne, a także - czy sprawdziła się wybrana przeze mnie ścieżka tych poszukiwań. Na pewno warto postawić pytanie o rozdział kończący tę książkę. Czy warto było analizować liberaturę w kontekście nowych mediów? Czy intuicja, że taki - wcale nie wyłącznie ze względu na chronologię wybrany - punkt dojścia moich rozważań będzie najlepszy, okazała się słuszna? Sądzę, że tak. W świetle przedstawionych wniosków, wydaje mi się również, że nie mogło być lepszego momentu na narodziny teorii liberackiej. Bo jest ona, jak sądzę, literackim oddźwiękiem rzeczywistości.

Rozpoczynając moje rozważania, stwierdzałam, że podejmuję pytania postawione przez Wysłouch $\mathrm{w}$ szkicu otwierającym tom Ut pictura poesis. Badaczka podkreślała, że wydawało się, iż XX w. - za sprawą m.in. Ingardenowskiej fenomenologicznej wizji dzieła literackiego (teraz mogę dodać: skrytykowanej przez liberatów) - porzucił w pełni formułę Horacjańską i, akcentując wyłącznie językowy charakter literatury, poddał się myśli Lessingowskiej. Nawiązywałam jednak wtedy przede wszystkim do twierdzeń Wysłouch mówiących o tym, że jedynie się tak „wydawało”, że w rzeczywistości pytania o problematykę związków słowa i obrazu powróciły. Tu powinnam dodać, że, zdaniem badaczki, do podjęcia ich na nowo, prowokowała również multimedialna kultura ${ }^{1}$. Sugerując się wskazaną przez Wysłouch potrzebą formułowania „nowej (alternatywnej?) teorii literatury”", zdolnej objąć nowe formy - nie tylko - literackie (gdyż „nie poddawały się lingwistycznym procedurom i wymagały innych narzędzi badawczych”), zastanawiałam się, czy sformułowana na przełomie tysiącleci teoria literatury totalnej nie jest właśnie odpowiedzią na charakteryzowany przez badaczkę brak.

${ }^{1}$ Seweryna Wysłouch, Ut pictura poesis - stara formuta i nowe problemy, [w:] Ut pictura poesis, red. Marek Skwara, Seweryna Wysłouch, s. 8.

${ }^{2}$ Ibidem, s. 17.

${ }^{3}$ Ibidem, s. 16. 
Jednak autorka Literatury $i$ semiotyki to nie jedyna inspiratorka moich rozważań. Prowadzony tu wywód w dużo większym stopniu dialoguje bowiem z diagnozami stawianymi przez Marylę Hopfinger, w poszczególnych częściach tej książki po wielokroć przywoływanej. Sądzę, że i w tym wypadku, moje wnioski podejmuja watki wskazane w przywoływanych opracowaniach. Przede wszystkim jednak - przedstawione tu spojrzenie na liberaturę (czy liberackość) jest związane z nieco już innym paradygmatem kultury niż ten, który przedmiotem swoich wnikliwych analiz czyniła badaczka. Stąd, odnosząc się do jej ustaleń (nawet tych najnowszych), pytam o ich adekwatność i użyteczność w czasie współczesnym teorii liberackiej, w gruncie rzeczy - raczej w XXI, nie w XX w. Stąd, niektóre z tez Hopfinger przywołuję po to, by poddać je aktualizacji.

Tak jest w przypadku formułowanych przez badaczkę ujęć reakcji literatury na nowe paradygmaty kultury. Moja chęć odpowiedzenia na pytanie, czy i obecnie sprawnie opisują one rzeczywistość sztuki słowa (ale i w ogóle: intencja postawienia takiego problemu) zrodziła się z głębokiego przekonania, że i liberatura, a ściślej: sformułowanie i (ciagle będace w toku) dopowiadanie jej teorii, również dają się postrzegać jako taka właśnie reakcja. By rozwinać tę myśl, trzeba wrócić do kategorii przekazu grafemicznego (co było już zapowiadane).

Analizując sposoby, w jakie literatura reaguje na kulturę audiowizualna, Hopfinger zwracała uwage na to, że sztuka słowa podejmuje tematy i motywy związane z pojawiajacymi się mediami i zmienia poetykę, adresując ją już - jak ujmuje to badaczka - do „człowieka kinowego”. Podkreślając złożoność tej sytuacji, badaczka charakteryzowała trzy możliwe rozwiązania. Po pierwsze, literaturze zdarza się podejmować gatunki audiowizualne i stawać się tym samym „literatura paraaudiowizualna”, współbrzmiąca, jak stwierdza autorka Doświadczeń audiowizualnych..., z otaczająca ja kultura. Po drugie, sztuka słowa może też sięgnać do sporej już tradycji intermedialnych tekstów kultury i odpowiedzieć tworzeniem takich właśnie form. Trzecia z opcji to próba zachowania swojej odrębności i przybrania formy literatury autotelicznej, skoncentrowanej na podkreślaniu własnej literackości i odgradzaniu się od tego, co audiowizualne.

Skupiajac się na utworach wpisujących się w tę ostatnią grupę, Hopfinger zwracała uwage na autotematyzm nouveau roman oraz omawiała inspirujacca dla mnie kategorię grafemizmu jako typu sztuki słowa eksponującego sam akt i okoliczności pisania, materialność literackiego artefaktu. Warto tu przywołać charakterystyki, w których podkreśla, że taki typ tekstu nie tylko jest przeznaczony dla oka (a nie ucha), ale i eksponuje książkowe medium. Jak pisała badaczka:

Powieść drukowana, głównie w postaci książkowej, eksponuje grafemiczną artykulację treści. Istnieje w przestrzeni książki, związana jest ściśle ze stronicami, z dwuwymiarowa przestrzenia, z porządkiem linearnym. Przestrzeń tę wypełniają serie zapisanych zdań, z których budowane są większe całości: frazy, akapity, rozdziały, części etc. Celem tej prozy jest konstruowanie form pisemnych, a nie naśladowanie mowy ${ }^{5}$.

${ }^{4}$ Maryla Hopfinger, Doświadczenia audiowizualne. O mediach w kulturze wspótczesnej, Warszawa 2003, s. 154. Dziś zapewne należałoby rozszerzyć tę kategorię o inne media.

${ }_{5}$ Ibidem, s. 172, podkreślenia moje. 
Niemniej, Hopfinger podkreśla przede wszystkim językowy charakter przekazów grafemicznych, traktując namysł nad językiem i sposobami jego funkcjonalizacji w strukturze tekstu pisanego jako ich fundament. Przez to, zwrócenie uwagi na eksponowanie nośnika, medium, jakim jest książka, nie ma szansy w jej wywodzie wybrzmieć. A, że mogłoby, przekonuje bliskość zaproponowanego ujęcia z myślą liberacką.

Dlatego warto zastanowić się, jak wyglądają reakcje literatury na kulturę już nie tyle audiowizualna, lecz nowomedialną i jak ma się do tego teoria literatury totalnej. Innymi słowy: proponuję odpowiedzieć na pytanie, czy (w gruncie rzeczy nie tak dawno temu) zaproponowana przez badaczke typologia użyteczna jest i obecnie. A owo „obecnie” jest dla mnie o tyle ważne, że określa właśnie moment, w którym sformułowano teorię liberacką. A i charakterystyki Hopfinger przywołuję przecież po to, by zastanowić się, czy mieści się w nich również liberatura.

Po pierwsze zatem: z perspektywy literatury elektronicznej wyraźniej widać, że dziś literatura może istotnie podejmować gatunki (a wręcz powiedziałabym: struktury) innych mediów. W ten sposób rodzi się nawet nie literatura paranowomedialna (jak można by próbować zaktualizować sugerowana wcześniej przez Hopfinger kategorię paraudiowizualności), lecz właściwa e-literatura: taka, w której wartości literackie ujęte są w sposób typowy dla funkcjonowania innych mediów (przykładami poemat flashowy czy powieść hipertekstowa). W istocie zatem literatura może nie tylko owe media naśladować, wykorzystywać (podchwytując proponowane w nich rozwiązania), lecz pełnoprawnie w nich funkcjonować (i to nie tylko na zasadzie tekstów przenoszonych do nowych mediów, lecz również - co tu najważniejsze - tworzonych w nich i dla nich).

Po drugie, aktualna pozostaje konstatacja Hopfinger, iż kiedy literatura „wyciaga wnioski z rozprzestrzeniania się [...] tekstów tak zwanych mieszanych i intermedialnych"6, może i sama przybierać takie formy (kilku dopowiedzeń wymaga tu jednak kwestia tego, jak dziś funkcjonują intermedialne przekazy, do czego wrócę za chwilę). Liberatura dałaby się przyporządkować do tej właśnie grupy tekstów: sięgających do różnych mediów, pozostajacych w obszarze literackości i chyba silniej inspirujących się tradycją gier międzymedialnych niż sztuką cyfrowa.

Po trzecie wreszcie, należy zastanowić się nad ostatnią z wyróżnionych przez Hopfinger kategorii. Nie sądzę, by mówiąc nie tyle (jak przywołana badaczka) o szerokim kontekście kultury audiowizualnej, lecz o reakcji literatury na świat nowych mediów, był sens odwoływać się do francuskiej nowej powieści, potrzebny byłby inny punkt odniesienia. Niemniej, rozważyć warto też użyteczność kategorii przekazu grafemicznego w opisywanej konfiguracji kulturowej. Nie bez powodu zwracałam już uwagę na bliskość tego ujęcia i teorii Fajfera mówiącej o literaturze pisanej w formie książki, o tekstach, które konstytuuje również ich (grafemiczna) materialność. Czy zatem liberatura

${ }^{6}$ Ibidem, s. 174 . 
dałaby się zaliczyć i do tej grupy? I, tym samym, czy - znów - staje ona ponad (kolejnym) podziałem?

Wydaje się, że tak: jest przecież zarówno typem twórczości integrującej w swym obrębie różne media, jak i literaturą broniącą swej literackości poprzez zwrócenie uwagi na to, że jest drukowana, ujęta w ramy książki właśnie. Interesujące wydaje się jednak to, czy taki stan rzeczy wiąże się z charakterem przywołanego podziału czy - samej liberatury. Ponadto - sądzę, że postulowane w obrębie jej teorii spojrzenie na książkę zmusza do oderwania takich kategorii jak przekaz grafemiczny od uwikłania w jednomedialność. Jednak by rozwinąc tę myśl - muszę powrócić do zapowiadanych dopowiedzeń.

\subsection{Intermedium na tle współczesności}

Aby rozważyć poruszoną kwestię chciałabym przywołać jeszcze jednego badacza. Lev Manovich, którego Język nowych mediów stanowi jedną z kanonicznych pozycji w kontekście sztuki na nich opartej, w 2001 r. opublikował esej Estetyka postmedialna ${ }^{7}$. Z tez, jakie tam stawia, inspirujace wydają mi się dwie. Po pierwsze: badacz - słusznie, jak sądzę - zwraca uwagę na to, że istotną konsekwencją rewolucji cyfrowej jest to, iż tradycyjna koncepcja medium przestała być użyteczna ${ }^{8}$. A co za tym idzie - należałoby znaleźć inny sposób porządkowania, dzielenia sztuk niż wiązanie ich z konkretnymi mediami. I rzeczywiście: czy dziśs literatura to tylko sztuka słowa?

Można by jednak postawić ważniejsze nawet (a związane z poprzednim) pytanie: czy kategoria intermedium w czasach postmedialnych jest jeszcze użyteczna? Jak słusznie podkreśla Rypson - dawniej rozumiana była jako rodzaj obrony przez zarzutami bezgatunkowości, usprawiedliwienie dla tworów przekraczajacych „tradycyjne ramy i podziały”. Dziś jednak, jeżeli medium nie określa już przynależności do dziedziny sztuki, termin ten będzie eksponował inne niż dotychczas aspekty dzieł. Zatem: w dobie konwergencji i remediacji, zgodnie z założeniem, że nowe media nie tylko zastępują stare, ale i je redefiniują (a odbiorca kultury ma kontakt z jednymi i drugimi), intermedia nie są już tak wyjątkowe, jak bywały dawniej ${ }^{10}$. Współczesność naznaczona jest związaną z intermediami „pomiędzością”, zaś - jak podkreśla w interesującym

${ }^{7}$ Polskie tłumaczenie, autorstwa Ewy Wójtowicz, dostępne jest w tomie Redefinicja pojęcia sztuka, red. Jolanta Dąbkowska-Zydroń, Poznań 2006.

8 Pierwsze zdanie eseju Manovicha mówi o tym wprost: „W ostatnich dekadach XX w. różne kulturowe i technologiczne perspektywy odebrały znaczenie jednej z kluczowych koncepcji sztuki nowoczesnej - koncepcji medium" (Lev Manovich, Estetyka postmedialna, tłum. Ewa Wójtowicz, [w:] Redefinicja pojęcia sztuka, s. 105).

${ }_{9}$ Piotr Rypson, Obraz stowa. Historia poezji wizualnej, Warszawa 1989, s. 13.

${ }^{10} \mathrm{Na}$ zjawisko konwergencji mediów jako impuls do konstruowania estetyki intermedialnej zwracał uwagę Konrad Chmielecki. Zob. idem, Od estetyki intermedialności do estetyki transmedialności. Perspektywy refleksji nad sztuka w kontekście problematyki konwergencji mediów i transgresji kulturowej, [w:] Sztuki w przestrzeni transmedialnej, red. Tomasz Załuski, Łódź 2010, s. 70. 
szkicu Prefiksy $w$ roli wyznaczników wspótczesności Krystyna Wilkoszewska - przejściowy charakter owego „między” nabiera nowych znaczeń, staje się definiujaccy ${ }^{11}$. Jak stwierdza Ewa Rewers:

Przyimek „między” stał się [...] słowem-kluczem w analizach kultury ponowoczesnej, ulubionym ujęciem relacji między izolowanymi dotychczas zjawiskami i procesami, i to nie tylko relacji przestrzennych oraz czasowych, jak na to wskazywałaby jego funkcja gramatyczna ${ }^{12}$.

Mając zatem świadomość, że współczesność nierozerwalnie związana jest z estetyką łączenia, a nie rozdzielania mediów (jak ujał to Konrad Chmielecki: „intermedialność [...] staje się niemal znakiem współczesnej kultury”13), inaczej wypada spojrzeć na liberaturę. Odnosząc przywołane tezy do moich badań - trzeba uznać, że w czasach intermedialnych literatura totalna nie wydaje się aż tak zaskakującym fenomenem, jak w kontekście literatury (i co za tym idzie: kultury) „tradycyjnej” (przede wszystkim: ukształtowanej w kontekście druku $\left.{ }^{14}\right)$. Zaś perspektywa, z której próbuję tu spojrzeć na teorię Fajfera zakłada wręcz wyjście jeszcze krok dalej - przywołując Manovicha wkraczam już przecież w obszar tego, co określane jako postmedialne. Zaś sytuacja „wyzucia z medium”, jaką opisuje przywołany badacz, wydaje się naturalną konsekwencją wyeksploatowania estetyki intermedialnej.

Z jednej strony - jeżeli operowanie tym, co pomiędzy staje się w sztuce swojego rodzaju normą (związana, rzeczywiście - tu trzeba zgodzić się z Chmieleckim - z konwergencją mediów, ale też z codziennym obcowaniem z transmediami, które czynią właśnie wielomedialny odbiór świata i sztuki chlebem powszednim), naturalna konsekwencją zaistniałej sytuacji jest szukanie możliwości opisu takiego świata (sztuki) w przestrzeni definiowania intermedialności. Tak pojęta estetyka intermedialna - przypomnę - obejmuje zaś nie tylko media elektroniczne (cyfrowe), lecz i literaturę, a w większości przypadków związana jest z współczesną ikonosferą ${ }^{15}$.

${ }^{11}$ Krystyna Wilkoszewska, Prefiksy w roli wyznaczników wspótczesności, [w:] Intermedialność w kulturze końca XX wieku, red. Andrzej Gwóźdź, Sław Krzemień-Ojak, Białystok 1998, s. 14.

12 Ewa Rewers, Post-polis. Wstę do filozofii ponowoczesnego miasta, Kraków 2005, s. 168.

${ }^{13}$ Konrad Chmielecki, Estetyka intermedialności, Kraków 2008, s. 26.

${ }_{14}$ Choć Ong podkreślał, że konsekwencją przejścia od oralności do piśmienności było związanie pisma z przestrzenią i wizualnością (Walter Ong, Oralność i piśmienność. Stowo poddane technologii, tłum. Józef Japola, Lublin 1992, s. 167) i przywoływał tych samych co liberaci artystów jako przykłady twórców czerpiących z tych jakości w swojej twórczości (m.in. Herberta, Sterne’a, Mallarmégo) (zob. s. 173-174), trzeba pamiętać, że ustalona w typograficznej kulturze konwencja druku nie czerpała zasadniczo z możliwości, jakie otwierał on przed sztuką słowa, na co zwracałam uwagę w rozdziale poświęconym liberaturze i eksperymentom typograficznym. Formuła „druk decyduje nie tylko o tym, jakich słów mamy użyć, by powstał tekst, lecz także o stosownym usytuowaniu słów na stronie oraz ich wzajemnych relacjach przestrzennych, sama przestrzeń - jak mówimy "pusta przestrzeń» (white space) - na zadrukowanej stronie zajmuje ważne miejsce” (s. 173) nie odnosi się wyłącznie do przywołanych wcześniej artystów, którzy owo „miejsce na stronie” wiążą z semantyką tekstu. „Stosowne usytuowanie słów na stronie” to przecież tė̇ kwestia zgodnego ze standardami druku ich ułożenia, dla znaczeń tekstu pozostającego raczej mało istotnym.

15 Por. K. Chmielecki, Estetyka intermedialności..., Kraków 2008. 
Z drugiej jednak strony - co dzieje się, gdy dominująca tendencją tworzenia przekazów artystycznych stają się metody łączenia w ich obrębie mediów, które w innych przypadkach funkcjonują oddzielnie, co więcej: łączenia ich na zasadzie konceptualnego zespolenia (jak trafnie komentuje teorię Higginsa Chmielecki), nie zaś prostego połączenia (co prowadzi ku tzw. mixed-mediom, mediom mieszanym, wyraźnie - szczególnie w późniejszych pracach - odróżnianych przez Higginsa od intermediów)? Rzeczywiście - jak uznaje Manovich - sama kategoria medium wydaje się wtedy zbędna. Warto tu też przypomnieć, że i Higgins (profetycznie?) w 1981 r. (komentując esej Intermedia publikowany w połowie lat sześćdziesiatych) stwierdzał, że „istnieje tendencja do tego, aby intermedia stały się powszechniejszymi środkami wyrazu"16. Z tych samych jednak powodów odbierał zaproponowanej przez siebie kategorii przełomowość. Pisał - przypomnę, gdyż zwracałam na to już uwagę w pierwszej części tej książki (w nieco innym kontekście) - że wydawała się ona użyteczna i nieodzowna w odniesieniu do wcześniejszych, awangardowych dzieł, które przez ówczesnych odbiorców kultury (do intermediów nieprzyzwyczajonych i potrzebujących wyraźnego wskazania możliwego sposobu ich interpretacji) zaliczane były do dzieł dla znawców, grupy utworów, za które nie wiadomo, jak się zabrać (zatem najlepiej pozostawić je właśnie tylko „wtajemniczonym”).

Jednak jak - niespełna dwadzieścia lat później (z dzisiejszej perspektywy zaś: trzydzieści lat temu) - zauważał autor Nowoczesności od czasów postmodernizmu, z czasem takie utwory stały się coraz popularniejsze, nie sprawiały już aż tylu problemów interpretacyjnych ${ }^{17}$. Marcin Składanek trafnie podkreśla,

${ }^{16}$ Dick Higgins, Intermedia, tłum. M. i T. Zielińscy [w:] idem, Nowoczesność od czasu postmodernizmu oraz inne eseje, oprac. Piotr Rypson, tłum. Marcin Giżycki i in., Gdańsk 2000, s. 130.

${ }_{17}$ Chmielecki, odnosząc się do kategorii intermedialności w kontekście refleksji medioznawczej, trafnie dostrzegał, że „żyjemy w epoce przekazów intermedialnych, funkcjonujących w sferze społecznej”. Tym samym - jak zauważa badacz - jednocześnie nie powinna dziwić „rozległość badań nad intermedialnością podejmowanych przez współczesnych teoretyków kultury" (K. Chmielecki, Estetyka intermedialności, s. 42). Warto dodać, że w swojej książce autor daje wartościową panoramę medioznawczej refleksji o intermedialności (rozdział 1.4. Intermedialność we wspótczesnej myśli filmo- i medioznawczej, s. 39-50). W odniesieniu do literatury z kolei warto tu raz jeszcze przywołać - podobnie jak wywód Chmieleckiego, silnie zakorzeniony w niemieckojęzycznych opracowaniach - szkic Andrzeja Hejmeja Literatura intermedialna oraz całą drugą część książki Komparatystyka. Studia literackie zatytułowaną Przestrzenie intermedialności, zob. także Irina Rajewsky, Intermediality, Intertextuality, and Remediation: A Literary Perspective on Intermediality, „Intermédialités” 2005, nr 6, s. 43-64. Moim jednak zdaniem, filologiczne rozważania o intermedialności winny być silniej inspirowane Higginsem. Uważam, że formułowanie teorii literackiej intermedialności w kontekście filmoznawczej refleksji szeroko traktujacej omawiana kategorię może prowadzić ku ujęciom tak szerokim, że rozmywa się sedno problemu. Przykładem tom Intermedialność (red. Roman Lewicki, Ingeborg Ohnheiser, Lublin 2001), w którym tytułowa kategorią określa się „ogół zjawisk towarzyszących zmianie medium przy przekazie komunikatów wszelkiego typu" (s. 10), co - jak zaznaczają autorzy - pozwala objać różnorodne zjawiska: filmowe adaptacje literatury, wzajemne relacje literatury i filozofii, problemy przekładu, kwestie kontaktów językowych, różnice między językiem mówionym i pisanym. W konsekwencji w publikacji znajdziemy artykuły takie jak Stefana Warchoła Stownictwo ukrainskie w polskiej gwarze wsi Eabunie koło Zamościa (ibidem, s. 231-240). Zdecydowanie za szerokie to spojrzenie, na pewno też nieprzydatne do moich rozważań. 
że w obliczu (z jednej strony) braku barier technologicznych i (z drugiej) możliwości łączenia w dziele sztuki wszelkich możliwych mediów, strategie intermedialne nie przynależą już wyłącznie do obszaru awangardy, eksperymentów artystycznych, lecz stają się „strategiami powszechnymi i powszechnie stymulowanymi" 18 . Kategoria intermediów przeradza się w takiej sytuacji w pojęcie klasyfikujace, a istota problemu interpretacji takich dzieł tkwi w próbie hermeneutycznego odczytania znaczeń owej wielomedialnej struktury (która już wcale się ową wielomedialnością na tle innych dzieł sztuki nie wyróżnia). Tym samym, można by rzec, Higgins otwiera Manovichowi drogę do mówienia o świecie sztuki, w którym kategoria medium więcej komplikuje niż wyjaśnia, zaś właściwe pytania odnosić powinny się do sposobu działania użytych struktur (tym samym - jak ujmuje autor Języka nowych mediów - interfejsu czy oprogramowania).

Konkludując, w czasach estetyki nawet nie tyle intermedialnej czy transmedialnej ${ }^{19}$ (w kontekście których Hopfinger formułowała swoje słuszne i nowatorskie tezy), lecz postmedialnej, kategoria intermedium niewiele mówi nam o dziele. Straciwszy sposobność łączenia konkretnych mediów z dziedzinami sztuki, straciliśmy zarazem możliwość wskazywania oryginalności dzieł, które te podziały przekraczaja. To one są bowiem typowe i „normalne”, transgresja stała się jedna z kluczowych cech współczesnej kultury. Również transgresja medialna, zakładająca znoszenie granic pomiędzy mediami (co leży u podstaw formułowanej przez Manovicha koncepcji). Ryszard Kluszczyński słusznie zauważał:

Problematyka transgresji wyznacza współcześnie jedną z kluczowych perspektyw opisu kultury, a zwłaszcza kultury artystycznej. Dzieje się tak nie tylko, a nawet nie przede wszystkim, za sprawą programów i rozwiązań metodologicznych preferowanych przez poszczególnych badaczy i ugruntowanych w przyjmowanych przez nich założeniach filozoficznych. Perspektywa taka jest przede wszystkim narzucana przez same rozwijające się dziś praktyki artystyczne. Współczesna sztuka nie mieści się już bowiem w ramach poszczególnych

${ }_{18}$ Marcin Składanek, Transmedialność i postmedialność - dialektyka konwergencji oraz dywergencji $w$ nowych mediach, [w:] Sztuki w przestrzeni transmedialnej, s. 73. Muszę jednak zaznaczyć, że Składanek posługuje się kategorią trans-, nie intermedialności. Jednak, jako że przywołuje w tym kontekście Higginsa, nie sądzę bym „przekręcając” jego słowa posuwała się ku niebezpiecznej nadinterpretacji (por. też następny przypis).

${ }_{19} \mathrm{~W}$ kontekście polskiej refleksji trudno pokusić się o pełne rozróżnienie tych terminów. Wydaje się, że oba bywają stosowane na określenie tych samych zjawisk (np. Składanek jako podstawę estetyki transmedialnej przywołuje teorię Higginsa, którą większość badaczy czyni raczej punktem wyjścia do formułowania estetyki intermedialnej, por. M. Składanek, Transmedialność i postmedialność..., s. 73). Zaś z prób konsekwentnego dokonywania takiego rozróżnienia podejmowanych choćby przez Chmieleckiego, który uznaje, że „zjawisko konwergencji mediów wyznacza obszar "estetyki intermedialności», [...] transgresja kulturowa staje się podstawą określenia [...] "estetyki transmedialności»" (K. Chmielecki, Od estetyki intermedialności..., s. 70), najważniejsza wydaje mi się konstatacja, iż obie są odpowiedzią na wyrażone już lata temu przez Wolfganga Welscha przekonanie, że nowe media wymagają nowej estetyki. Por. także zbiory szkiców: Piękno w sieci. Estetyka a nowe media, red. Krystyna Wilkoszewska, Kraków 1999 oraz Estetyka wirtualności, red. Michał Ostrowicki, Kraków 2005 oraz Wolfgang Welsch, Estetyka poza estetyka, tłum. Katarzyna Guczalska, Kraków 2005. 
dyscyplin, nie pozwala ując się analitycznie a tym bardziej uporządkować za pomocą tradycyjnych kategorii poznawczych. Epoka społeczeństw sieciowych, multiplikujaccych się światów i zmiennych, nieprzerwanie rekonstruowanych tożsamości, epoka, w której komunikowanie staje się podstawową formą aktywności społecznej oraz fundamentem i zasada funkcjonowania instytucji organizujących te praktyki, nie sprzyja artystycznej czystości rodzajowej ani poszukiwaniom cech specyficznych. Twórczość dnia dzisiejszego, ta przynajmniej, która prowadzi dialog ze współczesnościa, to polifoniczna, wielotworzywowa, wielowymiarowa sztuka medialna, intermedialna, hipermedialna, do skrajności doprowadzająca zainicjowany niegdyś przez Romantyzm proces korespondencji sztuk ${ }^{20}$.

\subsection{Książkowe interfejsy?}

W tym miejscu, by formułowane tu tezy mogły w pełni wybrzmieć, powinnam przywołać również druga z kluczowych dla mnie uwag Manovicha. W swoim szkicu przywołany badacz odwołuje się także do teorii komunikacji, zauważając, że dotychczasowe ujęcia lekceważyły kategorię kodu i kanału (medium), traktując je - jak mówi - ,jako pasywne, mechaniczne komponenty: są po prostu narzędziami koniecznymi do transmisji przekazu wcześniej istniejacej informacji”21. Zdaniem Manovicha w odniesieniu do współczesnych cyfrowych przekazów artystycznych takie ujęcie nie jest zasadne. W ich bowiem przypadku, by stać się odbiorca musimy opanować interfejs ${ }^{22}$ dzieła (zrozumieć sposób komunikacji między nami a komputerem). Ten zaś nie pozostaje bez znaczenia. Jak wypunktowuje uznany badacz nowych mediów:

Oprogramowanie wpływa na sposób rozumienia medium, w którym pracuje; w konsekwencji odgrywa kluczowa rolę w ostatecznej formie technokulturowego tekstu. Dla czytelnika, który dociera do tekstu poprzez interfejs programu, podobnie ten interfejs staje się narzędziem kształtującym jego rozumienie tekstu: jakie typy danych zawiera tekst, jak są one zorganizowane, co jest jeszcze możliwe do wyrażenia w procesie komunikacji ${ }^{23}$.

Jak odnieść te tezy do sztuki słowa? Nie tyle istotne staje się tu medium, lecz sposób przekazania tekstu zwiąany z jego struktura, sposobem działania, możliwościami. Tak jak dawniej literat zastanawiał się nad wyborem poszczególnych słów, form gatunkowych, konwencji, tak dziś - przynajmniej ten literat, który tworzy, wykorzystujac techniki nowomedialne - dodatkowo (ale podkreślę: dodatkowo, nie zamiast) rozważa, po jakie oprogramowanie sięgnać, by najlepiej wyrazić to, co chce przekazać ${ }^{24}$. Interfejs (nierzadko jak ujmuje to Nicholas Negroponte - „wielomodalny”, pozwalający odwołać

${ }^{20}$ Ryszard W. Kluszczyński, Stowo wstepne, [w:] (Nie)obecne granice, red. Katarzyna Kuropatwa, Dagmara Rode, Kraków 2003, s. 9.

${ }^{21}$ L. Manovich, Estetyka postmedialna, s. 114.

${ }_{22}$ Manovich posługuje się częściej określeniem oprogramowanie (software).

${ }^{23}$ L. Manovich, Estetyka postmedialna, s. 114, podkreślenia moje.

${ }^{24}$ O różnych oprogramowaniach służących do tworzenia literatury elektronicznej w Polsce pisała, przypomnę, Dorota Sikora na łamach „Techstów”. 
się do wielu doznań ${ }^{25}$ ) można by w takim układzie porównać do zastosowanego chwytu, środka stylistycznego. Jest (a przynajmniej z pewnością może być) celowym zabiegiem artystycznym. Tym samym, odbiorca, który dawniej wnikał w głębię metafor, analizował oksymorony, interpretował przerzutnie, zmuszony jest postawić w obliczu nowych tekstów nowe pytania: o kod, o funkcje, o metodę działania. Zasadniczo powinien też pamiętać, że w (niegrafomańskim) dziele i interfejs należy poddać interpretacji.

Zdaje się też, że rację ma Manovich, sugerując, iż lepiej uporządkujemy obszar sztuki, zwracając uwagę na różnice w działaniu interfejsu niż na użyte media. Na rodzimym gruncie podkreślała to m.in Ewa Szczęsna, zgrabnie podsumowując:

\begin{abstract}
Rozwój nowych technologii prowadzi do zatarcia granicy między rolą technologii jako przekaźnika i jako narzędzia kształtowania znaczeń. Żadna technologia nie może być postrzegana wyłącznie w kategoriach środka przekazu gdyż nie ma treści niezależnych od sposobu ich przekazywania. Inaczej mówiąc, tekst jest całością znaczeniowa, której sens współkreowany jest przez interakcje, w jakie wchodzi treść ze sposobem jej przekazywania i nadbudowywanym nad nim system [em - AP] reguł kształtowania znaczeń charakterystycznym dla danego medium (np. literatury, komiksu, teatru, komputera, filmu) ${ }^{26}$.
\end{abstract}

Warto dodać, że badaczka zwraca uwagę na to, że „nowa sytuacja medialna tekstu prowadzi do reinterpretacji sposobu jego funkcjonowania, wskazuje na potrzebę rewizji istniejacych narzędzi badawczych oraz stanu badań nad tekstem" ${ }^{27}$. O analogicznych rewizjach mówili i liberaci.

Innymi słowy: dziś już nie można podejść do dzieła i powiedzieć „oto obraz na płótnie - sztuka plastyczna; a to słowo na białej kartce - literatura; tu zaś dźwięk w przestrzeni - muzyka". Dziś podchodzimy i stwierdziwszy, że być może mamy do czynienia z dziełem, zaczynamy szukać zasady jego działania. Pytamy: „co z tym zrobić?”. Taka sytuacja zasadniczo zmienia sama kategorię czytania, doświadczenia czytelnicze (skupiam się na literaturze, stąd pozwalam sobie na mówienie o czytelniku, niemniej tezy te odnieść należy do całej współczesnej sztuki). Do podobnych pytań prowokuje liberatura. Postulowane przez Fajfera zrywanie z konwencja, związywanie kształtu książki (i co za tym idzie - jak doskonale uzmysławiają nam Nieszczęśni - sposobu, metody jej czytania) z jej przesłaniem sprawia, że widząc dzieło liberackie nie uruchamiamy automatycznych sposobów percepcji drukowanego słowa. W tym wypadku interfejs jest tylko pozornie staroświecki. Nie

${ }^{25}$ Pojęciem interfejsu wielomodalnego posługuje się Nicholas Negroponte w książce Cyfrowe życie. Jak odnaleźć się w świecie komputerów, tłum. Marian Łakomy, Bydgoszcz 1997. Termin ten określa interfejs wykorzystujący wiele kanałów dostarczających informacje i potrafiący tym samym dostosować się do potrzeb odbiorcy. Ten typ interfejsu jest przejawem tendencji do antropomorfizacji relacji między człowiekiem a maszyną (o takiej tendencji pisze też Paul Levinson, zob. idem, Miękkie ostrze, czyli historia i przyszłość rewolucji informacyjnej, tłum. Hanna Jankowska, Warszawa 2006).

${ }^{26}$ Ewa Szczęsna, Poetyka mediów. Polisemiczność, digitalizacja, reklama, Warszawa 2007, s. 232, podkreślenie autorki.

27 Ibidem, s. 234. 
jest bez znaczenia, nie jest nieistotny i - co najważniejsze - nie jest a priori opanowany - książki liberackie nie odwołują się do naszych przyzwyczajeń, raczej nawołuja do ich przekraczania.

Czy użycie w tym kontekście pojęcia interfejs jest zasadne? Czy mówiąc o książkowym interfejsie nie popełniam pewnego nadużycia terminologicznego? Z jednej strony - jak postaram się pokazać - Manovichowska koncepcja (łącząca go również z kategorią software) w pełni pozwala na takie użycie terminu, zaś liberatura zdaje się o nie dopraszać. Z drugiej strony: nie ja pierwsza to czynię. W książce Tekst jako świat i gra (niedocenianej, jak sądzę, przez większość młodych badaczy „odkrywających” Aarsethowską koncepcję cybertekstu) Katarzyna Prajzner stwierdzała:

\begin{abstract}
Jak każda technologia, zdolna do wygenerowania reprezentacji (a także wywołania zjawiska immersji), książka ulegała przemianom w procesie historycznym, który umożliwił [...] ujednolicenie jej cech materialnych, co z kolei jest gwarantem przezroczystości samego medium. [...] Nie sposób także nie zauważyć, że opanowanie zasad funkcjonowania książkowego interfejsu jest dziecinnie proste. Wystarczy otworzyć książkę i odwracać strona po stronie. W większości przypadków dane są zorganizowane w taki sposób, że ów prosty system zachowań okazuje się niezwykle skuteczny przy uzyskiwaniu informacji. Monotonna powtarzalność zachowań wobec medium, jakim jest książka, była niejednokrotnie krytykowana przez awangardowych teoretyków i twórców, którzy próbowali zorganizować dane w taki sposób, aby zmusić czytelnika do podjęcia niekonwencjonalnej lektury ${ }^{28}$.
\end{abstract}

Nie tylko twórcy awangardowi dążyli do odrzucenia owej powtarzalności (warto zresztą dodać, że Prajzner przywołuje jako przykład referowane już przeze mnie tezy Federmana). Liberaci, których - jak już zaznaczałam - wiele z tym twórcą łączy i którzy jego artystyczne realizacje wydają w swojej serii, również sprzeciwiają się temu, by książkę zawsze czytać tak samo. Innymi słowy - odrzucają interfejs konwencjonalny, traktowany jako jedyny możliwy. Aspirują do tego, by każdorazowo był on dobierany świadomie - jak sugerował Manovich - silnie wiązał się z samą ideą dzieła, by w interpretacji nie pozwalał się pominąć.

Co więcej: tak jak skonwencjonalizowanym interfejsem literatury jest „zwykła” książka, tak jest nim i ten typ poezji wizualnej, który nie satysfakcjonował liberatów (jak kaligramy), czy nieliberacki - jak wskazywałam - komiks. W obu tych przypadkach, choć forma podania tekstu literackiego wydaje się inna niż ta najbardziej klasyczna, uwikłana jest jednak w konwencję, a zatem: przewidywalna. Można by dodać, że nie dało się dostrzec prawdziwej liberackości w koncepcji druku funkcjonalnego dlatego, że kimś innym jest tu „programista” opracowania typograficznego, kimś innym - autor samego dzieła, a zatem „rewolucja” miała w tym wypadku dotyczyć wyłącznie samego (po Manovichowsku) software tekstu, nie utworu jako takiego. Zaśs - ubierając wypowiedziane tu już tezy w inną terminologię - można powiedzieć, że liberatom zależy na tym, by problem interfejsu należał do

${ }^{28}$ Katarzyna Prajzner, Tekst jako świat i gra. Modele narracyjności w kulturze wspótczesnej, Łódź 2009, s. 142-143. 
tego samego porządku, co problem użytych środków stylistycznych. Słowem - jeżeli interfejs (i software, jak doda Manovich) jest częścią dzieła i wpływa na jego sensy, nie może zależeć od kogoś innego niż jego autor. I nie jest wcale konieczne, by autor miał technologiczną wiedzę umożliwiająca realizację jego koncepcji, lecz wydaje się nieodzowne, by - opracowawszy taka koncepcję - dopilnował jej urzeczywistnienia ${ }^{29}$. Fajfer i Bazarnik nie drukowali przecież i nie składali Oka-leczenia sami ${ }^{30}$, jednak dokładnie opracowali jego typograficzny układ, przemyśleli kształt tomu, sposób, w jaki tekst ma się pokazywać odbiorcy (w tym i to, jak ma się przed nim ukrywać, co ściśle związane jest z tym, o czym mówi) ${ }^{31}$, innymi słowy: jak ma działać, jaki ma być jego - właśnie - interfejs.

Warto też zapytać o to, jakie inne zarzuty liberaci stawiają klasycznym książkowym interfejsom. Przede wszystkim, sprzeciwiają się temu, co McLuhan określił „podgrzaniem pisma do intensywności powtarzalnego druku” 32 . $\mathrm{W}$ rozumieniu tego zwolennika twardego determinizmu technologicznego ${ }^{33}$ książka jest medium gorącym. Prajzner jednak pytała: „Czy czytanie konwencjonalnie zbudowanej książki jest doświadczeniem, które angażuje tylko jeden zmysł?"34. Choć można by jeszcze zgodzić się z McLuhanem, że klasyczna (konwencjonalna) książka angażuje wyłącznie wzrok $^{35}$, na pewno nie ma takich aspiracji liberatura. Książki rozumianej w duchu teorii przedstawicieli tego nurtu nie można określić jako gorącego środka przekazu również dlatego, iż otwarta jest na czytelniczą interakcję, zmusza do zaangażowania.

${ }^{29}$ Cyfrowym przykładem tego, jak zgubnym wyjściem może być projektowanie interfejsu przez kogoś innego, gdy autor daje się tylko zwieść nowości konkretnego pomysłu i nie rozważy znaczenia zastosowanej formy dla przekazu jest, moim zdaniem, Blok Sławomira Shuty. Olinkowany przez Mariusza Pisarskiego tekst to w większości „przerobione” teksty wcześniej publikowanych opowiadań (które zresztąjuż po umieszczeniu Bloku w Sieci doczekały się kolejnego wydania w formie książkowej), w nowej przestrzeni więcej tracących niż zyskujących. Warto dodać, że sam Shuty na jednym ze spotkań autorskich przyznał, że nie projektował Bloku jako hipertekstu, że pomysł wyszedł od „kolegów”, że nie analizował możliwości, jakie daje mu struktura hipertekstowa. Szerzej o tej kwestii pisałam we wspominanej już pracy magisterskiej (analizując dokładnie zależności między Blokiem a „papierowymi” edycjami opowiadań autora), a także w przywoływanym już tu szkicu Porzadek czy chaos, sieć czy zbieranina, logiczna konstrukcja czy zagmatwany labirynt? Na marginesie hipertekstowej powieści Radosława Nowakowskiego.

${ }^{30}$ Choć w przypadku 21 liter rzeczywiście sami pracowicie zaginali poszczególne strony w każdym egzemplarzu.

31 Zob. przypis $66 \mathrm{w}$ rozdziale Liberatura i poezja wizualna.

${ }^{32}$ Marshall McLuhan, Gorqce i zimne środki przekazu, [w:] idem, Zrozumieć media. Przedłużenia człowieka, tłum. Natalia Szczucka, Warszawa 2004, s. 58.

${ }^{33}$ Która to perspektywa, co należy w końcu wyjaśnić, nie jest - w moim odczuciu - właściwa czy użyteczna, gdy mówimy o historii literatury i książki w różnych mediach, do czego sprowadza się momentami dyskusja o liberaturze. Jak widać w tej publikacji, jestem raczej zwolenniczka i miękkiego determinizmu, i wynikającego zeń spojrzenia na rozwój mediów w duchu remediacji, założenia, że nie mamy do czynienia z gwałtownymi zmianami, lecz stopniowym przekształcaniem się kultury, inspirowanym wzajemnym wpływaniem na siebie starych i nowych mediów.

${ }^{34}$ K. Prajzner, Tekst jako świat i gra..., s. 149.

${ }^{35}$ Choć Prajzner nawet to sformułowanie kwestionuje (por. K. Prajzner, Tekst jako świat $i$ gra..., s.149 i nast.). 
Derrick de Kerckhove pisał o książce jako o miejscu:

Gdzie odpoczywają słowa. Może to brzmi trywialnie, ale rzeczywiście zadrukowana strona jest jedynym miejscem, gdzie słowa mogą sobie odpocząc $c^{36}$.

Trudno powiedzieć, by w książce liberackiej miały one taką możliwość. Choć rozwijając swoją myśl, de Kerckhove opisuje jako aktywne słowa nowomedialne oraz wypowiadane, należałoby do jego „wyliczanki” dodać i te z literatury totalnej. I one, choć, rzeczywiście często „pozostają bez ruchu”37, nie odpoczywaja - podobnie jak ich czytelnicy. Liberackie słowo nie jest przezroczyste, nie daje się ogarnać jednym zmysłem, nie zawsze musi być jednowymiarowe. Zaś modelowy czytelnik literatury totalnej - jak podkreślałam w rozdziale o komiksie - winien mieć chęć poszukiwania niekonwencjonalnych sposobów czytania jej. Jakie zatem jest czytanie liberackie? Jakie zmysły angażuje/może angażować liberacki interfejs?

\subsection{Inne czytanie}

Na pytania te warto, jak sądzę, odpowiedzieć, mając w świadomości kontekst kultury i sztuki współczesnej: zapytać nie tylko o to, jak czyta się liberaturę, lecz i o to, jak ma się taka lektura do dzisiejszego doświadczania sztuki. By przypomnieć tezy, które już tu - w gruncie rzeczy - stawiałam, chciałabym przywołać (młodszą o niespełna dekadę od teorii liberatury) pracę Jeffreya Shawa Virtual Museum.

Oglądajacy (?) przywołaną instalację wchodzi do sali, na środku której znajduje się ruchoma platforma z ekranem i stojącym przed nim fotelem, w którym trzeba zasiasść, by rozpocząć obcowanie z dziełem. Wtedy każdy gest wywołuje ruch i na ekranie, a także obrót platformy. A jak zwiedza się tytułowe wirtualne muzeum? Przed sobą widzimy dokładną cyfrową replikę przestrzeni, w której się znajdujemy, a nasze ruchy - jak zaznaczyłam - owocują przemieszczaniem się w niej. W ten sposób możemy też zwiedzić jeszcze cztery inne sale wystawiennicze. Co w nich spotkamy? W pierwszej: obrazy. W drugiej: rzeźby. W trzeciej: projekcję kinowa. W czwartej: sztukę elektroniczna. Można by zatem powiedzieć, że w muzeum możemy doświadczyć obcowania z różnymi, odwołującymi się do wzroku, dziełami sztuki. Zasadniczo tak, ale...

W pokoju dedykowanym malarstwu obraz stanowią litery wędrujące między ramami obrazów. Na płótnach widzimy przesuwający się napis Something that appears like nothing can take the place of something that appears like nothing (Coś, co wydaje się niczym może zajać miejsce czegoś, co wydaje sie

${ }^{36}$ Derrick de Kerckhove, Inteligencja otwarta, tłum. Andrzej Hildebrant, Warszawa 2001, s. 125 .

${ }^{37}$ Ibidem. 
niczym $\left.{ }^{38}\right)$. Rzeźb w kolejnym pomieszczeniu muzealnym nieprzypadkowo jest pięć. Każda z nich zbudowana jest z liter, układających się w konkretne słowa: nazwy zmysłów. Kinowa projekcja w trzeciej sali wyświetlana jest zaś nie na jednym ekranie, lecz na przemieszczających się w jej obrębie zdaniach: wizualną historię śledzimy w poszczególnych literach składających się na słowa, z których zbudowane są frazy. Ostatnia - nienawiązująca już do sztuki tradycyjnej i przestrzeni muzeum - odsłona, to elektroniczna praca pokazująca trzy znaki: „A”, „2” i „Z”. Pamiętając o wywiedzionej z netspeaku (języka Internetu) skrótowości współczesnych elektronicznych zapisów, można je odczytać jako frazę „a to (two) z”, czyli przysłowiowe „od a do z”, czego już chyba dalej tłumaczyć nie trzeba.

Choć niejedyny to trop interpretacyjny, jaki praca Shawa wskazuje, sądzę że daje się odczytać właśnie jako wypowiedź o współczesnej sztuce i sposobach jej doświadczania, jako egzemplifikacja albo „wirtualne ucieleśnienie" tez o jej bezmedialności, o niemożliwości wprowadzania podziałów sztuk w oparciu o użyte medium. Żadna z doświadczanych (?) przy pomocy ekranu przestrzeni nie była w pełni związana z konkretną dziedziną sztuki. Przede wszystkim zaś - co dla mnie tu kluczowe - w każdej z nich pojawiło się pismo i słowo. Stąd praca ta - traktując o całej sztuce - mówi i o literaturze, o tym, że nie musi już ona być związana wyłącznie z drukiem, nudną (jak mówił Federman) papierową książką, ograniczającą nasze sposoby interakcji z dziełem.

Zatem przywoływanie w moim wywodzie kontekstu literatury elektronicznej nie było, jak sądzę, intelektualna „fanaberią”. Nie miałam na celu odwoływania się do przestrzeni nie do końca jeszcze w literaturze przedmiotu opisanych, interesujących i przykuwających uwagę choćby z racji swojej nowości. Zależało mi na wskazaniu ważnego dla liberatury kontekstu - innej przestrzeni sztuki słowa, w której interfejs bywa używany jako znaczący dla kreacji dzieła. W tym zestawieniu liberatura nie jawi się już jako wyjątkowa ze względu na swoje sięganie po mniej typowe i wykorzystujace rozmaite tworzywa zabiegi. Spojrzenie na nią z perspektywy teorii ergodyzmu pozwala wyraźniej dostrzec, iż łączy ją z literaturą elektroniczną właśnie podejście do medium, czytelniczych powinności, projektowanego sposobu lektury, zasadniczo: wykorzystanego sposobu kreowania znaczeń. Na podobne kwestie zwraca uwagę Pressman, charakteryzując fetyszyzujące swój książkowy (kodeksowy) kształt drukowane teksty jako wpisujące się w obszar tego, co określa jako digital modernism ${ }^{39}$.

${ }^{38}$ Fraza ta nie jest łatwa do przełożenia, nie sądzę, by mój (literalny) przekład pomógł tu odbiorcy nieznającemu angielskiego. Ważne jest również zaznaczenie, że pod nothing (nic) kryje się również aluzja do niematerialnej wirtualności. Tym samym, wirtualny obraz muzeum (będący niczym) zastępuje obraz muzeum, w którym nic nie ma (sala, w której ustawiony jest fotel - jak wspominałam - jest identyczna z ta, którą widzimy na ekranie, jednak pusta).

${ }^{39}$ Por. m.in. Jessica Pressman, CODA - Rereading: Digital Modernism in Print, Mark Z. Danielewski's “Only Revolutions”, [w:] eadem, Digital Modernism. Making It New in New Media, New York 2014. 
W przypadku e-literatury nowy kształt literackich interfejsów, jak słusznie podkreśla Roberto Simanowski, ewokuje konieczność przyjęcia innej strategii interpretacyjnej: „Musimy przejść od hermeneutyki znaków lingwistycznych ku hermeneutyce znaków intermedialnych, interaktywnych i przetwarzanych"40. To metodologiczne przesunięcie (niezakładające - podobnie jak w przypadku teoretycznych propozycji lektury tekstów liberackich - porzucenia filologicznej interpretacji, lecz jej pogłębienie ${ }^{41}$ ) wydaje się konieczne dlatego, że znaczenie współtworzone jest nie tylko przez werbalny poziom wypowiedzi, lecz również przez „znaczenie słownego performansu, w którego skład - o czym nie możemy zapomnieć - wchodzi również interakcja użytkownika ze słowami” ${ }^{42}$.

Podkreślane podobieństwo liberatury i e-literatury zdaje się więc iść w parze z powtarzaną tu płynąca (m.in.) z wywodu autora Języka nowych mediów teza, że podziału sztuk należy dziś dokonywać w oparciu o inne niż dawniej kryteria ${ }^{43}$. Manovich - przypomnę - stwierdzał, że „kategorie estetyki postmedialnej nie powinny być związane z żadnym medium zapisu czy komunikacji”, że powinny odnosić się właśnie do sposobu „funkcjonowania” dzieła. A w tym duchu - liberatura i literatura elektroniczna mogą być sobie bardzo bliskie.

Owo pokrewieństwo pokazywałam, nie bez powodu sięgając do Aarsetha. Jego teoria pozwala tropić takie właśnie analogie: ujmując teksty jako maszyny, badacz pozwala porównywać zasady ich funkcjonowania (stąd taka perspektywa wygodna jest do pokazywania rozwoju, ewolucji poszczególnych form medialnych, nie ich nie wiadomo skąd się biorących nagłych i drastycznych metamorfoz). Dostrzega to i Manovich, o pracy Aarsetha wypowiadający się pozytywnie:

Doskonałym przykładem nowej kategorii - stwierdza w Estetyce postmedialnej, - która bierze pod uwagę współczesne teksty komputerowe, ale również teksty sprzed ery komputera, jest koncepcja literatury ergodycznej rozwinięta przez Erspena [Espena - AP] Aarsetha w jego książce Cybertext: Perspectives on Ergodic Literature ${ }^{44}$.

${ }^{40}$ Roberto Simanowski, What is and to What End Do We Read Digital Literature?, [w:] Literary Art in Digital Performance. Case Studies in New Media Art and Criticism, ed. Francisco J. Ricardo, New York-London 2009, http://dm.postmediumcritique.org/Book_LiteraryArtInDigitalPerformance.pdf [dostęp 28.05.2013].

${ }^{41}$ Simanowski wielokrotnie podkreślał, że konieczne jest przejście od czysto teoretycznego omawiania e-literatury (w tym właśnie wykorzystujących tekst instalacji) ku dogłębnym interpretacjom poszczególnych jej egzemplifikacji. Przekonany o literackości e-literatury proponuje rzetelne, semiotyczne (z zacięciem formalno-strukturalnym, w duchu close reading) analizy jako najlepszy sposób charakterystyki opisywanego zjawiska. Przekonaniu o słuszności takiej postawy metodologicznej dawał wyraz w licznych szkicach, jako jej realizację należy też traktować ostatnią książkę badacza (Digital Art and Meaning. Reading Kinetic Poetry, Text Machines, Mapping Art, and Interactive Installations, Minneapolis 2011). Nowszą publikacją realizująca podobne założenia stające się obecnie coraz wyraźniejszym trendem w badaniach e-literatury jest wartościowe opracowanie Analizing Digital Fiction (ed. Alice Bell, Astrid Ensslin, Hans K. Rustad, New YorkLondon 2014).

${ }^{42}$ R. Simanowski, What is and to What End Do We Read Digital Literature?

${ }^{43}$ Por. też przywoływane zbiory: Piękno $w$ sieci. Estetyka a nowe media oraz Estetyka wirtualności.

${ }^{44}$ L. Manovich, Estetyka postmedialna, s. 109 (przypis 5). 
Nawiązując jeszcze do kategorii „nowego czytania”, warto przywołać tu również słowa, którymi Jörgen Schäfer i Peter Gendolla, redaktorzy wydanego w 2010 r. tomu Beyond the Screen. Transformations of Literary Structures, Interfaces and Genres, podsumowują nową sytuację literatury:

Rozpoczyna się nowa Odyseja. Czytelnicy muszą powstać z „foteli tradycji”, w których wygodnie zasiadaja; muszą udać się na zewnątrz, wyruszyć na niepewne terytoria, w poszukiwaniu doświadczeń i przygód, prowadzeni ku nienazwanym jeszcze celom, przez wciąż malejących elektronicznych pomocników, którzy kiedyś przestaną być przez nas zauważani. Nad tym właśnie powinni dziś wspólnie zastanowić się czytelnicy ${ }^{45}$.

Z drugiej strony, niemal równolegle - podczas Europejskiego Kongresu Kultury w 2011 r. - i Bazarnik dyskutowała na temat liberatury na tle nowszych odmian sztuki słowa. Podkreślała, że literatury totalnej nie da się zdygitalizować, jednak to, co dla mnie najważniejsze w jej wypowiedzi, to zwrócenie uwagi na sposób lektury, jakiego wymaga liberatura od swoich czytelników.

Tych książek nie da się przenieść na ekran komputera - stwierdzała badaczka w udzielanym wtedy wywiadzie. - Trzeba usiąść z nimi, wziąć je do ręki, otworzyć, zagłębić się w nie prawie że fizycznie i w ten sposób czytać. To są książki, które proponują bardzo fizyczne czytanie $^{46}$.

Zatem, jeśli chcemy patrzeć na liberaturę, jako na odpowiedź na głoszoną (ale - jak sądzę - bez specjalnego oddźwięku) śmierć książki (co sugerowała Bazarnik w szkicu Liberatura czyli o powstawaniu gatunków... ${ }^{47}$ ), warto podjąć właśnie kwestię tego, jak się ją czyta. Choć interfejs może być tu podobny

${ }^{45}$ Cyt. za: Monika Górska-Olesińska, Medialne zawirowania. O nowych publikacjach w serii Media Upheavals, „Techsty” 2011, nr 7 (http://www.techsty.art.pl/magazyn/magazyn7/gorska-olesinska.html, dostęp 30.09.2011).

${ }^{46} \mathrm{Z}$ wypowiedzi udokumentowanej na wideoblogu Europejskiego Kongresu Kultury 2011, podkreślenia moje (http://www.culturecongress.eu/videoblog/video/videoblog_ekk_readinglab, [dostęp 30.09.2011]). Ale trzeba tu pamiętać, że i w e-literaturze właśnie nierzadko fizyczne, cielesne działanie czytelnika staje się wręcz warunkiem uruchomienia tekstu, jego pełnego poznania. Lektura staje się rozgrywka, doświadczenie literackie nagrodą w niej, gdyż (odwrotnie niż w klasycznej grze) musimy konfigurować, by móc interpretować (zob. Markku Eskelinen, The Challenge of Cybertext Theory and Ludology to Literary Theory, [w:] The Aesthetics of Net Literature. Writing, Reading and Playing in Programmable Media, ed. Peter Gendolla, Jörgen Schäfer, Bielefeld 2007). Kanoniczne i po wielokroć już omawiane przykłady (jak choćby projekty: Screen, Text Rain czy - krytycznie się odnoszące do interaktywnych tekstów e-literackich - Still Standing) unaoczniaja, jak istotny staje się w tym momencie czytelnik-uczestnik performance'u, rozgrywający tekstową partyturę. Będąc odpowiedzialnym za kształt rozgrywki, staje się tym, który odpowiada również za ostateczną formę opowieści i kształtuje ją na nowo w każdym kolejnym odczytaniu. Bez niego (i bez rozgrywki) tekst nie stanie się, nie zaistnieje, nie wybrzmi, nie da się odczytać [stąd właśnie proponowane przez Hayles rozumienie takich dzieł literackich nie jako niezależnych od czasu i działań odbiorczych artefaktów, lecz - pozostajacych w ontologicznym związku z czasem i miejscem wykonania oraz samym rozgrywającym - eventów (zob. Katherine N. Hayles, The Time of Digital Poetry: From Object to Event, [w:] New Media Poetics: Contexts, Technotexts, and Theories, eds. Adelaide Morris and Thomas Swiss, Boston 2006)].

${ }_{47}$ K. Bazarnik, Liberatura czyli o powstawaniu gatunków (literackich), s. 156. 
do tego, który znajdziemy w literaturze elektronicznej - jest w pełni materialny. Czytanie liberackie pozostaje czytaniem literatury również dlatego, że nie będzie tak wirtualne, jak doświadczenie zwiedzającego Virtual Museum. A książkowa maszyna zadziała czasem wcale niemetaforycznie. I tak jak dopełniając rozdział o liberaturze i literaturze wizualnej, pokazywałam, że jedna z powieści Selznicka jest prawdziwą maszyną (Aarsethowskim cybertekstem), dzięki któremu czytelnik tworzy (i uruchamia) opowieść, tak kończąc swój $D i$ gital Modernism Pressman - podkreślając właśnie rolę interfejsu, „mediującej technologii: książki" 48 w czytaniu pewnych powieści - objaśnia, że Only Revolutions Marka Danielewskiego to księga-maszyna, kodeks (niczym u Szkłowskiego) „uniezwyklający książkowe medium i dobrze nam znany akt lektury” ${ }^{49}$, tom, którym „sterujemy” (steer) niczym kołem ${ }^{50}$. Warto też podkreślić przy okazji, jak bliskie sa przywołane analizy amerykańskiej badaczki rozważaniom Bazarnik o strukturze globalnej Finneganów Trenu ${ }^{51}$.

\subsection{Ocalić literaturę?}

W tym miejscu warto powrócić do zarzuconej dyskusji z Hopfinger, opisywanych przez badaczkę reakcji literatury na kulturę audiowizualną i moich pytań zarówno o miejsce liberatury w tych podziałach, jak i ich użyteczność do charakterystyki kultury, na której tle sformułowano teorię liberacka. Przypomnę, na jakich ustaleniach poprzestałam.

Kwestia pierwsza to intermedialność liberatury. Literatura totalna rozumiana mogła być jako dzieło intermedialne, gdy traktowaliśmy słowo i obraz (często w niej występujące) jako oddzielne media, tzn. media, które poza utworem, w którym (z racji jego intermedialności) są nierozerwalnie połaczone, funkcjonuja samodzielnie, wyznaczając też właściwe dla siebie przestrzenie sztuki. W dziele o strukturze intermedialnej te podziały sztuk sa, rzecz jasna, przekraczane. Oczywiście, trzeba też pamiętać, że literatura totalna nie musi operować obrazem, że może być w pełni niewizualna. Stąd zapewne pojawiła się propozycja, by traktować jako medium liberackie książkę i w ten sposób zyskać możliwość objęcia refleksją i tekstów sięgających w obszary wizualności i tych, które aktywizują inne aspekty swojej (książkowej) postaci.

Czas, by wrócić do kwestii tego, czy owo eksponowanie książki w liberaturze jest tym samym, czym grafemizm, o którym pisała Hopfinger. Jak wskazywałam - wydawać by się mogło, że ujęcia te są bliskie. Niemniej - jak téz już zaznaczałam - Hopfinger, traktując język jako podstawę takiego utworu, pozostaje w kręgu refleksji łączącej konkretne media z odpowiadającymi im

${ }^{48}$ Ibidem, s. 160.

${ }^{49}$ J. Pressman, CODA..., s. 161.

${ }^{50}$ Ibidem, s. 160, 161.

${ }^{51}$ Por. Katarzyna Bazarnik, Globalne spojrzenie na „Finnegans Wake”, [w:] Wokót Jamesa Joyce'a: szkice monograficzne, red. Katarzyna Bazarnik, Finn Fordham, Kraków 1998. 
przestrzeniami sztuki. W konsekwencji, zaproponowana przez nią perspektywa zakłada, że w „tekście grafemicznym” - jako należącym do literatury i eksponującym swoją literackość - kluczowa jest „materia językowa” i (jak już wspominałam) sposób sfunkcjonalizowania w tekście pisanym (graficznie utrwalonego) języka właśnie.

Zwracając uwage na te kwestie, można dostrzec, że zakres pojęcia liberatura (gdy ta definiowana jest jako literatura, której medium jest książka) nie pokrywa się z zakresem zaproponowanego przez Hopfinger terminu. Po pierwsze - sugerowane przez teoretyków literatury totalnej ujęcie miało pozwolić mówić o dziele literackim wykorzystujaccym rozmaite tworzywa. Innymi słowy: choć Fajfer czy Bazarnik wskazują na jedno medium (książkę), maja na myśli dzieło (potencjalnie przynajmniej - bo przecież niekoniecznie zawsze) wielomedialne. Dość to paradoksalne, niemniej - w świetle postawionych tu wcześniej tez, dające się - jak mniemam - zrozumieć.

Książka staje się w tym ujęciu sposobem udostępnienia odbiorcy artystycznego komunikatu, dzieła: umożliwia interakcję. Odwołując się po raz kolejny do nowomedialnych typologii - można powiedzieć, że jest nie tyle medium, co - podobnie jak Internet pozwalajacy wykorzystywać równolegle słowo, obraz, dźwięk itp. - transmedium. Z tych właśnie powodów napisałam wcześniej, że w sformułowanej przez Hopfinger charakterystyce, choć przekaz grafemiczny rozumiany jest jako związany z materią książki, z układem i porządkiem stron - nie ma szansy wybrzmieć jako (liberackie) dzieło w formie książki. Jest utworem w formie grafemicznej: językowej i wydrukowanej. To zaś znacznie mniej niż liberatura.

Stawiałam też pytanie o to, jak w podział zaproponowany przez Hopfinger wpisać liberaturę. Sugerowałam, że właśnie konieczność dopowiedzenia rozmaitych kwestii w związku z intermedialnością i grafemizmem sprawia, że wydaje się to problematyczne. Czy przedstawione uzupełnienia pozwalaja umieścić liberaturę w opisanym przez Hopfinger świecie literatury reagującej na media i kultury uwikłanej w relacje z nimi (lub odnieść ją do zaktualizowanej wersji tego opisu)?

Podsumowując dotychczasowe rozważania, można wypunktować, iż w ujęciu przywołanej badaczki literatura, reagując na kulturę audiowizualną albo (1) realizowała w swoim tworzywie (medium) struktury właściwe dla innego medium (by jeszcze inaczej scharakteryzować literature paraaudiowizualna), albo (2) korzystała z możliwości łączenia w swoim zakresie różnych mediów (kontynuując tradycję niecyfrowej twórczości intermedialnej) bądź też (3) broniła swojej literackości, obstając przy konkretnym medium (słowie drukowanym). Próba zaktualizowania tej charakterystyki w kontekście nie tyle audiowizualności, co - szerzej - nowomedialności prowadzi zaś ku zauważeniu, że literatura może (1) korzystać ze struktur, jakimi operują nowe media i stawać się w ten sposób naturalnie wykorzystująca rozmaite media literaturą elektroniczna, (2) nie sięgać do elektroniki, lecz w obszarze słowa i innych mediów - powiedzmy - tradycyjnych tworzyć dzieła intermedialne (które jednak w otoczeniu utworów nowomedialnych, które ex definitione buduja przekazy 
oparte o struktury wykorzystujące równolegle różne media, stają się mniej wyjątkowe), (3) obstawać przy literackości w tradycyjnym rozumieniu i skupić się na tekstach, które sa - można powiedzieć - (,po staremu”) jednomedialne, operują wyłącznie słowem.

Nie mam wcale wrażenia, że liberatura da się łatwo w tym schemacie umieścić. Raczej jestem przekonana, że wyrażane w pierwszej części tych rozważań poczucie, że jedną z ważniejszych jej cech jest właśnie bycie ponad wszelkimi podziałami, było słuszne. Jak bowiem zachowuje się liberatura w świecie nowych mediów? Po pierwsze - choć nie jest literaturą elektroniczna, jednak korzysta z podobnych, jak ona mechanizmów tworzenia znaczeń (tu sprawę komplikuje nam dodatkowo opisany casus hipertekstowego Końca świata wedtug Emeryka). Po drugie, rzeczywiście, przypomina również inne, nie-cyfrowe tradycje intermedialne, jednak - raczej w przeciwieństwie do nich - obstaje przy tym, że jest w pełni literacka (liberaci nie chca w gruncie rzeczy być postrzegani jako twórcy literackich intermediów, lecz jako: pisarze, literaci). Po trzecie, konsekwentnie broni swojej literackości, jednak właśnie wcale nie dbając o czystość tworzywa literatury, lecz je świadomie poszerzajac. Zatem jak by na to nie patrzeć - liberatura znów przekracza zaproponowane podziały, nijak nie mieszcząc się w ich ramach.

Czy jednak należy ją na siłę w nie wtłaczać? I czy jest sens formułować w tym celu nowe typologie (a zatem odrzucić nawet zaktualizowany i w takiej wersji, jak sądzę, słuszny obraz kreślony przez Hopfinger)? Podobnie jak nie zgadzałam się z tym, by dopisywać liberaturę do ustalonych genologicznych schematów, tak nie sądzę, by w tym wypadku warto było silić się na intelektualne akrobacje służące wpisaniu jej w ramy udoskonalonych podziałów. Istota literatury totalnej - i tym razem - tkwi w umiejętności wykpienia zaproponowanej typologii. A na czym polega fenomen jej niewpisywania się w żadna z wymienionych kategorii? Liberatura po prostu z każdej możliwości wybiera to, co pozwoli pogłębić lit(b)eracką komunikację - z literaturą elektroniczna oraz tekstami intermedialnymi łączy ją sposób kreowania znaczeń i angażowania czytelnika, również pewna atrakcyjność wynikająca z wyjątkowości poszczególnych dzieł, braku wyraźnych konwencjonalnych wyznaczników; od literatury „tradycyjnej” czerpie zaś wszystko to, co czyni jej komunikaty tak ekspresyjne: poszczególne tropy, formy itp., od niej uczy się też operowania słowem (które przecież uznaje za jedyne z obowiązkowych swoich mediów). Korzystając z wszelkich udogodnień w kreowaniu komunikatów pozwalajacych możliwie najpełniej wyrazić to, co ma w nich być wyrażone, liberatura zdaje się mówić, że w świecie literatury nie ma rzeczy niemożliwych, że nie ma czegoś, czego w książce (także jej forma) nie da się opowiedzieć. Wystarczy jedynie dobrze poszukać: nie tylko odpowiednie dać rzeczy słowo, lecz i ubrać ją we właściwy kształt.

Mówiąc inaczej - liberatura o tyle jest odpowiedzią na śmierć ksiażki, że pokazuje, iż wcale nie musimy sięgać po media elektroniczne, by móc „czytać inaczej”. Uzmysławia nam, że technologia nie jest tu różnica konstytutywna. Uświadamia, iż odmienny jest wyłącznie stosunek do materii komunikatu, 
umiejętność jej twórczego wykorzystania przy kreacji tekstu. Liberackie uwalnianie od konwencji to również wyzwalanie od myślenia, że książka musi być zawsze taka sama, że jest wyeksploatowanym interfejsem, że zawarte w niej słowa „odpoczywaja”, a forma jest „niema” i, że by było inaczej - musimy wkroczyć w świat wirtualny. Jak można było dowiedzieć się z materiałów prasowych Europejskiego Kongresu Kultury:

Czytelnik liberatury jest interaktywnym odbiorca analogowej instalacji. Musi być czujny i wrażliwy także na przekaz pozasłowny. Czyta wszystkimi zmysłami ${ }^{52}$.

Dobrze przywołać tu na zakończenie historię opowiadaną przez Dorotę Sikorę na łamach „Techstów”. Jackie Craven, autorka hipertekstowego dzieła In the Changing Room początkowo planowała stworzyć klasyczna, książkową narrację. Co sprawiło, że sięgnęła po inne niż klasyczna książka medium? Jak wyznaje artystka, forma taka była niewystarczająca dla spraw, o których chciała pisać. Craven pytała:

\begin{abstract}
Jak mogłabym stworzyć iluzję pojawiania się i zanikania głosów? W jaki sposób mogłabym podkreślić związki między zdarzeniami obecnymi w opowiadaniu różnych narratorów? W jaki sposób mogłabym ukazać owo napięcie, które rodzi się między ludźmi połączonymi relacjami podległości i władzy? [...] Wiedziałam, że istnieją techniki literackie, które byłyby pomocne. Mogłabym na przykład podzielić opowiadanie i przeplatać opowieści różnych postaci. Próbowałam tego. Jednak słowa na papierze, unieruchomione przez obecność innych słów i zdań, zaprzeczały fundamentalnym tematom mojej książki, opowiadania o niemocy, o braku zgody na podporządkowanie się komuś, w końcu o przemianach, jakie w ludziach następują w wyniku obcowania z innymi ludźmi. Dlatego też, gdy tylko dowiedziałam się o istnieniu hipertekstu, dowiedziałam się, co potrafi, zapisałam się na zajęcia Roberta Kendalla, które prowadził w New School for Social Research. To była miłość od pierwszego linku ${ }^{53}$.
\end{abstract}

Być może, gdyby zamiast do Kendalla trafiła do Fajfera (lub Bazarnik - co akurat z racji wykonywanego przez nią zawodu - bardziej prawdopodobne), ujęłaby swoją opowieść jednak w ramy książkowe. Liberaci pokazują bowiem, że nie trzeba uciekać się do elektroniki, by uwolnić słowa, by sprawić, żeby nie były już (jak sugerował też de Kerckhove) odpoczywające, nieruchome. Nie ma tematów, którym zaprzeczałaby forma liberackiej książki. Czasem tylko długo trzeba jej szukać. Nie tylko w świecie nowych mediów teksty mogą wyłaniać się i rodzić jedne z drugich, ukrywać na zawołanie, przeobrażać na oczach czytelnika. To wszystko udało się osiagnaç autorom Oka-leczenia w formie książki (nieco odbiegającej od standardów, jednak: materialnej, a nawet papierowej, czarno-białej i drukowanej). Zatem, być może, Przypadek (jak wiemy, w historii liberatury - istotny) sprawił tylko, że miłość Craven była miłością od pierwszego linku, a nie emanacji.

${ }^{52}$ http://www.culturecongress.eu/pressroom/press_reading_lab?print=1 [dostęp 30.09.2011].

${ }^{53}$ Cyt. za: Dorota Sikora, O Word Circuits Connection Muse-zestawie narzędzi do tworzenia poezji i prozy sieciowej, „Techsty” 2005, nr 5, http://techsty.art.pl/magazyn/magazyn5/artykuly/ sikora02.html [dostęp 30.09.2011]. 


\subsection{Liberackość nasza współczesna albo o zwrocie interfejsologicznym w literaturoznawstwie}

Nie sposób dyskutować z teza, iż przemiany wprowadzone przez nowe media zasadniczo rekonfiguruja kształt współczesnej sztuki słowa, zmieniając jednocześnie charakter aktu lektury. Ponadto, choć zgodnie z myśla wielu teoretyków (m.in. choćby: McLuhana, Onga czy Levinsona) poszczególne media spajały dotąd literaturę (i samo czytanie) z konkretnymi zmysłami ${ }^{54}$, współczesne konfiguracje medialne pozwalają snuć opowieści w pełni synestezyjne, działające naraz na wiele zmysłów i nieraz wymagające od odbiorców realnych działań. Jednak rzecz nie dotyczy tylko e-literatury: przeobraża się cała sztuka słowa. I książka - jako jedno z mediów literackich - w niektórych wypadkach staje się (jak chciał McLuhan) już nie tylko message, ale i massage, zaprasza do rozmaitych sposobów aktywnego, zmysłowego i nieraz pełnego (dosłownych, nie metaforycznych) czytelniczych gestów aktu lektury.

Istotnie, nie czytamy „zwyczajnie”, gdy odbijamy odrywające się od ścian wirtualnej jaskini dźwięczące słowa przywoływanego Screen, chcąc, by wróciły na swoje miejsce w zapisanej historii i pozwoliły nam ocalić wspomnienie, wygrać bitwę z pamięcia, której uczestnikami staliśmy się, rozpoczynając bliska grze lekturę. Jesteśmy wyzwoleni z dyktatury wzroku (i w ogóle lektury monozmysłowej) także wtedy, gdy - generując kolejne teksty - przesuwamy kolorową zasłonę text.curtain (Daniel C. Howe, 2005), czy kiedy - w przypadku Legible City (Jeffrey Shaw, 1989) - pedałujemy na rowerze, by przejechać przez zbudowane z liter miasto i poznać (odczytać) jego/jego mieszkańców historię/ $\mathrm{e}^{55}$. W'śród prac prezentowanych na (dopełnianych towarzyszacymi wystawami) międzynarodowych konferencjach poświęconych literaturze elektronicznej (jak choćby te organizowane corocznie przez Electronic Literature Organization) czy związanych z nią festiwalach (np. podczas odbywającego się co dwa lata e-Poetry) coraz częściej pojawiają się utwory, w których słów się dotyka, odbija czy gra nimi (projekty te, wykorzystując m.in. popularne konsole z czujnikami ruchu - np. konsolę XBox z Kinectem ${ }^{56}$ ). Sytuację tę dobrze oddają słowa, jakimi Pisarski podsumowuje ostatnie (2013) londyńskie biennale e-Poetry: „przestrzeń i ciało zastępują kartkę papieru jako pole pisma dla poetyckiej ekspresji” ${ }^{57}$.

${ }^{54}$ Inaczej sensualna była literatura ustna, wiążąca człowieka z tym, co słyszalne i sprzyjająca odbiorowi zbiorowemu, zaś galaktyka Gutenberga (i wcześniejsze, odręczne formy zapisu) splotła sztukę słowa z kulturą wzroku, wprowadziła indywidualne obcowanie z dziełem, a - jak dowodzi zadziwienie św. Augustyna cichym czytaniem Ambrożego (por. św. Augustyn, Wyznania, tłum. Zygmunt Kubiak, Kraków 2001, s. 139) - również lekturę odartą z audialności, ściśle wzrokocentryczna.

${ }_{55}$ Agnieszka Przybyszewska, Po(d)żeranie tekstu. Wstęp do rozważań o czytaniu kinetycznym, [w:] e-polonistyka 3, red. Aleksandra Dziak, Lublin [w druku].

${ }^{56}$ Przykładem prace Zuzany Husárovej i Lubo Panáka. Por. np. dokumentacja z e-Potery 2013 dostępna pod adresem: http://vimeo.com/71956353 [dostęp 15.09.2013].

${ }^{57} \mathrm{http}: / / \mathrm{www}$. techsty.art.pl/aktualnosci.html [dostęp 15.09.2013]. 
Ale do takiego „innego”, angażującego różne zmysły czytania powoli przyzwyczajają się nie tylko ci, którzy sięgają po wystawiane w galeriach (dostępne zatem nie zawsze i wcale nie tak szerokiemu przecież gronu odbiorców) literackie lub po części literackie instalacje interaktywne, najsilniej angażujące zarówno realną przestrzeń, jak i wspomniane ciało odbiorcy. Do takiej samej lektury zapraszają liczne prace dostępne on-line (a więc z założenia: dla wszystkich, zawsze i wszędzie). I tak - czytelnicy Toucher (Serge Bouchardon, Kevin Carpentier, Stéphanie Spenlé, 2009) muszą dmuchnąć na usypujące się na ekranie płatki śniegu, by odsłonić tekst, jeśli chca go przeczytać (w części zatytułowanej $B l o w)^{58}$, zaś inny fragment tej pracy wykorzystuje technologię śledzenia ruchu gałki ocznej, stąd, zagłębiając się weń - dosłownie, nie metaforycznie - nie sposób odeń oczu oderwać ${ }^{59}$. Sięgający po The Winter House Naomi Alderman (2010) część narracji poznają niczym w filmie czy nawet w grze (oglądając ruchome obrazy, kierując zmianą perspektywy, podejmując decyzje wpływające na sposób dalszego snucia opowieści), a odbiorcom Nio Jima Andrewsa raczej trudno zignorować warstwę dźwiękową utworu, gdyż to właśnie audialny i performatywny aspekt wydaje się kluczowy w tej - przywołującej nie tylko tradycję dźwiękowej poezji konkretnej, ale i projekty Kurta Schwittersa - pracy, której użytkownicy stają się kompozytorami korzystającymi $\mathrm{z}$ tekstu rozumianego jako instrument (tzw. instrumental text) ${ }^{60}$.

${ }^{58} \mathrm{~W}$ tej dostępnej w drugim tomie Electronic Literature Collection pracy (http://collection. eliterature.org) aktywowane są różne - zdecydowanie nieklasyczne - sposoby doświadczania tekstu, również dotyk, a Barthesowska przyjemność tekstu w części Caress staje się - dosłownie przyjemnością pieszczonego naszym dotykiem utworu. W tym fragmencie dostrzegalne jest, moim zdaniem, również subtelne nawiązanie do analizowanego tu wcześniej Le soir, couchée dans son lit... Marinettiego, co dałoby się interpretować jako przywołanie futurystycznych wierszy-plakatów jako form poszukujących podobnych (transmedialnych) rozwiązań komunikacyjnych. Jeśli pamiętać o tym, jak mało odpowiednią dla ich literatury wydawała się futurystom forma klasycznej książki, nie wydaje się, by taki trop interpretacyjny był nadużyciem.

${ }^{59} \mathrm{O}$ wykorzystujących już nie tyle cielesność, co wręcz fizjonomię, integrowanych z oddechem odbiorcy interfejsach wspomina też Górska-Olesińska: zob. Monika Górska-Olesińska, Playable poetry i gry komputerowe. Krytyczne negocjacje, [w:] Olbrzym w cieniu. Gry wideo w kulturze audiowizualnej, red. Andrzej Pitrus, Kraków 2012.

${ }^{60}$ Kategorie tekstowych instrumentów (textual instruments) i tekstów jako instrumentów (instrumental texts) przywołuję za Noahem Wardrip-Fruinem oraz Johnem Cayley'em, którzy określili tym mianem odmiany tzw. literatury grywalnej (playable literature), sztuki słowa zapraszającej czytelników-użytkowników do interakcji tak silnie, iż rozegranie utworu jest jedyną możliwościa jego poznania. Słowem - w ręce użytkowników oddany jest rodzaj partytury o otwartej (w przypadku tekstowych instrumentów) lub zamkniętej (w przypadku tekstów jako instrumentów) bazie danych. Por. Noahem Wardrip-Fruin, Playable Media and Textual Instruments, [w:] The Aesthetics of Net Literature. Writing, Reading and Playing in Programmable Media, ed. Peter Gendolla, Jörgen Schäfer, Bielfeld 2007; idem, From Instrumental Texts to Textual Instruments, [w:] Proceedings of Digital Art and Culture 2003, Melbourne 2003, http://www.hyperfiction.org/texts/textualInstrumentsShort.pdf [dostęp 28.05.2013]; From Byte to Inscription. An Interview with John Cayley by Brian Kims Stefans, „The Iowa Review Web”, February 2003, http://iowareview. uiowa.edu/TIRW/TIRW_Archive/tirweb/feature/cayley/cayley_interview.pdf [dostęp 28.05.2013]. Por. też M. Górska-Olesińska, Playable poetry... . Więcej o kategoriach literatury grywalnej, tekstach instrumentach i tekstach jako instrumentach piszę tė̇ w szkicach Po(d)żeranie tekstu. Wstep do rozważań o czytaniu kinetycznym oraz Ku literaturze grywalnej... . 
Również ci, którzy sięgają po teksty zremediowane, nowomedialne edycje dzieł planowanych i z sukcesem wydanych jako klasyczne książki, nierzadko czytaja „inaczej”. Interaktywne ilustracje (ruchome i zmienne dynamiczne obrazy reagujace na nasz dotyk - a nieraz choćby i na potrzasanie elektronicznym czytnikiem - ruchem czy dźwiękiem) nie są ozdobą wyłącznie e-książek adresowanych do najmłodszych. Z elementami świata przedstawionego wirtualnym dotykiem poigra nie tylko nieletni czytelnik jednej z wielu elektronicznych reedycji historii Czerwonego Kapturka, ale i dorosły sięgajacy po Poego, Wellesa czy Stockera. I w tej przestrzeni z czasem w coraz większej ilości projektów obraz (nierzadko ruchomy) i dźwięk stają się pełnoprawnymi „współopowiadaczami” słowa, a semantyczna wartość komunikatu oryginalnie projektowanego jako jednomedialny zostaje sprawnie rozpisana pomiędzy różne w gruncie rzeczy kanały komunikacji, wymuszając na odbiorcy lekturę polisensoryczną ${ }^{61}$.

Co jednak najciekawsze, równolegle publikacje „staromedialne”: w pełni „analogowe” książki nie stronią od form, które w niczym nie przypominaja tego, co zwykliśmy z książką kojarzyć. I wcale nie mam tu na myśli przede wszystkim publikacji wydawanych w ramach ha!artowskiej serii Liberatura, lecz - dużo istotniejsze w moim wywodzie - popularne, dostępne szerokiemu gronu odbiorców pozycje z literatury współczesnej. W'śród nagradzanych i - co chyba kluczowe - sprzedanych w milionach egzemplarzy książek znajdziemy przecież: Dziwny przypadek psa nocna porq Marka Haddona (2003²), w którym rysunki narratora - autystycznego chłopca - stanowią integralną część detektywistycznej opowieści (funkcjonując nieraz na zasadzie - powiedzmy - liberackich cytatów z rzeczywistości $\left.{ }^{63}\right)$, łączace obraz i słowo przywoływane już tu powieści Briana Selznicka: Wynalazek Hugona Cabreta (2007) oraz Wonderstruck (2011), cykl Griffin \& Sabine Nicka Bantocka (ukazujący się od 1991 r.), w którym poszczególne tomy pełne sa (pochowanych w kopertach) materialnych listów, Pamiętnik Cathy Seana Stewarta i Jordana Weismana (2006) ${ }^{64}$, zawierajacy (oprócz wyglądającego jak prawdziwy, pokreślony pamiętnik nastolatki notesu) rozmaite zbierane przez bohaterkę „dowody”, które czytelnicy - odnalazłszy dziennik - powinni (jako jego integralne elementy) wykorzystać, by rozwiązać zagadkę, czy Pożeracza myśli Stevena Halla (2007), opowieści, w której groźna tzw. ryba konceptualna (rekin Ludovician) dosłownie wyłania się z kart powieści. Autor ostatniej z wymienionych książek wyznał w jednym wywiadów, że jeszcze 10 lat temu czytelnicy nie byli gotowi na powieści w tym rodzaju. Czy rzeczywiście? I co takiego się zmieniło?

61 Więcej na ten temat zob. Agnieszka Przybyszewska, O niektórych strategiach otwarcia na czytelnika w wybranych przyktadach literatury nowomedialnej (rekonesans), [w:] Teksty kultury uczestnictwa, red. Andrzej Dąbrówka, Maciej Maryl, Aleksandra Wójtowicz [w druku].

${ }^{62}$ Podaję datę publikacji powieści w oryginale.

${ }^{63}$ Zamiast opisywać coś, do czego bohater się odnosi, przytacza to - zatem zamiast ekfrazy rysunku czy mapy daje sam rysunek czy mapę itd.

${ }^{64}$ Kolejne tomy autorów silniej już wchodziły na nowomedialne platformy (Cathy's Ring, Cathy's Key). 
Trudno chyba powiedzieć, że coś konkretnego stało się w literaturze, przyczyniając się do opisanej metamorfozy. Mamy raczej do czynienia z sytuacja, w której pewna jakość/możliwość sztuki słowa nagle silniej wybrzmiewa i równolegle jest coraz skrupulatniej opisywana. Stąd przełom XX i XXI w. to czas narodzin (czy „wysypu”) nie tylko „innych” książek (analogowych i elektronicznych), ale i teorii, które ową odmienność próbują jakoś zakwalifikować. Coraz więcej mówi się więc o „fetyszyzacji” książkowego, analogowego kształtu sztuki słowa (jak ujmuje to Pressman), o „powieści jako książce”, „literaturze w formie książki” (jak postulują Maziarczyk, Fajfer i Bazarnik) czy „materialności literatury" (jak podsumowywała Hayles). Słowem - coraz silniej wybrzmiewają głosy pokazujace istotność McLuhanowskich ustaleń dla sztuki słowa, zwracajace uwage na pewne „metodologiczne niedowidzenia” (że raz jeszcze przywołam Hausken) w pojmowaniu istoty literackiej komunikacji. A trzeba tu przypomnieć, że i Aarseth wyraźnie podkreślał, że koncepcja cybertekstu służyć ma opisaniu „strategii komunikacyjnych” ${ }^{65}$ pewnej odmiany tekstów.

Jednocześnie współczesność to czas, w którym teoretycy wychodzący od badania materialności „materialnej literatury”66 spotykają się w połowie drogi z tymi, którzy swoje poszukiwania zaczynają w obszarze materialności wirtualnej. A jak pokazuje Hayles: spojrzenie na niekonwencjonalne książki owocuje dostrzeżeniem, jak wiele z rzeczy, które wydawało się możliwych dopiero w nowych mediach, daje się zrealizować i w formie analogowej książki. Stąd - w teorii technotekstu (wyłożonej przez badaczkę w ramach Writing Machines... - co może warto raz jeszcze podkreślić - później niż Fajfer ogłosił teorię liberatury $\left.{ }^{67}\right)$, istotny staje się nieneutralny interfejs literatury. Wszystkie przywoływane tu teorie łaczy bowiem zwrócenie uwagi na to, że książka (konwencjonalna) to tylko jeden z wielu możliwych interfejsów sztuki słowa. Współczesność zaś to czas interfejsów niekoniecznie przezroczystych, stąd i książki czasem podają nam opowieści w sposób niecodzienny. Być może, w konsekwencji możemy wręcz mówić o początkach zwrotu interfejsologicznego w badaniach literackich ${ }^{68}$.

Słowem - z której strony by na dzisiejszą sztukę słowa nie spojrzeć - coraz silniej wybrzmiewa w niej pewna jakość, która - potencjalnie - cechowała ją od zawsze, jednak dopiero współczesność (ze swoją technologia, ale - co chyba ważniejsze - kulturą konwergencji i uczestnictwa, czasami po zwrocie ikonicznym i performatywnym) pozwoliła jej wybrzmieć w pełni. Stąd nic

${ }^{65}$ Espen J. Aarseth, Cybertext. Perspectives on Ergodic Literature, Baltimore-London 1997, s. 5 .

${ }_{66}$ Bywa ona określana czasem p-literatura (od paper-literature) w opozycji do e-literatury (electronic-literature).

${ }^{67}$ Aczkolwiek, sama kategoria materialności i medialności (eksplorowania swojego medium, materialności tekstu liberackiego) w wywodach Bazarnik i Fajfera wprost wybrzmiewa znacznie później, choć - przez twórców teorii nieprzywołana - wynikała od początku z ich wywodu.

68 Jego owocem byłyby publikacje takie jak przywoływane Reading Writing Interfaces Emerson czy trzeci numer „Tekstów Drugich” z 2014 r. (poświęcony zagadnieniu Nośnik jest przekazem). 
dziwnego, że teoretycy poszukują terminu, który ująłby ową coraz silniej się ujawniajaca kategorię. Liberatura, a przede wszystkim postulowana przeze mnie liberackość jest jedną z takich propozycji. Wygodną i użyteczna, jak sądzę, gdyż pozwalająca i mówić o tekstach realizowanych w różnych mediach, i porównywać utwory zatrudniające swój interfejs w proces komunikacji w różnym stopniu. Przywołując raz jeszcze słowa Higginsa, które stały się mottem dla pierwszych stron tej książki, można powiedzieć, iż współczesne słowa to słowa z krwi i kości, słowa „zmieniajace skórę”. Nie umarły - odrodziły się jako cielesne i niektóre z nich całkiem twórczo się z ową cielesnością obnosza. Liberacko obnoszą. 


\section{Konkluzje}

Zarysowawszy tło, na jakim kształtowała się teoria liberacka, pokazawszy kolejne konteksty, które pozwalają ciekawie mówić o literaturze totalnej, muszę powrócić do pytań zadanych na początku tej książki i formułowanych tam hipotez. Czy były słuszne? Czy potwierdziły się w toku wywodu? Czy gotowa jestem sformułować inna, lepszą definicję liberatury?

Przede wszystkim - postulowałam, by pozbawić wywód Bazarnik i Fajfera zbędnych tautologii i stwierdzałam, że wyłuskując z ich teorii najważniejsze kwestie (także: odsiewając te, które nie dadzą się obronić) można spróbować ujać liberature jako taki rodzaj literatury, w którym jej medialność jest świadomie eksplorowana przez artystę, używana do kreowania sensów dzieła. Pokazywałam, że w gruncie rzeczy formułowane przez Bazarnik wyznaczniki liberatury dają się sprowadzić do tej właśnie jednej cechy, (potencjalnie) realizowanej na poszczególnych poziomach dzieła (od typografii po całą książkę), co sprawnie pozwoliła też ujaćc kategoria interfejsu, która w miarę rozwoju mojego wywodu okazywała się coraz bardziej użyteczna.

Sugerowałam również, że sam termin liberatura jest mało poręczny, jako zmuszający do spoglądania na świat literatury jako czarno-biały, jakby nie było w nim odcieni szarości. Proponowałam w zamian mówić o liberackości jako cesze, którą mogą mieć dzieła z obszaru sztuki słowa, co pozwalałoby mówić o gradacyjności tego aspektu, porównywać ze sobą różne utwory, nie wyłącznie zaś opatrywać je etykietkami. Sądzę, że obie te hipotezy potwierdziły się w toku wywodu.

Teraz dodałabym do nich trzeci postulat: by uznać, że choć liberackie bywajac dzieła od antyku po współczesność, to właśnie przełom XX i XXI w., aktualny kształt kultury (z jej uwikłaniem w nowomedialność) wykreowały nad wyraz podatny grunt, na którym liberackie ziarno mogło zostać zasiane: był to idealny moment na narodziny takiej teorii (co starałam się pokazać w ostatnich rozdziałach). Warto może oddać na chwilę głos samej Bazarnik, która w 2010 r. stwierdzała:

Wywrotowy charakter liberatury polega też na tym, że pokazuje konwencje jako historyczne konstrukty, które można zmieniać, jeśli tego chcemy i uważamy za konieczne. Jako twórcy znaleźliśmy się w momencie, gdy w zasięgu naszych możliwości również społecznych, technologicznych i ekonomicznych, jest pisanie i wydawanie takich książek. Okazało się, że można je wydać, bo pojawiły się sprzyjające okoliczności i ludzie (mam na myśli wydawnictwo Korporacja Ha!art), którzy chcieli z nami współdziałać i wprowadzili te książki do obiegu ${ }^{69}$.

${ }^{69}$ Ile stron ma liberatura? Z Katarzyna Bazarnik i Zenonem Fajferem rozmawia Adam Poprawa, „Conrad”, dodatek tematyczny do „Tygodnika Powszechnego” 2010 (z 31 października), nr 44, s. 7. 
Jak pokazywałam, technologicznie - byliśmy w gruncie rzeczy przygotowani na to wcześniej, jednak liberatka ma rację w tym, że społecznie (myślę, że zgrabniej byłoby powiedzieć: kulturowo) jesteśmy na liberaturę gotowi właśnie teraz. Inną sprzyjającą okolicznością jest też na pewno przygotowanie, powiedzmy, medialne: obycie z kultura intermedialną/audiowizualna/multimedialna.

Nie wyklucza to, oczywiście, możliwości powstawania dzieł (i teorii) tego typu wcześniej. Dlatego właśnie przyglądałam się rozmaitym obszarom sztuki słowa (i jej pograniczom) podejrzewanym o liberackość. Celem było z jednej strony zweryfikowanie tego, czy podejrzenia te słusznie się pojawiały (jak się okazało - nie w każdym wypadku), z drugiej - próba pogłębienia odpowiedzi na pytanie, czym ma być liberackość, a przynajmniej sprawdzenia, czy sugerowane przeze mnie ujęcie jest zasadne. Jeżeli twierdzę, że moje hipotezy się sprawdziły, to dlatego, że w przypadku tych obszarów, w których rzeczywiście udało się ową liberackość odkryć, okazywało się, że sedno ich pokrewieństwa $\mathrm{z}$ literatura totalna tkwi w podejściu do medium literatury (w najszerszym ujęciu: do literackiej komunikacji).

Poezja wizualna bywa liberacka, gdy sensy rozpisane sa w niej pomiędzy dwa rodzaje znaczacych: wizualne i werbalne (gdy - jak w przypadku kaligramów - to samo znaczenie powtórzone jest dwukrotnie, liberackość jest już dyskusyjna). Poezja konkretna przypomina literaturę totalną w swoim podejściu do tworzywa, chęci wydobycia zeń „więcej”, choć odróżnia ją od liberatury chęć redukowania potencji semantycznej języka. Komiks nie zdał egzaminu z liberackości, gdyż mimo że łączy w sobie dwa tworzywa, nie eksploruje w żaden sposób swej medialności, lecz wyłącznie korzysta z wypracowanego schematu. A nawet: nie tyle świadomie zeń korzysta, co nieświadomie „papuguje”.

Liberacki charakter można przypisać działaniom futurystycznym, gdyż i tam potrzeba poszerzania literackiej ekspresji wynikała z braku adekwatnych środków do wyrażenia (w skonwencjonalizowanej formie) tego, co chciałoby się przekazać. Nowa typografia miała nie tyle uatrakcyjnić teksty, co zwiększyć ich siłę wyrazu. W tym też wypadku, inaczej niż np. w druku funkcjonalnym (który egzamin z liberackości „oblał”), sposób graficznego ukształtowania tekstu był uwzględniany już na etapie tworzenia utworu i dzięki temu część znaczeń od razu wyłącznie z nim (a nie słowem) była związana. Ten sam pomysł nieraz rządził u Marinettiego poziomem werbalnym i wizualnym, co pokazywałam na przykładzie stosowanych metafor; w tym wypadku eksplorowanie medialności prowadziło ku tekstom interesująco drażniącym rozmaite zmysły. Typografia nowomedialna, której omówienie zapowiadało późniejszy rozdział przywołujacy literaturę elektroniczna, pozwoliła zaś pokazać, jak nowe media umożliwiają wprowadzenie do utworu nowej składni, zrównanie hierarchii elementów. Na jej przykładzie można było zobaczyć, jak pogłębić moc słowa, wykorzystując jego materię (w tym wypadku wirtualna), czy - mówiąc inaczej: korzystając z jego (nowej) medialności.

Rozważania poświęcone książce artystycznej i książce konwencjonalnej pokazały, że istota liberackiego odżegnywania się od jednej i od drugiej tkwi 
tak naprawdę w tym, że żadna nie pozwala pogłębić procesu literackiej komunikacji. Pierwsza - gdyż nie o literacką komunikację jej chodzi (co, jak wskazywałam, potem liberaci zweryfikowali), druga - gdyż popada w konwencję i swój (jak nazwałam to później) interfejs czyni przezroczystym.

Ukoronowaniem tych poszukiwań było przyjrzenie się liberaturze na tle nowomedialnej sztuki słowa. Ta perspektywa pozwoliła mi utwierdzić się jeszcze mocniej we wcześniej formułowanych tezach. Przede wszystkim dlatego, że w przestrzeni dyskusji o tym, co elektroniczne, znalazłam wiele użytecznych teorii (np. ujęcie Aarsetha czy Hayles) czy myśli, które pozwoliły wyraźniej jeszcze wypunktować istotę liberackości. Przede wszystkim zaś pomogły uargumentować, że istnieje wielowiekowa tradycja takiego eksplorowania medium, o jakim mówię, definiując liberaturę i liberackość ${ }^{70}$. U inspirującego mnie Aarsetha pozostaje ona jeszcze nienazwana, gdyż kategoria ergodyczności wydaje się przypisana do nieco innego porządku (silnie akcentuje kategorię odbiorcy, ja poszukiwałam terminu zdolnego oddać charakterystykę samego dzieła).

Tym samym, kończę moje rozważania przekonana o czterech rzeczach. Po pierwsze - zaproponowany w 1999 r. termin jest użyteczny. Pozwala ujaćc coś, co dotychczas trwało nienazwane: taki wymiar literackości, który łączy rozmaite (ujęte $\mathrm{w}$ siatkach terminologicznych) zjawiska, jak choćby futurystyczne eksperymenty z typografia, poezję wizualna Mallarmégo czy niektóre wiersze konceptualne (Nieradzki). Formułowane już w pierwszych liberackich manifestach nakazy teoretycznoliterackich porządków terminologicznych wymierzone zaś były nie tylko w rozumienie przywołanych w tych szkicach terminów (forma, książka itp.), lecz i zasadniczo w nasz sposób pojmowania całej literackiej komunikacji (opartej na technice skonwencjonalizowanego używania przezroczystego medium i przyjęciu, że jedynym tworzywem literatury jest słowo, wyzute zresztą ze swej materialności). Kreowanie liberatury oznacza uważny namysł nad wszystkimi elementami tego procesu, potencjalne eksplorowanie tych $\mathrm{z}$ nich, które konwencjonalnie pozostają nieme. Pojęcie jest więc szerokie, zaś jednym z głównych atrybutów dzieł zaliczanych do liberackich jest to, że wymykają się przewidywalności formy, zaskakuja, gdyż odrzucaja skonwencjonalizowane metody literackiej komunikacji. Ucieleśniają w formie książki formułę „środek przekazu jest przekazem”. A użyteczność terminu, zwłaszcza w proponowanej tu przymiotnikowej formie, przejawia się również w tym, że pozwala on podkreślić ciagłość tradycji takiego podejścia do komunikowania się przez słowo pisane ${ }^{71}$.

${ }^{70}$ Dodam, że tak jak Glazier mówił o literaturze elektronicznej w kontekście awangardy, tak liberatura swoje dziesiąte urodziny obchodziła na festiwalu Ha!wangarda (zob. też: Piotr Marecki, Ha!wangarda, „Ha!art” 2010, nr 30, s. 3).

71 Jeżeli po tylokroć przywoływałam tu Manovicha dobrze byłoby choć marginalnie wspomnieć i o jego szkicu Awangarda jako software, w którym dodaje on kolejne (do tych formułowanych przez Glaziera) argumenty na rzecz bliskości działań artystów początku XX w. i tych działających w przestrzeni nowych mediów (Lev Manovich, Awangarda jako software, tłum. Iwona Kurz, „Kwartalnik Filmowy” 2001, nr 35/36). Przywołanym artykułem badacz uzmysławia, jak nowe media pozwalają wcielić w życie techniki wypracowane przez awangardę: m.in. pokazując, jak www 
Po drugie, jestem przekonana, że nie było lepszego momentu na narodziny takiej teorii. Współczesna literatura, zderzajacca się ze sztuką niezwiązana już z konkretnym medium, w naturalny sposób podważyła tezę, że jej literackość musi być konstytuowana przez słowo. Otoczona intermedialna codziennością w wirtualnym świecie multimedialnych artefaktów musiała się jakoś bronić, pokazać, że i ona ma coś równie ciekawego do zaoferowania. W takim kontekście liberatura wydaje się sztuką słowa, która sprawnie stawia czoła opowieściom-instalacjom interaktywnym, powieściom-grom, hiperfikcjom.

Jednak pozostaje tu, oczywiście, pytanie, czy jest zatem sens taka zrodzona w odpowiedzi na współczesność kategorię odnosić do literatury wcześniejszej, czy warto szukać liberackich sygnałów w literaturze antycznej czy barokowej? Sądzę, że nie tylko warto, ale i należy. Pozwoli to dostrzec, że owo eksperymentowanie z materia przekazu, z medialnością literackiego komunikatu nie jest możliwościa, która narodziła się współcześnie. Dziś jest to tylko bardziej - w innych niż książkowe obszarach literatury - popularne, łatwiejsze do osiagnięcia. A warto też przypominać, że i przed 1999 r. niemało było dzieł, które swą eksplorującą medium formą bliskie były współczesnym elektronicznym eksperymentom ze słowem. Funkcję takiego „przypominacza” zdaje się sprawnie spełniać liberacka seria wydawnicza.

Po trzecie wreszcie, jestem przekonana (co sygnalizowałam już we wstępie), że choć w moim wywodzie pojawiło się wiele dopowiedzeń do dotychczas formułowanych uwag o liberaturze, że spora część - nieraz pochopnie głoszonych - sądów została tu zweryfikowana, dyskusja nadal jest otwarta. Mimo iż tytuł tej książki sugerować może zgubną chęć powiedzenia wszystkiego podkreślę raz jeszcze, że wiem, iż na pewno tego nie zrobiłam. Nie tylko - mówiąc najkrócej - z braku wiedzy, czasu czy możliwości, lecz przede wszystkim dlatego, iż moje rozważania poświęciłam teorii dopiero się rodzącej. Gdy pisałam pracę doktorska, która stała się podstawą niniejszej publikacji, koncepcja liberatury ciagle była udoskonalana i nadal domaga się jeszcze rozmaitych „poprawek”. Nie ukrywam, że utrudniało mi to pisanie, niektóre fragmenty musiałam aktualizować z każdym kolejnym wystapieniem Fajfera i Bazarnik. Przekonana jestem też, że nieraz - mimo usilnych starań, by tak nie było coś, co poprawiłam w jednym miejscu, w innym pozostało bez zmian.

Kończąc pisanie mogę powiedzieć, że wiem, iż niemal każdy z rozdziałów mógłby zostać rozwinięty do rozmiarów osobnego opracowania. Mam też świadomość różnego rodzaju uproszczeń, wykluczeń, skrótów, których musiałam dokonywać. Żywię jednak nadzieję, że dzięki temu udało mi się wskazać

realizuje zaproponowany na początku XX w. proces komunikacji wizualnej czy - co w kontekście moich rozważań równie ciekawe - łącząc Nową Typografię z GUI: graficznym interfejsem użytkownika. „W najprostszym sensie - stwierdza - graficzny styl systemów Windows 2000 lub MAC OS w pełni wciela w życie tezę Tschicholda, że «istota nowej typografii to jasność»" (s. 328). Podsumowuje swoje rozważania, wypunktowując: „Krótko mówiąc, awangarda staje się oprogramowaniem (software). To twierdzenie należy rozumieć na dwa sposoby. Z jednej strony, software, kodyfikuje i naturalizuje techniki starej awangardy. Z drugiej nowe software'owe techniki pracy z mediami stanowią reprezentację nowej awangardy społeczeństwa metamedialnego" (s. 335). 
interesujace perspektywy dalszych badań, uprawomocnić status liberatury, a przede wszystkim liberackości jako ich przedmiotu i dokonać rekapitulacji obecnego ich stanu (zasadniczo: rozwoju formułowanej teorii w pierwszym dziesięcioleciu od jej powstania).

Wśród zagadnień najciekawszych, których sama na pewno nie porzucę w dalszych badaniach, wymieniłabym kwestię liberatury jako książkowej odpowiedzi na „bardziej atrakcyjna” literaturę elektroniczna, na świat nie tylko hipertekstów, lecz (zwłaszcza) literackich instalacji interaktywnych, dzieł opartych na technice animacji czy strukturze gry, ogólnie: literackich projektów, które oferują nam inne, bardziej współczesne sposoby lektury, czytania wszystkimi zmysłami. W tym kontekście liberatura pokazuje, że „książkowy interfejs" nie musi być nudny, oklepany, konwencjonalny, przezroczysty ani jednomedialny.

Niemniej, dalszych badań oczekują też inne poruszane tu kwestie - choćby relacja liberatury i futuryzmu. Ja skupiłam się na koncepcji Marinettiego, jednak do równie ciekawych wniosków mogłoby prowadzić przyjrzenie się koncepcji literatury totalnej w kontekście twórczości futurystów rosyjskich (i to nie tylko ich podejścia do typografii, ale i - tak ważnej przecież dla liberatów - samej książki).

Podobnie ma się rzecz z podejmowanymi przeze mnie watkami teoretycznymi. Teorię liberacką od 1999 r. da sie omówić w jednej książce, nawet w jednym jej rozdziale, jednak odniesienie jej do „wszystkiego, co było przed” (z zastrzeżeniem: do czego warto ją odnosić) przekracza, jak sądzę, ramy nawet niejednego opracowania. Ja wybierałam właściwie „cytaty-perełki” pokazujące, że nie tylko mówiono o tym, o czym rozprawiali liberaci, ale i w ten sam, co oni sposób. Moim celem było pokazanie, że sformułowana w 1999 r. teoria nie wspomina o problemach, z których teoria literatury nie zdaje sobie sprawy.

Odnosząc się (w rozdziale poświęconym eksperymentom typograficznym) do metodologii, dokonałam bardzo wybiórczego przeglądu stanowisk. Wybrałam takie, dzięki którym mogłam podkreślić interesujące, jak sądzę, kwestie, zarysowując tym samym horyzont dalszych poszukiwań. Z pewnością niejedyne to konteksty, do jakich można było się odwołać. Na pewno też warte rozwinięcia są kwestie teoretyczne, które sugerowałam we wstępie, przywołujac Dąbrowskiego: rozważenie liberackości w stosunku do kategorii literackości.

Kończąc pracę doktorska, byłam również pewna, że nie mam żadnej gwarancji, iż miesiąc, tydzień, dzień czy nawet godzinę po jej złożeniu w świecie liberackim nie wydarzy się coś, co należało uwzględnić, lub czego przywołanie w moim wywodzie pozwoliłoby dobitniej wyrazić pewne kwestie. Ku takiej refleksji skłaniały mnie wtedy zwłaszcza wydarzenia z września 2011 r., które w ostatniej chwili zdecydowałam się w składanej w tymże miesiacu pracy przywołać, właśnie dlatego, że pozwoliły silniej wyakcentować kluczowe dla mnie problemy. Nie muszę chyba tłumaczyć, że powrót do pisanego te kilka lat temu tekstu, związany z przygotowywaniem do druku niniejszej publikacji, musiał zaowocować podobnymi rozterkami. Nie wykluczyła ich nawet podkreślona 
tu we wstępie decyzja o pozostawieniu toku wywodu w raczej niezmienionej formie, zaktualizowania go jedynie w rzeczywiście niezbędnych miejscach, by wybrzmieć mógł jako dokumentacja konkretnego etapu liberackiej refleksji ${ }^{72}$.

Sądzę jednak, że z podobnymi problemami boryka się każdy badajacy współczesność. Stąd wierzę, że moje obawy o zdezaktualizowanie się rozmaitych sądów tu wyrażanych są tyleż zasadne, co i zrozumiałe. Przede wszystkim jednak mam nadzieję, że tym, co udało mi się pokazać, jest rozwój teorii liberackiej w pierwszej dekadzie (czy: ewentualnie, chwilami - pierwszym piętnastoleciu) jej tworzenia. To, co w tym okresie się stało, raczej się już nie zmieni. Podobnie, jak stanowiące trzon moich rozważań porównanie różnych odmian sztuki słowa z tym, co określa się jako liberackie. Żywię przekonanie, że odnoszące się do tych kwestii wnioski, podobnie jak tezy pokazujące liberaturę na tle innych teorii (które rzekomo nie poruszały kluczowych dla teoretyków literatury totalnej kwestii), mają charakter uniwersalny. Tym samym, mam nadzieję, że - choć pozostało wiele wątków, które da się jeszcze rozwijać - naszkicowany tu obraz liberackości można, mimo wszystko, uznać za względnie kompletny.

Ostatnia, czwarta kwestia, o jakiej jestem przekonana (a byłam i zaczynając swoje badania), to fakt, że liberatura jest literatura, że bezsprzecznie przynależy do obszaru sztuki słowa. Tym samym, powinna być poddawana lekturze (choć mówiłam tu o „innym czytaniu”) i, związanej z nia, analizie i interpretacji. Jak sugerowałam - interpretacja ta nie może być jednak „medialnie niedowidząca”. Mimo to, nie sądzę, by sam proces dochodzenia znaczeń, poszukiwania odpowiedzi na pytania o celowość zastosowania takich, a nie innych rozwiązań strukturalnych, stylistycznych, językowych (też liberackich: odnoszących się do kształtu samego tekstu, jego materialnej formy) był inny. Myślę, że trzeba w tym wypadku co najwyżej nieraz nieco uważniej czytać - w końcu twórcy literatury totalnej ważą każde słowo, a i położenie przecinka na stronie może być nie bez znaczenia. Warto także być gotowym podchwytywać czasami nieco inne niż w klasycznej książce tropy interpretacyjne. Jednak wystarczy uważnie je śledzić liberacko wrażliwym okiem, a lektura będzie owocna.

By to potwierdzić, swoją rozprawę doktorską uzupełniłam przykładem takiej właśnie analizy i interpretacji dzieła liberackiego, co wydawało mi się koniecznym dopełnieniem formułowanych sądów o charakterze teoretycznym. Czytajac wtedy Oka-leczenie, wykorzystałam warsztat filologiczny. Wyczulona na szczegóły, szukałam odpowiedzi na rodzące się w zderzeniu z tekstem pytania nie tylko w samych słowach, ale i w ich ukształtowaniu. Próbowałam odkryć, czemu myśl ubrano w formę trójksięgu, czy po co w książce pojawiaja się różnego rodzaju dziwne rysunki. Pytałam o te kwestie tak samo, jakbym pytała o znaczenie zastosowanych przerzutni czy oksymoronów. Dzięki temu udało mi się dotrzeć do sensu dzieła. Bo w przypadku tego tekstu znaczenia rzeczywiście rodzą się z eksplorowania każdego wymiaru jego medium (książki, papieru, języka...).

${ }^{72} \mathrm{Na}$ szczęście, poza owymi przywołanymi wydarzeniami z 2011 r. wielkich liberackich przełomów od tego czasu nie zaobserwowałam. 
Oddając w ręce czytelników tę książkę, (z żalem) rezygnuję z tego uzupełnienia. Za takim rozwiąaniem przemawiały jednak dwa silne argumenty. Po pierwsze - wspomniane analizy były już publikowane (co pozwoliło mi odsyłać do nich). Po drugie - całościowe spojrzenie na twórczość Fajfera pozwala dostrzec w niej spójna, ewoluująca opowieść o poszukiwaniu właściwej dla literackich opowieści formy, o dojrzewaniu do medium sztuki słowa. Stąd - co też już zaznaczałam - z czasem doszłam do wniosku, iż najwłaściwszym miejscem na powtórną publikację moich analiz byłaby monografia twórczości Fajfera czy duetu Zenkasi, nad którą rozpoczęłam prace ${ }^{73}$.

Tu zaś muszę nadmienić, że Oka-leczenie, okrzyknięte liberackim wzorcem, tekst, z winy którego i na potrzeby którego (jak mówią sami autorzy) stworzono teorię liberacka, powinno być ucieleśnieniem literatury totalnej. I jest nim istotnie. Dodam, że nawet gdyby teorię tę należało stworzyć wyłącznie dla tego jednego teksu - byłoby warto. Na szczęście jednak piszę te słowa, udowodniwszy, że tekstów liberackich (choć często - tu muszę zgodzić się z Bazarnik - liberackich w znacznie mniejszym stopniu) jest znacznie więcej.

${ }^{73} \mathrm{Na}$ korzyść takiego rozwiązania przemawia również fakt, iż - zwłaszcza zestawione ze sobą - teksty Fajfera (czy Fajfera i Bazarnik) okazują się w różnym stopniu liberackie, czego pokazanie w interpretacjach pozwoliłoby zweryfikować większą użyteczność postulowanej przeze mnie kategorii liberackości w porównaniu z terminem liberatura. 



\section{Bibliografia}

\section{Opracowania dotyczące liberatury}

W 2010 r. został wydany zbiór tekstów Fajfera publikowanych w latach 1999-2009 (Fajfer Zenon, Liberatura czyli literatura totalna. Teksty zebrane z lat 1999-2009/Liberature or total literature. Collected Essays 1999-2009, red. Katarzyna Bazarnik, Kraków 2010, oznaczane przeze mnie jako $L C L T$ ). Stąd, w swojej bibliografii nie uwzględniam pierwodruków zebranych tam esejów, ani też nie wyszczególniam kolejnych artykułów, podając tylko te, które we wspomnianym zbiorze nie zostały umieszczone.

Wspomniana publikacja zawiera również pełną bibliografię liberatury za ten okres (nienumerowane strony), stąd nie dubluję takowej w swojej pracy, umieszczając w poniższej bibliografii jedynie pozycje bezpośrednio przywoływane w wywodzie.

\section{A) Teksty Zenona Fajfera, Katarzyny Bazarnik i Radosława Nowakowskiego}

Bazarnik K., Chronotope in liberature, [w:] James Joyce and After: Writer and Time, ed. K. Bazarnik, B. Kucała, Newcastle 2010.

Bazarnik K., Globalne spojrzenie na „Finnegans Wake”, [w:] Wokót Jamesa Joyce’a: szkice monograficzne, red. K. Bazarnik, F. Fordham, Kraków 1998.

Bazarnik K., Introduction: Modernist Roots of Liberature, [w:] Incarnations of Material Textuality: From Modernism to Liberature, ed. Katarzyna Bazarnik, Izabela Curyłło-Klag, Cambridge 2014.

Bazarnik K., Joyce \& Liberature, Praga 2011.

Bazarnik K., Kilka uwag o liberaturze i ksiażce artystycznej (2009) [maszynopis udostępniony przez autorkę].

Bazarnik K., Krótkie wprowadzenie do liberatury, „Er(r)go” 2003, nr 2.

Bazarnik K., „Ksiażka jako przedmiot” Michela Butora czyli o liberaturze przed liberatura, [w:] Od Joyce'a do liberatury. Szkice o architekturze słowa, red. K. Bazarnik, Kraków 2002.

Bazarnik K., Liberatura czyli o powstawaniu gatunków (literackich), [w:] LCLT.

Bazarnik K., Liberatura, czyli literatura $w$ formie ksią̇ki, [w:] Druga rewolucja ksią̇ki, red. V. Trella, Gdynia 2008.

Bazarnik K., Liberatura: ikoniczne oka-leczenia literatury, [w:] TEKST-TURA, red. M. Dawidek Gryglicka, Kraków 2005.

Bazarnik K., Liberature: a New Literary Genre?, [w:] Insistent Image, ed. E. Tabakowska, C. Ljungberg, O. Fisher, Amsterdam 2007.

Bazarnik K., Materialność jako wyznacznik gatunkowy liberatury, [w:] Materia sztuki, red. M. Ostrowicki, Kraków 2010.

Bazarnik K., „Nieszczęśni” B. S. Johnsona. Liberacka gra z przypadkiem. Stowo od tłumaczki i redaktorki serii, [w:] B. S. Johnson, Nieszczęśni, tłum. K. Bazarnik, Kraków 2008.

Bazarnik K., Popsuta przestrzeń, „Autoportret” 2006, nr 4. 
Bazarnik K., Some Aspects of Spatiality of the Literary Work as Exemplified by James Joyce's "Giacomo Joyce", "Ulysses" and "Finnegans Wake" (with a reference to L. Sterne, S. Mallarmé, B. S. Johnson, and R. Federman) [rozprawa doktorska ukończona na UJ w 2006 r.].

Od Joyce’a do liberatury. Szkice o architekturze stowa, red. K. Bazarnik, Kraków 2002.

Fajfer Z., Liberatura czyli literatura totalna. Teksty zebrane z lat 1999-2009/Liberature or total literature. Collected Essays 1999-2009, red. K. Bazarnik, Kraków 2010.

Fajfer Z., Liberatura - literatura przestrzeni, „Autoportret” 4/2006.

Fajfer Z., Od kombinatoryki do libratury. O nieporozumieniach zwiazanych z tzw. „,iteraturq eksperymentalna”, [w:] R. Queneau, Sto tysięcy miliardów wierszy, tłum. J. Gondowicz, Kraków 2008.

Fajfer Z., Od liberatury do tekstu niewidzialnego (autoportret $z$ Ingardenem $w$ tle), [w:] Materia sztuki, red. M. Ostrowicki, Kraków 2010.

Bazarnik K., Fajfer Z., „Arw” z perspektywy liberatury (kilka słów od redaktorów serii), [w:] S. Czycz, Arw, oprac. D. Niedziałkowska, D. Pachocki, Kraków 2007.

Fajfer Z., Bazarnik K., Dwa „Rzuty kośćmi” czyli szczególna i ogólna teoria liberatury, [w:] S. Mallarmé, Rzut kośćmi nigdy nie zniesie przypadku, tłum. T. Różycki, Kraków 2005.

Fajfer Z., Bazarnik K., Liberature, Kraków 2005.

Fajfer Z., Bazarnik K., O wcześniejszych przypadkach „Rzutu kośćmi”. Nota redakcyjna, [w:] S. Mallarmé, Rzut kośćmi nigdy nie zniesie przypadku, tłum. T. Różycki, Kraków 2005.

Fajfer Z., Bazarnik K., Perec i liberatura. Nota redaktorów serii, [w:] G. Perec, Życie. Instrukcja obstugi, tłum. W. Brzozowski, Kraków 2009.

Nowakowski R., Dlaczego moje ksiażki sq takie jakie sa, [w:] Od Joyce’a do liberatury. Szkice o architekturze stowa, red. K. Bazarnik, Kraków 2002.

Nowakowski R., O czytaniu oczu tańczeniu, „Ha!art!” 2003, nr 2(15).

Nowakowski R., Pojedynek stowa $z$ obrazem, http://www.liberatorium.com/teksty/pojedynek.html [dostęp 11.05.2010].

Nowakowski R., Traktat kartkograficzny czyli rzecz o liberaturze, egzemplarz broszurowy numer czternaście, Bodzentyn 2002.

Nowakowski R., Utekstowienie znaku, uznakowienie tekstu, [w:] Druga rewolucja ksiażki, red. V. Trella, Gdynia 2008.

Nowakowski R., Zwodnik po Liberlandii, „Ha!art” 2010, nr 30.

\section{B) Inne teksty teoretyczne, wywiady, szkice}

Ankieta „Liberatura - awangarda XXI wieku czy nowe spojrzenie na stare dzieta literackie?, „Ha!art” 2010, nr 30.

Bartnicki K., O liberaturze bez-wiednie, „Ha!art” 2010, nr 30.

Borowczyk J., Hoffmann K., Wymarzona przygoda, „Polonistyka” 2009, nr 2.

Dumais C. A., Would You Like to Save Your Game Now? The Replayability of Liberture, „Systems. Journal of Transdisciplinary System Science" 2008, nr 1-2 (polski przekład ukazał się dwa lata później na łamach „Ha!artu”: C. A. Dumais, Wielogrywalność liberatury. Czy chciałbyś zapisać stan gry?, tłum. J. Pyra, „Ha!art” 2010, nr 30).

Husarzewska W., Linearna opowieść o literaturze nielinearnej [2], „Autoportret” 2006, nr 4.

Ile stron ma liberatura? Z Katarzyna Bazarnik i Zenonem Fajferem rozmawia Adam Poprawa, „Conrad”, dodatek tematyczny do „Tygodnika Powszechnego” 2010, nr 44 (z 31 października).

Johnson B. S., Czy tu nie za wcześnie piszesz wspomnienia, [w:] Od Joyce’a do liberatury. Szkice o architekturze słowa, red. K. Bazarnik, Kraków 2002.

Kalaga W., Liberatura: stowo, ikona, przestrzeń [wstęp], [w:] LCLT.

Kalaga W., Tekst hybrydyczny. Polifonie i aporie doświadczenia wizualnego, [w:] Wizualizacja, literatura i cała reszta, red. W. Bolecki, A. Dziadek, Warszawa 2010. 
Kołos A., Geneza liberatury. Filozofia, estetyka i polityka pisma, „Ha!art” 2010, nr 30.

Kołos A., Liberatura czyli „architektura słowa” a przestrzeń dzieła literackiego, „Ha!art” 2009, nr 1-2 (28/27) [dodatek „Liberatura”].

Liberatura - kalendarium, „Ha!art” 2010, nr 30.

Marecki P., Ha!wangarda, „Ha!art” 2010, nr 30.

Nowakowski R., powieść w przestrzeń i... o uksiażkowieniu fabryki, „Autoportret” 2006, nr 4.

Pisarski M., Kartografowie $i$ kompilatorzy. Pót żartem, pót serio o praktyce $i$ teorii hiperfikcji w Polsce, [w:] Liternet.pl

Przybyszewska A., Czytać... czyli uktadać. Liberackie (i nie tylko) modele do sktadania, „Autoportret”, nr 4/2006.

Przybyszewska A., Liberatura oraz E-liberatura, [w:] Stownik rodzajów i gatunków literackich. Nowe wydanie, red. G. Gazda, Warszawa 2012 [nowe wersje haseł].

Przybyszewska A., Liberatura oraz E-liberatura, „Zagadnienia Rodzajów Literackich” 2007, nr 50.

Rashomon do potęi entej. O hipertekstowej i hasarapańskiej opowieści „Koniec świata wedtug Emeryka” z Radostawem Nowakowskim rozmawia Piotr Marecki, „Ha!art” 2003, nr 2 (15), bez numeracji stron.

Sobczyński M., Antywzornictwo?, „2 + 3D” 2011, nr 38.

Żuchowski J., James Joyce versus Koziołek Matołek albo Święty Franciszek kontra Tarzan. O zwiazkach liberatury i sztuki komiksu, „Ha!art” 2007, nr 27.

\section{C) Analizy, recenzje publikacji liberackich itp.}

Cytadelski T., Liter dríenie, „Portret” 2004, nr 1.

Jeżyk Ł., Spod spodu. O „Spogladajac przez ozonowa dziurę” Zenona Fajfera, „Polonistyka” 2009, nr 2.

Jeżyk Ł., Widzieć - wierzyć - wiedzieć. Zenona Fajfera podejrzenia i spojrzenia, [w:] Między językiem a wizualnościa, red. M. Bednarek, M. Junkiert, J. Klausa-Wartacz, Poznań 2008 (lub przedruk w $L C L T$ ).

Pisarski M., Cyfrowe kaligramy Liberlandii, „Ha!art” 2010, nr 30.

Pisarski M., Podróż do wnętrza ksiażki, „Ha!art” 2010, nr 30.

Przybyszewska A., Close Reading of the Liberatic Canon: On "Oka-leczenie” by Zenon Fajfer and Katarzyna Bazarnik, [w:] Incarnations of Material Textuality: From Modernism to Liberature, ed. Katarzyna Bazarnik, Izabela Curyło-Klag, Newcastle 2014.

Przybyszewska A., Czytajace dzieci Stefana Themersona. Ku nowym (słowo-dźwięko-)obrazom literackim, [w:] Trajektorie obrazów. Strategie wizualne w sztuce wspótczesnej, red. R. W. Kluszczyński, D. Rode, Łódź 2015.

Przybyszewska A., Liberacka analiza tekstu (o czytaniu „Oka-leczenia” Zenona Fajfera i Katarzyny Bazarnik), [w:] Polska literatura najnowsza - poza kanonem, red. P. Kierzek, Łódź 2008.

Przybyszewska A., Liberacki kanon literatury. O czytaniu „Oka-leczenia” Zenona Fajfera i Katarzyny Bazarnik. Podwójne zapiski z lektury dwukrotnej, czyli w dialogu z sama soba, „ha!art”, nr 30/2010.

Przybyszewska A., Porzqdek czy chaos, sieć czy zbieranina, logiczna konstrukcja czy zagmatwany labirynt? Na marginesie hipertekstowej powieści Radosława Nowakowskiego, [w:] Hiperteksty literackie. Literatura i nowe media, red. P. Marecki, M. Pisarski, Kraków 2011.

Przybyszewska A., Sprzedać legendę. Jak zachwyca i rozczarowuje „Arw”Stanisława Czycza, „TECHSTY”, nr 4/2008, http://techsty.art.pl/magazyn4/recenzje/przybyszewska01.html

Przybyszewska A., W pudetku $i$ na wadze - o przestrzeni śmierci i przestrzeni tekstu $w$ utworach Bryana S. Johnsona oraz Zenona Fajfera i Katarzyny Bazarnik, [w:] Kulturowe obrazy śmierci: od przełomu romantycznego do dziś, red. I. Grzelak, T. Jermalonek, Łódź 2007.

Solski Z. W., Tadeusz Różewicz w sieci. Od liberatury do e-dramatu, [w:] Od liberatury do e-literatury, red. E. Wilk, M. Górska-Olesińska, Opole 2011.

Stamirowska K., B. S. Johnson's Novels: A paradigm of Truth, Kraków 2006. 
Szaket J., Oczu leczenie, „FA-art” 2002, nr 1.

Wielogłos o ksiażce Oka-leczenie, „Ha!art” 2003, nr 2.

Zgaińska M., Re-generacja sensów, „Czas Kultury” 2010, nr 4.

\section{D) Strony internetowe związane z liberaturą}

www.liberatura.pl

www.liberatorium.com

\section{Opracowania dotyczące literatury wizualnej}

\section{A) Opracowania o charakterze ogólnym oraz dotyczące poezji konkretnej i wizualnej}

Apollinaire G., Dwa manifesty, tłum. M. Żurowski, „Przegląd Humanistyczny” 1968, nr 6.

Bocian M., Przestrzeń w poezji konkretnej, Bydgoszcz 1979.

Bohn W., Kryzys znaku, tłum. K. Majer, „Literatura na Świecie” 2006, nr 11-12 (numer tematyczny dot. poezji konkretnej).

Bohn W., Modern Visual Poetry, Newark 2001.

Bujnowski J., Poezja konkretna, „Poezja” 1976, nr 6.

Corrosive Signs. Essays on Experimental Poetry (Visual, Concrete, Alternative), ed. C. Espinosa, tłum. H. Polkinhorn, Washington 1990.

Dawidek Gryglicka M., Historia tekstu wizualnego. Polska po 1967 roku, Kraków 2012.

Dawidek Gryglicka M., Poezja konkretna Emmetta Williamsa, „Czas Kultury” 2001, nr 4.

Dróżdż S., Makarewicz Z., Pojęcioksztatty. Rozbiór dramatyczny przedmiotu, „Odra” 1968, nr 12.

Drucker J., The Visible Word. Experimental Typography and Modern Art, 1909-1923, ChicagoLondon 1996.

Falicki J., Kod stowny a kod rysunkowy. Próba typologii utworów piktograficznych na przykładzie „Kaligramów” Apollinaire’a, [w:] Studia z literatury polskiej i obcej, red. L. Ludorowski, Lublin 1988.

Garbala M., Stanistawa Dróżḋ̇a poezja konkretna, „Agora” 1968, nr 20.

Gazda G., Poezja konkretna a problemy awangardy, [w:] The Structure and Semantics of Literary Text, red. M. Péter, Budapeszt 1977.

Hejmej A., Literatura intermedialna, [w:] Wizualizacja, literatura i cała reszta, red. W. Bolecki, A. Dziadek, Warszawa 2011.

Hejmej A., Komparatystyka. Studia literackie - studia kulturowe, Kraków 2013.

Higgins D., Pattern Poetry. Guide to Unknown Literature, New York 1987.

Higgins D., Strategia poezji wizualnej: trzy aspekty, tłum. K. Brzeziński, [w:] idem, Nowoczesność od czasu postmodernizmu oraz inne eseje, oprac. P. Rypson, tłum. M. Giżycki i in., Gdańsk 2000.

Hopfinger M., W laboratorium sztuki XX wieku. O roli słowa i obrazu, Warszawa 1993.

Inny rodzaj kontaktu. Z prof. Mary Ellen Solt rozmawia Marek Hołyński, „Nowy Wyraz” 1977, nr 10.

Jarniewiecz J., Ttumacze na urlop!, „Literatura na Świecie” 2006, nr 11-12 (numer tematyczny dot. poezji konkretnej).

Kwiatkowski J., Wstęp, [w:] G. Apollinaire, Wybór poezji, Wrocław 1975.

Lessing G. E., Laokoon, czyli o granicach malarstwa i poezji, tłum. H. Zymon-Dębicki, [w:] idem, Dzieła wybrane, t. III, Warszawa 1959. 
Łubowicz E., Rzeczywistość jest tekstem. O poezji konkretnej Stanisława Dróżḋ̇a, „Odra” 1999, nr 7-8.

Mallarmé S., Wariacje na pewien temat [fragment zatytułowany: Ksiażka, narzędziem duchowym], tłum. E. D. Żółkiewska, [w:] S. Mallarmé, Wybór poezji, red. A. Ważyk, Warszawa 1980.

Markiewicz H., Obrazowość a ikoniczność literatury, [w:] idem, Wymiary dzieła literackiego, Kraków 1984.

Markowski M. P., Nicość i czcionka. Wprowadzenie do lektury „Rzutu kośćmi” Stephane’a Mallarme, [w:] S. Mallarmé, Rzut kośćmi nigdy nie zniesie przypadku, tłum. T. Różycki, Kraków 2005.

Maziarczyk G., The Novel as Book. Textual Materiality in Contemporary Fiction in English, Lublin 2013.

Olczyk J., „Księga jest więc jak bóg: konieczna, obecna, nieistniejaca. O nieukończonym dziele Stéphane’a Mallarmégo, „Autoportret” 2006, nr 4.

Pogonowski W., Poezja konkretna - kształtowanie się ruchu artystycznego, Bydgoszcz 1979.

Pressman J., The Aesthetic of Bookishness in Twenty-First-Century Literature, „Michigan Quarterly Review", fall 2009.

Pressman J., CODA - Rereading: Digital Modernism in Print, Mark Z. Danielewski's “Only Revolutions”, [w:] eadem, Digital Modernism. Making It New in New Media, New York 2014.

Przybyszewska A., NIE-KONKRETNA KAWIARIA LIBERACKA. Na marginesie kilku nieodbytych rozmów liberatów i konkretystów, „ARTERIE”, nr 3 (9)/2010.

Rozmowy o sztuce (VIII). Ze Stanisławem Dróżḋem rozmawia Jaromir Jedliński, „Odra” 1999, nr 7-8.

Rypson P., Ksią̇ki i strony. Polska ksią̇ka awangardowa i artystyczna 1919-1992, Warszawa 1992.

Rypson P., Obraz słowa. Historia poezji wizualnej, Warszawa 1989.

Rypson P., Piramidy-stońca-labirynty. Poezja wizualna w Polsce od XVI do XVIII wieku, Warszawa 2002.

Sadowski W., Tekst graficzny Białoszewskiego, Warszawa 1999.

Sadowski W., Wiersz wolny jako tekst graficzny, Kraków 2004.

Sławek T., Między literami. Szkice o poezji konkretnej, Wrocław 1989.

Solt M. E., Concret Poetry. A world view, London 1971.

Solt M. E., poezja konkretna, „Nowy Wyraz” 1977, nr 10.

Śniecikowska B., Stowo-obraz-dźwięk. Literatura i sztuki wizualne w koncepcjach polskiej awangardy 1918-1939, Kraków 2005.

Trznadel J., Wszystko jest proste (nad poematem Mallarmégo: „Rzut kości nigdy nie obali przypadku”), [w:] idem, Ptomień obdarzony rozumem. Poezja w poezji i poza poezja. Eseje, Warszawa 1978.

Ważyk A., Przedmowa, [w:] S. Mallarmé, Wybór poezji, red. Adam Ważyk, Warszawa 1980.

Webster M., Reading Visual Poetry after Futurism. Marinetti, Apollinaire, Schwitters, Cummings, New York 1995.

Wiercińska J., Sztuka i obraz, Warszawa 1986.

Wilczek P., Funkcje wierszy wizualnych w utworze Adama Nieradzkiego „Kirys Hartowny starozytnego żotnierza”, [w:] O literackiej ramie wydawniczej w ksiażkach dawnych, red. R. Ocieczek, Katowice 1990.

Wysłouch S., Literatura a sztuki wizualne, Warszawa 1994.

Wysłouch S., Rewolucja Lessingowska, [w:] eadem, Literatura a sztuki wizualne, Warszawa 1994.

Wysłouch S., Ut pictura poesis - stara formuła $i$ nowe problemy, [w:] Ut pictura poesis, red. M. Skwara, S. Wysłouch, Gdańsk 2006.

\section{Strony internetowe}

http://www.ubu.com/historical/decampos_a/hearthead.html [dostęp 11.01.2011]. 


\section{B) Opracowania dotyczące komiksu}

Birek W., Główne problemy teorii komiksu, praca doktorska napisana pod kierunkiem prof. dra hab. S. Uliasza, Rzeszów 2004.

Duncan R., Smith M. J., The Power of Comics. History, Form \& Culture, New York 2009.

Dunin J., Prolegomena do „komiksologii”, „Literatura Ludowa” 1972, nr 6.

Gulda P., [recenzja komiksu Berlin - miasto gniewu], „Co jest grane”, weekendowy dodatek do „Gazety Wyborczej” (Łódź), 26 sierpnia-1 września 2011.

Janiak-Staszek A., Recenzja tomu „Antologii referatów 10. Sympozjum Komiksologicznego”, [w:] Komiks a komiksologia. Ku rozpoznaniu i charakterystyce wzajemnych relacji między gatunkiem a jego teoria, red. K. Skrzypczyk, Łódź 2010.

Jastrzębski J., Komiks i stereotypy, [w:] idem, Czas relaksu. O literaturze masowej i jej okolicach, Wrocław 1982.

Kurc B., Komiks - opowiadanie obrazem, Łódź 2003.

McCloud S., Understanding Comics. The Invisible Art, New York 1993.

Przybylski R. K., Stowo i obraz w komiksie, [w:] Pogranicza i korespondencje sztuk, red. T. Cieślikowska, J. Sławiński, Wrocław 1980.

Przybylski R. K., Świat komiksu, „Sztuka” 1978, nr 2.

Skarżyński J., Komiks (Comic strip), „Projekt” 1985, nr 6.

Smoldern T., Komiks i prawa pótkula, tłum. K. Uchańska, „Komiks-Fantastyka” 1989, nr 2.

Szwabowicz M., Po co nam Superman? Rozmyślania o komiksie, [internetowa publikacja pracy licencjackiej z 2005 roku], http://www.zeszytykomiksowe.org/skladnica/szwabowicz2005.pdf [dostęp 25.08.2011].

Szyłak J., Komiks w kulturze ikonicznej XX wieku, Gdańsk 1999.

Szyłak J., Komiks, Kraków 2000.

Szyłak J., Komiks: świat przerysowany, Gdańsk 1998.

Szyłak J., Poetyka komiksu. Warstwa ikoniczna i językowa, Gdańsk 2000.

Toeplitz K. T., Sztuka komiksu. Próba definicji nowego gatunku artystycznego, Warszawa 1985.

Wróblewski M., Komiks w perspektywie literaturoznawstwa. Projekt komiksologii w dobie kryzysu genologii esencjalnej, [w:] Komiks a komiksologia. Ku rozpoznaniu i charakterystyce wzajemnych relacji między gatunkiem a jego teoria, red. K. Skrzypczyk, Łódź 2010.

Wyrzykowski R. Internetowość komiksu internetowego, http://esensja.pl/magazyn/2007/08/ iso/09_30.html [dostęp 20.07.2011].

\section{Opracowania dotyczące historii książki i druku, typografii oraz książki artystycznej (pozycje dotychczas nieprzywoływane)}

Baines P., Haslam A., Pismo i typografia, tłum. D. Dziewońska, Warszawa 2010.

Bieńkowska B., Maruszczak E., Ksią̇ka na przestrzeni dziejów, Warszawa 2005.

Carrión U., Nowa sztuka robienia ksiażek. Z wystawy w Galerii „Remont”, „Linia. Jednodniówka warszawskiego środowiska studenckiego", luty-marzec 1977.

Chappell D., Typologising the artist's book, „Art Libraries Journal” 2003, no 4 (szkic dostępny jest również pod adresem: http://www.arts.ucsb.edu/faculty/reese/artist\%20books/chappell_typologising.pdf [dostęp 18.09.2011].

Chwałowski R., Typografia typowej książi, Gliwice 2002.

Corti M., Literatura i komunikacja, tłum. J. Ugniewska, „Teksty” 1980, nr 1.

Cybulski R., Ksiażka współczesna. Wydawcy-rynek-odbiorcy, Warszawa 1986.

Czerwiński M., System ksiażki, Warszawa 1976.

Dahl S., Dzieje ksiażki, red. B. Kocowski, tłum. E. Garbacik, T. Zapiór, H. Devechy, Wrocław 1965. 
Dodd R., From Gutenberg to Open Type. An illustrated history of type from the earliest letterforms to the latest digital fonts, Cambridge 2006.

Drucker J., Figuring the Word: Essays on Books, Writing and Visual Poetics, New York 1998.

Drucker J., The Century of Artists'Books, New York 2004.

Drucker J., The Visible Word. Experimental Typography and Modern Art, 1909-1923, ChicagoLondon 1996.

Druga rewolucja ksiażki, red. V. Trella, Gdynia 2008.

Dunin J., Ksią̇ka na miarę człowieka, Łódź 1989.

Duninowie C. i J., Philobiblon polski, Wrocław 1983.

Dutko M., Typografia Internetu - problemy badawcze, [w:] Oblicza kultury ksiażki. Prace $i$ studia $z$ bibliologii i informacji naukowej, red. M. Komza, K. Migoń, M. Skalska-Zlat, A. Żbikowska-Migoń, Wrocław 2005.

Escarpit R., Rewolucja ksiażki, Warszawa 1969.

Głombiowski K., Ksiażka w procesie komunikacji społecznej, Wrocław 1980.

Głombiowski K., O dwóch tendencjach badań bibliologicznych, „Studia o Książce” 1981, t. 11.

Jakubowicz R., Sztuka ksiażki. Odsłona trzecia, „Exit” 2000, nr 4, s. 2352-2357, dostępny również na stronie: http://free.art.pl/wilmanski/teksty/5_pl.htm [dostęp 26.09.2011].

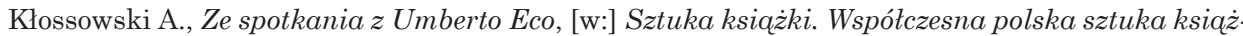
ki. Ksiażka artystyczna (katalog, edycja VI), Warszawa 2000.

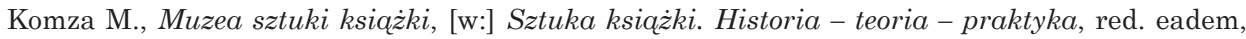
Wrocław 2003.

Kostelanetz R., Book art, http://www.richardkostelanetz.com/examples/bookart2.html [dostęp 20.11.2011].

Lachow W. N., Szkice z teorii sztuki ksiażki, tłum. B. Chrzanowska-Sokołowska, K. Gieda, M. Komza, G. Talar, Wrocław 1978.

Ladorucki J., Pozostawałem w kręu ksiażki... Rozmowy z profesorem Januszem Duninem o bibliologii, medioznawstwie i zwyczajnym życiu, Łódź 2007.

Lalewicz J., Ksiażka, [w:] idem, Komunikacja językowa i literatura, Wrocław 1975.

Lewis J., Weyers A., ActiveText: A Method for Creating Dynamic and Interactive Texts, [w:] Symposium in User Interface Software and Technology Proceeding in the 12th annual ACM symposium on User interface software and technology, Asheville 1999.

McGann J. J., The Textual Condition, Princeton 1991.

Migoń K., Nauka o ksiażce wśród innych nauk społecznych, Wrocław 1976.

Migoń K., Nauka o ksiażce. Zarys problematyki, Wrocław 1984.

Migoń K., Z dziejów nauki o ksiażce, Wrocław 1979.

Muszkowski J., Życie ksiażki, wyd. 2 rozszerzone, Warszawa 1951.

Nauka o ksiażce. Antologia tekstów, red. D. Kuźmina, M. Tobera, Warszawa 2006.

Olszewska A., Ksią̇ka konwencjonalna i ksiażka artystyczna, „Plastyka i Wychowanie” 1999, nr 5.

Phillpot C., Artists’ Booklets, „Printed Matter” Catalog 1986/1987; [http://www.printedmatter.org/ researchroom/essays/booklets.cfm (dostęp 28.08.2011)].

Phillpot Cl., Books book objects bookworks artists’ books, „Artforum” 1982, nr 9.

Pirożyński J., Johannes Gutenberg i poczatki ery druku, Warszawa 2002.

Rypson P., Sztuka ksiażki, http://free.art.pl/wilmanski/teksty/17_pl.htm [dostęp 20.08.2011].

Small D., Navigating large bodies of text, http://research.ibm.com/journal/sj/353/sectiond/small. txt [dostęp 20.10.2007].

Sowiński J., Typografia polskiej awangardy, „Studia o Książce” 1989, nr 18.

Świderkówna A., Nowicka M., Ksiażka się rozwija, Wrocław 2008.

Warde B., Kryształowy kielich, czyli druk powinien być niewidoczny, tłum. D. Dziewońska, [w:] Widzieć. Wiedzieć. Wybór najważniejszych tekstów o dizajnie, red. P. Dębrowski, J. Mrowczyk, Kraków 2011.

Wong Y. Y., Temporal Typography. A Proposal to Enrich Written Expression, [w:] Conference companion on Human factor in computing systems: common ground, Vancouver 1996.

Zbierski T., Semiotyka ksiażki, Wrocław 1978. 


\section{A) Opracowania dotyczące druku funkcjonalnego (pozycje dotychczas nieprzywoływane)}

Kwiatkowski J., Świat poetycki Juliana Przybosia, Warszawa 1972.

Lewandowska B., U źódet grafiki funkcjonalnej w Polsce, [w:] Ze studiów nad geneza plastyki nowoczesnej w Polsce, red. J. Starzyński, Wrocław 1966.

Listy Wtadystawa Strzemińskiego do Juliana Przybosia z lat 1929-1933, „Rocznik Historii Sztuki” 1973, t. IX.

Strzemiński W., Druk funkcjonalny, [w:] idem, Wybór pism estetycznych, Kraków 2006.

Tschichold J., Druk nowoczesny, tłum. A. Frank, red. W. Strzemiński, Łódź 1938.

Tschichold J., Nowe drukarstwo, „Europa”, nr 9 [6], czerwiec 1930.

Turowski A., Komentarz do korespondencji Wtadystawa Strzemińskiego, „Rocznik Historii Sztuki” 1973, t. IX.

Turowski A., Konstruktywistyczna typografia Wtadysława Strzemińskiego, „Projekt” 1971, nr 4.

Urbaniak I., Analiza zgodności znaczeniowo-graficznej „Sponad” Juliana Przybosia w opracowaniu typograficznym Wtadystawa Strzemińskiego, „Sprawozdania z Czynności i Posiedzeń Naukowych Łódzkiego Towarzystwa Naukowego" 1982, R. XXXVI, 5.

\section{B) Opracowania dotyczące futuryzmu (pozycje dotychczas nieprzywoływane)}

Przywoływane w książce teksty Marinettiego (manifesty w różnych tłumaczeniach oraz teksty artystyczne):

Marinetti F. T., Akt założycielski i manifest futuryzmu (1909), tłum. M. Czerwiński, [w:] Artyści o sztuce. Od van Gogha do Picassa, wybór i oprac. E. Grabska, H. Morawska, Warszawa 1969.

Marinetti F. T. Technical Manifesto of Futurist Literature, tłum. R. W. Flint, [w:] idem, Selected Writings, tłum. R. W. Flint, A. A. Coppotelli, red. R. W. Flint, London 1972, a także Marinetti F. T., Manifesto tecnico della Letteratura futurista oraz Supplemento al Manifesto tecnico della Letteratura futurysta, [w:] idem, Zang tumb tumb, Milano 1914.

Marinetti F. T., Destruction of syntax - Imagination without Strings - words-in-freedom (1913), tłum. R. W. Flint, [w:] The Book of the Book. Some Works \& Projections about the Book \& Writing, ed. J. Rothenberg, S. Clay, New York 2000, a także Marinetti F. T., Distruzione della sintassi. Immaginazione senza fili. Parole in libertá, [w:] idem, Zang tumb tumb, Milano 1914.

Marinetti F. T., Geometrical and Mechanical Splendor and the Numerical Sensibility, thum. R. W. Flint, [w:] idem, Selected Writings, tłum. R. W. Flint, A. A. Coppotelli, red. R. W. Flint, London 1972.

Marinetti F. T., Tactilism, [w:] idem, Selected Writings, tłum. R. W. Flint, A. A. Coppotelli, red. R. W. Flint, London 1972.

Marinetti F. T., Les mots en liberté futuristes, Milano 1919.

Marinetti F. T., Zang tumb tumb, Milano 1914.

Inne cytowane i przywolywane opracowania i utwory:

Antologia polskiego futuryzmu i Nowej Sztuki, oprac. Z. Jarosiński, Wrocław 1978.

Balcerzan E., Wstęp, [w:] B. Jasieński, Utwory poetyckie, manifesty, szkice, Kraków 1972.

Baluch A., Wizualność poezji Tytusa Czyżewskiego, „Rocznik Naukowo-Dydaktyczny WSP w Krakowie" 1986, z. 101 (Prace historycznoliterackie X).

Bartram A., Futurist Typography and the Liberated Text, London 2005.

Baumgarth C., Futuryzm, tłum. J. Tasarski, Warszawa 1987. 
Beauduin N., O potrzebie nowej techniki poetyckiej. Poemat synoptyczny, wieloplanowy [nie podano tłumacza], „Zwrotnica” 1923, nr 4.

Burek T., Futuryzm, [w:] Lektury i problemy, wyb. i oprac. J. Maciejewski, Warszawa 1976.

Chora fontanna (wiersze futurystów włoskich), przekład i esej wstępny J. Kurek, Kraków 1977.

Futuryzm i jego warianty w literaturze europejskiej, red. J. Heistein, Wrocław 1977.

Gazda G., O gatunkach polskiej poezji futurystycznej, Warszawa 1972 (odbitka autorska z tomu 4 Z polskich studiów slawistycznych. Seria 4).

Gazda G., Futuryzm w Polsce, Wrocław 1974.

Heistein J., Wprowadzenie do literaturoznawstwa porównawczego. Literatura awangardowa w świetle badań porównawczych, Wrocław 1990.

Hutnikiewicz A., Od czystej formy do literatury faktu. Gtówne teorie i programy literackie XX stulecie, Warszawa 1974.

International Futurism In Arts and Literature, ed. G. Berghaus, Berlin-New York 2000.

Jasieński B., But w butonierce. Stron dziewięćdziesią sześć, Warszawa 1921.

Jasieński B., Morze, „Zwrotnica” 1923, nr 4.

Kralowa H., Poezja w poczqtku XX stulecia, [w:] Historia literatury włoskiej, red. H. Kralowa, P. Salwa, J. Ugniewska, K. Żaboklicki, t. II, Warszawa 2002.

Kralowa H., Zmierzch i maszyna. Poezja poczqtku XX stulecia, [w:] Historia literatury włoskiej XX wieku, red. J. Ugniewska, Warszawa 2001.

Majerski P., Anarchia i formuły. Problemy twórczości poetyckiej Anatola Sterna, Katowice 2001.

Majerski P., Odmiany awangardy, Katowice 2001.

Miczka T., Czas przyszty niedokonany. O włoskiej sztuce futurystycznej, Katowice 1994.

Nieuważny F., Futuryzm, [w:] Literatura rosyjska, t. II, red. M. Jakóbiec, Warszawa 1971.

Palazzeschi A., La paseggiata, [w:] idem, Poesie 1904-1914, Firenze 1925.

Peiper T., Futuryzm (analiza i krytyka), „Zwrotnica” 1923, nr 6.

Perloff M., The Futurist Moment. Avant-Garde, Avant Guerre, and the Language of Ruptures, Chicago 1986.

Sławiński J., Koncepcja języka poetyckiego awangardy krakowskiej, Kraków 1998.

Strzemiński W., Sztuka nowoczesna w Polsce, [w:] idem, Wybór pism estetycznych, red. G. Sztabiński, Kraków 2006

Śniecikowska B., „Nuż w uhu”? Koncepcje dźwięku w poezji polskiego futuryzmu, Wrocław 2008.

Tarnogórska M., Formuła symultaniczna. O poemacie futurystycznym, [w:] eadem, Poemat międzywojenny. Studium z poetyki historycznej gatunku, Wrocław 1997.

Ula Pawlicka o adaptacji „Marszu” Jasieńskiego wg grupy Twożywo, http://www.techsty.art.pl/ magazyn/magazyn7/rec/marsz_jasienskiego.html [dostęp 29.09.2011].

Zaworska H., Futurystyczne koncepcje sztuki dla mas, „Pamiętnik Literacki” 1967, nr 3.

\section{Opracowania dotyczące intermedialności, audiowizualności, nowych mediów i literatury elektronicznej (pozycje dotychczas nieprzywoływane)}

Aarseth E. J., Cybertext. Perspectives on Ergodic Literature, Baltimore-London 1997.

Adamiec M., Dzieło literackie w Sieci. Pomysty, hipotezy i interpretacje z pogranicza wiedzy o literaturze, kultury masowej $i$ wspótczesnych technologii, Gdańsk 2004.

Analizing Digital Fiction, red. A. Bell, A. Ensslin, H. K. Rustad, New York-London 2014.

Ankudowicz J., Straus G., Ksiażki i ludzie na przełomie stuleci (więcej pytań niż odpowiedzi), [w:] Kultura i sztuka u progu XXI wieku, red. S. Krzemień-Ojak [i in.], Białystok 1997.

Bardziej epicki od Fecebooka. O Liternecie.pl rozmowa paczkujaca, „Techsty” 2011, nr 7 (http://www. techsty.art.pl/magazyn/magazyn7/wywiad_z_leszkiem_onakiem.html [dostęp 30.09.2011]). 
Bodzioch-Bryła B., Ku ciału post-ludzkiemu... poezja polska po 1989 roku wobec nowych mediów i nowej rzeczywistości, Kraków 2006.

Bolter D. J., Człowiek Turinga: kultura Zachodu w wieku komputera, tłum. T. Goban-Klas, Warszawa 1990.

Bolter J. D., Writing Space. Computers, Hypertext, and the Remediation of Print, wyd. 2, Mahwah 2001.

Branny E., O zwiqzkach poezji wizualnej $i$ hipertekstu. Rozważania w świetle „The Aesthetics of Visual Poetry 1914-1928” Williarda Bohna, „Techsty”, nr 5/2008, http://techsty.art.pl/magazyn/magazyn5/artykuly/branny01.html [dostęp 20.07.2009].

Branny-Jankowska E., Impresje z e-poetry 2009, „Techsty” 2009, nr 6, http://techsty.art.pl/magazyn/magazyn6/e-poetry01.html [dostęp 30.09.2011].

Branny-Jankowska E., Obietnice poezji elektronicznej, „Dekada Literacka” 2010, nr 1-2.

Chmielecki K., Estetyka intermedialności, Kraków 2008.

Chmielecki K., Od estetyki intermedialności do estetyki transmedialności. Perspektywy refleksji nad sztuka w kontekście problematyki konwergencji mediów i transgresji kulturowej, [w:] Sztuki w przestrzeni transmedialnej, red. T. Załuski, Łódź 2010.

Chymkowski R., Literatura na morzu i w sieci, czyli kim chce być czytelnik e-ksiqżek, [w:] Liternet. literatura i internet, red. Piotr Marecki, Kraków 2002, s. 81.

Ekrany piśmienności. O przyjemnościach tekstu w epoce nowych mediów, red. A. Gwóźdź, Warszawa 2008.

Emerson L., Reading Writing Interfaces. From the Digital to the Bookbound, Minneapolis-London 2014.

e-polonistyka, red. A. Dziak, S. J. Żurek, Lublin 2009.

e-polonistyka 2, red. A. Dziak, S. J. Żurek, Lublin 2011.

Eskelinen M., Teoria cybertekstu a badania literackie. Podręcznik użytkownika, tłum. D. Sikora, G. Mielcarek, „Techsty” 2006, nr 2, http://www.techsty.art.pl/magazyn2/ artykuly/eskelinen_cybertekst5.html [dostęp 20.11.2009].

Eskelinen M., The Challenge of Cybertext Theory and Ludology to Literary Theory, [w:] The Aesthetics of Net Literature. Writing, Reading and Playing in Programmable Media, red. P. Gendolla, J. Schäfer, Bielefeld 2007.

Estetyka wirtualności, red. M. Ostrowicki, Kraków 2005.

Fargier J.-P., Anioł obrazu cyfrowego. Czy Mallarmé wymyślit wideo?, tłum. I. Ostaszewska, [w:] Pejzaże audiowizualne..., red. A. Gwóźdź, Kraków 1997.

Funkhouser C. T., Prehistoric Digital Poetry. An Archeology of Forms, 1959-1995, Tuscaloosa 2007.

Glazier L. P., Digital Poetics. The Making of E-Poetries, Tuscaloosa 2002.

Goban-Klas T., Cywilizacja medialna. Geneza, ewolucja, eksplozja, Warszawa 2005.

Górska-Olesińska M., Animacje stowa. Poematy kinetyczne, „Este” 2010, nr 1.

Górska-Olesińska M., Elektroniczne uwolnienie słowa. W środowisku poematów cyfrowych, [w:] Materia sztuki, red. M. Ostrowicki, Kraków 2010.

Górska-Olesińska M., Medialne zawirowania. O nowych publikacjach w serii Media Upheavals, „Techsty” 2011, nr 7 (http://www.techsty.art.pl/magazyn/magazyn7/gorska-olesinska.html, dostęp 30.09.2011).

Górska-Olesińska M., Pisanie jaskiniowe (cave writing), „Autoportret” 2011, nr 1.

Górska-Olesińska M., Playable poetry i gry komputerowe. Krytyczne negocjacje, [w:] Olbrzym $w$ cieniu. Gry wideo w kulturze audiowizualnej, red. A. Pitrus, Kraków 2012.

Górska-Olesińska M., Tekstowe instrumenty do gier z pamięciq. Czas i pamięć w literaturze elektronicznej, „Kultura Popularna” 2010, nr 3-4.

Górska-Olesińska M., Wiersze Turinga?, [w:] Język @ multimedia 3. Dialog-konflikt, red. A. Dytman-Stasieńko, J. Stasieńko, Wrocław 2012.

Gwóźdź A., Spektakle pisma w stadium monitorowym filmu, [w:] Stowo w kulturze mediów, red. Z. Suszczyński, Białystok 1999.

Hayles K. N., Electronic Literature. New Horizons for the Literary, Notre Dame 2008.

Hayles K. N., The Time of Digital Poetry: From Object to Event, [w:] New Media Poetics: Contexts, Technotexts, and Theories, red. A. Morris i T. Swiss, Boston 2006. 
Hayles K. N., Writing Machines, London-Cambridge 2002.

Hejmej A., Literatura intermedialna, [w:] Wizualizacja, literatura i cała reszta, red. W. Bolecki, A. Dziadek, Warszawa 2011.

Higgins D., Nowoczesność o czasu postmodernizmu oraz inne eseje, oprac. P. Rypson, tłum. M. Giżycki i in., Gdańsk 2000.

Hiperteksty literackie. Literatura i nowe media, red. P. Marecki, M. Pisarski, Kraków 2011.

Hopfinger M., Audiowizualny kontekst kultury wspótczesnej, [w:] Kultura-komunikacja-literatura. Studia nad XX wiekiem, red. S. Żółkiewski, M. Hopfinger, Wrocław 1976.

Hopfinger M., Doświadczenia audiowizualne, O mediach w kulturze wspótczesnej, Warszawa 2003.

Hopfinger M., Kultura audiowizualna u progu XXI wieku, Warszawa 1997.

Hopfinger M., Literatura i media. Po 1989 roku, Warszawa 2010.

Hopfinger M., Słowo i obraz w kulturze współczesnej, „Kultura i Społeczeństwo” 1986, z. 1.

Intermedialność, red. R. Lewicki, I. Ohnheiser, Lublin 2001.

Kerckhove D. de, Inteligencja otwarta, tłum. A. Hildebrant, Warszawa 2001.

Kluszczyński R. W., Stowo wstępne, [w:] (Nie)obecne granice, red. K. Kuropatwa, D. Rode, Kraków 2003.

Kluszczyński R. W., Światy możliwe - światy wirtualne - światy sztuki. Fragmenty teorii doświadczenia rzeczywistości wirtualnej, [w:] Estetyka wirtualności, red. M. Ostrowicki, Kraków 2005.

Kluszczyński R. W., Sztuka interaktywna. Od dzieła-instrumentu do interaktywnego spektaklu, Warszawa 2010.

Landow G. P., Twenty minutes into the future, or how are we moving beyond the book?, [w:] The Future of the Book, ed. G. Nunberg, Belgium 1996.

Levinson P., Miękkie ostrze, czyli historia i przyszłość rewolucji informacyjnej, tłum. H. Jankowska, Warszawa 2006.

Liberatura, e-literatura i... Remiksy, remediacje, redefinicje, red. M. Górska-Olesińska, Opole 2012.

Literatura a nowe media. Rozmowa redakcyjna z udziałem Anny Eebkowskiej, Krzysztofa Uniłowskiego, Krystyny Wilkoszewskiej, „Dekada Literacka” 2010, nr 1-2.

Liternet. Literatura i internet, red. P. Marecki, Kraków 2002.

Liternet.pl, red. P. Marecki, Kraków 2003.

Loska K., Joyce i McLuhan: słowo w epoce technologii elektronicznej, [w:] Słowo w kulturze mediów, red. Z. Suszczyński, Białystok 1999.

Manovich L., Awangarda jako software, tłum. I. Kurz, „Kwartalnik Filmowy” 2001, nr 35/36.

Manovich L., Estetyka postmedialna, tłum. E. Wójtowicz, [w:] Redefinicja pojęcia sztuka, red. J. Dąbkowska-Zydroń, Poznań 2006.

Manovich L., Język nowych mediów, przeł. P. Cypryański, Warszawa 2006.

McLuhan M., Galaktyka Gutenberga, tłum. E. Różalska, [w:] idem, Wybór tekstów, Poznań 2001.

McLuhan M., Zrozumieć media. Przedłużenia człowieka, tłum. N. Szczucka, Warszawa 2004.

Negroponte N., Cyfrowe życie. Jak odnaleźć się w świecie komputerów, tłum. M. Łakomy, Bydgoszcz 1997

Od liberatury do e-literatury, red. E. Wilk, M. Górska-Olesińska, Opole 2011.

Ong W. J., Oralność i piśmienność. Słowo poddane technologii, tłum. J. Japola, Lublin 1992.

Ożóg M., Krytyczny wymiar sztuki interaktywnej, [w:] Estetyka wirtualności, red. M. Ostrowicki, Kraków 2005

Pająk A., Litteratura cybernetica, czyli burza w szklance wody, „Dekada Literacka” 2010, nr 1/2.

Pajak A., The Polish Way to E-literature from the Baroque to the 21th Century, http://elitineurope. net/node/23 [dostep 15.11.2009].

Pawlicka U., Literatura elektroniczna. Stan badań w Polsce, „Teksty Drugie”, nr 3/2014.

Pawlicka U., (Polska) poezja cybernetyczna. Konteksty i charakterystyka, Kraków 2012.

Pisarski M., Xanadu. Hipertekstowe przemiany prozy, Kraków 2013.

Piękno w sieci. Estetyka a nowe media, red. K. Wilkoszewska, Kraków 1999.

Prajzner K., Cybertekst. Nowa perspektywa postrzegania tekstualności, [w:] Język@ multimedia, red. A. Dytman-Stasieńko, J. Stasieńko, Wrocław 2005. 
Prajzner K., Interaktywność. Kilka uwag o definiowaniu pojęcia, [w:] Między słowem a obrazem, red. M. Jakubowska, T. Kłys, B. Stolarska, Kraków 2005.

Prajzner K., Tekst jako świat i gra. Modele narracyjności w kulturze wspótczesnej, Łódź 2009.

Przybyszewska A., Którędy do literatury nowomedialnej? „Fragile” 2008, nr 2.

Przybyszewska A., O niektórych strategiach otwarcia na czytelnika $w$ wybranych przyktadach literatury nowomedialnej (rekonesans), [w:] Teksty kultury uczestnictwa, red. A. Dąbrówka, M. Maryl, A. Wójtowicz, Warszawa [w druku].

Przybyszewska A., Ku literaturze grywalnej (kilka uwag wstepnych), „Przegląd Kulturoznawczy” 2014, nr 2.

Przybyszewska A., Po(d)i̇eranie tekstu. Wstep do rozważań o czytaniu kinetycznym, [w:] e-polonistyka 3, red. A. Dziak, Lublin [w druku].

Przybyszewska A., Liberackie marginesy tekstu sieciowego, [w:] Tekst [w] sieci, red. A. Gumkowska, Warszawa 2009.

Przybyszewska A., Nowa? Wizualna? Architektoniczna? Przestrzenna? Kilka stów o tym, co może literatura $w$ dobie Internetu, [w:] e-polonistyka, red. A. Dziak, S. J. Żurek, Lublin 2009.

Przybyszewska A., Czy (i jak) można mówić o e-liberaturze?, [w:] e-polonistyka 2, red. A. Dziak, S. J. Żurek, Lublin 2012.

Przybyszewska A., Niszczyć aby budować. O nowych jakościach liberatury $i$ hipertekstu, [w:] Tekst-tura. Wokół nowych form tekstu literackiego i tekstu jako dzieła sztuki, red. M. Dawidek Gryglicka, Kraków 2005.

Rajewsky I., Intermediality, Intertextuality, and Remediation: A Literary Perspective on Intermediality, „Intermédialités” 2005, nr 6.

Rewers E., Post-polis. Wstep do filozofii ponowoczesnego miasta, Kraków 2005.

Roszak J., Pisarski M., Ja tu a ty tam. Polska powieść hipertekstowa a literacki kanon, [w:] Polska literatura najnowsza - poza kanonem, red. P. Kierzek, Łódź 2008.

Sandbothe M., Transwersalne światy medialne. Filozoficzne rozważania o Internecie, tłum. K. Krzemieniowa, [w:] Widzieć, myśleć, być. Technologie mediów, red. A. Gwóźdź, Kraków 2001.

Sikora D., (Hiper)przestrzeń tekstu - o Storyspace, najstynniejszym programie do tworzenia literatury hipertekstowej, „Techsty”, nr 6 (2009) [dostęp 30.09.2011].

Sikora D., Muza połaczeń. O Word Circuits Connection Muse - zestawie narzędzi do tworzenia poezji i prozy sieciowej, „Techsty” 2008, nr 5, www.techsty.art.pl [dostęp 30.09.2011].

Simanowski R., What is and to What End Do We Read Digital Literature?, [w:] Literary Art in Digital Performance. Case Studies in New Media Art and Criticism, red. F. J. Ricardo, New York-London 2009.

Składanek M., Funology - homo ludens $i$ homo faber w projektowaniu interakcji, „Dyskurs. Pismo Naukowo-Artystyczne ASP we Wrocławiu" 2012, nr 13/14.

Składanek M., Transmedialność i postmedialność - dialektyka konwergencji oraz dywergencji w nowych mediach, [w:] Sztuki w przestrzeni transmedialnej, red. T. Załuski, Łódź 2010.

Strickland S., Lawson C., Vniverse, [w:] New Media Poetics. Contexts, Technotexts, and Theories, red. A. Morris, T. Swiss, London 2006.

Szczęsna E., Poetyka mediów. Polisemiczność, digitalizacja, reklama, Warszawa 2007.

Tekst $(w)$ sieci (tom 1 Tekst. Język. Gatunki, red. D. Ulicka, tom 2 Literatura. Społeczeństwo. Komunikacja, red. A. Gumkowska), Warszawa 2009.

Vandendorpe C., Od papirusu do hipertekstu. Esej o przemianach tekstu i lektury, tłum. A. Sawisz, Warszawa 2008.

Visel D., Multimedia vs intermedia, www.futureofbook.org/blog/archives/2005/11/multimedia_vs_ intermedia.html [dostęp 30.08.2008].

Welsch W., Estetyka poza estetyka, tłum. K. Guczalska, Kraków 2005.

Wendorff A., Vanguardias Poéticas en el Arte Digital en Latinoamérica, Caracas 2010.

Wilk E., N@wigacje stowa. Strategie werbalne w przekazach audiowizualnych, Kraków 2000.

Wilkoszewska K., Estetyka dotyku, [w:] Stowo w kulturze mediów, red. Z. Suszczyński, Białystok 1999.

Wilkoszewska K., Prefiksy w roli wyznaczników współczesności, [w:] Intermedialność w kulturze końca XX wieku, red. A. Gwóźdź, S. Krzemień-Ojak, Białystok 1998. 
Wrycza J., Galaktyka języka internetu, Gdynia 2008.

Zawojski P., „Soft Cinema”Lva Manovicha i Andreasa Kratky'ego. „Język nowych mediów” w praktyce, „Kwartalnik filmowy” 2007, nr 60.

\section{Strony internetowe}

www.nieszuflada.pl

www.techsty.art.pl

\section{Opracowania kontekstowe (teoria literatury, varia)}

Balbus S., Graficzny inwariant tekstu literackiego, [w:] O języku literatury, red. J. Bubak, A. Wilkoń, Katowice 1981.

Balcerzan E., Nowe formy w pisarstwie $i$ wynikajace stad porozumienia, [w:] Polska genologia literacka, red. D. Ostaszewska, R. Cudak, Warszawa 2007.

Balcerzan E., W strone genologii multimedialnej, [w:] Polska genologia literacka, red. D. Ostaszewska, R. Cudak, Warszawa 2007.

Barth J., Zagubiony w labiryncie śmiechu, tłum. M. Adamczyk-Garbowska, Warszawa 1991.

Bartoszyński K., O integracji badań nad tzw. komunikacja literacka, [w:] idem, Powieść w świecie literackości. Szkice, Warszawa 1991.

Beckett S., Dante... Bruno.Vico... Joyce, tłum. A. Libera, „Teatr” 1991, nr 4.

Bloom H., Lęk przed wpływem, tłum. A. Bielik-Robson, M. Szuster, Kraków 2002.

Brzękowski J., Dwudziestu czterech kochanków Perdity Loost, Londyn 1961.

Burzyńska A., Markowski M. P., Teorie literatury XX wieku. Podręcznik, Kraków 2006.

Cudak R., Rzut oka na polska genologie literacka, [w:] Polska genologia literacka, red. D. Ostaszewska, R. Cudak, Warszawa 2007.

Cudak R., Sytuacja gatunków we wspótczesnej poezji polskiej a perspektywy genologii, [w:] Genologia i konteksty, red. C. Dutka, Zielona Góra 2000.

Dąbrowski S., Literatura i literackość, Kraków 1977.

Eco U., Teoria semiotyki, tłum. M. Czerwiński, Kraków 2009.

Ejchenbaum B. M., Jak jest zrobiony „Płaszcz” Gogola?, tłum. M. Czermińska, [w:] Rosyjska szkoła stylistyki, red. M. R. Mayenowa, Z. Saloni, Warszawa 1970.

Ejchenbaum B. M., Teoria metody formalnej, [w:] Teoria badań literackich za granica. Antologia, red. S. Skwarczyńska, t. II, cz. III, Kraków 1986.

Escarpit R., Literatura a społeczeństwo, tłum. J. Lalewicz [w:] Współczesna teoria badań literackich za granica. Antologia, oprac. H. Markiewicz, t. III, Kraków 1973.

Federman R., Surfikcja - cztery propozycje w formie wstepu, tłum. J. Anders, [w:] Nowa proza amerykańska oprac. Z. Lewicki, Warszawa 1983.

Fischer O., Dowody na ikoniczność w języku, tłum. M. Majewska, [w:] Ikoniczność znaku. Słowo-przedmiot-obraz-gest, red. E. Tabakowska, Kraków 2006.

Fiske J., Wprowadzenie do badań nad komunikowaniem, tłum. L. Tkaczyk, Wrocław 2008.

Gazda G., Architektonika graficzna poetyckiego utworu drukowanego, [w:] Literatura i metodologia, red. J. Trzynadlowski, Wrocław 1970.

Genette G., Strukturalizm a krytyka literacka, tłum. W. Błońska, „Pamiętnik Literacki” 1974, nr 3.

Genologia dzisiaj, red. W. Bolecki, I. Opacki, Katowice 2000.

Górny W., O stylistyce praskiego koła, [w:] Praska szkoła strukturalna w latach 1926-1948. Wybór materiałów, red. M. R. Mayenowa, Warszawa 1966.

Hjelmslev L., Prolegomena do teorii języka, tłum. H. Kurkowska, A. Weinsberg, [w:] Językoznawstwo strukturalne. Wybór tekstów, red. H. Kurkowska, A. Weinsberg, Warszawa 1979.

Jakobson R., Co to jest poezja?, tłum. M. R. Mayenowa, [w:] idem, W poszukiwaniu istoty języka. Wybór pism, t. II, Warszawa 1989.

Jakobson R., Język a inne systemy komunikacji, tłum. A. Tanalska, [w:] idem, W poszukiwaniu istoty języka. Wybór pism, t. I, Warszawa 1989. 
Jakobson R., Kilka uwag o Peirce’ie, poszukiwaczu dróg w nauce o języku, tłum. S. Amsterdamski, [w:] idem, W poszukiwaniu istoty języka. Wybór pism, t. I, Warszawa 1989.

Jakobson R., Poetyka w świetle językoznawstwa, tłum. K. Pomorska, [w:] idem, W poszukiwaniu istoty języka. Wybór pism, t. II, Warszawa 1989.

Jakobson R., Problemy poetyki, [w:] Teoria badań literackich za granica. Antologia, red. S. Skwarczyńska, t. II, cz. III, Kraków 1986.

Jakobson R., Zwiazki językoznawstwa z innymi naukami, [w:] idem, W poszukiwaniu istoty języka. Wybór pism, t. I, Warszawa 1989.

Kalaga W., Mgtawice dyskursu: podmiot, tekst, interpretacja, Kraków 2001.

Klemensiewicz Z., Historia języka polskiego, wyd. 7 uzup., Warszawa 1999.

Lalewicz J., Proces i aparat komunikacji literackiej, „Teksty” 1978, nr 1.

Łotman J., Struktura tekstu artystycznego, tłum. A. Tanalska, Warszawa 1984.

Malmgren C. D., Fictional Space in the Modernist and Postmodernist American Novel, Lewisburg 1985.

Markiewicz H., Sposób istnienia i budowa dzieła literackiego, [w:] idem, Główne problemy wiedzy o literaturze, Kraków 1965.

Mayenowa M. R., Analiza doktryny stylistycznej praskiego koła, [w:] Praska szkoła strukturalna w latach 1926-1948. Wybór materiałów, red. M. R. Mayenowa, Warszawa 1966.

Mayenowa M. R., Propozycje teoretyczne w zakresie form poetyckich, [w:] Rosyjska szkoła stylistyki, red. M. R. Mayenowa, Z. Saloni, Warszawa 1970.

Michałowska T., Rodzaje czy rodzaj? Problemy taksonomii literackiej, [w:] Problemy teorii literatury, red. H. Markiewicz, ser. 4, Wrocław 1998.

Mitchell W. J. T., Iconology: Image, Text, Ideology, Chicago 1986.

Mukařovský J., Wśród znaków i struktur. Wybór szkiców, red. J. Sławiński, Warszawa 1970.

Mukařovský J., O języku poetyckim, tłum. W. Górny, [w:] Praska szkoła strukturalna w latach 1926-1948. Wybór materiałów, red. M. R. Mayenowa, Warszawa 1966.

Mukařovský J., Strukturalizm w estetyce i nauce o literaturze, [w:] Teoria badań literackich za granica. Antologia, red. S. Skwarczyńska, t. II, cz. III, Kraków 1986.

Mulvey L., Przyjemność wzrokowa a kino narracyjne, [w:] Panorama współczesnej myśli filmowej, tłum. J. Mach, red. A. Helman, Kraków 1992.

Norwid C., Rzecz o wolności słowa, [w:] idem, Pisma wszystkie, t. III (Poematy), oprac. J. W. Gomulicki, Warszawa 1971.

Nycz R., Tekstowy świat. Poststrukturalizm a wiedza o literaturze, Warszawa 1995.

Okopień-Sławińska A., Semantyka wypowiedzi poetyckiej (Preliminaria), wyd. 2, Kraków 1998.

Pelc J., Barok - epoka przeciwieństw, wyd. 2 popr., Kraków 2004.

Pisarek W., Wstep do nauki o komunikowaniu, Warszawa 2008.

Platon, Fajdros, tłum. W. Witwicki, Warszawa 1958.

Polska genologia literacka, red. D. Ostaszewska, R. Cudak, Warszawa 2007.

Saussure F. de, Kurs językoznawstwa ogólnego, tłum. K. Kasprzyk, Warszawa 1961.

Skwarczyńska S., O paru zagadnieniach poetyki nie podjętych przez badania języka poezji (literatury), [w:] Z zagadnień języka artystycznego, red. J. Bubak, A. Wilkoń, Kraków 1977.

Sterne L., Życie i myśli JW Pana Tristrama Shandy, tłum. K. Tarnowska, Warszawa 1958.

Szkłowski W. B., Sztuka jako chwyt, tłum. R. Łużny, [w:] Teoria badá́ literackich za granica. Antologia, red. S. Skwarczyńska, t. II, cz. III, Kraków 1986.

Szkłowski W. B., Wskrzeszenie słowa, tłum. F. Siedlecki, [w:] Rosyjska szkoła stylistyki, red. M. R. Mayenowa, Z. Saloni, Warszawa 1970.

Tezy praskiego koła (fragment), tłum. W. Górny, [w:] Praska szkoła strukturalna w latach 19261948. Wybór materiałów, red. M. R. Mayenowa, Warszawa 1966.

Tybetańska Księga Umartych, tłum. i oprac. I. Kania, Kraków 1991.

Tynianow J., Jakobson R., Problemy badania literatury i języka, [w:] Teoria badań literackich za granica. Antologia, red. S. Skwarczyńska, t. II, cz. III, Kraków 1986.

Urbaniak I., Romana Jakobsona poetyka w świetle językoznawstwa, „Zagadnienia Rodzajów Literackich" 2002, z. 1-2 (s. 89-90).

Wallis M., Napisy w obrazach, [w:] idem, Sztuki i znaki. Pisma semiotyczne, Warszawa 1983. 
Wańkowicz M., Ziele na kraterze, Warszawa 1957.

Wellek R., Pojęcie formy $i$ struktury $w$ krytyce XX wieku, tłum. I. Sieradzki, [w:] idem, Pojęcia i problemy nauki o literaturze, tłum. zbior., Warszawa 1979.

Wellek R., Warren A., Teoria literatury, tłum. M. Żurowski, J. Krynicki, I. Sieradzki, Warszawa 1976.

Witosz B., Gatunek - sporny (?) problem wspótczesnej refleksji tekstologicznej, „Teksty Drugie” 2001, nr 5, przedruk [w:] Sporne i bezsporne problemy wspótczesnej wiedzy o literaturze, red. W. Bolecki, R. Nycz, Warszawa 2002.

Wysłouch S., Nowa genologia - rewizje i reinterpretacje, [w:] Polonistyka $w$ przebudowie, red. M. Czermińska i in., t. I, Kraków 2005.

Wysłouch S., Problematyka symultanizmu w prozie, Poznań 1981.

Wysłouch S., Znak ikoniczny w koncepcji Umberta Eco - nowatorstwo i niekonsekwencje, [w:] eadem, Literatura i semiotyka, Warszawa 2001.

Ziomek J., Powinowactwa przez fabułe, [w:] idem, Powinowactwa literatury. Studia i szkice, Warszawa 1980.

Żegleń U. M., Wprowadzenie do semiotyki teoretycznej i semiotyki kultury, Toruń 2000.

\section{Słowniki, encyklopedie, leksykony}

Gazda G., Słownik europejskich kierunków i grup literackich XX wieku, wyd. 2, Warszawa 2009.

Potrykus-Woźniak P., Stownik nowych gatunków i zjawisk literackich, Warszawa 2010.

Encyklopedia wiedzy o ksiażce, red. A. Birkenmajer, B. Kocowski, J. Trzynadlowski, Wrocław 1971.

Stownik rodzajów i gatunków literackich, red. G. Gazda, S. Tynecka-Makowska, Kraków 2006.

Słownik rodzajów i gatunków literackich. Nowe wydanie, red. G. Gazda, Warszawa 2012.

Słownik terminów literackich, red. J. Sławiński, Wrocław 2000.

Stowniku wyrazów obcych PWN, oprac. L. Wiśniakowska, Warszawa 2004.

Tekstylia bis. Stownik młodej polskiej kultury, red. P. Marecki, Kraków 2006. 



\section{Nota bibliograficzna}

Do tego tomu w mniej lub bardziej zmodyfikowanej wersji weszły fragmenty publikowanych wcześniej szkiców:

Ksiażkowe interfejsy. Liberatura - przekaz grafemiczny w postmedialnym świecie konwergencji?, [w:] Liberatura, e-literatura i... Remiksy, remediacje, redefinicje, red. M. Górska-Olesińska, Opole 2012.

Czy (i jak) można mówić o e-liberaturze?, [w:] e-polonistyka 2, red. A. Dziak, S. J. Żurek, Lublin 2012.

Daleko czy jednak blisko? O tym co taczy liberatów i e-literatów, [w:] Od liberatury do e-literatury, red. M. Górska-Olesińska, E. Wilk, Opole 2011.

Dziesięć lat liberatury (historia w dużym skrócie) [posłowie], [w:] Z. Fajfer, Liberatura czyli literatura totalna. Teksty zebrane z lat 1999-2009, red. K. Bazarnik, Kraków 2010.

NIE-KONKRETNA KAWIARIA LIBERACKA. Na marginesie kilku nieodbytych rozmów liberatów $i$ konkretystów, „ARTERIE”, nr 3 (9)/2010.

Liberackie marginesy tekstu sieciowego, [w:] Tekst [w] sieci, red. A. Gumkowska, Warszawa 2009.

Nowa? Wizualna? Architektoniczna? Przestrzenna? Kilka stów o tym, co może literatura w dobie Internetu, [w:] e-polonistyka, red. A. Dziak, S. J. Żurek, Lublin 2009. 



\section{Spis ilustracji, wykresów i tabel}

\section{Ilustracje}

Ilustracja 1. Radosław Nowakowski, Ulica Sienkiewicza w Kielcach, Kielce 2003 (fragmenty) (źródło: zdjęcia własne autora)

Ilustracja 2. Radosław Nowakowski, Traktat kartkograficzny czyli rzecz o liberaturze, fragmenty dotyczące sposobu liberackiego kształtowania zdania (s. 59, 66) (źródło: zdjęcia własne autora)

Ilustracja 3. Radosław Nowakowski, Traktat kartkograficzny czyli rzecz o liberaturze, fragment (s. 20) (źródło: zdjęcie własne autora).

Ilustracja 4. Andrzej Bednarczyk, Pole anielskich szeptów (źródło: zdjęcia własne autora) .......

Ilustracja 5. Stéphane Mallarmé, Rzut kośćmi nigdy nie zniesie przypadku (fragmenty wersji z 1914 r. oraz 1897 r. w polskim tłumaczeniu Tomasza Różyckiego) (źródło: Stéphane Mallarmé, Rzut kośćmi nigdy nie zniesie przypadku, Kraków 2005, bez numeracji stron)........

Ilustracja 6. Guillaume Apollinaire, Kaligramy (od lewej: Deszcz oraz Krawat i zegarek) (źródło: Guillaume Apollinaire, Wybór poezji, oprac. J. Kwiatkowski, Wrocław 1975, s. 271 oraz s. 255).....

Ilustracja 7. Guillaume Apollinaire, List oceaniczny (wersja oryginalna oraz polskie tłumaczenie) (źródło: Willard Bohn, Modern Visual Poetry, Newark 2001, s. 41 oraz Maryla Hopfinger, W laboratorium sztuki XX wieku, Warszawa 1993, s. 96-97).

Ilustracja 8. Adam Nieradzki, Kirys hartowny starożytnego rycerza (źródło: Piotr Rypson, Piramidy-słońca-labirynty. Poezja wizualna w Polsce od XVI do XVIII wieku, Warszawa 2002, s. 336).

Ilustracja 9. Okładka Od Joyce’a do liberatury. Szkice o architekturze słowa, red. Katarzyna Bazarnik, Kraków 2002 (przód) (źródło: zdjęcie własne)

Ilustracja 10. Zenon Fajfer, Autoportret (źródło: zdjęcie własne autora) oraz Ian H. Finlay, Nienaturalne kamyki (źródło: „Literatura na Świecie” 2006, nr 11-12, s. 50) ...................... 102

Ilustracja 11. Okładka Od Joyce’a do liberatury. Szkice o architekturze słowa, red. Katarzyna Bazarnik, Kraków 2002 (tył) (źródło: zdjęcie własne)

Ilustracja 12. Zenon Fajfer, Portret artysty. Od lewej Portret artysty z czasów prenatalnych (1881), Portret artysty $z$ czasów dojrzewania (1904), Portret artysty wieku dojrzałego (1922), Portret artysty - maska pośmiertna (1941) (źródło: zdjęcia własne autora) .......... 126

Ilustracja 13. Mary E. Solt, Forsythia (źródło: Mary E. Solt, Concret Poetry. A world view, London 1971, s. 243)

Ilustracja 14. Reinhardt Döhl, Jabłko (źródło: Józef Bujnowski, Poezja konkretna, „Poezja” 1976, nr 6, s. 16)

Ilustracja 15. Fragment leksji świnia z Końca świata wedtug Emeryka Radosława Nowakowskiego (zrzut ekranu) (źródło: Radosław Nowakowski, Koniec świata według Emeryka, Bodzentyn 2004, CD)

Ilustracja 16. Fragment leksji mucha z Końca świata wedtug Emeryka Radosława Nowakowskiego (zrzut ekranu) (źródło: Radosław Nowakowski, Koniec świata według Emeryka, Bodzentyn 2004, CD)

Ilustracja 17. Fragment leksji cytryna z Końca świata według Emeryka Radosława Nowakowskiego (zrzut ekranu) (źródło: Radosław Nowakowski, Koniec świata według Emeryka, Bodzentyn 2004, CD) 
Ilustracja 18. Stronica z książki ksylograficznej z XV w. (Biblia pauperum) (́́ródło: Barbara Bieńkowska, Elżbieta Maruszczak, Ksiq̇̇ka na przestrzeni dziejów, Warszawa 2005, s. 58).

Ilustracja 19. Cypryjski list odpustowy (źródło: Jan Pirożyński, Johannes Gutenberg i poczatki ery druku, Warszawa 2002, s. 66)

Ilustracja 20. Typowe plakaty teatralne z XIX wieku (źródło: Robin Dodd, From Gutenberg to Open Type. An illustrated history of type from the earliest letterforms to the latest digital fonts, Cambridge 2006, s. 66).

Ilustracja 21. Użycie czcionki Clarendon (zaprojektowanej jako czcionka służąca wyróżnianiu informacji) w XIX w. i współcześnie (źródło: Robin Dodd, From Gutenberg to Open Type. An illustrated history of type from the earliest letterforms to the latest digital fonts, Cambridge 2006, s. 70)

Ilustracja 22. Użycie czcionki Franklin Gothic w motoryzacyjnych ulotkach reklamowych z 1902 r. i współcześnie (źródło: Robin Dodd, From Gutenberg to Open Type. An illustrated history of type from the earliest letterforms to the latest digital fonts, Cambridge 2006, s. 94-95)

Ilustracja 23. Poemat-znak Dante (embrion) Zenona Fajfera (źródło: zdjęcia własne autora) oraz praca Herba Lubalina z drugiej połowy XX wieku (źródło. Robin Dodd, From Gutenberg to Open Type. An illustrated history of type from the earliest letterforms to the latest digital fonts, Cambridge 2006, s. 149) .....

Ilustracja 24. Od lewej - Arw Stanisława Czycza, Albert Angelo Bryana S. Johnsona (źródło: zdjęcia własne), Dunes Filippo T. Marinettiego (źródło: Johanna Drucker, The Visible Word. Experimental Typography and Modern Art, 1909-1923, Chicago-London 1996, s. 122).

Ilustracja 25. Od lewej - Filippo T. Marinettiego Bataille à 9 étages (źródło: Alan Bartram, Futurist Typography and the Liberated Text, London 2005, s. 31) oraz Carta Sincrona (źródło: Michael Webster, Reading Visual Poetry after Futurism. Marinetti, Apollinaire, Schwitters, Cummings, New York 1995, il. 4)...

Ilustracja 26. Od lewej - Filippo T. Marinettiego Indiferenza (źródło: Filippo T. Marinetti, Zang, tumb, tumb, Milano 1914, s. 112-113) oraz Le soir, couchée dans son lit, elle relisait la lettre de son artilleur au front (źródło: Alan Bartram, Futurist Typography and the Liberated Text, London 2005, s. 30)

Ilustracja 27. Bruno Jasieński, But w butonierce - s. 80-81 (źródło: Bruno Jasieński, But $w$ butonierce, Warszawa 1921, zdjęcia własne ze zbiorów CIMELIA Biblioteki Uniwersytetu Łódzkiego)

Ilustracja 28. Dan Waber, Argument (zrzuty ekranowe) (źródło: Internet; http://vispo.com/ guests/DanWaber/argument.html)

Ilustracja 29. Dan Waber, Arms (zrzuty ekranowe) (źródło: Internet; http://vispo.com/guests/ DanWaber/arms.htm)

\section{Wykresy}

Wykres 1. Uproszczony schemat zasięgu sztuki książki wg Katarzyny Bazarnik (źródło: oprac. Agnieszka Przybyszewska)

Wykres 2. Schemat ujmujący relacje między książką artystyczna, liberatura, sztuką książki, książka, literaturą i sztuką (źródło: oprac. Agnieszka Przybyszewska)

\section{Tabele}

Tabela 1. Zestawienie cech Oka-leczenia i Końca świata wedtug Emeryka wg typologii E. Aarsetha (oprac. A. Przybyszewska) 


\section{Indeks}

Aarseth Espen 57, 319, 325, 328, 335-339, $345,354,372,374,381,385,399,410$

Achituv Romy 329, 344,

Adamiec Marek 328, 399

Adler Jeremy 81, 92, 93

Alderman Naomi 379

Andrews Jim 379

Ankudowicz Janusz 347, 399

Apollinaire Guillaume 38, 77-79, 84, 86-91, $99,118,126,163,245,226,314,315,344$, 394,395

Baines Phil 204, 205, 206, 396

Balbus Stanisław 32, 46, 341, 403

Balcerzan Edward 32, 33, 238, 256, 257, 398, 403

Baluch Alicja 228, 398

Banach Andrzej 134, 138

Bantock Nick 380

Barth John 254, 403

Barthes Roland 148, 379

Bartnicki Krzysztof 59, 60, 70, 250, 392

Bartram Alan 224, 225, 238, 239, 244, 246, $249,251,398,410$

Baumgarth Christa 225, 231, 398

Bayer Herbert 210

Bazarnik Katarzyna 11, 16, 17, 18, 24, 25, $27,29,32,33,34,35,39,43,44,45-$ $62,65-74,78,81-84,86,88,90,93$, $101,103-105,107,113,114,121,124$, $128,129,136,139,144,149,151,153$, $154,164,165,169,173,174,180-182$, 189-191, 193-195, 200, 207, 209, 215, $222,223,226,241,242,244,248,258$, 265, 273-279, 281-285, 287-292, 294, $309,311,312,314,317,318,319,322$, $329,335,337,339,340-343,349,350$, 353,354

Bednarczyk Andrzej 61, 145, 205, 251, 287, $335,344,355,409$

Bense Max 103, 106, 109, 110, 112, 117

Bieńkowska Barbara 195, 198, 199, 396, 410

Bill Max 117, 124

Birek Wojciech 134, 136, 145, 152, 154, 396

Blake William 51, 52, 61, 340

Blanchard Gérhard 134
Bocian Marianna 120, 122, 394

Bodzioch-Bryła Bogusława 328, 400

Bohn Willard 89, 349, 394, 400, 409

Bolter Jay David 41, 90, 264-268, 322, 328, $331,333,342,400$

Borowiak Xymena 175, 349

Bouchardon Serge 379

Boucq François 154

Branny (Branny-Jankowska) Emilia 175, 324, $326,349,400$

Bremer Claus 121

Brooks Cleanth 182

Brzękowski Jan 211, 242, 403

Bugajski Leszek 70

Bujnowski Józef 103, 104, 105, 107, 109, $110,112,113,115,119,120,122,129$, 394,409

Burzyńska Anna 168, 183, 186, 303, 403

Busch Wilhelm 134

Butor Michael 27, 47, 82, 88, 182, 200, 341, 350,391

Calvino Italo 157

Carpentier Kevin 379

Carrión Ulises 280-283, 396

Carroll Josh 343

Cayley John 379

Chappell Duncan 287, 396

Chlebnikow Welimir 163, 171, 172, 180, 189

Chmielecki Konrad 362, 363, 364, 365, 400

Chomsky Noam 183

Chymkowski Roman 354, 400

Cobbing Bob 105

Cooper Muriel 264

Coover Robert 343

Craven Jackie 377

Crepax Guido 153

Cudak Roman 32, 33, 34, 53, 403, 404

Cybulski Radosław 300, 301, 308, 396

Czerski Piotr 42, 43

Czerwiński Marcin 167, 229, 298, 300, 342, 396, 398, 403

Czycz Stanisław 70, 241, 242, 392, 393, 410

Czyżewski Tytus 227, 228, 241, 398 
Danielewski Mark 371, 374, 395

Dawidek Gryglicka Małgorzata 28, 47, 65, 67, $93,113,157,160,166,182,355,391,394$, 402

Dąbrowski Stanisław 13, 14, 387, 403

de Campos Augusto 110, 123, 126

de Campos Haroldo 110

de Courtenay Jan Baudouin 171, 172

de Geest Dirk 54

de Kerckhove Derrick 370, 377, 401

de Saussure Ferdinand 163-165, 168, 169, 171, 172, 181, 183, 184-186, 194, 206

Derrida Jacques 50, 161, 194, 206

Dodd Robin 196, 200, 201, 203, 206, 397, 410

Döhl Reinhardt 129, 409

Doré Gustave 134

Dróżdż Stanisław 101, 107, 115, 116, 123-126, 128. 256, 331, 344, 394, 395

Drucker Johanna 88, 89, 90, 163-166, 170, 181, 184, 189, 195, 196, 199, 200, 203, 204, 211, 225, 242, 244-247, 249, 251, 253-255, 279, 286, 287, 293, 294, 394, 397, 410

Dunajko Paweł 70

Duncan Randy 141, 287, 396

Dunin Janusz 134, 142, 147, 275, 279, 280, 299, 300, 396, 397

$\mathbf{E}_{\text {co Umberto 49, 56, 157, 167, 168, 169, 191, }}$ $251,275,276,379,403,405$

Eisner Will 151, 152

Ejchenbaum Boris M. 13, 14, 171, 173, 174, $178,179,180,181,182,403$

Emerson Lori 60, 345, 381, 400

Ernst Ulrich 81, 92, 134

Escarpit Robert 274, 275, 300, 302, 304, 305, 306, 397, 403

Eskelinen Markku 326, 333, 334, 337-339, 373,400

Espinosa César 118, 394

$\mathbf{F}_{\text {ajfer Dante 101, 107, 126, 128, 129, } 410}$

Fajfer Zenon 11, 13, 14, 16, 17, 18, 23-39, $42-62,65-76,78,80-84,86-88,90,92$, 93, 98-107, 109, 112, 1141-116, 118-120, 122-129, 131, 132, 134, 136, 139-142, $145,149,154,156,160,161,163,164$, $168,169,173,174,179-181,183,185$, 188-190, 194, 205-207, 209, 212, 215, 22-223, 226, 235-238, 241-242, 244, 248, $254,256,258,265,267,269,273,274$, 277-282, 284-286, 288, 291, 294-296, 300-302, 309, 310-312, 314, 315, 318, $319,321,322,327,329,335,337,339$,
$341,342,343,349,350,352,353,355$, $356,361,363,367,375,377,381,383$, 386, 389, 391, 392, 393, 407, 409, 410

Falicki Jerzy 86-88, 91, 394

Federman Raymond 48, 50, 51, 70, 222, 241, $334,341,368,371,392,403$

Filippo Tommaso Marinetti 223, 229, 230, 242, $245,247,249,410$

Finlay Ian Hamilton 102, 409

Focillon Henri 205

Fortunat Wenancjusz 93

Frank Joseph 50

Fresnault-Deruelle Pierre 134

Fujihata Masaki 350

Funkhouser Chris T. 324, 325, 400

Galloway Alexander 345

Garbala Marek 123, 394

Garnier Pierre 105, 118

Gazda Grzegorz 11, 46, 59, 78, 84, 88, 108, 111, 124, 224-227, 229-232, 238, 341, 393, 394, 399, 403, 405

Gendolla Peter 373, 379, 400

Genette Gérard 47, 166, 182, 403

Gill Eric 196

Glazier Loss Pequeño 67, 323, 325, 334, 339, $343,385,400$

Głombiowski Karol 195, 297-301，304，305, 312-315, 397

Głowiński Michał 26, 161

Gogol Nikołaj 178, 179, 182, 403

Gomringer Eugen 104, 110, 111, 112, 114, 116, $121,122,124,125$

Górny Wojciech 172, 185, 403

Górska-Olesińska Monika 56, 262, 264, 270, $324,328,331,332,344,373,379,393$, 400, 401, 407

Greenlee Shawn 343

Gretkowska Manuela 157

Groensteen Thierry 134

Grześczak Marian 105

Gwóźdź Andrzej 90, 265, 321, 322, 323, 328, 400, 402

Haddon Mark 157, 251, 380

Hall Steven 157, 380

Haslam Andrew 204-206, 396

Hausken Liv 339, 344, 381

Hayles Katherine N. 262, 267, 302, 317, 318, $319,325,328,332,333,335,339,343-$ $345,352,373,381,385,400,401$

Heistein Józef 224, 229, 230, 232, 241, 247, 248, 399

Hejmej Andrzej 99, 364, 394, 401 
Herbert George 90, 322

Higgins Dick 83, 92, 104, 108, 120, 121, 207, 262 , $267,286,339,343,364,365,382,394,401$

Hjelmslev Louis 166-168, 172, 183, 403

Hopfinger Maryla 32, 78, 80, 81, 86, 88, 89, 90, $99,131,148,230,328,329-332,340,342$, 343, 359-361, 365, 374-376, 394, 401, 409

Howe Daniel C. 378

Huhtamo Errki 351

Husárova Zuzana 378

Hutnikiewicz Artur 225, 231, 233, 399

Ingarden Roman 46, 57, 66, 341, 359, 392

Jackson Shelley 338

Jakobson Roman 168, 169, 180, 182-187, 303, 307, 403, 404

Janiak-Staszek Agnieszka 131, 396

Janusiewicz Małgorzata 328, 332

Jarniewicz Jerzy 108, 113, 114, 157, 207

Jarzębski Jerzy 141

Jasieński Bruno 227, 228, 235, 236, 237, 238, $246,255,256,398,399,410$

Jeżyk Łukasz 238, 355, 393

Jodorowsky Alexandro 154

Johann Benther 94

Johnson Bryan Stanley 27, 47, 48, 50, 51, 52, 70, 106, 149, 157, 160, 227, 241, 242, 242, $329,335,340,343,391,392,393,410$

Joyce James 24, 27, 28, 33, 36, 37, 45, 47, 48, $50,53,57,61,65,67,70,72,73,82,84$, $88,101,104,120,131,132,144,182,200$, $222,241,242,274,278,282,283,321-$ 323, 374, 391-393, 401, 403, 409

Kalaga Wojciech 18, 44, 100, 111, 112, 169, 223, 392, 404

Kendall Robert 377

Kestner Joseph 50

Kluszczyński W. Ryszard 11, 65, 157, 266, 365, 366, 393, 401

Kłoskowski Andrzej 276

Kołos Anna 162, 393

Koskimaa Raine 326

Kostelanetz Richard 58, 72, 73, 287, 288, 289, 290, 292, 295, 397

Kozłowski Paweł 352

Kralowa Halina 229, 230, 232, 238, 399

Kriwiet Ferdinand 124, 125

Kruczonych Aleksiej 163, 171, 180, 189

Kurc Bartosz 134, 142, 143, 147, 148, 153, 396

Kurt Schwitters 379

Kwiatkowski Jerzy 87-91, 214-218, 221, 394, 398, 409
Ladurocki Jacek 299

Lalewicz Janusz 302-307, 309, 310, 397, 403, 404

Landow George 333, 401

Lawson Cyntia 324, 334, 402

Lessing Gotthold Ephraim 27, 252, 359, 394, 395

Levinson Paul 40, 44, 230, 367, 378, 401

Lévi-Strauss Claude 183

Lewandowska Bożena 210, 228, 257, 398

Lewis Jason 260, 263, 271, 397

Lisicki El 210

List Giovanni 242

Loska Krzysztof 322, 323, 401

Lubalin Herb 206, 410

Lutes Jason 154

Łebkowska Anna 328, 401,

Łubowicz Elżbieta 115, 125, 395

Łysiak Waldemar 134

Maciejewski Cyprian 273

Majakowski Włodzimierz 210

Majerski Paweł 227, 228, 399

Malewicz Kazimierz 210

Malka Ariel 271

Mallarmé Stéphane 47, 48, 50, 52, 56, 61, 70, 77-86, 88, 90, 94, 99, 100, 104, 119, 172, $185,235,245,274,294,314,315,321$, $322,323,363,385,392,395,400,409$

Malmgren Carl Darryl 47-50, 52, 404

Manovich Lev 59, 261, 322, 362-364, 366-369, 372,385

Marecki Piotr 25, 38, 39, 67, 111, 175, 260, $327,328,330,347,354,385,393,400$, 401, 405

Marinetti Filippo Tommaso 118, 163, 189, 207, $210,223,224,226,228,229,230,231$, 232-238, 240-245, 247, 248-255, 257, $294,379,384,387,395,398,410$

Markiewicz Henryk 29, 57, 252, 301, 305, 341, 395, 403, 404

Markowski Michał Paweł 82, 168, 171, 172, $174,179,182,303,403$

Maryl Maciej 264, 265, 302, 402

Mayenowa Maria Renata 171, 173, 178, 185 , 186, 187, 403, 404

Maziarczyk Grzegorz 317, 381, 395

McCay Winsor 156

McClain Andrew 343

McCloud Scott 134, 143, 144, 148, 396

McGann Jerome 57, 312, 325, 397

McKenzi Donald Francis 50, 51, 195, 341 
McLuhan Marshal 259, 299, 304, 310, 312, $319,322,323,369,378,381,401$

Michałowska Teresa 29, 30, 33

Miczka Tadeusz 223-225, 232-234, 399

Mignonneau Laurent 351

Migoń Krzysztof 195, 259, 297, 298, 300, 397

Miller Frank 154

Miłosz Czesław 33, 68, 73

Mitchell W.J. Thomas 50, 77, 404

Mitre Eduardo 84

Moeglin-Delcroix Ann 276, 286

Moholy-Nagym Laszló 210

Mon Franz 119

Mondrian Piet 163

Montfort Nick 66, 70

Morris William 203, 334, 373, 400, 402

Mukařovský Jan 179, 183-194

Müller Herta 70

Muszkowski Jan 196, 199, 206, 397

Nadeau Bruno 271

Negroponte Nicholas 366, 367

Nieradzki Adam 95, 97, 98, 270, 385, 395, 409

Norwid Cyprian Kamil 61, 161, 341, 404

Nowakowski Radosław 16, 23, 24, 27, 35-42, $44,45,47,50,58,61,66,68,71,82,105$, $112,115,116,122,144,145,149,150$, 152, 155, 161-163, 169, 173, 175, 176, $178,215,218,219,222,226,243,244$, $248,252,253,265,278,280,281,284$, 285, 291, 311, 335, 337, 338, 347-350, $353,355,369,391-393,409$

Okopień-Sławińska Aleksandra 301, 302, 303, $310,311,404$

Olszewska Anna 275, 279, 397

Ong Walter 40, 44, 66, 230, 322, 334, 363, 378, 401

Optacjan Publiliusz Porfyriusz 92, 93

Orszulewski Dariusz 70, 160

Ożóg Maciej 351, 401

Pająk Andrzej 175, 326, 329, 330, 337, 349, 352,401

Palazzeschi Aldo 253, 399

Panák Lubo 378

Pawlicka Urszula 237, 324, 325, 327, 399

Perec Georges 67, 70, 392

Phillpot Clive 278, 286, 288, 289, 290, 292, 397

Pignatari Décio 110, 111, 115

Pinto Luiz Ángelo 111, 115

Pirożyński Jan 198, 199, 397, 410

Pisarek Walery 310, 311, 404
Pisarski Mariusz 28, 39, 175, 326, 328, 329, $330,334,339,342,347,348,349,352$, $353,355,369,378,393,401,402$

Platon 161, 404

Polak Monika 286

Poprawa Adam 161, 265, 349, 383, 392

Potiebnia Aleksandr Afanasjewicz 173, 176

Potrykus Woźniak Paulina 111, 122, 136, 405

Pound Ezra 104, 118, 163

Prajzner Katarzyna 56, 65, 336, 337, 338, 368, 369, 401, 402

Pressman Jessica 15, 60,-62, 66, 178, 181, 316-319, 327, 371, 374, 381, 395

Prévert Jacques 114

Przyboś Julian 170, 207, 212, 217

Przybylski Ryszard 141, 146, 147, 151, 396

Pynchon Thomas 157, 251

Queneau Raymond 67, 70, 71, 135, 339

$\mathbf{R}_{\text {aley Rita }} 333$

Rancíer Jacques 162

Ranocchi Emiliano 68

Ransom John C. 182

Rewers Ewa 363, 402

Roszak Joanna 125, 175, 347, 348, 353

Różewicz Tadeusz 61, 71, 393

Rypson Piotr 44, 83, 91-97, 104, 117, 143, 206, 210, 257, 262, 276, 278, 287-289, 339, $362,364,394,397,401,409$

Sadowski Witold 62, 324, 342, 395

Sandbothe Mike 89, 402

Scaliger Julius Caesar 93, 340

Schaeffer Pierre 305, 306

Schäfer Jörgen 373, 379, 400

Schmidt Siegfrid 103

Selznick Brian 157, 158, 159, 160, 374, 380

Shaw Jeffrey 343, 351, 370, 371, 378

Shuty Sławomir 348, 369

Sienkiewicz Bill 154, 155

Sikora Dorota 264, 328, 331, 334, 336, 366, $377,400,402$

Simanowski Roberto 372, 402

Składanek Marcin 331, 364, 365, 402

Skwarczyńska Stefania 14, 33, 46, 122, 171, $173,183,188,341,403,404$

Sławek Tadeusz 103-106, 122, 395

Sławiński Janusz 26, 29, 30, 43, 111, 151, 188, 189, 191, 224, 232, 264, 302, 310, 328, 353, 396, 399, 404, 405

Small David 260, 264, 267, 351, 397

Smith Matthew 141, 396

Solski Zbigniew Władysław 71, 393 
Solt Mary Ellen 106-114, 116, 117, 119, 121$125,127,128,394,409$

Sommerer Christa 351

Sowiński Janusz 204, 209, 210

Spencer Sharon 50

Spenlé Stéphanie 379

Staff Leopold 344

Stern Wawrzyniec 51, 52

Sterne Laurence 48, 50, 57, 53, 63, 164, 181, $182,227,238,241,257,258,322,339,363$, 392,404

Stewart Sean 380

Straus Grażyna 347, 399

Strickland Stephanie 324, 334, 402

Strzemiński Władysław 65, 170, 207, 209-222, 241, 246, 398, 399

Szczerbowski Robert 70

Szczęsna Ewa 266, 367, 402

Szkłowski Wiktor 114, 164, 167, 172-178, 181, 182, 186, 190, 374, 404

Szwabowicz Mirosław 147, 148, 396

Szyłak Jerzy 131, 132, 134, 137, 138, 141, 143, 144, 147-150, 152-156, 396

Śniecikowska Beata 172, 210, 212, 214, 217, 218, 220, 227-229, 246,

św. Augustyn 378

Taborska Agnieszka 114

Takasaki Shinsuke 68

Teige Karol 210

Toeplitz Krzysztof Teodor 134, 137, 139, 142144, 148, 149, 152-154

Tołstoj Lew 175

Töpffer Rudolphe 134

Toussaint Bernard 133, 142, 143, 146

Tschichold Jan 210, 213, 216, 386, 398

Turowski Andrzej 210, 214, 216, 219, 398

Twain Mark 131, 155

Tynianow Jurij 182, 183, 185, 404

Ulmer Gregory L. 334

Umberto Eco 49, 157, 167, 251, 275, 276, 397, 405

Uniłowski Krzysztof 328, 401

Urbaniak Irena 169, 170, 209, 398, 404

Utterback Camille 329, 344
Van Gorp Hendrik 54

Vaughn-James Martin 134

Visel Dan 43, 402

Waber Dan 260, 267-270, 410

Walker Mort 147

Walkup Kathleen 68, 69

Wallis Mieczysław 142, 204, 404

Wańkowicz Melchior 242, 405

Warde Beatrice 259, 397

Wardrip-Fruin Noah 343, 379

Warren Austin 162, 405

Ważyk Adam 80-82, 322, 395

Webster Michael 79, 89, 226, 230, 238, 243, 247-250, 252, 395, 410

Weisman Jordan 380

Wellek René 162, 174, 183, 405,

Wendorff Anna 324, 332, 402

Wesołowski Jacek 111

Weyers Alex 260, 263, 397

Wilczek Piotr 95-97, 395

Wilk Eugeniusz 56

Wilkoszewska Krystyna 328, 333, 363, 365, 401, 402

Witosz Bożena 32, 53, 405

Wonga Yin Yin 260, 262, 263, 338, 397

Wójcik Tadeusz 307

Wróblewski Michał 132, 396

Wyrzykowski Robert 136, 396

Wysłouch Seweryna 14, 15, 31-33, 54, 62, 91, $142,218,220,222,242,252,335,359$, 395,405

Zalewski Bogdan 72

Zawojski Piotr 322, 323

Zbierski Teodor 299, 300, 303-305, 307-310, 313, 397

Ziomek Jerzy 135, 405

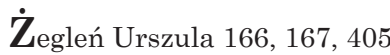

Żuchowski Jakub 66, 67, 132-139, 142, 146, 151,155

Żyrmunski Wiktor 172, 174 
